\title{
De strafvorderlijke inbeslagneming van gegevensdragers en de vrijheid van meningsuiting en drukpers in een internationaal en rechtsvergelijkend perspectief
}

Citation for published version (APA):

Tomesen, L. (1995). De strafvorderlijke inbeslagneming van gegevensdragers en de vrijheid van meningsuiting en drukpers in een internationaal en rechtsvergelijkend perspectief. [Doctoral Thesis, Maastricht University]. Gouda Quint. https://doi.org/10.26481/dis.19951124lt

Document status and date:

Published: 01/01/1995

DOI:

10.26481/dis.19951124lt

Document Version:

Publisher's PDF, also known as Version of record

Please check the document version of this publication:

- A submitted manuscript is the version of the article upon submission and before peer-review. There can be important differences between the submitted version and the official published version of record. People interested in the research are advised to contact the author for the final version of the publication, or visit the DOI to the publisher's website.

- The final author version and the galley proof are versions of the publication after peer review.

- The final published version features the final layout of the paper including the volume, issue and page numbers.

Link to publication

\footnotetext{
General rights rights.

- You may freely distribute the URL identifying the publication in the public portal. please follow below link for the End User Agreement:

www.umlib.nl/taverne-license

Take down policy

If you believe that this document breaches copyright please contact us at:

repository@maastrichtuniversity.nl

providing details and we will investigate your claim.
}

Copyright and moral rights for the publications made accessible in the public portal are retained by the authors and/or other copyright owners and it is a condition of accessing publications that users recognise and abide by the legal requirements associated with these

- Users may download and print one copy of any publication from the public portal for the purpose of private study or research.

- You may not further distribute the material or use it for any profit-making activity or commercial gain

If the publication is distributed under the terms of Article $25 \mathrm{fa}$ of the Dutch Copyright Act, indicated by the "Taverne" license above, 
De strafvorderlijke inbeslagneming van gegevensdragers en de vrijheid van meningsuiting en drukpers in een internationaal en rechtsvergelijkend perspectief 
Ogen spreken

klanken

rijgen zich aaneen

en klinken

woorden, woorden

Ogen herhalen

verhalen

met miljoenen handen

inbeslag genomen

mensen, mensen

verstommen

je ogen

zonder klanken

gesloten 


\section{De strafvorderlijke inbeslagneming van}

gegevensdragers en de vrijheid van meningsuiting en drukpers in een internationaal en rechtsvergelijkend perspectief

\section{PROEFSCHRIFT}

ter verkrijging van de graad van doctor aan de Rijksuniversiteit Limburg te Maastricht, op gezag van de Rector Magnificus, Prof.mr. M.J. Cohen, volgens het besluit van het College van Dekanen, in het openbaar te verdedigen op vrijdag 24 november 1995 om 12.00 uur

door

Luciënne Tomesen

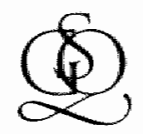

Gouda Quint bv

(S. Gouda Quint - D. Brouwer en Zoon)

Arnhem 
Promotoren:

Prof.mr. G.P.M.F. Mols

Prof.mr. Th.C. van Boven

Beoordelingscommissie:

Prof.mr. Th.A. de Roos (voorzitter)

Prof.mr. J.M. de Meij (Universiteit van Amsterdam)

Dr. H. Danelius (Hoge Raad Zweden, ECRM Straatsburg)

Colophon

Anet van de Elzen, foto en omslagontwerp (1994) 
"Een compromis is altijd noodig, doch het maakt buitengemeen groot werschil hoe men zoekt, van welk beginsel men daarbij uitgaat, welke opvatting men heeft omtrent de verhouding tusschen gemeenschap en individu, tusschen dwang en vrijheid."

D. Simons, Ons nieuw strafproces, Tijdschrift voor Strafrecht 1926, p.19. 



\section{Ten geleide}

Hongerig heb ik meters literatuur gelezen en, niet vertrouwende op mijn geheugen, bergen papier vol geschreven. De vrijheid van meningsuiting en drukpers nam me 'in beslag' eigenlijk al lang voordat ik met het 'officiële' onderzoek aan de RL begon.

Toen ik in mijn studententijd Friedrich Nietzsche en Jean-Jacques Rousseau las maakte vooral Nietzsches 'Die Geburt der Tragödie' grote indruk op mij. Zijn, maar ook Rousseau's, felle pleidooi voor de menselijke uniciteit die door bepaalde ontwikkelingen, zoals de vertechnologisering en vereconomisering van de samenleving, onder de voet dreigt te worden gelopen, is nog steeds uiterst actueel.

De vrijheid van meningsuiting en drukpers heeft voor alles te maken met het respect voor de menselijke uniciteit.

Ik wil dit boek dan ook opdragen aan de schrijfster Nawal El Sadaawi en afsluiten met haar woorden "hoe meer de politiek verbiedt hoe meer je moet publiceren." (De Volkskrant 27-8-1994) 


\section{Voorwoord}

Een dissertatie schrijven is een kwestie van een lange adem hebben. In een turbulente tijd zoals deze is het niet altijd even gemakkelijk je af te sluiten van de wereld om je heen. Ik heb dat dan ook niet gedaan. Juist het 'in de wereld zijn' heeft ertoe bijgedragen dat mijn adem lang genoeg was om tot het einde toe plezier te hebben in het schrijven van 'het boek'.

Bij de totstandkoming van deze dissertatie wil ük iedereen danken die daartoe op zijn of haar manier heeft bijgedragen in het bijzonder mijn promotores en de leden van de leescommissie. Verder Peter Bal, M.C.B. Burkens, Caroline Forder, Harry van der Linden en Ties Prakken voor het kritisch becommentariëren van delen uit mijn dissertatie. Het NWO en de universiteit voor de financiering van mijn tijdelijk verblijf in Cambridge, Freiburg, Nottingham, Straatsburg en Uppsala. Margot de Boer en Josta Mommertz voor hun plezierige samenwerking bij het 'camera-ready' maken van het mamuscript. Ook Anet van de Elzen wil ik hier danken voor de bijzondere foto en het prachtige omslagontwerp en dhr. G.J. Odenkirchen van Gouda Quint, dat hij ons uiteindelijk de ruimte bood af te wijken van de geijkte paden. Verder wil ik hier mw. Dejong niet vergeten. Zonder haar goede zorgen had ik het in Maastricht nooit zolang volgehouden. Ook jouw naam Guy wil ik hier apart vermelden. We hebben het beide niet altijd even gemakkelijk gehad. Jouw stimulans 'te worden die je bent', je levenswijsheid, de kunst, in het bijzonder je muziek, hebben mij soms letterlijk en figuurlijk op de been gehouden.

Luciënne Tomesen 


\section{Inhoudsopgave}

Lijst van afkortingen

XVII

\section{Inlleiding}

1

Onderzoeksvragen

1

2

Rechtsvergelijking

2

3

Opzet

3

Hoofdstuk 1 De vrijheid van meningsuiting en drukpers en het strafvorderlijke dwangmiddel inbeslagneming in Nederland

De vrijheid van meningsuiting en drukpers in art. 7 lid 1 en 3 van de Grondwet

2.2 Wat dient onder het medium 'drukpers' in art. 7 lid 1 van de Grondwet te worden verstaan?

2.3 Hoe wordt de vrijheid van drukpers door de overheid en de rechter geëffectueerd en beperkt?

2.4 De wrijheid van 'gedachten en gevoelens' in art. 7 lid 3 van de Grondwet

2.4.1 Inleiding

2.4.2 Wat dient onder 'gedachten en gevoelens' in art. 7 lid 3 Grondwet te worden verstaan?

2.4.3 Hoe wordt de vrijheid van 'gedachten en gevoelens' door de overheid en de rechter geëffectueerd en beperkt? 
De vrijheid van meningsuiting en drukpers in art. 10 EVRM en art. 19 IVBPR

3.1 Inleiding

3.2 De meerwaarde van art. 10 lid 1 EVRM en art. 19

lid 1 IVBPR ten opzichte van art. 7 lid 1 en 3 van de Grondwet

3.3 Conclusie

Wat is de meerwaarde van art. 10 lid 2 EVRM?

$3.5 \quad$ Conclusie

Het strafvorderlijke dwangmiddel inbeslagneming en de vrijheid van meningsuiting en drukpers

4.3 De materiële aspecten van de inbeslagneming en de vrijheid van meningsuiting en drukpers

4.3.1 De inbeslagneming voor het aan de dag brengen van de waarheid en de vrijheid van meningsuiting en drukpers in art. 7 van de Grondwet

4.3.2 De inbeslagneming ter verbeurdverklaring en de vrijheid van meningsuiting en drukpers in art. 7 van de Grondwet

4.3.3 De inbeslagneming ter onttrekking aan het verkeer en de vrijheid van meningsuiting en drukpers in art. 7 van de Grondwet

Bluf!

4.3.4 Onttrekking aan het verkeer en verbeurdverklaring en de vrijheid van meningsuiting en drukpers in aut. 7 van de Grondwet

4.3.5 De strafvorderlijke inbeslagneming van gegevensdragers en de vrijheid van meningsuiting en drukpers in art. 10 EVRM

4.4 Procedurele aspecten van de inbeslagneming en de vrijheid van meningsuiting en drukpers

4.4.1.1 Commissie Herijking Wetboek van Strafvordering Strafrechtelijke gevolgen van overschrijding van de bevoegdheid

4.4.3 De toetsing van de wijze van gebruikmaking van de inbeslagnemingsbevoegdheid aan de beginselen van een behoorlijke strafrechtspleging 
Hoofdstuk 2 De wrijheid van meningsuiting en drukpers en het strafvorderlijke dwangmiddel inbeslagneming in Duitsland

De inbeslagneming van gegevensdragers voor het aan de dag brengen van de waarheid (paragraph $97 \mathrm{StPO}$ ) en het verschoningsrecht woor persmedewerkers (paragraph 53 $\mathrm{StPO}$ ) in relatie tot de vrijheid van meningsuiting en drukpers (artikel 5 GG)

Inleiding

De zaak "Der Spiegel"

Wie zijn bevoegd tot de inbeslagneming van gegevensdragers wanneer het betreft het aan de dag brengen van de waarheid?

4 De 'Einziehungsbeschlagnahme' en de vrijheid van meningsuiting en drukpers

Wie zijn bevoegd tot de 'Einziehungsbeschlagnahme'?

Hoofdstuk 3 De vrijheid van meningsuiting en drukpers en het strafvorderlijke dwangmiddel inbeslagneming in Engeland

2.2 De 'Obscene Publications Act' 
2.2.1 Materiele problemen 124

2.2.2 Procedurele problemen 126

2.2.3 Hervormingen 127

2.3 De 'Official Secrets Act' 129

2.3.1 Inleiding 129

2.3.2 'Official Secrets Act' 130

2.3.3 Spycateher 133

2.3.4 'D-Notices' 138

2.3.5 Conclusie 138

2.4 De 'Race Relations Act' en de 'Public Order Act' 139

$\begin{array}{ll}2.4 .1 & 139\end{array}$

$2.4 .2 \quad$ Conclusie 143

2.5 De 'Poluce and Criminal Evidence Act 1984' 144

2.5.1 Inleilding 144

2.5.2 De inbeslagneming in de "Police and Criminal Evidence Act $1984^{\circ}$

2.5.2.1 Betekenis van 'legally privileged material' 146

2.5.2.2 Betekenis van 'excluded material' 146

2.5.2.2.1 Toegang tot 'excluded material' 148

2.5.2.3 Betekenis van 'special procedure material' 149

2.5.2.3.1 Toegang tot 'special procedure material' 150

2.5.2.3.1.1 Een 'search warrant' is nilet mogelijk onder een andere

2.5.2.3.1.2 Een 'search warrant' is mogelijk onder een oude 'statute' 151

$2.5 .3 \quad$ Conclusie 151

3 De betekenis van art. 10 EVRM in het Engelse recht 154

$4 \quad$ Conclusie 155

Hoofdstuk 4 De vrijheid van meningsuiting en drukpers en het strafvorderlijke dwangmiddel inbeslagneming in Zweden

1 Inleiding

2 De strafrechtelijke aspecten van 'Tryckfrihetsförordningen' 161

$2.1 \quad$ Hoofdstuk 7 paragraaf 4 'Tryckfrihetsförordningen' 161

2.2 Veranderingen 163

$2.3 \quad$ Hoofdstuk 7 paragraaf 5 'Tryckfrihetsförordningen' 164 
3.1 De strafvorderlijke dwangmiddelen in 'Tryckfrihetsförordningen'

$\begin{array}{lll}3.1 .1 & \text { Confiscatie } & 166\end{array}$

$\begin{array}{lll}3.1 .2 & \text { Uitgifteverbod } & 167\end{array}$

3.1.3 Imbeslagneming 167

3.1.3.1 De wettelijke bevoegdheid tot inbeslagneming 168

4 De juridische procedure bij uitings- en drukpersdelicten 168

$5 \quad$ De juridische aansprakelijkheid $\quad 170$

5.1 Zelfregulering door de pers 171

6 De betekenis van art. 10 EVRM in het Zweedse recht

\section{Hoofdstuk 5 Conclusie}

1 Inleiding

De vrijheid van meningsuiting en drukpers en de materiële aspecten van de inbeslagneming voor het aan de dag brengen van de waarheid

De vrijheid van meningsuiting en drukpers en de procedurele aspecten van de inbeslagneming voor het aan de dag brengen van de waarheid

De wrijheid van meningsuiting en drukpers en de materiële aspecten van de inbeslagneming ter verbeurdverklaring en ter onttrekking aan het verkeer

De vrijheid van meningsuiting en drukpers en de procedurele aspecten van de inbeslagneming ter verbeurdverklaring en ter onttrekking aan het verkeer 
Summary

Lijst van aangehaalde literatuur

231

Jurisprudentieregister

Curriculum vitae

251 


\section{Lijst van afkortingen}

$\begin{array}{ll}\text { AA } & \text { Ars Aequi } \\ \text { Abs. } & \text { Absatz } \\ \text { AC } & \text { The Law Reports Appeal Cases } \\ \text { AfP } & \text { Archiv für Presserecht } \\ \text { AG } & \text { Amtsgericht } \\ \text { All ER } & \text { All England Law Reports } \\ \text { ALR } & \text { American Law Reports } \\ \text { APV } & \text { Algemene politieverordening } \\ \text { ARRS } & \text { Afdeling Rechtspraak Raad van State } \\ \text { Art. } & \text { Artikel } \\ \text { Bd. } & \text { Band } \\ \text { Besch. } & \text { Beschikking } \\ \text { BGB } & \text { Bundesgesetzbuch } \\ \text { BGBl. } & \text { Bundesgesetzblatt } \\ \text { BGH } & \text { Bundesgesetzhof } \\ \text { BrB } & \text { Brottsbalken } \\ \text { Bijl. } & \text { Bijlage } \\ \text { CA } & \text { Court of Appeal } \\ \text { Cr.App.R. } & \text { Criminal Appeal Report } \\ \text { Crim. LR } & \text { Criminal Law Review } \\ \text { DD } & \text { Delikt en Delinkwent } \\ \text { diss. } & \text { dissertatie } \\ \text { DPP } & \text { Director of Public Prosecutions } \\ \text { DRiZ } & \text { Deutsche Richterzeitung } \\ \text { Ds.Ju. } & \text { Justitie Departementet } \\ \text { DVBl. } & \text { Deutsches Verwaltungsblatt } \\ \text { BVerfGE } & \text { Verzameling beslissingen van het Bundesverfassungsgericht } \\ \text { BVerwGE } & \text { Verzameling beslissingen van het Bundesverwaltungsgericht } \\ \text { ECHR } & \text { European Court of Human Rights } \\ \text { ECRM } & \text { Europese Commissie voor de Rechten van de Mens } \\ \text { edn. } & \text { edition } \\ \text { EHRM } & \text { Europees Hof voor de Rechten van de Mens } \\ \text { EK } & \text { Eerste Kamer der Staten-Generaal } \\ & \end{array}$




\begin{tabular}{ll} 
EuGRZ & Europäische Grundgesetz \\
EVRM & Europees Verdrag voor de Rechten van de Mens en de Fundamente- \\
& le Vrijheden \\
exp & ex parte \\
f. & folgende Seite \\
ff. & folgende Seiten \\
GG & Grundgesetz \\
GVG & Gerichtsverfassung \\
H & Handelingen \\
HL & House of Lords \\
HR & Hoge Raad der Nederlanden \\
Hrg. & Herausgeber \\
inaug. & inaugurele rede \\
IVBPR & Internationaal Verdrag inzake Burgerrechten en Politieke Rechten \\
JCL & Journal of Criminal Law \\
JK & justitiekansler \\
JZ & Juristenzeitung \\
Kap. & Kapitel \\
KG & Kort Geding \\
KU & Konstitutionsutskottets betänkande \\
LBR & Landelijk Bureau Racismebestrijding \\
LG & Landesgericht \\
LJ & Law Journal \\
LPG & Landespressegesetz \\
Ltd. & Litigant \\
MDR & Monatsschrift für Deutsches Recht \\
MvA & Memorie van Antwoord \\
MvT & Memorie van Toelichting \\
NBW & Nieuw Burgerlijk Wetboek \\
NJ & Nederlands Jurisprudentie \\
NJA & Nytt Juridiskt Arkiv \\
NJB & Nederlands Juristenblad \\
NJCM & Nederlands Juristen Comite voor de Mensenrechten \\
NJV & Nederlandse Juristen Vereniging \\
NJW & Neue Juristische Wochenschrift \\
NLJ & New Law Journal \\
NLR & New Left Review \\
nr. & nummer \\
NStZ & Neue Zeitschrift für Strafrecht \\
OLG & Oberlandesgericht \\
OM & Openbar Ministerie \\
OMedienG & Offentliche Medien Gesetz \\
Publ. & Publication \\
& \\
\hline
\end{tabular}




$\begin{array}{ll}\text { QB } & \text { Queens Bench } \\ \text { Rb. } & \text { Rechtbank } \\ \text { Rdn. } & \text { Randnummer } \\ \text { red. } & \text { redactie } \\ \text { RM } & \text { Rechtsgeleerd Magazijn } \\ \text { S. } & \text { Section } \\ \text { SFS } & \text { Svensk Författningssamling } \\ \text { SOU } & \text { Statens Offentliga Utredningar } \\ \text { Sr. } & \text { Strafrecht } \\ \text { St. } & \text { Stycket } \\ \text { Sv. } & \text { Strafvordering } \\ \text { SvJT } & \text { Svensk juristtidning } \\ \text { Stb. } & \text { Staatsblad } \\ \text { StPO } & \text { StrafprozeBordnung } \\ \text { StGB } & \text { Strafgesetzbuch } \\ \text { TF } & \text { Tryckfrihetsförordning } \\ \text { TvO } & \text { Tijdschrift voor overheidsadministratie } \\ \text { TvS } & \text { Tijdschrift voor Strafrecht } \\ \text { UFJTA } & \text { Archiv für Urheber-, Film-, Funk- und Theaterrecht } \\ \text { vol. } & \text { volume } \\ \text { vs. } & \text { versus } \\ \text { vZ. } & \text { voorzitter } \\ \text { Wet AB } & \text { Wet Algemene Bepalingen } \\ \text { WLR } & \text { Weekly Law Report } \\ \text { WOM } & \text { Wet Openbare Manifestaties } \\ \text { WVC } & \text { Welzijn Volksgezondheid en Cultuur } \\ \text { YF } & \text { Yttrandefrihetsgrundlag } \\ \text { z.j. } & \text { zonder jaartal } \\ \text { ZstrW } & \text { Zeitschrift für die gesamte Strafrechtswissenschaft } \\ \text { ZRP } & \text { Zeitschrift für Rechtspolitik } \\ \end{array}$




\section{Inleiding}

\section{Onderzoeksvragen}

De vrijheid van meningsuiting en drukpers wordt binnen de westerse traditie gezien als een uiterst belangrijk grondrecht. Het is een van de pijlers van onze westerse democratie. ${ }^{3}$ Overheden moeten zich in beginsel dan ook onthouden van handelingen die een inbreuk vormen op dit fundamentele grondrecht of die de uitoefening van dit grondrecht beperken. ${ }^{2}$ Het strafvorderlijke dwangmiddel inbeslagneming kan een beperking van de vrijheid van meningsuiting en drukpers met zich brengen voor zover het gericht is op het 'onder zich nemen' van geestesprodukten voor justitiële doeleinden. In zo'n geval staat de toepassing van dit dwangmiddel op gespannen voet met de vrijheid van meningsuiting en drukpers. In dit boek wordt het spanningsveld beschreven tussen het strafvorderlijke dwangmiddel inbeslagneming en de vrijheid van meningsuiting en drukpers in een internationaal en rechtsvergelijkend perspectief. Wanneer hier gesproken wordt over de vrijheid van meningsuíting en drukpers dan gaat het om het recht van individuen om ideeën, gevoelens en emoties te uiten met

1 Lingens, EHRM 8-7-1986, NJ 1987, 901 met noot van E.A. Alkema. In dit arrest stelde het Hof voorop dat de vrijheid van meningsuiting en drukpers "constitutes one of the essential foundations of a democratic society and one of the basic conditions for its progress and for each individuals selffulfilment." Zie ook Jersild, ECHR 23-9-1994, NJCM-Bulletin 1995, p. 170. In de zaak Sunday" Times, EHRM 26-4-1979, NJ 1980, 146, p.470, werd de de wrijheid van meningstiting en drukpers een kenunerk genoemd van de democratische samenleving.

2 Grondrechten waarborgen in een rechtsstaat de differentiatie wan een samenleving. Kenmerkend voor een democratie is een pluraliteit aan opvattingen en ideeën. Er bestlatt een samenhang tussen grondrechten en democratie maar ook een relatieve onafhankelijkheid. Grondrechten omwatten meer dan participatie aan de staat. Klassieke grondrechten zijn in de eerste plaats afweerrechten tegen de staat. De vrijheid van het individu staat centraal. Beperkingen op die vrijheid zijn witzondering en begrensd. Het instrument waarmee dit geschiedt is de wet die zeker en duidelijk noet zijn (legaliteitsbeginsel). Omdat de beperking een uitzondering vormt dient zij normatief gelegitimeerd te worden. Een doelstelling van de democratie is het verschaffen van normatieve legitimiteil aan bewoegdheidsuitoefening door de overheid. M.C. Burkens e.a., Beginselen van de democratische rechtsstaat, Zwolle 1992, p. 6, 14, 87-89; M.C. Burkens, Agemene leerstukken van grondrechten naar Nederlands constitutioneel recht, Handboeken staats- en bestuursrecht, decl II, Zwolle 1989, p. $30,43-45$. 
als doel openbare communicatie. ${ }^{3}$ Centraal staat de vraag in hoeverre de vrijheid van meningsuiting en drukpers, zoals geregeld in art. 7 Grondwet, art. 10 Europees Verdrag ter bescherming van de Rechten van de Mens en de Fundamentele Vrijheden (EVRM) en art. 19 Internationaal Verdrag inzake Burgerrechten en Politieke Rechten (IVBPR), een belemmering vormt voor de toepassing van het strafvorderlijke dwangmiddel inbeslagneming in Nederland. Wanneer hier gesproken wordt over het strafworderlijke dwangmiddel inbeslagneming dan betreft het de inbeslagneming van 'gegevensdragers'. Onder 'gegevensdragers' versta ik geschriften, pamfletten, beeld-, geluidsdragers, databanken, films, video's, toneelstukken, diskettes, sculpturen, schilderijen etcetera. Het gaat om geestelijke uitingen die omdat ze zijn opgeslagen op dragers "casu quo" voorwerpen in beslag genomen kunnen worden door de politie en justitie voor het aan de dag brengen van de waarheid, ter verbeurdverklaring en ter onttrekking aan het verkeer (art. $94 \mathrm{~Sv}$ ). De vraag is hoe zich dit verhoudt tot de vrijheid van meningsuiting en drukpers. Welke drempels werpen art. 7 Grondwet, art. 10 EVRM en art. 19 IVBPR op tegen de inbeslagneming van gegevensdragers? Is hiermee rekening gehouden bij het redigeren van de strafvorderlijke inbeslagnemingsbepalingen en zo niet, hoe kunnen deze bepalingen dusdanig veranderd worden dat er recht wordt gedaan aan communicatievrijheid aan de ene kant en handhaving van de openbare orde en waarheidsvinding aan de andere kant?

\section{Rechtsvergelijking}

Dit onderzoek is van rechtsvergelijkende aard. Het spanningsveld tussen de inbeslagneming van gegevensdragers en de vrijheid van meningsuiting en drukpers in de Nederlandse situatie wordt systematisch vergeleken met die in andere landen. Doel van deze rechtsvergelijking is na te gaan op welke wijze elders met genoemd spanningsveld is omgegaan en om te bezien of dit inzicht in andere rechtstelsels aanknopingspunten oplevert voor een eventuele verbetering van de Nederlandse regeling met betrekking tot het strafvorderlijke dwangmiddel inbeslagneming.

Gekozen is voor een vergelijking tussen Nederland en Duitsland, Engeland en Zweden. Deze keuze is ingegeven door het feit dat alle genoemde landen het EVRM hebben geratificeerd. Bovendien bestaat er tussen deze landen historisch gezien een aantal overeenkomsten. Zowel Duitsland als Nederland hebben hun wortels in het Germaanse recht. Het Zweedse recht is een mengeling van continentale ideeën, vooral Duitse en Franse, aan de ene kant en nationale tradities aan de andere kant. Ook het Engelse recht staat niet zover van ons af als we dikwijls geneigd zijn te denken. Het accusatoire proces heeft bij ons tot ver in de 16e eeuw, de periode waarin Nederland overheerst werd door Bourgondische en Habsburgse vorsten, ge- 
golden naast het inquisitoire proces. Het Engelse recht heeft het Franse recht beinvloed en via het Franse recht ook het Nederlandse en het Duitse.

Behalve deze meer algemene overeenkomsten is er binnen het kader van dit onderzoek nog een aantal specifieke overeenkomsten te noemen. $Z$ o hadden zowel Duitsland, Zweden als ook Nederland een perswet of perswetten. In deze landen was de verspreidingswrijheid een onderdeel van de Grondwet. Bovendien gold in deze staten alsook in Engeland bij drukpersdelicten juryrechtspraak. Sommige van genoemde landen hebben al deze elementen of enkele daarvan behouden. Nederland is na de afscheiding met België in 1839 een eigen weg ingeslagen. De drukperswet en de juryrechtspraak kennen we niet meer ${ }^{4}$ en de verspreidingsvrijheid vormt geen onderdeel meer wan de Grondwet. We zullen zien dat de manier waarop in Nederland de vrijheid van meningsuiting en drukpers en het strafvorderlijke dwangmiddel inbeslagneming is geregeld afwijkt van de regeling in de andere landen.

\section{Opzet}

In het eerste hoofdstuk zal de vrijheid van meningsuiting en drukpers en het strafvorderlijke dwangmiddel inbeslagneming in Nederland worden besproken. Paragraaf 1 behandelt de vrijheid van meningsuiting en drukpers in art. 7 van de Grondwet. In deze paragraaf word gekeken wat de reikwijdte is van de vrijheid van meningsuiting en drukpers. Hoe wordt de vrijheid van meningsuiting en drukpers, en dan in het bijzonder de verspreidingswrijheid, door de overheid en rechter geëffectueerd en zo mogelijk beperkt? ${ }^{s}$

In paragraaf 2 komt de vrijheid van meningsuiting en drukpers aan de orde in art. 10 EVRM en art. 19 IVBPR. Gekeken wordt naar de eventuele meerwaarde van deze artikelen ten opzichte van art. 7 Grondwet.

Tenslotte bespreek ik in paragraaf 3 het strafvorderlijke dwangmiddel inbeslagneming. Het strafvorderlijke dwangmiddel inbeslagneming bevat zowel materièle als procedurele aspecten. Beide aspecten worden in deze paragraaf behandeld. Vragen als, hoe is de inbeslagneming in het Wetboek van Strafvordering geregeld en wat is de ratio van de inbeslagneming (materiële aspecten), wie is bevoegd bij de inbeslagneming van gegevensdragers en hoe is de procedure geregeld (procedurele aspecten), staan hierin centraal. Bezien wordt hoe deze verschillende aspecten van dit dwangmiddel zich verhouden tot de vrijheid van meningsuiting en drukpers in art. 7 van de Grondwet, art. 10 EVRM en art. 19 IVBPR.

In hoofdstuk 2 wordt een begin gemaakt met het rechtsvergelijkende onderzoek. Gekeken zal worden hoe het strafvorderlijke dwangmiddel inbeslagneming en de

4 J.C. Voorduin, Geschiedenis en Beginselen der Nederlandsche Wetboeken, Utrecht 1839, p. 520 e.v.

5 Dit grondrecht wordt alleen in relatie tot de inbeslagneming besproken. 
vrijheid wan meningsuiting en drukpers zich in Duitsland tot elkaar verhouden. De opzet van dit hoofdstuk is iets anders dan de opzet van het eerste hoofdstuk. Hier wordt de vrijheid van meningsuiting en drukpers in Art. 5 'Grundgesetz' meteen gekoppeld aan het strafvorderlijk dwangmiddel inbeslagneming. Dit komt overeen met de manier waarop in Duitsland deze problematiek is aangepakt. Voor de inbeslagneming in het Duitse Wetboek van Strafvordering geldt dat ook hier zowel de materiêle als de procedurele aspecten van de inbeslagneming aan de orde komen.

Voor hoofdstuk 3, waarin Engeland besproken wordt, geldt een opzet die afwijkt van zowel de Duitse als de Nederlandse. Dit was noodzakelijk omdat in Engeland geen geschreven Grondwet bestaat. De vrijheid van meningsuiting en drukpers wordt dan ook in de afzonderlijk paragrafen aan de hand van de jurisprudentie en de verschillende 'Acts' besproken. Voor de inbeslagneming geldt hetzelfde. Deze is zowel geregeld in de 'Police and Criminal Evidence Act' als in verschillende andere 'Acts', zoals de 'Obscene Publications Act' en de 'Official Secrets Act'. Hoe deze 'Acts' zich tot elkaar verhouden wanneer het gaat om de inbeslagneming van gegevensdragers en de vrijheid van meningsuiting en drukpers zal in dit hoofdstuk aan de orde komen evenals de materiële en de procedurele aspecten van de inbeslagneming.

In hoofdstuk 4 tenslotte zal de Zweedse "Tryckfrihetsförordning" uitgebreid besproken worden. Alles wat betrekking heeft op de vrijheid van meningsuiting en drukpers is in bovengenoemde wet opgenomen. Hierin staan dus ook zowel de materiële aspecten als de procedurele aspecten van de inbeslagneming. In dit hoofdstuk zullen alle aspecten van deze wet aan de orde komen voorzover het betreft het spanningsveld tussen de vrijheid van meningsuiting en drukpers enerzijds en het strafvorderlijke dwangmiddel inbeslagneming anderzijds.

Het geheel zal worden afgesloten in hoofdstuk 5 met een conclusie en enige aanbevelingen. In de conclusie worden de werschillende landen met elkaar vergeleken. Daarbij wordt, omwille van overzichtelijkheid, een onderverdeling gematakt tussen de materiële- en de formele aspecten van de inbeslagneming voor het aan de dag brengen van de waarheid en de vrijheid van meningsuiting en drukpers. Ook bij de verbeurdverklaring en de onttrekking aan het verkeer wordt dit onderscheid gehanteerd. Uit deze rechtsvergelijkende exercitie vloeien aanbevelingen voort die kunnen worden gebruikt ter verbetering van de Nederlandse regelgeving. 


\section{De vrijheid van meningsuiting en drukpers en het straf- vorderlijke dwangmiddel inbeslagneming in Nederland}

\section{Inleiding}

Het tribunaal tegen Socrates is, met dat tegen Christus, een van de beroemdste uit onze westerse geschiedenis. Aan de orde was een van de fundamenten van onze hedendaagse westerse beschaving: het recht op een wrije meningsuiting. Hoe kon het gebeuren dat Athene, het eerste bolwerk van de westerse democratie, haar eigen principes geweld aandeed door een filosoof te veroordelen om zijn non-conformistische opvattingen en leerstellingen? ${ }^{1}$

Bovengenoemde vraag heeft nog niets van zijn actualiteitswaarde verloren ${ }^{2} \mathrm{Zo}$ werd in 1988 onder auspiciën van het Studium Generale van de Katholieke Universiteit Nijmegen een lezingenserie over censuur aangeboden. ${ }^{3}$ De aanleiding vormde een aantal actuele gebeurtenissen op het gebied van theater, film en literatuur die op gespannen voet stonden met de vrijheid wan meningsuiting en drukpers. ${ }^{4}$ De affaire

1 Bij zowel Socrates als zijn rechters ging het om het behoud van een moreel verantwoorde rechtvaardige samenleving. $Z_{\mathrm{ij}}$ verschilden van mening over de betekenis ervan. Socrates streelde de verwezenlijking van een inhoudelijk hogere rechtsorde na, terwijl zijn rechters daarentegen streefden naar het therstel van de dagelijkse orde waarin debatten mogelijk żjn. I.F. Stome, Het proces Socrates, Baarn 1988, p. 17-128; H.J. Aquina, De prijs van een goede samenleving, politicke kosten en baten volgens Socrates en zijn rechters, Wijsgerig perspectief op maatschappijen wetenschap, 1989/1990, p. $41-47$.

2 De geschiedenis is volgens Nietzsche, een "ewige Wiederkehr des Gleichen." Op 30 oktober 1888 schrijft Nietzsche aan Gast: "An meinem Geburtstag habe ich wieder etwas angefangen, das zu geraten scheint und bereits bedeutend avanciert ist. Es heiBt: 'Ecce homo'. Oder 'Wie man wird, was man ist'. (...) ich habe mich mit dies nicht nur vorstellen wollen vor dem ganz unheimlich solitaren Akt der Umwertung - ich möchte gern einmal eine Probe machen, was ich bei den deutschen Begriffen von Pressefreiheit eigentlich riskieren kann. Mein Argwohn ist, daB man das erstce Buch der Umwertung auf der Stelle konfisziert - Jegal mit allerbestem Recht." In: Friedrich Nietzsche, Ecce homo, Wie man wird. Was man ist, Frankfurt am Main 1977, p. 11.

3 Studium Generale Katholieke Universiteit Nijmegen, Documentatie censuur 1988.

4 Vanaf 1987 in Nederland o.a. Fassbinder's toneelstuk 'Hlet vuil, de stad en de dood', Huysmans tentoonstelling, Doesburg's toneelstuk, foto-exposities in galerie Intermale en de Mecrwart, de film van Godard 'Je vous salue Marie', het Heidegger-sym posium op de Universiteit van Amsterdam, boeken van Bukowski, boek van de BVD. Voor meerdere voorbeelden zic ook: Verboden boeken, Verboden door pausen, dictators, puriteinen en boekenhaters, samengesteld door C.J. Aarts en 
rond de publicatie van 'The satanic verses' van Salman Rushdie is daarvan de meest spraakmakende gebeurtenis." Net als Socrates wordt ook Salman Rushdie met de dood bedreigd woor het uiten van zijn ideeën. Met dit verschil dat Rushdie in tegenstelling tot Socrates, zijn 'vermeende' godslasterlijke ideeën heeft opgeschreven. Op het moment dat de Nederlandse vertaling verscheen bestond dan ook het risico dat het boek door de politie in beslag zou worden genomen. Hoe zich het strafvorderlijke dwangmiddel inbeslagneming verhoudt tot de vrijheid van meningsuiting en drukpers is hier voorwerp van onderzoek. Daarbij dienen we ons af te vragen welke drempels de vrijheid van meningsuiting en drukpers zoals geformuleerd in art. 7 van de Grondwet; art. 10 EVRM en art. 19 IVBPR opwerpt tegen toepassing van het strafvorderlijke dwangmiddel inbeslagneming.

De vrijheid van meningsuiting en de vrijheid van drukpers hebben betrekking op de allerindividueelste vrijheid, namelijk het recht om ideeën, gevoelens of emoties te uiten. Hieronder vallen ook uitingen die nauwelijks enige of geen artistieke- of wetenschappelijke waarde hebben. ${ }^{\circ}$ Voor zover de vrijheid van meningsuiting en de vrijheid van drukpers in concrete, door tijd en plaats bepaalde, situaties wordt verwezenlijkt, maakt zij deel uit van de basisvoorwaarden voor het bestaan van vrije en democratisch functionerende samenlevingen en politieke systemen.?

In weerwil van "harde" formuleringen in internationale verdragen en declaraties, alsmede in nationale grondwetten heeft de vrijheid van meningsuiting en drukpers iets ideaaltypisch; je kunt er naar streven, maar je zult het ideaal nooit ten volle gerealiseerd en voor altijd veiliggesteld zien." Naast pogingen tot beperking van de vrijheid van meningsuiting en drukpers bestaat er ook weerstand daartegen. Beide kanten van de medaille vragen de aandacht; communicatievrijheid en beperking van die vrijheid. De spanning tussen strafvordering aan de ene kant en de vrijheid van meningsuiting en drukpers aan de andere kant is, zoals we in de loop van het betoog zullen zien, problematisch.

In dit hoofdstuk wordt in paragraaf 2 de vrijheid van meningsuiting en drukpers besproken in de leden 1 en 3 van art. 7 van de Grondwet en in paragraaf 3 de vrijheid van meningsuiting en drukpers in art. 10 van het EVRM en art. 19 van het IVBPR. Gekeken wordt wat de meenwaarde is van art. 10 EVRM en art. 19 IVBPR ten

M. wan der Pluijm, Amsterdam 1989; Henri Beunders, De strij]d om het beeld, Over de behoefte aan censuur, 's-Gravenhage 1994.

5 D. Easterman, A Sense of Proportion, The Rushdie Affair, Index on Censorship 4-1990, p. 9 e.w.; M. Hussain, A Muslim's perspective, The Rushdie Affair, Index on Censorship 4-1990, p. 12 e.v;; A. Taheri, Reflections on an invalid fatwa, The Rushdie Affair, Index on Censorship 4-1990, p. 14 c.v.; N. Walter, Blasphemy: Punishment is worse than practice, The Rushdie Affair, Index on Censorship 4-1990, p. 21 e...

6 Handyside, EHRM 7-12-1976, NJ 1978, 236, p. 817.

7 Joan Hemels, De drukpers als middel tot misdrijf of machtsmisbruik?, Tijdschrift voor Criminologie, 1989 , p. 287.

8 Joan Hemels, De drukpers als middlel tot misdrijf of machtsmisbruik?, Tijdschrift voor Criminologie, 1989 , p. 287. 
opzichte van art. 7 Grondwet. In paragraaf 4 tenslotte komt het strafvorderlijke dwangmiddel inbeslagneming aan de orde. Bezien wordt hoe de strafvorderlijke regeling van de inbeslagneming zich verhoudt tot de vrijheid van meningsuiting en drukpers, in het bijzonder de verspreidingsvrijheid. Alle drie de onderdelen worden afgesloten met een conclusie.

\section{De vrijheid van meningsuiting en drukpers in art. 7 lid 1 en 3 vain de Grondwet}

\section{$2.1 \quad$ Inleiding}

In paragraaf 2 zal de vraag naar de reikwijdte van art. 7 lid 1 en 3 van de Grondwet aan de orde komen. De leden 2 (radio en televisie) en 4 (handelsireclame) blijven hier buiten beschouwing omdat deze bepalingen buten het kader van het onderzoek naar de inbeslagneming van gegevensdragers en de vrijheid van meningsuiting en drukpers vallen."

De vraag naar de reikwijdte van art. 7 lid 1 en 3 van de Grondwet wordt mede bepaald door de vraag wat onder het begrip 'drukpers' (lid 1) en 'gedachten en gevoelens door andere dan voornoemde middelen'(lid 3) moet worden verstaan. Het antwoord op deze vraag is belangrijk omdat voor beide leden een ander rechtsregiem geldt. De verschillende opvattingen over de begrippen 'drukpers' en 'gedachten en gevoelens' zullen voor wat betreft het medium 'drukpers' in paragraaf 2.2 aan de orde komen, en voor wat betreft 'gedachten en gevoelens door andere dan voornoemde middelen' in paragraaf 2.4. In paragraaf 2.3 en in paragraaf 2.5 wordt gekeken hoe de vrijheid van drukpers en de vrijheid om gedachten en gevoelens te uiten door de overheid en de rechter worden geëffectueerd en beperkt. Daarbij dient een onderscheid te worden gemaakt tussen openbaren en verspreiden en tussen preventieve - en repressieve beperkingen. Aan de hand van de wet, de literatuur en de jurisprudentie zal het onderscheid tussen openbaren en verspreiden en tussen preventieve en repressieve beperkingen zowel ten aanzien van de 'drukpers' als ten aanzien van 'gedachten en gevoelens' nader besproken worden in de desbetreffende paragrafen. Binnen het kader van dit onderzoek is vooral de interpretatie van het begrip verspreidingsrecht' belangrijk omdat dit begrip mede de omvang van de inbeslagneming van gegevensdragers bepaalt. In paragraaf 4 , dat handelt over het strafvorderlijke dwangmiddel inbeslagneming, zal worden gekeken hoe dit dwangmiddel inbeslagneming zich verhoudt tot de vrijheid van meningsuiting en drukpers. Paragraaf 2 van dit hoofdstuk zal worden afgesloten met een conclusie.

9 Zo mag de overheid een wergunningenstelsel hanteren woor radio en televisic en walt handelsreclame buiten de bescherming van de vrijheid van meningsunitimg en drukpers in art. 7 Grondwet. 
2.2 Wat dient onder het medium 'dnukpers" in art. 7 lid 1 van de Grondwet te wonden verstcian?

In art. 227 Grondwet (1815) staat dat "het aan elk geoorloofd is om zijne gedachten en gevoelens door de drukpers (...) te openbaren (...)." Bij de totstandkomingsgeschiedenis in 1848 wan een nieuwe Grondwet blijkt dat men geen inhoudelijke wijzigingen heeft willen aambrengen in bepaling over de vrijheid van drukpers. ${ }^{30}$ Over de vraag wat onder drukpers dient te worden verstaan oordeelde de Hoge Raad in een uitspraak uit 1915 dat hiertoe "niet alleen geschriften maar ook afbeeldingen, waaronder prentbriefkaarten" "behoren. "Tammes spreekt in zijn Preadvies voor de Nederlandse Juristen Vereniging (1949) van "schrift, afbeelding en tekening" waarmee dan "elke vastgelegde meningsuiting" wordt bedoeld. De term "vastgelegde meningsuiting" is eningszins misleidend omdat daar ook bandopnamen en films onder kunnen vallen terwijl dit artikel alleen betrekking heeft op geschreven of gedrukte informatie. De termen "schrift, afbeelding en tekening" dekken beter de lading. Daaronder vallen ook neonletters. Immers volgens de Hoge Raad gaat het bij het aanbrengen van neonletters op een toren om handelingen die "met het aanbrengen van gedrukte of geschreven stukken op één lijn moeten worden gesteld. "m3 In 1983 heeft men bij het nieuwe drukpersartikel aan deze interpretatie vastgehouden ondanks de voorstellen van Van den Bergh en Dresen voor een ruime uitleg van het begrip drukpers. ${ }^{14}$ Van den Bergh en Dresen hebben er immers voor gepleit om elke openbaarmaking die plaats en tijd overwint, zoals de film, de radio en de grammofoonplaat, te laten delen in de bescherming die de drukpersvrijheid biedt. Ook de Staatscommissie CalsDonner was van mening dat onder art. 7 lid 1 "alle modeme media zoals bandopnamen, grammofoonplaten, neonletters ${ }^{15}$ en fotoafdrukken" vallen. ${ }^{\text {t6 }}$ Dat deze uitbrei-

10 Alleen de zinsnede dat de drukpers cen middel is tot "uitbreiding van kennis en voortgang van verlichting" wordt geschrapt. Het artikel wordt hierdoor wat ruimer geformuleerd ondat nu ook feitelijke informatie onder art. 8 lid 1 valt (sinds 1887 art. 7 lid 1). limmers ook de weergave van bepaalde feiten houdt een mening in. Bovendien is vrije worming van een mening niet mogelijk zonder kennisneming van allerlei feitelijke informatie. In art. 7 van de Grondwet (1983) is deze ruime interpretatie overgenomen. Dit maakte het noodzakelijk dat in lid 4 van art. 7 handelsreclame uildrukkelijk buiten de werking van dit Grondrecht werd geplaatst. P.J. Boukema, Enkele aspecten van de vrijheid van meningsuiting in de Duitse Bondsrepubliek en in Nederland, diss. VU Amsterdam 1966, p. 113 e.v.

11 HR 8-3-1915, NJ 1915, p. 667 en W. 9797.

12. Handelingen NJV 1949, deel I, 's-Gravenhage 1949, eerste druk, p. 170.

13 HR 24-1-1967, NJ 1967, 270.

14 G. wan den Bergh, De artt. 7 en 9 van de Grondwet in het licht van de moderne techniek, NJB 1940, p. 62-72; P. Dresen, De vrije meningsuiting, Amsterdam 1949, p. 157-159.

15 HR 24-1-1967, NJ 1967, 270.

16 Staatscommissie Cals-Donner, Tweede Rapport, Staatsuitgeverij, 's-Gravenhage 1971, p. 72-73. 
ding van de drukpersvrijheid niet werd overgenomen door de regering is volgens De Meij "zonder reden." ${ }^{\text {"nर }}$ Immers

"waarom valt het uitlenen wan boeken wel onder het eerste lid en het verkopen van geluidsbanden of het verhuren van videobanden niet? Het antwoord op deze vraag is van belang omdat bij de verkoop of verhuur van de twee laatst genoemde categorieën op grond van art. 7 lid 3 een vergunning nodig is."

Zit achter dit onderscheid de impliciete vooronderstelling dat videobanden gevaarlijker zijn dan boeken? Volgens De Meij

"gaat het niet om het onderscheid tussen videobanden en boeken maar om de vraag of hiermee een publiek wordt bereikt of dat het gaat om individuele consultatie. Het derde lid geldt alleen voor eerstgenoemde situatie. Omdat bij het vertonen van een film zich openbare ordeproblemen voordoen of overlast kan worden veroorzaakt is een vergunning vereist. Dit geldt ook voor het ten gehore brengen van geluidsbanden of het voorlezen van poësie in een zaal. ${ }^{\text {mIs }}$

Ik denk dat het onderscheid in behandeling tussen boeken en videobanden of geluidsbanden alleen te rechtvaardigen is wanneer wetenschappelijk is bewezen dat de twee laatste categorieën gevaarlijker zijn en er dus een vergunning nodig is voor de koop, huur of vertoning hiervan. Anders is het bij bepaalde vormen van telecommunicatie. Dat deze niet vallen onder lid 3 valt, volgens De Meij, nog te verklaren "omdat hier de openbaamaking en verspreiding zozeer met elkaar samenvallen dat art. 7 lid 1 minder geschikt zou zijn. "199 Gesteld kan worden dat de regering bij de totstandkoming van het nieuwe artikel uiterst voorzichtig is geweest met het brengen van nieuwe communicatietechnieken onder lid 1 . Zij heeft aansluiting gezocht bij de jurisprudentie van de Hoge Raad. Deze heeft niet verder willen gaan dan de drukperswrijheid van toepassing te achten op "enige andere met de drukpers op een lijn te stellen vemeniguldigingstechniek. Uit de woorden "als hulpmiddel bij de openbaring in geschrifte van gedachten en gevoelens ${ }^{\prime 28}$ zou volgens De Meij, en volgens mij is dat juist, kunnen worden afgeleid dat men hier moet denken aan technieken als stencillen, fotograferen en fotokopiëren. ${ }^{22}$ Het rechtsregiem van art. 7 lid 1 Grondwet is dus als gevolg van

17 J.M. de Meij, Uitingsvrijheid, De vrije informatiestroom in grondwettelijk perspectief, Amsterdam 1989 , p. 92.

18 J.M. de Meij, Uitingsvrijheid, De vrije informatiestroom in grondwettelijk perspectief, Ansterdan 1989 , p. $92-93$.

19 J.M. de Meij, Uitingsvrijheid, De vrije informatiestroom in grondwettelijk perspectief, Amsterdam 1989, p. 93.

20 HR 23-5-1961, NJ 1961, 427.

21 HR 23-5-1961, NJ 1961, 427.

22 J.M. de Meij, Uitingsvrijheid, De vrije informatiestroom in grondwettelijk perspectief, Amsterdam 1989, p. 91. 
deze vrij strikte interpretatie slechts van toepassing op een beperkte categorie van gegevensidragers. Dit betekent dat alle overige gegevensdragers vallen onder lid 3 van art. 7 Grondwet.

\subsection{Hoe wordt de vrijheid van drukpers door de overheid en de rechter geëffectueerd en beperkt?}

Censuur is verboden wolgens art. 7 lid 1 van de Grondwet. ${ }^{2 A}$ Dit betekent dat lagere owerheden nooit het openbaren zelf kunnen reguleren via voorafgaand verlof of door middel van het geven van regels met betrekking tot de inhoud van gedachten en gevoelens. Slechts achteraf kunnen door de rechter grenzen worden gesteld aan de vrijheid van meningsuiting en drukpers op grond van een wet in formele in. $^{\text {s. Wel }}$ kan het aan het openbaringsrecht gekoppelde recht op het verspreiden van gedachten en gevoelens worden beperkt door zowel de formele wetgever als door de lagere wetgever,

De differentiatie tussen een "de geesteswereld betreffend" recht tot openbaren wan je mening en een "de ruimtelijke sfeer" betreffend recht tot verspreiden is door de Hoge Raad in 1950 in het Tilburg-arrest ${ }^{27}$ gemaakt en overgenomen in $\operatorname{art}_{\text {. }} 7$ wan de Grondwet. Voor die tijd werd openbaarmaking als overkoepelend begrip gebruikt voor het publiceren tot en met het verspreiden van geschriften onder het publiek.

23 In Zweden wordt er geen onderscheid gemaakt tussen de verschillende categorieën gegevensdragers. Zie hoofidstuk 4 .

24 Censun dankt haat ontstaan aan de instelling wan de techniek, nl de uitwinding van de boekdrukkunst. Als gevolg van de vergrote mogelijkheid om denkbeelden te verspreilden werd, eerst van kerkelljke zijde en later vamuit de pollitiek, gevreesd voor de gevaren hiervan. Men besloot een zeker toezicht uit te oefenen op het drukken en verspreiden van geschriften. W.P.C. Knuttel, Verboden boeken in de Republiek der Vereenigde Nederlanden, "s-Gravenhage 1914.

25 M.C. Burkens, Algemene leerstukken van grondrechten naar Nederlands constitutioneel recht, Handbocken stats- en bestuursrecht, deel II, Zwolle 1989, hoofdstuk 5 Beperking wan grondrechten em hoofdstuk 6 Algemene beperkingen van grondrechten, p. 91-136.

26 P. Boukema, Vrijheid van meningsuiting en art. 7 wan de Grondwet, $R$ M Themis 1969, p. 123 e.v., J.M de Meij, Uitingsvrijheid, De vrije informatiestroom in grondwettelijk perspectief, Amsterdam 1989, 1. 100 e.v.; C.W. van der Pot-Donner, Handboek van het Nederlandse staatsrecht, bewerkt door L. Prakke, Zwolle 1989, p. 284 e.v.

27 HR 28-11-1950, NJ 1951, 137.

28 Tn de Staatsregeling wan 1798 werd in het drukperswrijheidsartikel 'uiten en werspreiden' in cén adem genoemd. In de Grondwet van 1815 en bij de herziening van 1848 ging het in de eerste plaats om "de vrijmaking wan de drukpers wan alle preventieve matregelen." Zie ook Thorbecke, Aanteekening op de Grondwet, deel II, 1841 , tweede druk, p. 301: "Zij die openbaren zijn de uitgever die het stuk aan het licht brengt en de verspreider, dus ook elke handelaar die het verkoopt." En minister Modderman bij de totstandkoming van de artt. 53 en 54 Wetboek van Strafrecht toen hij in de "Tweede Kamer daaromtrent opmerkte dat: "Terecht zijjn door de Grondwet alle preventieve maătirëgelen tegen de drukpers uitgesloten." In: E. Diemer, Vrijheid van drukpers: Eenige opmer- 
In het Haagse ventwerordeningsarrest uit $1892^{29}$ werd immers beslist dat "het drukpersartikel elke preventieve maatregel uitsluit en dus niet slechts censuur. ${ }^{100}$ Dit betekende dat ook het verspreidingsrecht niet beperkt kon worden door de lagere overheid.

Pas later dus, in het Tilburgse-drukpersarrest, brengt de rechter een scheiding aan tussen het openbaren en het in het openbaar bekend maken (verspreiden). Dit door de rechter geconstrueerde verspreidingsrecht deelt niettemin tot op zekere hoogte in de bescherming van het grondrecht, daar een algeheel verbod of vergunningvereiste niet is toegestaan. Van der Hoeven heeft de verspreidingsvrijheid daarom gekarakteriseerd als "connex recht. ${ }^{\text {"ni }}$ Het "de geesteswereld betreffend" recht wordt uitgeoefend "behoudens ieders verantwoordelijkheid volgens de wet. "Slechts achteraf (repressief) kunnen hier dus door de rechter grenzen worden gesteld aan de vrijheid van meningsuiting op grond van een wet in formele zin (legaliteitsbeginsel) die zeker en duidelijk is (rechtszekerheidsbeginsel). ${ }^{32}$ Het niet in art. 7 neergelegde, maar door de rechtspraak erkende "de ruimtelijke sfeer betreffende" recht om het geopenbaarde bekend te maken aan het publiek, is ondergeschikt aan dit openbaringsrecht. Aan de vorm, in casu het verspreidingsrecht, kunnen ook vooraf (preventief) grenzen worden gesteld door zowel de materiële wetgever als de formele wetgever.

In de latere jurisprudentie is de constructie uit het arrest over de Tilburgse APV verder verfijnd. Niet alleen mocht de verspreidingsvrijheid niet in het algemeen verboden of van een voorafgaand verlof afhankelijk gesteld worden, maar ook dienen de beperkingen "gebruik van enige betekenis" (het zogenaamde 'Nuth-criterium')

kingen over haar statsrechtelijke regeling in Nederland, diss. VU, Rotterdam 1937, p. 122. Zie ook art. 10 EVRM en art. 19 IVBPR. Hier worden werspreidingshandelingen onder het begrip 'doorgeven' gebracht en op een lijm geplaatst met het 'zich uiten' en het 'ontvangen', Laatstgenoemde artikelen zullen aan de orde komen in $\$ 3$ van dit hoofdstuk.

29 HR 7-11-1892, W 6259.

30 Volgens Van der Pot-Donner gaf deze formulering aanleiding tot problemen. "Immers wanneer ook de werspreiding onder het 'openbaar maken' van art. 7 Grondwet zou moeten worden begrepein, dan waren alle preventieve beperkingen van de verspreiding door lagere regellingen uitgesloten." C.W.van der Pot-Donner, Handboek van het Nederlandse staatsrecht, bewerkt door L. Prakke, Zwolle 1989; p. 283; P.W.C. Akkermans. (red.), De Grondwet, Een artikelsgewijs commentaar, Zwolle 1992, p. 157.

31 J. van der Hoeven, De plaats van de Grondwet in het constitutionele recht, Zwolle 1958, p. 230; Wat tot de kern van een grondrecht behoort is betrekkelijk arbitrair wolgens Burkens. Het is dan ook bezwaarlijk om een bewoegdheid aan te nemen tot het maken wan inbreuk op grondrechten zolang de kern ervan niet wordt aangetast. Moeilijk aanwaardbaar is dat elke overheidsorgaan inbreuk op een grondrecht mag maken zolang de kern claarvan maar niet wordt aangetast. In: M.C. Burkens, Algemene leerstukken wan grondrechten naar Nederlands constitutioneel recht, Handboeken staats- en bestuursrecht, deel II, Zwolle 1989, p. 95-98.

32 Volgens de Grondwet uit 1983 dienen beperkingen van grondrechten begrensd te zijn. M.C. Burkens e.a., Beginselen van de democratische rechtsstatit, Inleiding tot de grondslagen van het Nederlandse staats* en besturursrecht, Zwolle 1992, p. 89.

33 HR 17-3-1953, NJ 1953, 389; HR 22-5-1979, NJ 1979, 505; HR 28-6-1983, NJ 1984, 64; HR 21-11986, NJ 1986, 441. 
van het verspreidingsmiddel over te laten. ${ }^{34}$ Door het feit dat hier nu toch een vergunning, zij het voor een gedeelte van het verspreidingsmiddel is toegestaan, heeft het rechtsregime ten aanzien wan de verspreidingswrijheid een heel ander karakter gekregen dan bij de openbaringswijheid van art. 7 lid 1 zelf. Daar staat het verbod van preventieve beperkingen centraal.

Het gevaar bestaat echter dat, nu preventieve beperkingen zoals een vergunning zijn toegestaan woor een gedeelte wan het verspreidingsmiddel, ook de inhoud bij de overwegingen voor het wel of niet verlenen van een vergunning, wordt betrokken. Het verbod van preventieve beperkingen op de inhoud wordt op deze manier via een achterdeur omzeild. Verschillende auteurs, zoals bijvoorbeeld De Meij ${ }^{35}$ en Kistenkas ${ }^{36}$ hebben het gebruik van een vergunning bij de verspreidingsregulering dan ook bekritiseerd wegens het gevaar van misbruik. De kans dat ook de aard wan de te verspreiden boodschap in de owerwegingen wordt betrokken, al is dat niet toegestaan, is volgens hun niet irreeel ondat het onderscheid tussen inhoud en verspreiding zeer precair is en niet altijd even zuiver is aan te brengen. ${ }^{37}$ De plakjurisprudentie toont aan dat de rechter hiermee diverse kanten uit kan en ook gegaan is, waardoor de justitiabele en de gemeentelijke regulator met een grillige en verrassende jurisprudentie opgescheept zitten."

\subsection{De vrijheid van 'gedacturen en gevoelens' in art. 7 lid 3 van de Grondwet}

\subsubsection{Inleiding}

Bij de grondwetsherziening van 1983 bracht het derde lid van het nieuwe art. 7 Grondwet een belangrijke uitbreiding van de uitingsvrijheid. Het eerste punt van aandacht is daarom de afbakening van de werkingssfeer van het derde lid ten opzichte

34 In de latere jurisprudentie is de Hoge Raad diezelfde eis gaan stellen bij elk verspreidingsmiddel, "hetwelk naast andere, zelfstandige betekenis heeft en met het oog op die verspreiding in een bepaalde behoefte kan voorzien"; ; Alkinaarse plakverboden HR 12-1-1960, NJ 1960, 273; HR 30-51967, NJ 1968, 4; Nederland ontwapent, HR 24-1-1967, NJ 1967, 270; Dordrechtse plakverboden, HR 2-10-1979, NJ 1980, 105; Nijmeegse plakverboden, HR 27-10-1981, NJ 1982, 103.

35 J.M. de Meij, Uitingswrijheid, De wrije informatiestroom in grondwettelijk perspectief, Amsterdam 1989, p. 107.

36 F.H. Kistenkas, Verspreidingsdogmatiek of belangenafweging?, TvO 1987, p. 356-358.

37 Denk bijwoorbeeld aan de kunstenaar, die aan zijn gevel een sculptuur of een kunstobject wil aanbrengen in een bepaalde kleur. Onder omstandigheden kan de kleur een belangrijk aspect van de inhoud vormen (zie ook A.W. Heringa in zijn noot onder HR 26-5-1987, NJCM-Bulletin 1987, p. 624).

38 Ik verwijs hier naar het artikel van A.W. Heringa en R.E. de Winter, De kleefkracht van de vrijheid van meningsuiting, NJB 1982, p. 352 e.v.; P.D.A. Claessen, Plakverordening en drukpersvrijheid, TwO 1983, p. 526 e.v.; J.M. de Meij, De feitelijke mogelijkheid tot vrije meningsuiting, Mediaforum 1989-2, p. 16; R.E. de Winter, De heersende leer, Honderd jaar verspreidingsjurisprudentie: 18921992, diss. RL, 's-Gravenhage 1993. 
van het eerste en tweede lid. Van belang is de vraag welke gedragingen wel en welke niet tot de beschermde overige uituingsmiddelen behoren. Is bijvoorbeeld het verbranden van de nationale vlag als symbolische handeling zoals in de Verenigde Staten gebeurde, onder de uitingsurijheid te brengen? Waar dient hier de grens te worden. getrokken? Immers aan zeer veel handelingen liggen bepaalde overtuigingen ten grondslag. Vallen deze allemaal onder art. 7 lid 3 Grondwet? Deze vragen komen in paragraaf 2.4.2 aan de orde. In die paragraaf zal de reikwijdte van het begrippenpaar 'gedachten en gevoelens' worden behandeld. In paragraaf 2.4 .3 wordt gekeken op welke manier de vrijheid om "gedachten en gevoelens' te uiten door de overheid en de rechter wordt geëffectueerd en beperkt.

\subsubsection{Wat dient onder 'gedachten en gevoelens' in art. 7 lid 3 Grondwet te worden} verstaan?

In het woorstel tot Grondwetswijziging 13872 van $1976 \mathrm{kreeg}$ het derde lid een open karakter. Het derde lid heeft duidelijk een complementaire functie. Het gaat hier om de uitingsvrijheid "door andere dan in de voorgande leden genoemde middelen." De opstellers geven slechts een aantal voorbeelden: de film, het toneel, de expositie, het concert, het ballet, het optreden van de cabaretier en de chansonnier. Verder ook zoals eerder bleek, produktie, verkoop en uitleen van films, banden, grammofoonplaten, compact discs en dergelijke. Ook het ten gehore brengen 'casu quo' vertonen hiervan wordt onder deze bepaling gebracht.

Onder dit derde lid vallen dus kort samengevat:

39 Door het gebruik wan de open term "andere middelen" zal bij het vaststellen van de uitingsmiddelen die hieronder vallen, ook rekening gehouden moeten worden met andere grondrechten of onderdelen hiervan in de uitingssfeer. Het gaat hier vooral om art. 6 Grondwet (de openbare godsdienstoefening en andere openbare samenkomsten in de sfeer van godsdicnst on levensovertuiging) en art. 9 Grondwet (vergaderingen en betogingen). Deze materie is nader uitgewerkt in de Wet Openbare Manifestaties van 20 april 1988 (WOM) Stb. 1988, 157. Volgens 3 van dle toelichting op de WOM vallen onder het begrip manifestaties slechts georganiseerde manifestaties van enigszins massaal karakter. Het gaalt om het uiten van gedachten en gevoelens "in min of meer collectief verband." Min of meer individuele toespraken, acties en betogingen op openbare plaatsen zullen onder het derde lid van art. 7 Grondwet vallen (EK 1987-1988, 19427, nr. 135b, p. 4). De vraag bliflt waar precies de grens ligt tussen de onder art. 7 lid 3 vallende vertoningen en de samenkomsten, vergadleringen en betogingen wan de WOM? "Het enkele feit", stelt De Meij, "dat bijvoorbeeld op een bijeenkomst van het Humanistisch Verbond ooken film wordt vertoond, brengt die bijeenkomst niet onder art. 7 Grondwet, maar anderzijds is een wertoning van een godsdienstige film nog geen samenkomst tot het belijden van godsdienst in de zin van de WOM. Waar ligt de grens, tussen een politieke vergadering en de opvoering van een politiek toneelstuk waarna met de aanwezigen wordt gediscussieerd? Ook bij de wertoning en de betoging zijn allerlei tussenvormen denkbaar." (J.M. de Meij, Uitingsvrijheid, De vrije informatiestroom in grondwettelijk perspectief "Amsterdam 1989, p. 192-193). De opstellers van de WOM bebben dit ook wel voorzien en verwijzen naar de rechter, die dergelijke problemen maar moet oplossen (TK 1985-1986, 19427, nr. 3, p. 9). 
1. uitingen die vastgelegd zijn op een teken-, beeld- of geluidsdrager;

2. vormen van telecommunicatie die niet kumnen worden beschouwd als radio en televisie in de zin van het tweede lid van art. 7 Grondwet;

3. vertoringen;

4. individuele expressievormen.

Ad 1: Voor wat de eerste categorie betreft gaat het hier om uitingsvormen waarbij bijzondere hulpmiddelen nodig zijn om van de boodschap kennis te nemen, zoals afspeelapparatuur of een projector. In de worige paragraaf bleek reeds dat er verschillende auteurs zijn die deze uitingen liever onder het eerste lid willen brengen. Het laten horen of vertonen daarvan aan het publiek zou dan onder het derde lid vallen. De opstellers van het nieuwe artikel voelden daar niet veel woor. Zij wilden het begrip drukpers, overeenkomstig de jurisprudentie, eng interpreteren."

Ad 2: Onder de tweede categorie vallen de vormen van telecommunicatie warbij de ontvanger zelf de te ontvangen boodschap selecteert op een door hem verkozen tijdstip. Dit noemen we ook well telematica; telecommunicatie waarbij de informatie in een computer ligt opgeslagen. Daarbij is de opgeslagen informatie voor iedereen beschikbaar, anders is er geen sprake van openbare communicatie, een noodzakelijke voorwaarde voor de toepasselijkheid van art. 7 Grondwet. Ook bij deze categorie is er kritiek op het gekozen uitgangspunt, omdat niet alle vormen van tele-consultatie onder het derde lid worden gebracht, met name teletekst niet. Ook wordt wel gezegd dat de databank als 'moderne drukpers" de bescherming van het eerste lid van art. 7 Grondwet zou moeten krijgen. ${ }^{42}$

Ad 3: De uitingsmiddelen die in de toelichting bij art. 7 lid 3 als voorbeelden worden genoemd (film, toneel, expositie, concert, ballet, cabaretier en chansonnier), betreffen steeds de derde categorie; de vertoningen. Een begrip dat nergens in de toelichting nader wordt omschreven. Het zijn manifestaties die niet vallen onder de geestelijke samenkomsten, de vergaderingen en de betogingen van de Wet Openbare Manifestaties, maar daarmee zijn nog niet alle overige manifestaties vertoningen in de geest

40) Nu is het zo dat de werstrekkjng van boeken en andere drukwerken valt onder het eerste lid en de openbare voorlezing onder het derde lid van art. 7 Grondwet. Een geheel sluitend systeem is dus niet bereikt: J M. de Meij, Uitingswijheid, De vrije informatiestroom in grondwettelijk perspectief, Amstordain 1989, p. 193-194.

41 Het mishkte Grondrechtenontwerp uit 1970 bevatte cen uitingsvrijheidsartikel dat leek op de artt. 10 EVRM en 19 IVBPR. Het voorgestelde artikel noemde namelijk geen bepaalde uitingsmiddelen en sprak over de wrijheid van gedachten of gevoelens te openbaren zonder meer (TK 1970-1971, $11051, p .15-18$ ) . De kritiek op dit voorstel richtie zich niet zozeer op de uitbreiding van de bescherming van de uitingsvrijheid tot alle middelen, alls wel tegen ongewille beperkingen die de nileuwe formule bij de drukpersvrijheid mogelink maakte. H.Tht.J.F. van Maarseveen, Grondwetswijziging inzake de drukpersvrijheid, NJB 1971, p. 37; TK 1975-1976, 13872, nrs. 1-5, p. 32-33.

42 L. Sprey, De databank en art. 7 Grondwet, Informatierech//AMI 1988, p. 71-7.4. 
van art. 7 lid 3 Grondwet. Er moet sprake zijn van een uiting van 'gedachten of gevoelens".

Ad 4: Bij de vierde categorie, de individuele expressievormen, gaat het in de eerste plaats om de vrijheid van het gesproken woord, die in vele Grondwetten afzonderlijk is vastgelegd (bijwoorbeeld de "freedom of speech" in de Amerikaanse Grondwet), maar die wij tot 1983 slechts in de geinstitutionaliseerde vorm van de vrijheid van vergadering kenden. Bij deze categorie zijn zeer verschillende wijzen om zich te uiten in het geding; de stem (al dan niet mechanisch versterkt), andere geluiden (muziek), gebaren (bijvoorbeeld een grievend gebaar, zoals het brengen van de Hitlergroet ${ }^{43}$ ), het dragen van bepaalde symbolen, kleding en bepaalde gedragingen. Daarbij zal in concrete gevallen de vraag naar voren kunnen komen of er nog wel van een uiting in de zin van de Grondwet sprake is.

De afbakening van individuele expressievormen die onder het derde lid van art. 7 Grondwet vallen is niet eenvoudig, want niet elke op expressie gerichte gedraging valt onder de uitingswrijheid. ${ }^{4}$ Het gaat volgens De Meij om

"uitingsmiddelen die gericht zijn op uitwisseling van meningen of informatie. Het gaat bij uitingen door gedragingen om symbolisch gedrag. Het communicatieproces dient als uitgangspunt te worden genomen. Het gaat om de bedoelingen van de zender en de geobjectiveerde reacties van de ontvangers van de boodschap. De boodschap voor het publiek dient voorop te staan. ${ }^{\mathrm{m} 45}$

2.4.3 Hoe wordt de vrijheid van 'gedachten en gevoelens' door de overheid en de rechter geëffectueerd en beperkt?

Nu de tekst van het derde lid in zekere zin gemodelleerd is naar die van het eerste lid, rijst hier, net zoals bij de drukpersvrijheid, de vraag of het woord 'openbaren' ook het verspreiden omvat, of dat een dergelijke vrijheid hier ook door de rechter zal moeten worden geconstrueerd. Uit de toelichting bij dit artikel door de regering. blijkt dat wij het begrip openbaren in het derde lid ruimer moeten opvatten en dat dit ook het verspreiden omvat, althans tot op zekere hoogte. Bij sommige uitingsvormen zoals het spreken in het openbaar vallen openbaren en verspreiden namelijk

43 Volgens de HR 11-3-1986, NJ 1987, 462 was het brengen wan de Hitlergroet door een groepje personen geen 'afbeelding' in de zin van art. $137 \mathrm{c} \mathrm{Sr}$, daar dit artikel slechts een vastgelegd beeld, zoals een (foto)grafisch beeld, een prent of eem plaat, maar niet een gebaar zou omwatten (art. 7 lid 3 Grondwet omwat wel gebaren).

44 Zic over de relatie zelfexpressie en uitingsvrijheid;H.Th.J.F. van Maarsseveen, Vrijheid van zelfexpressie, NJB 1980, p. 617-628.

45 J.M. de Meij, Uitingsvrijheid, De wrije informatiestroom in grondwettelijk perspectief, Amsterdam 1989 , p. 196. 
zo zeer samen dat van een onderscheid hiertussen geen sprake kan zijn aldus de toelichting,

Bij andere uitingswormen zoals bandopnamen of video's zal er well weer sprake zijn van een onderscheid tussen openbaren en verspreiden. Voor beide typen geldt echter het verbod van voorafgaand verlof op grond van de inhoud. ${ }^{47}$ Een vergunning voor de verhuur van videobanden met voorschriften over de inhoud van de banden in kwestie is in strijd met bet derde lid."

Het probleem is dat het niet alltijd eenvoudig zal zijn om de boodschap die verspreid wordt buiten beschouwing te laten als een vergunning gevraagd wordt. In de regel zal de beslissende instantie enig inzicht moeten hebben in de aard van de boodschap om de openbare orde aspecten goed te kunnen beoordelen. ${ }^{4}$ Zeker nu ongeregeldheden vaak veroorzaakt worden door juist de inhoud van een boodschap is een zekere voorafgaande toetsing van de inhoud dikwijls onoverkomelijk. Dit staat op gespannen voet met art. 7 lid 3 van de Grondwet. Immers op grond van dat artikel dient de boodschap buiten beschouwing te blijven wanneer een vergunning wordt gevraagd. Naar mijn mening mag een vergunning niet worden geweigerd op grond van de inhoud..$^{\text {so }}$ Ook niet wanneer het risico bestaat dat op grond van de inhoud ordeverstoringen ontstaan. Wordt er nog voor uitvoering met tegenacties gedreigd zoals bij de witvoering wan het toneelstuk 'Het vuil, de stad en de dood' van Fassbin-

Algehele grondwetsherziening, deel 1a, p. 35; TK 1975-1976, 13872, nrs. 1-5, p. 35.

47 Problemen rijgen in die gevallen, waarin inhoud en vorm van een uiting natuw zijn werweven of $2 \mathrm{ells}$ samenvallen. Een toneelwoorstelling biedt hierwan woorbeelden. Niet alleen wat wordt gezegd, maar ook hoe het wordt gezegd, met welke gebaren, in welke aankleding, met welke hulpmiddelen, al deze aspecten kunnen betrekking hebben op de inhoud van de geuite gedachten of gevoelens. Volgens de regering in de Memorie wan Antwoord spreekt het vanzelf, dat "vooral bij artistieke uitingen de artistieke vormgeving in het algemeen tot de inhoud in de zin van het tweede en derde lid zal behoren." Algehele grondwetsherziening, deel 1ta, p. 199.

48 Vandaar dat afspraken op dit katste punt binneri de videobranche slechts in overleg met het ministeric van WVC tot stand zijn gekomen (TK 1985-1986, 19519, nr. 2).

49 De Afdeling Rechtspraak Raad van State maakt daarbij een onderscheid tussen wanordelijkheden die geprovoceerd zijn door degene die zich uit en anderzijds de ordeverstoringen die het gevolg zajn van agressieve onverdraagxaamheid van tegenstanders onder hot publiek. Alleen bij een verbod van de eerste categorie, is sprake van een beoordeling van de inhoud. Zie Vijandig publiek bij markıkraamactie en art. 7 Grondwet, ARRS 8-4-1988, NJCM-Bulletin 1989, p. 821-835 met noot van J. van der Vellde; Demonstratieverbod Centrumdemocraten Rotterdam, Vz ARRS 16-1989, KG 1989, 272; Roze Front, Vz ARRS 27-5-1982, AB 1982, 62; Vz ARRS 22-9-1987, AB 1988, 249.

50 Zie ook TK 1975-1976, 13872, ars. 1-5, p. 36. 
der dan dient de communicator beschermd te worden." Het openbaringsrecht mag niet vooraf beperkt worden. ${ }^{52}$

Wel mogen voorschriften worden gesteld aan het middel van openbaarmaking zij het dat

"bedoelde voorschriften niet zover mogen gaan dat aan een middel van openbaarmaking, dat naast ander middelen zelstandige betekenis heeft en met het oog op de openbaarmaking in een bepaalde behoefte kan voorzien, redelijkerwijs geen gebruik van betekenis wordt gelaten"

aldus de regering bij haar toelichting aan de Eerste Kamer van art. 7 lid 3 Grondwet. ${ }^{52}$ In dit verband is ook de uitspraak van de Afdeling Rechtspraak in de Alkmaarse marktkraamactie van belang. In deze zaak heeft de Afdeling Rechtspraak uitgemaakt:

"Hoewel het derde lid van art. 7 Grondwet geen belemmeringen bevat voor voorschriften op grond van plaats, tijd en wijze van openbaarmaking mag door zodanige voorschriften het feitelijk functioneren van het recht om door deze andere middelen gedachten of gevoelens te openbaren niet volledig onmogelijk worden gemaakt. " ${ }^{\text {si }}$

Wat dit betekent voor de toepassing van het strafvorderlijke dwangmiddel inbeslagneming zullen we zien in paragraaf 4 van dit hoofdstuk.

\subsection{Conclusie}

Uit de voorafgaande paragrafen is gebleken dat er een spanning kan bestaan tussen zowel de openbaarmaking van gegevensdragers en de handhaving van de openbare orde als de verspreiding van gegevensdragers en de handhaving van de openbare orde. Bij de openbaarmaking van gegevensdragers dient de communicator beschermd te worden ook wanneer het risico bestaat dat op grond van de inhoud ordeversto-

51. O.a. Trouw 19-11-1987, Kamer tegen verbod 'Fassbinder'; Binnenhof 19-11-1987, Ergernis rond Fassbinder; E. vam Ree in De Volkskrant 29-10-1991, Sinelle gekwetstheid bedreigt wrijheid van meningsuiting. Wanneer het gaat om een reactie op de ordeverstoring kan de bevoegdheid van de burgemeester op grond van art. 219 Gemeentewet enig soclaas bieder. Daarbij tal natar alternatiewe middelen gezocht moeten worden. J.M. de Meij, Uitingsvrijheid, De vrije informatiestroom in grondwettelijk perspectief, Amsterdam 1989, p. 202 203, Platform "Ärate für Lebein", Pubi. ECHR 21-6-1988, Series A, wol. 139, \&32 en. NJCM-Bullletin 1988, p. 566 .

52 M.C. Burkens, Algemene leerstukken van grondrechten natar Nederlands constitutioneel recht, Handboeken staats- en bestuursrecht, deel l, Zwolle 1989, p. 104-108 inzake de vrijtheid van bettoging.

53 Algehele grondwetsherzicning, deel 1b, p. 76; TK 1975-1976, 13872, nrs. 1-5, p. 91; Geluidswagens Degstgeest ARRS, 19-1-1987, AB 1988, 58 met noot vam P.J. Bioon. 
ringen ontstaan. De lagere overheid mag nooit het openbaren zelf reguleren via voorafgaand verlof of door middel van het geven wan regels met betrekking tot de inhoud van gedachten en gevoelens. Slechts achteraf kumnen door de rechter grenzen worden gesteld aan de wrijheid van meningsuiting en drukpers op grond van een wet in formele zin. lets anders zijn beperkingen ten aanzien van de verspreiding van gegevensdragers. De verspreidingsvrijheid mag wel worden beperkt door zowel de formele als de lagere wetgever. De vraag is hoever deze beperkingen mogen gaan. Gaat het om een film dan zal er eerst een vergunning moeten worden gevraagd (art. 7 Jid 3 Grondwet). Deze mag niet geweigerd worden op grond van de inhoud. Wel mogen aan het middel van openbaarmaking voorschriften worden gesteld. Ook aan de verspreiding van een pamflet mogen op grond van art. 7 lid 1 Grondwet beperkingen worden gesteld zij het dat deze beperkingen niet dusdanig mogen zijn dat er van het verspreidingsvrijheid niets meer overblijft. De verspreidingsvrijheid is een 'conditio sine qua non' voor de drukpersvrijheid. De Hoge Raad omschreef zelf de verspreidingsvrijheid in het Tilburg-arrest, als het uiten van gedachten en gevoelens "zodat zij voor anderen kenbaar zijn." En een pamflet bijwoorbeeld is pas kenbaar voor anderen als het op straat wordt uitgedeeld of als het wordt aangeplakt. ${ }^{5}$ Kortom de meningsuiting wordt pas effectief door de verspreiding.

Wat betekent dit nu voor de inbeslagneming van gegevensdragers zoals bandopnamen, pamfletten etcetera. Welke drempels werpt de wrijheid van meningsuiting en drukpers op tegen de inbeslagneming van gegevensdragers. In hoeverre mag de verspreidingsvrijheid door de inbeslagneming van gegevensdragers worden beperkt in het kader van de waarheidsvinding of de ordehandhaving", waaronder het voorkomen van strafbare feiten. ${ }^{58}$ In paragraaf 4 waar het strafvorderlijke dwangmiddel inbeslagneming besproken wordt, zal worden onderzocht hoe dit strafvorderlijke dwangmiddel zich verhoudt tot de vrijheid van meningsuiting en drukpers in het bijzonder de verspreidingsvrijheid. Vooraleer het zover is zullen echter eerst de artt. 10 EVRM en 19 IVBPR besproken worden.

6h.L. Bellokom, Vrijheid van meningsuiting en de Grondwet in: Presidium Libertatis, Deventer 1975, p. 115-125; JM. De Meij, De feitelijke mogelijk heid tot vrije meningsuiting, Mediaforum 1989-2, p. 16-18; HR 12-1-1960, NI 1960, 273; Plakverbod Zovenaar, HR 28-6-1983, NJ 1984, 64; Rb. Amsterdam 18-4-1984, NJCM-Bulletin 1985, p; 58 met noot van F.H. Kistenkas; Rb Arnhem 8-2×1985, NJCM-Bulletin 1985, p. 303-309 met noot van F.H. Kistenkas; HR 21-1-1986, NJ 1986, 441; Haarlemse Plakverbod, HR 5-1-1988, Gemeentestem 1989, 6872, p. 77-79 en NJCM-Bulletin 1989 , p. 439446 met noot van R.E. de Winter. F.H. Kistenkals, Verspreidingsdogmatiek of belangenatweging, TVO 1987, p. 356-361; I.C. van der

58 Een voorbeeld hiervan is de strafuorderlijke inbeslagne openbare orde, TVO 1982, p. 455-461. 132 e.v. Sr). 


\subsection{Inlending}

In deze paragraaf zullen de artt. 10 EVRM en 19 IVBPR besproken en vergeleken worden met art. 7 Grondwet. De vraag in paragraaf 3.2 zal zijn of de artt. 10 EVRM lid 1 en 19 lid 1 IVBPR meer garanties bieden dan art. 7 lid 1 en 3 van de Grondwet. In paragraaf 3.3 wordt de meerwaarde besproken van art. 10 lid 2 EVRM in relatie tot art. 7 lid 1 en 3 van de Grondwet. Zoals we nog zullen zien wordt in dit hoofdstuk vooral aandacht geschonken aan art. 10 EVRM omdat, zoals nog nader zal worden toegelicht in paragraaf 3.2 en 3.3 , dit artikel binnen het perspectief van dit onderzoek meer garanties biedt voor een vrije meningsuiting en drukpers dan art. 19 IVBPR. Paragraaf 3 van dit hoofdstuk zal na de bespreking van de verschillende leden worden afgesloten met een korte conclusie.

3.2 De meenwarde van art. 10 lid 1 EVRM en art. 19 lid I IVBPR ten opzichte van art. 7 lid 1 en 3 van de Grondwet

Art. 10 lid 1 EVRM luidt als volgt:

"Everyone has the right to freedom of expression. This right shall include freedom to hold opinions and to receive and impart information and ideas without interference by public authority and regardless of frontiers. This article shall not prevent states from requiring the licensing of broadcasting, television or cinema enterprises."

Art. 19 lid 1:

"Everyone has the right to freedom of opinion and expression; this right includes freedom to hold opinions without interference and to seek, receive and impart information and ideas through any media and regardless of frontiers."

In paragraaf 2 hebben we kunnen lezen dat in art. 7 lid 1 van de Grondwet naast 'denkbeelden' niet uitdrukkelijk 'inlichtingen' als beschermde uitingen worden genoemd. ${ }^{\text {\$ }} \mathrm{De}$ 'freedom of information' is wel neergelegd in art. 19 van de Universele

59 Dit is miet vanzelfsprekend. Zo streefde de Statscommissie-Cals-Donner naar een tekst die art. 10 EVRM zou benaderen. De tekst luidde als volgt." "Niemand heeft voorafgaand verlof nodig om door geschrift gedachten of gevoelens te openbaren, of om inlichtingen te garen, te ontvangen en door te geven, onverminderd ieders verantwoordelijkheid volgens de wet. Bij of krachtens de wet kan het recht om inlichringen te garen worden beperkt." TK 1970-1971, 11051, p. 15-18. 
Verklaring van de Rechten van de Mens en in de art. 10 EVRM en 19 IVBPR. Beide verdragsartikelen omwatten het hele scala wan de eigen mening tot het verstrekken van puur feitelijke informatie. Ook valt ondler de bescherming van de artt. 10 EVRM en 19 IVBPR commerciële reclame. ${ }^{61}$ Er wordt geen onderscheid gemaakt tussen de verschillende vitingsmiddelen zoals dat in art. 7 van de Grondwet het geval is.

Een ander verschil met art: 7 van de Grondwet is dat behalve de "freedom of information" ook de verspreidingsvrijheid een onderdeel is van de artt. 10 EVRM en 19 IVBPR. De term "doorgeven", als een onderdeel van de vrijheid van meningsuiting en drukpers, versterkt de bescherming van verspreidingshandelingen. We hebben hier dus niet te maken met de complexe en ondoorzichtige verspreidingsjurisprudentie van art. 7 Grondwet.

De koppeling van de vrijheid van meningsuiting en drukpers aan de verspreidingsvrijheid en de "freedom of information' sluit aan bij de benadering van de uitingsvrijheid waarbij steeds meer de nadruk komt te liggen op de vrijheid van ontvangst door het publiek. Art. 10 EVRM en art. 19 IVBPR bevatten meer garanties dan art. 7 Grondwet ${ }^{23}$ omdat naast de 'freedom of information' en de verspreidingsvrijheid ook de ontvangstvrijheid wordt beschermd. ${ }^{64}$ Aan de ontvangstvrijheid wordt

60 Zie ook het Europees Hof woor de Rechten van de Mens in de zaak Sunday Times: "the right of the people to be properly informed." EHRM 26-4-1979, NJ 1980, 146, p. 470. In de zaak Handyside heeft het Europese Hof beslist dat art. 10 EVRM ook bescherming geeft aan inlichtingen en denkbeelden, die "offend, shock or disturb the State or any sector of the population. "EHRM 7-121976, NJ 1978, 236, p. 817; Thorgeirson, Publ. ECHR 25-6-1992, Series A, vol. 239, \$ 67; Lingens, Publ. ECHR 8-7-1986, Serics A, woll 103, \& 41. Zie ook Rechtbank Groningen 9-6-1994, proces tegen Schaafsma (journalist) in: Mediaforum 1995-7/8, p. B65 en Hof Leeuwarden 26-1-1995, parketnr. 24-000996-94, proces tegen Boomsma (schrijver) in: Mediaforum 1995-7/8, p. B37; Cock Buning, De zaak-Boomsma, politiek beladen storm in een glas water?, NJB 1994, p. 874-876; J.M. de Meij, 'Ze waren geen SS-ers, nee...', NJB 1995, p. 549-550. En in de zaak Oberschlick heeft het Hof bovendien beslist dat: "art 10 nict alleen de inhoud van de ideeën en informatie beschermt, maar ook de worm waatin zij worden gepresenteerd (in casu de vorm van cen openbare aanklacht)." ECHR 23-5-1991, Council of Europe nr. 6/1990/197/257, p. 18; Jersild, Publ. ECHR 23-9-1994, Series $A_{3}$ vol, 298, $\$ 31$ en NJCM-Bulletin 1995, p. 170. Het staat niet ter beoordeling aan het Hof, noch aan de nationale rechter of een journalist kiest voor het geschreven woord of voor een audio-visueel medium (ook al maakt de keuze van het medium voor de impact van de verslaggeving cen belangrijk verschil).

61 Barthold, EHRM 25-3-1985, NJ 1987, 900, p. 203; Affaire Markt Intern Verlag GmbH et Klaus Betrmarn, EHRM 20-11-1989, NJ 1991, 738, p. 3201.

62 P. van Dijk/G.J.H. van Hoof, De Europese Conventie in theorie en praktijk, Nijmegen 1990, p. 457 e.w.

63 Willem van Manen, De constitutie van de nitingsvrijheid, Mediaforum 1990-11/12, p. 115.

64 De woorden "to receive information' in art. 10 EVRM en art. 19 IVBPR geven aan dat het ontlenen van informatic aan welke bron dan ook in beginsel wrij dient te zijn. In beginsel, immers op grond van art. 10 lid 2 en art. 19 lid 2 is het mogelijk de wrijheid van meningsuiting en drukpers te beperken. P. van Dijk/G.J.H. van Hoof, De Europese Conventie in theorie en praktijk, Nijmegen 1990 , p. 459. 
in de uitspraken van het Europese Hof grote waarde gehecht. Een goed geïformeerd publiek en de mogelijkheid tot kritisch volgen van de overheid wordt gezien als een voorwaarde voor een democratische samenleving. Zo besliste het Europese Hof in de zaak Sunday Times dat: "Not only does the media impari such information and ideas; the public also has a right to receive them. "En even verder wordt ook gesproken over "the right of the public to be properly informed. " ${ }^{\text {"s }}$ In het Handyside-rapport werd aangegeven dat het doel van art. 10 EVRM is "to have a pluralistic, open, and tolerant society. ${ }^{\text {En }}$ in de zaak Barthold werd speciaal gewicht toegekend aan de taak van de pers als "purveyor of information and public watchdog. ${ }^{167}$

In art. 7 Grondwet is de ontvangstvrijheid evenals de 'freedom of information' niet opgenome ${ }^{68}$ omdat de regering vreesde dat dit zou leiden tot ongewenste aan-

65 EHRM 26-4-1979, NJ 1.980, 146, p. 470.

66 EHRM 7-12-1976, NJ 1978, 236, p. 817. Zie ook Lingens, Publ. ECHR 8-7-1986, Series A, vol. $103, \$ 41$. Het recht op informatie wereist een pluriformiteit in de informatieverschaffing welke door de owerheid en de Europese Gemeenschap gewaarborgd moet worden bijwoorbeeld door daar waar nodlig subsidie te verlenen aan informatieverschaffende instanties welke voor die pluriformiteit onmisbaar zijn. A. Nieuwenhuis, Perswrijheid en persbeleid, Mediaforum 1991-7/8, p. 76-78; T. Kupfer, Media concentration and diversions in opinion, Agenda Socialist Group European Parliament, p. 4.

67 Barthold, EHRM 25-3-1985, NJ 1987, 900, p. 2989. Zie ook Sunday Times, EHRM 26-4-1979, NJ 1980, 146, p. 470; Lingens, EHRM 8-7-1986, NJ 1987, 901, p. 2995; Müller and others (met betrekking tot kunstenaars), Publ. ECHR 24-5-1988, Series A, vol. $\$ 33$, 833 en NJCM-Bulletin 1988, p. 669-670 met noot wan Leo Zwaak; Oberschlick, ECHR 23-5-1991, Council of Europe mr. $6 / 1990 / 197 / 257$, p. 19; Alhoewel "the press must not overstep the bonds set, inter alia, for the protection of the reputation of (...) others. Jersild, Publ. ECHR 23-9-1994, Series A, wol. 298, 31 en NJCM-Bulletin 1995, p. 170.

68 Het niet overnemen van de ontvangstrrijheid in art. 7 Grondwet is niet in overeenstemming met het voorstel wan de Staatscommissie Cals-Donner. In dit woorstel woor cen nieww uitingswrijheidsartikel was naast de vrijheid om gedachten en gevoelens te openbaren ook opgenomen "de vrijheid om inlichtingen te garen, te ontvangen en door te geven." Tweede Rapport (1969), p. 69-71. 
spraken. De regering was bang voor een openbaarheidsplicht van de overheid* Volgenis De Meij is deze angst onterecht omdat

"de ontwangstwrifheid niet direct te maken heeft met een openbaarheidsplicht. Dit zou eventueel wel gezegd kunnen worden van de garingswrijheid. Dit is de actieve variant van de ontwangstvrijheid. De garingsvijheid geeft de burger het recht om zich actief op de hoogte te stellen van zaken warrvoor hij of zij belangstelling heeft. De garingsvrijheid (freediom to seek information') wordt alleen genoemd in art. 19 van de Universele Verklaring voor de Rechten wan de Mens en art. 19 TVBPR matar is niet opgenomen in art. 7 Grondwet en art. 10 EVRM."

Men was zich zowel in Nederland als ook in Straatsburg wel bewust van het belang van een onbelemmerde nieuwsgaring. Zo was de toenmalige Nederlandse minister van Justitie De Ruiter van mening dat "er sprake dient te zijn van grote terughoudendheid bij het in beslag nemen wan geschriften gelet op de belangen van een onbelemmerde nieuwsgaring. ${ }^{m}$ Ook de rechter pleegt soms an de vrijheid van nieuwsgaring een even grote bescherming te geven als aan de vrijheid van meningsuiting en drukpers zelf ${ }^{72}$

In Straatsburg was de Raadgevende Vergadering van de Raad van Europa aanvankelijk zelfs van plan om art. 10 EVRM via een protocol uit te breiden met de garingsvrijheid. Maar uiteindelijk heeft men het gelaten bij een interpretatieve verklaring

69 In Nederland is het recht op informatie, in de zin wan openbaarheid van overheidsdocumenten, neergelegd in de Wet Openbaarheid Bestutur van 9-11-1978 (Stb. 581). Daarbij is zorgvuldig vermeden een relatie met de uitingsvrijheid te leggen. Voor de grondslag van de openbaarheidsplicht wan de overheid kwam een afzonderlijk artikel in de Grondwet tot stand, namelijk art. 110. De openbaarheidsplicht is daarbij een uitvlocisel van een goede democratische uitvoering van de bestuurstaak. De uitwerking hiervan in de wet WOB leidt tot een recht op informatie die is vastgelegd in documenten die zich bij overheidsorganen bevinden. Het recht op kennisneming komt aan iedereen toe. MVT, TK 1974-1975, 13418, nrs. 1-4; J.M. de Meij, Ruime uitleg WOB bemoeilijkt journalistiek, Mediaforum 1990-7/8, p. 76 e.v.; De Volkskrant 17-5-1991 'Gevoelig' archief wordt beter toegankelijk. Archiefstukken over historische kwesties worden i.p.w. na 50 jaar ma 20 jaar al openbaar. Het voorstel voor een nieuwe archiefwet grijpt terug op een wijziging van de Wet Openbaarheid vat Bestuur die per 1-5-1992 in werking is getreden. Deze regelling bevat alleen beperkingen op de openbaarmaking "om de persoonlijke levenssfeer te eerbiedigen ${ }^{n} \mathrm{en}$ om "een onevenredige bewoordeling of bemadeling van betrokken natuurlijke personen of rechtspersonen dan wel wan derden te voorkomen." Een verbod als 'de veiligheid van de staat' vervalt.

70 J.M. de Meij, Uitingsvrijheid, De vrije informatiestroom in grondwettelijk perspectief, Amsterdam 1989 , p. 124 e.v.

71 TK 1982-1983.

72 Zie de zaak Scientology kerk tegen de VARA, pres. Rb. Amsterdam 6-11-1980, NJ 1981, 502. Van belang was hier dat het ging om opnamen van besprekingen met cen zakelijk-informatief karakter, dat de feiten niet werden betwist en die publicatie het algemeen belang diende. Zie ook Uitingen door VARA's Ombudsman, HR 27-1-1983, nr. 122158; Uitingen in de Telegraf, HR 24-6-1982, nr. 12275; Sunday Times, EHRM 26-4-1979, NJ 1980, 146. 
"dat de garingsvrijheid impliciet beschermd wordt door art. 10 EVRM. ${ }^{m 3}$ Bij de keuze voor een impliciete erkenning van de garingsvrijheid kan het feit dat in de verschillende Europese teksten steeds een direct verband wordt gelegd tussen de garingsvrijheid en de plicht van de overheid om informatie te verstrekken van invloed zijn geweest: ${ }^{7 *}$

Echter dit veronderstelde verband tussen de garingsvrijheid en de informatieplicht van de overheid weerhield de opstellers van art. 19 IVBPR en art. 19 van de Universelle Verklaring voor de Rechten van de Mens er niet van, zoals we hebben gezien, de garingsvrijheid expliciet te erkennen. In art. 19 IVBPR en in art. 19 van de Universele Verklaring voor de Rechten van de Mens wordt het woord 'to seek' genoemd naast 'to receive and impart'. ${ }^{35}$ Van een informatieplicht wordt niet expliciet gesproken. Wel is het zo dat in art. 19 IVBPR in combinatie met Resolutie 428 (1970) van de Raadgevende Vergadering van de Raad van Europa gekozen wordt voor een ontwikkeling die steeds meer gaat in de richting van een garingsvrijheid gekoppeld aan een informatieplicht. ${ }^{7}$

\subsection{Conclusie}

Uit het voorgaande lijkt art. 19 lid 1 IVBPR meer bescherming te bieden dan art. 10 lid 1 EVRM. Immers behalve de verspreidingsvrijheid en de ontvangstvrijheid wordt ook de garingsvrijheid genoemd. Toch is dit niet geheel juist. Zo moet de garingsvrijheid al spoedig wijken voor andere belangen zoals bijwoorbeeld de privacy, staatsveiligheid en openbare orde (art. 19 lid 3 IVBPR). Vooral het begrip openbare orde wordt in lid 3 van art. 19 IVBPR erg opgerekt doordat in de Engelse tekst

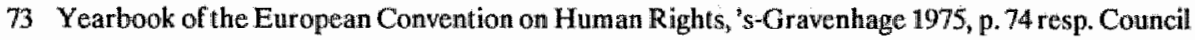
of Europe activities in the Mass media field, doc. DH-MM (86) 3, p. 9.

74 J.M. De Meij, Uitingsurijheid, De vrije informatiestroom ingrondwettelijk perspectief, Amsterdam 1989, p. 129.

J. Frowein/W. Peukert, Europaïsche Menschenrechtskonvention: EMRK.Konmentar, Kehll am Rhein 1985 , p. 229 e.v.

75 Art. 19 van de Universele Verklaring uit 1948 omschrift de vrijheid van drukpers en meningsuiting als "de vrijheid om zonder inmenging een mening te koesteren en om door alle middelen en ongeacht grenzen inlichtingen en denkbeelden 1. op te sporen "2. te ontvangen, 3. door te geven."

76 Zie de aanbevelingen van de Raadgewende Vergadering wan de Raad van Europa waarin een direct verband werd gelegd tussen de garingsvrijheid en de plicht van de overheid om informatie te verstrekken. "The right shall include freedom to seek, receive, impart, publish and distribute information and ideas. There shall be a corresponding duty for the public authorities to make available informatiton on matters of public interest within reasonable limits and a duty for mass communication media to give complete and general information on public affairs." Raadgevende Vergadering van de Raad van Europa Resolutie 428 (1970). Hoewel deze aanbevelingen niet bindend zijn indiceren zij wel wat de ontwikkelingen zijn in de rechtsopvatting binnen de (of althans enkele) verdragsstaten; E.A. Alkema, Studies over Europese Grondrechten, De invloed wan de Europese Conwentie op het Nederlandse recht, Deventer 1978, p. 79. 
van art, 19 lid 3 IVBPR de term 'public order' wordt toegelicht met de Franse term 'ordre public'. ${ }^{\pi 7}$ Dit in tegenstelling tot art. 10 EVRM warin het begrip openbare orde wordt ingeperkt tot the prevention of disorder". ${ }^{7}$ Dit gecombineerd met het gegeven dut in art. 19 IVBPR de formule "dat beperkingen nodig moeten zijn in een democratische samenleving' ontbreekt, maakt dat de garingsvrijheid niet die betekenis en die meerwaarde heeft voor Nederland die het zou kunnen hebben. In het hierna wolgende zal ik mijn aandacht dan ook vooral vestigen op de betekenis van art 10 EVRM voor de Nederlandse rechtsorde.

\subsection{Wat is de meenwarde van art. 10 lid 2 EVRM?}

Lid 2 is een uitzondering op de algemene regel. De algemene regel is de bescherming van de vrijheid van meringsuiting en drukpers zoals geformuleerd in art. 10 lid 1. Het tweede lid luidt als volgt"

"The exercise of these freedoms, since it carries with its duties and responsibilities, may be subject to such formalities, conditions, and restrictions or penalties as are necessary in a democratic society, in the interests of national security, territorial integrity or public safety, for the prevention of disorder or crime, for the protection of health or morals, for the reputation or rights of others, for preventing the disclosure of information received in confidence, or for maintaining the authority and impartiality of the judiciary."

In deze paragraaf zal ik de toetsingscriteria bespreken in art. 10 lid 2 EVRM. Deze toetsingscriteria bieden de mogelijkheid tot afweging of in een concreet geval beperkingen geoorloofd zijn. De toetsingscriteria gelden zowel voor beperkingen door de lagere overheid of opsporingsambtenaren als voor beperkingen door de rechter. Immers ook beperkingen door de rechter kunnen de vrijheid van meningsuiting en drukpers en de verspreidingsvrijheid belemmeren. Zo wees bijvoorbeeld het Europese Hof in de zaak Handyside op de bezwaren die ook voor een journalist of de gewone burger aan een veroordeling achteraf kunnen kleven: "It nevertheless anounted to a kind of censure, which would be likely to discourage him from making criticism of that kind again in future."

77 M. Nowak, UNO-Pakt über bürgerliche und politische Rechte und fakultativ Protokoll: CCPR-Kommentar, Kehl am Rhein 1989, p. 377-379; K.J. Partsch, Freedom of Conscience and Expression in: L. Henkin, The International Bill of Rights, New York 1981, p. 221.

78 A.M.F. Loof-Donker, E.M. Peeters en P.H. wan der Tang-Van Loenen, Kanttekeningen bij de wijze watap de Nederlandse wetgever omgatat met het begrip 'openbare orde' als doelcriterium voor de beperking van grond-en mensenrechten, NJCM-Bulletin 1994, p. 508, 51.1; P. wan Dijk en G.J.H. van Hoof, De Europese Conventie in theorie en praktijk, Nujmegen 1990, p. 643.

79 Ten aanzien van journalisten: Lingens, EHRM 8-7-1986, N`1987, 901, p. 2994. Ten aanxien van burgers: Barfod, Court Europeenne des droits de thomme 22-2-1989, Revue trimestrielle des droits de l'homme 1990, p. 58; Ezelin, ECHR 26-4-1991, Council of Europe nr. 21/1990/212/274, p.20. 
Welke zijn nu die toetsingscriteria die art. 10 lid 2 EVRM hanteert? Allereerst vereist het tweede lid van art. 10 EVRM dat er sprake moet zijn van een inbreuk ("interference) op een in lid 1 omschreven recht. Verder is vereist dat die inbreuk is prescribed by law' en tenslotte dient die inbreuk 'necessary' te zijn in 'a democratic society. Wat hiermee wordt bedoeld wordt duidelijk genalakt in de zaak Sunday Times. Aan de hand van de Sunday Times zaak zal ik bovengenoemde toetsingscriteria aan de orde stellen.

\subsubsection{De Sunday Times zaak}

In de Sunday Times zaak ging het om de relatie tussen de vrijheid van meningsuiting en drukpers en een 'fair trial' ('contempt of court'). ${ }^{8}$ De zaak was als volgt. Het farmaceutische concern 'Distillers Co. (Biochemicals) Ltd.' maakte in de jaren zeventig een medicijn 'thalidomide' dat gedistribueerd werd onder zwangere vrouwen. Vrouwen die dit medicjin tijdens thun zwangerschap hadden gebruikt kregen kinderen met ernstige afwijkingen. De Sunday Times was de eerste krant die aan deze gebeurtenis ruchtbaarheid gaf door middel van een publicatie. Volgens de "Attorney-General' ${ }^{12}$ in de 'Divisional Court' was er als gevolg van de publicatie sprake van 'contempt of court' omdat de "publication of the article complained of would create a serious risk of interference with Distillers' freedom of action in the litigation. ${ }^{\text {non }}$ Volgens Lord Denning in de 'Court of Appeal' daarentegen

"must it always be remembered that, besides the interest of the parties in a fair trial or a fair settlement of the case, there is another important interest to be considered. It is the interest of the public in matters of national concern, and the Freedom of the Press to make fair comment on such matters. The one interest must be balanced against the other. There may be cases where the subject-matter is such that the public interest counter-balances the private interest of the parties. ${ }^{\text {"IA }}$

80 Sunday Times, EHRM 26-4-1979, NJ 1980, 146, p. 466-470.

81 P.J. Dufly, The Sunday Times Case: Freedom of Expression, Contempt of Court and the European Convention on Human Rights, The Human Rights Review 1979, p. 17-53; M. Biesheuwel, Het Softenondrama en de vrije meningsuiting, NJCM-Bulletin 1979-16/17, p. 58-81.

82. De Atlorney-General is de juridische adviseur van de Kroon en hoofd van de Engelse orde van advocaten. Naast zijn politieke werplichtingen wertegenwoordigt hij de Kroon in civiele proced ures en in politieke en constitutioncle rechtszaken. Hij beschermt de "public interest". R.J. Walker and Walker, The English Legal System, London 1990, p. 230-231.

83. Attorney-General vs. Times Newspapers LAd (1973) 1 QB 710, 726, 727A, (1972) 3 All ER 1136, 1146C; Attorney-General ws. The Times Newspapers in: The Times 24-6-1979: "Reproduced ats Annex 11 to the Mentorial of the Applicants (registered 10-2-1978, Court (78) 5, p. 217)'. (1973) 1 QB 710, 739, EF, (1973) All ER 815, 822. 
Het belang van de vrijheid van meningsuiting en drukpers werd ook genoemd in de beslissing van de 'House of Lords'. ${ }^{\text {ss }}$ Desondanks beslisten de Lords dat:

"The defendlants; be restrained from publishing any article or matter which prejudges the issues of negligence, breach of contract or breach of duty, or deals with the evidence relating to any of the said issues arising in actions pending or imminent against Distillers Co. (Biochemicals) Ltd. in respect of the development, distribution or use of the drug "thalidomide."."

Tegen deze uitspraak werd een klacht ingediend door Sunday Times bij de Europese Commissie voor de Rechten van de Mens. In 1977, verklaarde de Europese Commissie voor de Rechten van de Mens de klacht, dat in strijd was gehandeld met de artt. 10, 14 en 18, ontvankelijk. ${ }^{86}$ In haar 'Report' van 18 mei 1977 besliste de Commissie dat "the injunction against publication had unjustifiably restricted the right to freedom of expression under Art. 10." De Commissie stuurde de zaak door naar het Europese Hof. Het Europese Hof besliste op 26 april 1979 dat art. 10 EVRM geschonden was. ${ }^{87}$

De vragen die rezen in de Sunday Times zaak kunnen verdeeld worden in drie categorieën. Allereerst onderzocht het Hof of de tussenkomst "by a public authority was prescribed by law" (1). Verder onderzocht het Hof of er sprake was van een 'aim or aims that is or are legitimate under Art. 10' (2) en of het 'necessary' was in a democratic society for the aforesaid aim or aims' (3). Alle drie deze categorieền worden hieronder besproken.

Ad 1: Allereerst vereist het verdrag in art. 10 lid 2 EVRM dat een beperking van de vrijheid van meningsuiting en drukpers is 'prescribed by law'. In de Sunday Times zaak wordt voor het eerst een gedetailleerde discussie gevoerd over de betekenis van de regel 'prescribed by law'. Volgens het Hof betekent het woord 'law' in de uitdrukking 'prescribed by law' niet alleen wetten in formele zin maar ook wetten in materiële zin en ongeschreven regelgeving. $\%$

Twee vereisten die rechtstreeks voortvloeien uit de regel "prescribed by law" zijn: "the law must be adequately accessible", dit betekent dat "the citizen must be able to

85 (1974) AC 273, (1973) 3 All ER 54. Het was voor het eerst in de Sunday Times zaak dat het 'House of Lords" "considered the limits of the contempt of court doctrine as applied to prevent the press discussing civil litigation." Murray Rosen, The Sunday Times Thalidomide case: Contempt of Court \& The Freedom of the Press, British Institute of Human Rights i.s.m. Writers Scholars Education Trust, London 1979, p. 3.

86 The Times, Application nr. 6538/74, Decision on admissibility 21-3-1975, Decisions and Reports vol. 2 ; p. 90.

87 Publ. ECHR 26-4-1979, Series A, vol. 30, $\$ 67$ en EHRM 26-4-1979, NJ 1980, 146, p. 465 met noot van E.A. Alkema.

PubL. ECHR 7-12-1976, Series A, vol. 24, \&43.

89 Klass and others, Human Rights Review 1979, p. 20 en p. 24-26.

90 Sunday Times, Publ. ECHR 7-12-1976, Series A, vol. 24, § 49. 
have an indication that is adequate in the circumstances of the legal rules applicable to a given case." Ten tweede kan een norm niet gezien worden als "law" wanneer zij niet voldoende precies is geformuleerd. Een 'law' moet de burger de mogelijkkheid bieden om zijn gedrag te reguleren. Ilemand moet in staat zijn "to foresee, to a degree that is reasonable in the circumstances, the consequences which a given action may entail." Het Hof benadrukt verder

"the need to allow the domestic legal system to balance the need for legal flexibility and the requirement of legal certainty: 'whilst certainty is highly desirable, it may bring in its train excessive rigidity and the law must be able to keep pace with changing circumstances'. Accordingly, many laws are inevitably couched in terms which, to a greater or lesser extent, are vague and whose interpretation and application are questions of practice. ${ }^{\text {not }}$

Het Hof verwerpt in deze uitspraak uitdrukkelijk de stelling van de Engelse regering dat 'prescribed by law' slechts betekent "lawful under the domestic law of the country concerned." Het Hof stemt in met de opvatting van de klagende partij dat

"the concept to which expressions like 'prescribed by law' are dlesigned to give effect is the principle of legal certainty. These statements and editorials illustrate with striking unanimity the very real restrictions which are being imposed upon the news media by the broad, vague and uncertain principles of this area of the law of contempt, dampening the vigour and limiting the variety of public debate, and inducing timidity and inertia in the expression of even the most vital information and ideas. ${ }^{\text {"92 }}$

\section{En verder:}

"Legal certainty can be regarded as a fundamental requirement of the Convention; and, as such, obviously it should be enforced as strongly as possible. Only when it is considered necessary in the circumstances will the level of certainty be pitched as low or lower than it was in the Sunday Times case. ${ }^{\text {ngs }}$

Ad 2: Volgens het Hof, en hierin volgt het Hof de opvatting van de Commissie, bevat art. 10 EVRM "a principle of freedom of expression that is subject to a number of exceptions which must narrowly be interpreted. De uitdrukking "authority and imparti-

91 Publ. ECHR 7-12-1976, Series A, vol. 24, 49.

92 Hof (78) 24 ("oral hearing'), p. 20 gepubliceerd in Series A, vol. 30. Zie ook de opvalting van het 'Phillimore Commiltee' in hatar 'Report.' van 1974: "The scope of the criminal contempt of cowrt is uncertain, producing far-reaching insecurity amongst journalists and muzzling the majority of them with caution. The development of contempt of court has been without parallel in the jurisprudence of other democracies and thas been subject to powerful criticism since the 18 th eentury." Hof (78) 24 ('oral hearing'), p. 20, gepubliceerd in Series $A$, wol. 30. 
ality of the judiciary has to be understood within the meaning of the Convention. In tegenstelling tot

"morals which varies from time to time and from place to place ${ }^{9 \%}$, especially in our area, and State authorities are in principle in a better position than the international judge to give an opinion on the exact content of these requirements" the authority of the judiciary corresponds to a less discretionary power of appreciation.

Hierover bestaat meer overeenstemming in de rechtspraktijk van de verdragstaten. Dit kan leiden tot een geringere beoordelingsmarge. De Commissie en het Hof beperkten zich hier niet tot een marginale toetsing gebaseerd op de doctrine van de 'margin of appreciation' maar stelden zelf een uitvoerig zelfstandig onderzoek in naar het al dan niet voldaan zijn aan het vereiste van 'noodzakelijk in een democratische samenleving".

Ad 3: Wat betekent nu het vereiste dat een beperking 'necessary" moet zijn "in a democratic society"? Volgens het Hof betekent dit dat een 'interference' ingegeven moet zijn door een 'pressing sociall need' en dat er bovendien een redelijke verhouding moet bestaan tussen de zwaarte van de inbreuk en het gewicht van het belang dat met de inbreuk werd gediend ("proportionality"). Ook moeten de aangevoerde rechtvaardigingsgronden voor de inbreuk relevant en toereikend zijn. Het gaat hier niet alleen om de rechtsregel zelf maar ook om de wijze waarop die wordt toegepast.

95 Publ. ECHR 26-4-1979, Series A, wol. 30, \$ 55. Zie ook de zaak Konig, Publ. ECHR 28-6-1978, Series A, vol. $27, \$ 88$.

96 Handyside, EHRM 7-12-1976, NJ 1978, 236, p. 815. Het Hof richtte zich vooral op de onstandigheid dat het hier ging om een jeugdig publick. Dat het boekje in verschillende andere Europese landen vrij verspreid kon worden, vond het Hof niet zo belangrijk.

97 Maar zells als verdragstaten hicrtoe beter in staat zijn dan nog dient de Europese rechter te controLeren of die wardering door de nationale rechter zorgvuldig en redelijk is geweest en of op $\mathrm{de}$ grondslagg wan die waardering bij alweging van de waarden die bij de in de Conventie gegarandeerde rechten zijin betrokken en de belangen waarvoor cen beperking van die rechten is toegestaan, de desbetreffende matregelen als "necessary in a democratic society" kunnen worden beschouwd. G.J. Wiarda, Extensieve en restrictieve verdragstoepassing door het Europese Hof woor de rechten van de mens; cen middenkoers? in: Ad Personam, Opstellen aangeboden aan Prof.mr. Ch.J. Enschede, Zwolle 1981, p. 371-385. Zie ook Jacubowski, EHRM 23-6-1994, NJCM-Bulletin 1995, p. 84 (oneerlijke concurrentie).

98 Alkema spreekt in zijn atnnotatie onder dit arrest van een 'integrale toetsing'. De Sunday Times (EHRM 26 4-1979, NJ 1980, 146, p. 472) zaak maakt volgens Alkema duidelijk dat de marge kan varièren naar gelang de beperkingsgrond die aan de orde is. Wanneer het betreft de goede zeden (zie Handyside, EHRM 7-12-1976, NJ 1978, 236) dan bebben verdragstaten weer een grotere beoordelingsvrijheid. Zie ook Müller, EHRM 24-5-1988, Series A, vol. 133, \$30, \& 35. Voor wat betreft de openbare orde: Chorherr, Publ. ECHR 25-8-1993, Series A, vol. 266B. Zie verder Jacubowski (oneerlijke concurrentie), EHRM 23-6-1994, NJCM-Bulletin 1995, p. 84; Otto-PremingerInstitut (godsdienstige levensovertuiging), Publ, ECHR 20-9-1994, Serics A, vol. 295, \$50 en NJCMBulletin 1995, p. 184 en NJ 1995, 366, p. 1619. 
Daarbij wil het Hof ook de feiten en omstandigheden die in dit concrete geval een rol spelen betrekken. Uitzonderingen moeten volgens het Hof strikt worden geïnterpreteerd. Het zwaartepunt van de toetsing in Straatsburg ligt bij de interpretatie van het begrip 'necessary in a democratic society'.

Volgens het Hof was er in deze concrete zaak geen sprake van een 'trial by newspaper'. Zelfs wanneer "to the extent that the article might have led some readers to form an opinion on the negligence issue, this would not have adverse consequences for the authority of the judiciary, especially since there had been a nationwide campaign in the meantime. "Hoo Ook was er geen sprake van "reasons given by the national authorities who are relevant and sufficient under Art. 10 (2)." Immers

"the freedom of expression constitutes one of the essential foundations of a democratic society; subject to paragraph 2 of Art. 10, it is applicable not only to information or ideas that are favourably received or regarded as inoffensive or as a matter of indifference, but also to those that offend, shock or disturb the State or any sector of the population. ${ }^{\text {ntot }}$

\section{Het Hof vervolgt dat}

"these principles are of particular importance as far as the press is concerned. They are equally applicable to the field of the administration of justice, which serves the interests of the community at large and requires the co-operation of an enlightened public. There is general recognition of the fact that the courts cannot operate in a vacuum. Whilst they are the forum for the settlement of disputes, this does not mean that there can be no prior discussion of disputes elsewhere, be it in specialised journals, in the general press or amongst the public at large. Furthermore, whilst the mass media must not overstep the bounds imposed in the interests of the proper administration of justice, it is incumbent on them to impart information and ideas concerning matters that come before the courts just as in other areas of public interest. Not only do the media have the task of imparting such information and ideas: the public also has a right to receive them. ${ }^{102}$ Whether the interference complained of was based on 'sufficient' reasons which rendered it 'necessary in a democratic society', account must thus be taken of any public aspect of the case. .103 $^{103}$

99 Sunday Times, EHRM 26-4-1979, NJ 1980, 146, p. 470; Handyside, EHRM 7-12-1976, NJJ 1978, 236 , p. 815.

100 Sunday Times, EHRM 26-41979, NJ 1980, 146, p. 469; Sunday Times (nr. 2), Observer and Guardian, ECHR 26-11-1991, Council of Europe nr. 50/1990/241/312, p. 27-28 en nir. 51/1990/242/313, p. 31 .

101 Handyside, EHRM 7-12-1976, NJ 1978, 236, p. 817 .

102 Lingens, EHRM 8-7-1986, NJ 1987, 901, p. 2994; Sunday Times (nr. 2), Observer and Guardian, ECHR 26-11-1991, Council of Europe, nr. 50/1990/241/312, p. 25-26 en 51/1990/242/313, p. 26.

103 M.C. Burkens, Algemene leerstukken van grondrechten naar Nederlands constitutioneel recht; Handboeken staats- en bestuursrecht, deel II, Zwolle 1989, p. 100-104. 
De klassieke individuele vrijheid van meningsuiting werd hier genoemd naast het belang van de vrije informatiestroom over allerlei zaken als kenmerken van een democratische samenleving.

Terwijl het Hof probeert een balans te winden tussen de conflicterende belangen was de 'House of Lords' van mening 'that it is not permissible to prejudge issues in pending cases: it was considered that the law would be too uncertain if the balance were to be struck anew in each case." Het Hof benadrukt dat het niet zijn taak is om de Engelse wet te interpreteren. Ook gaat het volgens het Hof niet om een keuze tussen twee conflicterende belangen ${ }^{105}$ maar om de "freedom of expression that is subject to a number of exceptions which must be namowly interpreted. "Het toezicht door het Hof met betrekking tot art. 10 bevat niet alleen "the basic legislation' maar ook the decision applying, "

It is not sufficient that the interference was imposed because its subject-matter fell within a particular category or was caught by a legal rule formulated in general or absolute terms: the Court has to be satisfied that the interference was necessary having regard to the facts and circumstances prevailing in the specific case before it. The measures restricting freedom of expression must be proportionate to the legitimate aim pursued."ta?

Het Hof concludeerde in de Sunday Times zaak dat de Thalidomide tragedie was "a matter of undisputed public concerm. "Verder kwam het Hof tot de conclusie dat "Art. 10 guarantees not only the freedom of the press to inform the public but also the right of the public to be properly informed. Het Hof bevestigt hiermee een eerdere uitspraak van de Commissie in de zaak "De Geillustreerde Pers". ${ }^{109}$ De Commissie besliste dat "in the area of information i.e., in the area of facts and news as opposed to 'ideas' and 'opinions', the protection which Art. 10 of the Convention seeks to secure concerns the free flow of such information to the public in general "In hetzelfde 'Report'

104 Sunday Times, EHRM 26-4-1979, NJ 1980, 146, p. 470; G.A.I. Schuijt, Media en de vrijheid van het politieke debat, Mediaforum 1991-9, p. 91 .

$1050 \mathrm{~m}$ twee conflicterende belangen ging het in de zaak Jersild, Publ. ECHR 23-9-1994, Series A, vol. 298, 27 en 29 en NJCM-Bulletir 1995, p. 168-169 (rassendiscriminatie (UN Convention against Racial Discrimination) contra de vrijheid van meningsuiting en drukpers (art. 10 EVRM). In dit verband is art. 17 EVRM van belang: "de bepalingen in het verdrag mogen miet zodanig worden uitgelegd dat burgers activiteiten aan de dag kunnen leggen die de rechten en vrijheden van derden teniet doen." Vgl. ECRM 11-10-1979, NJ 1980, 525, p. 1689 (met noot van E.A. Alkema): "een beroep op art. 10 EVRM faallt indien vastgesteld wordt dat de uiting van politieke ideeën die een beledigend karakter dragen, activiteiten in de zin van art. 17 EVRM zijn."

106 Zie ook Handyside, EHRM 7-12-1976, NJ 1978, 236, p. 23 en 49.

107 Sunday Times, EHRM 26-4-1979, NJ 1980, 146, p. 469; Zie ook Handyside, EHRM 7-12-1976, NJ 1978, 236, p. 817; Sunday Times (nr, 2), ECHR 26-11-1991, Council of Europe nr. 50/1990/241/* 312 , p. 26.

108 Het is de eerste keer dat het Hof dit met zoveel woorden zegt ( $\$ 65 \mathrm{en} 66$ ).

$109 \$ 85$ van het 'Report' aangenomen door de Commissie op 6-7-1976 in: Decisions and Reports vol. 8, p. 5 en p. 14. 
wees de Commissie erop dat "the public's right to receive information might sometimes ental positive obligations for the State to ensure the free flow of information.

\subsection{Conclusie}

Hoewel het Hof geen rangorde aanbrengt van de verdragsrechten heeft het wel gewezen op het grote belang van sommige rechten en vrijheden. Zo wordt de drukpersvrijheid beschouwd als een van de "essential foundations of a democratic society." Het is de taak van de pers "lo impart information and ideas on political issues and on other matters of general interest. ${ }^{\text {in }}$ Wanneer het gaat om zaken van algemeen maatschappelijk of politiek belang moet men volgens het Europese Hof voorzichtig zijn met het stellen van beperkingen ${ }^{102}$ die op gespannen woet staan met de bescherming van een democratische samenleving ${ }^{143}$ omdat een belemmering van de vrijheid van meningsuiting en drukpers het publiek kan ontmoedigen de overheid kritisch te blijwen controleren. ${ }^{114}$ Als dus de concrete grondrechtsuitoefening van de klager

$110 \$ 85$ van het "Report" aangenomen door de Commissie op 6-7-1976 in: Decisions and Reports vol. 8 , p. 5 en p. 14; M.C. Burkens e.a., Beginselen wan de democratische rechtsstaat, Zwolle 1992, p. 97.

111 Sunday Times, 26-4-1979, NJ 1980, 146, p. 470; Lingens, Publ. ECHR 8-7-1986, Series A, wol. 103, \$ 41; Oberschlick, ECHR 23-5-1991, Council of Europe nr. 6/1990/197/257, p. 19. Zie ook de zaak Thorgeirson, Publ. ECHR 25-6-1993, Series A, vol. 239, \$ 64: "there is no warrant in its case-law for distinguishing (...) between political discussion and discussion of other matters of public concern."

112 Concrete veroordelingen kunnen "capable of discouraging open discussion of matters of public concern" zijn. Thorgeirson, Publ. ECHR 26-6-1992, Series A. vol 239, 68.

113 Barthold, EHRM 25-3-1985, NJ 1987, 900 met noot van E.A. Alkema; Zie ook Schwabe, EHRM 28-8-1992, NJ 1994, 103 met noot van E. Dommering; Jersild, Publ. ECHR 23-9-1994, Series A, vol. 298 en NJCM-Bulletin 1995, p. 130: Het woeren van een publick debat is "(the) very core of the concept of a democratic society which prewails through the convention; ${ }^{\mathrm{n}}$; $\mathrm{J}_{\text {, wan der }}$ Velde, Raad van Europa, Het publieke debat en de wrijheid van meningsuiting (Castells ws. Spain, Thorgeirson vs. Island, Schwabe vs. Austria), NJCM-Bulletin 1993, p. 418-435. Drie van de negen rechters owerwogen in de Jacubowski-zaak, EHRM 23-6-1994, NJCM 1995, p. 84 (oneerlijke concurrentie) een gezamenlijke 'dissenting opinion' dat, nu de inhoud van de gewraakte artikelen reeds bekend waren, ze als bijdrage aan het publicke debat konden worden gezien en dat derhalve strikte toet sing door het Hof op zijn plaats was.

114 Ten aanzien van journalisten: Lingens, EHRM 8-7-1986, NJ 1987, 901, p. 2994; Jersild, Publ. ECHR 23-9-1994, Series A, vol. 298 (audio-visuele media) en NJCM-Bulletin 1995, p. 167-175; F. Janssens, Beledigende untlatingen in de medlia, NJCM-Bulletin 1995, p. 124-141. Ten aanzien van burgers: Barfod, Court Européenne des droits de l'homme 22-2-1989, Revue trimestrielle des droilts de I'homme 1990, p. 58; Ezelin, ECHR 26-41991, Council of Europe nr. 21/1990/212/274, p. 20. De grenzen van aanvaardbare kritielk dienen ruimer getrokken te worden als deze een politicus of de regering betreft. Zie de zaken Oberschlick, ECHR 23-5-1991, Council of Europe nr. 6/1990/* 197/257, p. 20; Castells, ECHR 23-4-1992, Council of Europe inr. 2/1991/254/325, p. 20; Schwabe, ECHR 28-8-1992, Council of Europe nr. 46/1991/298/369, p. 20; Luciènne Tomesen, The seizure of journalistic material and the freedom of speech and the press, Revista de la Facultad de Cienciats. 
behoort tot zaken van algemeen maatschappelijk of politiek belang is de 'margin of appreciation" geringer. " ${ }^{\prime \prime s}$ Ook overeenstemming in de rechtspraktijk van de verdragstaten kan leiden tot een geringere beoordelingsmarge. ${ }^{16}$ Bovendien speelt de specifieke aard en de ernst van de inbreuk op het verdragsrecht een rol bij het bepalen van de "margin of appreciation". "Is het Hof van mening dat de "margin of appreciation' gering dient te zijn, bijvoorbeeld omdat het gaat om 'public speech', dan stelt het Hof zelfstandig een onderzoek in of al dan niet voldaan is aan het vereiste van 'noodzakelijk in een democratische samenleving'. Beperkingen dienen wolgens het Hof strict te worden geïnterpreteerd. Er moet sprake zijn van een "pressing social need'. Verder moet er een redelijke verhouding bestaan tussen de zwaarte van de unbreuk en het gewicht van het belang dat met de inbreuk werd gediend ('proportionality'). Ook de aangevoerde rechtwaardigingsgronden voor de inbreuk moeten relevant en toereikend zijn. Of het Hof in een bepaalde zaak een ruime of een enge beoordelingsmarge zal vaststellen is moeilijk te voorspellen omdat bovengenoemde opsomming is samengesteld uit alleen die factoren welke door het Hof uitdrukkelijk als zodanig zign erkend. Met andere woorden, andere factoren kunnen ook een rol spelen en de lijst kan door het Hof worden vitgebreid. Op grond van de concrete casus zal het Hof bezien wat de "margin of appreciation' is voor de desbetreffende verdragsstaat. Is deze volgens het Hof gering dan zal het Hof een zelfstandig onderzock instellen of de beperking 'noodzakelijk is in een democratische samenleving".

Minder afhankelijk van de concrete situatie en dus voorspelbaarder is het eerst genoemde vereiste in bovengenoemde paragraaf. Wanneer het Hof immers ernstige twijfel heeft over de mate van 'clarity' en "precision" van een rechtsregel kan zij een schending construeren van het 'foreseeability'-criterium via de 'rule of law" in art. 10 EVRM. Het Hof kan dan over een breed terrein van verdragsvrijheden, onafhankelijk van de concrete omstandigheden, nationaal recht naar meer eigen, Straatsburgse maatstawen beoordelen op zijn geldigheid. Wat dit concreet betekent voor de bepalingen die betrekking hebben op het strafworderlijke dwangmiddel inbeslagneming zullen we zien in paragraaf 4.

de la linformación, Madrid 1994, p. 157-164.

115 Sunday Times 26-4-1979, NJ 1980, 146, p. 469; Markt intern Verlag GmbH and Klaus Beerman, Publ. ECHR 20-11-1989, Series A, wol. 165, $\$ 33$; Observer and Guardian, ECHR 26-11-1991, Council of Europe nr. $51 / 1990 / 242 / 313$, p. 27.

116 Sunday Times, EHRM 26-4-1979, NJ 1980, 146, p. 468 i.t. Handyside, EHRM 7.12-1976, NJ 1978, 236, p. 817.

1.17 In de zaak Leander werd aan de staat een ruime beoordelingsmarge gelaten omdat de geheime registratie van klagers persoonsgegevens hem niet werhinderden een privê-leven naar eigen keuze te leiden. Leander, Publ. ECHR 26-3-1987, Series A, vol. 116, \$59.

$118 \mathrm{~J}, G . C$. Schokkenbroek, De margin of appreciation-doctrine in de jurisprudentie van thet Europese Hof, NJCM-Bulletin 1990, p. 56 e.v. 
4 Het strafvorderlijke dwangmiddel inbeslagneming en de vrijheid van meningsuiting en drukpers

\subsection{Inleiding}

In de eerste paragraaf van dit hoofdstuk zal de betekenis van de inbeslagneming in thet Wetboek van Strafvordering worden besproken. Eerst zal duidelijk moeten worden gemaakt wat onder het begrip 'inbeslagneming' in het Wetboek van Strafvordering dient te worden verstaan. Daarna kan worden overgegaan tot een bespreking van de materiële aspecten van de inbeslagneming en de vrijheid van meningsuiting en drukpers. Onder de materiële aspecten van de inbeslagneming worden hier verstaan de ratio en de gronden op basis waarvan de inbeslagneming mogelijk is. In art. 94 Sv worden drie gronden genoemd voor inbeslagneming. Zo is de inbeslagneming van voorwerpen mogelijk met het oog op de waarheidsvinding, de verbeurdverklaring en de onttrekking aan het verkeer. In paragraaf 4.3.1 komt allereerst de inbeslagneming voor het aan de dag brengen van de waarheid aan de orde. Bezien wordt wat de ratio van de inbeslagneming van voorwerpen om de waarheid aan de dag te brengen is en hoe zich dit verhoudt tot de vrijheid van meningsuiting en drukpers. De vraag die bij de inbeslagneming voor het aan de dag brengen van de waarheid centraal staat is of 'gegevens' opgeslagen op 'dragers' vallen onder het begrip voorwerp van art. $94 \mathrm{~Sv}$. Een bevestigend antwoord op deze vraag, kan zoals we zullen zien in paragraaf 4.3.1, gevolgen hebben voor de vrijheid van meningsuiting en drukpers.

In de paragrafen 4.3.2 en 4.3.3 komen de inbeslagneming ter verbeurdverklaring en de inbeslagneming ter onttrekking aan het verkeer aan de orde en in paragraaf 4.3.4 de maatregel verbeurdverklaring en de straf onttrekking aan het verkeer. Strafrechtelijk verboden gegevensdragers, zoals bijvoorbeeld discriminatoir beledigende films, video's, geschriften etcetera kunnen in beslag worden genomen door de politie en door de rechter verbeurd worden verklaard of onttrokken worden aan het verkeer (artt. 33-36 Sr). In bovengenoemde paragrafen wordt gekeken hoe de strafvorderlijke regeling van de inbeslagneming ter verbeurdverklaring en ter onttrekking aan het verkeer zich verhoudt tot de wrijheid van meningsuiting en drukpers, in het bijzonder de verspreidingsvrijheid in art. 7 van de Grondwet en art. 10 EVRM. Mag bijvoorbeeld een hele oplage 'vermeende' discriminatoir beledigende geschriften of films in beslag genomen worden door de politie en door de rechter worden verbeurd verklaard of onttrokken worden aan het verkeer? Hoe verhoudt zich dit tot art. 7 van de Grondwet en art. 10 EVRM. De artt. 7 van de Grondwet en 10 EVRM werpen immers drempels op tegen een al te rigoureuze strafvorderlijke inbeslagneming.

Nadat de materiële aspecten van de inbeslagneming zijn besproken komen in paragraaf 4.4 en volgende de procedurele aspecten aan de orde. Zo wordt beschreven wie bevoegd zijn tot inbeslagneming (4.4.1) en wat de gevolgen zijin wan overschrijding van die bevoegdheid (4.4.2). Ook wordt de wijze van gebruikmaking van die inbeslagnemingsbevoegdheid getoetst aan beginselenvan een behoorlijke strafrechtspleging 
(4.4.3). De beginselen die in dit werband besproken worden zijn het vertrouwensbeginsel, het gelijkheidsbeginsel, het beginsel van zuiverheid van oogmerk, het beginsel van redelijke en billijke belangenafweging, het rechtszekerheidsbeginsel, het proportionaliteitsbeginsel en het subsidiariteitsbeginse . $^{399}$ Bekeken wordt hoe deze beginselen zich verhouden tot het strafvorderlijke dwangmiddel inbeslagneming en de teruggave van in beslag genomen voorwerpen. De teruggave van gegevensdragers dient zo spoedig mogelijk te geschieden. De inbeslagneming mag niet langer duren dan in het belang van de strafvordering noodzakelijk is. Ook is de inbeslagneming alleen mogelijk op de gronden in art. 94 van het Wetboek van Strafvordering genoemd. Uitbreiding van de in art. $94 \mathrm{~Sv}$ genoemde gronden of van de duur van de inbeslagneming is alleen aanvaardbaar onder strikte woorwaarden. Op deze manier wordt impliciet rekening gehouden met de vrijheid van meningsuiting en drukpers wanneer het gaat om de inbeslagneming van gegevensdragers. In paragraaf 4.6 zal de teruggave van in beslag genomen voorwerpen aan de orde komen en de voorstellen die hebben geleid tot de huidige wetsartikelen. De laatste paragraaf tenslotte, zal betrekking hebben op de beklagprocedure. De behandeling van het klaagschrift vindt in de raadkamer plaats. Naast de artt. $552 \mathrm{a}$ en volgende van het Wetboek van Strafvordering zijn hier de artt. 21 en volgende van het Wetboek van Strafvordering van toepassing. De art. 552a procedure vertoont leemten. Welke leemten dit zijn zal in paragraaf 4.7 duidelijk worden. De vraag is of de raadkamerprocedure, in die gevallen waarin het gaat om de vrijheid van meningsuiting en drukpers, op gespannen voet staat met art. 6 EVRM, art. 10 EVRM en art. 19 IVBPR. In paragraaf 4.7 worden de beklagprocedure en de voorstellen tot wijziging van de huidige beklagprocedure nader besproken. Paragraaf 4 wordt afgesloten met een conclusie.

\subsection{Begripsbepaling}

Bij een ingrijpend dwangmiddel als de inbeslagneming is het van wezenlijk belang dat duidelijk in de wet is uitgedrukt wat onder "inbeslagneming" moet worden verstaan. Immers, door een wettelijke omschrijving van het begrip inbeslagneming worden de grenzen aangegeven van de mogelijkheid om het dwangmiddel te hanteren. ${ }^{120}$ Desondanks ontbrak een begripsbepaling van de inbeslagneming in het ontwerp van het nieuwe Wetboek van Strafvordering van 1913. Volgens de minister kon inmers "uit de in elk concreet geval gegeven feiten in den regel zonder veel moeite blijken, of al dan niet eene inbeslagneming heeft plaatsgehad. "Verder veronderstelt volgens de minister

119 Hoe deze beginselen zich tot elkaar verhouden blift hier buiten beschouwing Zie M.C. Burkens, Algemene leerstukken van grondrechten naar Nederlands constitutioneel recht, Handboeken staatsen bestuurstecht, deel 11, Zwolle 1989, p. 55.

$120 \mathrm{~F}$. Vellinga-Schootstra, Inbeslagneming en huiszoeking, diss. RU Groningen, Alphen a/d Rujn 1982, p. 18. 
"eene naar de bepalingen van het ontwerp geoorloofde inbeslagneming natuurlijk, dat een geval aanwezig is, waarin de bevoegdheid tot inbeslagneming is gegeven, dat voorts het in beslag genomen goed behoort tot de voorwerpen, welker inbeslagneming is toegestaan, en eindelijk dat de inbeslagneming zelwe plaatsvond. Over al deze punten geve, zoo nodig de rechter eene beslissing. De waarborg dat buiten inbeslagneming zall blijven hetgeen daarin niet volstrekt noodzakelijk moet worden begrepen, is, behalve in de omschrijving van dit artikel (art. 94) te vinden in het 'gezond oordeel' van justitie en politie."

Toch drong de Commissie van Voorbereiding aan op een wettelijke omschrijving van de inbeslagneming. Een duidelijke definiëring was volgens de Commissie van belang in verband met de strafbaarheid wan het onttrekken van goederen aan het beslag. Inbeslagneming werd vervolgens omschreven als "het onder zich nemen of gaan houden van een voonwerp ten behoeve van strafvordering" (zie het huidige art. $134 \mathrm{~Sv}) .^{122}$

Uit de abstracte definitie van het huidige art. 134 Sv blijkt dat de vraag van de vorm en mitsdien van de geldigheid van de inbeslagneming tenslotte toch overeenkomstig de oorspronkelijke opvatting van de minister aan het "gezond oordeel" van de politie, justitie en rechter is overgelaten.

De aanvankelijk door de minister ontworpen tekst behelsde dat onder inbeslagneming moest worden verstaan het onder zich nemen of gaan houden van een voorwerp "ten behoeve van het onderzoek. "Deze laatste woorden zijn bij de eerste nota van wijziging vervangen door: "ten behoeve van de strafvordering." Deze wijziging was noodzakelijk, omdat op grond van het bepaalde in art. 94 inbeslagneming van voorwerpen behalve met het oog op de waarheidsvinding ook kon plaatsvinden ter verbeurdverklaring dan well tot vernietiging of onbruikbaarmaking (art. 354 oud), welke laatste maatregel in 1958 werd vervangen door die van de onttrekking aan het verkeer. In deze laatste gevallen dient de inbeslagneming niet ten bate van het onderzoek, maar om ten aanzien van het desbetreffende goed de mogelijkheid van tenuitvoerlegging van een straf (verbeurdverklaring) of maatregel (onttrekking aan het verkeer) te verzekeren. Met het oog op deze bijzondere doeleinden, die het eigenlijke onderzoek in strafzaken te buiten gaan, werd de inbeslagneming in de definitieve tekst van art. $134 \mathrm{~Sv}$ dan ook aangemerkt als een verrichting ten bate van het ruimere belang van de 'strafwordering'. Laatstbedoeld begrip heeft in het algemeen een zeer ruime betekenis. In art. $1 \mathrm{~Sv}$ betekent het volgens de Memorie van Toelichting de gehele procedure in strafzaken en omvat het volgens de Memorie van Antwoord zowel de opsporing als de vervolging, als tenslotte de tenuitwoerlegging. ${ }^{\text {iza }}$ In art.

121 Verslag Bijl. HTK 1917-1918.

122 Verslag Bijl. HTK 1917-1918.

123 A.L. Melaï, Het Wetboek van Strafwor dering verklaard en van aantekeningen voorzien (losbliadig), MS. Groenhuijsen, Th.A. de Roos en A.H.J. Swart (red.), Arnhem (2j.), art. 1 Sv, p. 2; C.P.M. Cleiren, De openheid van de wet, de geslotenheid van thet recht, rede Erasmus Uniwersitteit, Arnhem 1992. 
134 Sv kan men aan het begrip strafwordering dezelfde ruime betekenis toekennen, maar daarbij dient men wel te bedenken, dat de gehele inbeslagneming beheerst wordt door de algemene bepaling van art. $94 \mathrm{~Sv}^{124}$

Uit de geschie denis wan de totstandkoming van art. $134 \mathrm{Sw}^{125}$ en de jurisprudentie ${ }^{125}$ blijkt, dat met de inbeslagneming "ten behoeve wan de strafvordering" wordt bedoeld, dat de inbeslagneming van het goed moet kunnen dienen om de waarbeid aan het licht te brengen of om de mogelijkheid van verbeurdverklaring of onttrekking aan het verkeer veilig te stellen (art. $94 \mathrm{~Sv}$ ), ${ }^{127}$ Voor de vatbaarheid voor inbeslagneming is het voldoende dat het onder zich nemen of gaan houden én van de in art. 94 Sv genoemde doeleinden kan dienen. Enkel een goed in beslag nemen om het aan de rechtmatige eigenaar te doen toekomen, is onder de huidige wetgeving niet mogelijk. Met de belangen van de benadeelde kan alleen rekening worden gehouden als de inbeslagneming - en daarmee het voortduren van het beslag - mede dienstbaar is aan ến van de in art. $94 \mathrm{~Sv}$ genoemde doeleinden. ${ }^{128}$ Dit geeft problemen in gevallen waarin het gaat om goederen die de verdachte niet toebehoren en die ook niet voor de maatschappij gevaarlijk zijn in de zin van art. $36 \mathrm{c} \mathrm{Sr}$. Inbeslagneming ter verbeurdverklaring is dan niet mogelijk, ondat voor verbeurdverklaring als voorwaarde is gesteld dat de voorwerpen de dader toebehoren. Indien ook het in beslag nemen of houden met het oog op de waarheidswinding niet mogelijk is - bijwoorbeeld omdat meer dan voldoende ander bewijs voorhanden is - staan voor de rechter geen andere wegen meer open om de verdachte de beschikking over de voorwerpen te ontnemen, respectievelijk te onthouden. Deze onbevredigende situaties zouden volgens Vellinga-Schootstra

"door wijziging van art. 94 Sv kunnen worden voorkomen. In die bepaling zou de wetgever dan kunnen opnemen dat inbeslagneming toch mogelijk is, wanneer de verbeurdverklaring niet zou kunnen worden uitgesproken vanwege het enkele feit dat de voorwerpen toebehoren aan het slachtoffer van het strafbare feit."

De reikwijdte van de inbesllagneming wordt door deze voorgestelcle nieuwe grondslag aanzienlijk ruimer. De opsporingsambtenaren krijgen hierdoor meer mogelijkheden

$124 \mathrm{~F}_{*}$ Vellinga-Schootstra, Inbeslagneming en huiszoeking, diss. RU Groningen, Alphen a/d Rijn 1982 , p. 19.

125 Nota van wijzigingen Bijl. HTK 1919-1920.

126 HR 4-4-1950, NJ 1950, 693; HR 15-12-1959, NJ 1960, 255; Rb. 's-Hertogenbosch 2-5-1961, NJ 1961, 439; HR 3-12-1974, NII 1975, 163.

126 Deze tekst is ontleend aan $\$ 87$ cerste zin wan het woorontwerp van het Duitse Wetbock van Strafwordering (1908).

127 HR 6-4-1936, NJ 1936, 813 noot van W. Pompe; A.L. Melai, Het Wetboek van Strafvordering, verklaard en wan aantekeningen woorzien (losbladig), M.S. Groenhuijsen, Th.A. de Roos en A.H.J. Swart (red.), Arnhem (zij), anant. 3 op art. 118 Sv.

$128 \mathrm{~F}$. Vollinga-Schootstra, Inbeslagneming en huiszoeking, diss. RU Groningen, Alphen a/d Rijn 1982, p. 20. 
om voorwerpen in beslag te nemen cq. te houden. Dat dit niet de oorspronkelijke opzet van de wetgever is geweest, zal in paragraat 4.6 blijken.

De inbeslagneming dwingt opsporingsambtenaren, met inachtneming van de bijzondere omstandigheden van het geval, tot een oordeel over de geschiktheid van een voonwerp om de waarheid aan de dag te brengen en over de vatbaarheid van voonwerpen om verbeurd te worden verklaard of te worden onttrokken aan het verkeer. Daarbij zijn van belang de wettelijke voorschriften die bijkomende straf en maatregel beheersen, met narne de artt. 33a, 33b, 36a, 36b, 36c Sr (naast tal van bepalingen in bijzondere wetten). De vraag of een voorwerp rechtmatig in beslag kan worden genomen, hangt dus mede af van in de wet gestelde nadere voorwalarden, zoals art. 33 a lid 1 sub e $S r$ een voorwerp vatbaar verklaart voor inbeslagneming, indien "het vervaardigd of bestemd is tot het begaan van een misdrijf: "Bij de beantwoording van de vraag of aan die voorwaarden is voldaan, moet in het oog worden gehouden dat; aangezien het strafproces juist moet dienen om door de rechter te doen beslissen of, en zo ja door wie een strafbaar feit is gepleegd, in het voorbereidend onderzoek niet met zekerheid kan worden uitgemaakt of een voorwerp vervaardigd of geschikt gemaakt is tot het plegen van een strafbaar feit. Naar het oordeel van Blok en Besier kan dan ook "van de inbeslagnemende ambtenaar niet meer worden verlangd, dan dat hij een redelijk vermoeden heeft dat een voor verbeurdverklaring door de wet gestelde voorwaarde is vervuld. "mano Bakhoven legt een verband met art. 27 Sv.

"Beslissende betekenis moet worden toegekend aan feiten en omstandigheden, die thet redelijk vermoeden wettigen dat een strafbaar feit is begaan. Daarnaast zullen feitelijke gronden moeten zijn voor het vermoeden dat een goed zal kunnen dienen om de waarheid op te helderen ${ }^{13 i}$, dan wel zal kunnen worden onderworpen aan bowengenoemde bijkomende straf of maatregel. Voor de rechtmatigheid van inbeslagneming kan niet worden geëist dat gezegde bijkomende straf of maatregel ook zal worden opgelegd. .13z $^{\text {a }}$

Bakhoven voert in dit verband aan:

"Dit neemt natuurlijk niet weg, dat de opsporingsambtenaren bij de beantwoording van de vraag, of zij een bepaald voorwerp wel of niet in beslag zullen nemen, wel degelijk ook met laatstgemelde wraag rekening zullen houden. Het feit dat de opsporingsambtenaar bij waardering van deze gegevens afgaat op zijn intuitie, ontneemt aan het wermoeden niet de kracht van het redelijk vermoeden. Niet steeds wanneer het goed naar redelijk vermoeden vatbaar is woor inbeslagneming ten behoeve wan de warheidsvinding is de inbeslagneming toelaatbaar. Inbeslagneming van een op zichzelf daarvoor vatbaar voorwerp dient achterwege

130 A.J. Blok en L.Ch. Besier, Het Nederlandsche Strafproces, deel 1, Haarlem 1925, p. 302.

131. De Richtlijnen voor het beleid van het Openbaar Ministerie en de politie inzake inbeslagneming (Staatscourant 2-6-1980, nr. 103) schrijven woor dat de ambtenaar zich ook moet afvragen of te verwachten valt dat het voorwerp daadwerkelijk zal dienen woor de waarheidswinding dan wel onderwerp zal zijn van de genoemde sancties.

132 W.P. Bakhoven, Inbeslagneming en bare gevolgen, TvS 1938, p. 167. 
te blijven wanneer deze (kennelijk) onredelijk is, bijvoorbeeld omdat het in werkelijkheid niet in de rede ligt dat het voorwerp inderdaad zal worden gebrulkt om de waarheid aan de dag te brengen of omdat de betrokkene door de inbeslagneming onevenredig zwaar wordt getroffem.

Geconcludeerd kan worden dat een inbeslagneming wel degelijk kan worden getoetst aan de vraag of de toepassing van het dwangmiddel in het concrete geval op redelijke gronden berust. Immers de wending "ten behoeve van de strafwordering" in art. 134 Sv behoort te worden gelezen als "in het belang van de strafvordering." Deze uitleg is gerechtvaardigd omdat blijkens het bepaalde in art. 118 Sv het Openbaar Ministerie een in beslag genomen voorwerp doet teruggeven "zodra het belang van de strafuordering zich (dacrtegen) niet meer verzet." Hieruit valt niet alleen af te leiden, dat het belang van de strafvordering de inbeslagneming als handeling oorspronkelijk moet hebben gelegitimeerd, maar bovendien dat inbeslagneming als bedoeld in art. 94 Sv uitsluitend kan plaatsvinden in het belang van de strafvordering met het oog op de concrete omstandigheden van het geval. "Bijgevolg is", volgens Melai,

"de enkele omstandigheid dat een inbeslagneming plaatsvindt in het kader van de strafvordering, onafhankelijk van de vraag of concrete feiten een dergelijk middel rechtvaardigen, woor gezegde maatregel ontoereikend. Aangezien inbeslagneming valt aan te merken als de uitkomst van een bijzondere beleidsbeslissing en het bij de hierbedoelde toetsing mitsdien gaat om de redelijkheid van de beleidsgronden die gezegde beslissing moeten dragen, is er behoefte aan darop uit te oefenen controle."

De algemene beginselen van behoorlijk bestuur met name het proportionaliteitsen subsidiariteitsbeginsel, het 'fair-play' beginsel, het zorgvuldigheidsbeginsel, het beginsel van zuiverheid van oogmerk en evenwichtigheid en het rechtszekerheidsbeginsel spelen ook in het strafproces een belangrijke rol. Deze beginselen zal ik verder bespreken in paragraaf 4.4.3.

\subsection{De materiêle aspecten van de inbeslagneming en de vrijheid van meningsuiting en drukpers}

4.3.1 De inbeslagneming voor het aan de dag brengen van de waarheid en de vrijheid van meningsuiting en drukpers in art. 7 van de Grondwet

De inbeslagneming vam een voorwerp met het oog op de waarheidsfunctie zal als eerste worden behandeld. Het is van belang in te zien wat onder het begrip 'woorwerp'

132. W.P. Bakhoven, Inbeslagneming en hare gevolgen, TwS 1938 , p. 167 e.v.

134 A.L. Melai, Het Wetboek van Strafwordering, verklaard en van aantekeningen woorzien (losbladig), M.S. Groenhüjsen, Th.A. de Roos en A.H.J. Swart (red.), Arnhem (z.j), art. 94 Sv, p. 16. 
en 'gegevens' als ook wat onder het begrip 'waarheìd' dient te worden verstaan. Om met dit laatste te beginnen. Het in art. $94 \mathrm{~Sv}$ gebezigde begrip waarheid moet worden verstaan als voor de toepassing van het strafrecht relevante waarheid. Anders dan bij werbeurdverklaring en onttrekking aan het verkeer - waarbijwordt geanticipeerd op een straf of maatregel door de strafrechter - gaat het bij de inbeslagneming van voorwerpen voor het aan de dag brengen van de waarheid mede om de vraag of een vervolging moet worden ingesteld of voortgezet. De fase gedurende welke de inbeslagneming ten behoeve van de waarheid mogelijk is, begint wanneer er een vermoeden bestaat dat er een strafbaar feit is gepleegd en eilndigt indien er een eind komt aan de vervolging. Voor de inbeslagneming ten behoeve van de waarheidsvinding is het niet noodzakelijk dat het voorwerp aan de verdachte toebehoort. De uitoefening van dit dwangmiddel is immers slechts tijdelijk. ${ }^{135}$

De volgende vraag is wat onder het in beslag genomen 'voorwerp' dient te worden verstaan. Onder het begrip 'voorwerp' in art. $94 \mathrm{~Sv}$ dient volgens Melai niet te worden verstaan 'vordering'. ${ }^{136}$ Uit aantekening 4 bij art. $94 \mathrm{~Sv}$ valt op te maken dat onder voorwerpen moeten worden verstaan roerende goederen. Vellinga-Schootstra is iets meer uitgesproken. Volgens haar duidt het begrip 'voorwerp' in art. 94 Sv erop dat de wetgever bij de inbeslagneming het oog gehad heeft op stoffelijke zaken. ${ }^{137}$ 'Gegevens'vallen hier dus niet onder art. 94 Sv.

Het hof Arnhem daarentegen was van mening, in een zaak die betrekking had op het kopiëren van een computerprogramma ${ }^{158}$, dat onder het begrip 'goed" ook begrepen moet worden 'gegevens. ${ }^{1399}$ Volgens het Hof moeten "een computerprogramma, of meer gespecificeerd, gegevens, worden beschouwd als overdraagbaar, reproduceerbaar, beschikbaar en economisch waardeerbaar. "Het Hof Arnhem rekte in deze uitspraak het begrip 'voorwerpen' dusdanig op dat daar ook 'gegevens' onder vielen.

De Commissie Computercriminaliteit (in de wandeling de Commissie Franken, genoemd naar de voorzitter) was het hier niet mee eens. ${ }^{40}$ Volgens haar rapport 'Informatietechniek en strafrecht'(1987) kunnen gegevens los van een drager niet

135 F. Vellinga-Schootstra, Inbeslagneming en huiszoeking, diss. RU Groningen, Alphen a/d Rijn 1982 ; p. 31 .

136 A.L. Melai, Het Wetboek van Strafvordering, verklaard en van aantekeningen vootzien (losbladig), M.S. Groenhuijsen, Th.A. de Roos en A.H.J. Swart (red.), Arnhem (z.j), want. 5 op art. $552 \mathrm{~b}$.

137 F. Vellinga-Schootstra, Inbeslagneming en huiszoeking, diss. RU Groningen, Alphen a/d Rijn 1982 , p. 25; Handelingen NJV, Preadviezen van F. Vellinga-Schootstra e.a., Gegevensbescherming, 118, deel I, "s-Gravenhage 1988.

138 Hof Arnhem 27-10-1983, NJ 1984, 80.

139 Het Hof beroept zich daarbij woornamelijk op het 'Electriciteits-arrest' HR 21-5-1921, NJ 1921, 564, W 10728 met noot van Taverne. Zie ook M.S. Groenhuijsen, F.P.E. Wiemans, Van elektriciteit naar computercriminalitejt, monografieën strafrecht -9 , Arnhem 1989 , p. 27 e.v.

140 H. Franken e.a, Informatietechniek en strafrecht, Rapport van de Commissie Computercriminaliteit, Staatsuitgeverij, ministerie van Justitite 1987. 
onder het begrip "voorwerp' in art: 94 Sw gebracht worden. ${ }^{141}$ Dit in tegenstelling tot "gegevens" op een drager (zoals bijvoorbeeld een diskette). Deze zijn wel te beschouwen als 'goed' in de zin van art. 94 van het Wetboek van Strafvordering. ${ }^{142}$ Dit laatste is hier van belang. Vallen 'gegevens' op een drager inderdaad onder het begrip "goied'? En kunnen deze woor het aan de dag brengen wan de waarheid in beslag genomen worden? In 1991 deed zich een zaak voor die in dit verband van belang is. ${ }^{\text {is/3 }}$ In de zaak Beslag op videobanden $\mathrm{I}^{\text {njw4 }}$ ging het om de vraag of 'gegevens" op dragers (in casu videobanden) vallen onder het begrip 'goed' in art. $94 \mathrm{~Sv}$ en dus in beslag genomen kurnen worden voor het aan de dag brengen van de waarheild. Door requiranten was bij inleidend klaagschrift aangevoerd, dat

"in casu niet zozeer een woorwerp in beslag was genomen als wel, dat door middel van het beslag beoogd was om 'beslag' te leggen op 'informatie' cq. 'gegevens'. Het doel van het in besllag nemen - derhalve de verkrijging van de banden - was om te kunnen beschikken over de met behulp van deze banden te verkrijgen informatie. Indien het aan het Openbaar Ministerie zou zijn toegestaan het door de pers vervaardigde informatiemateriaal in beslag te nemen, zou dat het risico met zich mee kunnen brengen dat de vrijheid van meningsuiting en drukpers wordt geschondlen. Betogers zullen wegblijven, de pers zal worden geweerd en wan de werkelijkheid kan een vertekend beeld ontstaan, omdat de pers nieuwswaardige feiten tijdens de demonstratie niet meer zal verslaan uit vrees voor interventie van justitie. .145 $^{\text {.14 }}$

De Hoge Raad was het hier niet mee eens.

"De banden zijn voorwerpen in de zin wan de artt. 94, 104 en $105 \mathrm{~Sv}^{14 x}$ en de inbeslagneming is geschied in het kader van een gerechtelijk vooronderzoek terzake van misdrijven, in casu openlijk geweld tegen goederen en personen, gepleegd door nog onbekende verdachten.

141 Zie ook de opvatting van E.J. Dommering, De informatiedrichoek, Enige beschouwingen over de regulering van informatiestromen, rede UvA, Deventer 1989 , p. 31.

1.42 H. Franken e.a., Informatietechnick en strafrecht, Rapport wan de Commissie Computercriminaliteit, Staatsuitgeverij, ministerie van Justitie 1987, p. 78 e.v. De opvattingen van de Commissie sloten impliciet aan bij een arrest van de Hoge Raad van 8-10-1985, NJ 1986, 214.

143 Een tweetal andere zaken zijn: Journalisten stad radio Amsterdam, Hof Amsterdam 2-3-1992 in: Mediaforunin 1992-5, Bijl. p. 33; G.A.I. Schuigt; Politie en pers slaags, noot onder Hof Amsterdam 2-3-1992 in: Mediafiorum 1992-5, p. 61.

144 HR 19-2-1991, in: Mediaforum 1991-5, 2610, Bijl. p. 33 e.w.

145 In Duitsland, Engeland en Zweden wordt een onderscheid gemaakt tussen woorwerpen en gegevensdragers. Zie de hoofdstukken 2,3 en 4.

146 Beslag op videobanden II, HR 19-2-1991, Mediaforum 1991-5, 2610, Bijl. p. 33-37; Voor computersoftware is deze opvatting reeds neergelegd in een uitspraak van het Hof Arnhem 27-10-1983, NJ 1984, 80 en in een arrest van de HR 8-10-1985, NJ 1986, 214 met noot van 't Hart. 
Dït zijn feiten die zowel de nationale als internationale rechtsorde ernstig aantasten en in geen democratische samenleving geduld kunnen worden."

Unt het bovenstaande blijkt dat de Hoge Raad als ook de Commissie Computercriminaliteit bij de inbeslagneming van gegevensdragers de nadruk legt op het begrip 'drager' en niet op het begrip 'gegeven'. In de Wet Computercriminaliteit van 23 december 1992, Stb. 1993, 33 wordt deze interpretatie overgenomen. ${ }^{149}$ Als gevolg hiervan mogen films, video's, pamfletten etcetera in beslag worden genomen voor het aan de dag brengen van de waarheid ${ }^{199}$ (bijwoorbeeld in die gevallen waarin de politie of justitie geïnteresseerd zijn in de 'gegevens' op bijvoorbeeld een film omdat hierop belangrijke aanknopingspunten zouden kunnen staan voor het aan de dag brengen van bijvoorbeeld de identiteit van de verdachte van een strafbaar feit). Dit kan, bijvoorbeeld wanneer journalisten geen copy hebben van de film of video, op gespannen voet staan met de vrijheid van meningsuiting en drukpers (art. 7 Grondwet, art. 10 EVRM en art. 19 IVBPR), de ontvangstvrijheid (art. 7 Grondwet, art. 10 EVRM en art. 19 IVBPR) en de garingswrijheid (art. 19 Universele Verklaring van de Rechten van de Mens, art. 19 (VBPR). Door de inbeslagneming van foto-, filmopnamen of reportages van bijwoorbeeld een demonstratie kan het doel waarvoor deze opnamen zijn gemaakt, te weten publicatie en vertoning van beelden en geluiden van nieuwswaardige feiten, onmogelijk worden gemaakt. ${ }^{\text {isi }}$ Bij teruggave is het materiaal vaak al verouderd. De inbeslagneming kan bovendien financiële consequenties hebben voor een omroep of een krant. Ook kan de inbeslagneming maatschappelijke gevolgen hebben. Omdat journalisten in Nederland geen beroep kunnen doen op het verschoningsrecht ${ }^{\text {tsn }}$ zullen derden die informatie verschaffen aan medewerkers

147 Zie ook 'Beslag op Videobanden', Rb. 's-Gravenhage 15-5-1990 met noot van Willem F. Korthals Altes in: Mediaforum 1990-9, p. 91.

148 Wer wan 23-12-1992 tot wijziging van bet Wetboek van Strafrecht en van het Wetboek van Strafvordering in werband met de voortschrijdende toepassing wan informatietechnick (Wet Conputercriminaliteit), Stb. 1993, 33.

149 De Wet Computercriminaliteit maakt het zelfs mogelijk om onstoffelijke zaken waaronder gegevens die zijn opgeslagen of worden overgedragen met het oogmerk om de mens informatie ter beschikking te stellen als cok gegevens die sllechts bedoeld zjin om een computer te sturen (programmagegevems) in beslag te nemen. Wet van 23-12-1992 tot wijziging vam het Wetbock van Strafrecht en van het Wetboek van Straffordering in verband met de voortschrijdende toe passing wan informatietechnick (Wet Computercriminaliteit), Stb. 1993, 33; MvT bij de Wet Computercriminaliteit, TK 1989-1990, 21551 , nr. 3, p. 5.

150 Beslag op videobanden II, HR 19-2-1991, cassatiemiddel ad IV in: Mediaforum 1991-5, 2610, Bijl. p. $35=36$.

151 In de zaak KGB-affaire, HR 11-11-1977, NJ 1978, 399 (NJCM-Bulletin 1985, p. 50-56 met noot van $\mathbb{F}$. Kuitenbrouwer) besliste de Hoge Raad dat de stelling dat de journalist een verschoningsrecht toekomt in haar algemeenheid niet kan worden aarvaard. Met de woorden "niet in zijn algemeenheid kan worden aanvaard" gaf de HR een opening voor witzonderingsgevallen. Het Hof in Den Haag maakte gebruik wan deze door de HR geboden opening (Hof 24-11-1991, nr. 93.6307). Het Hof vindt het in een democratische samenleving van groot belang dat door de nicuwsgaring van de 
bij de media voorzichtiger worden. Journalisten lopen het gevaar te worden gezien als handlangers van justitie. Bovendien zal op de lange termijn een journalist, bij bijyoorbeeld demonstraties, nieuwswaardige feiten niet verslaan uit vrees voor interventíe van justitie. Mensen zullen dalardoor geconfronteerd worden met een vertekend beeld wan de werkelijkheid omdat ze bepaalde informatie niet meer ontwangen. Ik ben dan ook van mening dat bij de inbeslagneming van gegevensdragers voor het alan de dag brengen van de waarheid niet het accent behoort te liggen op 'dragers" maar op 'gegevens". Er bestaat immers een wezenlijk verschil tussen de inbeslagneming woor het aan de dag brengen van de waarheid en de inbeslagneming ter verbeurdverklaring of ontrekking aan het verkeer. In het eerst genoemde geval vindt geen verbeurdverklaring of onttrekking aan het verkeer plaats van de 'dragers' van informatie. Het gaat hier immers om het verkrijgen van informatie en niet om het beeindigen van op zichzelf strafbare feiten zoals opruiende of pornografische geschriften. Bij de verbeurdverklaring of onttrekking aan het verkeer gaat het niet alleen om de "informatie" maar ook om het voorwerp, oftewel de "drager" van informatie. Dexe 'dragers' kunnen in beslag worden genomen in het belang van een eventuele verbeurdverklaring of onttrekking aan het verkeer.

De huidige regeling is in tweererlei opzicht niet consequent. Niet alleen worden de verschillende achterliggende ideeën bij de inbeslagneming voor het aan de dag brengen van de waarheid en de inbeslagneming ter ontrekking aan het verkeer en ter verbeurdverklaring op een hoop gegooid ook is het niet consequent met de ene hand te geven en met de andere hand weer te nemen. Het eerste heb ik hierboven reeds uitgelegd. Met het laatste bedoel ik het volgende. Enerzijds mag op grond van het Wetboek van Strafvordering beeldmateriaal en dergelijke in beslag worden genomen door de politie voor het aan de dag brengen van de waarheid. Daardoor is het in sommige gevallen op dat moment niet meer mogelijk het beeldmateriaal te publiceren. Terwijl anderzijds in de 'Leidraad over de positie van de pers bij politie-optreden" van 9 mei 1988 staat dat "maatregelen er niet op gericht mogen zijn dat bepaalde publicaties onmogelijk gemaakt worden." Dit is tegenstrijdig. Immers als conform deze leidraad het vervaardigen van reportages en opnamen niet onmogelijk gemaakt mag worden dan is daarmede niet in overeenstemming dat de gemaakte

media misstanden aan het licht komen. Het spreekt vanzelf dat dat bellang in hoge mate gediend is als de journalust de identiteit ven zijn bronnen niet hoeft te onthullen. Anders droogt de informatie op. Y p. $v$, de joumalist kan beter de geheimschendende ambtenaar worden aangepakt door een strafrechtelijk onderzoek uit te lokken. Vgl. HR 18-5-1979. NJ 1980, 213, NJCM-Bulletin 1985, p. 310-318 met noot wan F. Kuitenbrouwer; Hof Amsterdam 16-2-1989, ongepubliceerd, te kennen uit W.F. Korthals Altes dissertatie 'Nare en journalistiek priwilege, Amsterdam 1989, P. 15; P.J.R. Habraken, Het lek van Nootdorp, Beschouwingen over het verschoningsrecht wan journalisten, AA 1989, p. 825-833; Volgens minister de Ruiter in HTK 1982-1983, nrs. 57 en 172 getuigt het van "wijs beleid" wanneer de met opsporing en verwolging belaste organen een "grote terughoudendheid" in acht nemen tegenover journalisten. Ook wanneer het belang van Strafvordering onder omstandigheden zwaarder weegt dient duidelijk te bljken dat de inlichtingen niet op een andere
wijze achterhaald kunnen worden. 
opnamen vervolgens in beslag worden genomen. Ook is dit niet in overeenstemming met de richtlijn van de procureurs-generaal bij de gerechtshoven (juli 1981) waarin staat dat journalisten hun werkzaamheden zo goed mogelijk moeten kunnen verichten. ${ }^{152}$ Volgens Korthals Altes dienen eerst voldoende pogingen in het werk te worden gesteld om het bewijsmateriaal op een andere wijze te verkrijgen. ${ }^{153}$ Hij doelt hiermee op het subsidiariteitsbeginsel. Ook moet er eerst worden gekeken of het materiaal daadwerkelijk zal worden gebruikt om de waarheid aan de dag te brengen (richtlijnen voor het beleid van het Openbaar Ministerie en de politie inzake inbeslag* neming). ${ }^{154}$ Dat er ondanks deze leidraad en richtlijnen toch beeldmaterialal in beslag wordt genomen komt doordat de wet geen beperkende voorwaarden stelt. Volgens Jurgens moet de rechter een aanknopingspunt hebben in de wet. ${ }^{15 s} \mathrm{Nu}$ de vrijheid van meningsuiting en drukpers, en dan in het bijzonder de ontvangst- en garingsvrijheid, in het gedrang kunnen komen dient wettelijk te worden vastgelegd dat het journalistiek privilege uitgangspunt is. In zijn Voorontwerp wan Wet op het Journalistiek Privilege en in zijn initiatiefvoorstel van Wet (4 mei 1993) ) $^{\text {156 }}$ zegt hij dat wanneer het gaat om de inbeslagneming voor het aan de dag brengen van de waarheid het accent ligt op 'gegevens' ${ }^{1.57}$ Gegevens op dragers mogen, wanneer het gaat om journalistieke werkzaamheden niet in beslag worden genomen. ${ }^{15}$ Hieronder vallen zowel eigen materiaal als materiaal van derden verkregen. Het begrip journalistiek" duidt op de soort van werkzaamheid, het moet gaan om journalistieke werkzaamheden, en 'privilege' ${ }^{\text {'159 }}$ betekent dat een journalist niet langer verplicht is zijn

152 De richtlijn is gepubliceerd in de 'Leidraad over de positie van de pers bij polifie-optreden'.

153 W.F. Korthals Altes, Beslag op videobanden, noot bij beschikking Rb. "s-Gravenhage 15-5-1990 in: Mediaforum 1990-9, p. 91; R.A. Vecht, Informatieverstrekking door de media, Mediaforum 1991-1, p. 6.

154 Im: F. Vellinga-Schootstra, Inbeslagneming en huiszocking, diss. RU Groningen, Alphen a/d Rijn 1982, Biji. 1, p. 289.

155 Jurgens wil het rechtersrecht - geen verschoningsrecht, tenzij - vervangen door een wettelijke regel ondat dit meer rechtszekerheid biedt; Zie ook het Europees Parlement dat begin 1994 in een resolutie aandrong op een wettelijke regeling in alle Janden van de Europese Unie. Resolutie A30434/93, Publicatieblad EG C 44/34 d.d. 14-2-1994.

156 Voorstel van Wet en MVT, TK 4-5-1993, 23133, nrs. 1-3.

157 E. Jurgens en C.J. Glorie, Wet op het Journalistiek Privilege, Mediaforum 1991-2, Bijl. p. 13; E. Jurgens, Een journalistiek verschoningsrech!!, Mediaforum 1991-2, p. 13; E. Jurgens, Nogmaals: Journalistiek "verschoningsrecht", Mediaforum 1991-11/12, p. 119. Ook in andere landen zijn op dit terrein ontwikkelingen gaande. Zie Hugo Coveliers, Verschonüngsrecht, ook in Belgie?, Mediaforum 1991-5, p. 56; Patricia Wilhelm, Protection of Sources, An International Review of Journalistic and Legal Practice, The Norwegian Institute of Journalism, International Federation of Journalism, Frederikstad 1988; H.M. van Niftrik, Spreken is zilver, zwijgen een privilege, Mediaforum 1990-3; p. 33; R.A. Vecht, Informatieverstrekking door de media, Mediaforum 1991-1, p. 4 e.v; T. Koopmans, Het verschoningsrecht van de journalist, Preadvies, Deventer 1978.

158 Voorstel van Wet en MvT, TK 4-5-1993, 23133, nrs. 1-3.

159 Het begrip 'privilege' is hier meer op zijn plaats dan het begrip 'verschoningsrecht" omdat hier het element van hulpwerlening ontbreekt en er geen plicht tot geheimhouding te construeren valt. 
bronnen te onthullen. ${ }^{\text {it }}$ Zo wordt vermeden dat journalisten worden gezien als een verlengde arm van politie en justitie. ${ }^{161}$ Verder wordt voorkomen dat journalistiek material, zoals dat nu in Nederland het geval is, in beslag genomen (en teruggegeven) wordt zonder dat een rechtscollege zich inhoudelijk over de rechtmatigheid van het beslag een mening heeft kunnen vormen.

Ik ben het met Jurgens eens dat door wettelijk vast te leggen dat het journalistiek privilege en het inbeslagnemingsverbod als uitgangspunt dient, de rechter, in het concrete geval, slechts bij aanwezigheid van zeer dringende redenen, en rekening houdend met het proportionaliteits- ${ }^{\text {i6s }}$ en subsidiariteitsbeginsel ${ }^{14}$, het gaat hier immers om een bestanddeel van de communicatievrijheid en wel om de vrijheid van nieuwsgaring, zal kunnen komen tot een inbreuk op dit recht. ${ }^{\text {is }}$ Als zeer dringende reden noemt Jurgens dan misdrijven waardoor zwaar lichamelijk letsel is toegebracht en de misdrijven die worden genoemd in art. $98 \mathrm{Sr}$ (o.a. misdrijven tegen de staatsveiligheid). ${ }^{\text {it }}$ Daarbij geldt ook weer als voorwaarde dat de politie of justitie eerst zelf moet proberen de gewenste informatie te vergaren. Ook nu dient er dus

Ook ontbreekt een tuchtrechtelijke regeling bij het journalistieke beroep. E. Jurgens, Nogmaals: Journalistiek 'verschoningsrecht', Mediaforum 1991-11/12, p. 120.

$160 \mathrm{Nu}$ is een journalist nog verplicht te getuigen (art. $191 \mathrm{Rv}$ ), op straffe van dwangsom. De getuige is onder ede verplicht de waarheid te zeggen (art. $203 \mathrm{Rv}$ ). De journalist hoeft in het wetswoorstel ên als procespartij ên als getuige zijn bron niet te onthullen. In beide gevallen liep en loopt hij wel alls gedaagde in een civiel proces de kans het proces te verliezen wanneer hij iets beweert dat hij op geen andere manier kan staven dan met een beroep op een anonieme bron. E. Jurgens, Nogmaals: Journalistiek "verschoningsrecht", Mediaforum 1991-11/12, p. 121; O. de Jong, Zonder 'besloten beroep' werschoningsrecht mogelijk, De journalist 1991, p. 30; Lex Dura, Verschoning in: Vrij Nederland 9-2-1991, nr. 6.

$161 \mathrm{C}$. Glorie, Opsporing verzocht, Inbeslagneming van journalistiek materiaal. Journalist verlengstuk van justitie?, doctoraal scriptice UvA, Instituut woor Informatierecht.

162 Immers de klager verlest zijn belang zodra het inbeslaggenomene is teruggegeven, Rb. Rotterdam 15-7-1988; Willem F. Korthals Altes, Beslag op vidicobanden, noot bij beschikking Rb. "s-Gravenhage 15-5-1990 in: Medialorum 1990-9, p. 91 .

163 Inbeslagneming is slechts in zeer uitzonderlijke situaties te rechtvaardigen. Bijvoorbeeld bij zeer zware misdrijven, reële gewaarzetting of misstanden die anders nict het daglicht zouden hebben gezien. In eerste instantic zal moeten worden bekeken in hoeverre de politie of jusititie zelf redelijkerwijs bij machte is de gewenste informatie te vergaren. R. A. Vecht, Informatieverstrekking door de media, Mediaforum 1991-1, p. 6; Inge Brakman en Reinier Hopmans, NJV Positief over verschoningsrecht voor journalisten, Mediaforum 1991-5, p. 55.

164 R.A. Vecht, Informatieverstrekking door de media, Mediaforum 1991-1, p. 6; Inge Brakman en Reinier Hopmans, NJV Positief over verschoningsrecht voor journalisten, Mediaforum 1991-5, p. 55; W.F. Korthals Altes ${ }_{\mathrm{u}}$ Beslag op videobanden, Mediaforum 1990-9, p. 91.

165 Inge Brakman en Reinier Hopmans, NJV Positief over verschoningsrecht voor journalisten, Mediaforum 1991-5, p. 55; Nederlandse Juristen Vereniging, Brochure Verschoningsrecht, 1989.

166 Zie het voorgestelde art. 218 a Sv dat verwijst naar art. $98 \mathrm{Sr}$ in: E. Jurgens en C.J. Glorie, Wet op het Journalistiek Privilege, Mediaforum 1991-2, Bijl. p. 18. 
rekening te worden gehouden met het proportionaliteits- en subsidiariteitsbeginsel. ${ }^{10}$ Ik kan mij wel vinden in het criterium zwaar lichamelijk letsel, mazir niet in het criterium "staatsvelligheid" omdat ik dit criterium, nu een grondrecht in het geding kan zijn, te vaag vind. Zwaar lichamelijk letsel is voldoende feitelijk en concreet: ${ }^{170}$ Eenvoudige mishandeling is niet voldoende om een inbreuk op het inbeslagnemingswerbod en het verschoningsrecht te rechtvaardigen. Dwangmiddelen zoals de voorlopige hechtenis zijn immers ook eerst mogelijk bij zware mishandeling. In de volgende hoofdstukken zullen we zien hoe deze problematiek is uitgewerkt in andere landen.

\subsubsection{De inbeslagneming ter verbeurdverklaring en de vrijheid van meningsuiting en drukpers in art. 7 van de Grondwet}

In tegenstelling tot de inbeslagneming van een voorwerp voor het aan de dag brengen van de waarheid wordt bij de inbeslagneming ter verbeurdverklaring geanticipeerd op het oordeel van de rechter waarbij het goed bij een veroordeling wegens enig strafbaar feit definitief aan de macht van de veroordeelde wordt onttrokken. ${ }^{17}$

De verbeurdverklaring is een vermogensstraf. ${ }^{172} \mathrm{Het}$ doel van de verbeurdverklaring is niet alleen leedtoewoeging, maar ook preventie. Er wordt door de verbeurdverklaring van voorwerpen een einde gemaakt aan een onrechtmatige situatie. De dader wordt getroffen in die goederen die hij door het delict heeft verkregen of die hem bij het plegen ten dienste stonden. Wanneer er meerdere voorwerpen van dezelfde soort worden aangetroffen kan inbeslagneming platsvinden door de politie van de gehele voorraad. Zo kan bij verdenking van het ter verspreiding in voorraad hebben van pornografie (artt. $240,240 \mathrm{a}_{*} 240 \mathrm{~b} \mathrm{Sr}$ ), beslag worden gelegd op alle pornografische geschriften met het oog op de verbeurdverklaring. Meestal zal dat niet gebeuren.

167 D. Voorhoof en J. Bact, Rechter en perswijheid (Tribunes), Tegenspratak 1984, p. 16; D. Voorhoof, De zaak Melro: een aanslag op de perswrijheid?, Panoplicon 1985, p. 228; W. Verwey, Inval bij de Morgen alweer vergeten! in: Documentatie Censuur, Studium Generale, Nijmegen 1988, p. $35-36$.

168 Wetten dienen helder en düdelijk te zijn (legaliteitsbeginsel). M.C. Burkenis e.a., Beginselen wan de democratische rechtsstaat, Inleiding tot de grondslagen van het Nederlandse staats en bestumursrecht, Zwolle 1992 , p. 29 e.v.

169 Inge Brakman en Reinier Hopmans, NJV Postief over verschoningsrecht voor journalisten, Mediaforum $1991-5$, p. 55 .

170 M.C. Burkens, Algemene leerstukken van grondrechten naar Nederliands constitutioneel recht, Handboeken staats- en bestuurstecht, deel 11, Zwolle 1989, hoofldstuk 7 Grondrechtsconflicten en hoofdstuk 8 horizontale werking van grondrechten. Deze onderwerpen blijwen binnen het kader wan dit onderzoek buitten beschowwing.

171 F. Vellinga-Schootstra, Inbeslagneming en lhuiszoeking, diss. RU Groningen, Alphen a/d Rijn 1982 , p. 31 e.\%.

172 M.E. W. Muskens, H.M. Poelman, Art. 33a Sr: verbeurdverklaring en 'derden', DD 1985 , p. 844 e. $v_{n}$ 
Immers de rubricering van de verbeurdverklaring als bijkomende straf impliceert dat de oplegging facultatief is. De verbeurdverklaring behoeft niet steeds te worden voorbereild door de inbeslagneming. Ook niet in beslag genomen voorwerpen kunnen worden verbeurd verklaard. De inbeslagneming dient er enkel toe orm te voorkomen dat het goed door de betrokkene wordt weggemaakt zodat de executie wan de verbeurdverklaring onmogelijk wordt. Omdat de inbeslagneming niet noodzakelijk is, heeft de beslagleggende ambtenaar een grote beleidsvrijheid bij het beslissen of het voorwerp wel of niet in beslag genomen dient te worden. Bepallend is daarbij niet slechts, volgens de Commissie Vermogensstraffen, of het goed formeel naar redelijk vermoeden vatbaar is voor inbeslagneming, maar ook of de inbeslagneming gezien de daarbij betrokken belangen niet (kennelijk) onredelijk is. De Commissie Vermogensstraffen heeft in haar eindrapport voorgesteld om in art. 94 Sv op te nemen dat andere voorwerpen dan die welke kunnen dienen om de waarheid aan de dag te brengen alleen in beslag kunnen worden genomen wanneer de opsporingsambtenaar redelijkerwijs kan verwachten dat zij door de rechter zullen worden verbeurd verklaard. ${ }^{\text {t3 }}$ Volgens de Commissie is er dus meer nodig dan enkel het voldaan hebben aan de formele vereisten voor verbeurdverklaring. Er zal bij de inbeslagneming ook rekening moeten worden gehouden met de beginselen van een behoorlijke strafrechtspleging, die onder meer meebrengen dat de inbeslagneming achterwege moet blijven wanneer deze duidelijk onredelijk zou zijn. Wanneer wordt overgegaan tot de inbeslagneming van een gehele oplage kan het proportionaliteits- en subsidiariteitsbeginsel zijn overschreven. ${ }^{17}$ Ook bij de inbeslagneming ter verbeurdverklaring dient rekening te worden gehouden met het proportionaliteits-en subsidiariteitsbeginsel.

4.3.3 De inbeslagneming ter onttrekking aan het verkeer en de vrijheid van meningsuiting en drukpers in art. 7 van de Grondwet ${ }^{75}$

Tussen de inbeslagneming ter verbeurdverklaring en de inbeslagneming ter onttrekking aan het verkeer bestaan een aantal opmerkelijke verschillen. Allereerst is er

173 Eindrapport van de Commissic Vermogensstraffen, Staatsuitgeverij, 's-Gravenhage 1972; Richtlijnen voor het beleid wan het Openbaar Mimisterie en de politie inzake inbeslagneming, Staatscourant 2-6-1980, nr. 103.

174 D. Voorhoof en J. Bacr, Rechter en perswrijheid (Tribunes), Tegenspraak 1984, p. 16; D. Voorhoof De zaak Metro: een aanslag op de perswrijheid?, Panopticon 1985, p. 228; W. Verwey, Invall bij de Morgen alweer vergeten! in: Documcntatie Censuur, Studium Generale, Nijmegen 1988, p. $35-36$.

175 De regeling van de inbeslagneming ter onttrekking aan het verkeer is in de plats gekomen van de 'vernietiging of onbruikbarmaking' in art. 354 Sv (oud) bij de wet van 22 mei 1958, Stb. 296. Zie de preadviczen van de. NJV 1948 en 1954 in het bijzonder de bjjdragen van Bakhowen, Van Rijn van Alkemade, Hollander en Bockwinkel; J. Remmelink, Iets over de verbeurdverklaring en onttrekking aan het verkecr, N.IB 1965, p. 85 c.v. en p. 109 e.v. 
een verschil van wetssystematische aard. Een straf kan slechts worden opgelegd bij een veroordeling (art. $351 \mathrm{~Sv}$ ) terwijl een maatregel, in casu de onttrekking aan het verkeer, ook op grond van art. 36b Sr kan worden opgelegd bij een afzonderlijke rechterlijke beslissing, los van de veroordeling en straftoemeting. ${ }^{176}$ Immers de rechterlijke beslissing, waarbij de goederen worden onttrokken verklaard, kan behalve binnen het kader van een normale procedure eindigend met een eindbeslissing, ook genomen worden door de raadkamer, los van een veroordeling, in een speciale door het Openbaar Ministerie langs de weg van bij een afzonderlijk ingediende vordering uitgelokte beslissing (art. 552f Sv) ${ }^{i 7 t}$ De raadkamerprocedure voldoet niet aan het openbaarheidsvereiste van art. 6 EVRM. Nu het hier bij de strafvorderlijke inbeslagneming kan gaan om de inbeslagneming van gegevensdragers vraag ik me af of de procedure niet openbaar behoort te zijn. Immers, zoals we in het voorafgaande hebben kunnen lezen, kan bij de inbeslagneming van gegevensdragers de vrijheid van meningsuiting en drukpers in het gedrang komen. In paragraaf 4.7 waar de beklagprocedure wordt besproken zal deze problematiek nog nader aan de orde komen.

Verder is bij de inbeslagneming ter onttrekking aan het verkeer, in tegenstelling tot de inbeslagneming ter verbeurdverklaring, de inbeslagneming een noodzakelijke voorwaarde. Dit blijkt uit de tekst van art. 36c Sr. Het doel van de inbeslagneming ter onttrekking aan het verkeer is beveiliging van de maatschappij. Het betreft bier een typische politie- $\propto$. veiligheidsmaatregel ten dienste van justitie. Voor de opsporingsambtenaar betekent dit dat de waarderingsvrijheid ten aanzien van de vraag of het naar redelijk vermoeden voor inbeslagneming ter onttrekking vatbare voorwerp wel of niet in beslag moet worden genomen, kleiner is dan bij de inbeslagneming ter verbeurdverklaring. Immers door af te zien wan inbeslagneming ontneemt hij de rechter de mogelijkheid om het voorwerp aan het verkeer onttrokken te verklaren. Kennelijke onredelijkheid van de inbeslagneming zal dan ook minder snel worden aangenomen. ${ }^{178}$ Wanneer er meerdere voorwerpen wan dezelfde soort worden aangetroffen kan al snel inbeslagneming plaatsvinden wan de gehele woorraad. De vraag

176 D. wan der Landen, Straf en maatregel, diss. KU Brabant, Arnhem 1992, p. 11.

177 In de MvT kan men lezen, dat men bij deze procedure had gedacht aan die gevallen waarin helemaal geen uitspraak wordt gedaan bijwoorbeld omdat de dader overleden, onbekend is of om een andere reden nict te berechten is. Over de wijze waarop het aftonderlijk procesje gevoerd moet worden geeft de wet in art. $552 \mathrm{fv}$ enkele summiere woorscliriften. Zo wordt gesteld, dat de beschikking niet wordt gegeven dan op cen met redenen onklede wordering wan de officier. Zulks zal impliceren dat het $O M$ in zijn vordering duidelijk doct uitkomen, welke de onderliggende strafzaak is: waarom het goed in beslag genomen is en zall hij de voorwaarden die zi. de onttrekking legitimeren moeten wermelden. Pas nadat de belanghebbende in de gelegentheid is gesteld to worden gelloord, neemt de rechter zijn beslissing. Deze moet net redenem zijn onkleed en wordt onverwijld aan de belang. hebbende, zo deze bekend is, betekend. MVT, Bujl. HTK 1954-1955, 4034; Noyon-Langemeijer/Rem. melink, Het Wetboek van Strafrecht, 1984, Boek 1, Titel ILA, art. 36b, p. 188 a.

$178 \mathrm{~F}$. Vellinga-Schootstra, Inbeslagneming en huiszocking, diss. RU Groningen, Alphen a/d Rijn 1982 , p. 36. 
wis alleen hoe zich dit verhoudt tot de vrijheid wan meningsuiting en drakpers. Dreigt de drukperswrijheid niet illusoir te worden indien de mogelijkheid bestaat dat bepaalde meningsuitingen niet via de drukpers kumen worden verspreid? Kan de inbeslagname wan een substantieel gedeelte of de gehele oplage van bijwoorbeeld een tijdschrift gezien worden als een ongrondwettelijke maatregel, en dus als een fundamentele aantasting van de drukpersvrijheid? In de zaak Bluf! 'kwam deze vraag expliciet aan de orde. Het ging in deze zaak om de spanning tussen de inbeslagneming ter onttrekking aan het verkeer en de vrijheid van meningsuiting en drukpers. In de volgende paragraaf zal ik de zaak Bluf! weergeven omdat deze zaak exemplarisch is voor bovengenoemde problematiek. Daarbij komen zowel de visie van de Hoge Raad als de visie van de Europese Commissie aan de orde. Ook de opvattingen in de literatuur worden besproken.

\subsubsection{Bluf!}

In de zaak Bluf! stond de publicatie van een oud kwartaaloverzicht van de BVD uit 1981 centraal. In het weekblad Bluf! nr. 267 werd dit kwartaaloverzicht afgedrukt. Toen Bluf! nr. 267 net van de pers kwam en voor verzending gereed gemaakt werd viel een politiemacht binnen bij de drukker en nam de hele oplage in beslag op grond van de artt. $98 \mathrm{en} /$ of $98 \mathrm{a} \mathrm{Sr}$ (staatsgeheimen) in het kader van een gerechtelijk vooronderzoek tegen NN. Doordat de politie en rechter-commissaris wel alle papier in beslag namen maar vergaten de drukplaten mee te nemen vond er een herdruk plaats en de volgende dag; koninginnedag, werd Bluf! nr. 267 alsnog uitgedeeld aan het publiek."

Op vordering van de officier van Justitie werd de gehele oplage van het weekblad Bluf! van 29 april 1987 door de rechtbank te Amsterdam onttrokken aan het verkeer (vergelijk art. 36c Sr). De inhoud van Bluf! mr. 267 kon -zo werd door de officier van Justitie gesteld en door de rechtbank aangenomen- niet door de beugel; geheimhouding was, met het oog op de veiligheid van de staat of zijn bondgenoten, geboden (artt. 98 en/of $98 \mathrm{a} \mathrm{Sr}$ ). Bluf! tekende tegen de beschikking van de rechtbank cassatieberoep aan bij de Hoge Raad. De belangrijkste argumenten van Bluf! waren:

1. Dat de drukperswrijheid betekent dat alleen achteraf, dus na publicatie ${ }^{1 * 0}$, door een strafrechter besloten kan worden dat een oplage moet worden verbeurd verklaard of onttrokken aan het verkeer. Door de helle oplage van te voren ${ }^{\text {ga }}$ in

179 Ties Prakken, De affaire Bluf!, Crimineel Jaarboek 1989, p. 134; Ties Prakken, Met de NJ de politiek in? NJB 1990; p. 460.

180 Bedoeld wordt hier volgens mij na openbaarmaking en verspreiding.

181. Met wan te voren wordt hier waarschijnlijk bedoeld "voor de verspreiding". 
beslag te nemen zou justitie censuur hebben uitgeoffend. Art. 7 van de Grondwet laat slechts repressieve controle van de staat op publicaties toe. ${ }^{122}$

2. Bovendien komt daar nog bij dat om het beslag te handhaven een aparte wordering tot onttrekking aan het verkeer nodig is. Wel moet dan zijn vastgesteld dat het feit strafbaar is en het ongecontroleerd bezit van de in beslag genomen oplage in strijd is met de wet of het algemeen belang. Doordat de inhoud van het onderhavig in beslag genomen materiaal te gedateerd is om nog te kunnen spreken van schending van staatsgeheimen en als gevolg van de gehouden straatverkopen, is de ongewenst geachte publicatie reeds een feit zodat het belang van de inbeslagneming komt te vervallen. Het in beslag genomene dient dan ook te worden teruggegeven worden omdat er geen belang van strafvordering meer is dat het beslag vereist. Het algemeen belang is door de herdruk all geschonden.

Volgens de Hoge Raad is de inbeslagneming van het weekblad Bluf! niet in strijd met art. 7 van de Grondwet immers dit artikel vindt zijn beperking in de zinsnede 'behoudens ieders verantwoordelijkheid volgens de wet'. Voorts zijn er op het in art. 10 EVRM en art. 19 IVBPR neergelegde recht op de vrijheid van meningsuiting beperkingen toegelaten bij het tweede lid van die bepalingen, die volgens de verklaring van de officier van Justitie, in het onderhavige geval van toepassing zijn. Het Openbaar Ministerie gaat vooral uit van art. 98 en $98 \mathrm{a} \mathrm{Sr}$.

"Tot de middelen waarmee de belangen, die de artt. 98 en $98 \mathrm{a} \mathrm{Sr}$ beogen te beschermen, behoren niet alleen de strafrechtelijke vervolging en eventuele veroordeling van degenen die de in deze artikelen strafbarr gestelde feiten hebben begaan, maar ook de inbeslagneming en de onttrekking aan het verkeer volgens de bepalingen van het Wetboek wan Strafvordering van voor het begaan van zodanige feiten bestemde drukwerken. Toepassing van deze middelen valt te rekenen tot de bij de genoemde verdragsbepalingen toegelaten beperkingen van het in die bepaling verzekerde recht en kan niet worden gelijkgesteld met het onderwerpen aan de voorwaarde van 'voorafgaand verlof' als bedoeld in voormeld grondwetsartikell, ook al wordt als gevolg daarvan het desbetreffende drukwerk met de daarin neergelegde gedach" ten en gevoelens niet openbaar. ${ }^{\text {nis }}$

Er was hier dus geen sprake van censuur. De inbeslagneming en de onttrekking aan het verkeer waren volgens de Hoge Raad in de zaak Bluf! géen beperkingen die konden worden gelijkgesteld met het onderwerpen aan de voorwaarde van voorafgaand verlof als bedoeld in art. 7 lid 1 Grondwet.

Ook Van Veen onder het arrest van Hoge Raad 18 sept. 1989, NJ 1990, 94 is van mening dat "er geen sprake is van censuur bij de inbeslagneming en onttrekking aan het verkeervan reeds gedrukte stukken, die gereed zijn voor verspreiding en waarvan

182 Preventieve beperkingen mogen niet ten aanzien van de inhoud matr well ten aanzien van de verspreiding zolang er maar gebruik wan enige betekenis owerblijft. Zie $\$ 4.3$.

183 De Hoge Raad zal hier in plaats wan 'niet openbaar', 'niet verspreid" bedoeld hebben. 
het voorradig hebben om de inhoud van die stukken strafbaar is. "Nu de ingreep pas plaats vond na de openbaring maar voor de verspreiding valt er strikt genomen niets op aan te merken. Dat wil zeggen dat het hier om een repressieve maatregel gaat. ${ }^{184}$

De vraag is of hier inderdaad niets op aan te merken valt. Waar het in bovengenoemde discussie om draait is het onderscheid tussen preventieve en repressieve beperkingen. Preventieve beperkingen ten aanzien van de inhoud zijn verboden op grond van art. 7 lid 1 en 3 van de Grondwet. Zo mag de lagere overheid nooit het openbaren zelf reguleren via voorafgaand verlof of door middel van het geven van regels met betrekking tot de inhoud van gedachten en gevoelens. Slechts achteraf (repressief) kunnen door de rechter grenzen worden gesteld aan de vrijheid van meningsuiting en drukpers bij een wet in formele zin.

Iets anders zijn preventieve beperkingen ten aanzien van de verspreiding van gegevensdragers. Daarover ging het in de zaak Bluf! De verspreiding van bijvoorbeeld geschriften die vermeende staatsgeheimen bevatten, mag wel beperkt worden door de politie in het belang van de openbare orde of de veiligheid van anderen zolang er maar geen sprake is van een 'algeheel verbod'. Van een 'algeheel verbod' is sprake wanneer er geen mogelijkheid meer bestaat om de geschriften te verspreiden, bijvoorbeeld doordat een hele oplage in beslag is genomen. Sinds het Tilburg-arrest, zoals we in paragraaf 2.3 hebben kunnen zien, is het vaste jurisprudentie dat een zelfstandig verspreidingsmiddel "niet in het algemeen verboden mag worden of van een voorafgaand verlof der overheid afhankelijk mag worden gesteld. "mss

Beperkingen mogen op grond van art. 7 lid 1 Grondwet ten aanzien van de verspreiding van gegevensdragers, zoals prentbriefkaarten, schilderijen, tekeningen, foto's, pamfletten, geschriften, maar dienen "gebruikvan enige betekenis van het verspreidingsmiddel over te laten. ${ }^{m \mathrm{~B}}$ Wanneer een hele oplage pamfletten in beslag wordt genomen kan dit op gespannen voet komen te staan met het criterium zoals geformuleerd in de jurisprudentie op art. 7 lid 1 van de Grondwet dat beperkingen gebruik van enige betekenis van het verspreidingsmiddel dienen over te laten.

184 HR 18-9-1989, NJ 1990, 94 met noot van Th.W. Van Veen. Ook volgens R.E. de Winter gaat het hier om een repressieve maatregel. In: De Heersende Leer, Honderd jaar verspreidingsjurisprudentie: 1892-1992, diss. RL, "s-Graventhage 1993, p. 241.

185 HR 28-11-1950, NJ 1951, 137.

186 'Nuth-arrest' HR 17-3-1953, N.J 1953, 389; 'Haarlemse Plakverbod' HR 5-1-1988, Gemeentestem 1989, 6872, p. 77-79 en NJCM-Bulletin 1989, p. $439-446$ met noot wan R.E. de Winter. Het Haarlemse arrest geeft aan dat "(enig) reęel gebruik wan het verspreidingsrecht mogelijk moet zijn." Dit is een nog positievere benadering van het Nuth-criterium waarbij als maatstaf gold "of de gemeentelijke regeling wel gebruik van enige betekenis overlaat." Plakken mag sinds het Haarlemse arrest niet meer van toestemming afhankelijk worden gesteld. De overheid moet er voor zorgen dat er voldoendle plakmogelijkheden zijn. De overheid mag zich bovendien weinig gelegen laten liggen aan de houding van het publiek ten opzichte van de uit te dragen meningen. Zie ook 'Alkmaarse marktkraamactie", ARRS 8-4-1988, AB 1989, 88 met noot van P.J. Boon; J.M. de Meij, De feitelijke nuogelijkheid tot vrije meningsuiting, Mediaforum 1989-2, p. 16 e.v. Deze arresten dienen ter ondersteuning van de stelling dat het verspreidingsrecht serïeus genomen moet worden. 
Ook op grond van art. 7 lid 3 Grondwet zijn beperkingen toegestaan. Art. 7 lid 3 heeft zoals we in paragraaf 2.4 .2 hebben gezien betrekking op 'gedachten en gevoelens'. Hieronder vallen onder andere fillms, bandopnamen. De verspreiding hiervan kan beperkt worden maar zo heeft de Afdeling Rechtspraak in de Alkmaarse marktkraamactie uitgemaakt "deze voorschriften op grond van plaats, tijd en wijze van openbaarmaking mogen niet zover gaan dat daardoor het feitelijk functioneren van het recht om door deze andere middelen gedachten of gevoelens te openbaren volledig onmogelijk wordt gemaakt. ${ }^{\text {mbt }}$ De verspreidingsvrijheid is immers een belangrijk onderdeel van de vrijheid van meningsuiting en drukpers. Zonder de verspreidingsvrijheid wordt de vrijheid van meningsuiting en drukpers een lege huls. Dat bovengenoemd criterium geformuleerd is in gevallen waarin het ging om materiële bepalingen doet er volgens mij niet aan af dat ook wanneer het gaat om formele bepalingen, zoals de inbeslagnemingbepalingen in het Wetboek van Strafvordering, met dit criterium rekening dient te worden gehouden. Bij de inbeslagneming van de gehele oplage films kan het feitelijk functioneren van het recht om gedachten en gevoelens te openbaren door middel van het medium film onmogelijk worden gemaakt. ${ }^{1}$ De maatregelen van de overheid, zoals de inbeslagneming van gegevensdragers door de politie, die erop gericht zijn of tot gevolg hebben dat bepaalde meningen niet kunnen worden verspreid kunnen zelfs indirect censuur zijn omdat uitgevers en drukkers voorzichtiger worden bij het openbaar maken van bepaalde gegevens (maatschappelijke gevolgen). Volgens De Meij ligt de grens daar waar de maatregel, in casu de inbeslagneming, een wezenlijke belemmering vormt voor de voortzetting van het publiceren. ${ }^{129}$ De inbeslagneming van drukpersen vormt een wezenlijke belemmering voor de voortzetting van het publiceren. De inbeslagneming van een hele oplage geschriften vormt niet altijd een belemmering voor de voortzetting van het publiceren wel voor de voorzetting van het verspreiden. Nu de verspreiding een wezenlijk onderdeel vormt van de vrijheid van meningsuiting en drukpers geldt volgens mij niet alleen voor het publiceren maar ook voor het verspreiden de regel dat 'de maatregel geen wezenlijke belemmering mag vormen voor de voorzetting van het publiceren en/of verspreiden'. Inbeslagneming kan wel maar dient proportioneel en subsidair te zijn. Wanneer wordt overgegaan tot de inbeslagneming van een gehele oplage zal veelal het proportionaliteitsen subsidiariteitsbeginsel zijn overschreden. Zeker wanneer in beslag wordt genomen

187 ARRS 8-4-1988, AB 1989, 88 met noot van P.J. Boon.

188 In feite kunnen op deze manier matregelen van de overheid die thuishoren in het opsporingsen verwolgingsbeleid als middel aangewend worden om ongewenste activiteiten te dwarsbomen ('détournement de pouvoir').

189 Zie ook de wetsgeschiedenis (minister Modderman) en de wetgeving. Voor drukpersdelicten geldt een speciale wettelijke regeling. Voor de inhoud van het gedrukte zijn niet als eersten aansprakelik de uitgever en de drukker maar dle opdrachtgever van de uitgever of drukker. Is deze bekend of wordt deze door hen bekend gemaakt op de eerste aanmaning nadat tot het instellen van een gerechtelijk vooronderzoek is overgegaan dan worden zij niet vervolgd (art. 53 en 54 Sr). 
bij uitgevers, drukkers (zoals in de zaak Bluf!) of de media is extra voorzichtigheid geboden.

In de zaak Bluf! ging het om vermeende staatsgeheimen. Opvallend in deze zaak is dat de Hoge Raad geen aandacht besteedt aan een nadere motivering van zijn beschikking dat het hier gaat om staatsgeheimen. Zij verwees alleen naar de beperkingen in de desbetreffende grondrechtenbepalingen ('national security') en volstond met de constatering dat de rechtbank niet had blijk gegeven van een onjuiste rechtopvatting. Of artikelen die het stempel geheim hebben gekregen ook inderdaad geheim zijn werd niet nader besproken. Dat de inhoud van Bluf! reeds zes jaar oud was kwam in deze zaak niet aan de orde. In feite nam de Hoge Raad hier niet zijn verantwoordelijkheid want of een bepaald gegeven een staatsgeheim is in de zin van art. $98 \mathrm{Sr}$ is uiteindelijk ter beoordeling aan de rechter. ${ }^{100}$ De betekenis van het begrip 'staatsgeheim' in de artikelen $98-98 \mathrm{c} \mathrm{Sr}$ is ruim. Wanneer een foto of een geschrift een staatsgeheim is staat niet duidelijk in de wet aangegeven. ${ }^{199}$

Dit geldt eveneens voor de vraag of een uitlating beledigend is voor een groep mensen. Deze vraag moet beantwoord worden aan de hand van betrekkelijk vage criteria als 'kwetsend' en 'grievend' die in de rechtspraak op delicten als eenvoudige belediging ${ }^{192}$, smaad en laster zijn gevormd. De verspreider die op de hoogte is of althans ernstige reden heeft om te vermoeden dat in een geschrift of film een belediging voorkomt is al zeer snel strafbaar. ${ }^{103} \mathrm{In}$ art. $137 \mathrm{e} \mathrm{Sr}$ is de verspreiding van discriminatoir beledigend materiaal strafbaar gesteld. ${ }^{1921}$ Dit maakt dat het in

190 A. Heijder, Enkele aspecten van de strafrechtelijke bescherming van staatsgeheimen in: J. Remmelink, Naar eer en geweten, Liber Amicorum, Arnhem 1987, p. 183-184; EK 1950-1951, 1554, ar. 59 (Memorie van Antwoord op thet voorlopig verslag van de Commissie van Rapporteurs).

191 Het moet betreffen "enig gegeven waarvan de geheimhouding door het belang van de staat of van zijn bondgenoten wordt geboden." Het begrip gegeven zal naar de strekking van de wet zo ruim mogelijk moeten worden opgevat dus in de betekenis van alles wat voorwerp van weten kan zijn. Daarbij is niet uitgesloten dat niet de afzonderlijke bijzonderheden het gegeven opleveren, maar het geheel daarvan. Noyon-Langemeijer/Remmelink, Het Wetboek van Strafrecht, 1984, Boek Il, titel 1, art 98 Sr. Zie ook HR 16-12-1958, NJ 1959, 156. Wetten dienen helder en duidelijk to zijn geformuleerd (legalitcitsbeginsel). M.C. Burkens e.a, Beginselen van de democratische rechtsstaat, Zwolle 1992, p. 35 e.w.

192 J.L. van der Neut, Dient eenvoudige belediging straflbaar te blijwen, DD 1981, p. 732-735; J.M. van Bemmelen, belediging en de vrijheid van meningsuiting, NJB 1969, p. 443-448.

193 Opgrond van art. 4 van het Verdrag inzake Uitbanning van Alle Vormen van Rassendiscriminatie is de beperking van de verspreiding van discriminatoir beledigende geschriften niet mogelijk. Wel zijn beperkingen mogelijk wanneer het betreft geschriften die aamzetten tot haat. Dilt in het belang van de veiligheid van anderen. Zie ook J. Boerefijn, Extreem rechts en het internationale recht, LBR Bulletin 1993, p. 7-12.

194 J.L. van der Neut, Discriminatie en Strafrecht, monografieèn Strafrecht, deel 6, Arnhem 1986: Noyon-Langerneijer/Remmelink, Het Wetboek van Strafrecht, 1984, Misdrijwen tegen de openbare orde, Titel $\mathrm{V}$, aantekeningen op de artt. 137c-e Sr; J. Hoens, Regels tegen rassendiscriminatie in het Nederlandse recht; inhoud, ontwikkelingen en mogelijke verbeteringen, Nijmegen 1985; $J$ A. Peters, Commentaar op 'De strijd tegen rassendiscriminatie als beperkingsgrond woor de vrijheid van meningsuiting', NJCM-Bulletin 1987, p. 139 e.v. 
Nederland mogelijk is om bijwoorbeeld de verspreiding van 'Mein Kámpf' te verbieden. Uit art. $137 \mathrm{e}$ Sr volgt dat behalve de verspreider ook de bezitter van discriminatoir materiaal, die dat materiaal ter verspreiding in voorraad heeft, vervolgd kan worden. Het woord 'in voorraad' hebben houdt reeds een bestemming in. Hoeveel exemplaren het zijn is niet van belang. ${ }^{195}$ Het gaat om de intentie om te verspreiden, om de vraag of iemand een voorwerp onder zich heeft om het in omloop te brengen. Wanneer de intentie om te verspreiden moeilijk te bewijzen is kan gekeken worden of er sprake is van ongevraagd aanbieden of toezenden van discriminatoire geschriften. In de wet van 14 november 1991 is hieraan tegemoet gekomen door strafbaar te stellen "het anders dan op verzoek aan iemand toezenden van geschriften of afbeeldingen waarin beledigende uitlatingen worden gedaan over een groep mensen wegens hun ras. "Ths Vermeende discriminatoir beledigende pamfletten en dergelijke kunnen dus al voordat de verspreiding is geschied en de mogelijke daders niet meer te achterhalen zijn in beslag genomen worden door de politie. De verspreider is min of meer gedwongen om een zekere censuur uit te oefenen op de door hem verspreide geschriften, hetgeen volgens van Bemmelen niet juist is ${ }^{197} \mathrm{Het}$ is immers aan de rechter om te beoordelen of er sprake is van 'staatsgeheimen' of 'discriminatoire belediging' oftewel, meer in zijn algemeenheid, van strafrechtelijk verboden gegevensdragers.

4.3.4 Onttrekking aan het verkeer en verbeurdverklaring en de vrijheid van meningsuiting en drukpers in art. 7 van de Grondwet

In de zaak Bluf! ging het om de onttrekking aan het verkeer maar in feite geldt hetzelfde voor de verbeurdverklaring. Is er volgens de rechter sprake van bijvoorbeeld geschriften die staatsgeheimen bevatten dan kan hij op grond van de clausule "behoudens ieders verantwoordelijkheid volgens de wet' onttrekken aan het verkeer of verbeurd verklaren. Zij het dat "het in den geest der Grondwet is repressieve maatregelen, met andere woorden de strafbaarstelling en vervolging van drukpersdelicten op zoodanige wijze te regelen, dat niet indirect het preventieve toezicht weder insiuipe", aldus minister Modderman tijdens de parlementaire behandeling van het Wetboek van Strafrecht in de Tweede Kamer. ${ }^{198}$ Deze noodzaak tot terughoudendieid kunnen we ook lezen in het drukpersartikel 227 van de Grondwet uit 1815. Daarin wordt de drukpersvrijheid: "eene der eerste behoeften van een liberaal gotvernement, hetwelke niet schuwt alle deszelfs handelingen aan het publiek oordeel te onderwerpen, maar integendeel wenscht te worden ingeligt omtrent bestaande abuizen en misbruiken, die

195 Zie Pompe in zijn annotatie onder het arrest HR 14-4-1964, NJ 1964, 435.

196 Wet van 14-11-1991, Wetsvoorstel 20239, Stb. 1991, 623.

197 J.M. van Bemmelen, Belediging en de vrijheid van menüngsuiting, NJB 1969, p. 441.

198 In: E. Diemer, Vrijheid van drukpers: Eenige opmerkingen over haar staatsrechtelijke regeling in Nederland, diss. VU, Rotterdam 1937, p. 122. 
anders welligt kunnen worden verborgen of verbloemd. ${ }^{\text {ns }}$ Een dergelijke visie op de drukperswrijheid houdt in dat repressieve beperkingen zodanig moeten zijn dat kritische publicaties over alle mogelijke zaken kunnen verschijnen. De opstellers van de Proeve van een nieuwe grondwet zeggen dan ook, dat in de behoudens-formule "naar algemeen wordt aangenomen is uitgedrukt dat de Grondwet alleen repressief optreden in geval van misbruik van het recht mogelijk maakt. De wetgever houdt daarbij de instandhouding van een vrije informatiestroom zoveel mogelijk als richtsnoer. Volgens de Grondwet van 1983 dienen beperkingen van grondrechten begrensd te zijn. ${ }^{3 i 1}$ Dit uitgangspunt geldt ook voor de rechter bij de toepassing van deze wetgeving. Wanneer het betreft discussies over publieke aangelegenheden in de media dient de rechter zeer voorzichtig te zijn. Niet alleen omdat door de verbeurdverklaring van een hele oplage de bestaanspositie van bijvoorbeeld een dagblad of tijdschrift in gevaar gebracht kan worden, maar ook omdat het discussiëren over publieke aangelegenheden een basisvoorwaarde is voor een democratische rechtsorde en voor de fundering van de overige grondwettelijke vrijheden. De media nemen hier een speciale positie in. Het is hun taak om het publiek te informeren zodat de mogelijkheid bestaat tot kritisch volgen van de overheid ${ }^{203}$ (waarbij de overheid dan meer kritiek moet kunnen incasseren dan de burger). In de jurisprudentie op art. 10 EVRM is, zoals we in de volgende paragraaf zullen zien, deze benadering neergelegd in een aantal uitspraken van het Europese Hof. In Nederland volstaat men met te wijzen op het belang van de periodieke pers bij de realisering van de uitingsvrijheid ${ }^{204}$,

199 Vermeld bij H.T. Colenbrander, Ontstaan der Grondwet, deel II, "s-Gravenhage 1909, p. 476.

200 Proeve van een nieuwe Grondwet, 's-Gravenhage 1966, p. 66.

201 M.C. Burkens e.a., Beginselen van de democratische rechtsstaat, Inleiding tot de grondslagen van het Nederlandse staats- en bestuursrecht, Zwolle 1989, p. 89.

202 J.M. dte Meij, Uitingsvrijheid, De vrije informatiestroom in grondwettelijk perspectief, Amsterdam 1989 , p. 134 .

203 In Duitsland genict de 'Rundfunk' en de drukpers een bevoorrechte positie. Men heeft hier geprobeerd te komen tol een evenwicht tussen de 'Rundfunk'- en drukpersvrijheid enerzijds en een. effectieve strallechtspleging anderzijds (zie hoofdstuk 2).

204 Het heeft in Nederland lang geduurd voordat de drukperswrijheid ook voor dagbladen en tijdschriften gold. Nog in de jaren vijftig werd over de mogelijkheid van een verschijningsverbod woor dagbladen en tijulschriften gediscussicerd uit vrees voor wergiftiging wan de geest van het publiek door het lezen wan communistisch georienteerde persorganen. In: J.M. de Meij, Uitingsvrijheid, De vrije informatiestroom in grondwettelijk perspectiel, Amsterdam 1989, p. 19. (Wij kennen ook nu nog geen perswet, geen bijzondere vermelding wan de pers in art. 7 , geen erkenning van een zwijgrecht voor journalisten en geen bijzondere beschermingsregeling voor de pers tegen inbeslagnemingsmaatregelen in de strafrechtelijke sfeer.) De omroep is zelfs tot de Grondwetsherzieaing van 1983 buiten de grondwettelijke garantie van de utitingswijheid gehouden. Het is dan ook met recht dat de 'Declaration on mass-communication media and human rights', die de Raadgevende Vergadering wan de Raad wan Europa in 1970 aanvaardde, voorop stelt dat de uitingsvrijheid van art. 10 van het Europees Verdrag ook woor de massamedia geldt. 
zonder daaraan verdere consequenties te verbinden. ${ }^{\text {as }}$ Wel is men in Nederland geneigd om positieve, bevorderende maatregelen voor de media te beargumenteren door te wijzen op hun betekenis voor de instandhouding van de democratie en de cultuurvorming. ${ }^{206}$ Dit is ook in overeenstemming met de grondslag van de vrijheid van meningsuiting en drukpers waarbij naast het argument van de individuele vrijheid ook het algemeen belang gediend wordt door een vrije gedachtenwisseling. ${ }^{207}$

Naar aanleiding van het voorafgaande kan geconcludeerd worden dat de verbeurdverklaring of onttrekking aan het verkeer door de rechter, op grond van de clausule behoudens ieders verantwoordelijkheid volgens de wet', van een gehele oplage gegevensdragers die bijdragen aan de discussie over publieke aangelegenheden ${ }^{\text {as }}$

205 In het voorstel van de Staatscommissie Cals-Domner voor een nieuw uitingsvrijheid-artikel was naast de vrijheid om gedachten en gevoelens te openbaren ook opgenomen "de wrijheid om inlichtingen te garen, te ontwangen en door te geven", maar dit is door de regering uiteindelijk niet overgenomen omdat men op grond wan een misverstand vreesde dat dit tot ongewenste aanspraken zou leiden (Tweede Rapport 1969, p. 69.) Volgens de Meij hebben de ontvangstvrijheid en de wrijheid om informatie door te geven niets met de openbaarheidsplicht te maken. Dat geldt hooguit woor de garingsvrijheid. J.M. de Meij, Uitingswrijheid, De vrije informatiestroom in grondwettelijkk perspectief, Amsterdam 1989, p. 122 e.v.

206 Zie de Medianota van 1983 (TK 1982-1983, 18035, nrs. 1-2, p. 9 ) en de nota 'Overheidsbeleid op het terrein van de informatie" (TK 1980-1981, 16406, nrs. 1-2, p. 9 ) en art. 22 lid 3 Grondwet dat betrekking heeft op de taak van de overheid met betrekking tot de culturele ontplooiing. Verder onderzoekt de Nederlandse rechter bij de toepassing van art. $1401 \mathrm{BW}$ of er ter zake van een bepaalde publicatie een beroep op het algemeen belang als rechtvaardigingsgrond mogelijk is. Het belang dat misstanden aan het grote publick bekend worden gemaakt door de media en de bescherming van de individuele burgers tegen lichtvaardige publiciteit worden tegenower elkaar geplaatst (HR 24-6-1983, NJ 1983, 548.) Een recht van pers en omroep om onthullingen te doen wordt daarbij gemakkelijker geaccepteerd dan bij individuele burgers, gezien de werkzaamheid. van de massamedia in het algemeen belang. Een institutionele benadering vindt men tot op zekere hoogte ook in cle verspreidingsjurisprudentie van de Hoge Raad (zic de arresten boekverkopersen leesbibliotheekbedrijf, HR 22-3-1960, NJ 1960, 274; HR 29-11-1960, NJ 1961, 206; HR 23-5-1961, NJ 1961, 427.)

207 Zie ook art. 227 Grondwet van 1815 waarin de drukpers werd gezien als "een middel tot uitbreiding van kennis en voortgang van verlichting."

208 De grondlegger van het onderscheid tussen 'private' en 'public speech' is Meilklejohn. Een scherpe grens tussen beide valt niet te trekken. Volgens Meiklejohn valt onder "public speech": "public discussion of public issues together with the spreading of information and opinion." In de theorie wan Meiklejohn wordt de vrijheid wan meningsuiting en drukpers vooral gezien als voorwaarde voor en basis van ons democratisch stelsel. Hij stelt het gemeenscliapsbelang in de vrijheid vari meningsuiting en drukpers woorop. Wanuit die gedachte is ook de vrijheid van meningsuiting gecodif ceerd in art. 227 van de Grondwet wan 1815 (") (...) als doelmatig middel tot uitbreiding van kennis en voortgang van verlichting $\left.(. . .)^{4}\right)$ De opstellers van dit artikel dachten in de eerste plaats aan de "freedom to criticize". Later is daar ook de "freedom of expression' bijgekomen. De vrije ontplooiing wan het individu vormt nu ook een belangrijke component wan de vrijhelid van meningsuiting en drukpers. J.A. Peters, Het primaat van de vrijheid wan meningsuiting vergelijkende aspecten Nederland-Amerika, Leiden 1981; p. 171-173. M.C. Burkens, Algemene leerstukken van grondrechten. naar Nederlands constitutioneel recht, Handboeken staats-en besturursrecht, deel II, Zwolle 1989, 
vanuit democratisch oogpunt problematisch is ${ }^{\text {Er }}$ kan dan op dat moment niets meer verspreid worden. Indirect is er sprake van censuur. Zo zullen onder andere witgevers en drukkers woorzichtiger worden bij het uitgeven en drukken. Dit is een maatschappelijk gevolg van de inbeslagneming.

Hierboven werd gesproken over de verbeurdverklaring of onttrekking aan het verkeer van gegevensdragers die bujdragen aan een discussie over publieke aangelegenheden. ${ }^{210}$ Een andere vragg is of de rechter bijwoorbeeld een hele oplage geschriften in beslag mag nemen die discriminatoir beledigend zijn. Het gaat dan niet om geschriften die bijdragen aan een discussie over publieke aangelegenheden.

Volgens Goldschmidt zijn zowel de vrijheid van meningsuiting en drukpers als de anti-discriminatie bepalingen gebaseerd op het gelijkheidsbeginsel. ${ }^{2 n 1}$ Het gelijkheidsbeginsel betekent in zijn visie dat een ieder het recht heeft op gelijke deelname aan de basisrechten van de democratie. ${ }^{2 n a}$ Wanneer individuen of groepen van het democratisch marktmechanisme worden uitgesloten en dus geen weerwoord meer mogelikk is kan het gebruik, volgens Bellekom, van de vrijheid van meningsuiting aan banden worden gelegd. ${ }^{23}$ Het prediken van rassendiscriminatie is in deze visie dus geen zelfstandig verbodscriterum. ${ }^{214}$ Een democratie is niet gediend met verbieden hoezeer verwerpelijk opvattingen ook kunnen zijn. ${ }^{2.5}$ Alleen als er werkelijk

p. 30, 100-104. De staat moet volgens Burkens de individuele vrijheidssfeer ten volle respecteren. De inhoud van de vrijheid en de wijze waarop de burger van deze vrijheid gebruik maakt ligt buiten de regelingsbevoegdheid van de staat. De wrijheid van de individu is niet een vrijheid tot de verwezenlijking van bepaalde doelleinden zoals de bevordering van het democratische proces.

209 Th. L. Bellekom, Botsing van grondrechten: De vrijheid van meningsuiting contra bet gelijkheidsbeginsel, NJCM-Bulletin 1983, p. 270.

210 Ook geschriften die niet bijdragen aan publieke aangelegenheden behoren tot het wezen van de democratie.

211 Algemene Wet Gelijke Behandeling, K 1991-1992, 22014, nrs. 7-8.

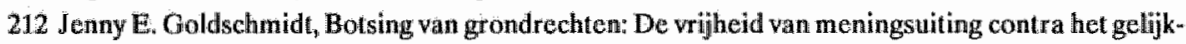
heidsbeginsel, NJCM-Bulletin 1983, p. 277.

213 Th. L. Bellekom, Botsing van grondrechten: De vrijheid van meningsuiting contra het gelijkheidsbeginsel, NJCM-Bulletin 1983, p. 272. Zie ook art. 18 van het Duitse 'Grundgesetz' waarin het "misbruikcriterium" staat geformuleerd. M.C. Burkens, Algenene leersiukken van grondrechten natur Nederlands constitutioneel recht, Handboeken staats- en bestuursrecht, deel II, Zwolle 1989, p. $163-164$

214 In art. $137 \mathrm{c}$ e.y. Sr wordt prioriteit toegekend aan het gelijkheidsbeginsel zonder dat er een principiele keuze wordt gemaakt voor een bepaalde conceptie van democratie. Th.L. Bellekom, Botsing van grondrechten: De vrijheid van meningsuiting contra het gelijkheidsbeginsel, NJCM-Bulletin 1983, p. 272 .

215 Th.L. Bellekom, Botsing wan grondrechten: De vrijheid van meningsuiting contra het gelijkheidsbeginsel, NJCM-Bulletin 1983, p. 271; R.E. de Winter, Straffeloos beledigen, NJB 1993, p.638; J.C.M. Leijten, Niet straffeloos beledigen, NJB 1993, p. 639 heeft in dit artikel een andere mening dan De Winter en Bellekom. Hij is van mening dat je niet straffeloos mag beledigen. M.C. Burkens, Algemene leerstukken van grondrechten naar Nederlands constitutioneel recht, Handboeken staatsen bestuursrecht, deel II; Zwolle 1989, p. 157-159. 
reè gevaar bestaat mag een meningsuiting verboden worden als "ult timum remedium?. ${ }^{36}$ Dit betekent dat er een direct gevaar moet zijin voor onwettig handelen waartegen geen argumentatie meer mogelijk is. Er moet een rechtstreeks en aantoonbaar verband bestaan tussen de meningsuiting en een ermstige strafbare gedraging. Daarbij dient geen onderscheid te worden gemaakt, volgens Goldschmidt, tussen de verschillende soorten discriminatie. ${ }^{2 \pi}$

Wanneer wij het voorafgaande toepassen op de verbeurdverklaring of onttrekking aan het verkeer van discriminatoire geschriften door de rechter dan kunnen we concluderen dat de rechter in het concrete geval een afweging zal moeten maken tussen de verbeurdverklaring of onttrekking aan het verkeer van eén exemplaar of van een hele oplage. Wanneer er sprake is van een aantoonbaar verband tussen de meningsuiting en fysiek geweld zal in het uiterste geval ${ }^{218}$, wanneer andere maatregelem zoals een boete niet helpen, de gehele oplage verbeurd kunnen worden verklaard of onttrokken worden aan het verkeer. Er kan dan niet met succes een beroep worden gedaan op de vrijheid van meningsuiting en drukpers.

4.3.5 De strafvorderlijke inbeslagneming van gegevensdragers en de vrijheid van meningsuiting en drukpers in art. 10 EVRM

In art. 10 EVRM wordt geen onderscheid gemaakt tussen preventieve en repressieve beperkingen. Zowel voor opsporingsambtenaren als voor de rechter geldt, op grond van art. 10 lid 2, dat beperkingen 'nodig moeten zijn in een democratische samenleving". Wat dit precies betekent zal hierna worden uitgewerkt. Het Europese Hof heeft in de loop der tijd een stappenschema ontwikkeld ter beantwoording van de vraag of in een concreet geval sprake is van een schending van art. 10 EVRM. Allereerst dient er sprake te zijn van een inbreuk op het in lid 1 omschreven recht. Verder dient die inbreuk een basis te hebben in "domestic law". Dat nationale recht dient te voldoen aan het vereiste van 'accessibility' en 'forseeability'. Zoals we in hoofdstuk 1 hebben kunnen lezen wordt onder het begrip 'accessibility' door het Hof in de Sunday Times zaak verstaan dat: "the citizen must be able to have an indica" tion that is adequate in the circumstances of the legal rules applicable to a given case." Het vereiste van 'foreseeability' omschreef het Hof all:

216 M.C. Burkens, Algemene leerstukken van grondrechten naar Nederlands constitutioneel recht, Handboeken staats- en bestuursrecht, deel II, Zwolle 1989, hoofdstuk 7 Grondrechtsconllicten en hoofdstuk 8 Horizontale werking van grondrechten, p. 139-192.

217 Jenny E. Goldschmidt, Botsing van grondrechten: De vrijheid van meningsuiting contra het gelijkheildsbeginsel, NJCM-Bulletin 1983, p. 278.

218 Alleen dus in het uitterste geval is repressieve censum mogelijk ook al loop je hierdoor het risico dat de zaken ondergronds gaan. Zelf zou ik weel mecr de nadruk willen leggen op niet-juridische preventieve maatregelen $n_{y}$ zoals onderwijs en werkgelegenheid opdat voorkomen wordt dat mensen marginaliseren en vervreemden wan de samenleving. 
(w. ) a norm camnot be regarded as 'law unless it is formulated with sufficient precision to enable the citizen to regulate his conduct; he must be able' - if need be with appropriate advice - to foresee, to a dlegree that is reasonable in the circumstances, the consequences which a given action may entail.

Wanneer het Hof ernstige twijfel heeft over de mate van "accessibility", "clarity" en 'precision" kan het een schending van art. 10 EVRM construeren via het 'accessibilitycriterium" en/of het "foreseeability'-criterium. Toegepast op de inbeslagneming betekent dit het wolgende. Volgens art. 94 Sv dwingt de inbeslagneming met inachtneming van de bijzondere omstandigheden van het geval tot een oordeel over de geschiktheid van een voorwerp om de warheid aan de dag te brengen en over de vatbaarheid van voorwerpen om verbeurd te worden verklaard of te worden onttrokken aan het verkeer. Daarbij zijn beslissend de wettelijke voorschriften die de bijkomende straf en maatregel beheersen met name de artt. 33a, 33b, 36a-c Sr. De vraag of een voorwerp rechtmatig in beslag kan worden genomen, hangt dus mede af van daartoe nader in de wet gestelde voorwaarden. Personen die gebruik maken van hun grondrechten moeten voldoende kunnen inschatten op welke inbreuken van staatswege zijonder bepaalde omstandigheden kunnen rekenen (rechtszekerheidsbeginsel). In de Grondwet van 1983 staat dlat beperkingen uitzondering zijn en begrensd. Beperkingen moeten gebaseerd zijn op een wet in formele zin die zeker en duidelijk is (legaliteitsbeginsel). ${ }^{20}$ Wanneer we kijken naar de inbeslagneming ter onttrekking aan het verkeer dan is het nog maar de vraag of de artikelen 94 Sv en 36 b en $36 \mathrm{c} \mathrm{Sr}$ voldoen aan bovengenoemde criteria. Op grond van art. $94 \mathrm{~Sv}$ kan de verspreidingsvrijheid in zijn geheel worden beperkt. Of en hoeveel gegevensdragers in beslag worden genomen is uiteindelijk gebaseerd op het 'gezond oordeel' van de opsporingsambtenaren (art. $94 \mathrm{~Sv}$ ). $\mathrm{Er}$ is bij het redigeren van de inbeslagneming geen rekening gehouden met het grondrecht van de vrijheid van meningsuiting en drukpers in het bijzonder de verspreidingsvrijheid. Bovendien zijn de artt. $36 \mathrm{~b}$ en $36 \mathrm{c} \mathrm{Sr}$, die betrekking hebben op de onttrekking aan het verkeer, onduidelijke tot de rechter gerichte voorschriften (rechtszekerheidsbeginsel). In theorie zou dus het Europese Hof kunnen concluderen dat de regeling van de inbeslagneming ter ontrekking aan het verkeer in Nederland op gespannen voet staat met het "forseeability-criterium" (en eventueel het rechtszekerheidsbeginsel). ${ }^{22}$ De kans is echter gering dat het Hof dit zal doen enkel en alleen op grond van schending van het "forseeability-criterium'. Op die grond heeft het Hof nog nooit een schending van én van de artt. 8 tot en met 11 wan het Verdrag aangenomen. Dit is wel gebeurd nadat het Hof aan

219 EHRM 26-4-1979, NJ 1980, 146, p. 466.

220 M.C. Burkens e.an, Beginselen van de democratische rechtsstaat, Inleiding tor de grondslagen van het Nederlandse staats- en bestuursrecht, Zwolle 1992, p. 14.

221 J. van der Hoeven, Toetsen aan de Grondwet. Hoe en door wie?, NJB 1991, p. 784787; M.C. Burkens, e.a., Beginselen van de democratische rechtsstaat, Inleiding tot de grondslagen van het Nederlandse staats- en bestuursrecht, Zwolle 1992, p. 119-122. 
dit vereiste meer profiel is gaan geven door het te verheffen tot een meer algemene en van de bijzonderheden van het voorgelegde geval enigermate geabstraheerde toetsingsmaatstaf namelijk door de toevoeging van het 'rule of law'-element. Het 'rule of law'- vereiste (ook genoemd in de preambule van het EVRM), dat in eerdere jurisprudentie incidenteel al als beoordelingselement voor de "forseeability" van nationaal recht had dienst gedaan ${ }^{22}$ werd in de zaak Malone ${ }^{223}$ tot een algemene kwaliteitseis waaraan nationaal recht dient te voldoen als het inbreuk maakt op een vrijheid. ${ }^{224}$ Met het 'rule of law'-vereiste kan, onder omstandigheden, hetzelfde worden bereikt als met de toetsingsgrond 'necessary in a democratic society'. Een voordeel daarbij is dat nationaal recht naar meer eigen Straatsburgse maatstaven beoordeeld kan worden. Het Hof zit dan ook veel minder vast aan de 'margin of appreciation', zoals dat bij natoetsing van het 'necessary'-criterium het geval is. ${ }^{225}$

De toetsingsgrond "necessary in a democratic society" is voor het eerst door het Hof toegepast in de zaak Sunday Times. In deze zaak werd voor het eerst het begrip 'necessary' als voorwaarde bij elke beperking aangescherpt tot "a social need sufficiently pressing to outweigh the public interest in freedom of expression, within the meaning of the Convention. ${ }^{m 23}$ Uitzonderingen moeten hier volgens het Hof strikt worden geïnterpreteerd. Dat wil zeggen dat de 'interference' in casu de strafvorderlijke inbeslagneming, verbeurdverklaring of onttrekking aan het verkeer ingegeven moet zijn door een 'pressing social need' en dat er een redelijke verhouding ('proportionality') moet bestaan tussen de zwaarte van de inbreuk en het gewicht van het belang dat met de inbreuk werd gediend. Wellicht zal het Hof de inbeslagneming van drukpersen en andere technische apparatuur al snel zien als een te zwaar middel omdat hierdoor de bestaanspositie van bijvoorbeeld een dagblad of tijdschrift in gevaar gebracht kan worden ${ }^{27}$ Ook wanneer het gaat om discussies over publieke aangelegenheden, zoals in de zaak. Sunday Times, zal de inbeslagneming door opsporingsambtenaren van een gehele oplage geschriften of films of de verbeurdverklaring c.q. onttrekking aan het verkeer door de rechter niet snel door het Europese Hof worden gezien als een beperking die noodzakelijk is in een democratische samenleving. Het is

222 Golder, Publ. ECHR 21-2-1975, Series A, voll. 18, § 34; Klass, Publ. ECHR 6-9-1978, Series A, vol. 28 , \$ 55; Silver, Publ. ECHR 25-3-1983, Series A, vol. 61, \$ 61.

223 Publ. ECHR 2-8-1984, Series A, wol. 82, 867.

224 Zie ook de zaken Huvig, Publ. ECHR 24-4-1990, Series A, vol. 176 B, $\$ 29-35$ en Kruslin, Publ. ECHR 24-4-1990, Series $A$, wol. 176B, $\$ 30-36$.

225 Th.L. Bellekom, De jurisprudentie van het EHRM met betrekking tot de beperkingsgronden van de artt. $8 \mathrm{t} / \mathrm{m} 11$ Europese Conventie, NJCM-Bulletin 1990, p. 72-73.

226 Sunday Times, EHRM 26-4-1979, NJ 1980, 146, p. 471.

227 J.M. de Meij, Overheid en uitingsvrijheid, WRR-rapport in de serie Voorstudies en achtergronden mediabeleid, 's-Gravenhage 1982, p. 37. Zie ook Sunday Times (nr. 2), ECHR 26-11-1991, Council of Europe nr. 50/1990/241/312, p. 26. In dece zalk besliste het Hof dat "prior restraints on publication" wel mogelijk zijn op grond van art. 10 lid 2 EVRM maar dat het Hof daar erg voorzichtig mee moet omspringen. Zeker wanneer het gaat om de pers. lmmers "news is a perishable commodity and to delay its publication, even for a short period, may well deprive it of all its value and interest." 
immers in beginsel juist in het belang van een democratische samenleving dat dit materiaal wordt gepubliceerd en verspreid.

Wanneer het daarentegen gaat om de verbeurdverklaring van een helle oplage onzedelijke schilderijen zoals in de zaak Müller ${ }^{2 x}$ of de onttrekking aan het verkeer van een hele oplage onzedelijke boekjes zoals in de zaak Handyside ${ }^{20}$ zal het Europese Hof anders beslissen. De Europese rechter kijkt dan veel meer naar de concrete situatie en laat staten in deze een ruime beoordelingsmarge. Zij zijn, volgens het Europese Hof, immers beter in staat om dit soort zaken op hun merites te beoordelen. ${ }^{21}$ Volgens Spielman in zijn 'dissenting opinion' en Zwaak in zijn annotatie onder dit arrest is deze opvatting van het Europese Hof wat te gemakkelijk. ${ }^{232} \mathrm{Zij}$ zijn van mening dat jüist wanneer er tussen staten geen algemene overeenstemming bestaat over de 'conception' van 'morals' het de taak van het Hof is om in zijn jurisprudentie aan een dergelijke 'conception' inhoud te geven. Reeds in 1981 schreef Wiarda dat "ook wanneer het gaat om zaken die nationale staten beter kumnen beoordelen het Hof er zorg voor moet dragen dat de in het Verdrag gegarandeerde rechten worden gerespecteerd. "Volgens Wiarda moet "het Europese Hof controleren of de waardering door de nationale rechter zorgvuldig en redelijk is geweest en of de beperkingen door de lidstaat opgelegd 'necessary' zijn in 'a democratic society'. "2azs Volgens de Europese

228 Zie de Sunday Times zaak waarin het maatschappelijk belang van de publicatie in kwestie ook met het oog op de rechten van het publiek nauwkeurigg werd onderzocht (EHRM 26-4-1979, NJ 1980, 146). Een democratie beoogt openheid. Grondrechten, zoals de vrijheid van meningsuiting en drukpers, waarborgen die openheid en differentiatie van de samenleving. M.C. Burkens, Algemene leerstukken van grondrechten naar Nederlands constitutioneel recht, Handboeken staats- en bestaursrecht, deel II; p. 42.44 .

229 Müller, EHRM 24-5-1988, NJCM-Bulletin 1988, p. 666.

230 Handyside, EHRM 7-12-1976, NJ 1978, 236, p. 814-815.

231 Zie Otto-Preminger-Institut, Publ. ECHR 20-9-1994, Series A, vol, 295 en NJCM-Bulletin 1995, p. 176-191 met moot van R.E. de Winter en NJ 1995, 366 met noot van E.J. Dommering. In deze. zaak ging het on de vrijheid wan godsdienst (art. 9 EVRM) en de vrijheid van meningsuiting en drukpers (art. 10 EVRM). Het Hof verwijst hier naar de Klass-beslissing (EHRM 6-9-1978, AA 1979, 327 met noot van E.A. Alkema. Hierin besliste het Hof dat het verdrag als een eenheid moet worden geinterpreteerd). Bij het zoeken naar een maatstaf voor de keuze tussen de twee: viijheden knoopt het Hof aan bij de Handyside beslissing (EHRM 7-12-1976, NJ 1978, 236). Evenals in het geval wan de goede zeden, "a concept linked to the rights of others" is er geen uniforme Europese standiard ten aanzien van het recht op respect van godsdienstige gevoelens van cen ander en op het voorkomen van wanordelijkheden.

232 Müller, EHRM 24-5-1988, NJCM-Bulletin 1988, p. 675.

233. G.J. Wiarda, Extensieve en restricticve verdragstoepassing door het Europese Hof voor de rechten van de mens; cen middenkoers? in: Ad Personam, Opstellen aangeboden aan Prof.mr. Ch.J. Enschede, Zwolle 1981, p. 371-385. Zie ook het Hof in de zaak Otto-Preminger-Institut, Publ. ECHR 20-9-1994, Series A, vol. 295, 50 en NJCM-Bulletin 1995, p. 184: "The authorities margin of appreciation, however, is not unlimited. It goes hand in hand with Convention supervision, the scope of which will vary according to the circumstances. In cases such as the present one, where there has been an interference with the exercise of the freedoms guaranteed in paragraph 1 of Article 10, the supervision must be strict because of the importance of the freedoms in question." 
Commissie was in de zaak Müller de inbeslagneming ter verbeurdverklaring van alle schilderijen disproportioneel en niet noodzakellik in een democratische samenleving. ${ }^{24}$ De 'confiscation' dient, of het nu well of niet gaat om pornografie, proportioneel te zijn. Zeker wanneer het gaat om de vrijheid van meningsuiting en drukpers. ${ }^{23 s}$ Uitzonderingen moeten volgens de Commissie strict worden geinterpreteerd.

Wanneer het gaat om mensen met een speciale verantwoordelijkheid kan dit voor betrokkene zowel tot een ruimere als tot een engere interpretatie wan de beperkingsmogelijkheden van zijn wrijheid van meningsuiting leiden. ${ }^{236}$ In de zaak Handyside werd door het Hof gewezen op de "duties and responsibilities" van degenen die het in het eerste lid omschreven recht uitoefenen. ${ }^{23 z}$ In de zaak Sunday Times werd gewezen op de speciale verantwoordelijkheid van journalisten wat leidde tot een engere interpretatie van de beperkingsmogelijkheden. Ook op kunstenaars rust net als op journalisten een speciale verantwoordelijkheid. Volgens het Hof dragen kunstenaars bij aan de uitwisseling van "ideas and opinions which is essential for a

\section{EHRM 24-5-1988, NJCM-Bulletin 1988, p. 672.}

235 In de xaak Otto-Preminger-Institut (het ging hier om de rechten vam derde belanghebbenden (godsdienstige levensovertuiging)) werd dit niet duidelijk (Publ. ECHR 20-9-1994, Seriés A, vol. 295, \& 54 en NJCM-Bulletin 1995, p. 190-191). In vergelijking met de Jersild zaak kent het Hof, terwijl het hier toch ging om een 'prior restraint' (de film werd in beslag genomen en verbeurd verklaard en kon niet meer worden vertoond), geen enkele betekenis toe aan de context waarin de film werd vertoond ('art cinema' huis, voor een groep geïnformeerde abonnees, leeftijdgrens). In de Jersild zaak (Publ. ECHR 23-9-1994, Series A, vol. 298, \$33 en \$34 en N.JCM-Bulletin 1995, p. 171-172 (ook hier ging het om de rechten wan derde belanghebbenden (rassendiscriminatie)) achtte het Hof doorslaggevend dat het televisieprogramma woor een geünformeerd publiek door cen serieuze televisierubriek werd wertoond. Dat in de Jersild zaak ook een ander publiek naar de uitzending kan hebben gekeken bleef buiten beschouwing. Vgl. Sunday Times (nr. 2), Observer and Guardian, ECHR 26-1-1991, Council of Europe nr. 50/1990/241/312, p. 26 en 51/1990/242/313, p. 27).

236 Handyside, Publ. ECHR 7-12-1976, Series A, vol. 24, \$ 49; Handyside, Rapport van de Commissie 30-9-1975, B. 22, p. 4.

237 Handyside, Publ. ECHR 7-12-1976, Scries A, vol. 24, 39; Handyside, Rapport van de Commissie $30-9-1975$, B. 22 , p. 4.

238 Sunday Times, EHRM 26-4-1979, NJ 1980, 146, p. 470. Zic ook Barthold, EHRM 25-3-1985, NJ 1987,900, p. 2989; Lingens, EHRM 8-7-1986, NJ 1987, 901, p. 2995; Oberschlick, ECHR 23-5-1991, Council of Europe nr. 6/1990/197/257, p. 19; Castells, ECHR 23-4-1992, Council of Europe nr. 2/1991/254/325, p. 20; Thorgeirson, Publ. ECHR 25-6-1992, Series A, vol. 239, \$61; Jersild, Publ. ECHR 23-9-1994, Series A, vol. 298, \$31 eerste alinea; Volgens De Mcij mogen "auteurs en journalisten slechts in heel duidelijke gevallen aan strafrechtelijke verwolging worden blootgesteld." J.M. de Meij, 'Ze waren geen SS-ers, nee...', NJB 1995, p. 550; "Niet alleen wanneer politieke zaken in het geding zijn maar ook wanneer zij andere zaken bekritiscert is zij in grote mate vrij" aldus Janssens in: F. Janssens, Beledigende witlatingen in de nedia, NJCM-Bulletin 1995, p. 127; J. van der Velde, Raad van Europa, Het publieke debat en de vrijheid van meningsuiting (Castells vs. Spain, Thorgeirson ws. Island, Schwabe vs. Austria), NJCM-Bulletin 1993, p. 418-435; J. Naeye, Deel IV - De reikwijdte van fundamentele rechten in strafraken - enkele thema's in: Nederlandse Juristen Vereniging Handelingen 1995, Preadviezen van E.A. Alkema, H.A. Groen, P.J. Wattèl, J. Nacyé, De reilkwijdte van fundamentele rechten, deel 1, Zwolle 1995; p. 223-303. 
democratic socieby. Toch verbindt het Hof hieraan in de zaak Müller niet hetzelfde gevolg als bijvoorbeeld in de zaak Sunday Times. Het Hof kende de lidstaat in deze een ruime "margin of appreciation' toe. ${ }^{20}$

Dit in tegenstelling tot de zaak Spycatcher waarin het ging om staatsgeheimen. In deze zaak besliste het Hof dat het zijn taak is: "to exercise its supenvisory jurisdiction." Dit betekent dat het Hof kijkt of de "interference complained of in the light of the case as a whole is proportionate to the legitimate aim pursued and whether the reasons adduced by the national authorities to justify it are relevant and sufficient. Volgens het Hof was "the continuation of the interlocutory injunctions during the period from 30 July 1987 to 13 October 1988" niet "necessary in terms of Article 10 for maintaining the authority of the judiciary and thereby protecting the interests of national security. "Het boek Spycatcher was immers vanaf 30 juli 1987 al in Engelse dagbladen gepubliceerd. ${ }^{242} \mathrm{De}$ "confidentiality" was als gevolg hiervan "destroyed. "Voortzetting van de beperkingen jegens de kranten zou hen volgens het Hof verhinderen in "their right and duty to purvey information, already available, on a matter of legitimate public concern. ${ }^{123}$

Ook in 1993 oordeelde de Europese Commissie in de zaak Bluf! dat de onttrekking aan het verkeer van Bluf! nr. 267 met daarin een zes jaar oud kwartaaloverzicht van de BVD niet noodzakelijk was in een democratische samenleving ter bescherming van de staatsveiligheid nu deze informatie bovendien als gevolg van de "unimpede sale of the publication on 30 april 1987 was so widely disseminated. "De onttrekking aan het verkeer van Bluf! nr. 267 was dan ook niet gerechtvaardigd onder art. 10 lid 2 EVRM. ${ }^{24}$ Over de verhouding tussen strafvorderlijke inbeslagneming en de vrijheid van meningsuiting en drukpers heeft de Europese Commissie zich in deze zaak niet uitgesproken. Dit geldt eveneens voor het Europese Hof. Op 9 februari 1995 besliste het Hof dat:

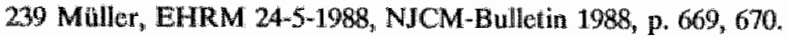

240 Maar ook al is deze 'margin of appreciation' ruim dan nog dient bet Hof te controleren of de beperkingen proportioneel zijn. Vergl. Jacubowski (oneerlijke concurrentie), EHRM 23-6-1994, NJCM-Bulletin 1995, p. 84. Ook in deze zaak was de "margin of appreciation" ruim. Het rechterlijke bevel dat niet verder ging dan het verbieden van het verspreiden van het rondschrijven werd door het Hof proportioneel geacht. Nu het hier om een beeldend kunstenaar ging had het Hof niet alleen bij zijn overwegingen met betrekking tot de toegestane beperkingen moeten kijken naar de inhoud wan de geuite mening maar ook naar het middel. Juist een beeldend kunstenaar beschikt over geen ander middel om zijn kunstuiting vorm te geven. Leo Zwaak in zijn noot onder de zaak Müller, EHRM 24-5-1988, NJCM-Bulletin 1988, p. 674.

241. Sunday Times (nr. 2), ECHR 26-11-1991, Council of Europe nr. 50/1990/241/312, p. 26 . 242 Sunday Times (nr. 2), ECHR 26-11-1991, Council of Europe nr. 50/1990/241/312, p. 27. 243 Sunday Times (nr. 2), ECHR 26-11-1991, Council of Europe nr. 50/1990/241/312, p. 28 . 244 Vereniging Weekblad 'Blufl', Application nr. 16616/90, Report of the Commission 9-9-1993, p. 8. Zie ook NJCM-Bulletin 1994, p. 146-153 met noot van R.E. de Winter. 
However, the information in question was made accessible to a large number of people, who were able in their turn to communicate it to others. Furthermore, the events were commented on by the media. That being so, the protection of the information as a State secret was no longer justified and the withdrawal of issue no. 267 of Bluf! no longer appeared necessary to achieve the legitimate aim pursued. ${ }^{\text {ins }}$

\subsubsection{Conclusie}

In de voorafgaande paragrafen kwam de relatie tussen de strafvorderlijke inbeslagneming en de vrijheid van meningsuiting en drukpers in art. 7 van de Grondwet en art. $10 \mathrm{EVRM}$ aan de orde. Deze relatie is soms problematisch. Uit het voorafgaande is gebleken dat de inbeslagneming mogelijk is voor het aan de dag brengen van de waarheid, ter verbeurdverklaring en ter onttrekking aan het verkeer (art. 94 Sv). Bij de inbeslagneming voor het aan de dag brengen van de waarheid kan het gaan om filmopnamen die gemaakt zijn van een demonstratie. Wanneer deze filmopnamen in beslag worden genomen kan dit tot gevolg hebben dat de vertoning van beelden en geluiden van nieuwswaardige feiten onmogelijk wordt gemaakt. Dit is een ernstige inbreuk op de informatievrijheid van de journalist, wiens taak het is informatie te garen, vast te leggen en voor openbaarmaking te selecteren. Op de lange termijn kan dit zelfs beteken dat een journalist nieuwswaardige feiten niet zal verslaan uit vrees voor interventie van justitie. Op grond van art. 7 van de Grondwet en art. 10 van het EVRM is de ontvangstvrijheid een belangrijk aspect van de vrijheid van meningsuiting en drukpers. Van communicatie is immers eerst sprake als de zender met zijn boodschap de beoogde ontvanger ook inderdaad bereikt. Bovendien is een democratische samenleving niet mogelijk zonder een goed geïnformeerd publiek. ${ }^{2 A 6}$ Om dat publiek goed te informeren is het voor de journalist van belang dat er een garingswrijheid bestaat. ${ }^{247}$ In art. 19 IVBPR wordt de vrijheid van nieuwsgaring genoemd naast de andere vrijheden. Om te voorkomen dat er zoals nu het geval is beeldmateriaal etcetera in beslag wordt genomen dient er in de wet een inbeslagnemingsverbod, zowel ten aanzien van eigen- als ten aanzien van materiaal van derden verkregen, te worden geformuleerd. Slechts bij aanwezigheid van dringende redenen, zoals bij misdrijven waarbij zwaar lichamelijk letsel wordt toegebracht, mag de rechter, rekening houdend met het proportionaliteits- en subsidiariteitsbeginsel, komen tot een inbreuk van dit recht. Verder moet een ieder die journalistieke werkzaamheden

245 Vereniging Weekblad 'Bluf!', ECHR 9-2-1995, Council of Europe nr, 44/1993/439/518, p. 13. Zie ook NJCM-Bulletin 1995, p. 65-66 en p. 480-487 met noot van J.M. de Meij.

246 Zo besliste het Europese Hof in de zaak Sunday Times dat: "not only does the media impart such information and ideas; the public also has a right to receive them" en "the public thas the right to be properly informed." EHRM 26-4-1979, NJ 1980, 146, p. 470.

247 In de zaak Barthold werd de pers gezien als "purveyor of information and public watchdog." Barthold, EHRM 25-3-1985, NJ 1987, 900, p. 2989; Lingens, EHRM 8-7-1986, NJ 1987, 901 , p. 2995; Oberschlick, ECHR 23-5-1991, Council of Europe nr. 6/1990/197/257, p. 19. 
verricht een beroep kunnen doen op het journalistieke privilege.. Dit journalistieke privilege houdt in dat iemand die journalistieke werkzaamheden verricht niet langer verplicht is zijn bronnen te onthallen. Op deze manier wordt voorkomen dat mensen die journalistieke werkzaamheden verrichten worden gezien als handlangers van politie en justitie.

Bij de inbesiagneming ter verbeurdverklaring en ter onttrekking aan het verkeer kan het gaan om vermeende pornografische geschriften of staatsgeheimen. Deze kunnen in beslag worden genomen door de politie en door de rechter worden verbeurd verklaard of onttrokken aan het verkeer. Wanneer het gaat om de inbeslagneming van een hele oplage op grond van art. 94 Sv door de politie kan de verspreidingsvrijheid in het gedrang komen. ${ }^{248}$ De inbeslagneming van een hele oplage of van een eenmalige uitgave dient dan ook voorkomen te worden. Beperkingen op grondrechten dienen begrensd te zijn. ${ }^{29}$ Zeker bij de inbeslagneming van een complete oplage van een periodiek, zoals bijvoorbeeld van een dagblad, kan de uitgever onevenredig zwaar getroffen worden omdat een dagblad zijn waarde na een dag grotendeels verloren heeft. Beperkingen behoren dan ook subsidiair en proportioneel te zijn. Dit geldt zowel voor inbeslagneming van een hele oplage geschriften als voor de inbeslagneming van een hele oplage video's. Hoewel op grond van het eerste en het derde lid van art. 7 Grondwet het verspreidingsrecht in meer of mindere mate, afhankelijk van het bewuste lid, mag worden beperkt door opsporingsambtenaren mag dit niet zover gaan dat "het feitelijk functioneren van het recht om gedachten of gevoelens te openbaren onmogelijk wordt gemaakt.

Iets anders is het wanneer de rechter zijn bevoegdheid uitoefent op grond van de clausule "behoudens ieders verantwoordelijkheid volgens de wet'. De rechter mag een hele oplage onttrekken aan het verkeer of verbeurd verklaren ${ }^{251}$ zij het dat ook de rechter bij de beperking van de vrijheid van meningsuiting en drukpers rekening dient te houden met het proportionaliteits- en subsidiariteitsbeginsel. Zeker wanneer het betreft zaken over publieke aangelegenheden dient de rechter extra alert te zijn bij de verbeurdverklaring of de onttrekking aan het verkeer van een hele oplage of een eenmalige uitgave. Niet alleen omdat door de verbeurdverklaring of onttrekking aan het verkeer van een hele oplage de bestaanspositie van bijvoorbeeld een dagblad of tijdschrift in gevaar gebracht kan worden, maar ook omdat het discussiëren over publieke aangelegenheden een basisvoorwaarde is voor een

248 Hiermee is bij het redigeren van art. 94 Sv geen rekening gehouden. Zie hoofdstuk 5 Aanbevelingen.

249 M.C. Burkens, Algemene leerstukken wan grondrechten naar Nederlands constitutioneel recht, Handboeken staats- en bestuursrecht, deel II, Zwolle 1989, p. 95-97.

250 TK $1975-1976,13872$, nrs. 11.5, p. 91.

251. De bepalingen die betrekking bebben op de onttrekking aan het verkeer en de verbeurdverklaring (artt. $36 \mathrm{~b}$ en $36 \mathrm{c} \mathrm{Sr}$ ) zijn onduidelijke tot de rechter gerichte voorschriften die niet voldoen aan het rechtszekerheidsbeginsel. Beperkingen van grondrechten dienen begrensd, zeker en duidelijk te zijn. 
democratische rechtsorde en voor de fundering van de overige grondwettelijke vrijheden. $^{232}$

Wanneer het gaat om discussies over publieke aangelegenheden ikijt het Europese Hof, zoals we hebben gezien in de zaak Sunday Times ${ }^{233}$, heel precies of een interference' is ingegeven door een 'pressing social need' en of er een redelijke verhouding bestaat tussen de zwaarte van de inbreuk en het gewicht van het belang dat met de inbreuk is gediend. Het Hof onderzoekt bij de afweging of een bepaalde publicatie kan worden verboden of op andere wijze tegengegaan wat de aard is van de publicatie en in welke context deze plaatsvindt. Wanneer het gaat om zaken van algemeen maatschappelijk en politiek belang moet men volgens het Hof meer ruimte laten voor de vrijheid van meningsuiting en drukpers dan wanneer dat niet het geval is. Ook wanneer het gaat om journalisten en kunstenaars, die uit hoofde van hun werkzaamheden bijdragen aan het publieke debat, dienen de beperkingsmogelijkheden op de vrijheid van meningsuiting en drukpers enger te worden geïnterpreteerd. De inbeslagneming van een hele oplage geschriften of films of de onttrekking aan het verkeer of de verbeurdverklaring van genoemde gegevensdragers zal door het Hof wellicht niet zo snel worden gezien als een beperking die noodzakelijk is in een democratische samenleving in die gevallen waarin het gaat publicaties en personen die bijdragen aan het publieke debat. ${ }^{254}$ Of een publicatie zoals Bluf! nr. 267 ook

252 In het oude art. 227 van de Grondwet (1815) stond het gemeenschapsbelang in de vrijheid van meningsuiting en drukpers voorop ("...) als doelmatig middel tot uitbreiding van kennis en voortgang van verlichting $\left.(. . .)^{\mathrm{m}}\right)$. De opstellers van dit artikel dachten in de eerste plaats aan de vrijheid om kritick te leveren op de staat. Later is daar ook de vrijheid van meningsuiting bij gekomen in de betekenis van ontplooiing van het individu (J.A. Peters, Het primaat van de vrijheid van meningsuiting, wergelijkende aspecten Nederland-Amerika, Leiden 1981, p. 171-173). Het belang van de wrijheid van meningsuiting voor de ontplooiing van het individu speelt ook in de jurisprudentie van het Europese Hof, zij het in mindere mate, een rol. Zie de zaak Müller, EHRM 25-5-1988, NJCMBulletin 1988, p. 455-676 en de zaak Otto-Preminger-Institut, Publ. ECHR 20-9-1994, Series A, vol. 295 en NJCM-Bullletin 1995, p. 176-191 met noot van R.E. de Winter en NJ 1995, 366 met noot van E.J. Dommering.

253 EHRM 26-4-1979, N.J 1980, 146, p. 469.

254 Het publieke debat en de pers worden sterk beschermd in de jurisprudentic van het Hof. Zie de zaak Jersild (Publ, ECHR 23-9-1994, Series A, vol. 298 en NJCM-Bulletin 1995, p. 167-175). Documentaire van een journalist over neo-nazi's droeg volgens het Hof bij aan het publieke debat. In de zaak Otto-Preminger-Institut (Publ. ECHR 20-9-1994, Series A, vol. 295 en NJCM-Bulletin 1995, p. 176-191 en NJ 1995, 366) daarentegen, het ging hier om de film 'Das Liebeskonzil', was het Hof de mening toegedaan dat in zaken waarin vastgesteld wordt dat religieuze gevoelens van derden in het geding zijn, kunstuitingen niet bijdragen "to any form of public debate capable of furthering progress in human affairs" (\$ 47). Dit tatste "capable of furthering progress in human affairs" is nieuw in de jurisprudentie van het Hof en staat op gespannen woet met cerdere uitspraken van het Hof. Zo besliste het Hof in de zaak Handyside dat ook uitingen die 'offend and shock' (Handyside, EHRM 7-12-1976, NJ 1978, 236) bescherming genieten. Zie ook R.E. de Winter in żjn noot onder bowengenoemd arrest, NJCM-Bulletin 1995, p. 190: "Niet alleen dle positiwo's dienen te worden beschermd." Het lijkt erop, zeker na de Otto-Preminger-Institut zaak, dat de politieke uitingswrijheid meer bescherming geniet dan de artistieke uitingsvrijheid (Vgl. ook de zaak Müller, 
kan bijdragen aan het publieke debat daarover spreekt de Commissie en het Hof zich niet expliciet uit. De "piermanent injunctions" en de onttrekking aan het verkeer werden niet noodzakelijk geacht in een democratische samenleving omdat iedereen van de publicatie kennis kon nemen. De publicatie was niet langer geheim. ${ }^{25 s}$

\subsection{Procedurele aspecten van de inbeslagneming en de vrijheid van meningsuiting en drukpers}

\subsubsection{De wettelijke bevoegdheden tot inbeslagneming}

In de derde afdeling van titel vier van het Wetboek van Strafvordering en in bijzondere wetten is te vinden welke personen onder welke omstandigheden bevoegd zijn tot inbeslagneming. De bevoegdheden tot inbeslagneming op grond van het Wetboek van Strafvordering zijn in 1926 aanmerkelijk uitgebreid. Deze uitbreiding werd nodig geacht, omdat de toen bestaande bevoegdheden niet bleken te voldoen aan de eisen van de praktijk. In de Memorie van Toelichting werd hierover opgemerkt:

"Het bestaan van tal wan bijzondere bepalingen inzake de inbeslagneming mag veilig worden aangemerkt als een aanwijzing voor de onvoldoendheid der algemeene regeling van dat ontwerp in het Wetboek, eene regeling welker leemten trouwens algemeen wordt erkend (...). In de Invoeringswet tot het ontworpen Wetboek zal in deze materie naar eenheid van wetgeving zijn te streven. De behoefte aan ruimere bevoegdheden ten deze deed zich in de gewone justitiële en politiële praktijk in sterke mate gevoelen. Dat dit nog niet in sterkere mate het geval is geweest, en dat eene herziening van genoemde algemeene regeling tot dusver achterwege is gebleven, is enkel een gevolg van de omstandigheid, dat het voor de inbeslagneming van stukken van overtuiging thans dikwijls vereischte goedvinden van bijzon-

EHRM 24-5-1988, NJCM-Bulletin 1988, p. 455). Gaat het om confrontaties met het publiek dan owerheerst toch vrij snel de zorg voor de openbare orde (ook in de zaak Otto-Preminger-Institut speelde dit een rol) en de goede zeden. Toneelvoorstellingen en films zijn bijwoorbeeld veel langer aan overheidsrepressie onderworpen geweest dan het geschreven woord. (Vgl. Oberschlick, EHRM 23-5-1992, NJ 1992, 456 met noot van E.J. Dommering onder punt 6; Vgl. ook E.A. Alkema, De vrijheid wan de kunst als onderdeel van de grondrechtelijke communicatievrijheid mede in het licht van het EVRM in: G.A.I. Schujit, T. Pronk (red.), Hoe vrij is de kunst?: onderdrukking censuur en andere beperkingen aan de vrijheid van expressie, Amsterdam 1992, p. 9-19). Zowel de artistiekeals de politieke uitingsvijijheid wallen onder art. 10 EVRM (Zie ook de zaak Jacubowksi, Publ. 23-6-1994, Series A* vol. 291 en NJCM-Bulletin 1995, p. 82-85. Hier besliste het Hof dat wanneer in een bepaalde zaak de vrijheid van meningsuiting wordt uitgeoflend anders dan in de discussie over zaken van openbaar belang de bescherming van art. 10 gehandhafd blijft).

255 In de zaak Spycatcher ging het ook om wermeende staatsgeheimen. Volgens het Hof was ook in deze zaak de publicatie niet langer geheim op het moment dat een ieder er kennis van kon nemen. Hier sprak het Hof zich wel expliciet uit over de bijdrage aan het publiek debat. Sunday Times (nr. 2), ECHR 26-11-1991, Council of Europe nr. 50/1990/241/312, p. 28.

$256 \mathrm{MVT}$, Bijl. HTK 1913-1914, 286. 
dere personen den onderzoekenden rechters of ambtenaren nuiet pleegt te worden onthouden. Voor het vervolg dient echter de justitie met krachtiger wapenen te worden toegerust en aan dat goedvinden eene minder ruime plaats toe te komen, diene met andere woorden scherper te worden omschreven de gevallen, waarin de bevoegdheid tot inbeslagneming. of op inbeslagneming gerichte handelingen als een zelfstandig recht der ambtenaren wan justitie en politie mag worden uitgeoefend."

In de bedoeling van de wetgever stonden dus centraal het brengen van eenheid in de veelvoud van afzonderlijke bepalingen in bijzondere wetten door een nieuwe regeling in het Wetboek van Strafvordering en - in verband daarmee - het duidelijk vastleggen in de wet van ruimere bevoegdheden tot inbeslagneming door politie en justitie. Over de wijze waarop dit laatste zou moeten gebeuren zegt de Memorie van Toelichting ${ }^{207}$.

"men kan aan de vervolgende Overheid hare rechten zoo zuinig mogelijk toebedeelen, haar" niet meer macht toekennen dan streng noodzakelijk, ten einde op die wijze de belangen van de individuen zoo $\mathrm{min}$ mogelijk te treffen, en dan daartegenover ook de rechten van het individu bij het optreden van die overheid aan zeer beperkende maatregelen binden, dat wil zeggen men kan uit wantrouwen tegenover beide partijen, aan beide niet meer bevoegdheden toekennen dan even noodzakelijk is."

"Of wel men kan, vertrouwende op het beleid der personen, die met de vervolgingstaak zijn belast, hun ook tegenover de bijzonder personen alle bevoegdheden verleenen, welke zij naar omstandigheden kunnen behoeven, doch dan tevens aan alle bij het onderzoek betrokkenen zooveel rechten verleenen als met het belang van het onderzoek slechts eeven bestaanbaar is. Men kan ruime rechten toekennen aan politie en justitie, doch de uitoefening ervan, voorzoover dit mogelijk is, stellen onder de controle van den onafhankelijken rechter, tegen de beslissing van den lageren beroep open stellen op den hoogeren rechter, er voor zorgen, dat ledere betrokkene in zijne belangen door den rechter kan worden gehoord, hem voor de behartiging van die belangen toestaan zich ten allen tijde met een raadsman te beraden. Met andere woorden men kan beproeven het noodzakelijke compromis op zoodanige wijze te vinden, dat aan de vervolging alle rechten worden gegeven, die zij woor hare taak behoeft, aan de verdachten en aan de verdediging alle bevoegdheden welke met het doel van het strafproces niet onvoorwaardelijk in strijd komen.

De wetgever heeft gekozen voor een regeling in laatstbedoelde zin. Op deze wijze kan - aldus de wetgever - een krachtige repressie worden verkregen en worden toch de rechten van het individu niet meer dan noodzakelijk aangetast. Het bleek echter wel noodzakelijk om de rechten van zowel het Openbaar Ministerie als de verdachte te beknotten. Soms zijn de rechten van het Openbaar Ministerie beperkt, omdat de gevaren voor misbruik te groot lijken te zijn in verband met de in aanmerking komende belangen. Soms zijn de rechten van de verdachte aan beperkende bepalingen 
onderworpen, omdat vrije uitcefening het belang van het onderzoek zou kunnen benadelen. "Het blijft bij dit alles een wikken en wegen, een geven en nemen", zo zegt de Memorie van Toelichting op het Ontwerp.

In het hiervoor geciteerde gedeelte uit de Memorie van Toelichting wordt gesproken over de bevoegdheid tot inbeslagneming en de bevoegdheid tot het verrichten van op de inbeslagneming gerichte handelingen als 'zelfstandig recht' van justitie en politie. Een bevoegdheid is een zelfstandig recht wanneer zij kan worden uitgeoefend zonder voorafgaande toestemming van de betrokkene. ${ }^{200}$ Dit optreden zonder toestemming, zonder goedvinden van de burger, is slechts toegestaan als de wet daartoe uitdrukkelijk de bevoegdheid verschaft. Omdat men vóór 1926 te veel afhankelijk was van het goedvinden van de burger, met andere woorden, omdat de wet te weinig bevoegdheden verschafte, zijn aan justitie en politie in het nieuwe Wetboek grotere zelfstandige bevoegdheden gegeven. Maar daarnaast is, zoals blijkt uit de jurisprudentie van de Hoge Raad ${ }^{2 a n}$ nog plaats voor de bevoegdheid als niet-zelfstandig recht; het recht tot handelen vloeit dan niet voort uit de wet, maar uit het goedvinden van de betrokken burger. Dit betekent dat in gevallen waarin de wet daartoe geen bevoegdheid bevat, toch een rechtsgeldige inbeslagneming tot stand kan komen, namelijk indien degene onder wie wordt in beslag genomen - de verdachte, het slachtoffer, een instantie - daartoe toestemming geeft. ${ }^{2 ⿰ 2} \mathrm{Bij}$ de bewijsvoering worden geen strenge eisengesteld aan het aannemen van een geval van 'toestemming'. Integendeel, de toestemming wordt geacht aanwezig te zijn wanneer van het ontbreken ervan - dus van het niet goedvinden - niet is gebleken. ${ }^{233}$ Volgens Vellinga-Schootstra is echte controle op de bevoegdheden van politie en justitie - waaraan de wetgever gezien het geciteerde uit de Memorie van Toelichting grote waarde hecht - pas mogelijk als de opsporingsambtenaar verplicht zou zijn om in zijn proces-verbaal te vermelden of er toestemming door de betrokkene is verleend en zo ja, uit welke feiten en omstandigheden hij het bestaan van die toestemming concludeert. ${ }^{264}$ De huidige situatie, waarin de controlemogelijkheden sterk zijn verschraald, lijkt volgens VellingaSchootstra ${ }^{265}$ in strijd te zijn met de geest van het Ontwerp van $1926^{266}$ en met

$259 \mathrm{MVT}$, Bijl. HTK 1913×1914, 286.

$260 \mathrm{~F}$. Vellinga-Schootstra, Inbeslagneming en huiszoeking, diss. RU Groningen, Alphen a/d Rijn 1982, p. 42 e.r.

261 HR 31-5-1937 NJ1938, 150.

262 HR 2-11-1927, NJ 1927, 533.

263 Marconist-arrest HR 7-12-1971, NJ 1972, 197 (gedeeltelijk gepubliceerd) en in AA. 1973, p. 237 met noot van Peters (volledig gepubliceerd).

264 Reeds in 1937 werd door F. Visser gesteld dat de grootste terughoudendheid in acht moet worden genomen bij het anwezig achten van het geval van vrijwillige medewerking. Zie het artikel wan zijn hand: Drie onderwerpen betreffende de inbeslagneming ten behoeve van de strafvordering, Tijdschrift voor de politic 1937, p. 312 .

265 F. Vellinga-Schootstra, Inbeshagnening en huiszoeking, diss. RU Groningen, Alphen a/d Rijn, 1982 , p. 44.

266 MvT, Bijl. HTK 1913-1914, 286. 
de grondrechten zoals het recht op privacy (art. 10 Grondwet) en de vrijheid van meningsuiting en drukpers (in die gevallen waarin het gaat om gegevensdragers.)

\subsubsection{Commissie Herijking Wetboek van Strafvordering}

Ook de Commissie Herijking Wetboek van Strafvordering stond het uitgangspunt voor ogen dat er meer eenheid moest komen in de veelvoud van afzonderlijke inbeslagnemingsbepalingen in bijzondere wetten ${ }^{207}$ Het uitgangspunt van de Commissie Herijking is de inbeslagnemingsbepalingen te harmoniseren en de inbeslagnemingsbevoegdheden te verruimen ${ }^{208} \mathrm{Het}$ huidige Wetboek van Strafvordering kent, in tegenstelling tot vele bijzondere wetten, aan de gewone opsporingsambtenaar in principe alleen speciale inbeslagnemingsbevoegdheden toe ${ }^{2 \infty}$ Alleen wanneer zij in de uitoefening van een andere bevoegdheid een daarvoor vatbaar voorwerp aantreffen zijn zij tot inbeslagneming daarvan bevoegd. In navolging van pleidoolen in de literatuur $^{2 m}$ stelt de Commissie Herijking Wetboek van Strafvordering voor om in plaats van het huidige art. $96 \mathrm{~Sv}$ aan elke opsporingsambtenaar een algemene bevoegdheid tot inbeslagneming te geven. De enige beperking is dat voor een situatie buiten heterdaad sprake dient te zijn van een misdrijf als omschreven in art. 67 eerste lid Sv. Door het grote aantal misdrijven dat onder dit artikellid wordt aangeduid of opgesomd bestaan er praktisch weinig belemmeringen meer voor opsporingsambtenaren. ${ }^{2 n}$ Volgens Aler brengt dit weinig risico's van misbruik met zich mee; de inbeslagneming mag immers niet vormvrij plaatsvinden. Ook brengt de inbeslagneming in het algemeen geen vergaande inbreuk mee op een belangrijk recht van de burger. ${ }^{2 / 2}$ In zijn algemeenheid zal dat inderdaad het geval zijn. Echter wanneer het gaat om de inbeslagneming van gegevensdragers kunnen wel degelijk vergaande inbreuken worden gemaakt op de rechten van de burger. Ik denk hier aan de vrijheid

267 Herziening wan het gerechtellijk vooronderzoek, Een rapport van de Commissie Herijking Wetboek van Strafwordering (vz. Ch.M.J.A. Moons), Arnhem 1990, p. 87.

268. Herziening van het gerechtelijk vooronderzoek, Een rapport van de Commüsie Herijking Welboek van Strafwordering (vz, Ch.M.J.A. Moons), Arnhem, 1990, p. 95 c.v.

269 Alleen op grond van art. $539 \mathrm{p}$ en 551 lid 1 Sv zijn opsporingsambtenaren te allen tijd tot inbeslagneming bevoegd. P.A.M. Mevis, Inbeslagneming en huiszoeking in: D.R. Doorenbos en R.J. Verweij (red.) Hercodificatie Wetboek van Strafvordering, Nijmegen 1991, p. 106.

270 G.P.A. Aler, De politiebewoegdheid bij opsporing en controle, Enige aspecten wan de regeling van de dwangmiddelen in het Wetboek van Strafvordering en in bijzondere wetten, Zwolle 1982, p. 317-333; J.J.H. Suyver, Vergelijkend onderzoek naar enige dwangmiddelen tijdens de opsporing, Preadvies voor de Vereniging woor de vergelijkende studie van het recht van Belgie en Nederland, ministerie van Justitie, 's-Gravenhage 1979, p. 60-61.

271 Commentaar NJCM rapport Commissie, NJCM-Bulletin 1991, p. 361.

272 G.P.A. Aler in: Herziening van het gerechtelijk vooronderzoek, Een rapport van de Commissie Herijking Wetboek van Strafvordering (vz.. Ch.M.J.A. Moons), Arnhem 1990, p. 95. In dit rapport word verwezen naar: G.P.A. Aler, De politiebevoegdheid bij opsporing en controle. Enige aspecten van de regeling van dwangmiddelen in het Wetboek van Strafvordering en in bijzondere wetten, Zwolle 1982, p. 356. 
van meningsuiting en drukpers. ${ }^{2 ⿰ 5}$ Door opsporingsambtenaren nog ruimere inbeslagnemingsbevoegdheden te geven kan de vrijheid van meningsuiting en drukpers meer in gevaar worden gebracht. Met de inbeslagneming van gegevensdragers dient niet alleen het opsporingsbelang maar ook de communicatievrijheid in acht te worden genomen. Opsporingsambtenaren zullen geneigd zijn te kiezen voor het opsporingsbelang oftewel voor handhaving van de rechtsorde. Zoals ik in de paragrafen over de materiéle aspecten van de inbeslagneming reeds opmerkte wordt bij de strafvorderlijke inbeslagneming vooruit gelopen op de rechterlijke beslissing. Op grond van art. 94 Sv kan de opsporingsambtenaar gegevensdragers in beslag nemen voor het aan de dag brengen van de waarheid, ter verbeurdverklaring en ter onttrekking aan het verkeer. Bij de inbeslagneming voor het aan de dag brengen wan de waarheid kan de ontvangstvrijheid (art: 10 EVRM) en de garingsvrijheid (art. 19 IVBPR) in gevaar worden gebracht. Ik ben van mening dat gegevens op dragers niet in beslag mogen worden genomen, tenzij mensen zwaar lichamelijk letsel is toegebracht tijdens bijvoorbeeld een uit de hand gelopen demonstratie. De argumenten staan genoemd in paragraaf 4.3.1. Ik volsta hier met een verwijzing. Wanneer het gaat om de inbeslagneming wan 'vermeende' strafrechtelijk verboden gegevensdragers mag de opsporingsambtenaar wel gegevensdragers in beslag nemen zij het dat hij rekening dient te houden met het proportionaliteits- en subsidiariteitsbeginsel. Op grond van art. 10 EVRM dienen beperkingen noodzakelijk te zijn in een democratische samenleving. Uitzonderingen moeten volgens het Europese Hof strikt worden geïnterpreteerd. Dat wil zeggen dat de 'interference' ingegeven moet zijn door een 'pressing social need' en dat er een redelijke verhouding moet bestaan tussen de zwaarte van de inbreuk en het gewicht van het belang dat met de inbreuk werd gediend. Zeker wanneer het gaat om discussies over publieke aangelegenheden dienen, volgens mij, niet alleen rechters maar ook opsporingsambtenaren extra voorzichtig zijn. De inbeslagneming van een hele oplage gegevensdragers door opsporingsambtenaren zal door de Europese rechter, wanneer het betreft 'public speech' waarschijnlijk niet snel worden gezien als een beperking die noodzakelijk is in een democratische samenleving. Het is immers juist in beginsel in het belang van een democratische samenleving dat dit materiaal wordt gepubliceerd en verspreid. Betekent dit nu dat bij de inbeslagneming, onttrekking aan het verkeer of verbeurdverklaring van staatsgeheimen of pornografische geschriften geen rekening hoeft te worden gehouden met de vraag of beperkingen noodzakelijk zijn in een democratische samenleving. Zoals we in paragraaf 4.3.5 hebben kunnen lezen moet volgens het Hof en de Commissie ook bij 'interim injunctions', de onttrekking aan het verkeer en de verbeurdverklaring van een hele oplage staatsgeheimen of pornografische geschriften rekening worden gehouden met het proportionaliteitsbeginsel. Naar mijn mening is dit juist. Niet alleen alleen bij de onttrekking aan het verkeer en de verbeurdverklaring maar ook bij

273 Luciènne Tomesen, De strafvorderlijke inbesllagneming en het rapport van de Commissie Moons. Een gemiste kans? in: G.P.M.F. Mols. (eindred.), Schaduwen vooruit, Rechtsgeleerde opstellen over het voorbereidend onderzock in strafzaken, Arnhem 1992, p. 37-44. 
de inbeslagneming van vermeende strafrechtelijk verboden gegevensdragers dient rekening te worden gehouden met het proportionaliteits-en subsidiariteitsbeginsel. Immers wat bijvoorbeeld 'staatsgeheimen' (art. $98 \mathrm{Sr}$ ) zijn staat niet duidelijk in de wet aangegeven. Dit geldt eveneens voor de bepalingen die betrekking hebben op smalende godslastering (artt. 147, 147a, 429 bis Sr), pornografie (artt. 240, 240a, $240 \mathrm{~b} \mathrm{Sr}$ ), discriminatoire belediging van bevolkingsgroepen (artt. 137c-e Sr), de belediging van het hoofd of lid van de regering of een vertegenwoordiger van een bevriende staat (artt. 118 en $119 \mathrm{Sr}$ ). Nu deze strafbare feiten niet duidelijk in de wet staan geformuleerd is het niet vanzelfsprekend om de politie ruime inbeslagnemingsbevoegdheden te geven. Zeker niet mu in dit soort gevallen de vrijheid van meningsuiting en drukpers een rol kan spelen.

\subsubsection{Strafrechtelijke gevolgen van overschrijding van de bevoegdheid}

Als het onbevoegd in beslag genomen voorwerp niet mag meewerken aan het bewijs zal het te laste gelegde feit onder omstandigheden niet bewezen kunnen worden. Aan de problematiek van de verbeurdverklaring, een (bijkomende) straf, komt men in die gevallen niet meer toe. Wel aan die van de onttrekking wan het verkeer, omdat de onttrekking - een maatregel - ook bij afzonderlijke beschikking kan worden uitgesproken (art. 36b sub $4 \mathrm{Sr}$ ). ${ }^{274}$ Dat is het wetssystematische onderscheid tussen de straf 'verbeurdverklaring' en de maatregel 'onttrekking aan het verkeer'. Het doel van de onttrekking aan het verkeer is immers beveiliging van de maatschappij. ${ }^{275}$ Omdat de wet geen onderscheid maakt tussen voorwerpen en gegevensdragers kunnen ook gegevensdragers, bijvoorbeeld pornografische geschriften of staatsgeheimen worden onttrokken worden aan het verkeer bij een afzonderlijke beschikking van de rechter in de raadkamer (art. $552 \mathrm{f} \mathrm{Sv}$ ) zelfs als het tenlastegelegde feit niet bewezen kan worden. Het gaat daarbij om gevallen waarin is komen vast te staan dat een strafbaar feit is begaan, maar niet dat deze verdachte de dader is. ${ }^{276}$ De problemen die aan deze procedure kleven komen aan de orde in paragraaf 4.6.

4.4.3 De toetsing van de wijze van gebruikmaking van de inbeslagnemingsbevoegdheid aan de beginselen van een behoorlijke strafrechtspleging

In deze paragraaf zal ik de beginselen van een behoorlijke strafrechtspleging bespreken die betrekking hebben op het gedrag van politie en justitie met betrekking tot het in beslag nemen. De wetgever kent aan de politie en het Openbaar Ministerie

274 W.J.G.M. Eissens en B. Staal, Dwangmiddelen in het strafproces, diss. KU Brabamt, Arnhem 1981, p. 49.

275 D. van der Landen, Straf en maatregel, diss. KU Brabant, Arnhem 1992, p. 11-12.

276 D. van der Landen, Straf en maatregel, diss. KU Brabant, Arnhem 1992, p. 11-112. 
bevoegdheden toe. Deze bevoegdheden kunnen imperatief zijn dat wil zeggen dat het 'handelend" justitieel orgaan geen keuzeruimte heeft, zie bijvoorbeeld de vormvoorschriften in art. $358 \mathrm{~Sv}$, dan wel discretionair, dat wil zeggen dat de wettelijke bepaling aan het 'handelend' justitieel orgaan een keuzevrijheid laat om een beslissing al dan niet te nemen, zoals bijvoorbeeld bij art. 94 Sv en volgende. ${ }^{277}$ Bij discretionaire bevoegdheden dienen er dus belangen te worden afgewogen. Onder omstandigheden kan er in beslag genomen worden; maar daarvan mag ook worden afgezien. Geconfronteerd met de verdenking van een strafbaar feit kan de opsporingsambtenaar besluiten van een bepaalde bevoegdheid al dan niet gebruik te maken. In gevallen waarin het handelend orgaan een discretionaire bevoegdheid toekomt, toetst de rechter de bevoegdheidsuitoefening of aan de strekking van de wettelijke bevoegdheid, of binnen de grenzen van het gevoerde beleid aan de ongeschreven materiële rechtsbeginselen: vertrouwensbeginsel, gelijkheidsbeginsel, beginsel van zuiverheid van oogmerk en van evenredige belangenafweging, proportionaliteits-en subsidiariteitsbeginsel. De rechter toetst niet of de handeling op grond van de wettellike bevoegdheid of het beleid opportuun was, maar slechts of door de uitoefening in concreto de belangen die volgens de strekking van die bevoegdheid met de uitoefening daarvan moeten worden gediend, niet zijn geschonden. De rechter toetst slechts marginaal. De toetsingsbevoegdheid van de rechter aan de beginselen is gebaseerd op art. 1 Wetboek van Strafvordering. ${ }^{2 n}$ Dit artikel brengt met zich mee dat aan justitiële organen slechts strafworderlijke bevoegdheden toekomen indien de wet hen daartoe bevoegd verklaart. Het stelsel van Strafvordering is een gesloten stelsel van bevoegdheidsverlenende normen. Het strafvorderlijk legaliteitsbeginsel beschermt de burger tegen niet in de wet in formele zin begrepen inbreuken op zijn vrijheidsrechten. Het belet de burger niet een bescherming te eisen die verder gaat dan de wet. ${ }^{2 x}$ Vanuit het gezichtspunt van effecten voor de burger en de verdachte kunnen die beginselen wordlen omschreven als een instrument tot verhoogde rechtsbescherming. ${ }^{200}$

Wanneer we spreken over beginselen dient een onderscheid gemaakt te worden tussen formele en materiêle beginselen. De materiële beginselen zien op de inhoud van de handeling of het besluit. Processuele beginselen zien op de wijze van totstandkoming van de handeling of het besluit en de uitvoering daarvan. Duk onderscheidt drie groepen van processuele beginselen: de eerste groep wordt gekenmerkt door de eis van zorgvuldige voorbereiding, de tweede door de eis van correcte bejegening en de derde door de eis van consciëntieuze besluitvorming. ${ }^{281}$

277 G.J.M. Corstens, Beginselen wan behoorlijk procesrecht, Trema 1985, p. 173 e.v.

278 C.P.M. Cleiren, Beginselen van een goede procesorde, een analyse van rechtspraak in strafzaken, Arrahem 1989, p. 385.

279 J. Remmelink, In het Strafrecht zit een spelmoment, AA 1992, p. 145.

280 G.J.M. Corstens, Beginselen van behoorlijk procesrecht, Trema 1985, p. 173.

281 W. Duk, Beoordelingsvrijheid en beleidsvrijheid, RM Themis 1988, p. 1.56. 
In geval van willekeurige hantering van een discretionaire bevoegdheid kan het verwijt worden gemaakt dat die bevoegdheid ten onrechte niet plichtmatig, dat wil zeggen naar nadere normen is uitgeoefend. De discretionaire bevoegdheid is niet gegeven om willekeurig op te treden in de zin van zonder criteria beslissen, maar om stelselmatig volgens een bepaald plan op te treden. De discretionaire bevoegdheíd wordt getypeerd door de vrijheid die daarmee aan de hanteerder van de bevoegdheid wordt gegeven om zelf dat plan nader te ontwikkelen. Volgens Duk gaat het verbod van willekeur aan de beginselen van behoorlijk bestuur vooraf. ${ }^{222}$

Verder zijn er een viertal materiële beginselen te onderscheiden, waaronder het vertrouwensbeginsel, het gellijkheidsbeginsel, het beginsel van zuiverheid van oogmerk en het beginsel van redelijke en billijke belangenafweging. In het navolgende zullen deze materiële beginselen uiteengezet worden omdat ze een belangrijke rol spelen bij de inbeslagneming van gegevensdragers.

Onder het vertrouwensbeginsel wordt verstaan, dat door de over heid opgewekte verwachtingen in redelijkheid dienen te worden gehonoreerd, tenzij zwaarwichtige belangen zich daartegen verzetten. ${ }^{233}$ Het vertrouwensbeginsel speelt een rol wanneer het gaat om gedragingen van personen die behoren tot een bepaalde kring. Zoals gedragingen van het Openbaar Ministerie zelf, van functionarissen die voor het Openbaar Ministerie verantwoordelijk zijn of van functionarissen voor wie het Openbaar Ministerie verantwoordelijkheid draagt. Als dus de officier van Justitie besluit een zaak die betrekking heeft op de inbeslagneming van gegevensdragers te seponeren, kan hij daarop niet zonder meer terugkomen. ${ }^{24}$ Toezeggingen omtrent niet-vervolging door personen of instanties die buiten de kring vallen, behoeven in beginsel niet te worden gehonoreerd, omdat het Openbaar Ministerie daarvoor niet ter verantwoording kan worden geroepen. ${ }^{2 a s}$ Behalve een sepotmededeling kunnen ook vervolgings- of transactierichtlijnen worden genoemd. Door openbaarmaking van dergelijke richtlijnen wekt het Openbaar Ministerie de verwachting dat het stelselmatig conform de daarin neergelegde normen zal vervolgen. ${ }^{206}$ Het niet voldoen aan die opgewekte verwachtingen staat niet alleen op gespannen voet met het vertrouwensbeginsel maar kan ook op gespannen voet staan met het gelijkheidsbeginsel, het beginsel van een redelijke en billijke belangenafweging en met het verbod van willekeur. Voor het strafvorderlijke dwangmiddel inbeslagneming bestaan enkele richtlijnen. Zo moet als gevolg van een richtlijn uit 1980 worden nagegaan of bij de inbeslagneming van een voorwerp daadwerkelijk door de rechter zal worden verbeurd verklaard of ont-

282 W. Duk, Beoordelingsvrijheid en beleidsvrijheid, RM Themis 1988 , p. 156.

283 De eerste stap tot erkenning van het vertrouwensbeginsel werd door de Hoge Raad gezet in het eerste Menten-arrest (HR 29-5-1978, NJ 1978, 358).

284 Het nadeel van sepot is dat bij de inbeslagneming van gegevensdragers, zoals dagbladen, de zaak niet voor de rechter komt terwijl "tijdsgevoelig nieuws" wel woor een tijd uit de roulatie is genomen. 285 HR 28-6-1983, NJ 1984, 64; HR 17-12-1985, NJ 1986, 591; HR 13-9-1988, NI 1989, 403.

286 HR 13-9-1983, NJ 1984, 151 . 
trokken zal worden aan het verkeer. ${ }^{267}$ Ook mogen maatregelen er niet op gericht zijn dat bepaalde publicaties onmogelijk gemaakt worden. Dit staat in de richtlijn (van de procureurs-generaal bij de gerechtshoven van juli 1981) als ook in de leidraad (van de ministers uit 1988) over de positie van de pers bij politie-optreden. ${ }^{2}$ Het idee achter deze richtlijn en leidraad is dat journalisten verslag moeten kunnen doen van 'brandhaarden'. Dat is de taak van de journalistiek: nieuws garen. Foto- en filmapparatuur van journalisten afnemen door de politie zonder dat er een redelijk vermoeden bestaat dat zij zich schuldig hebben gemaakt aan een strafbaar feit kan tot gevolg hebben dat journalisten op ernstige wijze worden belemmerd in hun beroepswerkxaamheden. De garingsvrijheidd zoals expliciet genoemd in art. 19 IVBPR is een belangrijk element van de vrijheid van meningsuiting en drukpers. In een aantal zaken, zoals de zaak 'Journalisten stad radio Amsterdam's en de zaak 'Beslag op Videobanden $\mathrm{II}^{3200}$ werden film- en videobanden alsook foto-en opname-apparatuur in beslag genomen teneinde gegevens voor het strafrechtelijk onderzoek ter beschikking te krijgen. Daardoor werd het doel waarvoor de opnamen waren gemaakt, te weten publicatie en vertoning van beelden en geluiden van nieuwswaardige feiten (in de toekomst) onmogelijk gemaakt, althans bemoeilijkt. Dit staat op gespannen voet met de door de richtlijn en leidraad opgewekte verwachtingen.

Een ander materieel beginsel dat ik hierboven noemde is het gelijkheidsbeginsel Ook dit beginsel kan een rol spelen bij de inbeslagneming van gegevensdragers. Het gelijkheidsbeginsel verwijst maar de eis van gelijke behandeling van vergelijkbare gevallen. ${ }^{201}$ In de rechtspraak heeft dit beginsel in de context van opsporing en vervolging tot nu toe geen grote rol gespeeld. Meestal wordt het willekeurbeginsel gekozen.

Het beginsel van zuiverheid van oogmerk ofwel het verbod van 'détourmement de pouvoir' houdt in, dat de overheid een bevoegdheid niet voor een ander doel mag gebruiken dan waarvoor deze is gegeven. Ook bij de inbeslagneming geldt dat bevoegde personen en instanties hun bevoegdheid slechts mogen aanwenden ter bereilking van het doel waarvoor de bevoegdheid is gegeven. Zoals in het voorafgaande is uiteengezet, kan dat doel zijn het aan de dag brengen van de waarheid, de verbeurdverklaring of de onttrekking aan het verkeer (art. 94 Sv). Inbeslagneming met een ander doel, bijwoorbeeld de inbeslagneming van drukpersen on onwelgevallige meningen te voorkomen of om het goed aan de rechtmatige eigenaar terug te

287 Richtlingen voor het beleid van het Openbaar Ministerie en de politie inzake inbeslagneming (algemeen) 2 in: Statscourant 2-6-1980, ar. 103 en in: $F$. Vellinga-Schootstra. Inbeslagneming en huiszoeking, diss. RU Groningen, Alphen a/d Rijn 1982, p. 289.

288. De richtlijn is gepubliceerd in de leidraiad van 1988 over de positie van de pers bij polltie-optreden en te verkrijgen bij het ministerie van Justitie en het ministerie van Binnenlandse Zaken.

289 Hof Amsterdan 2-3-1992 in: Mediaforum 1992-5, p. 61-62 en Bijl, p. B33-B34.

290 HIR 19-2-1991 in: Mediaforum 1991-5, 2610, Bijl. p. 33\%37.

291 Zie ook art. 1 Grondwet, art. 26 IVBPR en art. 14 EVRM in relatie tot art. 2 van het Eerste Protocol bij het EVRM. 
geven is onrechtmatig wegens schending van het - uit het bestuursrecht afkomstige beginsel van behoorlijk bestuur - verbod van 'détournement de pouvoir'.

Als laatste beginsel noemde ik de redelijke en billijke belangenafweging. Dit beginsel betekent dat de in aanmerking komende belangen behoorlijk tegen elkaar moeten worden afgewogen. Van politie en Openbaar Ministerie mag verlangd worden, dat zij de belangen volledig redelijk tegen elkaar afwegen. Ook hier geldt dat die eis zowel op de afweging in abstracto (het beleidsniveau) als op die in concreto betrekking kan hebben. In abstracto: het gekozen beleid moet het resultaat zijn van een redelijke en billijke afweging van de belangen die in het geding zijn. In concreto: de genomen beslissing of de gestelde handeling of het gebleken nalaten moet het resultaat zijn van een redelijke en billijke belangenafweging. Bij de inbeslagneming van gegevensdragers voor het aan de dag brengen van de waarheid en bij de inbeslagneming van gegevensdragers ter onttrekking aan het verkeer staat veelal het opsporingsbelang tegenover de communicatievrijheid. De inbreuk op de vrijheid van meningsuiting en drukpers, indien noodzakelijk, mag dan niet groter zijn dan gerechtvaardigd is door de omstandigheden. Dat wil zeggen er moet voldaan zijn aan de beginselen van subsidiariteit en proportionaliteit. ${ }^{2 z}$ Oftewel in de woorden van het Europese Hof: beperkingen moeten noodzakelijk zijn in een democratische samenleving (noodzakelijkheidscriterium). Er moet sprake zijn van een 'pressing social need' en er dient een redelijk verhouding te bestaan tussen de zwaarte van de inbreuk en het gewicht van het belang dat met de inbreuk is gediend (evenredigheidscriterium).

\subsection{Teruggave van in beslag genomen voorwerpen}

Bij de inbeslagneming kunnen vele belangen betrokken zijn; niet alleen de belangen van de justitie en de beslagene, maar ook die van derden. De wetgever heeft gepoogd bij de regeling van de teruggave van in beslag genomen goederen recht te doen aan al de betrokkenen. Dit heeft geresulteerd in de voorschriften van de artt. 118, 118a, 552a, 552c, 552d en art. 353 Sv. De artt. 552 a, 552c en 552d Sv, die betrekking hebben op het beklag over inbeslagneming, zullen in de volgende paragraaf apart worden behandeld. ${ }^{23}$

Voor 1958 lag de beslissing over teruggave van in beslag genomen goederen in handen van de rechter die op grond van art. 353 (oud) over het lot van de voorwerpen beschikte. Werd de zaak echter niet of niet opnieuw vervolgd of eindigde de zaak zonder einduitspraak, dan behoorde ingevolge art. $118 \mathrm{~Sv}$ (oud) het Openbaar Ministerie zorg te dragen voor teruggave. Het Openbaar Ministerie kon in andere gevallen vóór beëindiging van de strafzaak niet uit eigen beweging tot teruggave overgaan. Dit had nadelen voor 'tijdsgevoelige' gegevensdragers zoals dagbladen. Art. $118 \mathrm{~Sv}$

292 HR 12-12-1978, NJ 1979, 142 .

293 A.L. Melai, Het Wetboek van Strafvordering, verklaard en van aantekeningen voorzien (losbladig), M.S. Groenhuijsen, Th.A. de Roos en A.H.J. Swart, Arnhen (zj), art. 118 e.V. Sv. 
(oud) schreef bowendien voor dat het Openbaar Ministerie het in beslag genomen goed alleen aan degene bij wie het in beslag was genomen mocht teruggeven. De rechter, teruggave bevelend op grond van art. $353 \mathrm{~Sv}$ (oud), had meer armslag: hij kon het voorwerp doen teruggeven niet alleen aan de beslagene, bijvoorbeeld de drukker, maar ook aan een ander bijwoorbeeld de redactie van het in beslag genomen geschrift indien deze rechthebbende op het woorwerp was.

In 1958 is deze regeling grondig gewijzigd. Sinds de wetswijziging die toen plaatswond is het Openbaar Ministerie verplicht om reeds in de opsporingsfase tot teruggave over te gaan zodra het belang der strafvordering zich daartegen niet meer verzet. Het nadeel hiervan is dat de zaak niet voor de rechter komt zodat deze de rechtmatigheid van de inbeslagneming niet kan toetsen terwijl toch bijvoorbeelld het dagblad een tijd uit de circulatie is geweest en waarschijnlijk zijn actualiteitswaarde heeft verloren. Een manier om dit probleem bij de inbeslagneming van gegevensdragers voor het aan de dag brengen van de waarheid te ontlopen is, zoals ik reeds in het voorafgaande opmerkte, door het accent te leggen op 'gegevens" en niet op "dragers' "Gegevens' vallen immers niet onder het begrip 'voorwerp' in art. 94 Sv en kunnen volgens mij onder de huidige wetgeving niet in beslag worden genomen.. Het gaat de politie en justitie bij de inbeslagneming van bijvoorbeeld filmbanden immers om de informatie en niet om die band. Die band kan niet de waarheid aan de dag brengen. Het gaat om de informatie op die band. De informatie op die band wordt pas zichtbaar wanneer er apparatuur beschikbaar is die de informatie omzet in beeld en geluid. In paragraaf 4.3.1 heb ik de problematiek van de inbeslagneming voor het aan de dag brengen van de waarheid en de vrijheid van meningsuiting en drukpers uitgebreid behandeld zodat ik hier met een verwijzing kan volstaan.

Op grond van de wetgeving uit $1958^{297} \mathrm{kan}$ men bij de teruggave van in beslag genomen goederen drie situaties onderscheiden:

1. teruggave v6ór de einduitspraak;

2. teruggave bij de einduitspraak;

3. teruggave na de einduitspraak.

Het gewijzigde art. $118 \mathrm{~Sv}$ geeft voorschriften voor de teruggave vóór de einduitspraak, art. $353 \mathrm{~Sv}$ (nieuw) over teruggave bij de einduitspraak. Indien de rechter

294 A.L. Melai, Het Wetboek wan Strafvordering, verklaard en van aantekeningen voorzien (losbladig), M.S. Groenhuijsen, Th.A. de Roos en A.H.J. Swart, Arnhem (zj.), art. 118 e.w. Sv.

295 Wet 22-5-1958, Stb. 1958, 296.

296 In de Wet Computercriminalitét wordt echter het accent gelegd op dragers. Wet Computercriminaliteit 23-12-1992, Stb. 1993, 33.

297 Op 12 aprill 1995 is de Wet tot wijziging van cnige bepalingen in het Wetboek wan Strafvordering en enkele andere weiten inzake de bewaring en teruggave wan inbeslaggenomen voorwerpen in werking getreden, Stb. 1995, 254. Voor zover deze afwijkt wan de regeling uit 1958 zall ik dat aangeven maar niet woordat ik de regeling uit 1958 en her woorstel van de Commissie Partiële Herziening Strafvordering uit 1982 heb besproken. 
niet in staat is om bij de einduitspraak te beslissen over de nog niet terug gegeven voorwerpen of in de einduitspraak geen beslissing heeft gegeven over deze voorwerpen, geldt weer de regeling van art. $118 \mathrm{~Sv}{ }^{38}$

\section{Ad 1 en 3: Teruggave vóór en na de einduitspraak}

De teruggave van voorwerpen vóór en na de einduitspraak is grotendeels in handen van het Openbaar Ministerie; 6́k als het voorwerp door de politie of de rechtercommissaris in beslag genomen is. Voor beide situaties geldt dezelfde regeling. Daarin is zowel voorzien in: a. teruggave aan degene bij wie in beslag is genomen, als in b. teruggave aan iemand onder wie het voorwerp niet in beslag is genomen. In dit verband zou dan beter van 'afgifte' kunnen worden gesproken.

a. Teruggave aan degene bij wie in beslag is genomen

Art. 118 lid $1 \mathrm{~Sv}$ bepaalt dat het Openbaar Ministerie het in beslag genomen voorwerp door de bewaarder doet teruggeven aan degene bij wie het in beslag is genomen zodra het belang der strafvordering zich daartegen niet meer verzet. Daarvan is sprake als het doen voortduren van het beslag niet meer dient tot het veilig stellen van de belangen waarvoor art. $94 \mathrm{~Sv}$ inbeslagneming toelaat, te weten het aan de dag brengen van de waarheid, de verbeurdverklaring of de onttrekking aan het verkeer van het voorwerp. ${ }^{200}$ Dat betekent dat het in beslag houden van een voorwerp enkel en alleen met het oog op teruggave aan de rechthebbende (bijvoorbeeld de bestolene) niet toelaatbaar is. Immers, nu het belang van de rechthebbende om het voorwerp terug te krijgen geen grond is om tot inbeslagneming over te gaan, kan dat belang ook niet leiden tot continuering van het beslag. ${ }^{300}$

In de praktijk blijkt art. $118 \mathrm{~Sv}$ dan ook aanleiding te geven tot tal van onbevredigende beslissingen. Het komt niet zelden voor dat het gestolen goed terug gaat naar degene die het hoogstwaarschijnlijk heeft ontvreemd, met name in die gevallen waarin de bestolene niet bekend is. Als de rechthebbende bekend is, kan en zal de zaak vaak in orde komen doordat een van de leden twee, drie en vier van art. $118 \mathrm{~Sv}$ van toepassing is. Een voorbeeld van een zaak waarin de rechthebbende niet bekend was, is te vinden in HR 20 maart 1979, NJ 1979, 310 met noot van G.E. Mulder. In deze zaak had de wegens diefstal veroordeelde $M$. bij de rechtbank beklag gedaan over het uitblijven van een last tot teruggave van de onder hem in beslag genomen gestolen voorwerpen, te weten 2463 oude kaarten en prenten, 145 langspeelplaten en 174 boeken. De rechtbank had naar aanleiding van het beklag beslist dat de in beslag genomen en nog niet teruggegeven voorwerpen aan $M$. afgegeven moesten worden. Deze beslissing was gemotiveerd met de overweging "dat het nader ingestelde

298 MvT op art. $118 \mathrm{Sw}$, Bijl. HTK 1954-1955.

299 HR 24-4-1984, NJ 1985, 115 met noot van Mulder.

300 HR 27-4-1971, NJ 1972, 341; HR 3-12-1974, NJ 1975, 163. 
onderzoek niet heeft geleid tot het bekend worden van een of meer eigenaars van de goederen", en "dat het belang der strafvordering zich thans niet meer tegen de teruggave van die goederen verzet. "Remmelink meent dat in dit soort onbevredigende situaties de staat en de officier van Justitie dienen op te treden als zaakwaarnemers. ${ }^{301}$ Men zou volgens hem misschien zelfs op basis van de wetshistorie kunnen stellen dat het Openbaar Ministerie, dat op grond van art. 118 lid 1 Sv een voorwerp teruggeeft aan de kennelijke dief, misbruik van recht maakt. ${ }^{302}$ Remmelink beperkt de mogelijkheid tot teruggave aan een ander uitdrukkelijk tot het geval dat die andere persoonde rechthebbende - ook werkelijk bekend is. Is die rechthebbende niet te vinden, dan moeten de in beslag genomen voorwerpen - ook in de visie van de wetgever terug naar de beslagene. De rechtbank heeft het geprobeerd met art. $353 \mathrm{~Sv}$, verklarende niet in staat te zijn tot een bevel tot teruggave. ${ }^{305}$ Maar ook dit denkbeeld kon geen genade vinden in de ogen van de Hoge Raad. Morele remmingen leveren, geconfronteerd met de duidelijke tekst van de wet, mu eenmaal geen overmacht op. De dief is in de ogen van de wetgever belanghebbende als het gestolene onder hem in beslag is genomen. ${ }^{300}$ Mulder heeft in zijn noot bij Hoge Raad 24 januari 1978, NJ 1978, 323, een andere oplossing aan de hand gedaan:

"(...) ik meen dat men althans voor het onderhavige geval kan verdedigen, dat de in beslag genomen goederen nog steeds konden dienen om de waarheid aan het licht te brengen. Goederen waarvan aannemelijk is dat ze gestolen zijn, doch waarvan de herkomst niet bekend is kunnen in beslag worden genomen omdat ze kunnen dienen om de waarheid aan het licht te brengen. Welnu, zolang de kans daartoe bestaat, lijkt het gerechtvaardigd ze onder beslag te houden, behalve in het geval wanneer de diefstal van die goederen mocht zijn telastegelegd en niet tot een veroordeling heeft geleid. Maar dat zal in de regel niet gebeuren, met name niet wanneer de verdachte goederen heeft gestolen waarvan de rechthebbende wel bekend is. Dan zal de officier van Justitie er de voorkeur aan geven de diefstal van die goederen te laste te leggen."

Volgens Mulder heeft de Hoge Raad een stap in bovengenoemde richting gedaan in zijn arrest van 9 oktober 1951, NJ 1952, 23 waarin het geschil ging om de vraag of de officier van Justitie teruggave mag weigeren omdat deze teruggave het beleid der opsporing verstoort. In zulk een geval zal de rechter die teruggave gelast, moeten

301. Conclusie van Advocaat-Generaal Remmelink vồo HR 24-1-1978, NJ 1978, 323; Conclusie van Advocaat-Generaal Remmelink wò̀r HR 20-3-1979, NJ 1979, 310.

302 Conclusie van Advocaat-Generaal Remmelink vŏ̀r HR 28-6-1977, NJ 1977, 508 ; Conclusie van Advocaat-Generaal Remmelink woor HR 24-1-1978, NJ 1978, 323; Conclusie van Advocaat-Generaal Remmelink voòr HR 24-4-1984, NJ 1985, 115; J.C.M. Leijten, Van vogels, vuurwapens en door rechters bevoordeelde dieven in: Naar eer en geweten, Liber Amicorum J. Remmelink, Arnhem 1987, p. 316-317.

303 Conclusie van Advocaat-Generaal Remmelink vòòr HR 28-6-1977, NJ 1977, 508.

304 HR 28-6-1977, NJ 1977, 508. 
aangeven waarom het belang van de strafvordering voortduring van het beslag niet langer noodzakelijk maakt.

Hoe aantrekkelijk deze interpretatie van het begrip 'belang der strafvordering' ook mag lijken, toch is ze niet te rijmen met het uitgangspunt dat mede ten grondslag heeft gelegen aan de wetswijziging van $1958^{306}$; het zoveel mogelijk beperken van de duur van de inbeslagneming. ${ }^{307}$ Immers, voor het aan de dag brengen van de waarheid is veelal voldoende dat de gestolen goederen duidelijk in het proces-verbaal worden omschreven; bovendien kunnen ze worden gefotografeerd. Zeker als de kans op vervolging klein is, is er geen enkel wettelijk beletsel om tot teruggave over te gaan. Integendeel, in de visie van de wetgever lijkt afgifte van de goederen ondanks alles toch geïndiceerd. Om beslissingen als in HR 24 januari 1978 , NJ 1978, 323 en HR 20 maart 1979, NJ 1979, 310 te voorkomen zal men er volgens Mulder niet aan ontkomen om de wet op dit punt te wijzigen. ${ }^{308}$ Men zou daarbij kunnen denken aan een regeling als in paragraaf $111 \mathrm{k}$ 'StrafprozeBordnung' (StPO). Deze bepaling houdt in dat de in beslag genomen voorwerpen zoveel mogelijk moeten worden teruggegeven aan degene aan wie ze door het misdrijf zijn onttrokken. Is deze niet bekend dan moeten de voorwerpen worden afgegeven aan de beslagene, behalve wanneer vaststaat dat de goederen op onrechtmatige wijze in diens bezit zijn gekomen, dan moet het in beslag genomene met toepassing van paragraaf 983 'Bundesgesetzbuch' (BGB) in bewaring worden gesteld; na het verstrijken van een bepaalde termijn (bijwoorbeeld drie jaren, vergelijk art. 119 lid $3 \mathrm{~Sv}$ ) zouden de goederen indien de rechthebbende nog steeds niet is komen opdagen - toch teruggegeven moeten worden aan de beslagene. ${ }^{309}$

Wat Vellinga-Schootstra bepleit is dat de hoofdregel 'teruggave aan de rechthebbende' die gold vóór 1886, weer wordt ingevoerd. In de praktijk worden reeds goederen in beslag genomen enkel en alleen om ze aan de rechtmatige eigenaar te doen

305 HR 20-3-1979, NJ 1979, 310 met noot van G.E. Mulder.

306 Bijl. HTK 1954-1955, 4034; Bül. HTK 1956-1957, 4034; HEK, 1957-1958, p. 2553 en Bijl. HEK 1957-1958, 4034; HTK 1957-1958, p. 2315-2323 en Bijl. HTK 1957-1958, 4034.

307 Art. 118 lid 1 schrijft imperatief voor dat als het belang van de strafvordering zich niet meer werzet tegen de teruggave van een in beslag genomen voorwerp, het Openbaar Ministerie dit door de bewaarder doet teruggeven aan degene bij wie het in beslag genomen is. Het belang van strafvordering is niet dat het ontvreemde goed wordt teruggeven aan de rechthebbende. Art. 552a e.v. Sv betreft het beëindigen van het beslag door de afgifte aan wie dan ook en juist niet handhaving van het beslag.

308 Volgens G.E. Mulder in zijn annotalie onder het arrest van de HR 20-3-1979, NJ 1979,310 dient de wetgever in te grijpen door inbewaringstelling van in beslag genomen goederen mogelijk te maken als duidelijk is dat de goederen door teruggave aan de beslagene in verkeerde handen komen; HR 9-1-1990, NJB 1990, 2409, p. 1324. De Commissie Moons zou bij de voorgestelde wijziging van het Wetboek van Strafwordering hier rekening mee moeten houden; J.C.M. Leijten, Van vogels, vuurwapens en door rechters bevoordeelde dieven in: Naar eer en geweten, Liber Amicorum J. Remmelink, Arnhem 1987, p. 314 e.v.

309 F. Vellinga-Schootstra, Teruggave van in beslag genomen voorwerpen, DD 1989, p. 124 e.w. 
toekomen. Dit is in strijd met de grondgedachte van de wetgever op art. $94 \mathrm{~Sv}^{\text {sut }}$ als ook schending van het verbod van "détournement de pouvoir". Bovendien is dit ook niet overeenkomstig de Memorie wan Toelichting op art. $118 \mathrm{~Sv}$. De hoofdregel is dat teruggave geschiedt aan degene onder wie in beslag "is genomen. ${ }^{31}$ De wet eist niet dat degene aan wie het goed wordt teruggegeven rechthebbende op het voorwerp is; integendeel, teruggave aan de beslagene moet zelfs plaatsvinden als dit het Openbaar Ministerie uitgesproken onredelijk voorkomt. ${ }^{3 / 2}$

Verder kan uit het woordje 'doet' in art. $118 \mathrm{~Sv}$ worden afgeleid dat het in casu gaat om een plicht tot teruggave van het Openbaar Ministerie. Zodra het Openbaar Ministerie bemerkt dat met het voortduren van het beslag niet (meer) een van de genoemde doeleinden wordt gediend - dus wanneer het niet te verwachten valt dat het voorwerp daadwerkelijk gebruikt zal worden om de waarheid aan de dag te brengen, dan wel dat verbeurdverklaring of onttrekking aan het verkeer ervan bevolen zal worden - moet het voorwerp worden teruggegeven. ${ }^{3 / 3}$ In sommige gevallen bieden echter het tweede en het derde lid van art. 118 Sv de mogelijkheid om het voorwerp toch aan een ander te geven.

b. Teruggave aan een ander dan aan degene bij wie in beslag is genomen

Teruggave aan de beslagene is niet wenselijk wanneer er sterke aanwijzingen bestaan dat deze niet de rechthebbende op het voorwerp is. ${ }^{314}$ Dit behoeft niet alleen het geval te zijn wanneer het voorwerp door een strafbaar feit aan de rechthebbende is onttrokken. Art. 118 lid $2 \mathrm{Sw}$ bepaalt om die reden dat het Openbaar Ministerie het voorwerp terug kan geven aan een ander dan de beslagene. ${ }^{315}$ Deze uitzondering op de hoofdregel 'teruggave aan de beslagene' mag alleen worden gemaakt in geval:

a. de beslagene ten overstaan van de (hulp)officier van Justitie verklaart het voorwerp door een strafbaar feit te hebben onttrokken aan een bepaald persoon (een

310 Onder het 'belang van de strafwordering' kan niet worden verstaan het belang dat de ontvreemde goederen worden teruggegeven aan de rechthebbende in: HR 6-4-1936, NJ 1936, 813.

311 Zie ook HR 13-11-1963, NJ 1963, 38.

312 Het redelijkheidscriteritum geldt niet voor teruggave als gevolg van 118 lid 1 Sv (HR 24-1-1978, NJ 1978, 323 met noot van G.E. Mulder).

313 HR 13-1-1948, NJ 1948, 158; HR 27-4-1971, NJ 1972, 341. Leijten pleit voor een civielrechtelijk strafrecht. De dief maakt misbruik van recht. Op grond daarvan mag het goed niet terug gegeven worden. Het belang van de strafvordering kan in dle loop van de strafprocedure uitgroeien boven die belangen welke volgens art. 94 Sw een voorwerp vatbaar maken voor beslag. J.C.M. Leijten, Van vogels, vuurwapens en door rechters bevoordeelde dieven in: Naar eer en geweten, Liber Amicorum J. Remmellink, Arnhem 1987, p. 317.

314 Het recht van de ander moet manifest zijn. Rb. "s-Hertogenbosch 21-4-1965, NJ 1966.

315 Het woordje 'kan' duidt op een bevoegdheid en niet op een verplichting, zoals 'doet' in art. 118 lid $1 \mathrm{~Sv}$. 
afzonderlijke verklaring wan geen bezwaar als hierna bedoeld onder b is dan niet nodig);

b. de beslagene geen bezwaar verklaart te hebben tegen teruggave van het voorwerp aan een bepaald persoon (meestal de rechthebbende).

Een verklaring als onder a. bedoeld kan natuurlijk alleen worden afgelegd door de verdachte-beslagene die het feit bekent. De ontkennende verdachte daarentegen kan de verklaring afleggen geen bezwaar te hebben tegen teruggave van het woorwerp aan een bepaald persoon. De woorden van de wet sluiten bovendien niet uit dat zo"n laatste verklaring wordt afgelegd door de niet-verdachte beslagene.

Zowel in geval a. als in geval b. is met een bepaald persoon' bedoeld een met name aangeduid persoon. Een aanduiding als 'de rechthebbende' is onvoldoende; bij beantwoording van de vraag aan wie het voorwerp moet worden teruggegeven zou de bewaarder - die immers met de eigenlijke teruggave is belast - dan worden gedwongen om op de stoel van de burgerlijke rechter te gaan zitten. ${ }^{316}$ Dit zou in strijd zijn met de wil van de wetgever. Teruggave aan een vooralsnog onbekende is dus niet mogelijk. ${ }^{37}$ Bij de beantwoording van de vraag wie als rechthebbende is aan te merken mag het Openbaar Ministerie zich laten leiden door hetgeen op het eerste gezicht redelijk en maatschappelijk niet onverantwoord is, aldus de Memorie van Toelichting op art. $118 \mathrm{~Sv}$. Wil teruggave aan een ander maatschappelijk niet verantwoord zijn, dan moet het recht van die ander dus wel duidelijk sterker zijn dan dat van de beslagene. ${ }^{3 ! *}$

Hoewel de regels van burgerlijk recht niet doorslaggevend zijn ${ }^{319}$, wordt het antwoord op de vraag wanneer er sprake is van een op het eerste gezicht redelijke en maatschappelijk niet onverantwoorde teruggave aan een ander dan de beslagene natuurlijk wel beïnvloed door de voorschriften van het civiele recht. De artt. 86 , 87 NBW (titel 4 afdeling 2) bieden immers bescherming aan degene die een ontvreemde zaak te goeder trouw heeft verkregen. Hij is slechts tot overdracht verplicht indien de koper hem de door hem bestede koopprijs vergoedt.

Voor het geval de beslagene zijn medewerking weigert om teruggave aan een ander mogelijk te maken, bepaalt het derde lid van art. 118 Sv dat het Openbaar Ministerie het voorwerp desondanks kan doen teruggeven aan een ander dan degene onder wie het in beslag is genomen, indien de beslagene niet binnen veertien dagen

316 HR 4-1-1969, NJ 1970, 42.

317 In het Wetboek van Strafwordering voor de Antillen is woorgesteld om strafvorderlijk beslag op voorwerpen mogelijk te maken louter met het oog op de belangen van de rechthebbende. P.A.M. Mevis, Inbeslagneming en huiszoeking in: Hercodificatie wetboek wan Strafwordering, Nijmegen 1991, p. 111.

318 Hof Leeuwarden 24-3-1964, NJ 1965, 285; HR 27-4-1976, NI 1976, 427; HR 4-9-1979, NJ 1979, 636; Rb. Middelburg 29-2-1980, NJ 1980, 596; HR 6-5-1980, NJ 1981, 427; HR 20-1-1981, NJ 1981, 351 .

319 De beslissing van het Openbaar Ministerie heeft geen ciwielrechtelijke gevolgen. Hof " $\mathrm{s}$-Hertogen-" bosch 6-10-1976, NJ 1981, 38. 
nadat het Openbaar Ministerie een mededeling tot een dergelije teruggave heeft doen betekenen, zich daarover heeft beklaagd of het beklag ongegrond is verklaard (art. $552 \mathrm{a} \mathrm{Sw}$ ). In de richtlijnen wordt er in dit verband op gewezen dat het van belang is dat de officier van Justitie zo spoedig mogelijk na ontvangst van het proces-verbaal en of de kennisgeving van inbeslagneming de mededeling van zijn voornemen tot teruggave betekent aan de beslagene; op deze wijze kunnen - aldus de richtlijnen bewaringsproblemen worden voorkomen. Want ook als de betekening niet in persoon heeft plaatsgevonden kan na veertien dagen tot teruggawe worden overgegaan. Evenals bij teruggave op grond van art. 118 Iid $2 \mathrm{~Sv}$, geldt bij afgifte op grond van het derde lid van dat artikel dat het voorwerp slechts aan een ander dan de beslagene mag worden teruggegeven als dit op het eerste gezicht redelijk en maatschappelijk niet onverantwoord is. ${ }^{30}$ Een dergelijke beoordeling veronderstelt dus dat die ander bekend is: als de rechthebbende niet bekend is, kan art. 118 lid 3 Sv niet worden toegepast. Wanneer het Openbaar Ministerie een kennisgeving omtrent het voornemen tot teruggave aan een ander achterwege laat, kan de beslagene zich daarover beklagen op grond van art. 552a Sv. Wordt het beklag gegrond verklaard, dan behoort het voorwerp alsnog aan de beslagene te worden teruggegeven. Is dit niet meer mogelijk omdat het Openbaar Ministerie zijn woomemen al heeft uitgevoerd, dan moet aan de beslagene de prijs worden uitbetaald die het voorwerp bij verkoop redelijkerwijs had moeten opbrengen (conform art. 119 lid $2 \mathrm{~Sv}$ ). ${ }^{321}$

Kan geen gebruik worden gemaakt van het bepaalde in art. $118 \mathrm{~Sv}$, tweede en derde lid - bijvoorbeeld omdat de rechthebbende vooralsnog onbekend is - dan gaat het voorwerp terug naar degene onder wie het is in beslag genomen, ook al staat vast dat deze het gestolen heeft. ${ }^{322}$ Dit is onbillijk omdat de dief die de voorwerpen heeft gestolen, alles terug krijgt alleen omdat de eigenaar onbekend is. De Subcommissie onder voorzitterschap van G.E. Mulder van de Commissie Partiële Herziening Strafvordering heeft in 1982 woorstellen ingediend tot wijziging van art. $118 \mathrm{~Sv}$, art. $353 \mathrm{~Sv}$ en art. $552 \mathrm{a} \mathrm{Sv}{ }^{323}$ In deze voorstellen heeft de Commissie vastgehouden

320 HR 49-1979, NJ 1979, 636; HR 6-6-1978, NJ 1979, 29.

321 HR $26-6-1979$, NJ $1979,620$.

322 HR 20-3-1979, NJ 1979, 310 met noot wan G.E. Mulder. Een uitzondering hierop vormt art. 118 lid 4 Sw. Art. 118 lid 4 Sv biedt de rechthebbende de mogelijkheid schriftelijk te verklaren afstand van het voorwerp te doen. In de richtlijnen wordt, behalwe van afstand na inbeslagneming op grond van art. 118 lid $45 v$, ook nog gesproken over afstand zonder dlat een inbeslagneming is voorafgegaan. Volgens de richllijnen bestaat deze mogelijkheid in twee gevallen: als het voorwerpen betreft waarvan inbeslagneming niet nodig is en als de rechthebbende vrijwillig 'afstand ter vernietiging' doet, waarna de politie maatregelen neemt tot vernietiging van de goederen. Voor de politie brengt de afstand zonder woorafgaande inbeslagneming veel minder administratieve rompslomp met zich mee dan de afstand na inbeslagneming; een uiterst praktische oplossing dus. Toch is voorzichtigheid wel geboden, want op deze wijze zou een 'informele' inbeslagneming kunnen ontstaan, die de betrokkene niet de wettelijke garanties biedt van de afstand na imbeslagneming ex art. 118 lid $4 \mathrm{~Sv}$.

323 Vellinga-Schootstra, Beklagenswaardig beslag, enkele opmerkingen over de positie van de derdebelanghebbende, DD 1988, p. 300 e.v. 
aan het uifgangspunt dat in beslag genomen voorwerpen aan de beslagene behoren te worden teruggegeven. "Het behoort tot de beginselen wan het strafproces, dat de toestand die door een voorlopige maatregel -inbeslagneming, die naw haar aard nuet alleen tegen verdachten wordt toegepast - is ontstaan, na afloop wan het strafrechtelijk onderzoek zoveel mogelijk ongedaan wordt gemaakt" "aldus de Commissie, " Daarom blijft het eerste lid van art. $118 \mathrm{~Sv}$ in het voorstel van de Commissie gehandhaafi. In lid twee van art. $118 \mathrm{~Sv}$ treedt de afstandswerklaring in de plaats van de verklaring 'het goed door een strafbaar feit aan een ander te hebben onttrokken' en van de verklaring 'geen bezwaar te hebben tegen teruggave aan een bepaald persoon'. Het huidige lid 4 van art. 118 Sv komt te vervallen; ook van woorwerpen van geringe waarde kan afstand worden gedaan op de in het tweede lid geschetste wijze. In tegenstelling tot de nu geldende regeling kan de betrokkene alleen schriftelijk afstand doen van de in beslag genomen voorwerpen ten overstaan van de rechter-commissaris of (hulp) officier van Justitie ${ }^{320}$ Kern van de wijziging is, dat het voorwerp na afstand kan worden bewaard ten behoeve van de onbekende rechthebbende. ${ }^{327}$ Deze inbewaringstelling dient echter zo kort mogellikk te zijn. ${ }^{328}$ Zeker wanneer het gaat om gegevensdragers. Dit in verband met de vrijheid van meningsuiting en drukpers. Mell zich de rechthebbende binnen een bepaalde periode niet dan houdt de behartiging van diens belangen door de overheid op. Onder omstandigheden kan het voorwerp dus toch teruggaan naar de beslagene te kwader trouw. De gevolgen van het huidige systeem blijwen dus bestaan." Volgens Mevis is het "niet de taak van het strafrecht civielrechtelijke aanspraken wan eigenaars en bezitters van voorwerpen als zelfstandig belang te beschernen. "*300 Een belanghebbende kan tegen een teruggave aan de beslagene nog altijd zijn civielrechtelijke aanspraken geldend maken. Ik ben. het met Mevis eens dat het niet de taak is van het strafrecht civielrechtelijk aanspraken van eigenaars en bezitter van voorwerpen als zelfstandig belang te beschermen. Bovendien bestaat het risico dat de vrijheid van meniningsuiting en drukpers, in die gevallen dat nieuwsgevoelige gegevensdragers in beslag zijn genomen, in het gedrang komt:

\section{Rapport p. 9.}

325 Dit woorstel is overgenomen in de Wet 12-4-1995, Stb, 1995, 254 (art. 116 lid 2 Sw).

326 Zie ook Wet 12-4-1995, Stb. 1995, 254 (art. 1.16 lid 2 Sw).

327 Zie ook Wet 12-4-1995, Stb. 1995, 254 (art. 116 lid 2 sub b Sv); F. Vellinga-Schootstra, Teruggave van in beslag genornen voorwerpen, DD 1983, p. 125-126.

328 Mevis stelt een periode voor van wijf jaar. Het is de officier van Justitie die bij de traadkamer van de rechtbank een beslissing uitlokt dlat het voorwerp gedurende wif jaar ten behocve wan de rechthobbende zal worden bewaard. P.A.M. Mevis, Inbeslagneming en huiszoeking in: D.R. Doorenbos en R.J. Verweij (red.), Hercodificatie wetboek van Strafvordering, Nijmegen 1991, p. 113. In de nieuwe Wet is de periode gesteld op 2 jaar (art. 118 lid 3 Sw).

329 P.A.M. Mevis, Inbeslagneming en huiszoeking in: D.R. Doorenbos en R.J. Verweij (red.), Hercodificatie Wetboek van Strafvordering, Nijmegen 1991 , p. 114.

330 P.A.M. Mevis, Inbeslagneming en huiszoeking in: D.R. Doorenbos en R.J. Venweij (red.), Hercodificatic Wetboek wan Strafvordering, Nijmegen 1991, p. 114. 
In sommige fasen van de vervolging kan het Openbaar Ministerie niet op eigen houtje tot afgifte van het in beslag genomen voorwerp overgaan. Zo heeft het Openbaar Ministerie volgens art. 118 lid $2 \mathrm{~Sv}$ gedurende het gerechtelijk vooronderzoek een schriftelijke machtiging van de rechter-commissaris nodig alvorens het voorwerp mag worden terug gegeven. Wordt het gerechtelijk vooronderzoek gesloten en wordt daarna afgezien wan verdere verwolging, dan kan het Openbaar Ministerie weer zelfstandig de bevoegdheden uitoefenen die art. 118 Sv het Openbaar Ministerie toekent. Vanaf het moment dat de zaak ter terechtzitting aanhangig is gemaakt (door dagvaarding of oproeping) tot de einduitspraak dient het Openbaar Ministerie tot teruggave gemachtigd te zijn door het gerecht waarvoor de zaak wordt vervolgd. Van de inhoud van de einduitspraak hangt het af of het Openbaar Ministerie 'überhaupt' nog tot afgifte van het voorwerp mag besluiten. De einduitspraak behoort in beginsel een uitspraak te bevatten over de nog niet teruggegeven, in beslag genomen voorwerpen. Dat kan zijn de verbeurdverklaring of de onttrekking aan het verkeer van het woorwerp, maar ook de beslissing tot teruggave aan een in de uitspraak met name genoemd persoon. Wordt in de einduitspraak niet bepaald wat met het voorwerp moet gebeuren, dan kan het Openbaar Ministerie, volgens Vellinga-Schootstra, totdat de dagvaarding in hoger beroep wordt uitgebracht, zelfstandig tot afgifte overgaan. Daarna is tot de einduitspraak in hoger beroep voor teruggave weer een machtiging van hett betreffende gerecht vereist; de zaak is dan weer 'onder de rechter'. ${ }^{391}$ Melai stelt echter dat het Openbaar Ministerie pas tot teruggave kan overgaan als de einduitspraak, die geen beslissing over het voorwerp inhoudt, in kracht van gewijsde is gegaan. ${ }^{332}$ Voor deze opvatting is volgens Vellinga-Schootstra geen steun te vinden in de wet of in de wetshistorie. De ratio van de regeling, zoals we hebben gezien, brengt mee dat teruggave door het Openbaar Ministerie ook mogelijk is voor het in kracht van gewijsde gaan van een einduitspraak die geen beslissing inhoudt over de in beslag genomen voorwerpen; het in kracht van gewijsde gaan van een uitspraak kan in een verstekzaak immers lang op zich laten wachten (zie bijvoorbeeld art. $408 \mathrm{Sw}$ ). ${ }^{\text {as }}$ Deze snelle teruggave verhoudt zich ook beter met de vrijheid van meningsuiting en drukpers in die gevallen waarin het gaat om de teruggave van gegevensdragers.

$331 \mathrm{~F}$. Vellinga-Schootstra, Teruggave van in beslag genomen voorwerpen, DD 1983, p. 125-126.

332 A.L. Melai, Het Wetboek van Strafvordering, werklaard em van aantekeningen voorzien (losbladig), M.S. Groenhuijsen, Th.A. de Roos en A.H.J. Swart (red.), Arnhem (z.j.), aant. 4 op art. 552a Sv.

333 Art. 355 Sv geldt immers alleen indien de rechter wel een beslissing over de voorwerpen heeft genomen. F. Vellinga-Schootstra, Inbeslagneming en huiszoeking, diss. RU Groningen, Alphen a/d Rijn, 1982, p. 231. 
Art. 353 Sv schrijft voor dat de rechtbank in geval van oplegging van een straf of maatregel, van vrijspraak of ontslag van rechtsvervolging teruggave gelast van in beslag genomen, nog niet teruggegeven voorwerpen. De gedachte achter dit woorschrift is, dat de rechter door behandeling van de hoofdzaak voldoende geïnformeerd is over de feiten om een beslissing over de voorwerpen te kunnen nemen; bovendien is na een uitspraak over de vragen van art. 350 Sv hernieuwde vervolging niet meer mogelijk. Daarom dient dan de rechter - en niet het Openbaar Ministerie - in beginsel over de voorwerpen te beslissen. Dit is anders indien de nietigverklaring van de dagvaarding, de onbevoegdverklaring, de niet-ontvankelijkheid van het Openbaar Ministerie of de schorsing van de vervolging wordt uitgesproken. In die gevallen blijven de voorwerpen waar ze zijn en kan het Openbaar Ministerie eventueel beshuiten tot teruggave. Uit de Memorie van Toelichting op art. $353 \mathrm{~Sv}$ blijkt dat de wetgever de rechter niet heeft willen verplichten om bij de einduitspraak het lot te bepalen van alle nog aanwezige in beslag genomen voorwerpen: "in sommige gevallen ware dit van de rechter te veel gevergd, omdat hij niet in het hem gegeven korte tijdsbestek een overzicht wan het inbeslaggenomene heeft kunnen verkrijgen." Om die reden zegt art. $353 \mathrm{~Sv}$ dat de rechter kan verklaren tot het doen van een uitspraak over de in beslag genomen voorwerpen niet in staat te zijn. Bovendien kan teruggave onmogelijk zijn indien er geen met name bekend persoon is. De rechtbank mag zich dan niet in staat verklaren het bevel tot teruggave te geven ${ }^{334}$

In afwijking van art. $118 \mathrm{~Sv}$ staat in art. $353 \mathrm{~Sv}$ niet de teruggave aan degene onder wie het goed in beslag genomen is voorop. Het voorschrift spreekt over 'teruggave aan een met name genoemd persoon'; dit kan degene zijn onder wie het voorwerp in beslag is genomen, tevens rechthebbende, maar ook een ander dan de beslagene, indien de beslagene niet rechthebbende op het voorwerp is. De rechter heeft in dezen dus een grotere vrijheid dan het Openbaar Ministerie. ${ }^{3 x}$ Het Openbaar Ministerie is slechts na toepassing van het tweede of derde lid van art. $118 \mathrm{~Sv}$ vrij om het voorwerp aan een ander dan de beslagene terug te geven. Is er reeds een civiel geding over het voorwerp aanhangig, dan kan de rechtbank gelasten dat het voorwerp waarover de procedure gevoerd wordt, hangende het geding op een bepaalde wijze zal worden bewaard (art. 353 lid 2 Sv). In verstekzaken geldt bovendien

334 J. M. van Bemmelen, Strafprocesrecht, Ons Strafrectht 4, bewerkt door Th.W. wan Veen, 1989, p. 174-177; F. Vellinga-Schootstra, Inbeslagneming en tuiszocking diss. RU Groningen, Alphen a/d Rijn 1982, p. 232.

335 HR 1-12-1981, NJ 1982, 234; De rechter mag teruggeven aan wie hij will en dal kan een ander zijn dan degene bij wie het goed in beslag is genomen. HR 12-6-1984, NJ 1985, 36; F. VellingaSchootstra, Inbeslagneming en huiszoeking, diss. RU Groningen, Alphen a/d Rijn 1982, p. 233. 
art. $355 \mathrm{Sw}$. Dit voorschrift is uiteraard alleen van toepassing indien in het wonnis is beslist over de in beslag genomen voorwerpen.

De Commissie Partięle Herziening Wetboek van Strafvordering onder leiding van Mulder heeft bij de herziening van art. $353 \mathrm{Sw}$ aansluiting gezocht bij art. 118 Sv. Door het uitbreiden van de mogelijkheden, waaruit de rechtbank bij het afdoen van het beslag een keuze kan maken, wordt, zo verwacht de Commissie, handhaving van de uitspraak 'niet in staat tot het geven van een last tot teruggave' overbodig. Wanneer de rechtbank niet de onttrekking aan het verkeer of de verbeurdverklaring van de voorwerpen uitspreekt, kan zij immers teruggave aan de beslagene gelasten, de rechthebbende dan well de bewaring van het voorwerp ten behoeve van de onbekende rechthebbende bevelen. ${ }^{33}$

\subsection{Beklag over inbeslagneming}

Het doel van de regeling van het beklag is de rechten van belanghebbenden in de hier bedoelde gevallen zoveel mogelijk te beschermen. Uitgangspunt is dat deze rechten niet meer worden beperkt of aangetast dan uit het oogpunt van strafvordering noodzakelijk is. In 1958 (Stb. 296) werd de regeling van teruggave van in beslag genomen goederen herzien. De belangrijkste wijziging bestond hierin, dat de beslissing tot teruggave in meer gevallen dan voorheen ook door het Openbaar Ministerie kan worden genomen, terwijl bovendien de mogelijkheid werd geopend dat het Openbaar Ministerie het goed teruggeeft alan een ander dan de beslagene: deze bevoegdheid had aanvankelijk alleen de rechter op grond van art. $353 \mathrm{~Sv}$ (oud). Omdat de bevoegdheid van het Openbaar Ministerie werd uitgebreid, achtte de wetgever het wenselijk om de hantering van die bevoegdheid aan de controle van de rechter te onderwerpen. In verband hiermee werd eveneens in 1958 een verruimde beklagmogelijkheid ingevoerd; art. $552 \mathrm{a}$ Sv jo. art. $552 \mathrm{~d} \mathrm{~Sv}$. Na 1958 is de tekst van art. $552 a \mathrm{~Sv}$ nog op enkele ondergeschikte punten gewijzigd.

Bij bestudering van het huidige art. 552 a Sv rijzen verschillende vragen zoals:

1. over welke handelingen en beslissingen kan worden geklaagd?

2. in welke fasen van opsporing en vervolging is beklag mogelijk?

3. wie is "belanghebbende"?

4. bij welke instantie moet het klaagschrift worden ingediend?

5. welke voorschriften gelden voor de behandeling van het klaagschrift?

6. welke zijn de gronden van het beklag?

336 F. Vellinga-Schootstra, Inbesllagmeming en huiszoeking, diss. RU Groningen, Alphen a/d Rijn 1982, p. 233

337 Dit voorstel is overgenomen in de Wet 12-4-1995, Stb. 1995, 254 (art. 353 lid 2 Sv); F. VellingaSchootstra, Teruggave van in beslag genomen voorwerpen, DD 1983, p. 132 e.v. 
7. staat hoger beroep of cassatie open tegen de uitspraak van de rechter op het klaagschrift?

8. kan men de inbeslagneming tot inzet maken van een civiele procedure?

Ad 1: De beslissingen en handelingen waarover beklag mogelijk is

Het eerste lid van art. 552a Sv opent de mogelijkheid om te klagen over de inbeslagneming zelf en over het gebruik van de in beslag genomen voorwerpen, verder kan ook worden geklaagd over het uitblijven van een last tot teruggave etcetera. ${ }^{33}$ Behalve over het handelen van het Openbaar Ministerie kan ook worden geklaagd over de wijze van optreden van de politie of van de rechter-commissaris. Wanneer het beklag gericht is tegen het uitblijven van een last tot teruggave is er vrijwel steeds sprake van klagen over het handelen van het Openbaar Ministerie. Want in beginsel is alleen het Openbaar Ministerie tot teruggave bevoegd, zelfs als het voorwerp in beslaggenomen is door een opsporingsambtenaar of door de rechter-commissaris. ${ }^{39}$ Is daarentegen het beklag gericht tegen de inbeslagneming zelf, dan richt de klacht zich in feite tegen het optreden door de beslaglegger; dat kan heel goed een ander zijn dan de officier van Justitie. Evenals in art. $118 \mathrm{~Sv}$ moet het woordje 'teruggave' worden uitgelegd als 'afgifte'. Immers, ook een ander dan de beslagene kan zich beklagen over het feit dat het Openbaar Ministerie niet besluit tot afgifte van het voorwerp aan hem. ${ }^{30}$ Als het Openbaar Ministerie al een last tot teruggave heeft gegeven, is beklag niet meer mogelijk..$^{345}$ Dat is alleen anders, indien het Openbaar Ministerie die last heeft verstrekt zonder het voornemen daartoe te hebben betekend aan de beslagene, dan wordt het beklag over de reeds gegeven last beschouwd als beklag tegen het voornemen van het Openbaar Ministerie om het voorwerp aan een ander terug te geven; het beklag is dan dus toch ontvankelijk, ondanks de reeds gegeven last.

Onderneemt het Openbaar Ministerie geen activiteiten in de zin van art. 118 lid $3 \mathrm{~Sv}$ dan kan de derde-belanghebbende, al dan niet na een mededeling ex art.

338 Een beklag kan leiden tot teruggave, maar niet tot schadevergoeding. In plaats van een kostbare civiele procedure zou er wat te zeggen zijn woor een eenvoudige procedure bij een gespecialiseerde rechter: de raadkamer van de rechtbank (art. 21 e.w. Sv). Commentaar NJCM-rapport Commissie Moons, NJCM-Bulletin 1991, p. 361.

339 Tenzij zich de situatie genoemd in art. 118a voordoet waarin de officier van Justitie tijdens het gerechtelijk wooronderzoek een schriftelijke machtiging wan de rechter-commissaris nodig heeft. Ook vanaf het ogenblik dat de zaak ter terechtzitting aanhangig is gemaakt tot aan de einduitspraak heeft de officier van Justitie een schriftelijke machtiging van het gerecht nodig voor dle uitoefening van deze bevoegdheid (art. $118 \mathrm{~Sv}$ ).

340 De term beklag is gekozen om duidelijk te doen uitkomen dat het in deze artikelen gaat om een rechtsmiddel dat niet alleen door de werdachte (of weroordeelde) kan worden aangewend, maar evenzeer door anderen. De term 'bezwaarschrift' die in de artt. 103 en 115 (oud) woorkwam, wordt gereserveerd voor de verdachte. MvT, Bijl. HTK 1954-1955, 4034, p. 13.

341 HR 29-1-1974, NJ 1974, 125. 
552 Sw te hebben ontvangen, zijn lot in eigen hand nemen door een klaagschrift ex art. 552a lid 1 Sv in te dienen. In 1987 oordeelde de Hoge Raad over een zaak waarin de vrijheid die de rechter in een klaagschriftprocedure ex art. $552 \mathrm{a} \mathrm{Sv}$ heeft on in beslag genomen gestolen goederen aan de bestolene terug te geven centraal stond. Volgens annotator Th. W. van Veen wordt in de beschikking een nieuwe weg ingeslagen, die aan slachtoffers van diefstal een redelijk perspectief biedt in het geval dat de gestolen voorwerpen door justitie in beslag zijn genomen. Uit een. beslissing was eerder al gebleken dat de rechter meer mogelijkheden tot herstel in de oude toestand' ter beschikking staan. De Hoge Raad oordeelde dat de derdebelanghebbende ook buiten het geval van art. 118 lid 3 Sv ten overstaan van de rechter, oordelend naar aanleiding van een door deze ingediend klaagschrift ex art. $552 \mathrm{a}$ Sv, aamnemelijk kan maken dat het op het eerste gezicht redelijk en maatschappelijk niet onverantwoord is het voorwerp aan hem, en niet aan de beslagene, terug te geven. Nieuw is wel dat de Hoge Raad in NJ 1988, 43 aangeeft dat de beslagene in de gelegentheid moet worden gesteld om te worden gehoord. Hiermee is nog geen oplossing gevonden voor het geval waarin het evident is dat in beslag genomen voorwerpen zijn gestolen, maar geen bestolene zich meldt of zijn aanspraken waar kan maken en de rechter de teruggave van het gestolene dient te bevelen aan de dief, indien deze laatste daarom uitdrukkelijk vraagt. Art. 552 a biedt niet de mogelijkheid om te klagen over het feit dat het beslag nilet wordt gehandhaafd, omdat de grondslag van de wetswijziging van 1958 was gelegen in het zoveel mogelijk beperken van de duur van de inbeslagneming. Ik vind dat dit nog steeds het uitgangspunt moet zijn van deze wet. De civielrechtelijke aanspraken van de rechthebbende blijven immers onaangetast.

Ad 2: De fasen van het proces waarin een klaagschrift tegen de inbeslagneming kan worden ingediend

Niet in alle fasen van het proces kan een klaagschrift tegen de inbeslagneming worden ingediend. Wanneer de rechter zich al heeft uitgesproken over het lot van de voorwerpen kan do weg van art. 552 Sv uiteraard niet meer worden bewandeld. ${ }^{3 a}$ Indien de bezwaren wan de betrokkene zich richten tegen de inbeslagneming zelf of tegen het gebruik van de in beslag genomen voorwerpen, is het indienen van een klaagschrift mogelijk tot de einduitspraak waarin een beslissing wordt genomen over het inbeslaggenomene; bevat de einduitspraak daarover geen beslissing, dan kan ook na de einduitspraak een klaagschrift worden ingediend. Het indienen van een klaagschrift tegen het uitblijven van een last tot teruggave is alleen mogelijk indien het Openbaar Ministerie ook werkelijk bevoegd is om over het lot van de in beslag genomen goederen te beslissen. Dat is niet altijd het geval. Wanneer de zaak (nog) niet

342 HIR 23-6-1987, NJ 1988, 43.

343 Wel indien de woorwerpen ex art. 117 Sv zijn wernietigd, prijsgegeven, etc. HR 13-1-1981, NJ 1981, 363. 
tot een einduitspraak van de rechter heeft geleid behoort de officier van Justitie het in beslag genomen voorwerp terug te geven, zodra het belang der strafvordering zich daartegen niet meer verzet (art. $118 \mathrm{~Sv}$ ). In de gevallen van art. 118a Sv heeft hij daartoe een machtiging nodig. Over het niet voldoen aan deze verplichting kan de belanghebbende zich op grond van art. 552a Sv bij de rechter beklagen. Eveneens kan beklag worden gedaan over de door het Openbaar Ministerie voorgenomen teruggave aan een ander dan de beslagene; deze bevoegdheid ontleent de beslagene niet aan art. $552 \mathrm{a} \mathrm{Sv}$, maar aan art. 118 lid $3 \mathrm{~Sv}$. Van de inhoud van de einduitspraak hangt het af of het Openbaar Ministerie na de einduitspraak tot teruggave bevoegd is, en daarmee of de belanghebbende zich over het uitblijven van een last tot teruggave via art. 552a Sw kan beklagen. Wordt in de einduitspraak de teruggave van het voorwerp bevolen, dan staan de verdachte die het niet eens is met de beslissing van de rechter tot teruggave aan een ander, de rechtsmiddelen ten dienste die hij heeft tegen het vonnis in zijn geheel. De overige belanghebbenden kumnen tegen het bij de uitspraak gegeven bevel tot teruggave niet meer opkomen bij de rechter; art. $552 \mathrm{a}$ Sv biedt daartoe geen mogelijkheid. ${ }^{344}$ Is bij de einduitspraak de verbeurdverklaring of de onttrekking aan het verkeer bevolen, dan kan de weroordeelde gebruik maken van de normale rechtsmiddelen tegen het vonnis. Andere belanghebbenden kunnen zich - nadat de uitspraak vatbaar is voor tenuitvoerlegging ${ }^{345}$ - over deze beslissing beklagen via de speciaal daarvoor gecreëerde procedure van art. $552 \mathrm{~b}$ $\mathrm{Sv}^{346}$ Bevat de einduitspraak geen oordeel over het lot van de in beslag genomen voorwerpen, of beslist de rechter dat hij tot het geven van een last tot teruggave niet in staat is, dan is het Openbaar Ministerie weer tot teruggave bevoegd. De belanghebbende is in dat geval weer aangewezen op art. $552 \mathrm{a} \mathrm{Sv}{ }^{347}$ Volgens Vellinga-Schootstra is het niet van belang of de einduitspraak wel of niet in kracht van gewijsde is gegaan. Melai is echter van mening dat het Openbaar Ministerie pas bevoegd is tot afgifte van het voorwerp over te gaan wanneer hetzij de uitspraak in kracht van gewijsde is gegaan, hetzij de partijen tegen het vonnis een rechtsmiddel

344 De wet biedt de belanghebbende niet de mogelijkheid om de teruggawe bij einduitspraak ongedaan te maken (HR 4-9-1979, N.J 1979, 636). Als teruggave aan een ander al cen voldongen feit is, staat beklag tegen die teruggave niet open; HR 25-10-1966, NJ 1967, 175. In 1987 aanvaardde de Hoge Raad dat een belanghebbende die stelt dat de in beslaggenomen voorwerpen aan haar tocbehoren, om een last tot teruggave kan verzoeken als de officier van Justitic ant. 118 lid 3 Sv buiten toepassing: heeft gelaten (HR 23-6-1987, NJ 1988, 43).

345 Tenuitwoerlegging is soms mogelijk als de uitspraak nog niet in kracht van gewijsde is gegaan (art. 557 lid 2 Sv).

346. Wanneer de rechter een dergelijk beklag gegrond acht, moet de verbeurdverklaring of de onttrekking aan het verkeer ongedaan worden gemaakt en alsnog een last als bedoeld in art. $353 \mathrm{~Sv}$ worden gegeven (art. 552b lid 4 Sv). Onttrekking aan het verkeer is behalve bij de einduitspraak ook mogelijk bij afzonderlijke beschikking (art. $36 \mathrm{c} \mathrm{Sr}$ ); Ook de verdachte kan gebruik maken van het rechtsmiddel van art. 552b Sv (zie de MVT op art. 552b Sv, Bijl. HTK 1954-1955, 4034).

347 De rechter moet na beklag ex art. $552 \mathrm{a}$ Sv een beslissing geven ower het in beslag genomen voorwerp en kan niet verklaren daartoe niet in staat te zijn. 
instellen. Volgens Vellinga-Schootstra is het Openbaar Ministerie ook in deze fase bevoegd tot teruggave. Bovendien is het niet wenselijk om het bestaan van het recht om een klaagschrift in te dienen afhankelijk te maken van het animo van de partijen om hoger beroep aan te tekenen; degene die zich wil beklagen over de inbeslagneming behoeft immers niet 'partij' te zijn.

\section{Ad 3: De belanghebbende}

Belanghebbende is in de eerste plaats degene onder wie het goed in beslag werd geniome $n^{248}$, zelfs als deze degene is die het goed door een strafbaar feit aan een ander heeft onttrokken, ook al is hij daarvoor veroordeeld. In verband met het hierna te noemen art. $552 \mathrm{c}$ Sv wordt ook als belanghebbende gezien de eigenaar van en de anderszins rechthebbende op het in beslag genomen voorwerp of de in beslag genomen vordering. Dus ook de verkoper bij huurkoop en de drukker die een retentierecht heeft wanneer de rekening niet wordt betaald. ${ }^{309}$

Ad 4: De indiening van het klaagschrift

Uiterlijk drie jaar na de inbeslagneming moet een klaagschrift worden ingediend ter griffie van het gerecht in feitelijke aanleg waarvoor de zaak wordt vervolgd of het laatst werd vervolgd. ${ }^{350}$

Ad 5: De behandeling van het klaagschrift

Op grond van art. 552f Sv is het mogelijk om de maatregel onttrekking aan het verkeer op te leggen bij een afzonderlijke beschikking van de rechter in de raadkamer, ook wanneer in het geheel geen strafvervolging is of zal worden ingesteld, bijvoorbeeld wanneer, aldus de Memorie van Toelichting "de dader onbekend of overleden of om een andere reden niet te berechten is. ${ }^{\text {rast }}$ Naturllijk zal er altijd een relatie tot een strafbaar feit moeten zijn, omdat er alleen maar voorwerpen onttrokken kunnen worden, die in beslag zijn genomen. Welnu, inbeslagneming ten behoeve van de strafvordering zal alleen maar plaats kunnen vinden, wanneer er een redelijk vermoeden is, dat er door iemand een strafbaar feit is begaan. Deze niet van een strafvonnis afhankelijke onttrekkingsmogelijkheid was vroeger in veel grover en radicaler vorm te vinden in art. 10 lid 5 Opiumwet, volgens hetwelk ongeoorloofd aanwezig bevonden opium van rechtswege verviel aan de staat. ${ }^{352}$ Deze drastische bepaling, die nu uiteraard kon vervallen, zal de wetgever vermoedelijk mede tot

348 HR 18-3-1975, NJ 1975, 232.

349 HR 27-2-1990, NJ 1990, 612 .

350 Art. 552a lid 2 Sv; HR 16-3-1993, NJB 1993, 127, p. 291.

351 MvT, Bijl. HTK 1954-1955, 4034.

352 HTK 1957-1958, p. 2320. 
dit vergelijkenderwijs veel betere stelsel hebben geïnspireerd. Men mag verwachten, dat in een dergelijke extra-judiciële procedure het Openbaar Ministerie in zijn vordering de strafrechtelijke aspecten zodanig zal belichten en ook overigens zoveel materiaal zal bijeenbrengen, dat daaruit inderdaad van een strafbaar feit, althans van een redelijk vermoeden, dat de inbeslagneming wettigde, blijkt. ${ }^{353}$ De rechter moet immers op de vordering op adequate wijze kunnen reageren. Men zou zelfs kunnen stellen, dat er zoveel moet blijken, dat de rechter - ware er sprake van een gewone procedure - aan een veroordeling, een ontslag van rechtsvervolging of een vrijspraak zou zijn toegekomen, omdat immers in de gewone procedure alleen in deze gevallen aan thet verkeer kan worden onttrokken, en beide procedures, betrekking hebbend op hetzelfde substraat, min of meer een tweespan zijn. Toch zijn ze niet geheel equivalent, omdat de raadkamerbeschikking van rechtbank of kantonrechter ook bedoeld is voor gevallen dat het recht tot strafvordering reeds is vervallen en het Openbaar Ministerie dus niet ontvankelijk moet worden verklaard. In dit geval is in de normale procedure geen onttrekking mogelijk. Wel zal de rechter - ook in de extra-judiciële procedure - bevoegd moeten zijn. Er moet toch enige relatie zijn tussen het (potentiële) strafbare feit en de rechter. Deze bevoegdheidsvraag moet worden beantwoord aan de hand van het plaatsgehad hebbende of vermoede 'onderliggende' strafbare feit. ${ }^{3 s}$

Een ander verschil met de normale procedure is dat de raadkamerprocedure tot voor kort niet openbaar was (art. 552a (oud) jo. art. 21 e.v. Sv). ${ }^{3.5 s}$ Wie, om een behandeling in het openbaar te bewerkstelligen, met terzijdestelling van art. $552 \mathrm{a}$ Sv, koos voor de weg van het Kort Geding werd waarschijnlijk niet-ontvankelijk worden verklaard omdat er een speciale procedure bestond, ook al vertoonde deze procedure gebreken. ${ }^{366} \mathrm{Op} 24$ april 1992 werd een wetsvoorstel ingediend ter herziening van de raadkamerprocedure ${ }^{35}$ en op 1 januari 1994 trad de 'Wet Herziening wan de Raadkamerprocedure' in werking. ${ }^{358}$ De wet is van toepassing wanneer het betreft een beklagprocedure over in beslag genomen voorwerpen en de verbeurdverklaring of onttrekking aan het verkeer hiervan. In die gevallen voorziet de wet in een aampassing van de hiervoor in aanmerking komende strafvorderlijke raadkamer*

353 J. Remmelink, Iets over de verbeurdverklaring en onttrekking aan het verkeer, NJB 1965, p. 85 e.v. en p. 109 e.v.

354 HTK $1957-1958$, p. 2320.

355 Volgens Noyon-Langemeijer/Remmelink is dat ook niet nodig omdat bij de inbeslagneming ter onttrekking aan het verkeer geen burgerlijke rechten en verplichtingen worden wastgesteld. De behandeling behoeft niet in het openbaar plaats te vinden. Art. 6 EVRM is hier wolgens NoyonLangemeijer/Remmelink dan ook niet wan toepassing. HR 3-6-1986, NJ 1987, 174; Hof 's-Gravenhage 11-12-1986, KG 1987, 97 en NJ 1988, 143; Noyon-Langemeijer/Remmelink, Het Wetboek van Strafrecht 1984, Titel ll en ILA, aant. op de artt. $33 \mathrm{t} / \mathrm{m} 36 \mathrm{c} \mathrm{Sr}$, p. 166b-178, 184a-192; Ratadkamerprocedures, Vademecum Strafzaken/Suppl. 30-5-1989, (51)-217.

356 Hof 's-Gravenhage 11-12-1986, KG 1987, 97 en NJ 1988, 143.

357 TK 1991-1992, 22584, nrs. 1-3, p. 714-715.

358 Wet van 8-11-1993, Stb. 1993, 591 . 
procedures aan de verplichting in art. 6 EVRM tot openbaarheid van behandeling. Om een beroep te kunnen doen op art. 6 EVRM moet er sprake zijn van 'ciwil rights'. 350 Bij de inbeslagneming van gegevensdragers spelen 'civil rights' een rol, namelijk het eigendomsrecht en de vrijheid van meningsuiting en drukpers. ${ }^{360}$ In een zaak uit 1989 bij de rechtbank te Alkmaar werd een klacht ingediend tegen de onttrekking aan het verkeer van het affiche 'Eenwording Europa' ${ }^{361}$ Omdat het volgens de rechtbank ging om de vaststelling van "civil rights, namelijk het eigendomsrecht, moet er voldaan worden aan art. 14 IVBPR. De art. $552 \mathrm{a}$ Sv-procedure kon, wolgens de rechtbank, "alsnog gerepareerd worden door de openbaarheid te gelasten. Of het in deze zaak ook ging om de vrijheid van meningsuiting en drukpers, dat zou dus nog een sterker argument voor openbaarheid zijn geweest, kwam niet aan de orde. Ook de Memorie van Toelichting op de Wet Herziening Raadkamerprocedure noemt de vrijheid van meningsuiting en drukpers niet. ${ }^{3.33}$

\section{Ad 6: De gronden van het beklag}

Het beklag in art. 552a $\$ \mathrm{w}$ heeft betrekking op de inbeslagneming zelf en het voortduren van het beslag of het uitblijven van een last tot teruggave. In art. 552a Sv is geen criterium opgenomen waaraan de rechter de inbeslagneming behoort te toetsen. ${ }^{364}$ De rechter zal de gegrondheid van het beklag dienen te beoordelen aan de hand van de vraag of voldaan is aan de objectieve en subjectieve eisen die voor rechtmatige inbeslagneming gelden. Maar woor alles zal moeten worden onderzocht of het gaat om een doel met het oog warop inbeslagneming is toegelaten. Blijkens het bepaalde in art. 94 Sv zijn vatbaar voor inbeslagneming voorwerpen, die kunnen dienen om de waarheid aan de dag te brengen of waarvan de verbeurdverklaring dan wel de onttrekking aan het verkeer kan worden bevolen. De rechtmatigheid van de inbeslagneming wordt dus allereerst bepaald door de vraag of de toepassing daarvan én van de genoemde doeleinden kan dienen. De inbeslagneming kan vervolgens worden getoetst aan de vraag of de toepassing van het dwangmiddel in het concrete geval op redelijke gronden heeft berust. Aangezien inbeslagneming vallt aan te merken als de uitkomst van een bijzondere beleidsbeslissing en het mitsclien gaat om de redelijkheid van de beleidsgronden die deze beslissing moeten dragen, is er behoefte daarop controle te kunnen uitoefenen. Deze controle kan door de rechter worden

359 MVT, TK 1991-1992, 22584, nr. 3, p. 3-4.

360 J.ES. Fawcett, The Application of the European Convention on Human Rights, Oxford 1987, p. 127-128; In de MvT op de Wet Herziening Raadkamerprocedure wordt alleen het eigendomsrecht genoemd. MvT, TK 1991-1992, 22584, nr. 3, p. 3-4 en p. 13.

361 Uitsprak Rb. Alkmaar 14-6-1989, Parketnr. 14.007144.89. Art. 6 is van toepassing op de art. $552 \mathrm{f}$ Sw-procedure ("undue delay"); HR 29-11-1988, DD 1989, 2205E-2210E, p. 459-460.

362 HR 29-11-1988, NJ 1988, 598; HR 29-11-1988, DD 1989, 2205E-2210E, p. 459-460.

363 MVT, TK 1991-1992, 22584, nr. 3, p. 3-4 en p. 13.

364 Art. 103 Sv gaf als grond voor het beklag dat de inbeslagneming of het gebruik van gegevens in strijd was met de wet of miet (meer) door het bellang der strafvordering werd gevorderd. 
uitgeoefend door toetsing van het beleid van de officier van Justitie aan algemene beginselen van behoorlijk bestuur, toegesneden op de specifieke eisen die het strafproces stelt. Het wetmatigheidsvereiste is dus tot een rechtmatigheidsvereiste geworden. ${ }^{36 s} \mathrm{De}$ rechtmatigheid van een inbeslagneming aanvechten is onmogelijk wanneer de goederen al zijn teruggegeven (art. $552 \mathrm{~Sv}$ ). ${ }^{360}$

\section{A Strijd met het recht}

Wanneer de rechter moet beoordelen of een inbeslagneming in strijd is met het recht, zal hij eerst nagaan of de voorschriften van het geschreven recht zijn nageleefd. Dit betekent dat moet worden vastgesteld of de persoon die de inbeslagneming heeft verricht daartoe bevoegd was, of deze de voorschriften betreffende de middelen om inbeslagneming mogelijk te maken heeft nageleefd en of het voorwerp vatbaar was voor inbeslagneming. Voor dit laatste, de vatbaarheid van het voorwerp voor inbeslagneming, is het voldoende dat degene die tot inbeslagneming overgaat, op het moment van het hanteren van het dwangmiddel een redelijk vermoeden heeft dat de inbeslagneming het belang der strafvordering kan dienen. Absolute zekerheid daarover is niet vereist. De eis van het redelijk vermoeden dwingt de rechter tot een terughoudende toetsing; want of er sprake is van een dergelijk vermoeden wordt deels bepaald door de intuitie van de politie-ambtenaar.

Behalve aan het geschreven recht, vindt ook toetsing plaats aan het verbod van 'détournement de pouvoir' en het verbod van onredelijkheid. De rechter is evenwel in dezen niet meer dan een grensrechter; hij toetst het gevoerde beleid slechts marginaal. Daarnaast moet bij de beoordeling van de rechtmatigheid van de inbeslagneming rekening worden gehouden met het vertrouwensbeginsel en de beginselen van proportionaliteit en subsidiariteit.

\section{B Het belang der strafvordering}

Het belang der strafvordering speelt bij de vraag naar de rechtmatigheid van de inbeslagneming op drieërlei wijze een rol: bij de vatbaarheid wan het voorwerp voor unbeslagneming, bij het voortduren van de inbeslagneming en bij het gebruik van de in beslag genomen voorwerpen. Is voor de vatbaarheid van het voorwerp voor de inbeslagneming voldoende dat de beslag leggende ambtenaar een redelijk vermoeden had dat het voorwerp zou kunnen dienen om de waarheid aan het licht te brengen, door de rechter verbeurd verklaard zou worden of aan het verkeer onttrokken zou worden verklaard, voor het voortduren van het beslag of het gebruik van de in beslag genomen voorwerpen is vereist dat het niet hoogst onwaarschijnlijk is dat het voortduren van het beslag, respectievelijk het gebruik van het voorwerp het belang

365 A.L. Melai, Het Wetboek van Strafwordering, verklaard en van aantekeningen voorzien (losbladig), M.S. Groenhuijsen, Th.A. de Roos en A.H.J. Swart (red.), Arnhem (z.j.), artt. 552a-552g Sv. 366 HR 24-6-1983, NJ 1984, 38; HR 9-1-1990, NJB 1990, 2409, p. 1324. 
der strafvordering kan dienen. ${ }^{30 \gamma}$ De ruimte voor toetsing door de rechter is hier dus uiterst marginal. Het beklag tegen het doen voortduren van het beslag had succes in de zaak van het Nationale Dagblad ${ }^{368}$; het beslag op de inkttoevoerbakken van de drukpers - ter zake van een niet in de beschikking genoemd delict - werd Joor de rechter opgeheven nu de verdachte het strafbare feit tegenover de rechtercommissaris had bekend en er geen termen aanwezig waren voor verbeurdverklaring of onttrekking aan het verkeer.

Het is denkbaar dat het beslag op het voorwerp op zichzelf wel dienstig kan zijn aan het belang der strafvordering, maar dat het Openbaar Ministerie een hele tijd lang niets onderneemt in de zaak waarin de inbeslagneming heeft plaatsgevonden. ${ }^{3 *}$ Dit is vooral problematisch wanneer het betreft de inbeslagneming van gegevensdragers die 'tijdsgevoelig' zijn. Een beklag tegen de inbeslagneming zou dan gegrond kunnen worden verklaard, omdat een onredelijk passieve houding van het Openbaar Ministerie zich niet verdraagt met het uitgangspunt van de wetgever dat het beslag niet langer moet voortduren dan nodig is.

\section{Strijd met het redelijkheidscriterium}

Zoals reeds is besproken gaat het om de toetsing van de inbeslagneming en kan het Openbaar Ministerie het in beslag genomen voorwerp doen teruggeven aan een ander dan degene onder wie het in beslag was genomen, mits dit op het eerste gezicht redelijk en maatschappelijk niet onverantwoord is. Vereist is dan dat het Openbaar Ministerie het voornemen daartoe aan de beslagene betekent. Deze kan zich daarop beklagen bij de rechter. Als degene aan wie de betekening heeft plaatsgevonden inderdaad een klaagschrift indient mag het Openbaar Ministerie totdat de uitspraak op het beklag gegeven is het voornemen tot teruggave aan een ander dan de beslagene niet uitvoeren. Verklaart de rechter het beklag gegrond, dan is het Openbaar Ministerie in het geheel niet meer tot teruggave bevoegd. Wordt het beklag ongegrond verklaard, dan staat niets de verwezenlijking van het voornemen in de weg. De rechter die het voornemen van het Openbaar Ministerie tot teruggave moet toetsen naar aanleiding van het ingediende bezwaarschrift, hanteert daarbij uit de aard der zaak een andere maatstaf dan bij het beklag tegen de inbeslagneming. Vastgesteld moet worden of de voorgenomen teruggave op het eerste gezicht inderdaad redelijk

367 HR 27-4-1972, NJ 1972, 341.

368 Rb. "s-Gravenhage 28-1-1938, NJ 1939, 880.

369 HR 31-10-1989, NJ 1990, 257. Zie ook beroep op "undue delay' in het kader van een beslag strekkende tot teruggave van in beslag genomen woorwerpen. HR 8-1-1991, NJB 1991, 2633, p. 1073. 
een maatschappelijk niet onverantwoord is ${ }^{3 \pi}$ Evenmin als van het Openbaar Ministerie wordt van de rechter hierbij een diepgaand civielrechtelijk onderzoek verwacht.

\section{Ad 7: Rechtsmiddelen}

Tegen de beschikking van het gerecht kan zowel door het Openbaar Ministerie als door de klager beroep in cassatie worden ingesteld; appel is niet mogelijk (art. 552d Sv) ${ }^{371}$

Ad 8: Het beroep op de burgerlijke rechter

In het algemeen wordt de bevoegdheid van de burgerlijke rechter op grond van art. 2 Rechtelijke Organisatie (RO) aangenomen, indien de eiser bescherming vraagt in een burgerlijk recht, ongeacht of het geschil zijn grond vindt in een privaat- of publiekrechtelijke rechtsverhouding. Deze ruime bevoegdheid wordt echter niet geacht te bestaan als er een andere rechtsgang openstaat, in casu is dat art. 552a Sv, ook all bevat die rechtsgang leemten. ${ }^{3 / 2}$

Met Corstens $^{373}$ en Vellinga-Schootstra ${ }^{374}$ acht ik het onbillijk dat in geval van leemten in de rechtsgang van art. $552 \mathrm{a}$ Sv niet tegen de inbeslagneming kan worden opgekomen bij de burgerlijke rechter. ${ }^{375}$ Dit is een merkwaardige gedachtengang die niet in overeenstemming is met art. 6 van het EVRM. Ik zal dit adstrueren met een voorbeeld.

Wanneer bijvoorbeeld de verdachte ten overstaan van de officier van Justitie verklaart de in beslag genomen voorwerpen te hebben gestolen, en de officier daarop teruggave beveelt aan rechthebbende $\mathrm{A}$, is voor $\mathrm{B}$ - die meent een beter recht te

370 Voor dat laatste is nodig dat het recht van de 'ander' duidelijk sterker is dan dat van de beslagene. Om dat te beoordelen moet die 'ander' uit de aard der zaak bekend zijn; teruggave op grond van het derde lid wan art. $118 \mathrm{~Sv}$ jo, art. $552 \mathrm{a} \mathrm{Sv}$ kan dus niet plaatswinden aan een vooralsnog onbekende rechthebbende. HR 6-5-1980, NJ 1981, 427.

371 In haar rapport heeft de Commissie 'Inbeslagneming gestolen voorwerpen' het belang van èen appèlregeling benadrukt.

372 Schellen-en deuropener-arrest, HR 22-2-1957, NJ 1957, 310; Rb. Breda 16-5-1988, KG 1988, 239; Raadkamerprocedures, Vademecum Stralzaken/Suppl. 30-5-1989, (51)-186-188 e.v.

373 G.J.M. Corstens, Waarborgen rondom het vervolgingsbeleid, Unmuiden 1974, p. 60.

374 F. Vellinga-Schootstra, llnbeslagneming en huiszoeking, diss. RU Gromingen, Alphen a/d Rijn 1982, p. 255 .

375 Niet alleen in het geval van leemten in de rechtsgang maar ook indien de belangen van de betrokkene een zodanig snelle voorziening zouden eisen dat niet gewach kan worden op de beslissing op het klaagschrift dient de burgerlijke rechter in kort geding de mogellijkheid te hebben eem oordeel te geven over de inbeslagneming (hof"s-Gravenhage 6-2-1922, W 10977); Verder kan via de rechter in kort geding een uitspraak gekregen worden over het beleid van de officier van Justitie in die gevallen dat er sprake is van misbruik of van willekeur. Een belanghebbende in kort geding kan eisen dat een voorgenomen inbeslagneming zo zorgvuldig mogelijk zal geschieden (HR 15-12-1950, NJ 1951, 221). 
hebben - beklag op grond van art. 552a Sv niet mogelijk. Er zou dan oftewel een wijziging moeten plaatswinden van art. 552a Sv of het zou mogelijk moeten worden om de weg naar de burgerilijke rechter te bewandelen. ${ }^{36}$ In een aantal uitspraken werd aangenomen dat de burgerlike rechter bevoegd is bij een vordering tot schadevergoeding wegens onrechtmatige inbeslagneming. ${ }^{37}$ Er bestaat alleen meningsverschill over de vraag of de vordering tot schadevergoeding ontvankelijk is, als iemand verzuimd heeft de rechtsgang van art. $552 \mathrm{a}$ Sv te voligen. De Hoge Raad besliste dat als de bijzondere rechtsgang niet was gevolgd ook de weg naar de burgerlijke rechter moest worden geacht te zijn afgesloten, zodat een vordering tot schadevergoeding niet-ontvankelijk moest worden verklaard. ${ }^{\text {iz }}$ Tegen deze beslissing zijn bezwaren aan te voeren omdat de regeling van art. 552a Sv geen mogelijkheid omvat vergoeding te krijgen voor geleden schade. In dat opzicht is er geen sprake van een bijzondere rechtsgang die een algemene zou uitsluiten, zodat in geval van misbruik van bevoegdheid of van willekeur en daaruit voortvloeiende schade een vergoeding van de staat moet kunnen worden gevorderd in een burgerlijk geding. ${ }^{379}$ Ook is de burgerlijke rechter bevoegd om kennis te nemen van de eis tot vergoeding van de schade die is ontstaan door de slechte behandeling van het in beslag genomen goed $^{330}$ of door verkoop van het goed tegen een prijs die veel lager is dan de werkelijke waarde ervan.

Er kan zich een samenloop voordoen tussen een beklag omtrent onrechtmatige inbeslagneming en een beklag over het uitblijven van een last tot teruggave aan een ander dan degene onder wie in beslag is genomen. De vraag rijst dan, welk beklag het eerste aan de orde komt: dat van degene die klaagt over onrechtmatig overheidsoptreden of het beklag inhoudende een pretentie van beter recht. Volgens de Memorie van Toelichting dient in geval van samenloop aan het eerste beklag voorrang te worden verleend, omdat het beklagrecht van art. $552 \mathrm{a}$ Sv in de eerste plaats een toetsing van het hanteren van publiekrechtelijke bevoegdheden wil bevorderen. Voor het beslechten van burgerrechtelijke twisten zijn de procedures van het strafprocesrecht in principe niet geschreven. ${ }^{389}$

376 J.H. Blaanw, Kort Geding in het strafrecht, studiepockets nr. 23, Zwolle 1992, p. 47.

377 Hof 's-Gravenhage 26-2-1940, NJ 1940, 486; Hof 's-Gravenhage 17-4-1941, NJ 1941, 716; HR 15-51942, NJ 1942, 538 .

378 Vergelijk Hof 's-Gravenhage 26-4-1972, NJ 1972, 431.

379 A.L. Molai, Wetboek van Strafvordering, verklaard en wan aantekeningen voorzien (losbladig), M.S. Groenhwijsen, Th.A. de Roos en A.H.J. Swart (red.), Arnhem (z.j.), art. 552a Sv.

$380 \mathrm{Rb}$. "s-Gravenhage 10-12-1929, NJ 1930, 459.

381 Zie MvT, Bijl. TK 1954-1955, 4034, p. 13;A. Hejider, De strafrechtelijke beschermingvan de eigendom, RM Themis 1976 , p. 354 e.v. 


\subsection{Concluste}

Een van de doeleinden die de ontwerpers van het Wetboek van Strafvordering in $1926^{32}$ voor ogen stond ten aanzien van de strafvorderlijke inbeslagneming was thet brengen van eenheid in de veelvoud van afzonderlijke bepalingen in bijzondere wetten door een nieuwe inbeslagnemingsregeling in het wetboek en -in verband daarmeehet duidelijk vastleggen in de wet van ruimere bevoegdheden tot inbeslagneming door politie en justitie. "Ook de Commissie Herijking Wetboek van Strafvordering stond dit uitgangspunt voor ogen. ${ }^{3}$ Het huidige Wetboek van Strafvordering kent, in tegenstelling tot vele bijzondere wetten, aan de gewone opsporingsambtenaar in principe alleen speciale inbeslagnemingsbevoegdheden toe. Alleen wanneer zij in de uitoefening van een andere bevoegdheid een daarvoor vatbaar voorwerp aantreffen zijn zij tot inbeslagneming daarvan bevoegd. In navolging van pleidooien in de literatuur ${ }^{\text {3as }}$ stelt de Commissie Herijking Wetboek van Strafvordering voor om in plaats van het huidige art. $96 \mathrm{~Sv}$ aan elke opsporingsambtenaar een algemene bevoegdheid tot inbeslagneming te geven. De enige beperking is dat voor een situatie buiten heterdaad sprake dient te zijn van een misdrijf als omschreven in art. 67 eerste lid Sv. Volgens Aler brengt dit weinig risico's van misbruik met zich mee; de inbeslagneming mag immers niet vormvrij plaatsvinden. Ook brengt de inbeslagneming in het algemeen geen vergaande inbreuk mee op een belangrijk recht van de burger. ${ }^{366}$ In zijn algemeenheid zal dat inderdaad het geval zijn. Echter wanneer het gaat om de inbeslagneming van gegevensdragers kunnen wel degelijk vergaande inbreuken worden gemaakt op de rechten van de burger. Ik denk hier aan de vrijheid van meningsuiting en drukpers. Door opsporingsambtenaren nog ruimere inbeslagnemingsbevoegdheden te geven kan de vrijheid van meningsuiting en drukpers meer in gevaar worden gebracht. Met de inbeslagneming van gegevensdragers dient niet alleen het opsporingsbelang maar ook de communicatievrijheid in acht te worden genomen.

382 MvT, Bijl. HTK 1913-1914, 286.

383 Herziening van het gerechtelijk vooronderzock, Een rapport van de Commissie Herijking Wetboek van Strafvordering (vz. Ch.M.J.A. Moons), Arnhem 1990, p. 87.

384 Alleen op grond van art. 539 p en 551 lid 1 Sw zijn opsporingsambtenaren tc allen tijd tot inbeslagneming bevoegd. P.A.M. Mevis, Inbeslagneming en huiszocking, Hercodificatie Wetboek van Strafvordering, Nijmegen 1991, p. 106.

385 G.P.A. Aler, De politiebevoegdheid bij opsporing en controle, Enige aspecten van de regelling van de dwangmiddelen in het Wetboek van Strafvordering en in bijzondere wettem, Zwolle 1982, p. 317-333; J J.H. Suywer, Vergelijkend onderzoek maar enige dwangmiddelen tijdens de opsporing, Preadwies woor de Vereniging woor de vergelijkende studie van het recht van België en Nederland, ministerie van Justitie, 's-Gravenhage 1979, p. 60-61.

386 G.P.A. Aler in: Herziening van het gerechtelijk vooronderzoek, Een rapport van de Commissie Herijking Wetboek van Strafvordering (vz. Ch.M.J.A. Moons), Arnihem 1990, p. 95. In dit rapport wordt verwezen naar: G.P.A. Aller, De politiebevoegdheid bij opsporing en controle. Enige aspecten van de regeling van dwangmiddelen in thet Wetboek van Strafvordering en in bijzondere wetten, Zwolle 1982, p. 356. 
Opsporingsambtenaren zullen geneigd zijn te kiezen voor het opsporingsbelang oftewel woor handhaving wan de rechtsorde. Volgens mij dient bij de inbeslagneming wan gegevensdragers de opsporingsambtenaar geen ruimere inbeslagnemingsbevoegdhen te krijgen.

Ook ben ik geen voorstander van witbreiding van de gronden voor inbeslagneming louter met het oog op de belangen van de rechthebbende. Nu is het nog zo dat de officier van Justitie die de zaak aanhangig maakt bij de rechter de gegevensdragers kan teruggeven aan de beslagene of aan de rechthebbende indien hij afziet van een vervolging, bijwoorbeeld omdat het moeilijk wordt te bewijzen dat er sprake is van staatsgeheimen. De beslagene hoeft niet de rechthebbende te zijn. Het kan ook degene zijn die het voorwerp gestolen heeft. Alleen wanneer de rechthebbende bekend is, kan art. 118 lid $3 \mathrm{~Sv}$ worden toegepast. Het is niet de taak van het strafrecht civielrechtelijke aanspraken van eigenaars en bezitters van voorwerpen als zelfstandig belang te beschermen. Wijziging van art. $118 \mathrm{~Sv}$, art. $353 \mathrm{~Sv}$ en art. $552 \mathrm{a}$ Sv zoals door de Subcommissie onder voorzitterschap van G.E. Mulder van de Commissie Partiële Herziening Strafvordering in 1982 is woorgesteld en overgenomen in de Wetvan 12-4-1995 in de zin dat het voorwerp na afstand korte tijd kan worden bewaard ten behoeve van de onbekende rechthebbende, is in het geval dat het gaat om nieuwsgevoelige feiten problematisch. Het kan op gespannen voet staan met de vrijheid van meningsuiting en drukpers. ${ }^{387}$

Een voorstel dat niet op gespannen voet staat met bovengenoemd grondrecht is de inwoering van de openbare behandeling bij raadkamerprocedures waarin beklag wordt gedaan over in beslag genomen voorwerpen en de onttrekking aan het verkeer en de verbeurdverklaring hiervan. Op 1 januari 1994 trad de 'Wet Herziening van de Raadkamerprocedure' in werking. ${ }^{388}$ Om een beroep te kunnen doen op een openbare behandeling moet er sprake zijn van 'civil rights' (art. 6 EVRM). ${ }^{\text {Bij }}$ de inbeslagneming van gegevensdragers spelen 'civil rights' een rol, namelijk het eigendomsrecht en de vrijheid van meningsuiting en drukpers. ${ }^{3 \%}$ In de Memorie van Toelichting op bovengenoemde wordt alleen het eigendomsrecht genoemd en niet de vrijheid van meningsuiting en drukpers wellicht omdat er gesproken wordt van voorwerpen en niet ook van gegevensdragers

$387 \mathrm{~F}$. Vellinga-Schootstra, Teruggawe van in beslag genomen voorwerpen, DD 1983, p. 125-126. 388 Wet wan 8-11-1993, Stb. 1993, 591 .

$389 \mathrm{MvT}$, TK 1991-1992, 22584, nr. 3, p. 3-4.

390 J.E.S. Fawcett, The Application of the European Convention on Human Rights, Oxford 1987 , p. 127-128; In de MvT op de Wet Herziening Raadkamerprocedure wordt alleen het eigendomsrecht genoemd. MVT, TK 1991-1992, 22584, nr. 3, p. 3-4 en p. 13. 


\section{De vrijheid van meningsuiting en drukpers en het straf- vorderlijke dwangmiddel inbeslagneming in Duitsland}

\section{Inleiding}

In dit hoofdstuk zal ik de vrijheid van meningsuiting en drukpers en het strafvorderlijke dwangmiddel inbeslagneming in Duitsland bespreken. Centraal staat de vraag in hoeverre de vrijheid van meningsuiting en drukpers, zoals geregeld in art. 5 van de Duitse Grondwet ('Grundgesetz' (GGi)), een belemmering vormt voor de toepassing van het strafvorderlijke dwangmiddel inbeslagneming. Het gaat om de spanning tussen de vrijheid van meningsuiting en drukpers enerzijds en het strafvorderlijke dwangmiddel inbeslagneming anderzijds. In paragraaf 2 komen eerst de materiële aspecten aan de orde van de inbeslagneming voor het aan de dag brengen van de waarheid in het Duitse Wetboek van Strafvordering (Paragraph 97 StrafprozeBordnung' (StPO)). Besproken wordt de relatie tussen het verschoningsrecht voor persen 'Rundfunk'medewerkers ('Zeugniswerweigerungsrecht'), de inbeslagneming van gegevensdragers en de vrijheid van meningsuiting en drukpers. Bij de bespreking van bovengenoemde relatie wordt rekening gehouden met het onderscheid in de wet tussen eigen materiaal en materiaal van derden verkregen. In paragraaf 3 komen de formele vragen ten aanzien van de inbeslagneming aan de orde. Gekeken worct wie er bevoegd zijn tot de inbeslagneming van gegevensdragers voor het aan de dag brengen van de waarheid alsook of er bij de bevoegdheidswraag rekening is gehouden met de vrijheid van meningsuiting en drukpers.

In paragraaf 4 komt een andere vorm van inbeslagneming aan de orde. Immers naast de inbeslagneming voor het aan de dag brengen van de waarheid kent men in Duitsland ook nog de 'Einziehungsbeschlagnahme'. Deze heeft betrekking op de inbeslagneming ter verbeurdverklaring en de inbeslagneming om onbruikbaarmaking te voorkomen. Beide zijn geregeld in 'Paragraph $111 \mathrm{~m}$ ' en 'Paragraph $111 \mathrm{n}$ StPO' en komen uitgebreid aan de orde in paragraaf 4. In paragraaf 5 wordt ook ten aanzien van de 'Einziehungsbeschlagnahme' de bevoegheidsvraag besproken. In de voorlaatste paragraaf van dit hoofdstuk zullen nog de rechtmiddelen behandeld worden (paragraaf 6). Een bespreking van art. 10 EVRM zal hier in dit hoofdstuk achterwege blijven omdat de Duitse Grondwet zoals we nog zullen zien, verder gaat in zijn bescherming dan art. 10 EVRM. Bovendien bestaat er naar mijn mening geen 
jurisprudentie in Duitsland op grond van art. 10 EVRM die hier relevant zou kunnen zijn. ${ }^{1}$

2 De inbeslagneming van gegevensdragers voor het aan de dag brengen van de waarheid (Paragraph 97 StPO) en het verschoningsrecht voor persmedewerkers (Paragraph 53 StPO) in relatie tot de vrijheid van meningsuiting en drukpers (Artikel 5 GG)

"Mit jeder Freiheit, auch mit der Pressefreiheit, ist ein Risiko verbunden, daß in einem freiheitlichen Staat im Kauf genommen werden muB. Will man jedes Risiko ausschließen, endet man zwangsläufig im Polizeistaat, dessen Schrecken wir erlebt haben."

Martin Löffler

\subsection{Inleiding}

Het eerste wat in het oog springt wanneer je de bepalingen, die betrekking hebben op de strafvorderlijke inbeslagneming in de 'Strafprozeßordnung'(StPO) vergelijkt met de Nederlandse bepalingen in het Wetboek van Strafvordering is, dat in de StPO voor een andere invalshoek is gekozen. In Duitsland heeft men bij het redigeren van de strafvorderlijke inbeslagnemingsbepalingen rekening gehouden met het 'Grundgesetz' (GG), in casu de vrijheid van meningsuiting en drukpers. ${ }^{3}$ In het Nederlandse Wetboek van Strafvordering wordt, zoals we gezien hebben in hoofdstuk 1, geen onderscheid gemaakt tussen 'voorwerpen' en 'gegevensdragers'. In Duitsland daarentegen bezitten gegevensdragers zoals geschriften, geluids- en beelddragers, databanken, afbeeldingen etcetera strafprocessueel een bijzondere positie. Dat wil zeggen dat de inbeslagneming van bovengenoemd materiaal, ten behoeve van de waarheidsvinding, verboden is, wanneer het bewaard wordt door pers- of 'Rundfunk'medewerkers of wanneer het zich bevindt op de redactie, bij een uitgever, drukker, radioof televisiestation. De voorwaarde is wel dat het moet gaan om materiaal dat van derden verkregen is (eigen materiaal van bovengenoemde medewerkers kan dus

1 Duitsland kent een constitutioneel toetsingsrecht dat wil zeggen dat wetten getoetst kunnen worden aan de Grondwet. J. Polakiewica, V. Foltzer, The European Human Rights Constitution in Domestic Law, Human Rights Law Journal 1991, p. 81. R. Herzog, Hierarchie der Verfassungsnormen und ihre Funktion bein Schutz der Grundrechte, Europäische Grundrechte 1990, p. 486.

2 Martin Loffler, Der Verfassungsauftrag der Presse, Modelfall Spiegel, Karlsruhe 1963, p. 11.

3 Missehien juist omdat men aan den lijve heeft ondervonden tot welke desastreuze gevolgen het kan leiden wanneer de vrijheid wan meningsuiting en drukpers niet of nauwelijks wordt beschermd. Kleinknecht/Meyer,Kurz-Kommentar,StrafprozeBordnung,Gerichtsverfassungsgesetz, Nebengesetze und ergänzende Bestimmungen, 1989, p. 399; Löwe-Rosenberg, Giroßkommentar, Die Strafprozeßordnung und das Gerichtsverfassungsgesetz, Erster Band 1989, Einleitung, \$1-111n, p. 554. 
wel in beslag genomen worden). ${ }^{4}$ De verschoningsgerechtigden, en dat zijn degenen die werkzaam zijn bij een dagblad, tijdschrift, de radio of bij de televisie kunnen net als advocaten en artsen een beroep doen op het verschoningsrecht ('Zeugnisverweigerungsrecht'). Typerend voor Duitsland is dat dit 'Zeugnisverweigerungsrecht' gekoppeld wordt aan een verbod tot inbeslagneming. De vraag is waarom men deze koppeling heeft gemaakt. Alvorens deze vraag te beantwoorden is het van belang te weten wat de reikwijdte is van "Art. 5 GG'. Immers het verschoningsrecht, de inbeslagneming van gegevensdragers en de drukpersvrijheid zijn niet van elkaar te scheiden grootheden. 'Artikel 5 GG' luidt als volgt:

1. "Jeder hat das Recht, seine meinung in Wort, Schrift und Bild frei zu äußern und zu verbreiten und sich aus allgemein zugänglichen Quellen ungehindert zu unterrichten. Die Pressefreiheit und die Freiheit der Berichterstattung durch Rundfunk ${ }^{s}$ und Film werden gewahrleistet. Eine Zensur findet nicht statt.

2. Diese Rechte finden ihre Schranken in den Vorschriften der allgemeinen Gesetze, in den gesetzlichen Bestimmungen zum Schutz der Jugend und in dem Recht der persönlichen Ehre.

3. Kunst und Wissenschaft, Forschung und Lehre sind frei. Die Freiheit der Lehre entbindet nicht von der Treue zur Verfassung."

Wat meteen opvalt is dat in 'Art. $5 \mathrm{GG}$ ' in tegenstelling tot art. 7 van de Nederlandse Grondwet naast de vrijheid van meningsuiting, drukpers, 'Rundfunk" en fillm ook de verspreidingsvrijheid, de vrijheid van informatie en de kunst- en wetenschappelijke vrijheid expliciet in de Grondwet worden genoemd. ${ }^{6}$ Verder garandeert 'Art. 5 Abs. 1 Satz 2 GG' "die institutionelle Eigenständigkeit der Medien. " Dat wil in de eerste plaats zeggen dat het instituut 'media' wordt beschermd. Immers zonder bijvoorbeeld vrije persondernemingen is het idee van drukpersvrijheid niet te realiseren. Maar ook betekent deze "institutionelle Eigenständigkeit" dat de media evenals politieke

4. Hier gaat het om de spanningsverhouding tussen enerzijds de vrijheid om te kunnen publiceren en anderzijds de behoefte aan een goede strafrechtspleging (in casu een effectieve verwolging en bescherming van de rechten van de beschuldigde).

5 Radio, televisie en video vallen onder het begrip 'Rundfuak' ("die C̈bermitthing von Gedankeninhalten in der Form won elektromagnetischen Wellen"); A.Pauli, Der Schutz won Presse und Rundfunk vor dem Zugriff staatlicher Verfolgungsorgane, diss Albertus-Magnus-Universität Köln, München 1988 , p. 13-14.

6 Peter Tettingen, Schutz der Kommunikationsfreiheiten im deutschen Verfassungsrecht, JZ 1990, p. 846 e.v.; Konrad Löw, Die Grundrechte, Das Recht der freien Meinungsäußerung, München New York - London - Paris 1982, p. 261 e.v; A.B. van Rijn, De functie van de vrijheid wan meningsuiting in beide Duitse staten, diss. RL, Zwolle 1985, p. $12 \tau_{j}$ e.v.; PJ. Boukema, Enkele aspecten van de wrijheid wan meningsuiting in de Duitse Bondsrepubliek en in Nederland, diss. VU, Amsterdam 1966, p. 30 e.v.

7 BVerfGE 6-10-1959, 10, 118 $\mathrm{f}_{\sharp}$ Helmut Kohl, Press Law in the Federall Republic of Germany in: Phina Lahav, A Comparative Study: Press Law in Modern Democracies, New York 1985, p. 188 e.v. 
partijen een grondwettelijk beschermde openbare functie uitoefent. Het is de taak van de media mensen te informeren. Dat is niet alleen het wezen van de pers maar ook het wezen van de democratie. ${ }^{8}$ De democratische gedachte is gebaseerd op het geloof dat het welzijn van een staat en zijn burgers het beste tot zijn recht komt wanneer alle vragen van openbaar belang worden besproken in een vrije en open discussie. Het vertrouwen in discussies berust op de overtuiging dat zich in een vrije strijd wan ideeën het juiste en verstandige vanzelf uitkristalliseert. In een democratische staat is niet de "manipulierte Bildung" maar de "öffentliche Meinung" belangrijk. Aan die "öffentliche Meinung" draagt de media bij. Zij zijn "die scharfäugigen Wächter, die Mißstände des öffentlichen Lebens aufspüren. ${ }^{\prime}$ Volgens het 'Bundesverfassungsgericht' in de zaak 'Der Spiegel' behoort de drukpersvrijheid "zu den unverletzlichen und unveräußerlichen Menschenrechten, die für unsere freiheitliche Demokratie 'schlechthin konstituierend' sind und deshalb auch nicht im Wege einer Verfassungsänderung aufgehoben oder eingeschränkt werden können. ${ }^{\text {mo }}$ Voor het functioneren van ons democratische systeem en voor de "institutionelle Eigenständigkeit ${ }^{\text {nil }}$ van de media zijn onder andere het redactiegeheim en het beperkte 'Zeugnisverweigerungsrecht' alsook het beperkte 'inbeslagnemingsverbod' onontbeerlijk. De inbeslagneming vangegevensdragers, ten behoeve van de waarheidsvinding en van derden verkregen, is dan ook verboden in Duitsland wanneer deze bewaard worden door gepriviligeerde mediamedewerkers of wanneer deze zich bevinden op de redactie, bij een uitgever, drukker of radio- c.q. televisiestation. Zo kan bijvoorbeeld een journalist een beroep doen op het verschoningsrecht en/of het redactiegeheim wanneer de rechter probeert materiaal, dat van derden verkregen is, in beslag te nemen om dat materiaal eventueel te gebruiken voor het aan de dag brengen van de waarheid van een strafbaar feit. Het redactiegeheim, het verschoningsrecht en het inbeslagnemingsverbod horen bij elkaar. Tussen de uitwerking van beide laatstgenoemde begrippen in de 'Strafprozeßordnung' en de vrijheid van meningsuiting en drukpers in het 'Grundgesetz' bestaat een wisselwerking. In de volgende paragraaf zal aan de hand van de zaak 'Der Spiegel' de reikwijdte en de ontwikkeling van de inbeslagneming van gegevensdragers voor het aan de dag brengen van de waarheid ('Paragraph 97 StPO') en het verschoningsrecht ('Paragraph 53 StPO') in relatie tot de vrijheid van meningsuiting en

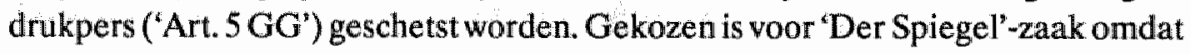
deze laat zien hoe men in de loop van de tijd heeft geprobeerd een evenwicht te

8 A.B. van Rijn, De functie van de vrigheid van meningsuiting in beïde Duitse staten, diss. RL, Zwolle 1985, p. $138-158$.

9 BGH 22-12-1959, 31, 312 ; Martin Loffler, Die öffentliche Aufgabe der Medien, Bitburger Gespräche 1974-1976, Jahrbuch 1974-1976, Trier 1977, pi 29, 31; Martin Löfler, Der Verfassungsauftrag der Presse, Modelfall Spiegel, Karlsruhe 1963, p. 5; W. Mallmann, Pressepflichten und öfentliche Aufgabe der Presse, JZ 1966, p. 626 .

10 Martin Löffler, Der Verfassungsauftrag der Presse, Modelfall Spiegel, Karisruhe 1963, p. 7; A.B. van $R$ ijn, De functie van de vrijheid van meningsuiting in beide Duitse staten, diss. RL, Zwolle 1985, p. 133-135.

11 BVerfGE 5-8-1966, 20, 162 (175 ff, 176) - 'Der Spiegel'. 
vinden tussen het strafprocesrecht aan de ene kant en de vrijheid van meningsuiting en drukpers aan de andere kant.

\subsection{De zaak Der Spiegel ${ }^{\text {n2 }}$}

Deze zaak deed in 1962 veel stof opwaaien. Het weekblad 'Der Spiegel' had in een artikel stelling genomen tegen de uitrusting van de West-Duitse krijgsmacht met nucleaire wapens en in plaats daarvan gepleit voor een sterkere conventionele bewapening. Het tijdschrift stond met deze opvatting lijnrecht tegenover de mening van de toenmalige minister van Defensie Franz-Josef Strauss. Het artikel bevatte detaills over de militaire planning van de NAVO en het West-Duitse leger en was voorzien van foto's van de nieuwe nucleaire wapens. Toen het Openbaar Ministerie lucht kreeg van deze publicatie viel het de redactieruimten van 'Der Spiegel' binnen en nam alles in beslag. ${ }^{13}$ De uitgever, Rudolf Augstein, werd beschuldigd van "publizistischer Landesverrat" ("Paragraphen 99, $100 \mathrm{StGB}$ " (oud)) ${ }^{14}$ en gearresteerd. De actie leidde tot een regeringscrisis en het aftreden van Strauss. Of van "publizistischer Landesverrat" sprake was en waarom zal hier niet worden besproken. ${ }^{15}$ Het gaat in deze context veel meer om een andere vraag namelijk om de vraag of de inbeslagneming van geschriften bij de redactie van een tijdschrift toelaatbaar is." ${ }^{1 *}$ op pagina 37 van de uitspraak van het 'Bundesverfassungsgericht' kunnen we lezen dat: ${ }^{17}$

"Die Notwendigkeit, der Pressefreiheit und ihrer Bedeutung für die freiheitliche demokratische Grundordnung bei der Auslegung und Anwendung der allgemeinen Gesetze Rechnung zu tragen, gilt auch für die StrafprozeBordnung, besonders für strafprozessuale ZwangsmaB-

12 BVerfGE 5-8-1966, 20, 162 (176) - "Der Spiegel."

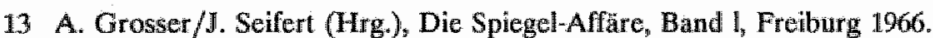

14 Op grond van de toenmalige \$99 StGB (BGBL. 1951, 1, 739) kon reeds het publiceren van een. artikel dat bestond uit een samenwoging van bekende en openbaar toegankelijke details landverraad zujg (mozaiektheorie). Geheimen waren "Tatsachen, Gegenstände oder Erkenntmisse, insbesondere Schriften, Zeichnungen, Modelle oder Formeln, oder Nachrichten darüber, deren Geheimhallumg vor einer fremden Regierung fur das Wohl der Bundesnepublik Deutscluland oder einer ihrer Länder erforderlich ist:" Na "Der Spiegel'-zaak heeft de wetgever besloten het begrip staatsgeheim opnieuw te definiëren. Sttaattsgeheimen zijn voortaan uitsluitend: "Tatsachen, Gegenstände odver Erkenntnisse, die nur eimem begrenzien Personenkreis zugänglich sind und vor einer fremden Macht geheimgehalten werden müssen, um die Gefahr eines schweren Nachteils für die äufere Sicherheit der Bundesrepublik Deutschland abzwwenden (\$ 93 Abs. 1 StGB, BGBI. 1968, 1, 741)."

15 A.B. van Rijn, De functie van de vrijheid van meningsuiting in beide Duitse staten, diss. RL, Zwolle: 1985, p. 163-165; Ernst-Werner Fuss, Pressefreiheit und Geheimnisschutz, NJW 1962, p. 2225-2228; Peter Schneider, Pressefreiheit und Statsicherheit, Mainz 1968.

Heinrich Jagusch, Pressefreiheit, Redaktionsgeheimnis, Bekanntmachen won Staatsgeheimnissen, NIN 1962 ; p. $177-183$.

BVerfGE 5-7-1963, nr. 50308, 'Spiegel-fall'. 
nahmen, die wegen einer Presseveroffentlichung oder im Zusammenhang damit bei einem Pressewntemehmen oder einem beteiligten Presseangehörigen vorgenommen werden:"

En verder:

"Bei Durchsuchungen und Beschlagnahmen in Presseuntermehmen fällt zusätzlich der mög" liche oder wahrscheinliche Eingriff in die Pressefreiheit ins Gewicht. Dies betrifft zunächst die Behinderung in der Ausübung des Grundrechts, die infolge der Durchsuchung und Beschlagnahme eintreten kann, mehr noch aber den Einbruch in das Redaktionsgeheimnis, der regelmäBig mit diesen $\mathrm{Zwangsma}$ Bna hmen verbunden ist. Da das Vertrauensverháltnis zwischen der Presse und ihren Mitarbeitern und Informanten eine wesentliche Voraussetzung fur die Funktionsfähigkeit eines Presseorgans biddet und eine Gefährdung dieses Vertraulensverhalltnisses geeignet sein kann, über den vorliegenden Einzelfall hinaus nachteilige Auswirkungen auf andere Presseorgane und damit für die Pressefreiheit überhaupt nach sich zu ziehen, besteht hier zwangsläufig ein Konflikt zwischen dem Interesse an der Strafverfolgung und dem Schutz der Pressefreiheit."

Daarbij is het uiteindelijk aan de wetgever "diese Güterabwägung vorzunehmen." De vraag is dan alleen nog welke wetgever? De 'Landesgesetzgebers' of de 'Bundesgesetzgeber", en op welke manier.

In de loop van de procedure hadden de 'Landesgesetzgebers' al het initiatief genomen tot herziening van het 'Zeugnisverweigerungsrecht' in hun perswetten. Ondat dit recht ook was geregeld in het StPO, maar na 'der Spiegel'-u itspraak niet meer voldeed, ontstond er een competentiestrijd. ${ }^{18}$ Op 28 november 1973 besliste het 'Bundesverfassungsgericht' dat "de voorschriften betreffende het strafprocessuele werschoningsrecht in wezen behoren tot het bewijsrecht, tot de juridische procedure, en dus geregeld dienen te worden in het StPO ${ }^{\text {Mg }}$ De 'Landesgesetzgebers' werden incompetent geacht zich met deze materie bezig te houden omdat het hier niet gaat om "Presse sondern strafiverfahrensrechtliche Materie. ${ }^{100}$ Zo werd de weg vrijgemaakt voor de 'Bundesgesetzgeber' om de strafprocessuele regeling van het verschoningsrecht voor medewerkers van de pers en 'Rundfunk' met daaraan gekoppeld de inbeslagneming van gegevensdragers voor het aan de dag brengen van de waarheid in het StPO te herzien.

Op welke manier en in hoeverre het verschoningsrecht en het redactiegeheim beperkt mag worden ten gunste van de strafrechtelijke vervolging is een vraag die binnen

18 P.J. Boukema, Enkele aspecten van de vrijheid van meningsuiting in de Duitse Bondsrepubliek en in Nederland, diss. VU, Amsterdam 1966, p. 27-29; M. Löfler, Die Gesetzgebungskompetenz von Bund und Ländern auf dem Gebiet des Presserechts, NJW 1972, p. 1515; Karl Heinz Kunert, Das Gesetz iuber das Zeugniswerweigerungsrecht der Mitarbeiter von Presse und Rund funk, MDR $11 / 1975$, p. 885 .

19 BVerfGE 28-11-1973, 36, 193. Zie ook BVerfGE 13-2-1974, 36, 314, BVerfGE 8-10-1974, 38, 103.

20 BVerfGE 28-11-1973, 36, 193. Zie ook BVerfGE 13-2-1974, 36, 314, BVerfGE 8-10-1974, 38, 103. 
het kader van de Grondwet beantwoord dient te worden. ${ }^{21}$ De Grondwet biedt het kader in hoeverre strafprocessuele maatregelen zoals de inbeslagneming van gegevensdragers voor het aan de dag brengen van de waarheid mogelijk zijn. Daarbij moet de bevoorrechte positie van de media worden gezien in relatie tot haar functie. "Befreiungen von allgemein geltenden Rechtsnormen müssen nach Ant und Reichweite stets von der Sache her sich rechtfertigen lassen. ${ }^{102}$ Een absolute voorrang van de drukpersvrijheid zonder beperkingen van het verschoningsrecht en het redactiegeheim, is volgens het Bundesverfassungsgericht in 'Der Spiegel'-zaak niet te rijmen met de Grondwet. Het 'Bundesverfassungsgericht" spreekt dan ook van een "gewissen Schutz"van de vertrouwensrelatie tussen pers en informant. ${ }^{23}$ In dit perspectief moet dan ook het onderscheid worden gezien in de 'Strafprozeßordnung' tussen eigen materiaal en materiaal van derden verkregen. In de volgende paragraaf volgt een bespreking van de laatst genoemde categorie. De categorie 'eigen materiaal' komt in paragraaf 2.4 aan de orde.

\subsection{Materiaal van derden verkregen}

In Duitsland wordt de inbeslagneming van gegevensdragers voor het aan de dag brengen van de waarheid in 'Paragraph 97 Abs. 5 StPO', anders dan in Nederland ${ }^{2 \mathrm{~s}}$,

21 Het verschoningsrecht van persmedewerkers houdt het parlement al meer dan een eeuw bezig. Uitgangspunt van deze ontwikkeling is het jaar 1848. Dan wordt in Pruisen, net als ook in andere Duitse deelstaten de censuur opgeheven. Om echter toch invloed te kunnen blijven uitoefenen op de pers hanteerde men de gijzeling of dwong men medewerkers bij de pers te getuigen. Eerst in de Perswet van Baden en het Wetboek van Strafvordering wan Württemberg werd in 1868 een beperkt verschoningsrecht ingevoerd. Poging tot inwoering van een verschoningsirecht voor de pers in de 'Reichspressegesetz' van 1874 en de 'ReichsstrafprozeBiordnung' van 1877 mislukte. Pas in 1926 werd een beperkt verschoningsrecht woor persmedewerkers in de StPO opgenomen. K. Brandt, Strafprozessuale Zwangsmaßnahmen gegen Presseunternehmen, Göttingen 1969, p. 20 e.\%; M. Delitz, Zeugnisverweigerungsrecht und Beschlagnahmeprivileg der Presse unter besonderer Berücksiw chtigung des anglo-amerikanischen Rechts, diss. Ludwig-Maximilians-Universität Münclen, Münchem 1976, p. 1-15; U. Klug, Presseschutz im StrafprozeB, Ein Rechtsgutachten im 'Spiegel-Verfahren", Berlin und Neuwied 1965, p. 28-47. BVerfGE 5-8-1966, 20, 162 (176) - 'Der Spiegel'; U. Klug, Presseschutz in StralprozeB, Ein Rechtsgutachten im 'Spiegel-Verfahren', Berlin und Neuwied 1965, p. 17-104.

23 BVerfGE 5-8-1966, 20, 162 (176) - "Der Spiegel; BVerfGE 28-11-1973, 36, 193 (204) - Hessen; BVerfGE 25-1-1984, 66, 117 (133f) - Wallraff.

24 In Nederland werd lange tijd een verschoningsrecht woor journalisten afgewezen op grond wan het feit dat zij geen typisch vertrouwensberoep uitoefenen (HR 14-12-1948, NJ 1949, 95; HR 11-111977, NJ 1978, 399; Rb. Zwolle 19-12-1984, NJCM-Bulletin 1985, p. 50-56) Ook was men bang dat de erkenning van het verschoningsrecht door roddelbladen misbruikt zou gaan worden (zie Bijl. HTK 1913-1914, 286, nr. 3.) De laatste jaren gaan er echter stecds meer stemmen op om ook in Nederland een journalistiek verschoningsirecht in te voeren (Zie hoofdstuk 1, 4.3.1). 
gekoppeld aan het 'Zeugnisverweigerungsrecht' in 'Paragraph $53 \mathrm{StPO}$. ${ }^{8}$ Voorop staat het strafprocessuele dwangmiddel 'Zeugniszwang' ('Paragraph 70 StPO'). In Duitsland wordt dit dwangmiddel in de wet begrensd door het proportionaliteitsbeginsel. De rechter moet in het concrete geval een afweging maken tussen de plicht te getuigen of niet te getuigen. Voor informanten die aan de media informatie doorgegeven hebben zal het belangrijk zijn te weten dat deze gegevens niet in handen komen van het opsporingsapparaat. ${ }^{27}$ Voor materiaal van derden verkregen geldt, ook bij ernstige strafbare feiten, dan ook een verschoningsrecht voor gepriviligeerde mediamedewerkers ('Paragraph $53 \mathrm{Abs}$. $1 \mathrm{Satz} 5 \mathrm{StPO}$ ). De inbeslagneming van geschriften, geluids-; beeld - en databanden, afbeeldingen etcetera die zich in bewaring bevinden bij een gepriviligeerde mediamedewerker of de redactie, een uitgever, drukkerij of een radio- c.q. televisiestation, is niet toelaatbaar wanneer het verschoningsrecht een rol speelt. Er mag dan wel geen sprake zijn van deelneming aan een strafbaar feit, begunstiging, of heling door de werschoningsgerechtigde.$^{28}$ Ook mag het niet gaan om zaken die verkregen zijn door een strafbaar feit of die tot het begaan van een strafbaar feit worden gebruikt ('Paragraph 97 Abs. 5 Satz 2 StPO').

De grondgedachte achter de 'Paragraphen 53 en 97 Abs. 5 StPO' is de bescherming van de vertrouwensrelatie tussen de media en hun informanten meer nog dan de bescherming van de vrijheid van meningsuiting en drukpers. Een absolute voorrang van de drukperswrijheid zonder beperkingen van het verschoningsrecht is niet te rijmen met de Grondwet. Het 'Bundesverfassungsgericht' spreekt van een "gewissen

25 H. Lisken, Pressefreiheit und StrafprozeB, ZRP 1988, p. 193-197; A. Pauli, Der Schutz won Presse und R undfunk vor dem Zugriff staatlicher Verfolgungsorgane, diss. Albertus Magnus Universität. Köln, München 1988, Zweites Kapittel: Der Schutz der Medien nach der StrafprozeBordnung, p. 64-138; R. Groß, Zum Zeugnisverweigerungsrecht der Mitarbeiter von Presse und Rundfunk in: Festschrift für Gerhard Schiedermair, München 1976, p. 223-243; Karl Heinz Kunert, Das Gesetz über das Zeugnisverweigerungsrecht der Mitarbeiter von Presse und Rundfunk, MDR 11/1975, p. 885-893; Jurgen Meyer, Zur Beschlagnahme selbstrecherchierten Materiats von Journalisten in: Hans-Heinrich Jeseheck und Theo Vogler (Hrg.), Festschrift für H. Tröndle, Berlin-New York 1989, p. 839-854; M. Delitz, Zeugnisverweigerungsrecht und Beschlagnahmeprivileg der Presse unter besonderer Berücksichtigung des anglo-amerikanischen Rechts, diss. Ludwig-MaximiliansUniversitat München, München 1976, p. 38-79. Deze koppeling zien we ook in Oostenrijk (\$1 Abs. 2 OMedienG, Bundesgesetz van 12-6-1981, BGBl, 314). In Zweden gaat men nog verder. Daar hebben journalisten een zwijgplicht. Zie hoofdstuk 4.

26 BGH 25-5-1965, NJW 1965, p. 1388 - 'Berufswerbot gegen einen Journalisten'.

27 BVerfGE 5-8-1966, 20, 162 (176, 187) - 'Der Spiegel'.

28 In tegenstelling tot de vroegere redactie (Wet van 1953) en de meeste deelstaatregelingen zijn journalisten in het bijzonder bij de publicatie van artikelen met een strafbare inhoud, verdacht van medeplichtigheid of begunstiging. Ex kan dan inbeslagnenaing of huiszoeking plaatsvinden bij de pers en 'Rundfunk'. Dit is dus een belangrijke beperking van de vrijheid van drukpers en de 'Rundfunk', zeker nu de begrippen medeplichtigheid en begunstiging erg rekbaar zijn. Martin Lölfher, Lücken und Mãngel in neuen Zeugniswerweigerungs- und Beschlagnahnerecht won Presse und Rundfunk, NJW 1978, p. 914. 
Schutz" wan de vertrouwensrelatie tussen mediamedewerkers en hun informanten. ${ }^{2}$ Deze bescherming van de vertrouwensrelatie tussen de media en hun informanten zorgt ervoor dat mediamedewerkers onafhankelijk kunnen functioneren. Alleen wanneer het verschoningsrecht en het redactiegeheim gewaarborgd is, kan de media haar controle- en informatieve functie goed vervullen. ${ }^{39}$ De informatievrijheid en de grondwettelijke bescherming van de informatiebronnen tegen inbeslagneming staan in direct verband met elkaar. De 'Informationsschutz' is een logisch gevolg van de in 'Art. 5 Abs. $1 \mathrm{Satz} 2 \mathrm{GG}$ ' genoemde karakteristieke positie van de media." De taak van de media is het publiek te informeren over politieke gebeurtenissen. ${ }^{32}$ Door het weergeven van verschillende opvattingen wordt het voor burgers mogelijk gemaakt om kritisch te kunnen beslissen. ${ }^{33} \mathrm{Zij}$ zijn "die orientierende Kraft in der offentlichen Auseinandersetzung. ${ }^{1{ }^{134}}$ Er wordt grote betekenis toegekend aan een goed geïnformeerd publiek. ${ }^{35}$ Daarmee hangt samen het recht dat het 'Bundesverfassungsgericht' aan iedereen heeft toegekend, om informatie te vergaren uit bronnen die algemeen toegankelijk zijn (bijvoorbeeld daglbladen, tijdschriften etcetera) ${ }^{36} \mathrm{De}$ een ieder toekomende informatievrijheid impliceert geen informatieplicht van de staat. ${ }^{37}$ Niet algemeen toegankelijke bronnen vallen buiten de strekking van deze bepaling ('Art. 5 Abs. 1 Satz 1 GG'). De vraag of voor mediamedewerkers niet een uitzondering zou moeten worden gemaakt, zodat zij wel het recht hebben tegenover de staat om aanspraak te maken op inlichtingen, wordt door het 'Bundesverfassungsgericht" in de zaak Spiegel als volgt beslist: "Der Staat ist verpflichter, in seiner Rechts" ordnung überall, wo der Geltungsbereich einer Norm die Presse berïhrt, dem Postulat ihrer Freiheit Rechnung zu tragen (..) Auskünftspflichten der Behörden sind prinzipielle

29 BVerfGE 5-8-1966, 20, 162 (176) - 'Der Spiegel'.

30 BVerfGE 28-11-1973, 36, 193 = NJW 1974, p. 358. Zie ook BVerfGE 6-10-1959, 10, 118, (121) $=$ NJW 1960; p. 29; BVerfGE 28-2-1961, 12, 202, (260) = NJW 1961, p. 547; BVerfGE 5-8-1966, $20,162,(175 \mathrm{f})=$ NJW 1966, p. 1603.

31 M. Delitz, Zeugnisverweigerungsrecht und Beschlagnahmeprivileg der Presse unter besonderer Berücksichtigung des anglo-amerikanischen Rechts, diss. Ladwig-Maximilians-Universität München München 1976 , p. 96 e.v.

32 P.J. Boukema, Enkele aspecten wan de vrijheid van meningsuiting in de Duitse Bondsrepubliek en in Nederland, diss. VU, Amsterdam 1978, p. 172-175.

33 BVerfGE 5-8-1966, 20, 162 (175) - 'Der Spiegel'.

34 BVerfGE 5-8-1966, 20, 162 (174f.) - 'Der Spiegel'; P. Dagtoglou, Wesen und Grenzen der Pressefreiheit, res publica, Beiträge zum ôffentlichen Recht, Bd. Il, Stuttgart 1963, p. 23 e.v.

35 BVerfGE 5-8-1966, 20, 162 (176, 187) - 'Der Spiegel'; BVerfGE 28-11-1973, 36, 193 (204) - Hessen; BVerfGE 6-2-1979, 50, 234 (240) - Kölner Volksblatt; vgl. cok BVerfGE 10-5-1983, 64, 108, (144f.) Chiffregeheimnis; OLG Köln 9-1-1968, NJW 1968, p. 666 - Springer-Verlag; Matunz/Dürig/Herzog/Scholz Bd. 1 LPG Rdn. 136 Art. 5 GG; M. Löfler (3), Bd. 1LPG Rdn. 116; Von Münch, Bd. 1 LPG Rdn. 24 - 'Redaktionsgeheimnis'. 
Folgen darcus (..)." ${ }^{\text {"3o }}$ Het gevolg van deze uitsprask is dat mensen die bij de media werken toegang moeten krijgen tot bronnen die niet algemeen toegankellik zijn. De staat is echter niet verplicht om informatie te verstrekken.

\subsection{Eigen materiaal}

Eigen materiaal kan wel in beslag worden genomen. ${ }^{48}$ Hier speelt het verschoningsrecht geen rol. In de zaak Brokdorf ${ }^{\mathrm{Az}}$ besliste het 'Bundesverfassungsgericht' dat het in overeenstemming is met het strafprocesrecht en met 'Art. 5 Abs. $2 \mathrm{GG}^{24}$, wanineer eigen materiaal van journalisten in beslag wordt genomen. In deze zaak betrof het een demonstratie tegen de kernenergiefabriek Brokdorf. Tijdens deze demonstratie kwam het tot ernstige ongeregeldheden. Om achter de identiteit van de verdachten te komen vorderde de officier van Justitie kopieën van het nog niet geopenbaard filmmateriaal. De medewerkers bij de televisie wilden slechts het reeds uitgezonden materiaal afgeven. Daarom werden huiszoeking en inbeslagneming gevorderd. Om een huiszoeking te omzeilen werd alsnog het niet geopenbaarde filmmateriaal afgegeven aan justitie. ${ }^{44}$

38 BVerfGE 5-8-1966, 20, 162 (176) - 'Der Spiegel'. Verg. ook BVerfGE 6-2-1979, 50, 234 (240) Kölner Volksblatt.

39 M. Löfler (3), Bd, 1, \& 4 LPG, Rx̉n. 15; M. Löfler, Die Gesetzgebungskompetenz von Bund und Ländern auf dem Gebiet des Presserechts, NJW 1972, p. 1515. Zie voor wat betreft de ontwikkelingen binnen de Raad van Europa hoofdstuk 1, \$3.2.

40 Manfred Lepa, Der Inhalt der Grundrechte nach der Rechtsprechung, Köln 1976, Art. 5 GG, p. 85. In de perswetten van de 'Bundesländer' bestatat wel cen 'Ausk hinftsanspruch' van de pers tegenover de overheid: A. Pauli, Der Schutz won Presse und Rundfunk vor dem Zugriff staatlicher Verfolgungsorgane, diss. Albertus-Magnus-Universitä̈t Köln, München 1988, p. 26-27.

41 BVerfoE 1-10-1987, NJW 1988, p. $329=$ EuGRZ 1987, p. 438 - 'Beschlagnahme von selbstrecherchiertem Filmmaterial einer Fernsehanstall': BVerfGE 1-10-1987, NStZ 1988, p. 33 = EuGRZ 1987 , p. 438 - 'Beschlagnahme selbstrecherchierten Materials beim Rundfunk'.

42 BVerfGE 14-5-1985, NIW 1985, p. 2395-Fall 'Brokdor?.

43 De reikwijdte van art. $5 \mathrm{GG}$ wordt begrensd door algemene wetten zoals de 'StrafprozeBordnung'. Het gaat om een afweging van belangen tussen enerzijds het aan de dag brengen van de waarheid in het strafproces en anderzijids de bescherming van de vrijheid van meningsuiting en drukpers. Hierower beslist in eerste instantie de wetgever. BVerfGE 11-3-1969, 25, 296 (306) $=$ NJW 1969, p. 1019; BVerfGE 15-12-1965, 19, 342 (347) = NJW 1966, p. 243; BVerfGE 3-8-1966, 20, 45 (49) $=$ NJW 1966, p. 1259; BVcrfGE 27-7-1966, 20, 144 (147) = NJW 1966, p. 1703; BVerGE 19-7-1972, $33,367(383)=$ NJW 1972, p. 2214.

44 Deze uitspraak is bevestigd in o.a. BVerfGE 5-8-1966, 20, 162, (189); BVerfGE 19-7-1972, 33, $367,(375)$. 
De zeer verschillende reacties ${ }^{45}$ op de Brokdorf beslissing maken duidelijk, dat de regeling uit 1975 met betrekking tot het verschoningsrecht voor medewerkers van pers en 'Rundfunk', nog niet een overtuigende oplossing heeft gegeven ten aanzien van het spanningsveld tussen de perswrijheid en 'Rundfunk'vrijheid enerzijds en een effectieve strafvervolging anderzijds. De vele inbeslagnemingen van journalistiek film- en beeldmateriaal bij de redacties van dagbladen en de 'Rundfunk' hebben geleid tot irritaties bij medewerkers van de media. Gedacht kan hierbij worden aan de inbeslagneming bij de NDR in Bremen, de 'Neue Hannoversche Presse ${ }^{346}$ en bij de SFB en ZDF in Berlijn ${ }^{47}$ en Mainz. ${ }^{48}$

Kuritiek wordt in de eerste plaats geleverd op het onderscheid tussen derden materiaal en eigen materiaal. Door het verschoningsrecht niet te erkennen voor het materiaal dat bijvoorbeeld een journalist zelf verzamelt, wordt het wezen van journalistieke arbeid in feite miskend. Immers een journalist verzamelt zijn informatie onopvallend en overal. Reporters en journalisten kunnen in een moeilijke situatic terecht komen

45 H. Lisken, Pressefreiheit und StrafprozeB, ZRP 1988, p. 194-196 is het met de uilspraak van de rechter in deze zaak eens, dit in tegenstelling tot $M$. Reissenberger, 'ZDF-BeschluB - unzumutbar', DRiZ 1988, p. 189. Zie ook de officier van Justitie Ulrich, 'Reporter sind keine Buttel der Pollizei', DRiZ 1988 , p. 53 ff.

46 Vgl. het besluit van het LG Hannover 22-12-1980, NStZ 1981, p. 154 met BVerfGE 4-3-1981, 56, 247ff. - 'Newe Hannoversche Presse' en de hieraan ten grondslag liggende besluiten van het AG Hannover 18-11-1980, Az. 44 Gs 638/80. Het ging hier om een uit de hand gelopen 'Feierliche Rekrutengelobnis' in Niedersachsen. Groepen demonstranten trokken door de stad en vernielden en plunderden winkels. Daarbij kwam het tot een treffen met de politie waarbijeen aantal agenten gewond raakten. Een reporter yan de 'Neue Hannoversche Presse' maakte opnamen van de strafbare. feiten die door de demonstranten werden begaan. Later werden deze beelden in de krant gepublliceerd. Op bewel van de officier van Justitie vond er een huiszoeking plaats bij de redactie van de 'Neue Hannoversche Presse'. Er werden foto's als bewijsmateriaal in besllag genomen. De 'Neue Hannoversche Presse" diende tegen dit besluit tot huiszoeking een bezwaarschrift in ondat volgens hen het journalistieke verschoningsrecht en het inbeslagnenimgsverbod in het geding waren. Het bezwar had echter geen succes.

47 LG Berlin 16-7-1981, ArP 1981, p. 417fI. Zie ook de annotatie wan Krone, AfP 1981, p. 420If. Als gevolg van een demonstratie van de "Alternative Liste" kwam het in Berlijn tot gewelddadigheden waarbij een groot aantal personen werden betrokken. Carmeramensen van de 'Sender Freies Berlin' (SFB) maakiten hiervan fillmopnamen, die in een actualiteitemprogramma wan het SFB en de ZDF werden uitgezonden, In de veronderstelling dat misschien nog niet uitgezonden materiaal kon bijdragen tot het identificeren van de daders, die o.a. van landvredebreuk werden verdacht, gelastte de officier van Justitie een huiszoeking bij de redactie van de SFB en de ZDF. Het gehele filmmateriaal werd in beslag genomen. De bezwaren van de SFB en de ZDF tegen de huiszoeking en de inbeslagneming thadden geen succes.

48 BVerIGE 1-10-1987, NJW 1988, p. 330 = EuGRZ 1987, p. 438 (439). Door de ZDF in Mainz werden filmopnamen aan de politie afgestaan om een dreigende huiszoeking bij de redactie te woorkomen. Zie voor cen bespreking van deze zaak; B. Erhard, Mediales Zeugnisverweigerungsrecht und Beschlagnahmeverbot im Spannungsverhältnis zwischen Medienfreiheit und Strafverfolgung, Schriftenreihe für Rundfunkrecht an der Universităt Köln, Band 38, 1984, p. 5-14; H. Lisken, Pressefreiheit und StrafprozeB, ZRP 1988, p. 194-197. 
wanneer zij op grond van de door het Openbaar Ministerie gevorderde medewerking worden gezien als handlangers van justitie. Gezien het feit dat in de praktijk is gebleken dat het onderscheid tussen eigen materiaal en materiaal dat van derden verkregen is niet duidelijk is te maken, valt de houdbaarheid van dit onderscheid te betwijfelen." In het Nederlandse wetsvoorstel 'Journalistiek Privilege' van Jurgens wordt, zoals we in hoofdstuk 1 hebben kunnen zien, dit onderscheid dan ook niet gemaakt. In een individueel geval kan het probleem opgelost worden door toepassing van 'Art. 5 Abs. 1 Satz 2 GG' rekening houdend met het proportionaliteitsbeginsel ${ }_{*}^{\text {s. }}$ Zelfcensuur dient in elk geval vermeden te worden. Ook mogen journalisten geen slachtoffer worden van gewelddadige acties door demonstranten. De verslaggeving van "brandhaarden moet inmers mogelijk blijwen.

Een ander punt van kritiek is het onderscheid tussen mensen die wel en mensen die niet beroepshalwe bij de pers of 'Rundfunk' werken. Volgens 'Paragraph 53 Abs. $1 \mathrm{Satz} 5 \mathrm{StPO}$ 'zijn personen die met de voorbereiding, samenstelling of verspreiding van dagbladen, tijdschriften of 'Rundfunk'uitzendingen beroepshalve meewerken of meegewerkt hebben, gerechtigd tot het weigeren om te getuigen. Löffler levert hier kritiek op. Volgens hem is de informatievrijheid zoals geformuleerd in "Art. 5 Abs. $1 \mathrm{GG}^{\prime}$ er voor een ieder. Ook personen die niet beroepsmatig bij de pers

49 A. Pauli, Der Schutz won Presse und Rundfunk vor dem Zugriff staatlicher Verfolgungsorgane, diss. Albertus-Magnus-Universität Köln, München 1988, p. 74-94. In de Verenigde Staten wordt dit onderscheid dan ook niet gemaakt. Zurcher tegen Stanford Daily 1978 (436 US 547; 98 S.Ct. 1970; 56 L.Ed. 2d 5225 (1978); Rie, UFJTA 88 (1980), p. 163-184). Het betrof in deze zaak een onaangekondigde huiszoeking bij een studentenkrant-redactie in de hoop daar foto's van demonstranten te vinden die bij de bezetting van de kamers van het bestuur van het universiteitsziekenhuis enkele politie-agenten zwaar mishandeld hadden. In dit arrest gaf een meerderheid van de 'Supreme Court" te kennen dat huiszoeking en inbeslagneming bij de pers toelaatbaar was zolang er maar was voldaan aan een drietal voorwaardem:

1. Er moet sprake zijn van een ernstig strafbaar feit.

2. Verder moet er duidelijk worden aangegewen wat doorzocht mag worden

3. en dient er rekening te worden gehouden met het proportionaliteitsbeginsel.

Met zogenaamde 'Shield laws' beschermen veel Amerikaanse staten de pers tegen opsporingsdwangmiddelen van het Openbaar Ministerie. In 1980 werd door de wetgever van de deelstat Washington een wet aringenomen waarin niet alleen de wertrouwensrelatie tussen de journalisten en informanten beschermd werd maar ook het eigen materiaal van journalisten ('working materials"). De officier van Justitie mag hier alleen ingrijpen wanneer een krant, radio of journalist verdacht wordt wan een ernstig strafbaar feit. Daarbij mag het niet betreffen de opheldering van een ernstig strafbaar feit door een derde gepleegd. De inbeslagneming van "working materials" is wel weer mogelijk oin de dood of zware mishandeling van een derde te voorkomen. Jürgen Meyer, Zur Beschlagnahme selbstrecherchierten Materials von Journalisten in: Hans-Heinrich Jescheck und Theo Vogler (Hrg.), Festschrift für H. Tröndle, Berlin-New York 1.989, p. 848 e.v.; J. Bornkamm, Pressefreiheit und Fairness des Strafverfahrens, Rechtswergleichung, Baden-Baden 1980; M. Delitz, Zeugniswerweigerungsrecht und Beschlagnahmeprivileg der Presse unter besonderer Berücksichtigung des angloamerikamischen Rechts, diss. Ludwig-Maximilians-Universität München, München 1976, p. $38-69$.

50 OLG - Frankfurt 21-8-1973, NJW 1973, p. 2074. \$94 StPO. De inbeslagneming voor het aan de dag brengen van de warkeid van twee exemplaren van een film is voldoende. 
of 'Rundfunk' werken, moeten een beroep kunnen doen op het verschoningsrecht. Volgens Löffler is het ook niet juist dat een politicus die zijn memoires publiceert in een opinieblad, bijvoorbeeld een tijdschrift, op grond van 'Paragraph 53 Abs. 1 Satz 5 StPO' wel een beroep kan doen op het verschoningsrecht en een politicus die zijn memoires wil publiceren in een boek niet. Ook het uitsluiten van cineasten van het verschoningsrecht staat op gespannen voet met Art. 5 Abs. 1 Satz 2 GG. Immers algemeen aanvaard is dat de in de Grondwet gegarandeerde vrijheid van alle media (Art. 5 Abs. 1 Satz 2 GG) de grondslag is van het verschoningsrecht. ${ }^{\text {sn }}$

Een laatste beperking van het 'Zeugnisverweigerungsrecht' en het inbeslagnemingsverbod die in dit verband nog vermeld dient te worden is het feit dat het niet-redactionele deel van een krant niet beschermd wordt. Aanvankelijk was het nog zo dat de perswetten van de deelstaten het niet-redactionele deel van een dagblad waaronder de advertenties, gezien hun hoge informatiewaarde, beschermden. Ook het 'Bundes. verfassungsgericht' erkende in 1967 in het bekende 'Südkurier-Urteil' ${ }^{\text {s2 }}$ de hoge informatiewaarde van het niet-redactionele deel in dagbladen. Werknemers die niet inhoudelijk betrokken waren bij een dagblad konden ook een beroep doen op "Paragraph 53 Abs. 1 Satz 5 StPO'.93 In de nieuwe wet van 1975 wordt het niet-redactionele deel echter uitgesloten van het verschoningsrecht. Men was van mening dat dit recht alleen betrekking heeft op het redactionele deel van de pers, radio en televiesie en niet op advertenties. Alleen nog werknemers die inhoudelijk betrokken zijn bij een krant kunnen een beroep doen op 'Paragraph 53 Abs. 1 Satz 5 StPO', zoals de uitgever, de redacteur, journalist etcetera. Voor andere medewerkers blijft een beroep op de vrijheid van meningsuiting in 'Art. 5 GG' mogelijk.ss

Volgens Löffler en van Ginkel is deze beperking onterecht en in strijd met 'Art. 5 Abs. 1 Satz 2 GG'. Ook werknemers die niet inhoudelijk bij een dagblad betrokken zijn moeten een beroep kunnen doen op het verschoningsrecht. Advertenties geven immers meningen weer van anderen en zijn noodzakelijk voor de economische positie van de media. Inbreuk op de hulpmiddelen betekent uiteindelijk inbreuk op de publicatie. $^{\$ 6}$

51 M. Löffler, Lücken und Mangel im neuen Zeugnisverweigerungs- und Beschlagnahmerecht won Presse und Rundfunk, NJW 1978, p. 913-914; M. Löffler, Das neue Zeugnisverweigerungs- und Beschlagnahmerecht im Presse- und Rundfiunkbereich, NJW 1978, p. 1617-1618. BVerfGE 4-41967, 21, 271 = NJW 1967, 976. BVerfGE 11-3-1969, 25, 296 (304) - 'Stern'.

54 BVerfGE 6-11-1979, 52, 283 (297) - "Tendenzschut $z$ ".

35. A. Pauli, Der Schutz won Presse und Rundfunk wor dem Zugriff staallicher Verfolgungsorgane, diss. Albertus-Magnus-Universitåt Köln, München 1988, p. 38; M. Loffler (3), Bd. 1, \$1 LPG, Rdm.. $75,78$.

56 M. Löfler, Lücken und Mängel im neuen Zeugnisverweigerungs- und Beschlagnahmerecht won Presse und Rundfunk, NJW 1978, p. 915; A. Paull, Der Schutz won Presse und Rundfunk vor dem Zugriff staatlicher Verfolgungsorgane, diss. Albertus-Magnus-Unuversitüt. Köln, München 1988, p. 32; M. Löffler, Das neue Zeugniswerweigerungsrecht und Beschlagnahmerecht im Presse- und Rundfunkbereich, NJW 1978, p. 1617. 
3 We zijn bewoegd tot de inbeslagneming wan gegevensdragers wanneer het betreft het aan de dag brengen van de warheid?

Volgens 'Paragraph 98 StPO Abs. 1 ' is de rechter bevoegd tot de inbeslagneming van eigen materiaal woor het aan de dag brengen van de waarheid. ${ }^{57}$ Wanneer er echter 'Gefahr im Verzug' dreigt is ook de officier van Justitie en de hulp-officier bevoegd tot inbeslagneming: 'Gefahr im Verzug' ontstaat wanneer het doel van de maatregel in gevaar komt bijvoorbeeld wanneer er gevaar bestaat "des öffentlichen Interesses an unverzögerter Verbreitung. ${ }^{\text {Of }}$ of het geval is beslist de betreffende ambtenaar naar "pflichrgemäßen Emessen. Er dient echter een uitzondering te worden gemaakt voor de inbeslagneming van eigen materiaal bij de redactie, een uitgever, een drukkerij of een radio- c.q. televisiestation. Hier is alleen de rechter bevoegd, ook als het gaat om 'Gefahr im Verzug'. Gezien de hoge rang die de vrijheid vain meningsuiting en drukpers volgens Art. $5 \mathrm{GG}$ toekomt, is de inbeslagneming bij de pers en bij de "Rundfunk" slechts bij 'dringende noodzakelijkheid" mogelijk." Er dient rekening te worden gehouden met het proportionaliteitsbeginsel. ${ }^{62}$

\section{De 'Einziehungsbeschlagnahme' en de vrijheid van meningsuiting en drukpers}

Behalve de inbeslagneming van gegevensdragers voor het aan de dag brengen van de waarheid kent men in Duitsland ook nog de op inbeslagneming van gegevensdragers zoals geschriften, geluids- en beelddrager, afbeeldingen ('Paragraph 74d StGB') ter verbeurdverklaring of om onbruikbaarmaking te voorkomen ('Paragraph $111 \mathrm{~m}$ ' en 'Paragraph $111 \mathrm{n}$ StPO'). Voór 1975 stonden deze bepalingen in de speciaal

57 Materiaal van derden werkregen mag niet in beslag worden genomen. Het inbeslagnemingsverbod vervalt echter, zoals we in de vorige paragraaf reeds hebben kumen lezen, wanneer de verschoningsgerechtigde verdacht wordt wan medeplichtigheid of deelneming aan cen strafbaar feit, begunstiging of holing. Ook mag het niet gaan om zaken die verkregen zijin door een strafbaar feit of die tot het begaan van osin strafbaar feit worden gebruikt (S 97 Abs. 5 Satz 2 StPO).

58 Kleinknecht/Meyer,Strafproze Bordnung,Kurz-Kommentar, StrafprozeBordinung, Gerïchtsverfas-

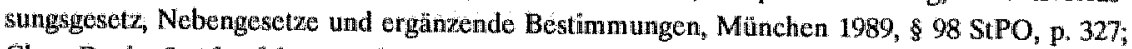
Claus. Roxin, Strafverfalurensrecht, Ein Studienbuch, München 1.987, p. 216; H. Dünnebier, Das Problem einer Sonderstellung der Presse im Strafwerfahren, Verhandlungen der Fachgruppe für Stralrechtswergleichung, Kiel 1965, p. 44-45.

59 Kleinknecht/Meyer, Kurz-Kommentar, St tafprozefordnung,Gerichtsverfassungsgesek, Nebenge-setzo und ergämende Bestỉmmungen, München 1989, p. 328, Löwe-Rosenberg, Großkommentar, Die Strafproze Bordnung und das Gerichtswerfassungsgesetz, Erster Band, 1989, Einleitung, \$1-111n, p. 587; BVerfGE 34-1979, 51, 97 (111) = NJW 1979, p. 153, 154.

60 OLG Koln 9-1-1968, NJW 1968, p. 666.

61 BVerfGE 5-8-1966, 20, 162 - 'Spiegel-Urteil".

62 LG Luneburg 12-12-1982, $\sqrt{2} 1984$, p. 343 = MDR 1984, p. 603.

63 Kleinknecht/Mexer, Kurz-Kommentar,StrafprozeBordnung, Gerichtsverfassungsgesetz, Nebengesetze und ergathende Bestimmungen, München 1989 , $111 \mathrm{~m}$ en $\$ 111 \mathrm{n}$, p. 399 e.v. 
woor de dnukpers in het leven geroepen 'Pressegesetze' van de 'Bundeshander' Onder de dekmantel van een nieuwe regeling van het 'Zeugnisverweigerungsrecht' in de StPO werd de "Pressebeschlagnahme"ss meegenomen. Vanuit rechtshistorisch perspectief kunnen hierbij kanttekeningen worden geplaatst. ${ }^{*}$ Er bestond in Duitsland een sterke band tussen de 'Pressebeschlagnahme' en het 'Presserecht'. Toch is de 'Bundesgesetzgeber' deze materie gaan regelen omdat de 'Bundesreglerung" wan mening was dat het hier betrof "strafierfahrensrechliche Materie". Volgens GroB is dit niet juist wanneer het betreft de 'Pressebeschlagnahme', wel wanneer het gaat om het 'Zeugnisverweigerungsrecht' en de inbeslagneming voor het aan de dag brengen van de waarheid. Een ander argument dat de 'Bundesregierung' gebruikte om haar optreden te rechtvaardigen was dat: "ein bundeseinheitliches Beschlagrwalwnerecht liege im Interesse eines effektiveren Beschlagnahmeverfahrens "Echter volgens het Bundesverfassungsgericht" "entspricht die Kompetenzaufteilung zwischen Bund und Ländern einem bewujten Willensakt der Verfassung der vom Gesetzgeber nicht unter Berufung auf ein angeblich besseres Funktionieren bei andenweitiger Regelung negient werden kann. ${ }^{\text {ma }}$

Enkele bijzonderheden van 'Paragraph 111m StPO':

1. In 'Paragraph $111 \mathrm{~m}$ Abs. 1 StPO' wordt uitdrukkelijk gewezen op het proportionaliteitsbeginsel.

2. Volgens 'Paragraph $111 \mathrm{~m}$ Abs. 2' worden bepaalde delen van een geschrift waarin. geen strafbare feiten staan van een inbeslagneming uitgesloten. Zo kan de inbeslagneming bijvoorbeeld tot de bijlage van een krant beperkt blijven. "Absatz 2 ' laat nog verdergaande beperkingen toe in die zin dat de inbeslagneming enkele archiefexemplaren uitzondert. (Dit is een nadere concretisering van het proportionaliteitsbeginsel zoals geformuleerd in 'Paragraph $111 \mathrm{~m}$ Abs. 1 StPO').

64 R. Groß, Pressestrafrechtliche Verantwortlichkeit, NJW 1978, p. 918.

65 Hieronder dient te worden verstaan "die Beschlagnahme der Gesamtauflage ciner Z̈eitung oder Zeitschrift mit Verbreitungs- und Wiederabdruckverbot." R. GroB, Beschlagmalhme von Druckwerken, NJW 1976, p. 171; H.J. Reh und R. Groß, Die Presse beschlagnahme, NJW 1962, p. 518.

H.J. Reh und R. Grofl, Die Pressebeschlagnahme, NJW 1962, p. 517-519; M. Löfler, Lücken und Mängel im neuen Zeugnisverweigerungs- und Beschlagnahmerecht von Presse und Rundfunk, NJW 1978, p. 917-918; K. Brand, Strafprozessuale ZwangsmaBnahmen gegen Presseunternehmen, Göttingen 1969 , p. 21 e.v.

67 BT-Drucks $7 / 2539$, p. 9.

68 R. Groß, Beschlagnahme von Druckwerken, NJW 1976, p. 171; M. Löfler, Lücken und Mångel im neuen Zeugnisverweigerungs- und Beschlagnahmerecht, NJW 1978, p. 913-918.

69 BT-Drucks 7/2539, p. 9-10.

70 BVerfGE 4-6-1957, 7,29(44, 45) = NJW 1957, p. 1355. 
3. 'Absatz 3 van Paragraph $111 \mathrm{~m}$ ': In het inbeslagnemingsbevel dient precies te worden aangegeven welke delen van een geschrift tot inbeslagneming aanleiding geven. ${ }^{\text {II }}$

4. 'Paragraph $111 \mathrm{~m}$ Abs. 4' maakt het voor de betrokkenen mogelijk om de inbeslagneming af te wenden doordat dezen gebruik kunnen maken van de mogelijkheid, om het gedeelte van een geschrift waarop de inbeslagneming betrekking heeft, niet te verspreiden of te vermenigvuldigen. ${ }^{72}$

Zoals we hierboven hebben kunnen lezen is het uitgangspunt bij de 'Einziehungsbeschlagnahme" het proportionaliteitsbeginsel. ${ }^{3}$ Alleen bij zeer ernstige strafbare feiten zoals landverraad mag de rechter of de officier van Justitie een hele oplage in beslag nemen met als doel "eine künftige Einziehung sicherzustellen. ${ }^{n 4} \mathrm{De}$ inbeslagneming met als doel "künftige Straftaten dadurch zu verhindern oder zu erschweren, daß bestimmte Gegenstände weggenommen werden" is niet toegestaan. ${ }^{75}$ Inbeslagneming is immers alleen mogelijk op grond van drie doelstellingen namelijk voor het aan dle dag brengen van de waarheid, ter onbruikbaarmaking en ter verbeurdverklaring.

\section{Wie zijn bevoegd tot de 'Einziehungsbeschlagnahme'?}

'Paragraph 111n Abs. 1' geeft weer wie bevoegd zijn tot inbesllagneming.

a. Bij de inbeslagneming van opiniebladen, (waaronder ook dagbladen vallen) en gegevensdragers die hiermee overeenkomen ('Paragraph $74 \mathrm{~d} \mathrm{StGB'})^{76}$ is de rechter bevoegd. Dit omdat hier de inbeslagneming grote gevolgen kan hebben, zeker wanneer het een hele oplage betreft. Het gaat hier om actuele informatie die de openbaarheid betreft.

71 H. Kunert, Das Gesetzuber dlas Zeugniswerweigerungsrecht der Mitarbeiter von Presse und Rundfunk, MDR 11/1975, p. 892.

72 De inbeslagneming is alleen mogelijk ten aanzien van stukken die werspreid zijn of voor verspreiding bestemd zijn ( $\$ 74 \mathrm{~d}$ Abs. 1 Satz 1 StGB). Verspreiding betekent toegankelijk maken woor een grotere groep personen en heeft betrekking op minstens 1 exemplaar (\$74a Abs. 1 Satz 1 StGB). In de zaak OLG Frankfurt 21-8-1973, NJW 1973, p. 2074 besliste de rechter dat de inbeslagneming vian twee exemplaren van elke titel voldoende was. Zie ook \$ 74d SIGB Abs. 3 (proportionaliteitsbeginsel).

74 Kileinknecht/Meyer,Kurz-Kommentar,Strafprozeßordnung, Gerichtsverfassungsgesetz, Nebengesetze und ergänzende Bestimmungen, München 1989, p. 400.

75 Lowwe-Rosenberg, Großkommentar, Die Strafprozeßordnung und das Gerichtsverfassungsgesetz, Erster Band, 1989, Einleitung, \$1-111n, p. 553.

76 Onder het begrip "Schriften" dienen begrepen te worden "Ton, Bildiräger, Abbildungen, Darstellungen’ ( $\$ 74 \mathrm{~d}$ Abs. 1 Satz 1 StGB jo $\$ 11$ Abs. 3 StGB). Ook drukplaten, matrijzen, negatieven kunnen in beslag worden genomen (\$ 74d Abs. 1 Satz 2 StGB). 
b. Voor wat betreft de inbeslagneming van andere drukwerken en hiermee overeenkomende gegevensdragers (Paragraph 74d StGB') is behalve de rechter bij "Gefahr im Verzug" ook de officier van Justitie bevoegd. De hulp-officieren zijn niet bevoegd. De vordering dient binnen drie dagen door de rechter te worden bekrachtigd.

Volgens Kunert zou het juister zijn geweest bij de categorie gegevensdragers onder b; in die gevallen waarin het gaat om staatsgeheimen, pornografie of discriminatoire belediging, de politie bevoegd te verklaren tot inbeslagneming. Nu is het zo dat wanmeer de politie zulke geschriften ontdekt een rechter of bij 'Gefahr im Verzug' een officier van Justitie moet worden ingeschakeld. De strafbare drukwerken zijn dan vaak al verdwenen. Wanneer er bij een huiszoeking in het kader van bijvoorbeeld drugs, ook drukwerken met een strafbare inhoud worden gevonden mogen deze niet door de politie in beslag worden genomen ('Paragraph $108 \mathrm{StPO}$ )."

Dat men in Duitsland ondanks bovengenoemd reëel bezwaar toch heeft gekozen voor de rechter en de officier van Justitie bij de inbeslagneming van gegevensdragers heeft te maken met het feit dat hier de vrijheid van meningsuiting en drukpers in het geding is. Zeker wanneer het gaat om gegevensdragers zoals dagbladen en tijdschriften die tijdsgevoelig zijn is extra behoedzaamheid noodzakelijk. Ook kan door de inbeslagneming van een hele oplage kranten of tijdschriften de bestaanspositie van een krant of uitgever in gevaar worden gebracht. Daarom is wanneer het gaat om de inbeslagneming van opiniebladen alleen de rechter bevoegd. Gaat het om andere zaken dan opiniebladen dan is bij 'Gefahr im Verzug' alleen de officier van Justitie bevoegd en niet de hulp-officier of een politieagent. Men acht hen beter in staat een juiste afweging te maken tussen grondrechten en het opsporings- en vervolgingsbelang dan de politie zeker nu de strafrechtelijke bepalingen die terzake relevant zijn zoals de pornografiebepalingen, de bepalingen die betrekking hebben op staatsgeheimen en discriminatoire belediging vaag zijn gedefinieerd. ${ }^{78}$

\section{Rechtsmiddelen}

In Nederland kan, bij de inbeslagneming, tegen een beschikking van het gerecht zowel door het Openbaar Ministerie als door de klager beroep in cassatie worden ingesteld; appèl is niet mogelijk (art. 552d Sv). In Duitsland staat tegen een beslissing

77 Karl Heinz Kunert, Das Gesetz über das Zeugnisverweigerungsrecht der Mitarbeiter von Presse und Rundfunk, MDR 11/1975, p. 892; Klleinknecht/Meyer, Kurz-Kommentar, Straflprozeßordinung, Gerichtsverfassungsgesetz, Nebengesetze und ergänzende Bestimmungen, München 1989, p. 363. Volgens de wetgever van 1874 dient de "vorläufige nichtrichterliche Beschlagnahme auf ein Mindestmaß beschränkt werden, da man die Gefahren durch eine juristisch nicht genügend vorgebildete Polizei, die zudem den Weisungen politischer Stellen unterworfen ist, eindämmen wollte." Deutsche Reichstag, 2 Legislaturperiode, I Session, 1874, Bd. 3, nr. 67, p. 250ff, (255). 
van de rechter tot toepassing van dwangmiddelen het rechtsmiddel van bezwat ('Beschwerde') open ('Paragraph 304 StPO'). ${ }^{79}$ Het doel van het rechtsmiddel bezwaar is er in gelegen de rechter om zijn oordeel te vragen omtrent de toelaatbaarheid van de toepassing van het dwangmiddel. Met het rechtsmiddel van bezwaar wordt de aangevochten beslissing zowel juridisch als feitelijk getoetst. Het voor deze toetsing competente gerecht is de strafkamer van het 'Landgericht' (Art. 73 GVG). Het rechtsmiddel van bezwaar kent twee varianten; het eenvoudige bezwaar en het onmiddellijke bezwaar ( $P a r a g r a p h " 311$ StPO). Het eenvoudige bezwaar is niet aan een termijn gebonden en kan door de 'iudex a quo' zelf worden afgedaan voorzover het gegrond wordt verklaard. Het onmiddellijke bezwaar is wel aan een termijn gebonden en moet binnen een week bij de 'iudex a quo' worden ingesteld ('Paragraph' 311 Abs. 2 StPO). Deze mag het bezwaar, op een enkele uitzondering na ('Paragraph' 311 Abs. 3 StPO), niet zelf afdoen maar moet het bezwaar aan de strafkamer van het 'Landgericht' voorleggen. Deze wint informatie in, geeft partijen gelegenheid gehoord te worden en beslist op grond van de stukken. Het eenvoudig bezwaar is het meest gebruikelijke rechtsmiddel dat openstaat tegen beslissingen van de rechter inzake dwangmiddelen. Het onmiddellijke bezwaar wordt door de wet als te hanteren rechtsmiddel voorgeschreven wanneer met het oog op de rechtszekerheid een snelle definitieve beslissing noodzakelijk is. ${ }^{80}$

Voorzover het beslissingen van de officier van Justitie of de politie betreft inzake de toepassing van dwangmiddelen staat in beginsel de mogelijkheid open de rechtmatigheid daarvan te doen toetsen bij de rechter, en wel de 'Amtsrichter' of het 'Landgericht'. ${ }^{81}$ Zo bepaalt 'Paragraph $98 \mathrm{Abs.} 2 \mathrm{StPO}$ ' dat ingeval van beslagneming zonder rechterlijk bevel degene onder wie een voorwerp in beslag genomen is, of degene die dat voorwerp vrijwillig heeft uitgeleverd, te allen tijde een rechterlijke beslissing kan vragen. De rechter moet dan onderzoeken of de wettelijke voorwaarden voor de inbeslagneming op het moment van zijn beslissing vervuld zijn. De rechterlijke beslissing achteraf komt dan in de plaats van de niet door de rechter bevolen inbeslagnerning. ${ }^{82}$

79 K. Amelung Probleme des Rechtsschutzes gegen strafprozessuale Grundrechtseingriffe, NJW $1979, p, 1687$.

80 Kleinknechl/Meyer, Kurz-Konmentar,StrafprozeBordnung, Gerichtsverfassungsgesetz, Nebengesetze und ergänzende Bestimmungen, München 1989, p. 1000; P.J.P. Tak, J.A.W. Lensing, Het vooronderzoek rechiswergelijkend onderzocht, Arnhem 1990, p. 54 .

81 T. Kalsbach, Die gerichtliche Nachpruffung von Maßnahmen der Staatsanwaltschaft in Strafverfahren, Berlin 1967, p. 7. 


\section{Conclusie}

In dit hoofdstuk werd de vrijheid van meningsuiting en drukpers in 'Art. 5 GG' besproken in relatie tot het strafvorderlijke dwangmiddel inbeslagneming. Wanneer we spreken over de inbeslagneming dan dient er een onderscheid te worden gemaakt tussen de inbeslagneming voor het aan de dag brengen van de waarheid en de inbeslagneming ter verbeurdverklaring of om onbruikbaarmaking te voorkomen. Voor eerst genoemde categorie geldt dat de inbeslagneming verboden is wanneer het betreft de inbeslagneming van gegevensdragers bij een verschoningsgerechtigde, een uitgever, drukker, de 'Rundfunk', of op de redactie van een dagblad of tijdschrift. Het moet dan wel gaan om materiaal dat van derden verkregen is ('Paragraph 97 Abs. 5 Satz 1 StPO' jo 'Paragraph 53 Abs. 1 Satz 5') en er mag geen sprake zijn van deelneming aan een strafbaar feit, begunstiging, of heling. Ook mag het niet gaan om zaken die verkregen zijn door een strafbaar feit of die tot het begaan van een strafbaar feit worden gebruikt ('Paragraph 97 Abs. 5 Satz 2 StPO'). In al deze gevallen kan er wel in beslag worden genomen. Dit is een aanzienlijke beperking van het inbeslagnemingsverbod. Wanneer artikelen met een strafbare inhoud worden gepubliceerd zal een journalist al snel worden verdacht van medeplichtigheid of begunstiging. Deze begrippen zijn immers zeer rekbaar.

Eigen materiaal mag, rekening houdend met het proportionaliteitsbeginsel, altijd in beslag worden genomen bij een verschoningsgerechtigde, een uitgever, drukker, de 'Rundfunk' of op de redactie van een dagblad of tijdschrift. Met deze beperking dat alleen de rechter bevoegd is in beslag te nemen bif een uitgever, drukker, de 'Rundfunk' of op de redactie van een dagblad of tijdsehrift. Ook wanneer er 'Gefahr im Verzug' dreigt. Gaat het niet om inbeslagneming bij de media dan is bij 'Gefahr im Verzug' ook de officier van Justitie en de hulp-officier bevoegd ('Paragraph 98 StPO Abs. 1).

Dat eigen materiaal niet dezelfde bescherming geniet alls materiaal van derden verkregen heeft te maken met het 'Zeugnisverweigerungsrecht' ('Paragraph 53 StPO'). De grondgedachte achter het 'Zeugnisverweigerungsrecht' is de bescherming van de vertrouwensrelatie tussen de media en hun informanten. Het 'Zeugnisverweigerungsrecht' is dan ook alleen van toepassing op mensen die het materiaal van derden verkregen hebben. Deze mensen moeten beroepsmatig bij de media werken. Een schrijver die een boek schrijft of burgers die een pamflet schrijven kunnen geen beroep doen op het verschoningsrecht en het inbeslagnemingsverbod. Zowel eigen materiaal als materiaal van derden verkregen mag dan, rekening houdend met het proportionaliteitsbeginse], in beslag worden genomen door de rechter en, wanneer 'Gefahr im Verzug' dreigt, door de officier van Jusitie of de hulp-officier. 'Gefahr im Verzug' ontstaat wanneer het doel van de maatregel in gevaar komt, bijvoorbeeld wanneer er gevaar bestaat "des öffentlichen Interesses an unverzögerter Verbreiting." Of dit het geval is is afhankelijk van het concrete geval.

Uit het voorafgaande kunnen we concluderen dat het verschoningsrecht en het inbeslagnemingsverbod sterk institutioneel bepaald zijn. In 'Art. 5 Abs. 1 Satz 2 GG' 
wordt expliciet de pers als instituut genoemd. Deze institutionele bescherming van de pers heeft te maken met de bijzondere taak van de pers. Zij dient mensen te informeren en de overheid te controleren. I $\mathrm{k}$ ben van mening dat dit een te beperkte opvatting is van de perswrijheid. Een ieder die zich bezig houdt met journalistieke arbeid moet een beroep kunnen doen op het verschoningsrecht en dient beschermd te worden tegen inbeslagneming. Of het dan gaat om eigen materiaal of materiaal van derden verkregen is niet relevant. Dit onderscheid is immers moeilijk te maken en werkt misbruik in de hand.

Iets anders is de 'Einziehungsbeschlagnahme'. Dit is de inbeslagneming van gegevensdragers ter verbeurdverklaring of om onbruikbaarmaking te voorkomen ('Paragraph 111m' en 'Paragraph 111n StPO'). Hier speelt het onderscheid eigen materiaal en materiaal van derden verkregen niet. Het gaat hier om de inbeslagneming van vermeende strafrechtelijk verboden gegevensdragers ter verbeurdverklaring of om onbruikbaarmaking te voorkomen. Bij de inbeslagneming van vermeende strafrechtelijk verboden gegevensdragers wordt rekening gehouden met het proportionaliteitsbeginsel. Dit beginsel is nader in de wet geconcretiseerd ('Paragraph $111 \mathrm{~m} \mathrm{StPO').}$ In principe dient volstaan te worden met de inbeslagneming van een bepaald deel of enkele exemplaren van een dagblad of ander drukwerk. Alleen wanneer het gaat om ernstige strafbare feiten zoals landverraad mag een hele oplage in beslag genomen worden. Daarbij wordt procedureel een onderscheid gemaakt tussen dagbladen/tijdschriften en andere gegevensdragers. Gaat het om vermeende staatsgeheimen in tijdschriften of dagbladen dan is alleen de rechter bevoegd, ook wanneer er 'Gefahr im Verzug' dreigt. De officier van Justitie is slechts dan bevoegd wanneer het gaat om andere zaken dan opiniebladen en er bovendien 'Gefahr im Verzug' dreigt. De wetgever heeft gekozen voor de rechter bij de inbeslagneming van dagbladen of tijdschriften omdat het hier gaat om nieuws dat vaak tijdsgevoelig is. Bovendien kan door de inbeslagneming de bestaanspositie van een krant of uitgever in gevaar worden gebracht. Bij de inbeslagneming van ander materiaal zoals boeken of films heeft de wetgever bij 'Gefahr im Verzug' niet gekozen voor de politie maar voor de officier van Justitie, omdat de officier van Justitie geacht wordt beter in staat te zijn de bescherming van de grondrechten af te wegen tegen het opsporings- en vervolgingsbelang zeker nu de terzake relevante strafbepalingen niet altijd even welomlijnd geformuleerd (kunnen) zijn. 


\section{De vrijheid van meningsuiting en drukpers en het straf- vorderlijke dwangmiddel inbeslagneming in Engeland}

\section{Inleiding}

In dit hoofdstuk zal ik de verhouding bespreken tussen de vrijheid van meningsuiting en drukpers en het strafvorderlijke dwangmiddel inbeslagneming in Engeland. Cen* traal staat de vraag in hoeverre de vrijheid van meningsuiting en drukpers een belemmering vormt voor de toepassing van het strafvorderlijke dwangmiddel inbeslagneming. De vrijheid van meningsuiting en drukpers is in Engeland niet vastgelegd in een geschreven Grondwet. Ook heeft men in Engeland geen geschreven declarations of freedom', en geen algemeen statuut dat de vrijheid van meningsuiting en drukpers vastlegt. Grondrechten vallen onder dezelfde 'statute law' en 'common law' als andere rechten en plichten. Vrijheid bestaat zolang deze niet verboden is bij de wet en de jurisprudentie. De rechter wordt gevraagd in een strafrechtelijk of civielrechtelijk geding de reikwijdte te bepalen van de betreffende vrijheid. In dit hoofdstuk zullen daarom de wetten en de jurisprudentie besproken worden die van belang zijn voor het bepalen van de reikwijdte van de vrijheid van meningsuiting en drukpers. Voor de inbeslagneming geldt hetzelfde als voor de vrijheid van meningsuiting en drukpers in die zin dat ook de inbeslagneming in de verschillende wetten en jurisprudentie aan de orde zal komen. ${ }^{2}$ Bezien wordt welke ruimte de 'Acts' en de jurisprudentie bieden aan de inbeslagneming en de vrijheid van meningsuiting en drukpers.

\section{Inleiding 'Acts"}

In de volgende paragrafen zal in het kort aan de hand van de "Contempt of Court Act', de 'Obscene Publications Act', de 'Official Secrets Act', de 'Race Relations Act', de 'Public Order Act', de 'Police and Criminal Evidence Act' en de jurispruden-

1 David Pollard and David Hughes, Constitutional and Administrative Law: Text and Materials, London 1990, p. 508; J.D. Duchacek, Freedom of Expression in: J.D. Duchacek, Rights and Liberties in the World Today, Constitutional Promise and Reality, Studies in Comparative Polities, Santa Barbara 1990, Chapter 5; Malcolm Hurwitt and Peter Thornton, Civil Liberty, London 1978, Introduction, p. 3.

2 P.G. Polyviou, Search and Seizure, Constitutional and Common Law, London 1982, p. 271. 
tie duidelijk worden gemaakt wat de ruimte is die aan de vrijhelid van meningsuiting en drukpers en de inbeslagneming van gegevensdragers wordt toegekend.

\subsection{De 'Contempt of Court Act'}

Bij de "contempt of court" wetgeving gaat het om het afwegen van belangen tussen een 'fair trial' en de vrijheid van meningsuiting en drukpers. De term 'a criminal contempt", want daar gaat het hier om, staat voor een grote groep van gedragingen die "obstnuct or tend to obstruct or interfere with the administration of justice. "Globaal is de strekking van de regel dat een leder zich moet onthouden van het publiekelijk geven van een oordeel over zaken die bij de rechter aanhangig zijn en waarover deze het laatste woord nog niet heeft gesproken. Daarbij moet men in de eerste plats denken an de schrijuende pers, de radio en de televisie. Schending is echter ook mogelijk in het kader van wetenschappelijke voordrachten, politieke redevoeringen oftewel, meer in zijn algemeenheid, alle meningsuitingen gedaan in het openbaar. $^{3}$

De belangrijkste worm van 'contempt of court' is die waarbij het gaat om inbreuk op de 'sub judice-regel'. Wie de 'sub judice-regel' overtreedt maakt zich schuldig aan het misdrijt van 'contempt of court', letterlijk 'minachting van het gerecht'. De regel dat de pers en anderen hebben te zwijgen over aanhangige procedures heeft te maken met het feit dat men heeft willen voorkomen dat jury"s van buitenaf worden beinnvloed. Evenwel geldt de 'sub judice-regel' in Engeland nu voor alle rechtsgedingen, ook al treedt er geen jury op. Verdiept men zich in het Engelse recht op het gebied van de "sub judice-regel", dan valt op dat als rechtsgrond niet langer in de eerste plaats wordt genoend de vrees voor beïnvloeding van juryleden en rechters. De regel wordt een rol toegedacht bij het garanderen van een 'fair trial' in het algemeen. Overeenkomstig de "fair trial" gedachte denkt men bij het gevaar van beïnvloeding niet alleen aan rechters en juryleden maar ook aan de invloed van publicaties op de onbevangenheid van getuigen, deskundigen en niet in de laatste plaats de procespartijen zelf:s Globaal gesproken betreft de 'sub judice-regel" inmenging in de vorm van commentaar en meer in het algemeen 'mee-procederen'. Wanneer dit

3 S.H. Bailley, D.J. Harris, B.L. Jones, Civil Liberties, Cases and Materials, London 1991, p. 265-311; C.J. Miller, Contempt of Court, Crim. LR 1982, p. 71-84; J. Bornkamm, Pressefreiheit und FairneB des Strafverfahrens, Rechtswergleichende. Untersuchungen, Baden-Baden 1980, p. 23-95.

4 Andere vormen van "contempt of court" zijn o.a. de poging tot omkoping van rechters, juryleden en getuigen, de bedreiging vat deze personen, en wangedrag ter zitting. Dit laatste noemt men "contempt in the face of the court". Robin Callender Smith, Press Law, Contempt and the Phillimore Committee, London 1978, p. $94-95$.

5. Murray Rosen, The Sunday Times Thalidomide Case: Contempt of Court and the Freedom of the Press, British Institute of Human Rights i.s.m. Writers Scholars Education Trust, London 1979, p. 16-26; N.J.P. Giltay Veth, De sub judice-regell, fatsoensregel of rechtsregel?, Enige verkenningen, inaugurele rede RUL, Leiden 1980 , p. 8. 
het geval is, is niet steeds in concreto voorspelbaar. De grens tussen toelaatbare mededelingen van feitelijke of juridische aard en ontoelaatbare inmenging in the administration of justice" is nu eenmaal onmogelijk scherp te trekken. Dit is een reden om het belang van een vrije pers, noodzakelijk voor het aan de kaak stellen van onrecht en ongerechtigheden, zwaar te laten wegen. Te allen tijde moet in het oog worden gehouden, dat de pers een belangrijke en positieve rol kan spelen ook nadat een procedure eenmaal is begonnen. De Watergate-affaire is pas in volle omvang tot ontwikkeling gekomen nadat over een onderdeel al werd geprocedeerd. ${ }^{6}$

De 'sub judice-regel' is al toepasselijk wanneer de zaak nog niet aanhangig is maar slechts 'imminent'. ' De vraag is wanneer een zaak 'imminent' is. Onzekerheid hierover geeft het gerecht een flexibel en 'open-ended' middel in handen om artikelen te censureren. De regel dat wetten helder en duidelijk behoren te zijn ("rule of law') staat met het bovenstaande op gespannen voet. Bovendien gaat dit ten koste van de vrijheid van meningsuiting en drukpers zeker nu de 'sub judice-regel' blijft gelden totdat de appè-termijn is verstreken' en bovengenoemde gedragingen bovendien bestraft kunnen worden met een gevangenisstraf van onbeperkte duur, een geldboete of met straffen die de gevolgen van het strafbaar feit beperken. Een van de straffen die de gevolgen van het strafbaar feit beperken is de inbeslagneming. Wanneer er sprake is van 'contempt of court' kan een gehele oplage in beslag worden genomen. Dit alles "by a summary process with a judge alone without the usual procedure, preparation and protection of trial by jury. ${ }^{\text {mo }}$

Al in de 19 e eeuw klonken er geluiden binnen de rechterlijke macht om de 'contempt of court' wetgeving te herzien. In deze periode waarin de informatiemaatschappij zich snel ontwikkelde vonden sommige rechters het belangrijk dat "the practically arbitrany and unlimited contempt jurisdiction, should be most jealously and carefully watched and exercised with the greatest reluctance and greatest anxiety. ${ }^{\mathrm{ml}} \mathrm{De}$ 'contempt of court' jurisprudentie was immers in strijd met twee kenmerken van het Engelse recht namelijk het beginsel van 'no prior restraint' en het beginsel "nullum crimen sine lege, nulla poena sine lege'. Het eerste beginsel houdt in dat er geen voorafgaande beperkingen mogen plaatsvinden ten aanzien van de openbaarmaking van

6 Murray Rosen, The Sunday Times Thalidomide Case: Contempt of Court and the Freedom of the Press, British Institute of Human Rights i.s.m. Writers Scholars Education Trust, London 1979, p. 28-31.

7 R. W. Savundranayagan and Walker (1968) 3 All ER 439.

8 Sunday Times, Publ. ECHR 26-4-1979, Series A, vol. 30, 49.

9 Tot 1960 was de definitie van het begrip 'contempt of court' niet statutair geregeld. Ook was er geen hoger beroep mogelijk. Het gerecht in cerste aanleg was de enige instantie dic beslissingsbevoegd was. Er was geen democratische controle door het parlement of door een jury. N J.P. Giltay Veth, De sub judice-regel, fatsoensregel of rechtsregel?, Enige verkenningen, inaugurele rede, RUL, Leiden 1980, p. 11.

10 Michael Supperstone, Press Law in the United Kingdom in: Phina Lahaw, Press Law in Modern Democracies, A Comparative Study, New York 1985, p. 24.

11 Costa Rica ws. Erlanger (1877) 46 L J 375, Ch. 
publicaties. Het tweecle beginsel "nullum crimen sine lege, nulla poena sine lege* betekent dat er geen straf is zonder voorafgaande wettelijke strafbepaling. Burgers moeten vam te voren weten waar ze aan toe zijn. Wet betekent hier een verzameling duidelike regels. ${ }^{12}$

In de 20 e euw lijkt het erop dat de pragmatische opvattingen de overhand krijgen. Alleen wanneer 'a fair hearing" echt in het gedrang komt mag het beginsel 'contempt of court" worden toegepast. Desalniettemin blift er in het individuele geval grote onzekerheid bestaan mede als gevolg van het gebruik van twee onduidelijke principes namelijk het 'pressure' en bet 'prejudgment" principe. Het "pressure" principe wordt ingevoerd door de House of Lords en heeft betrekking op "public criticism of litigants." Het 'prejudgement principle" betekent dat "a publication created a risk of prejudice to a particular case. "Volgens het Europese Hof in de Sunday Times zaak: "amounted the prejudgement test to an absolute prohibition irrespective of the risks of prejudice to an indidvidual case and as such was inconsistent with the European Court's decision." Volgens het Europese Hof is het noodzakelijk: "to weigh the balance in each case." In plaats van de "prejudgement" test is het beter te spreken, allus het Hof, over het criterium 'necessary' of 'pressing social need' (art. 10 lid 2 EVRM).

\subsubsection{Hervormingen}

Op 8 juni 1971 wordt er, na de uitspraak van het Europese Hof in de Sunday Times zaak $^{16}$, door de regering een Comité opgericht onder voorzitterschap van Lord Justice Phillimore om de "contempt of court' doctrine te herzien. "Tien jaar nadat het 'Phillimore Committee" werd benoemd treedt een nieuwe 'Contempt of Court Act 1981' in werking. Deze nieuwe 'Act" is in zekere zin een verbetering. Zo wordt bijvoorbeeld de omvang van de 'sub judice' periode beperkt. Is een zaak beslist en wordt die zaak aangebracht in appèl dan walt die tussenperiode niet onder de term "the proceeding is active. "In appèl geldt dan wel weer de "sub judice-regel'. Men was van mening dat ook 'the Court of Criminal Appeal' met zijn ervaren rechters beinvloed kan

Michael Supperstone, Press Law in the United Kingdon in: Phina Lahav, Press Law in Modern Democracies, A Comparative Study, New York 1985, p. 24.

13 Attorney-General vs. "Times Newspapers Ltd. (1973) 1 OB 710, 726, 727, (1972) 3 All ER 1136, 1146, C; P. J. Duffy, The Sunday Times Case: Freedom of Expression, Contempt of Court and the European Convention on Human Rights, The Human Rights Review 1979, p. 21.

14 Sunday Times, Publ. ECHR 26-5-1979, Series A, vol. 30, \$65. Zie ook hoofdstuk 1 , \$ 3.4.1.

15 Sunday Times, Publ. ECHR 26-4-1979, Series A, vol. 30, \$4; P.J. Duffy, The Suruday Times Case: Freedom of Expression, Contempt of Court and The European Convention on Human Rights, The Human Rights Review 1979, p. 34 .

16 Sunday Times, Publ ECHR 26-4-1979, Series A, vol. 30, \&49; P.J. Duffy, The Sunday Times Case: Freedom of Expression, Contempt of Court and The European Convention on Human Rights, The Human Rights Review 1979 , p. 34.

17 The 'Phillimore Report', Cmind. 5794, 1974. 
worden door 'press reports'. Of degene die iets publiceert in het openbaar de intentie had to interfere with the cousse of justice" doet er niet toe. Wel is het van belang om te weten of het een publicatie is die kan worden gezien als part of a discussion in good faith of public affairs or other matters of general public interest" ('section' 5). De "contempt of court" regelgeving is niet van toepassing in die gevallen waarin "the risk of impediment or prejudice to particular legal proceedings is merely incidental to the discussion. De huidige opvatting is dat rechters kritiek, ook al is deze misplaatst moeten tolereren. Alleen "serious allegations of corruption or other impropriety could possibly prompt a prosecution "Een verdere verbetering met de situatie voor 1981 is 'section' 10 van de 'Contempt of Court Act'. Daarin staat dat

"no court may require a person to disclose, nor is any person guilty of contempt of court for refusing to disclose, the source of information contained in a publication for which he is responsible, unless it be established to the satisfaction of the court that disclosure is necessary in the interests of justice or national security or for the prevention of disorder or crime.

Het gaat in deze bepaling om de bescherming van degenen die vertrouwelijke informatie hebben verstrekt oftewel om het recht op anonimiteit. ${ }^{22}$ Dit recht hangt nauw samen met de inbeslagneming van gegevensdragers. Op grond van de "Police and Criminal Evidence Act 1984' wordt de inbeslagneming wan 'confidential material' bij een 'search' met extra waarborgen omkleed. Zoals we zullen zilen in paragraaf 2.5.2.2 van dit hoofdstuk is 'confidential journalistic material' materiaal dat bestaat uit documenten etcetera "which held in confidence." Dit materiaal mag door de politie alleen onder bepaalde voorwaarden in beslag worden genomen. Zo vraagt de politie Democracies, A Comparative Study, New York 1985, p. 27-28.

19 Attorney-General vs. Times Niewspapers Lid. (1973) 1 QB 710, 726, 727, (1972) 3 All EiR 1136, 1146, C; Michael Supperstone, Press Law in the United Kingdom in: Phina Lahav, Press Law in Modern Democracies, A Comparative Study, New York 1985, p. 29; C. Miller, Contempt of Court:

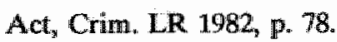

20 Malcolm Hurwitt and Peter Thornton, Civill Liberty London 1978, p. 43.

21 De vraag is of deze bepaling praktisch van betekenis is zeker nu de bepalingen over "nationall security", "disorder and crime' en de 'interests of justice" 'vaag zijn gedelinicerd. $X$ Ltd, and another vs. Morgan-Grampian (Publishers) Lid. and another (1990) 2 WLR 421, 1 All ER 616, CA, 2 WLR 1000, 2 All ER 1, HL (E). British Steel Corporation vs. Granada Television Ltd. (1981) 1. All ER 417, CJ. Miller, Contempt of Court Act, Crim. LR 1982, p. 82.

22 Attorney-General us. Mulholland and vs. Foster (1963) 1 All ER 767; Attorney-General ws. Clough (1963) 1 OB 773; British Steel Corporation ws. Granada Television LId. (1981) 1 All ER 417; G. Anastassopoulos, Professional Secrecy, IFI Information wol. XXX1 (1982), p. 10; Attorney-General vs. Lundin (1982) 75 Cr. App. R. 90; The Times, 16-12-1983 en 17-12-1983; Geoffrey Robertson and Andrew G.L. Nicol, Media Law, The Rights of Journalists and Broadleasters, London 1990, p. 200-230; Patricia Wilhelm, Protection of Sources, An International Review of Journalistic and Legal Practice, The Norwegian Institute of Journalism, Norway 1988, p. 40. 
een 'production order' bij. de 'cilrcuil judge'. Het gevolg van een 'production order' is dat een huiszoeking kan worden voorkomen. Een journalist heeft bovendien he: recht om tegen een inbeslagneming te klagen bij de rechter. Wanneer echter de rechter van mening is dat het bevel to inbeslagneming terecht is gegeven omdat er sprake is van 'contempt of court' kan de gehele oplage in beslag worden genomen daarbij rekening houdend met het proportionaliteitsbeginsel. ${ }^{23}$

\subsection{De 'Obscene Publications Act'}

\subsubsection{Materiële problemen}

Obscene publicaties worden geregeld in de "Obscene Publications Acts" van 1959 en 1964." De bedoeling van deze Acts was "to provide greater safeguards for those who create or deal in works of at or literature" en tegelijkertijd "making better provision for the prosecution of those who create or deal in pornography and for the seizure and forfeiture of such material. "In 'section" 2 (1) van de "Act" uit 1959 staat dat "a person who publishes, whether for gain or not, an obscene article is, subject to the defences for excusable ignorance and public good, guilty of an offence (..). "Een 'article' betekent "matter to be read or looked at or both, any sound record, and any film or other record of a picture or pictures (such as a video-cassette). ${ }^{\text {net }}$ Met 'obscene" ${ }^{37}$ wordt hier bedoeld "if its effect, or the effect of any one of its items, is, taken as a whole" such

23 Reynolds vs. Commissioner of Police of the Metropolis (1984) 3 All ER 649, CA.

24 S.H. Bailey, D.J. Harris, B.L. Jones, Civil Liberties, Cases and Materials, London 1991, p. 230-263; R. Cross, P.A. Jones and R. Card, Introduction to Criminal Law, London 1988, p.487-491; Patricia Hewitt, The Abuse of Power, Civil Liberties in the UK, London 1982, p. 81-106; G. Robertson, Freedom, The Individual and the Law, Harmondsworth 1989, 6th. edn., p. 177-228; D.N. MacCormick, Privacy and Obscenity in: R. Dhavan and C. Davis (ed.), Censorship and Obscenity, London $1978, \mathrm{p} .76-97$.

25 S.H. Bailley, D.J. Harris, B.L. Jones, Ciwil Liberties, Cases and Materials, London 1991, p. 243.

26 Attorney-General's Reference (nr, 5) (1980) 3 All ER 816, CA (CD), (1981) 1 WLR 88, CA (CD). Obscene toneelstukken en uitzendingen vallen niet onder deze 'Acts' maar onder speciale statuiten zoals de 'Theatres Act 1968' en de 'Independent Broadcasting Authority Acts 1973 and 1974'. Onder uitzendingen worden zowel radio- als televisie-uitzendingen en kabelprogramma"s verstaan. Obscene Publications Act 1959 1 (3); S.H. Bailey, D.J. Harris, B.L. Jones, Civil Liberties, London 1991, p. 244; R. Cross, P.A. Jones and R. Card, Introduction to Criminal Law, London 1988, p. 487.

27 DPP vs. Whyte (1972) AC 849, 860, HL. Lord Wilberforce: "(..) the Act has adopted a relative conception of obscenity. An article cannot be considered obscene in itself, it can only be so in relation to its likely readers."

28 Een novelle moet in haar geheel worden beoordeeld op vermeende obsceniteiten ondat je door een bepalde passage eruit te lichten het thenta kunt aantasten. Een tijdschrift daarentegen moet artikel woor artikel bekeken worden. R. vs. Anderson and others (1972) 1 QB 304, 313, (1971) 3 All ER 1152, 1158; S.H. Bailley, D.J. Harris, B.L. Jones, Civil Liberties, London 1991, p. 245-250; R. Cross, P.A. Jones and R. Card, Introduction to Criminal Law, London 1988, p. 487-488. 
as to tend to deprave and compt $t^{x /}$ persons who are likeb, having regard to all the circumstances, to read, see or hear the matter contained in it." In "section" 2(5) staat dat de beschuldigde zich kan verweren door aan te tonen dat "he had not examined the article in question, and had no reasonable cause to suspect that it was obscene." Of zoals in section 4 (1) "to show that the publication was for the public good", on the ground that it was in the interests of science, literature, or other objects of general concern $^{\text {s1 }}$ zoals "matters involwing intellectual or aesthetic values.

29 "Obscene" heeft hier niet alleen betrekking op "a tendency to corrupt sexual morals." De 'Act" heeft ook betrekking op "a book depicting the career of a drug addict." Maar wat betekent "deprave and corrupt" dan nog wanneer deze termen ook betrekking hebben op handelingen "outside the sexual context." John Calder (Publications) Ltd. ws. Powell (1965) 1 OB 509, 1 All ER 159; DC; DPP vs. A and BC Chewing Gum Ltd. (1968) 1 QB 159, (1967) 2 All ER 504, DC. Met "deprave and corrupt" wordt bedoeld "the effect of the article on the mind, including the emotions." De "deprave and corrupt test" geeft de jury de gelegenheid "to apply the standards of the community in deciding whether an article is obscene." Zie de zaak R. vs. Calder and Boyars Lid. (1968) 3 All ER 644 waarin de "Court of Appeal' sugereerde dat "it was in balancing the strength of the public good against the strength of the obscenity that the jury must set the standards of what is acceptable, of what is for the public good in the age in which we live. What is a significant proportion of persons to deprave and corrupt is a matter entirely for the jury to decide" aldus Lord Salmon in de zaak R. ws. Calder and Bioyars Ltd. (1969) 1 QB 151; Knuller ws. DPP (1973) AC 435, 456, HL; DPP vs. Whyte (1972) AC 849; R. vs. Stamford, All ER 1972; C.H. Rolph (ed.), The Trial of Lady Chatterley, London 1961; T. Palmer, The Trials of Oz, London 1971 (Alleen bij erg jonge kinderen is deskundigenbewijs toegestaan; $R$. vs. Anderson (1972) 1 QB 304, 313, CA; $R$. ws. Calder and Boyars (1969) 1 OB 151; DPP vs. A and BC Chewing Gum Lid. (1968) 1 OB 159, (1967) 2 All ER 504). Uit al deze uitspraken blijkt dat de jury liberaler beslist in zaken die betrekking hebben op "obscene publications" dan de rechters. Het doel van de "Acts", de bescherming van kunst en literatuur, is wooral afhankelijk van de tolerantiegraad van jury's en rechters en niet zozeer van de wet. Zie ook de opvattingen van S.H. Bailey, D.J. Harris and B.L. Jones, Civil Liberties, London 1991, Chapter 5 Freedom of expression.

30. Het 'public good' verweer voor 'picture film or soundtrack' valt hier buiten on is in $54(1 \mathrm{~A})$ als volgt geformuleerd; "the accused has a defence if he can show that publication of the film or soundtrack was for the public good on the ground that it is in the interests of drama, opera, ballet or any other art, or of literature or learning." Verder kan bij films "a prosecntion for publishing il or having it for publication for gain" alleen ingesteld worden mat toestemming van de "Director of Public Prosecutions.'. Obscene Publications Act 1959, 'section' 2 (3A); R. Cross, P.A. Jones, and R. Card, Introduction to Criminal Law, London 1988, p. 488-489.

31 Literaire of artistieke werken kunnen obsceen zjp ("deprawing or corrupting") maar "their great significance might outweigh the harm they could do, and take them out of the prima facie criminal category established by section 1 of the Act." Wat de criteria zijn woor het onderscheid tussen literatuur en pornografie is niet duidelijk. Zie de "Obscene Publications Act 1959", "section" 1 (2); G. Robertson, Freedom, The Individual and the Law, Harmondsworth 1989, 6th, edn., p. 182 c. $\%$. Attorney-General's Reference (nr. 3) (1978) 3 All ER 1166, 1 WLR. 1123, CA; R. ws. Calder and Boyars Ltd. (1969) 1 OB 151; R. vs. Staniforth (1976) 2 WLR 849; R. vs. Anderson (1972) 1 QB 304, 312, 36 JCL 158; R. ws. Metropolitan Police Commissioner ex p Blackburn (nr. 3) (1973) QB 241, 37 JCL 268; DPP vs. Jordan (1976) 3 All ER 775, (1977) AC 699. 


\subsubsection{Procedurele problemen}

"Obscene articles for publication for gain" kunnen in beslag worden genomen door middel van een 'search warrant, ${ }^{\text {s33 }}$ afgegeven door een 'magistrate'. Een 'warrant' mag alleen gegeven worden "on an information laid by or on behalf of the Director of Public prosecutions or a constable. "Geeft een wan beiden toestemming tot een "warrant" dan kunnen grote hoeveelheden materiaal in beslag genomen worden door de polities (section 3 of the $1959 \mathrm{Act}^{36}$ ). De politie beoordeelt in welke categorie een artikel valt, dus of er sprake is van een artikel dat 'least obscene' of "most obscene' is. In de zaak R. vs. Croydon magistrates ex p Rickman" ${ }^{37}$, besliste de rechter dat "he would reach a decision on the basis of the evidence of a police officer consisting of descriptons of the nature of the material. Dit is vreemd. Immers het is toch uiteindelijk een onafhankelijke rechter die hierover een onafhankelijk oordeel dient te vellen. Zeker nu de vraag wat onder het begrip 'obscene' valt onduidelijk is en voor meerderlei uitleg vatbaar.

Behalve dat grote hoeveelheden 'articles' in beslag genomen kunnen worden op grond van een 'search warrant", zonder dat de rechter "would reach an own decision on the basis of the evidence," is het daarnaast ook nog mogelijk om een "jury trial' volledig te omzeilen. De politie kan boeken in beslag nemen bij lokale boekhandels en vragen om een 'forfeiture order' aan een 'magistrates court'. Onder andere in situaties waarin een eigenaar van een boekenwinkel slechts enkele obscene boeken in zijn bezit heeft en "does not deserve to be convicted of a criminal offence" zal het hierbij blijven. "The forfeiture power' wordt dan gebruikt om uitgevers en auteurs van hun recht op een 'trial by jury' te beroven. ${ }^{39}$ In theorie zou het zo moeten zijn

33 Adams (1980) QB 575, 1 All ER 473, CA.

34 'Obscene Publications. Act 1959 section 3' en de 'Criminal Justice Act 1967 section 25'.

35 In 1969 werden er slechts 31 'forfeiture orders' gegeven in Engeland en Wales, in 1978 waren er dat al 550. Het aantal voorwerpen dat in beslag werd genomen door de "Metropolitan Police" name toe valu 35,390 in 1969 tot 1,229,111 in 1978 en 2,071,190 in 1983 (Williams Report, Appendix 7 ).

36 R. ws. Snaresbrook Crown Court exp Commissioner of Police for the Metropolis (1984) $79 \mathrm{Cr}_{\text {n }}$ App. R. 184, 190; Roandale vs. Metropolitan Police Commissioner (1979) Crim. LR 255.

37 The Times 8-4-1985.

38 Voor wat betreft de omvang van het material dat in beslag is genomen gelde volgens de 'Divisional Court' de regel dat 'inàgistrates' en 'judges' niet elke woorwerp onderzoeken maar "reaching decisions having examined representative samples selected by the police and the defendant." R. vs. Snaresbrook Crown Court ex p Commissioner of Police of the Metropolis (1984), 79 Cr. App. R. 184, 189; Roandale Litd. vs. Matropolitan Police Commissioner (1979) Crim. LR 255.

39 Het is uitermate belangrijk dat er een "trial by jury" plaatsvindt. Zij beslissen immers wat "public morals" inhouden en wanneer mensen "depraved and corrupted" kunnen zijn als gevolg van een bepaatde publicatie. Bovendien blijkt uit de praktijk dat jury's liberaler beslissen dan rechters. Zie de zaken 'Nasty Tales' (1973) 137 IPN 82; "Inside Linda Lovelace" (1976) 126 NLJ 126; G. Robertson, Freedom, The Individual and the Law, Harmondsworth 1989, 6th. edn., Chapter 5 , p. $177.214_{\text {; }}$ Fome Office, Report of the Committee on Obscenity and film censorship, London 
dat zowel de auteur als de uitgever in de gelegenheid worden gesteld om te worden gehoord. ${ }^{40}$ Echter omdat $z$ ij in de praktijk veelal niet op de hoogte gesteld worden van lopende zaken, is het niet ongewoon dat materiaal wordt vernietigd zonder dat de auteur of de uitgever de mogelijkheid heeft gehad "to oppose the case. "In feite stelt de 'forfeiture order procedure ${ }^{s, 2}$, die kan worden afgehandeld bij een 'magistrates court', de 'prosecutor' in staat "to avoud completely the need for jury trial.

\subsubsection{Hervormingen}

In 1977 noemt het 'Williams Committee on Obscenity and film censorship' de huidige wet een 'mess' en beveelt aan "the scrapping of all restriction on the written word, with a new system for control of the public display of pictorial material. "Het enige materiaal dat volledig verboden mag worden zijn "images whose production involved the infliction of actual physical harm", or the involvement of someone aged under 16", for purposes

$1979, \$ 2.21$; R. vs. Calder and Boyars Lud. (1968) 3 All ER 11.52.

40 Dit zou ook meer in overeenstemming zijn met het "fair trial" beginsel dat een vast onderdeel wormt van het 'common-law' systeem in Engeland. De bedoeling van de 'Obscene Publications Act' uit 1964 was de 'Act' uit 1959 op dit punt te veranderen. In 'section' 3(4) van de 'Act' uit 1964 wordt het recht gegarandeerd voor "interested parties other than the occupier to appear to a forfeiture proceeding." Echter, en dat is een tekortkoming er bestaat geen procedure om mensen die geinteresseerd zijn in zo'n 'forfeiture proceeding' hiervan op de hoogte te stellen. Veel is afhankelijk van publiciteit in de media of van acties ondernomen door die personen wan wie de 'articles' in beslag zijn genomen. Noch de verspreider noch de uitgever en auteur heeft het recht "to insist on being charged with a criminal offence under the Act of 1964." Het voorstel om de uitgever cq. auteur 'an option' te geven of "jury trial" wanneer hun boeken het gevaar lopen te worden vernietigd is niet gerealiseerd. Zolang er dus geen "arrangements of informing publishers that their publications have been seized from retailers" zijn zullen zij valk niet weten dat er sprake is van een proces. S.H. Bailey, D. J Harris, B.L. Jones, Civil Liberties, London 1991, p. 251-253; G. Robertson, Free-

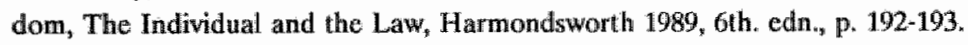

41. De verspreider heeft vaak geen behoefte om de zaak te betwisten en alls hij/zij een zaak al will betwisten zal dit veelal betekenen dat er een beroep wordt gedaan op a special defence" ( hij/zij heef het artikel miet onderzocht en had geen reden om te geloven dat het artikel 'obscene" was). Graham Zellick, Two Comments on Search and Seizure under the Obscene Publications Adt, Crim. LR 1971 , p. 126.

42 'Forfeiture orders' zijn verder arbitrair. Immers zij zijn afhankelijk van de wraag of de politie het initiatief hiertoe neemt. Er bestaan discrepanties in beleid tussen de verschillende delen van het land. Om te voorkomen dat er teveel rechtsongelijkheid ontstaat dient er een mationaal beleid te worden gevoerd door de politie (bijwoorbeeld door midddel wan 'test-case prosecutions of publishers'). G. Robertson, Freedom, The Individual and the Law, Harmondsworth 1989, 6th. edn., p. $192-193$.

43 Zie 'section' 2 van de 'Obscene Publications Act 1959 (...) jury at the Crown Court'. G. Robertson, Freedom, The Individual and the Law, Harmondsworth 1989, 6th. edn., p. 192-193.

J. Zellick, Violence as Pornography, Crim. LR 1970, p. 189-200. 
of sexuat exploultation " Onder 'images' zijn films begrepen. Films zijn onderworpen aan een "fourfold censorship" systeem. De "British Board of film Censors certifies films for public showing. ${ }^{\text {"ht }}$ Verder zijn films onderworpen aan "licensing by local councils ${ }^{\text {nd }}$ en, wanneer ze geïmporteerd" worden, ook nog eens aan de "Customs and Excise" wetgeving. . Ook kunnen films sinds 1977 getoetst worden aan de 'Obscene Publications Act'. ${ }^{\text {si }}$ Op 3 februari 1970 werd de film 'Flesh' van Andy Warhol in beslag geno-

45 'Protection of Children Act 1978'; I ohn Graham-Kerr (1989) 88 Cr. App. R. 302; R. ws. Owen (1988) 86 Cr. App. R. 291.

46 Het 'Committee' stelt woor de termen 'obscene", "indecent' en 'deprave and corrupt" te schrappen. Cmond $7772 \$ 13.4 .1,1979$. Verder onderzocht het "Committee" de relatie tussen pornografie en misdaad en kwam tot de conclusie dat er geen bewijsrechtelijk verband bestaat tussen beide. Home Office Report of the Committee on Obscenity and Film Censorship 1979, p. 12 e.v.

47 De 'British Board of Film Censors' is niet officied, on heeft geen statutaire verplichtingen. Zij geniet het vertrouwen van filmproducenten en werkt samen met lokale "licensing authorities". Het bestaan wan filmcensuur biedt slechts 'de facto' en niet 'de jure' bescherming tegen vervolging. Graham Zellick, Films and the Law of Obscenity, The 'Flesh' Case, Crim. LR 1971, p. 135 e.v.

48 Het 'Williams Comnittee' stelt voor een einde te maken aan thet systeem van 'local council licensing. Het 'Committee' wenst de 'Board of Film Censors' te verwangen door een 'Statutory Film Examining Board'. Deze zou moeten bekijken of beperkingen dienen te worden opgelegd wanneer het gaat om jeugdige personen. Verder zouden bijzonder beledigende films alleen vertoond mogen worden in "licensed cimemas. Onder bijzonder beledigende films vallen films die materiaal bevatten dat werboden is bij de wet of materiaal dat is "unacceptable because it depicts violence or sexual activity or crime." De taak van de lokale autoriteiten is dan "to grant or withhold a licence to a cinema to show restricted films." Home Office Report of the Committee on Obscenity and Film Censorship 1979 , p. 12 e.v.

49 'Customs officers' hebben de bevoegdheid huiszoeking te verrichten en kunnen in beslag nemen "any indecent articles imported into England." De "indecent" test is zwakker en niet onderworpen aan de interpretatic van een jury. Ook de 'public good defence' is niet van toepassing in 'Customs legislation'. De importeur moet bewijzen voor een 'magistrates court' dat het materital niet "indecent" was. Zie in dit verband ook de 'Indecent Displays Act 1981' en de 'Post Office Act 1953". Ook hier is het een 'offence" wanneer door muddel van de post materiaal wordt verzonden dat "indlecent or obscene print, painting, photograph, lithograph, engraving cinemalographic film, book and written communication, articte" betreft zelfs wanneer dit "has been ordered and paid for by the recipient." Bovendien is het mogelijk dat gepost materiaal "indecent' wordt bevonden door de rechter terwigl datzelfde materiaal wel mag worden verkocht. Patricia Hewitt, The Abuse of Power ${ }_{*}$ Civil Libertics in the UK, London 1982 , p. 81 .

$50{ }^{\circ}$ 'Customs Consolidation Aet 1876; Derrick vs. Customs and Excise Commissioners (1972) 2 QB 28; R. ws. Bow St Magistrates ex pocyp Ltd (1988) 3 WLR 827; In de Gold Star Publications Ltd. vs. DPP (1981) 2 All ER 257, 1 WLR 732, HL besliste het 'House of Lords' dat "the provisions relating to forleiture of obscene articles kept for publication for gain apply even where the intended publications was to occur outside the jurisdiction of the English courts." Het probleein hiervan is echter dat het bij artikelen die bedoeld zijn voor de export naar cen ander land moeilijk is uit te maken of er sprake is van "obscene" inmers de betekenis van "to deprave and corrupt" varieert wan land tot land.

51 Voor 1977 was dat niet het geval. Toen konden films niet rechtmatig in beslag worden genomen op grond van de 'Obscene Publications Acts' (zie section 1(3)(b)). 
men. ${ }^{\text {sa }}$ De zaak verliep als volgt. Er werd een klacht ingediend bij de politie. De politie vroeg een 'search warrant' bij een 'magistrate' op grond van 'section 3'. De "warrant" werd toegestaan en uitgevoerd. De film werd in beslag genomen. De 'Commissioner of Police' won advies in bij de 'Director of Public Prosecutions', ${ }^{\text {, }}$ Vijf weken later zei de 'Attorney-General' in de 'House of Commons' dat de 'Director of Public Prosecutions" bevolen had dat "no action for obscenity should be taken. De film werd teruggegeven zonder dat de zaak voor de rechter was geweest. In de zaak "Thomson vs. Chain Libraries Ltd.'ss besliste de rechter dat "it is for the justices to look at the publications themselves. "Immers het is onjuist dat de politie in eerste instantie beslist of het in beslag genomen materiaal aan de eigenaar moet worden teruggegeven of dat het moet worden onderworpen aan een oordeel door de rechter. Het is aan de rechter om te bepalen of materiaal obsceen is of niet.

De vraag is of het niet beter zou zijn geweest wanneer het advies van de 'Director of Public Prosecutions' plaats vindt voordat er in beslag wordt genomen, zeker nu de term obsceen moeilijk te definiëren valt. ${ }^{56}$ Dit zou ook meer in overeenstemming zijn met de vrijheid van meningsuiting en drukpers. De taak van de 'Director of Public Prosecutions' is dan "to supervise the strict application of the law before the damage is done and to ensure some degree of uniformity throughout the country. ${ }^{157}$

\subsection{De 'Official Secrets Act'}

\subsubsection{Inleiding}

De regering Thatcher ondersteunde niet alleen een vrije markteconomie maar ook een sterke staat. Hierin ligt een verklaring voor het grote aantal restricties in de 'Official Secrets Act' ten aanzien van de vrijheid van meningsuiting en drukpers. Wanneer mogelijkerwijs het gevaar aanwezig was dat de autoriteit van de regering

52 Grallam Zellick, Films and the Law of Obscenity, The 'Flesh' Case, Crim. LR 1971, p. 126 e.w.

53 De 'Obscenity Act' vereist dat elke 'offence of obscenity' wordt gemeld aan de 'Director or Public Prosecutions'. Zijn fiat is echter niet vereist voor het beginnen van cem procedure. Graham Zellick, Two Comments on Search and Seizure under the Obscene Publications Act, Crim. LR 1971, p. 126 e. $\mathrm{v}$.

54 H.C. Deb., Voll, 7a97, W.A., col, 1371 (12-3-1970).

55 (1954) 2 All ER 616.

56 De 'Little Red Schoolbook' zaak "Publ. ECHR 7-12-1976, Series A, vol. 24, maakte de beperkingen zichtbaar van de 'Obscenity Act'. Zo werden door de politie niet alleen artikelen in beslaggenomen waarvan men dacht dat deze obsceen zouden kunnen zijn maar ook veel ander materiaal dat in rellatie stond tot dexe artikelen werd in beslag genomen. Verder bestonden er grote discrepanties tussen het ene gedeelte wan bet land en een ander gedeclte van het land met betrekking tot de toellaatbaarheid van deze artikelcn.

57 Graham Zellick, Two Comments on Search and Seizure, Crim. LR 1971, p. 126; R.I. Walker and Walker, The English Legal System, London 1990, Bül. p. 230 e.w. 
werd ondermulind kon de vrijheid van meningsuiting en drukpers worden beperkt: De "Thatcher Gowernment", gebaseerd op een sterke centralistische staat, had een intolerante, autoritaire houding ten opzichte van mediamedewerkers. Er was, in de loop van haar regeringsperiode, sprake van een reeks van confrontaties tussen de regering en de pers zoals in de Zircon' affaire", Spycatcher", "My Country Right or Wrong" ${ }^{\text {"6in }}$, de "Gibraltar shooting" "the banning of interviews with IRA sympathisers", "the Sarah Tisdall case" ${ }^{36}$, de 'Harrods takeover affair', "the Ponting trial", "the $\mathrm{ABC}$ trial' etcetera. ${ }^{65}$ In al deze zaken ging het om vermeende staatsgeheimen. Soms werden, zoals in de zaak Zircon, grote hoeveelheden filmmateriaal bij de media in beslag genomen. In deze paragraaf zal vooral de Spycatcher-affaire aan de orde komen. Deze zaak is het meest interessant omdat hier een aantal problemen wordt besproken zoals de relatie tussen de 'Official Secrets Act', het 'D-notice' systeem, de civiele procedure en de vrijheid van meningsuiting en drukpers. Bovendien heeft ook het Europees Hof woor de Rechten van de Mens een uitspraak gedaan in deze zakk. Daaruit blijkt in hoeverre de uitspraak van het 'House of Lords' afwijkt van de opvattingen van het Europese Hof. In de volgende paragraaf komt eerst de 'Official Secrets Act' aan de orde. Gekeken wordt hoe zich deze 'Act' verhoudt tot de vrijheid van meningsuiting en drukpers. Daarna wordt de zaak Spycatcher besproken. De paragraaf zal worden afgesloten met een conclusie.

\subsection{2 'Official Secrets Act"}

Naar aanleiding van de uitspraken door de 'House of Lords' in de zaken Ponting ${ }^{67}$ en Spycatcher alsook als gevolg van de uitspraken van de Europese Commissie en het Europese Hof in de zaak Spycatcher" werd besloten de 'Official Secrets

58 K.D. Ewing and C.A. Goarty, Freedom under Thatcher, Oxford 1990, p. 129-208.

59 D. Campbell, Paradoxes of Sectecy, Index on Censorghip 8-1988, p. 17.

60 J. Scot, Government, Press and the Public Interest, Index on Censorsthip 2-1988, p. 2.

61 B. Wenham, Whose Standards?; Index on Censorship 8-1988, p. 33,

62 J. Mortimer, So where do we go for Fredom?, Index on Censorship 8-1985, p. 35.

63 B. Wenham, Whose Standards?, Index on Censorship $8-1988$; p. 32.

64 D. Campbell, Paradoxes of Secrecy, Index on Censorship 8-1988, p. 19.

65 Clive Ponting, The Right to Know, Index on Censorship 8-1988, p. 18.

66 John Lloyd, The Culture of Press Freedom, Index on Censorship 8-1989, p. 20.

67 R. vs. Fonting (1985) Crim. LR 318; P. Birkinshaw, Reforming the Secret State, Open Uniwersity Press 1991, p. 5; Clive Ponting. The Right to Know, Index on Censorship 8-1988, p. 16-19.

68 AttorneywCeneral vs. Guardian Newspapers Ltd. (1987) 3 All ER 316, (nr. 2) (1988) 3 All ER 545; P. Hennessy, British secrecy and the proposed reform of the Official Secrets Act, Index on Censorship 8-1988, p. 11; P. Birkinshaw, Reforming the Secret State, Open University Press 1991, p. $5-7$.

69 The Independent 24-4-1990; Sunday Times (nr. 2), Observer and Guardian, ECHR 26-11-1991, Council of Europe nr. $50 / 1990 / 242 / 312$ en $51 / 1990 / 242 / 313$. 
Acts' uit 1911 en 1939 te herzien. ${ }^{70}$ De nieuwe 'Official Secrets Act' trad op 1 Maart 1990 in werking en is van toepassing op strafbare feiten die begaan zijn in GrootBritannië, Noord-Ierland en op strafbare feiten die begaan zijn door Britse onderdanen en "Crown servants" in het buitenland ('section" 15). Conform dit artikel zouden zowel Ponting $g^{n}$ als Peter Wright (auteur van het boek Spycatcher ${ }^{72}$ ) strafbaar zijn geweest. ${ }^{\text {s3 }}$ Beide hadden hun daden begaan in het buitenland.

Dat nu ook strafbare feiten die in het buitenland zijn begaan onder de nieuwe 'Official Secrets Act' vallen is in overeenstemming met het doel van de 'Act' namelijk

"to deter all leakage of information about security and intelligence matters by making disclosure and publication of sinister information an absolute criminal offence, without any scope for acquittal on grounds of public interest ${ }^{74}$ or even on the common-sense basis that the information had already been published, in Britain or abroad."175

Het aantal strafbare feiten wordt uitgebreid met "the disclosure or publication of information about defence, foreign policy, police operations and relations with other countries and international organisations. ${ }^{\text {"76 }}$ Niet alleen 'civil servants' zijn strafbaar who make such disclosures" maar ook journalisten en uitgevers "who encourage them or publish their information with reason to believe that it has been divulged without

70 Reform of Section 2 of the Secrets Act 1911, Home Office 1978; Report of the Departmental Committee on Section 2 of the Official Secrets Act 1911 (1972) Cmnd. 5104, $\$ 88$; Jonathan Caplan, The Criminal Liability of the Media under section 2 of the Official Secrets Act, Journal of Criminal Law 1987, p. 67 e.v; Peter Hennessy, British Secrecy and Proposed Reform of the Official Secrets Act, Index on Censorship 8-1988, p. 9-10; Michael Supperstone, Press Law in the United Kingdom in: Phina Lahav, Press Law in Modern Democracies, New York 1985, p. 13-16; Naast de "Official Secrets Acts' zijn er nog een aantal specifieke 'statutory offences'. Malcolm Hurwitt and Peter Thornton, Civil Liberty, London 1978, p. 47-49; R. Cross, P.A. Jones, R. Card, Introduction to Criminal Law, London 1988, p. 437-439; M. Supperstone, Brownlie"s Law of Public Order and National Security, London 1981, p. 247-258.

71 R. vs. Ponting (1985) Crim. LR 318.

72 Attorney-General vs, Newspaper Publishing Ldd. (1987) 3 All ER 276; Attorney-Generall vs. Guardian Newspapers Ltd. (1987) 3 All ER 316, (nr. 2) (1988) 3 All ER 545.

73 R. vs. Secretary of State for the Home Department ex p Ruddock (1987) 2 All ER 518.

74 Er bestaat geen "public interest defence" voor de media. J. Caplan, The Criminal Liability of the media under section 2 of the Official Secrets Act, Journal of Criminal llaw 1987, p. 67-74; M. Supperstone, Brownlie"s Law of Public Order and National Security, 1981, p. 267; Sunday Times (nn. 2), The Observer and Guardian, ECHR 26-11-1991, Council of Europe nt. 50/1990/241/312, p. 28 en $51 / 1990 / 242 / 313$, p. 31 .

75 Attorney-General ws. Guardian Newspapers Ltd. (1987) 3 All ER 316, (nr. 2) (1988) 3 All ER 545; R. vis. Galvin (1987) 3 WLR 93.

76. Deze nieuw strafbare feiten beperken de media in haar berichtgeving over de buitenlandse politick en diplomatie. P. Birkinshaw, Reforming the Secret State, Open University Press 1991, p. 1. 
lawful authority." Voldoende is dat er sprake is van "damage" die "endangers the interests of the United Kingdom abroad" of "damages the capability of any part of the armed forces" of "impedes the prevention or detection of offences. "Als gevolg van deze bepalingen is het dus bijna onmogelijk om iets te weten te komen van "security and intelligence operations other than what the government chooses to make public. ${ }^{m s} \mathrm{De}$ 'Act' verbiedt "the process of gathering or communicating official information."

Tot op de dag van vandaag bestaat er in Engeland geen wetgeving die burgers het recht geeft op toegang tot informatie die in het bezit is van de regering. De openbaarmaking van een 'public scandal' is een strafbaar feit wanneer 'it is damaging'. Laatstgenoemde term kan zeer ruim worden geïnterpreteerd. Burgers kunnen geen beroep doen op openbaarmaking van een bepaald overheidsdocument. In Engeland bestaat geen 'Freedom of Information Act'. De regering kan na dertig jaar gegevens van de 'civil-service' onder brengen bij de 'Public Record Office' in Kew. Deze gegevens zijn dan toegankelijk voor historici en journalisten. De regering heeft echter ook de mogelijkheid om gegevens achter te houden voor een periode van vijftig tot honderd jaar, ja zelfs voor altijd, wanneer zij dat noodzakelijk acht." ${ }^{\text {}}$ Het is immers aan de regering te bepalen wanneer en in welke omvang zulke informatie geopenbaard mag worden aan het publiek. Zelfs na een aanbeveling over de toegang tot informatie van openbare instellingen van het 'Committee of Ministers of the Council of Europe', welke in november 1981 werd aangenomen, besliste Thatcher dat "the United Kingdom Government had no intention of introducing legislation on freedom of information in the United Kingdom. "In Engeland wordt door de rechters soms wel gerefereerd naar "the public interest in receiving information" en soms zelfs naar "the value of investigative joumalism" als een facet van de vrijheid van meningsuiting. ${ }^{20}$ Zo werd in de zaak 'Crossman Diaries' een beroep op "the public interest in receiving information" gehonoreerd. ${ }^{81}$ Echter een positief "claim-right to know"

77 Een 'serious injury' is niet vereist. De bewijslast rust op de verdedigende partij. Deze dient te bewijzen dat hij of zij "had no reasonable cause to believe that the disclosure would have any such consequences." P. Birkinsluaw, Reforming the Secret State, Open University Press 1991, p. 22.

78. Centraal in de 'Act' uit 1989 staat het onderscheid tussen 'authorised' en 'unauthorised disclosure'. Dit ondat men wan mening was dat "to seek to frustrate policies or decisions of minister by the disclosure outside the government of information to which they have had access as a civil servant" onmogelijk gemaakt diende te worden. Openbaarmaking van gegevens door een overheidsfunctionaris kan alleen wanneer dit in owereenstemming is met een "official authorisation" (section 7(3)), i.c. een minister.

P. Birkinshaw, Reforming the Secret State, Open University Press 1991, p. 16-18; Report of the Departmental Committee on Section 2 of the Official Secrets Act 1911. (1972) Cmnd. 5104, 18.

79 Norman S. Marsh, Public Access to Government held Information, London 1987, p. 265-266; Sarah MeCabe, National Security and Freedom of Information in: L. Gostin, Civil Liberties in Conflict, London 1988, p. 202

80 Attorney-General vs. Times Newspapers Lid. (1974) AC 273.

81 Toen de Labour regering probecrde om op grond van de law of confidence ${ }^{x}$ de publicatic van de Crossman dagboeken te verbieden mislukte dat ondat datgene wat Crossman beschreef te lang geleden had plaats gevonden. Het ging hier om een afweging tussen "the interest in preserving. 
en een 'public interest defence' bestaat niet in Engeland. ${ }^{32}$ In de volgende paragraaf zullen we zien aan de hand van de zaak Spycatcher wat hiervan de consequenties zijn voor de vrijheid van meningsuiting en drukpers.

\subsubsection{Spycatcher ${ }^{83}$}

In de zaak Spycatcher waren de feiten als wolgt. Peter Wright, ex-lid van de Britse geheime dienst M.1. 5, was de auteur van het book Spycatcher.4 In dit boek schrifft hij over onregelmatigheden en illegale activiteiten van leden van de M.I. 5. Deze onthullingen kwamen in een tijd dat de geheime dienst ter discussie stond. Er werd kritiek geleverd op het gebrek aan controle van de wetgevende, uitwoerende en rechterlijke macht. Gezien zijn 'contract of service' met de Kroon en de bepalingen van de 'Official Secrets Act 1911' bestond er geen enkele mogelijkheid om het boek in Engeland te publiceren. Wright besluit uiteindelijk het boek te publiceren in Australië. ${ }^{\text {ss }}$ 'The Crown Court' probeert dit in 1985 te verhinderen. Echter zonder succes. In 1988 verklaart de 'High Court' in Australië de 'Attorney-General' niet ontvankelijk omdat een 'High Court' in Engeland de rechter in Australië niet kan dwingen uitspraken over te nemen die betrekking hebben op de bescherming van Engelse staatsgeheimen. ${ }^{86}$ In 1986 publiceren The Observer and The Guardian een artikel over dit proces. In juli 1987 publiceert The Sunday Times delen uit het boek dat een paar dagen later in Amerika gepubliceerd wordt. De 'Attorney-General' probeert via een interlocutoir vonnis het artikel in de The Sunday Times over de zaak Spycatcher te verbieden. ${ }^{87}$ Volgens de kranten is "now that the information had become public knowledge any duty of non-disclosure ceased to be legally binding;

confidence" en "the interest in publication." AG ws. Jonathan Cape (1976) OB 752, (1975) 3 All ER 484.

82 J. Caplan, The Criminal Liability of the media under section 2 of the Official Secrets Act, Journal of Criminal Law 1987, p. 67-74; M. Supperstone, Brownlie's Law of Public Order and National Security, London 1981, p. 267; Norman S. Marsh, Public access to Government held Information, London 1987, p. 265-266; Sarah McCabe, National Security and freedom of information in: $\mathbf{L}$. Gostin, Civil Liberties in conflict, London 1988, p. 202.

83 Attorney-General ws. Newspaper Publishing Ltd. (1987) 3 All ER 276; Allorney-General vs. Guardian Newspapers Ltd. (1987) 1 WLR 1248, (nr. 2) (1988) 3 WLR 776.

84 Spycatcher, Index on Censorship 8-1988, p. 11.

85 David Pannick, Legal Indignations, 'Spycatcher' in: Dimitry Kingsford Smith and Dawn Oliwer, Economical with the Truth: The Law and the Media in a Democratic Society, Oxford 1990, p. 17-26.

86 Attorney-Gencral (UK) vs. Heinemann Publishers Australia Pty Lid. (1987) 8 WLR 341 NS; Attorney-General (UK) vs. Heinemann Publishers Australia Pty Ltd. (1987) 75 ALR 353; AttorneyGeneral (UK) vs. Heinemann Publishers Australia Pty Ltd. (1987) 78 ALR 449.

87 Volgens de Attorney-General zijn 'Crown servants' levenslang verplicht "to owe confidence and. silence to which no exceptions are permissible." Attorney-General vs. Guardian Newspapers Lid. (1987) 1. WLR 1248, (nr. 2) (1988) 3 WLR 776. 
and secondly, continuation of the permanent injunctions would be futile in the sense that damage had already been done to the security senice and there was no funther damage which could be done." Met andere woorden "although publication would be a breach of Wright's dury of confidentiality there was now no public interest to be sened in restricting the publication. "Ook volgens de "Court of Appeal' is "since the world-wide publication of Spycatcher had destroyed any secrecy as to its contents, and copies of it were readily available to any individual who wished to obtain it, the continuation of the injunctions" niet noodzakelijk. De 'House of Lords' daarentegen was van mening dat publication of matters contained in Spycatcher would be a breach of the duty of the confidentiality owed by Wright to the Crown and that such publication would do great harm to the British Security Senvice." Een uitzondering hierop vormt Lord Bridge. In een toespraak in de 'House of Lords' zegt hij:

"Having no written constitution, we have no equivalent in our law to the First Amendment to the constitution of the United States of America. Some think that puts freedom of speech on too lofy a pedestal. Perhaps they are right. We have not adopted as part of our law the European Convention on Human Rights to which this country is a signatory. Many think that we should. I have hitherto not been of that persuasion, in large part because I have had confidence in the capacity of the common law to safeguard the fundamental freedoms essential to a free society including the right to freedom of speech which is specifically safeguarded by art. 10 of the Convention. My confidence is seriously undermined by your Lordships' decision (..) I can see nothing whatever, either in law or on the merits, to be said for the maintenance of a total ban on discussion in the press of this country of matters of undoubted public interest and concern which the rest of the world now knows all about and can discuss freely. Still less can I approve your Lordships' decision to throw in for good measure a restriction on reporting court proceedings in Australia which the Attorney-General had never even asked for.

Tegen de regering zegt hij het volgende*:

"Freedom of speech is always the first casualty under a totalitarian regime. Such a regime cannot affiord to allow the free circulation of information and ideas among its citizens. Censorship is the indispensable tool to regulate what the public may and what they may not know. The present attempt to insolate the public in this country from information which is freely available elsewhere is a significant step down that very dangerous road. The maintenance of the ban, as more and more copies of the book Spycatcher enter this country and circulate here, will seem more and more ridiculous. If the government are determined to fight to maintain the ban to the end, they will face inevitable condemnation and humiliation by the European Court of Human Rights in Strasbourg. Long before that they will have been condemned at the bar of public opinion in the free world.

88 Attorney.General vs. Guardian Newspapers Ltd. (1987) 1 WLR 1248, (nr. 2) (1988) 3 WLR 777.

89 Attorney-General vs. Guardian Newspapers Ltd, (1987) 1 WLR 1286, BCDE.

90. Attorney-General ws. Guardian Newspapers Ld. (1987) 1 WLR 1286, FG. 
In 1991 komt er inderdaad een uitspraak van de Europese Commissie en van het Europese Hof voor de Rechten van de Mens. Volgens de Europese Commissie en het Europese Hof moeten beperkingen 'necessary' zijn in 'a democratic society' en gezien worden in het licht van de 'public interest'. Tijdelijke rechterlijke verboden mogen volgens het Europese Hof maar dienen dan wel 'noodzakelijk' te zijn in een 'democratische samenleving'. De rechter dient bij de toepassing hiervan, zeker wanneer het de persvrijheid betreft, heel voorzichtig te zijn. Volgens het Hof waren de beperkingen niet langer noodzakelijk in een democratische samenleving op het moment dat het boek over de hele wereld verspreid was. ${ }^{91}$ Het Europese Hof was van mening dat:

"the purpose of the restrictions had, since the material in question was no longer secret, become confined to the promotion of the efficiency and reputation of the Security Service and their continuation prevented newspapers from purveying information, already available, on a matter of legitimate public concern. ${ }^{102}$

Het Europese Hof weegt in het concrete geval de verschillende belangen tegen elkaar af en houdt bij het eindoordeel rekening met de 'public interest'. Zeker in die gevallen waarin het gaat om de pers. De pers heeft een belangrijke functie in een democratische samenleving. Zij is het die mensen informeert "to enable the public to assert meaningful control over the political process. ${ }^{n 3}$ Tijdelijke rechterlijke verboden staan hiermee op gespannen voet.

Wanneer de regering in Engeland informatie wil verbieden kan zij dit op een aantal manieren doen. Een daarvan is een vervolging ${ }^{24}$ starten en het materiaal in beslag nemen op grond van de 'Official Secrets Act 1989'. Op het moment dat de politie vermoedde dat het boek Spycatcher 'official secrets' bevatte had zij de hele oplage in beslag kunnen nemen op grond van de 'Official Secrets Act' ('section' 9(1)). Het probleem is dat vervolging op grond van de 'Official Secrets Act' risico's met zich mee brengt zoals de Ponting zaak ${ }^{25}$ laat zien. De bewijslast is zwaar in

91 Na 30 juli 1987.

92 Sunday Times (nr. 2), Observer and Guardian, ECHR 26-11-1991, Council of Europe nr. 50/1990/$241 / 312$, p: 28 en $51 / 1990 / 242 / 313$, p. 31.

93 Anthony Lewis, Bentham"s View of Journallists' Privilege and The Independent Case in: Dimitry Kingsford Smith and Dawn Oliver, Economical with the Truth: The Law and the Media in a Demow cratic Society, Oxford 1990, p. 127.

94 Verder is een verwolging alleen mogelijk met de toestemming van de 'Attorney-General'. De 'Attorney-Generall' is in veel gevallen niet alleen een 'prosecutor', een beschermer van de 'public interest', maar ook een gekozen politicus, een lid van de regering, en een juridisch adviseur van de regering en Kroon. Het gevaar van deze dubbelfunctie is dat de "interests of the state" en de "interests of the government of the day" samen gaan. P. Burkinshaw, Reforming the Secret State; Open University Press 1991, p. 16; Report of the Departmental Commiltee on Section 2 of the Olficial Secrets Act 1911 (1972) Cmand. 5104, $\$ 37$; R.J. Walker and Walker, The English Legal System, Bijl. p. 230-231; Zie de zaak R. vs. Ponting (1985) Crim. LR 318.

95 R. vs. Ponting (1985) Crim. LR 318. 
strafrechtelijke zaken, en jury"s oordelen soepel wanneer de openbaarmaking "does no harm to the public interest." Bovendien vindt de vervolging vaak plaats wanneer de zaken al openbaar zijn gemaakt. Dan is het vaak te laat.*

Civielrechtelijk zijn er minder belemmeringen. Zo bestaat er de mogelijkheid wan "prior restraint" ten aanzien van een publicatie via 'interim injunctions ${ }^{k p 7}$ wanneer er sprake is van een 'breach of confidence'. Een rechterlijk verbod veroorzaakt een 'prior restraint" wanneer de drukpersen moeten worden stop gezet en films niet meer gedraaid mogen worden. Een voorbeeld van een 'prior restraint" is een 'interim injunction'. Een 'interim injunction' heeft tot gevolg dat een publicatie gestaakt moet worden zolang het civiele proces duurt. Na afloop van het proces, wanneer blijkt dat er bijvoorbeeld geen sprake is van een 'breach of confidence" vaak verouderd en dus oninteressant geworden. Een 'breach of confidence' was oorspronkelijk bedoeld woor commerciële-informatie verkregen door middel van industriële spionage. Later heeft men een 'breach of confidence' ook gebruikt in privế-zaken en in me dia aangelegenheden. Sinds 1986 wordt er geen strafrechtelijke vervolging meer ingesteld op basis van de 'Official Secrets Act' maar gebruikt men de civiele actie van 'breach of confidence' als substituut. In civiele zaken is de bewijslast lichter en zijn er geen jury's. De regering koos dan ook in de zaak Spycatcher voor een civiele procedure om de publicatie te stoppen. ${ }^{99}$ De vraag is echter of 'private law of confidence' een geschikte methode is om publicatie van staatsgeheimen te voorkomen. Volgens Rodney Austin is de privaatrechtelijke "law of confidence"

Bovendien is een beroep op 'section' 2 (2) van de 'Official Secrets Act' politiek niet zo populair omdat de regering dan gedwongen is om uitgevers wan kranten en journalisten persoonlijk aan te spreken.

97 Zie de zaak Spycatcher: Attorney-General vs. Newspaper Publishing Lid. (1987) 3 All ER 276; Attorney-General ws. Guardian Newspapers Ltd. (1987) 3 All ER 316, (nr. 2) (1988) 3 All ER 545; Zie ook Lord Advocate vs. Scotsman Publishing Ltd. (1989) 2 All ER 852.

Sinds 1986 vervolgt de regering meestal niet meer op grond van de "Official Secrets Act" maar gebruikt ze de civiele actie van "breach of confidence" als substituut.

99 Men had ook kunnen 'kiezen voor her ' $D$-notice' systeem. 'The services, press and broadcasting committee' geeft een 'notice' aan de media dat het materiaal niet gepubliceerd dient te worden. Probleem is wel dat het "D-Notice" systeem bedoetd is "to prevent specific harm and not to uphold general governmental secrecy." Een ander mechanisme is de "civil service discipline code of the establishment officers guide?. Dit zijn interne disciplinaire maatregelen. Probleem is echter dat niet duidelijk is of deze niaatregelen ook van toepassing zijn op ambtenaren van de veiligheidsdienst omdat deze regels buiten de "Home Civil Service" vallen. Bovendien hebben disciplinaire maatregelen alleen zin ten aanzien van ambtenaren die nog in dienst zijn en niet ten aanzien van ambtenaren die bijwoorbeeld met pensioen zijin. Rodney Austin, The Spycatcher Saga: Public Secrecy from Private Rights in: Dimitry Kingsford Smith and Dawn Oliver, Economical with the Truth: The Law and the Media in a Democratic Society, Oxford 1990, p. 32-33; David Astor, How the British Press censors itself, Index on Censorship 6-1977, p. 4; Robert McDonald, Film Censor's Bulletin, Index on Censorship 6-1977 p. 26-28; Nicholas Garnham, How free is British Broadcasting?, Index on Censorship 5-1982, p. 26, Denis Forman, Threats to British Broadcasting, Index on Censorship
8-1987, p. 1. 
miet geschikt voor het voorkomen van publicaties over staatsgeheimen. ${ }^{100}$ Het gaat đ̉aar meer om commercièle geheimen en private aangelegenheden. Hij stelt voor om een nieuw statuut in het leven te roepen dat zich onder andere met staatsgeheimen bezighoudt. ${ }^{101}$ Volgens Blackstone zijn 'previous restraints on publications' een schending van de vrijheid van meningsuiting en drukpers. Dit kunnen we ook lezen in het 'First Amendment' van de Amerikaanse Grondwet. Alleen achteraf, na publicatie kan er ingegrepen worden in de vrijheid van meningsuiting en drukpers. ${ }^{102}$ Ook de Europese Commissie is van mening dat tijdelijke rechterlijke verboden een inbreuk vormen op art. 10 EVRM. ${ }^{103}$

In Engeland waar geen geschreven Grondwet bestaat, is de regel 'no prior restraint' uitgehold. Bijna elke week, tijdens hoorzittingen van de 'High Court' wordt door een civiele partij aan rechters gevraagd een rechterlijk verbod uit te spreken tegen de media. ${ }^{104}$

100 Rodney Austin, The Spycatcher Saga: Public Secrecy from Private Rights in: Dimitry Kingsford Smith and Dawn Oliver, Economical with the Truth: The Law and the Media in a Democratic Society, Oxford 1990, p. 27.

101. Ook is het volgens hem noodzakelijk dat ambtenaren die werken bij de weiligheidsdienst onderworpen zijn aan een effectieve onafhankelijke controle. Rodney Austin, The Spycatcher Sage: Public Secrecy from Private Rights in: Dimitry Kingsford Smith and Dawn Oliwer, Economical with the Truth; The Law and the Media in a Democratic Society Oxford 1990, p. 27.

102 In de zaak. 'Pentagon Papers' werd "prior restraint' door de US 'Supreme Court' ontoelaatbaar geacht. Toen de regering lucht kreeg van het feit dat de New York Times van plan was een atantal millitaire onderzoeksrapporten over de geschiedenis van de US inval in Vietnam te publiceren wilde ze dit voorkomen omdat dit materiaal wolgens de regering militaire en diplomatieke geheimen bevalte waarvan openbaarmaking de nationalle belangen in gevaar kon brengen. De 'Supreme Court' echter weigerde de publicaties te verbieden op grond wan het principe dat "any system of prior restraint on expression comes to the court bearing a heavy presumption against its constitutional validity." Achteraf kon de krant ter verantwoording worden geroepen wanneer bleek dat "disclosure woukd substantially harm the national interest." De krant is dan stralbaar op grond van de "Espionage Act:. Alleen wanneer de regering kan bewijzen dat openbaarmaking "grave and irreparable injury to the public interest" veroorzaakt kan de rechter de persen stoppen. Eric Barendt, Freedom of Speech, Oxford 1985, p. 136.

103 ECHR 25-6-1991, Human Rights News 1991, zaak 273.

104 Attorney-General vs. Leveller Magazine Ltd. (1979) AC 440, 449, 459; Attorney-General vs. Times Newspapers Ltd. (1974) AC 273, 294; Attorney-General w5. Butterworth (1963) 1 QB 696. 


\subsubsection{D-Notices ${ }^{\text {s.tes }}$}

Behalve door middel van 'prior restraints' en de 'Official Secrets Act" kan de vrijheid van meningsuituing in geval van 'state secrets' ook beperkt worden op grond van het 'D-Notice' systeem. ${ }^{106}$ Het niet op een statut gebaseerde 'Services, Press and Broadcasting Committee" stuurt brieven naar uitgevers "requesting that material should not be published because it would have an effect prejudicial to the national interest." Het doel van het syteem is "to prevent top secret matters on defence from being published:" In feite is hier sprake van censuur. Het niet opvolgen van een 'D-Notice' is geen strafbaar feit. Wel kan dit leiden tot een vervolging, omdat er in strijd is gehandeld met de 'Official Secrets Acts ${ }^{\text {s07 }}$, en tot een inbeslagneming. Een duidelijk woorbeeld hilervan is de inval bij de BBC in Glasgow door 'Special Branch Officers'. Deze namen alle bandopnamen, films en documentaires in beslag van Duncan Campbell's 'Secret Society series". ${ }^{158}$ Dit programma dat op de BBC zou worden uitgezonden onthulde het bestaan van een spionage satelliet die gebouwd was in Engeland en bedoeld was om de toenmalige Sowjet-Unie in de gaten te houden. De 'warrants' werden gegeven op grond wan 'Section 2 of the Official Secrets Act'. In tegenstelling tot de 'Police And Criminal Evidence Act' zoals we in paragraaf 2.5 zullen zien, bestaat in deze wet geen 'special procedure'. Er hoeft dus geen 'notice' te worden afgegeven aan de persoon die in het bezit is van het materiaal zodat "the application can be contested by the court. "Nu kan de "search warrant be granted at a secret court" zonder dat de vertegenwoordigers van de 'New Statesman' konden worden gehoord. Dit staat op gespannen voet met het recht op een 'fair" trial' (art. 6 EVRM).

\subsubsection{Conclusie}

Zoals we in het voorafgaande hebben kunnen lezen beperkt de 'Official Secrets Act', de civiele procedure en het 'D-notice' systeem de vrijheid van meningsuiting ver-

105 P. Birkinshaw, Reforming the Secret State, 1991, p. 29; M. Supperstone, Brownlie's Law of Public Order and National Security, London 1981, p. 259-261; R. Callender Smith, Press Law, Contempt and the Phillimore Committee, London 1978, p. 145-156; Brian Wenham, Whose standards? Index on Censorship 8-1988, p. 31.

106 S.H. Bailey, D.J. Harris, B.L. Jones, Civil Liberties, Cases and Materials, London 1991, p. 328-333; R. Callender Smith, Press Law, Contempt and the Phillimore Committee, London 1978, Chapter 7, Official Secrets Acts and The 'D-Notice' System, p. 145-156; G. Robertson, Freedom, The Individual and the Law, Harmondsworth 1989, 6th. edn., p. 141-143; M. Supperstone, Press Law in the UK in: Phina Lahav, Press Law in Modern Democracies, 1985, p. 16-17; Brian Wenham, Whose standards?, Index on Censorship 8-1988, p. 31.

107 M. Supperstone, Brownlie's Law of Public Order and National Security, London 1981, p. 259-262.

108 D. Campbell, Paradoxes of Secrecy, Index on Censorship 8-1988, p. 17. 
gaand. ${ }^{109}$ Nog meer dan bij de 'Contempt of Court Act' wordt er door de wetgever en de rechter nauwelijks rekening gehouden met de vrijheid van meningsuiting en drukpers. Dit in tegenstelling tot het Europese Hof voor de Rechten van de Mens. In de zaak Spycatcher werd het belang van de veiligheid van de staat zorgvuldig afgewogen tegen de vrijheid van meningsuiting en drukpers. Zeker wanneer het gaat om de pers dient men, aldus het Hof, extra voorzichtig te zijn. Er moet de mogelijkheid bestaan voor de pers om een beroep te doen op 'public interest'. Dat de wetgever in Engeland bij het redigeren van de nieuwe 'Official Secrets Act' hier geen rekening mee heeft gehouden is vreemd. Journalisten hebben er dan ook de grootste problemen mee om documentatiemateriaal te gebruiken dat betrekking heeft op misstanden binnen de regering of machtige corporaties. ${ }^{110}$ Hun materiaal en bronnen genieten geen enkele bescherming tegen een inbeslagneming. Alleen wanneer het gaat om "incitement to racial hatred" speelt de vrijheid van meningsuiting en drukpers plots wel weer een rol zoals we zullen zien in paragraaf 2.4.2.

\subsection{De 'Race Relations Act' en de 'Public Order Act'}

\subsection{1 'Incitement to racial hatred"}

In het 'common law' systeem in Engeland was er weinig bescherming voor raciale groepen tegen 'incitement ${ }^{111}$ to hatred'. ${ }^{112}$ Meestal werd 'section' $5^{113}$ van de 'Public

109 James Michael, The Politics of Secrecy: The Case for a Freedom of Information Law, London 1979, p. 5 e.v.

110 Er bestaat een verschil tussen 'belediging' en 'vertrouwelijke informatie" en 'contempt of court'. In de laatste twee gevallen zal de rechter eerder overgaan tot het stop zetten van de publicaties of uitzendingen omdat het hier meestal gaat on kritische artikelen. Een voorbeeld van een zaak waarin een 'interim injunction' werd gegeves is de zaak 'My Country Right or Wrong" uit 1987. Deze zaak had betrekking op de veiligheidsdienst. De regering vroeg aan de 'High Court' een 'interim injunction' tegen de uitzending op de BBC radio 4 omdat ze bang was dat ex-werknemers van de veiligheidsdienst 'breached confidence" tijdens de intervieuws. In een 'interim injunction' werd de $\mathrm{BBC}$ gedwongen de uitzendingen te stoppen en bewal de rechter de bandopnamen af te geven aan de 'Attorney-General'. Nadat de bandopnamen waren belluisterd en men ervan overtuigd was dat er geen sprake was van een 'breach of confidence' werd de BBC weer in de gelegenheid gesteld om de uitzendingen voort te zetten.

111 The Law Commission Working Paper nr. 50, 5-6-1973, Second Programme, stem XVIII, oodification of the criminal law, general principles, inchoate offences, conspiracy, attempt, incitement.

112 De bepalingen die betrekking hebben op "sedition" of 'criminal libel' woldoen niet omdat de bewijslast te zwaar is. Ze worden dan ook zelden toegepast. D.G.T. Williams, Racial Incitement and Public Order, Crim. LR 1966, p. 321.

113 In 'section 5" van de "Public Order Act 1936' heeft het parlement geprobeerd "to solve the difficult question how far freediom of speech and behaviour must be limited in the general public interest." J. Marston, Public Order, A Guide to the Public Order Act 1986, London 1987, p. 77-110; D.G.T. Williams, London Government Act 1963, The Modern Law Review 1964, p. 447 e.v. 
Order Act' uil 1936 toegepast. Maar de voorwaarde dat er sprake moest zijn van een 'breach of the peace' beperkte het effect van deze 'section"." Bovendien was deze wet niet effectief tegen meer verraderlijke wormen van 'incitement' of 'incitements which occurred privately.

Eerst de 'Race Relations Act $1965^{\text {H6 }}$ maakte het mogelijk "to deal with the mischief $f^{\text {n17 }}$ (section" 6) zij het dat ook de reikwijdte van deze bepaling beperkt werd door "the need to prove both an intention" to incite racial hatred and a likelihood of racial hatred being stired up." De ratio wan deze bepaling was dat alleen in gevallen van "a serious threat to public order inherent in the expression of racial hatred" vervolgd kon worden. Het moest, volgens de 'Home Secretary' en de 'Solicitor-General', gaan om extreme gevallen. Anders zou er sprake zijn van "interferes unnecessarily wih free speech. "wis

In 'Section' 70 van de 'Race Relations Act 1976', die "section' 6 van de 'Race Relations Act' uit. 1965 vervangt en "section" $5 \mathrm{~A}^{\text {i2s }}$ introduceert in de 'Public Order $\mathrm{Act}^{321}$, wordt strafbaar gesteld "incitement to macial hatred." Het vereiste dat er sprake moet zijn van een intentie vervalt. ${ }^{122}$ Toch kent ook deze 'section' beperkingen. Zo is het mogelijk om materiaal te verspreiden onder leden van een club of organisa-

114 De 'Public Order Act 1936 ' werd vooral gebruikt om raciale toespraken te voorkomen. A.N. Khan, A.F. Dickey, Incitement to Raciall Hatred, Australia 1976, p. 48.

115 D.G.T. Williams, Racial Incitement and Public Order, Crim. LR 1966, p. 320.

116 De Act uit 1965 is ingevoerd door de regering "to prevent arising in this country, in relation to the coloured irnmigrants, the kind of situation which arose in relation to the Jews in this country in 1935 and 1936", Commons, Vol. 711, col. 1047, 3-5-1965.

117 De Britse 'Race Relations Act' verbiedt uitingen, ook al leidt dat niet onmiddellijk tot geweld en wamorde. In zowel Engeland als de VS hoeft niet bewezen te worden dat "violence is a likely and imminent result of the speech." Als argument wordt aangewoerd dat het toleren van uitingen die raciale en etnische groepen beledigen, kan leiden tot racistische gedragingen welke weer kunnen leiden tot 'public disorder". Religieuze groepen vallen hier niet onder. Deze moeten een beroep doen op vage wetten zoals 'blasphemy" en 'public mischief. D.G.T. Williams, Racial Incitement and Public Order, Crim. LR 1966, p. 320.

118 R. Card, Public Ordler, The New Law, London 1987, p. 98; J. Marston, Public Order, A Guide to the Public Order Act 1986, London 1987, p. 105; A.N. Khan and A.F. Dickey, Incitement to Racial Hatred, Australia 1976, p. 49-51; M. Supperstone, Brownlie's Law of Public Order and National Security, London 1981, p. 16.

119 Standing Committee $B$, col.56,27-51965. De Times zag 'section' 6 als een 'instrument of potential censorship'. 8-4-1965, p. 13. 'Section' 6 wordt toegepast in extreme gevallen. Zie A. Dickey (1968) Crim. LR 489, 496. Zie ook R. vs. Malik (1968) 1 All ER 582, 1 WLR 353, CA; R. vs. Britton (1967) 1 All ER 486.

120 De begrippen 'publishing" of "distributing' hebben betrekking op "the public at large' of op "any section of the public." Dit is exact hetzelfde als in "section" 6 of the 1965 "Act'. Wat onder "public at large" en "any section of the public" moet worden verstaan is niet geheel duidelijk. A.N. Khan, A.F. Dickey, Incitement to Racial Hatred, Australia 1976, p. 52.

121 De 'Public Order Act 1936" is in 1963 en in 1986 herzien.

122 Gekeken wordt naar "all the circumstances". 
tie zonder dat er ingegrepen kan worden door de politie of justitie. ${ }^{123}$ De eis dat het moet gaan om "the public at large" of "any section of the public" blijft bestaan.

In 1986 wordt er een nieuwe 'Public Order Act' ingevoerd. Deze "Act' zal ik hier het meest uitgebreid bespreken omdat deze het meest recent is. De woorden 'racial hatred" in 'section' 17 wan deze 'Act' dienen betrekking te hebben op een groep die leeft in Engeland. De defönitie wan groep is afkomstig uit de Race Relations Act 1976 . Hieronder dient te worden verstaan "a group of persons defined by reference of colour, race, nationality (includes citizenship ${ }^{i 2}$ ) or ethinc ${ }^{23}$ or national origins." Religie valt er niet onder. ${ }^{126}$ Ook de bescherming wan een individu valt niet onder deze bepaling. ${ }^{1.7}$

Het is een strafbaar feit:

a. "to use threatening, abusive or insulting words or behaviour" ${ }^{\text {mizg }}$ of

b. "to display threatening, abusive or insulting written material ${ }^{129}$, either where the defendant intends racial hatred ${ }^{130}$ to be stirred up by such use, or where, having regard to all the circumstances, racial hatred is likely ${ }^{133}$ to be stirred up by such use."1322

123 M. Supperstone, Brownlie's Law of Public Order and National Security, London 1981, p. 18; R. vs. Britton (1967) 1 All R 486; J. Marston, Public Order, A Guide to the Public Order Act 1986, London 1987, p. 103.

124 Dit begrip is ingevoerd in 1976 . Ealing BC vs. RRB (1972) 2 WLR 71.

125 In de zaak Mandla vs. Dowell Lee (1983) 2 AC 548, 1 All ER 1062, 2 WLR 620, geeft het 'House of Lords' aan welke criteria dienen te worden gehanteerd om te kunnen beslissen wanneer een groep geclassificeerd kan worden als "having ethnic origins". In beginsel wordt dit begrip ruim geinterpreteerd. Ook bijvoorbeeld Joden en Sikths vallen onder deze bepaling.

1266 Bij religieuze belediging zal een beroep moeten worden gedaan op vage wetten alls 'blaspherny' en 'public mischief. J. Marston, Public Order, A Guide to the Public Order Act 1986, London 1987, p. 103.

127 "Thorme vs. BBC (1967) 2 All ER 1225.

128 Onder 'behaviour" vallen ook, onder bepaalde omstandigheden, gebaren ("section' 18(6)), 22(1)). J. Marston, Public Order, A Guide to the Public Order Act 1986, London 1987, p. 103-104 In de 'Race Relations Act 1976' en 'section' 5 A van de 'Public Order Act" werd 'behaviour' nog niet genoemd.

129 Hieronder vallen getypte, gedrukte en gefotografeerde geschriften. Video's en films vallen onder "section" 21 en 22.

130 Bij "hatred" gaat het om "gross excesses of racialist propaganda." 'Race Relations Act 1965' p. 314.

131 Wat 'likely' betekent is niet duidelijk. Afhankelijk van het subjectieve oordeel van de 'magistrate' of de 'jury' en gegeven de omstandigheden zal dit begrip nader worden ingevuld, Zie ook het begrip 'to tend' in de 'Obscene Publications. Act'.

132. Een 'defence' voor de 'defendant" kan het feit zijn dat "he was not aware of the content of the materiall and did not suspect or have reason to suspect that it was threatening" ('section' 19(2)). 
Bij alle strafbare feiten kan er nu een keuze worden gemaakt tussen de intentie "to stir up racial hatred" ${ }^{\text {n33 }}$ of "the likelihood of racial hatred being stimed up." De "Act" verbiedt bovengenoemd gedrag in "public and private places." Ook besloten bijeenkomsten vallen hieronder. ${ }^{1{ }^{34}}$ Uitgezonderd zijn bijeenkomsten in een woonhuis "observed by people inside that or any other house. ${ }^{\text {"nss }}$ De woorden 'threatening" 'abusive' en 'insulting' beperken de reikwijdte van de regeling. ${ }^{136}$ Immers openlijke propaganda valt er wel onder maar meer 'sophisticated" propaganda niet. ${ }^{\text {137 }}$

Het is eveneens een strafbaar feit wanneer iemand "to distribute, show or play a recording of visual images or sounds which are threatening, abusive or insulting if he intends thereby to stir up racial hatred or whereby racial hatred is likely to be stirred up ('section' 21). ${ }^{\text {m38 }}$ Deze bepaling heeft zowel betrekking op "public and private places. "Ook "private meetings" in een woonhuis vallen onder deze bepaling.

Bepaalde personen die vallen onder 'section' 22(2) kunnen schuldig zijn aan een strafbaar feit wanneer programma"s $\mathrm{s}^{3}$ "involving threatening, abusive or insulting wisual images or sounds is broadcast or is included in a cable programme service". Er moet dan oftewel sprake zijn van een "intent" of van een "likelihood of racial hatred being stirred up."

133 Ook in andere 'Acts' wordt er gesproken over "incitements of racial hatred." Zie 0.a. de "Cable and Broadcasting Act 1984', "Theatres Act 1968'. Samen met 'section" 5 A zijn deze regels vervallen en vervangen door zes nieuwe strafbare feiten in "section" 18-23. In alle gevallen geldt hier dat de soort materiaal van belang is.

134 In de 'Race Relations Act' uit 1976 (zie ook 'section' SA wan de 'Public Order Act') beging iemand een strafbaar feit wanneer: "he publishes or distributes written matter which is threatening, abusive or insulting." De betekenis van "publish" of "distribute to the public at large or to any section of the public"' had geen betrekking op "members of an association of which the person publishing. or distributing is a member."

135 'Public Order Act 1986', 'section" 29.

136 Deze woorden zijn onduidelijk, hetgeen interpretatie problemen kan opleveren. D.G.T. Williams, Racial Incitement and Public Order, Crim. LR 1966, p. 321; J. Marston, Public Order, A Guide to the Public Order Act 1986, London 1987, p. 104; G. Bindman, Incitement to Racial Hatred in the United Kingdom, Hawe we got the Law we need? in: S. Coliwer (ed.), Striking a Ballance, Hate Speech, Freedom of Expression and Non-discrimination, London 1992, p. 261.

137 Jury's konnen alleen tot een veroordeling in die gevallen wanneer het betreft "overtones of violence." Via een achterdeur wordt 'a breach of the peace' weer ingevoerd. Zie o.a. de zaken $R$. vs. Britton (1967) 1 All ER 486; R. vs. Malik (1968) 1 WLR 353, CA, 1 All ER 582. Wanneer het betreft artikelen geschreven in een gematigde toon dan vallen deze niet onder 'section' 6 'Race Relations Act 1976', 'section" 5A "Public Order Act 1939". Voor de "Public Order Act' uit 1986 geldt hetzelfde immers ook 'section' 19 gebruikt de woorden "threatening, abusive or insulting." Echter misschien leidt het woord "likelihood", dat zoveel betekent als "having regard to all circumstances," en dat ook al gebruikt werd in 'section' 5A, tot een ruimere benadering van deze 'Act'. A.N. Khan, A.F. Dickey, Incitement to Racial Hatred, Australia 1976, p. 55.

138 Het betreft hier video"s ('Public Order Act 1986').

139 Sommige televisie- of kabelprogramma's vallen niet onder deze bepaling ('section' 22(7)). 
Naast de intentie "to stir up racial hatred", zoals in de 'Theatres Act uit 1968', kan het ook voldoende zijn voor het begaan van een strafbaar feit dat "in all the circumstances, racial hatred is likely to be stirred up ('section" 20). "40

Het bezit van "racially inflammatory written material or recordings" ter openbaarmaking of ter verspreiding is strafbaar op grond van 'section" 23. Een journalist kan op grond van 'section' 23 een beroep doen op een 'defence'. Hij kan zeggen dat hij 'racially inflammatory material' verzamelt voor onderzoeksdoeleinden bijvoorbeeld als achtergrond materiaal, voor een wetenschappelijk tijdschrift of als onderdeel wan een onderwijsprogramma.

Het is de "justice of the peace die een "search warrant" beveelt wanneer het materiaal betreft dat valt onder 'section' 24'. (1), (3) en (4). De waarborgen die gelden in de 'Police and Criminal Evidence Act' zijn hier niet van toepassing. Net als bij de 'Obscene Publications Act' en de 'State Secrets Act' kan een hele oplage, met toestemming van de 'Attorney-General' ('section' 27 (1)), in beslag worden genomen.

\subsubsection{Conclusie}

De poging die men in Engeland in het werk heeft gesteld om een effectieve wetgeving in het leven te roepen die de verspreiding van racistische propaganda tegen gaat is ten dele in de praktijk mislukt. Dit is enerzijds te wijten aan de wet zelf die niet op alle punten even duidelijk is. De 'Attorney-General' is veelal niet geneigd om bij dit soort delicten tot een vervolging over te gaan omdat de bewijslast veelal zwaar is. ${ }^{141}$ Anderzijds heeft het ook te maken met een bepaalde mentaliteit. De vrijheid van meningsuiting en drukpers weegt in dit soort zaken zwaar. ${ }^{142}$ Dit in tegenstelling tot 'state secrets' of 'obscenity' of 'contempt of court' zaken. In dit soort zaken houdt de wetgever en de rechter nauwelijks tot geen rekening met de vrijheid van meningsuiting en drukpers.

140 Deze bepalingen vervangen de bepalingen in de "Theatres Act 1968".

$141 \mathrm{G}$. Bindman, Incitement to Racial Hatred in the United Kingdom: Have we got the Law we need? in: S. Coliver, Striking a Balance, Hate Speech, Freedom of Expression and Non-discrimination, London 1992, p. 260.

$142 \mathrm{G}$. Bindman, Incitement to Racial Hatred in the United Kingdom: Have we got the Law we need? in: S. Coliver, Striking a Balance, Hate Speech, Freedom of Expression and Non-discrimination, London 1992, p. 262. 


\subsubsection{Inleiding}

In de vorige paragrafen hebben we gezien dat de verschillende 'Acts' nauwelijks enige ruimte bieden voor de vrijheid van meningsuiting en drukpers. De inbeslagneming van gegevensdragers is niet met extra waarborgen omkleed. Dit is anders in de 'Police and Criminal Evidence Act 1984'. In deze 'Act' is de bevoegdheid tot inbeslagneming gekoppeld aan de bevoegdheid tot huiszoeking. Wanneer je gaat onderzoeken hoe de inbeslagnerning geregeld is in deze 'Act' dan dient dat te geschieden in combinatie met de bevoegdheid tot huiszoeking. ${ }^{1.3}$ Immers de inbeslagneming van 'excluded material', 'legally privileged material' en 'special procedure material" is met extra waarborgen omkleed wanneer er sprake is van een huiszoeking.

De wetgeving inzake de huiszoeking en inbeslagneming van "articles" ${ }^{\text {"t4 }}$ is gewijzigd in de 'Police and Criminal Evidence Act 1984'. 'Part Il' van de 'Police and Criminal Evidence Act 1984' heeft betrekking op de bevoegdheid tot binnentreden, huiszoeking en inbeslagneming. Reden voor invoering van deze wet was, volgens de 'Home Secretary', het feit dat de huidige wet aan duidelijkheid te wensen overliet. Volgens hem dient de politie duidelijke en adequate machtsmiddelen te hebben tegen de misdaad. Daarvoor is een effectieve wetgeving noodzakelijk. ${ }^{\text {145 }}$ De uitgangspunten van de 'Royal Commission on Criminal Procedure' waren dat de wet 'fair, open, and workable ${ }^{m 46}$ moest zijn. Verder diende er een balans te bestaan tussen individuele rechten ${ }^{147}$ en de behoeften van de samenleving. Of men hierin geslaagd is zal in de loop van het betoog duidelijk worden. Om te beginnen zal de inbeslagneming, zoals deze geregeld is in de 'Police and Criminal Evidence Act 1984', worden besproken. Daarbij zal worden gekeken wat de betekenis is van de verschillende soorten 'materials' en hoe de inbeslagneming van deze 'materials' zich verhoudt met de vrijheid van meningsuiting en drukpers. Wanneer het gaat om de inbeslagneming bij een huiszoeking gelden voor elke categorie 'materials' andere beschermingsconstructies.

143 Celia Hampton, Criminal Procedure, London 1982, p. 37 e.w.; M. Zander, The Police and Criminall Evidence Act 1984, London 1990, p. 20 e.w.; H.R. Balmer, Search and Seizure: A Comment, Crim. LR 1967, p. 19 e.w.

144 Net als in Duitsland ( 96 'StrafprozeBordnung") wordt er in de "Police and Criminal Evidence Act 1984' een onderscheid gemakkt tussen voorwerpen en gegevensdragers. Zie hoofdstuk 2.

145 De 'Police and Criminal Evidence Act' is de hoeksteen van de 'Law and Order' politiek. Home Office, Police and Criminal Evidence Act 1984, Codes of Practice, London 1985, p. 25 e.v.

146 Of de wet werkbaar is, is de vraag. H. Levenson and F. Fairweather, Police Powers, A Practitioner's Guide, London 1990, Chapter 3, p. 37 e.v. en Chapter 4, p. 78 e.w.

147 De rechten staan eerder in de 'Code of Practice' dan in de 'Act'. Home Office, Police and Criminal Evidlence Act 1984, Codes of Practice, London 1985, p. 25 e.v. 
Een politieagent mag op grond van 'section' 19 van de 'Police and Criminal Evidence Act 1984', rekening houdend met het proportionaliteitsbeginsel ${ }^{\text {148 }}$, 'materials' in beslag nemen. Voorwaarde voor inbeslagneming is dat er redelijke gronden zijn om aan te nemen dat:

- het 'material' verkregen is als gevolg van het begaan van een strafbaar feit (section 19(2)(a)) of

- dat het bewijsmateriaal is dat in relatie staat tot een misdrijf hetwelk de politieagent onderzoekt of een ander strafbaar feit ('section' 19(3)(a)) en

- in beide van de hierboven genoemde gevallen is vereist dat het noodzakelijk is "to seize the property in order to prevent it being concealed, lost, altered or destroyed ('section' 19(2)(b) en (3)(b))."

Bovengenoemd is de algemene regel. Hierop bestaan uitzonderingen. Zo mag 'legally privileged material' ('section' 19(6)) s $^{\text {s4 }}$ onder geen enkele voorwaarde in beslag genomen worden en is de inbeslagneming van 'excluded' en 'special procedure material' bij een huiszoeking aan procedurele beperkingen onderworpen.

In de volgende paragrafen zullen de afzonderlijke soorten materiaal aan de orde komen. Gekeken zal worden hoe elk type 'material' zich verhoudt tot de inbeslagneming en de vrijheid van meningsuiting en drukpers. ${ }^{\text {iso }}$

148 Reynolds vs. Commissioner of Police of the Metropolis (1984) 3 All ER 649, CA. In deze zaak besliste de 'Court of Appeal' dat de politie nict bevoegd is om grote atantallen documenten in besllag te nemen zonder aan te geven dat "each filc or bundle might reasonably constitute evidence." Zie ook 'section' 22 (4). De politie zal niets in haar bezit houden indien volstaan kan worden met een 'copy' of een foto.

149 F. Hargreaves and H. Levenson, A Practitioner's Guide to the Police and Criminal Evidence Act 1984, Legal Action Group 1985, p. 200 e.v.; Vaughan Bevan Ken Lidstone, A Guide to the Police and Criminal Evidence Act 1984, London 1985, p. 374 e.v.; M. Zander, The Police and Criminal Evidence A.ct 1984, London 1990, p. 20 e.v.; Scottish Current Law Statutes 1985, p. 60 e.v.; H. Levenson and F. Fairweather, Pollice Powers, A Practitioner's Guide, London 1990, Chapter 3, p. 37 e.v. en Chapter 4, p. 78 e.v; E.K. Banakas (ed), United Kingdom Law in the 1980s, Comparitive and Common Law Studies for the XIIth. International Congress of Comparative Law, London 1988 , p. 235.

150 M. Zander, The Police and Criminal Evidence Ad. 1984, London 1990, p. 20 e. $\psi_{;}$; H. Levenson and F. Fair-weather, Police Powers, A Practitioner"s Guide, London 1990, Chapter 3, p. 37 e.w. en Chapter 4, p. 78 e.v.; Scottish Current Law Statutes, 1985, p. 60 e.v.; Patricia Willielm, Protection of Sources, An International Review of Journalistic and Legal Practice, The Norwegian Institute of Journalism, Fredrikstad 1988, p. 40 e.w. 
Het begrip 'legally privileged material' wordt gedefinieerd in 'section' 10 van de 'Police and Criminal Evidence Act 1984'. Deze definitie is van belang omdat, zoals we in de vorige paragraaf hebben kunnen lezen, 'legally privileged material' van een huiszoeking ('search") en van een inbeslagneming is uitgesloten onder de 'Police and Criminal Evidence Act 1984'. ${ }^{151}$ Wanneer zulk materiaal wordt gevonden gedurende een 'search" dan mag dit materiaal niet in beslag genomen worden. Een voorbeeld van "legally privileged" materiaal is materiaal dat betrekking heeft op de 'communications' tussen een juridisch adviseur en zijn cliènt in die gevallen waarin het gaat om juridisch advies ('section' 10(1)(a)). Volgens "section" 10(2) vallen niet onder het 'legal privilege' onderwerpen die een strafbaar feit tot doel hebben. ${ }^{152}$ Ook journalistiek materiaal valt niet onder "legally privileged" materiaal maar wel onder 'excluded material".

\subsubsection{Betekenis van "excluded material"}

Een ander soort materiaal is 'excluded material'. 'Excluded materials' zijn:

1. 'personal records" of ('section' $11(1)(a)$ )

2. 'human tissue' of 'human tissue fluid' ('section' 11 (1)(b))

3. 'journalistic material' ('section" $11(1)(\mathrm{c})$ )).

'Journalistic material' moet betreffen 'documents' of 'records other than documents' 153

Onder documenten wordt hier verstaan: a. geschreven stukken, een plan, tekening etcetera, b. een foto, c. een diskette, geluidsband, c.d. etcetera, c. films, microfilms, negatieven etcetera. ${ }^{1.54}$

Voor alle drie de categorieën geldt dat het materiaal "must be held in confidence." Dit betekent dat het bewijsmateriaal:

1. "must be held subject to an express or implied undertaking to hold it in confiden$c e^{\ln (55}$ of

151. Andere 'statutes' zijn niet langer geldig ('section' $9(2)(a)$ ).

152 M. Zander, The Police and Criminal Evidence Act 1984, London 1990, p. 32, 33; H. Levenson en F. Fairweather, Police Powers, A Practitioner's Guide, London 1990, p. 45.

153 Hoewel het begrip "records' niet wordt gedelinieerd in de 'Act' is het moeilijk om iets te werzinnen wat wel een 'record' is maar miet valt onder het begrip "document'.

154 H. Levenson and F. Fairweather, Police Powers, A Practitioner's Guide London 1990, p. 48.

155 De wet met betrekking tot 'confidentiality' is complex en onzeker. Wel is duidelijk dat 'section' 11 (2) ruim is geformuleerd (zie het woord 'implied'). 
2. "a restriction on disclosure or an abligation of secrecy contained in any statute, inchuding an Act passed after the 1984 Act ('section' 11(2)). "nss

De volgende elementen zijn van belang woor de vraag of materiaal "confidential" is of niet.

1. Allereerst moet de informatie zelf "the necessary quality of confidence" hebben.

2. Verder moet zij "have been imparted in circumstances importing an obligation of confidence."

Het eerste element is niet van toepassing wanneer de informatie "is in the public domain. "Verder verliest informatie haar vertrouwelijke karakter wanneer "it enters the public domain. ${ }^{\text {m.5 }}$

Waar het in deze context vooral om gat is 'journalistic material'. Immers alleen bij deze categorie speelt de vrijheid van meningsuiting en drukpers een rol. 'Journalistic material' is 'excluded material" wanneer het betreft 'documents' of "records other than documents' die een vertrouwelijk karakter hebben. Daaronder vallen documenten die verkregen zijn van derden. Foto's gemaakt van een demonstratie vallen hier niet onder omdat hier die vertrouwensrelatie geen rol speelt. ${ }^{130}$ In feite wordt in de 'Police and Criminal Evidence Act 1984' hetzelfde onderscheid gehanteerd als in de Duitse 'Strafprozeßordnung' zij het dat daar niet dezelfde consequenties aan worden verbonden. In Duitsland is de inbeslagneming voor het aan de dag brengen van de waarheid van journalistiek materiaal dat van derden verkregen is niet toelaatbaar. Dit ter bescherming van de informatiebronnen en in het belang van de vrijheid van meningsuiting en drukpers. In Engeland kunnen documenten van derden verkregen wel in beslag worden genomen bij journalisten zij het dat hier

156 Een woorbeeld wan een "statute' die beperkingen oplegt "on disclosure and obligations of secrecy" is de 'Official Secrets Act 1911'.

157 Vaughan Bevan Ken Lidstone, Guide to the Police and Criminal Evidence Act 1984, London 1985, p. 377; M. Zander, The police and Criminal Evidence Act 1984, London 1990, p. 34; H. Levenson and F. Fairweather, Police Powers, A Practitioner's Guide, London 1990, p. 46.

158 Journalistiek materiaal hoeft niet van een journalist afkomstig te zjjn. Het gaat om het journalistieke doel. Hieronder valt zowel journalistiek onderzoeksmateriaal, als materiaal van derden verkregen. woor journalisticke doeleinden. F. Hargreases and H. Levenson, A Practitioner's Guide to the Police and Criminal Evidence Act, 1984, Legal Action Group 1985, p. 202; H. Levenson and $F_{\text {. }}$ Fairweather, Police Powers, A Practitioner's Guide, London 1990, p. 48.

159 J. Lloyd, The Culture of Press. Freedom, The Police and Criminal Evidence Act, Index on Censorship 8-1988, p. 23. Omdat foto's, tapes, films etc. wan o.a. demonstraties er niet onder wallen zijn journalisten bang dat, wanneer de politie gebiedt dit ongepubliceerde materiaal af te staan, zij door het publiek worden gezien als handlangers wan de politie; Scottish Current Law Statutes 1985, p. 60/1060/11; H. Levenson and F. Fairweather, Police Powers, A Practitioner's Guide, London 1990, p. 48; Zie ook de Duitse regeling in hoofdstuk 2. 
voorwaarden alan worden verbonden wanneer het gaat om een inbeslagneming op de redactie of bij een uitgever of drukker.

\subsection{Toegang tot "excluded material"}

Het belangrijkste verschil tussen een procedure waarin de politie op zoek is naar 'excluded material' en een procedure waarin de politie op zoek is naar materiaal dat geen speciale bescherming geniet is dat met betrekking tot 'excluded material' de politie vraagt om een 'production order' (of een 'warrant' in exceptionele gevallen ${ }^{100}$ ) bij een "circuit judge' (wanneer het niet mogelijk is om toegang te krijgen met de toestemming van de eigenaar). Een 'production order' vereist van de persoon die het bewijsmateriaal bezit dat hij/zij dit materiaal aan de politie overdraagt of dat hij/zij toestaat dat een politieagent toegang krijgt tot het bewijsmateriaal. De persoon voorkomt hiermee een huiszoeking (wordt er nagelaten 'to produce material' dan kan dat "contempt of court' opleveren zie 'Schedule 1 paragraph 15 (1)'). Zodra de bezitter op de hoogte wordt gebracht door de politie door middel van een 'notice' is het verboden om het bewijsmateriaal te vernietigen of te doen verdwijnen. In tegenstelling tot een "search warrant" is een "production order' altijd 'inter partes" ${ }^{\text {164 }}$ Dat wil zeggen dat je de mogelijkheid krijgt om bij de rechter te klagen tegen een voorgenomen of een reeds uitgevoerde inbeslagneming.

Voordat een 'production order' wordt gegeven moet de 'circuit judge' zich ervan overtuigen dat:"

a. er sprake is van materiaal dat bestaat uit of dat bevat "excluded material"152 en

b. dat "the issue of such a warrant would have been appropriate" "Schedule 1 paragraph $\left.3^{\prime}\right)^{1 / 3}$ en

c. er een bevoegdheid bestaat onder een andere "Act" die al bestond vór de 'Police and Criminal Evidence (PACE) Act' uit 1984 ('section' 9(2)).

Wanneer er gến 'Act' bestond vóór 1984 dan is de 'PACE Act' ook niet van toepassing.

160 In bijzondere omstandigheden, bijwoorbeeld in het geval van 'disorder and crüme, mational security and interests of justice' is het mogelijk dat een 'judge' een 'warrant" verstrekt in plaats van een 'production order'. H. Levenson and F. Fairweather, Police Powers, A. Practitioner's Guide, London 1990 , p. 39.

161 R. ws. Leicester Crown Court ex p DPP (1987) 1 WLR 1371.

162 Een 'circuit judge' mag ook een 'production order' bevelen wanmeer het betreft bewijsmateriaal dat 'additional' is "to the excluded materiall'. H. Levenson and F. Fairweather, Police Powers, A. Practitioner's Guide, London 1990 , p. 49.

163 H. Lovenson and F. Fairweather, Police Powers, A Practitioner's Guide, London 1990, p. 49-50. 
Men wilde voorkomen dat de mogelijkheden uitgebreid zouden worden in de nieuwe regeling. Het gaat hier immers om de bescherming van informatiebronnen $n^{i s}$ en de vrijheid van meningsuiting en drukpers alsook om de privacy. Vooral dit laatste heeft een rol gespeeld bij het redigeren van procedurele waarborgen bij een huiszoeking ter inbeslagneming van 'excluded material'. Bestond er vór 1984 wel al een andere 'Act' dan is nu de 'Act' uit 1984 van toepassing tenzij er onder de oude 'Act' een "written authority other than a warrant" nodig was om toegang te verkrijgen tot 'excluded material'. Dan behouden deze 'Acts' hun geldigheid (zie onder andere de 'Official Secrets Act', de 'Obscene Publications Act" en de "Public Order Act'). ${ }^{165}$

\subsubsection{Betekenis van 'special procedure material'}

a. In 'section' 14 (2) staat dat 'special procedure material' 'evidence' is "which is subject to an express or implied undertaking of confidentiality or a statutory restriction on disclosure of obligation of secrecy (for instance under the Official Secrets Act) by someone who acquired it or created it in the course of a trade, business, profession of other occupation or for the purpose of any office wether paid or unpaid."

b. Verder is op grond van 'section' 14 (1)(b) 'journalistic material" 'special procedure material' in die gevallen dat het niet geclassificeerd kan worden als 'excluded material', oftewel omdat het geen documenten betreft oftewel zijn het documenten maar voldoen ze niet aan de eis van vertrouwelijkheid (bijvoorbeeld een film of foto van een demonstratie). ${ }^{106}$

Wanneer de politie toegang wil krijgen tot bewijsmateriaal dat geclassificeerd kan worden als 'special procedure material', en dit is niet mogelijk op grond van toestemming, dan kan dat door een "magistrate" te vragen om een "search warrant" of een 'circuit judge' voor een 'production order' (of 'warrant'). De keuze tussen een 'search warrant' en een 'production order' is afhankelijk van het soort materiaal en van de vraag of er onder een bestaande "statute" de mogelijkheid bestaat om bij een 'magistrate' voor een 'search warrant' te vragen.

164 Attorney-General ws. Mulholland and Foster (1963) 1. All ER 767; Attorney-General ws. Clough (1963) 1 QB 773; British Steel Corporation ws. Granada Television Lid. (1981) 1 All ER 417; O. Robertson and A. Nicol, Media Law: The Rights of Journalists and Broadcasters, London 1990, p. 152.

165 Zie voor een lijst van zulke 'Statutes' appendix 6 'PACE Act'. Zo is het mogclijk voor cen hoofdeommissaris een "written order" te geven woor een huiszoeking in een gevall valn "great emergency if it were in the interests of the State to do so" ('Official Secrets Act 1911 section $9(2)$ '). H. Levenson and F, Fairweather, Police Powers, A Practitioner's Guide, London 1990, p. 49-50.

166 R. vs. Bristol Crown Court ex p Bristol Press and Picture Agency Lid. (1987) Crim. LR 329, 330; F. Hargreawes and H. Levenson, A Practitioner's Guide to the Police and Criminal Evidence Act

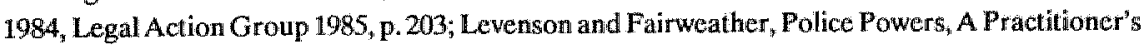
Guide, London 1990, p. 48-50; M. Zander, The Police and Criminal Evidence Aet 1984, London 1990 , p. 35. 
Wanneer het 'special procedure' materiaal niet bestaat uit documenten of andere 'records', en er bestaat de mogelijkheid onder een andere 'statute' om een 'magistrate' te wragen woor een 'search warrant' dan zal de politie dat doen. 'Section' $9(2)$ heeft geen betrekking op 'non-documents or records" wanneer er in een andere "statute" de mogelijkheid bestaat tot een 'search warrant". Echter betreft het "non-documentary special procedure' materiaal waarvoor geen 'statute' geldt en waarvoor dus geen "warrant" kan worden gevraagd of betreft het "special procedure" materiaal hetwelk bestaat uit documenten of 'records' (onafhankelijk van de vraag of er nu wel of niet een bevoegdheid bestaat onder een andere 'statute' om een 'warrant' te vragen); dan kan bij de 'circuit judge' om een 'production order' worden gevraagd. Dit is een uitbreiding van de 'Act'. Blijkbaar was men van mening dat, nu het hier geen vertrouwelijke informatie betreft, dit niet zo'n probleem zou zijn. De vraag is of dit wel zo is. Zo speelt bij journalistiek materiaal of dit nu eigen materiaal betreft of materiaal dat van derden is verkregen de vrijheid van meningsuiting en drukpers een rol. In de volgende paragraaf kunnen we lezen in hoeverre men daar rekening mee heeft gehouden.

\subsection{Toegang tot 'special procedure material'}

\subsection{Een 'search warrant' is niet mogelijk onder een andere "statute"}

De eerste reeks van voorwaarden kunnen we vinden in 'Schedule 1 paragraph 2' Deze reeks van voorwaarden is van toepassing wanneer een 'search warrant" niet verkregen kan of kon worden voor 'documents (records)' en 'non-documents onder een andere 'statute". Deze reeks van voorwaarden geeft de politie een nieuwe bevoegdheid om toegang te krijgen tot bewijsmateriaal. Deze reeks van voorwaarden is echter alleen toepasbaar op 'special procedure' materiaal dat gezien kan worden alls 'evidence of a serious arrestable offence'.

De rechter moet ervan overtuigd zijn dat er redelijke gronden zijn om aan te nemen dat er sprake is van:

1. een 'serious arrestable offence' en

2. er sprake is van materiaal dat bestaat uit 'special procedure' materiaal en niet betreft 'excluded material',

3. verder moet het materiaal 'of substantial value' zijn 'to the investigation of the offence' en

4. moet het materiaal 'relevant evidence' zijn dat wil zeggen 'likely to be admissible at a trial for the offence'. ${ }^{60}$

167 De voorwaarden in a, cen d zijn identiek aan de voorwaarden genoemd in 'section' 8 . Deze voorwalarden hebben betrekking op gewoon materiaal. De politie kan hier om een 'search warrant" vragen bij een 'magistrate', F. Hargreaves and H. Levenson, A Practitioner's Guide to the Police and Criminal Evidence Act 1984, Legal Action Group 1985, p. 203 e.v. 
Bovengenoemde voorwaarden beperken de mogelijkheden van de politie om toegang te krijgen tot bewijsmateriaal door middel van een 'production order'. Op deze manier probeert men rekening te houden met de vrijheid van meningsuiting en drukpers. Alleen is men niet altijd even consequent. Zeker wanneer het gaat om een 'serious arrestable offence' is men geneigd om een 'production order' te onzeilen op grond van de clausule 'public interest'. Er is dan sprake van een uitbreiding van bevoegdheden in de tweede graad. De clausule 'public interest' kan, wanneer zij ruim geïnterpreteerd wordt door de rechter, de hele bescherming die geboden wordt door een 'production order' ondermijnen. In de zaak 'R. vs. Bristol Crown Court ex p Bristol Press and picture Agency Ltd.' moest de 'Divisional Court' bezien of de rechter de voorwaarde 'public interest' juist had geïnterpreteerd. ${ }^{168}$ In deze zaak wilde de politie toegang verkrijgen tot foto's gemaakt van gewelddadige openbare ordeverstoringen. Omdat het ging om journalistiek materiaal ('special procedure material'), en er volgens de politie sprake was van 'evidence of a serious arrestable offence', vroegen zij aan de rechter om een 'order' ('section' 9 en 'Schedule' 1). De 'Divisional Court' echter weigerde het materiaal deze bijzondere bescherming te geven omdat er volgens haar "a very great public interest" aanwezig was. Immers "those guilty of crime, and particularly of serious crime involving widespread public disorder, should be brought to justice."

\subsection{Een 'search warrant' is mogelijk onder een oude 'statute'}

De tweede categorie voorwaarden in 'Schedule 1 paragraph 3' heeft betrekking op 'special procedure material' hetwelk bestaat uit documenten of 'records'. Voordat de 'Act' in werking trad gold hiervoor een 'statute' en een 'search warrant'. Net als bij 'excluded material' is het ook hier niet noodzakelijk voor het geven van een 'production order' dat er sprake is van een 'serious arrestable offence'. Bij beide categorieën van voorwaarden mag een 'production order' worden gegeven ook wanneer het bewijsmateriaal betreft dat 'additional' is 'to the special procedure material'. Het betreft dan de eerste set van voorwaarden ("evidence of a serious arrestable offence for which there were no existing powers to obtain a warrant") en het extra materiaal moet betreffen 'excluded material', dit om te vermijden dat de politie zowel bij de 'magistrate' als bij de 'circuit judge' een verzoek moet indienen. ${ }^{\text {(6) }}$

\subsubsection{Conclusie}

De 'search' van 'articles' is beperkt dit in tegenstelling tot de inbeslagneming die erg ruim is. In principe is de politie bevoegd om grote aantallen documenten in beslag

168 (1987) Crim. LR 329, 330.

$169 \mathrm{H}$. Levenson and F. Fairweather, Police Powers, A Practitioner's Guide, London 1990, p. 49. 
te nemen, Zij het dat de 'Court of Appeal' in de zaak 'Reynolds vs. Commissioner of Pollice of the Metropolis' heeft beslist dat de politie niet bevoegd is om grote aantallen documenten in beslag te nemen zonder aan te geven dat "each file or bundle might reasonably constitute evidence. ${ }^{m 7 x}$ Ook staat in de 'PACE Act' dat de politie niets in haar bezit zal houden wanneer een foto of een "copy' ook voldoende is ('section' 22(4)). Naar mijn mening is dit juist. Op deze manier wordt recht gedaan aan de vrijheid van meningsuiting en drukpers en het proportionaliteitsbeginsel.

Wanneer we het hebben over de inbeslagneming van 'articles' gekoppeld aan de huiszoeking dan dient er een onderscheid gemaakt te worden tussen "legally privileged material', 'excluded material' en 'special procedure material'.

Bij 'legally privileged material' is de inbeslagneming in het geheel niet toegestaan. Voor "excluded material" geldt dat de huiszoeking gebonden is aan een aantal voorwaarden. Om toegang te verkrijgen tot 'excluded material' vraagt de politie bij een "circuit judge" om een 'production order'. Een 'production order' is altijd 'inter partes'. Als gevolg van een 'production order' kan een huiszoeking worden voorkomen. De 'circuit judge' onderzoekt of er een wet bestaat voor $1984^{171}$ en of 'the issue of such a warrant would have been appropiate'. Is dat het geval, en bestaat er geen mogelijkheid onder die oude wet om een 'written order' te geven, dan geldt 'section' 9 (set 2) van de wet uit 1984 .

Bovenstaand geldt eveneens voor de inbeslagneming van "special procedure material'. Zij het dat hier een onderscheid dient te worden gemaakt tussen documenten en 'non-documents'. Voor documenten geldt dat het er niet toe doet of er voor 1984 een wet bestond. In beide gevallen is de wet van 1984 van toepassing. Met dit verschil dat wanneer er al een wet voor 1984 bestond set 2 van toepassing is tenzij er sprake is van een 'written order' dan geldt de desbetreffende 'statute'. Bestond er voor 1984 geen wet en gaat het om documenten die niet vertrouwelijk zijn dan is set 1 van toepassing (er moet sprake zijn van een 'serious arrestable offence'). Dit is een uitbreiding van de "Act".

Gaat het om 'non-documents' en bestond er voor 1984 al een wet dan geldt die oude wet. Indien er geen wet bestond voor 1984 dan geldt de nieuwe wet en is set 1 van toepassing. Ook dit is een uitbreiding van de 'Act'.

170 Slade LJ zei dat: "It is not correct in law for the judge to direct the jury that the reasonableness of the police in executing the search warrant was the only criterion. The jury should have been asked whether in regard to each file, book, bundle or separate document, the officer in question, at the time of the removal, had reasonable cause to believe that it might contain either forged material or evidence showing that the plaintiff was guilty of some other crime." In: Reynolds vs. Commissioner of Police of the Metropolis (1984) 3 All ER 649, CA.

171 Wanneer er geen wet bestat voor 1984 is de "Act' niet van toepassing. 
Schematisch weergegeven:

\section{'Excluded material'}

voorwaarden: 1. 'personal records', 'human tissue or human tissue fluid', 'journalistic material" (betreft 'documents or records other than documents');

2. 'confidential material'.

Een wet vóór 1984: dan is de 'Act' uit 1984, 'section' 9 set 2 van toepassing, tenzij er sprake is van een 'written order' dan is de wet voor 1984 van toepassing.

Geen wet vóór 1984: dan is de 'Act' ook niet van toepassing.

\section{'Special procedure material'}

voorwaarden: 1. "Confidential material which is held by a person who has acquired or created it in the course of any trade, business, profession or other occupation or for the purpose of any paid or unpaid office" ('section' 14 (2));

2. journalistiek materiaal dat oftewel geen documenten betreft oftewel zijn het documenten maar voldoen ze niet aan de eis van vertrouwelijkheid ('section" 14 (1)(10)).

Documenten: vó́r 1984; een wet; set 2 van de 'Act', tenzij een 'written order'. Documenten: vóór 1984; geen wet; set 1 van de 'Act'. Dit is een uitbreiding van de 'Act'.

Geen documenten: vóór 1984; een wet; dan geldt oude wet.

Geen documenten: vór 1984; geen wet; set 1 van de 'Act'. Dit is een uitbreiding van de 'Act'.

Documenten die in strijd met de wet in beslag genomen zijn blijven "admissible evidence'. Voor een persoon waarvan de documenten in beslag zijn genomen of dreigen te worden genomen bestaat de mogelijkheid om 'ex parte' aan de 'judge' te vragen voor een 'interim" of een interlocutoir vonnis. Dit om een inbeslagneming en een 'disclosure' te voorkomen of om aan de rechter een uitspraak te vragen inzake de teruggave van bijvoorbeeld de documenten. ${ }^{1 / 2}$

172 H. Levenson and F. Fairweather, Police Powers, A Practitioner's Guide, London 1990, p. 81. 


\section{De betekenis van art. 10 EVRM in het Engelse recht}

Ondanks de antipathie tegen "declarations of rights and freedoms" was het Verenigd Koninkrijk bet eerste lid van de Raad wan Europa dat de bindende bepalingen van het EVRM ratificeerde. Het Verenigd Koninkrijk accepteerde in eerste instantie niet een wan de belangrijkste elementen van het Verdrag, namelijk de mogelijkheid van een individu om te klagen bij de Commissie in Straatsburg. ${ }^{173}$ Pas in 1966 maakte de Engelse regering de weg vrij voor het individueel klachtrecht. ${ }^{174}$

Het Verenigd Koninkrijk hanteert een dualistisch stelsel. Voor de implementatie van art. 10 EVRM is verdere actie noodzakelijk van de regering of het parlement. ${ }^{25}$ Het Verenigd Koninkrijk is een van de weinige landen die hebben verklaard dat de Conventie niet afdwingbaar is bij de Engelse gerechten. ${ }^{176}$ Een van de belangrijkste redenen hiervoor is de 'sovereignty of parliament'. ${ }^{17}$

De impact van de Conventie op de klassieke grondrechten in het 'Common Law' stelsel was, tot eind jaren zeventig, vrijwel nihil. Individuele rechters in de 'Court of Appeal' en de 'House of Lords' hielden bij hun uitspraken nauwelijks rekening. met de Corventie. De Conventie had bijna geen inwloed op de ontwikkeling van het 'Common Law' stelsel wanneer het ging om "civil liberties'. Het 'Home Office", het orgaan waar de meeste wetgevingsherzieningen worden voorgesteld, verwees zelden in haar openbare documenten naar de Conventie. En wanneer er al gekeken

173 Men dacht dat dat niet nodig zou zijn. De bescherming van de klassieke grondrechten in het Verenigd Koninkrijk woldeed immers, althans zo dacht men toen, aan de Conwentie. Echter in alle gevallen die voor het Hof kwamen eiste de Conventie een grotere bescherming dan de regering of het parlement geboden had of had kumnen bieden. Zie o.a. de Sunday Times case (Times Newspapers Ltd. ws. UK (1979), European Human Rights Reports 1979, p. 245).

174 Patricia Hewitt, The Abuse of Power, Civil Liberties in the UK, London 1982, p. 81; M.P. Furmston/ R. Kerridge/ B.E. Sufrin, The Effect on English Domestic Law of Membership of the EC and the Ratification of the European Convention on Human Rights into United Kingdom Domestic Law, The Hague 1983, p. 248; J. McBride, The ECHR and the Protection of Civil Liberties in the UK in: P. Wallington, Civil Liberties, Oxford 1984, p. 201.

175 D. Pollard and D. Hughes, Constitutional and Administrative Law; Text and Materials, London 1990; Roger Kerridge, Incorporation of the European Convention on Human Rights into United Kingdom Domestic Law, The Hague 1983 in: M.P. Furmston/R. Kerridge/B.E. Sufrin, The Effect of Membership of the EC and the Ratification of the European Convention on Human Rights into United Kingdom Domestic Law; A.L. Drzenczewski, European Human Rights Convention in Donestic Law, A Comparative Study, Oxford 1983.

176 Patricia Hewitt, The Abuse of Power, Civil Liberties in the UK, London 1982, p. 81.

177 S.A. de Smith, Constitutional and Administrative Law, London/Harmondsworth 1985, 5th edn., p. 75-94; D. Pollart and D. Hughes, Constitutional and Administrative Law: Text and Materials, London 1990 , p. 240-246; Roger Kerridge, Incorporation of the European Convention on Human Rights into United Kingdom Domestic Law in: M.P. Furmston/R. Kerridge/B.E. Sufrin, The Effed on English Domestic Law of Membership of the EC and the Ratification of the European Convention on Human Rights into United Kingdon Domestic Law, The Hague 1983, p. 251; A. L. Drzemcrewski, European Human Rights Convention in Domestic Law, A Comparative Study, Oxford 1983, p. 178. 
werd naar de bepalingen in de Conventie dan was dat vaak onvolledig. $Z$ o keek het 'Phillimore Committee" voor wat betreft het rapport over "Contempt of Court" alleen naar de bepalingen die betrekking hebben op een "fair trial' en niet naar de bepalingen die betrekking hebben op de vrijheid van meningsuiting en drukpers.

Sinds eind jaren zeventig is dat wat aan het veranderen. In een toenemend aantal gevallen refereren de gerechten naar de Conventie "to try to resolve uncertainties in the common law. ${ }^{\text {n78 }}$ Om de invloed van de Conventie te vergroten zou het goed zijn wanneer alle wetgevingsorganen in hun "White Paper' aangaven wat de relatie is tussen hun wetgevingsvoorstellen en de Conventie. Ook zouden parlementaire overwegingen met betrekking tot de Conventie moeten worden geïnstitutionaliseerd in bijwoorbeeld een 'Committee Stage of a Bill' ${ }_{x}$ "

\section{Conclusie}

In dit hoofdstuk werd de relatie tussen de vrijheid van meningsuiting en drukpers en het dwangmiddel inbeslagneming besproken in Engeland. Centraal stond de vraag in hoeverre de vrijheid van meningsuiting en drukpers een belemmering vormt voor de toepassing van het dwangmiddel inbeslagneming. Aangezien Engeland geen geschreven constitutie kent werden in dit hoofdstuk een aantal van de belangrijkste 'Acts' besproken. Belangrijk omdat deze 'Acts', in casu de 'Contempt of Court Act', de "Obscenity Act”, de 'Official Secrets Act', de 'Race Relations Act' en de 'Public Order Act' op negatieve wijze de reikwijdte weergeven van de vrijheid van meningsuiting en drukpers. Wat op grond van de diverse 'Acts' en de jurisprudentie geconcludeerd kan worden is dat in Engeland door de ruime formulering in de wet van bijwoorbeeld begrippen als 'official secrets' nauwelijks enige speelruimte bestaat voor de vrijheid van meningsuiting en drukpers. Ook is de regel "no prior restraint' die. van belang is voor de vrijheid van meningsuiting en drukpers witgehold door de "interim injunctions' uit het civiele recht. Zoals we hebben gezien in de vorige paragrafen is de "interim injunction" een civiele sanctie die tot gevolg heeft dat een publicatie gestaakt moet worden zolang het civiele proces duurt. Blijkt er na afloop van thet proces dat er geen sprake is van een 'breach of confidence' dan kan de publicatie verouderd zijn. Een reden waarom een civiele procedure en geen strafrechtelijke procedure wordt aangespannen is de mogelijkheid om zonder jury en zonder een zware strafrechtelijke bewijslast te procederen. In feite komt dit neer op 'détournement de pouvoir" en is het in strijd met het recht op een 'fair trial'. In art. 10 van het EVRM staat dat beperkingen op de vrijheid van meningsuliting en drukpers "noodzakelijk moeten zijn in een democratische samenleving." De wraag is of deze civiele

178 Zie de zaak R. vs. Lemon and Gay News Lid. (1979) 1 All ER 898; G.leaves vs. Deakin and Others (1979) 2 All ER 497.

179 Jeremy McBride, The European Convention on Human Rights and The Protection of Civil Liberties in the UK in: P. Wallington, Civil Liberties, Oxford 1984, p. 216-218. 
procedure en sanctie noodzakelijk is? Nu er een alternatief bestaat, namelijk een strafrechtelijke procedure en een strafrechtelijke sanctie achteraf, moet deze vraag volgens mij ontkennend worden beantwoord.

Een ander voorbeeld dat ik reeds heb besproken en dat goed weergeeft in welke mate de vrijheid van meningsuiting en drukpers in Engeland bestaansrecht heeft is het informele systeem van censuur. Niet alleen bestaat er formele censuur als gevolg van 'pre-trial injunctions' ook bestaat er een informeel systeem van censuur en controle zoals de 'Services, Press and Broadcasting Committee', 'British Board of Film Censors', en 'D-notices'. Aan uitgevers wordt gevraagd om bijvoorbeeld materiaal dat "would have an effect prejudicial to the national interest" niet te publiceren. Het nadeel van dit informele systeem van censuur is dat veel zaken niet meer binnen het juridische circuit worden afgehandeld. Er vindt geen rechterlijke toetsing plaats of er wel sprake is van "material that would have an effect prejudicial to the national interest. "nso

De conclusie die we uit het voorafgaande kunnen trekken is dat de vrijheid van meningsuiting en drukpers, zoals deze op negatieve wijze is geformuleerd in de 'Acts', nauwelijks belemmeringen opwerpt voor de toepassing van het dwangmiddel inbeslagneming. De vrijheid van meningsuiting en drukpers zoals deze staat geformuleerd in art. 10 EVRM verandert hier niet zoveel aan omdat de Engelse rechter, ondanks de vele art. 10 EVRM procedures waarin Engeland partij was, nauwelijks rekening houdt met de art. 10 uitspraken van het Europese Hof. ${ }^{\text {s1 }}$

De geringe ruimte die aan de vrijheid van meningsuiting en drukpers wordt geboden heeft zijn weerslag op de inbeslagneming van gegevensdragers. Deze is in alle

180 En dit terwijl in Engeland bij de 'contempt of court' wetgeving, wanneer het gaat om een afweging tussen het 'fair trial' beginsel en het recht van de pers om gegevens opentbaar te maken, veellal gekozen wordt voor het eerste ook al is dit niet altijd in overeenstemming met art. 10 EVRM. Volgens het Europese Hof bevat art. 10 "a principle of freedom of expression that is subject to a number of exceptions which must be narrowly interpreted." De uitdrukking "authority and impartiality of the judiciary has to be understood within the meaning of the Convention." Vervolgens onderzoekt het Hof of "the interference corresponded to a pressing scoilal need whether it was proportionate to the legitimate aim pursued, whether the reasons given by the national authorities to justify it are relevant and sufficient under art. 10 (2) EVRM."

181. Waar het in Engeland veelal aan ontbreekt is 'visie'. Beslissingen worden veelal ad-hoc genomen, dat brengt ook het systeem wan 'juridical law-making' met zich mee. Een constitutionele garantic van de drukpersvrijheid in een 'Bill of Rights' zou de rechters wellicht meer houvast bieden bij de interpretatie van "liberties". M. Supperstone, Brownlie's Law of Public Order and National Security, London 1981, p. 334-340; P. O'Higgens, Cases and Materials on Civil Liberties, London 1980, p. 49-61; G. Robertson, Freedom, The Individual and the Law, Harmondsworth 1989, 6th edn., p. 387-402; Lord of Hampstead, Do we need a Bill of Rights?, The Modern Law Review 1976, p. 121-129; Lord Scarman, Human Rights, The Current Situation in: C. Campbell (ed.), Do we need a Bill of Rights?, 1980, p. 2.9\% R.J. Lawrence, Rights and Remedies in: C. Campbell (ed.), Do we need a Bill of Rights?, 1980, p. 10-16; Lord Wade, Introducing a Bill of Rights in: C. Campbell (ed.), Do we need a Bill of Rights?, London 1980, p. 17-22; J. Jaconelli, Enacting a Bill of Rights, The Legal Problems, Oxford 1980. 
bovengenoemde 'Acts", met uitzondering van de 'Contempt of Court Act', zeer ruim geregeld. In de "Contempt of Court Act" is aansluiting gezocht met de 'Police and: Criminal Evidence Act 1984". Op grond van de PACE-Act is de inbeslagneming van 'materials' bij een huiszoeking aan beperkingen onderworpen. Dit heeft vooral te maken met de bescherming van de privacy. Men heeft hierbij niet in eerste instantie gedacht aan een bescherming van de vrijheid van meningsuiting en drukpers. Toch doen de procedurele waarborgen die in het leven zijn geroepen bij een huiszoeking indirect recht aan de vrijheid van meningsuiting en drukpers. Bij een 'search' wordt speciale bescherming toegekend aan 'excluded material', 'special procedure material' en 'legally privileged material'. Zo mag 'legally privileged material' niet in beslag worden genomen en is de inbeslagneming van 'excluded' en 'special procedure material' alleen mogelijk wanneer de politie een 'production order' aanvraagt bij de 'circuit judge'. Een huiszoeking kan op deze manier worden voorkomen. Ook krijg je de mogelijkheid om bij de rechter te klagen tegen een voorgenomen of een reeds uitgevoerde inbeslagneming. De inbeslagneming van een hele oplage geschriften blijft wel mogelijk zij het dat er rekening wordt gehouden met het proportionaliteitsbeginsel. 
४ै। 


\section{De vrijheid van meningsuiting en drukpers en het straf- vorderlijke dwangmiddel inbeslagneming in Zweden}

\section{Inleiding}

Ook in dit hoofdstuk zal, net als in de voorafgaande rechtsvergeli.jkende hoofdstukken, de relatie worden besproken tussen het strafvorderlijke dwangmiddel inbeslagneming en de vrijheid van meningsuiting en drukpers in $Z$ weden. Centraal staat ook in dit hoofdstuk de vraag in hoeverre de vrijheid van meningsuiting en drukpers een belemmering vormt voor de toepassing van het strafvorderlijke dwangmiddel inbeslagneming. Het bijzondere van Zweden in dezen is, als je het vergelijkt met Nederland, Duitsland of Engeland, dat Zweden een 'Tryckfrihetsförordning' (TF), oftewel een Drukperswet, heeft welke een onderdeel vormt van de Grondwet.' Dit betekent dat 'Tryckfrihetsförordningen' een 'fundamental law" is. Als onderdeel van de Grondwet kan deze wet slechts door een bijzondere gebeurtenis veranderd worden. Allereerst is daarvoor een beslissing nodig, met algemene stemmen, van de 'Riksdag' (parlement). Daarna een bevestigende beslissing, opnieuw met algemene stemmen, in de daaropvolgende zittingsperiode van de 'Riksdag'(die sinds de grondwetswijziging van 1968-1969 nog slechts bestaat uit 1 kamer) ${ }^{2}$ Een rechtvaardiging voor deze extra bescherming van de drukpers is historisch. Het doel van de vrijheid van drukpers in Zweden was in eerste instantie politiek. De vrijheid van drukpers werd gezien als de basis van een vrije en democratische samenleving. Kritiek op het politieke systeem of op zijn machthebbers is niet strafbaar gesteld in het Wotboek van Strafrecht ('Brottsbalken') en de Drukperswet. Nu is het niet zo dat de TF alleen de politieke uitingsvrijheid beschermt. Het eerste artikel van de TF definieert het doel van de perswrijheid als "de vrije uitwisseling van ideeën en het voorlichten van het publiek." De Grondwet garandeert niet alleen de uitingsvrijheid in de politieke sfeer

1 De Zweedse Grondwet bestaat uit het Regeringsdocument ('Regeringsformen'), de Troonopvolgings. wet ('Successionsondningen"), de Drulkperswet ("Tryckfrihetsförordningen") en de Uitingswijheidswet (Yttrandefrihetsgrundlagen'). Zie "Regeringsformen".

2 Olle Nyman, Some Basic Features of Swed dish Constitutional Law in : Stg Strơmhohi, An Introduction to Swedish Law, Uppsalla 1988, p. 47; Hilding Eek, Die Sonderstellung der Presse im Strafverfahren in Schweden, Verhandlungen der Fachgruppe fir Strafrechtsworghlehohung Kiel, Frankfurt a/M $1965-29$, p. 67. 
maar ook in de religieuze, wetenschappelijke, culturele, literaire en sociale sfeer. Alleen reclame wordt niet beschermd in de Drukperswet. ${ }^{3}$

De oudste Drukperswet stamt uit $1766^{*}$ en de jongste uit 1991 . Deze is op 1 januari 1992 in werking getreden. De huidige TF is gebaseerd op de TF van 1949 en is geamendeerd in 1988 en 1991. Daarnaast is in 1992 de Wet op de Uitingsvrujheid ('Yttrandefrihetsgrundlagen" (YF)) in werking getreden. De TF heeft alleen betrekking op gedrukt materiaal en de YF alleen op onder andere geluidsbanden, film ${ }^{\sigma}$, video, radio? en televisie. Alle uitingsvormen worden nu op min of meer dezelfde

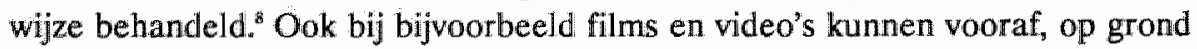
van de inhoud, niet langer beperkingen worden gesteld. Dit was in de periode hieraan voorafgaand wel mogelijk. In de YF wordt uitdrukkelijk verwezen naar de TF. Veel bepalingen zijn hetzelfde. Uitgangspunt is de TF. Deze wet is ook het oudste.

In de TF staan speciale procedureregels voor vitings- en drukpersdelicten. Welke delieten dit zijn zullen we zien in paragraaf 2. Het moge duidelijk zijn dat onder ultings- en drukpersdelicten alleen de in deze wet genoemde strafbare feiten vallen. Andere strafbare feiten vallen gewoon onder de bijzondere wetten zoals het Wetboek van Strafrecht ('Brottsbalken' $(\mathrm{Br} B)$ ) en genieten dus niet de bescherming van de TF." In dit hoofdstuk zuilen zowel de strafrechtelijke-, niet alle strafbare feiten genieten immers de bescherming van de TF, als de strafvorderlijke aspecten van voornoemde wet alan de orde komen. In paragraaf 2.1 tot en met paragraaf 2.3 wor-

3 Hakkan Strömberg, Press Law in Sweden in: Phina Lahav, Press Law in Modern Democracies, A Comparative Study, New York 1985, p. 230-231.

4 Hảkan Strömberg, Press Law in Sweden in: Phina Lahav, Press Law in Modern Democracies, A Comparative Study, New York 1985, p. 229; Olle Nyman, Some Basic Features of Swedish Constitutional Law in: Stig Strömholm, An Introduction to Swedish Law, Uppsala 1988, p. 52; H. Eek, Die Sonderstellung der Presse im Strafverfahren in Schweden, Verhandlungen der Fachgruppe für Strafrechtsvergleichung Kiel, Frankfurt a/M 1965-29, p. 67.

5 (SOU) 1983:70, Vărna Yitrandefriheten, Förslag av Yttrandefrihetsutredningen; (Ds. Ju.) 1985:4, Remissyttranden över Yttrandefrihetsutredningens betänkande; Regeringsformen in: Massmedia 1991, Appendix p. 455; (SFS) (14-11-1991) 1991:1469, 1470, 1500.

6 In de periode voorafgaand aan 'Yitrandefrihetsgrundlagen' van 1991 konden films, voordat ze aan het publiek werden vertoond, gecensureerd worden door de Nationale Film Raad. Deze kon bepaalde passages uitwissen of de film in zijn geheel verbieden. SOU 1969:14, Filmen - censur och answar.

7 Erik Holmberg, Frihet och answar i tryck och radio, Stock holm 1968; C.W. Nisser, The Freedom of Expression in the Swedish Radio and TV, Revue des droits de l'homme, nr. 1, 1975.

8 Erik Holmberg, Frihet och answar i tryck och radio, Stockholm 1968; C.W. Nisser, The Freedom. of Expression in the Swedish Radio and TV, Revue des droits de l'homme 1975, p. 145-150. Voor radio en film gelden technische beperkingen ondat er maar cen beperkt aantal golffrequenties. beschikbaar zijn. SFS (14-11-1991) 1991:1469, 1991:1500. Ds. Ju. 1975:49, Massmediegrundlag; Ds. Ju. 1976:2, Remissytranden över massmedieutredningens betärnkande; SOU 1983: 70, Varna Yttrandeliriheten, Förslag av Yutrandefrihetsutredningen Ds. Ju. 1985:4, Remissyttranden över Yttrandefrihetsutredningens betänkande.

9 Håkan Strömberg, Tryckfrihetsrätt, Lund 1989 p. 45. 
den de verschillende delicten opgesomd die onder de speciale bescherming van de TF vallen. In paragraaf 3 komen dan de strafvorderlijke aspecten van de TF aan de orde. In deze paragraaf zal vooral aandacht worden besteed aan de vraag wat de reikwijdte is van de inbeslagneming van gegevensdragers en wie er bevoegd zijn tot de inbeslagneming van gegevensdragers. Verder zal in paragraaf 4 de juridische procedure aan de orde komen ondat deze bij uitings- en drukpersdelicten afwijkt van de reguliere strafrechtelijke procedure. Ook zal ik in paragraaf 5 de juridische aansprakelijkheid bij drukpersdelicten bespreken. In de laatste paragraaf komt dan nog het Europees Verdrag voor de Rechten van de Mens aan de orde, voor zover het betrekking heeft op de vrijheid van meningsuiting en drukpers.

\section{De strafrechtelijke aspecten van 'Tryckfrihetsförordningen'}

In hoofdstuk 2 paragraaf 1 sub 1 en 2 van 'Regeringsformen' staat dat elke burger het recht heeft mondeling, door middel van geschriften en afbeeldingen, gedachten, ideeën en gevoelens te uiten. Behalve de uitingsvrijheid valt ook de informatievrijheid, de verspreidings- en de ontvangstvrijheid onder paragraaf 1 van 'Regeringsformen'. In paragraaf 12 en 13 van datzelfde hoofdstuk kunnen we lezen dat de uitingsvrijheid en de informatievrijheid kunnen worden beperkt. ${ }^{10}$ In Zweden is, evenals in andere landen, de vrijheid van meningsuiting en drukpers aan grenzen gebonden in die zin dat misbruik van de vrijheid van meningsuiting en drukpers strafbaar wordt gesteld. ${ }^{11}$ In hoofdstuk 7 paragraaf 4 en 5 van de TF staat nauwkeurig aangeven wat de uitingsen drukpersdelicten zijn.

\subsection{Hoofdstuk 7 paragraaf 4 "Tyckfrihetsförordningen" ${ }^{12}$}

Volgens paragraaf 4 van de TF uit $1991^{13}$ zijn uitings- en drukpersdelicten:

1. Hoogverraad (dat wil zeggen het onderwerpen van Zweden of een deel van Zweden aan een buitenlandse mogendheid) (BrB 19:1, 14).

2. Het aansporen tot oorlog waarbij Zweden het risico loopt betrokken te worden (BrB 19:2).

3. Spionage (BrB 19:5, 6).

4. Onbevoegde handelingen ten aanzien van een geheim bericht.

5. Idem 4 in geval van nalatigheid.

10 Ur Regeringsformen in: Massmedia 1991, Appendix p. 455.

11 SOU 1969:38 Yttrandefrihetens, gränser; Hans-Gunner Axberger, Tryckfrilhetens Gränser, Stockhoilm 1984 , p. 163 e.v.

12 SFS 1991:1469, 1470, 1500.

13 SFS 1991:1469, 1470, 1500 . 
6. Opruing, met de intentie de regering met geweld omver te werpen (BrB 18:1, 7)

7. Verraad in tijden van oorlog, noodtoestand en bezetting (BrB 22:1-2,7).

8. Idem 7 in geval van nalatigheid (BrB 22:3).

9. Het verspreiden van geruchten in tijden van oorlog of noodtoestand (BrB 22:5).

10. Het opruien tot bepaalde strafbare feiten (onder andere het verwaarlozen van de burgerlijke plichten) ( $\mathrm{BrB} 16: 5)$.

11. Bedreigingen tegen een groep mensen van een bepaald ras, huidskleur, nationaliteil, etnische minderheid of religieuze overtuiging ( $\mathrm{Br} B$ 16:8) ${ }^{\text {i4 }}$

12. Pornografische afbeeldingen van kinderen ( $\mathrm{BrB} 16: 10 \mathrm{a}) .^{15}$

13. Pornografie met geweld ( $\mathrm{BrB} 16: 10 \mathrm{~b}, 10 \mathrm{c})$. $^{16}$

14. Inbreuken op de privacy (BrB 5:1 lid 2).

15. Sexediscriminatie (BrB 16:9 3e lid).

16. Laster, smaad (BrB 5:1, 2, 4), ${ }^{\text {: }}$ laster ten aanzien van een overleden persoon (BrB 5:4) en belediging door middel van aanstootgevende taal gericht tot een bepaald persoon (BrB 5:3).

Bovengenoemde strafbare gedragingen staan, zoals we hierboven hebben kunnen zien, ook genoemd in het Wetboek van Strafrecht ('Brottsbalken' (BrB)). ${ }^{19}$ Dit is van belang omdat voor de verboden uiting en publicatie geldt, dat deze slechts dan strafbaar zijn indien deze zowel in de TF als in de BrB staan opgesomd. ${ }^{20}$ In het

14 Hoofdstuk 16 \% Brottsbalken'. Niet alleen de in het openbaar uitgesproken uitingen maar elke bedreigende of vernederende uiting die verspreid wordt is strafbaar gesteld. SOU 1981:38, Om hets mot folkgrupp; H. Danelius, Mänsliga Rättigheter, Lund 1989, p. 218; NJA. 1969, p. 364; NJA 1978, p. 3; JK Beslut 1981-4-16, Dnr. 944-82-31, p. 196-197 (B2) en 1983-01-17, Dnr. 79-83-30, p. 271-272 (B1).

15 Ds. Ju. 1978:8, Barnpornografi betänkande av Yttrandefrihetsutredningen, Stockholm 1978; NJA 1979, p. 535 c.w. Lagstiftning mot barnpornografi; JK Beshat 1982-11-16, Dnr. 2626-82-30, p. 200-202 (B5).

16 Dit artikel vervangt de oude artikelen die betrekking hadden op films en video's met sexuele geweldscenes. Daardoor is de reikwijdte van de pormografiewetgeving wergroot. Ook het maken en verspreiden van foto's, films en video's of TV-uitzendingen met sexuele geweldscenes of het gebruik van ernstig geweld tegen mensen of dieren wordt bedreigd met 6 maanden gevangenisstraf. Verder is het verboden om films en video's met een gewelddadige inhoud beschilkbaar te stellen aan kinderen beneden de 15 jaar (hoofdstuk 16 \$ 10e 'Brottsbalken'). Lag 1990:894, SFS 1991, 1500; SFS 1985:989-993, 1060; SFS 1986:18.

17 Ten aanzien van de nrs. 14 en 15 geldt dat de $\mathrm{BrB}$ enigszins afwijkt in betekenis van de TF.

18 NJA 1966, p. 565; SvJT 1970 rf, p. 2; NJA 1976, p. 150; NJA 1987, p. 285 1; NJA 1987, p. 285 11; NJA 1988, p. 118.

19 Sveriges Rikes Lag 1991; Nils Jareborg, Brotten III, Institutet för Rättswetenskaplig Forskning, Lund 1982, p. 215 e.v; Nills Jareborg, Yttrandefrihetsbrott, Institutet för Rättvetenskaplig Forskning Skrifter 14, Stockholm 1987, p. 233 e.v.

20 Wordt er een nieuwe restrictievere strafwet ingevoerd dan betckent dit dat eerst de Drukperswet moet worden geamendeerd willen deze nïeuwe bepalingen toegepast kunnen worden ${ }_{n}$ Van de andere 
algemeen corresponderen de betreffende bepalingen in de $\mathrm{BrB}^{\mathrm{n}}$ met de bepalingen in de TF. Uitzonderingen zijn commerciele advertenties (TF 1:9 ${ }^{23}$, het in het openbaar tentoonstellen van pornografische foto's of het tegen iemands wil aan hen opsturen van pornografische foto's (TF 6:2, BrB 16:11), het verspreiden van pornografische publicaties of foto's onder jongeren en kinderen (TF 6:2, BrB 16:12) ${ }^{24}$, de verspreiding aanstootgevende folders op een openbare plaats (BrB 16:16) ${ }^{2 s}$, en de verspreiding van kaarten en foto"s die informatie bevatten die de nationale veiligheid in gevaar zou kunnen brengen (TF 6:2, BrB 20:3) ${ }^{26}$. Deze zaken worden door de gewone wet of de strafwet verder afgehandeld en genieten niet de bijzondere bescherming van de TF (TF 6:2).

\subsection{Veranderingen}

Sinds de jaren zestig zijn de strafbaarstellingen van bepaalde uitingsvormen geschrapt uit 'Tryckfrihetsförordningen' en uit 'Brottsbalken', zoals smalende godslastering, belediging van de 'Riksdag' en belediging van buitenlandse staatshoofden of diplomaten. In 1971 zijn de bepalingen die belediging en vernedering van de nationale Zweedse symbolen of van een buitenlandse staat inhouden afgeschaft. En in 1976 zijn de bepalingen inzake opruiend smaadschrift, belediging van de koning en/of functionarissen in een overheidsfunctie afgeschaft evenals de regels die de verspreiding van geruchten verbieden wanneer deze de voedselvoorziening in gevaar brengen of die het gezag van publieke functionarissen of de nationale veiligheid ondermijnen in perioden van relatieve rust. Koningen, publieke functionarissen en buitenlandse staatshoofden en diplomaten worden gelijk gesteld aan de burger. Kritiek op de staat, het politieke systeem, de constitutie, regering, 'Riksdag' en gerecht ${ }^{27}$ is toegestaan.

kant is het zo dat wanneer de strafwet liberaler wordt deze verandering direct in werking treedt. Nils Jareborg, Brotten 11, Institutet för Rättvetenskaplig Forskning Lund 1982, p. 214 ; Nills Jareborg, Yttrandefrihetsbrott, Institutet för Rättwetenskaplig Forskning, Skrifter 14, Stockholm 1987, p. 233.

21 Nils Jareborg, Yttrandefrihetsbrott, Institutet fòr Rättvetenskaplig Forskning, Skrifter 14, Stockholm 1987, p. 234; Nils Jarcborg Brotten III, Lund 1982, p. 214-215.

22 Sveriges Grundlagar 1989, Riksdagen, p. 71 e.v.; Regeringsformen, Massmedia 1991, p. 455 e.v.; 14-11-1991, Svensk. Författningssarnling 1991:1469; 1470, 1500.

Lag 1978:763, 764; Hăkkan Strömberg, Tryckfrihetsrält, Lund 1989, p. 51.

NillsJareborg, Brotten III, Irastitutet för Rättswetenskaplig Forskning, Lund 1982, p. 116-120; Hakan Strömberg, Tryckfrihetsrätt, Lund 1989, p. 54-55.

25 NJA 1935, p. 113; NJA 1944, p. 702. Het ging hier on anti-nazist ische en anti-semitische folders. Zie ook NJA 1956, p. 48; NJA 1957, p. 352.

6 Lag 1975:370; Lag 1970:371.

De regel "Contempt of Cowrt" uit het Angelsaksische rechtssysteem is in Zweden onbekend. 
Ondanks bovengenoemde liberalisering is de catalogus met verboden uitingen in 'Tryckfrihetsförordningen' en 'Brottsbalken' ook uitgebreid. In 1970 werd, onder invloed van het Internationale Verdrag ter bestrijding van Rassendiscriminatie, smaadschrift strafbaar gesteld ten aanzien van raciale, etnische, nationale en religieuze groepen. ${ }^{28}$ Daarnaast werd in 1965 opruiing tot oorlog en in 1979 kinderpornografie

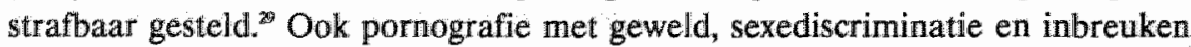
op de privacy (hoewel dit laatste waarschijnlijk een zaak zal blijven van zelfregulering door de pers) zijn sinds 1 januari 1989 in "Brottsbalken" en in "Tryckfrihetsförordningen ${ }^{393}$ verboden (voor de twee laatst genoemde geldt het verbod echter eerst sinds januari 1992). . $^{32}$

\subsection{Hoofdstuk 7 paragraaf 5 'Tryckfrihetsförordningen'}

Paragraaf 5 van de TF is hetzelfde gebleven als paragraaf 5 van de TF uit 1988 . In TF 7:5 en in de 'Brottsbalken' (hoofdstuk 19, 20, 21, 22) ${ }^{3 x}$ staan de publicatieverboden die betrekking hebben op het openbaar maken van geprivilegeerd materiaal. Zo is het verboden feiten te publiceren die een misdaad zijn tegen de nationale veiligheid, zoals bijwoorbeeld spionage ${ }^{34}$ Ook is het verboden opzettelijk officiële documenten te publiceren die vallen onder 'Sekretesslagen'. In 'Sekretesslagen' uit 1980 hoofdstuk 16 staat precies aangegeven wat onder geheim materiaal wordt verstaan. ${ }^{39}$ Deze wet omvat 43 eng geredigeerde categorieën van documenten ${ }^{36}$ die

28 Lag 1970:225.

29 Lag 1979:375.

30 SFS 1988:835.

31 Lag 1988:1448. Ook is in "Tryckfrihetsförordningen' $v a n 1989$ het onderscheid tussen ontoelaatbare meningsuitingen in drukwerken en ontoelaatbare openbaarmaking van bepaalde gegevens in drukwerken vervallen.

32 SFS 1991:1469, 1470, 1500 .

33 Nils Jareborg, Yttrandefrihetsbrott, Institutet för Rättvetenskaplig Forskning Skrifter 14, Stockholm 1987, p. 235; Hakkan Strômberg, Tryckfrihetsrätt, Lund 1989, p. 60-62; Nils Jareborg, Bronten Ill, Instilutet fồ Răttwetenskaplig Forskning, Lund 1982, p. 215 e.v.

34 NJA 1975, p. 585; SwJT 1974, p. 84; KU 1974: 22, p. 6ff en p. 166ff; NJA 1978, p. 81.(c). De Zweedse 'Watergate' affaire in: Jan Guillou, 'A Swedish Watergate', Index on Censorship 2-1974, p. 29-33; Hugo Melander, More on the Swedish Watergate', Index on Censorship 3-1974, p. 107-108; Propositioner 1975/1976: 204, p. 76; SOU 1976: 36 Anonymitet och tvagsmedel; Hans-Gunner Axberger, Tryckfrihetens Gränser, Stockholm 1984, p. 312.

35 Nils Jareborg, Yttrandefrihetsbrott, Institutet tör Rättwetenskaplig Forskning Skrifter 14, Stockholm 1987 , p. 235 e.v; ; Hakan Strömberg, Handlingsoffentlighet och sekretess, Lund 1986; S. Wernstedt, Offentlighets- och sekretesspraxis efter 1980 Stockholm 1985; Ds. Ju. 1981:17 Sekretessydd- och informationsbehov; Sekretesslagen 1980 års lagstiftning, med kommentarer, 1980; L. Lillieroth, Lärobok om Sekretesslagstiftningen, Göteborg 1984; Propositioner 1979/1980: 2 Sekretess; H. Corell, O. Egerstedt, S. Heuman, G. Regner, Sekretesslagen, 1980 års lagstiftning med kommentarer, Stockbolm 1980. 
onder andere betrekking hebben op de staatsveiligheid en buitenlandse betrekkingen als ook op strafrechtelijk onderzoek, de persoonlijke integriteit en de tinanciele situatie van burgers. ${ }^{37}$ Wanneer informatie, die valt onder bovengenoemde categorieen, uitlekt en gepubliceerd wordt door de pers, dan is alleen de redacteur aansprakelijk. De informatiebron wordt door de wet beschermd. Een ambtenaar die een krant geheime informatie geeft die hij heeft verzameld in zijn functie heeft het recht deze informatie te geven aan een krant ook al is deze informatie geheim. Sinds 1976 is een ambtenaar die weigert documenten openbatar te maken persoonlijk aansprakelijk voor die beslissing, en onderworpen aan sancties indien de weigering niet gerechtvaardigd kan worden door 'Sekretesslagen". ${ }^{\text {.11 }}$ De geheimhoudingsplicht. is dus nauw gelleerd aan het openbaringsrecht en kan alleen doorbroken worden wanneer het gaat om een opzettelijke inbreuk op de verplichting tot geheimhouding in de zaken die genoemd worden in het laatste hoofdstuk van "Sekretesslagen". Het principe dat burgers toegang moeten hebben tot publieke documenten is geba-

36. De indexen van alle documenten, ook die documenten die onder een van de 43 categorieèn vallen, zijn voor het publiek beschikbaar. Dit geldt eveneens voor de titel van de stukken. James Michael, The Politics of Secrecy: The Case for a Freedom of Information Law, London 1979, p. 23.

37 Ook werkmateriaal is niet beschikbaar totdat er een beslissing is genomen. Dit geldt alleen voor werkmateriaal binnen een bepaald departement. Wanneer deze papieren worden gestuurd naar andere departementen voor commentaar dan worden het documenten die openbaar zijn voor het publiek. James Michael, The Politics of Secrecy: The Case for a Freedom of Information Law, London 1979, p. 23.

38 De beperking van de verantwoordelijkheid zal nog uitgebreid aan de orde komen.

39 Patricia Wilhelm, Protection of Sources, An International Review of Journalistic and Legal Practice, The Niorwegian Institute of Journalism/International Federation of Journallists, Fredrikstad 1988, p. 166 e.v.

40 Zijn superieuren hebben niet het reclit uit te zoeken wie deze informatic heeft verspreid. Op deze manier komen kranten in het bezit wan veel informatie over publieke instellingen en het werk dat daar wordt verricht. Olle Nyman, Some Basic Features of Swedish Constîution in: Stig Strömholm, An Introduction to Swedish Law, Uppsala 1988, p. 76.

41 Er bestaat de mogelijkheid om in appel te gaan tegen cen weigering om een document te openbaren en wel bij de Ombudsman of de hoogste administratieve rechter. Tegen cen beslissing van de minister kan niet in beroep worden gegaan. Dit komt omdat de Zweedse ministeries kleine organen zijn die de minister adviseren in politieke kwesties. Zij hebben niets te maken met de administratie. De administratieve departementen voeren de politiek uit en zijn onafhankelijk. De minister is niet verantwoordelijk voor wat zij docn. De documenten waarover deze administratieve departementen beschikken zijn openbaar. Hier bestaat wel de mogelijkheid om \|cgen een beroep op geheimhouding in beroep te gaan. Het Zweedse systeem is overgenomen door Finland, Denemarken en Noorwegen. De Nederlandse Wet Openbaarheid van Bestuur uit 1978 is geïspireerd door de Deense. James Michael, The Politics of Secrecy, The Case for a Freedom of Information Law, London 1979, p. 24.

42 H. Corell, O. Egerstedt, S. Heuman, G. Regner, Sekretsesslagen, 1980 ärs lagstiftuing med kommentarer, Stockholm 1980, p. 72 e.v.; Ds. Ju. 1981:17, Sekretessydd - och informationsbehov; E. Holmberg, Offentlighetsprincipen och myndigheterna, Siockholm 1987, p. 20 e.w. 
seerd op de TF $2: 1$, wit 1949.3 Niet alleen omdat er burgers zijn die wensen die documenten te drukken maar ook omdat er mensen zijn die van de inhoud gebruik willen maken bij het schrijven van een artikel of die graag het document willen lezen uit persoonlijke interesse.

\section{De strafvorderlikke aspecten van "Tryckfrihetsförordningen"}

In Zweden zijn er bij de vervolging wan drukpers- en uitingsdelicten speciale procedurele regels in het leven geroepen. Zo schrijft de wet voor dat bij bijwoorbeeld een drukpersdelict (TF 7:4,5) niemand vervolgd of veroordeeld mag worden en dat de publicatie niet mag worden verbeurd verklaard of in beslag genomen anders dan in deze wet is voorgeschreven (TF 1:3).

\subsection{De strafvorderlijke dwangmiddelen in "Tyckfrihetsförordningen"}

De Zweedse burger heeft het recht te publiceren zonder beperkingen wooraf. Zowel het openbaringsrecht als het verspreidingsrecht wordt beschermd (TF 1:2). Censuur is verboden. Met censuur wordt bedoeld; beperkingen vooraf op het openbaringsrecht. $^{45}$ In paragraaf 2 van hoofdstuk 1 van de TF staat dat eerst na openbaarmaking door justitie opgetreden mag worden. "Geen staatsmacht of andere openbare instantie mag wegens de inhoud maatregelen nemen die het drukken, de openbaamaking of de verspreiding verhinderen." Wel mogen, in geval van misbruik van "tryckfriheten" gegevensdragers in beslag worden genomen of geconfisqueerd (TF 1:3). Het moet dan wel betreffen gegevensdragers die bestemd zijn om verspreid te worden (TF 10:8). Het verspreidingsrecht kan dus wel worden beperkt (TF 10:7, 8). Dit om de schadelijke gevolgen van verspreiding van strafrechtelijk verboden gegevensdragers te beperken of te woorkomen. ${ }^{46}$ Manieren om de schadelijke gevolgen van verspreiding van strafrechtelijk verboden gegewensdragers te beperken of te voorkomen zijn: confiscatie, een uitgifteverbod en inbeslagneming.

\subsubsection{Confiscatie}

Op grond van de TF 10:1 kan gedrukt materiaal in beslag worden genomen wanneer er redenen bestaan te vermoeden dat het materiaall later mogelijkerwijs zal worden

43 James Michael, The Politics of Secrecy: The Case for a Freedom of Information Law, London 1979 , p. 23 e.x.

44 Onder 'Yttrandefrihetsgrundlagen' vallen ook films, video's, toneelstukken, radio en tv programma's.

45 Håkan Strömberg, Oversikt över tryckfrihetsrätten, Lund 1978, p. 18 e.v.

46 Hăkan Strömberg, Tryckfrihetsrätt, Lund 1989 , p. 62 e.v. 
geconfisceerd en verder dat een uitgifteverbod onder bepaalde omstandigheden kan worden opgelegd in afwachting van een rechterlijke uitspraak met betrekking tot de confiscatie. De confiscatie mag slechts plaatsvinden na een juridische procedure waaruit voor de rechter blijkt dat er een drukpersdelict is gepleegd (TF 10:5). Voor de confiscatie geldt dat in geval van misbruik van de drukpersvrijheid alle materiaal dat bestemd is om verspreid te worden kan worden vernietigd inclusief de drukplaten $(\text { TF } 7: 7)^{47}$ en exclusief het archiefmateriaal (TF 4:4).

\subsubsection{Uitgifteverbod}

Ook een uitgifteverbod van tijdschriften is slechts mogelijk nadat een juridische procedure heeft plaats gevonden waaruit blijkt dat er sprake is van een uitings- of drukpersdelict (TF 10:5). Bovendien is een verbod om tijdschriften uit te geven aan een aantal voorwaarden gebonden (TF 10:2). Zo mag een uitgifteverbod niet langer duren dan zes maanden en moet het gaan om ernstige strafbare feiten genoemd in hoofdstuk 4:1-3, 4 en 6, 7 (TF 7:8). Bovendien is een uitgifteverbod alleen mogelijk wanneer Zweden zich in staat van oorlog bevindt. ${ }^{\mathrm{ds}}$

\subsubsection{Inbeslagneming}

In tegenstelling tot de confiscatie welke slechts mag plaatsvinden na een juridische procedure waaruit voor de rechter blijkt dat een drukpersdelict is gepleegd, kan de 'justitiekansler' (JK) en een officier van Justitie voorafgaand aan een juridische procedure in beslag nemen. De officier van Justitie moet echter de JK onmiddellijk van de inbeslagneming op de hoogte stellen. Deze laatste beslist dan of de inbeslagneming in stand blijft of niet. De inbeslagneming is een voorlopige maatregel. Binnen twee weken moet de JK een klacht (TF 10:2) indienen bij de rechter die dan uiteindelijk beslist of de inbeslagneming dient te worden gecontinueerd (TF 10:4, 5). De gronden die de JK kan aanvoeren voor de inbeslagneming zijn:

1. dat de inbeslagneming dient voor het aan de dag brengen van de waarheid;

2. of dat de inbeslagneming plaats vindt ten behoeve van een eventuele confiscatie;

3. of dat de inbeslagneming noodzakelijk is om de verspreiding van uitings-en drukpersdelicten te voorkomen. ${ }^{30}$

47 De verspreiding van geconfisceerd materiaal is strafbaar (TF 6:3 2st).

48. Hăkan Strömberg, Tryckfrihetsrätt, Lund 1989, p. 6465.

49. De functie van "justitiekansler" wordt uitgelegd in \$ 3.1.3.1.

50 Slechts zelden vindt er inbeslagneming plaats onder deze wet. Hăkan Strömberg, Tryckfrihetsrätt, Lund 1989 , p. 81 e.v. 
De JK dient erop te letten dat de inbeslagneming alleen betrekking mag hebben op exemplaren die bestemd zijn voor de verspreiding (TF 10:8). Exemplaren die aan burgers verkocht zijn of aan bibliotheken zijn gegeven mogen niet in beslag genomen worden. Exemplaren die zich bevinden bij een drukker, uitgever of een boekhandel mogen wel in beslag worden genomen. Ook mag de inbeslagneming de gehele oplage betreffen (TF 10:8) of, indien mogelijk, een bepaald deel, de bladzijde of de passage (proportionaliteitsbeginsel) (TF 10:6). ${ }^{31}$ Als bewijsmateriaal is de inbeslagneming van een exemplaar voldoende (TF 10:8, 14).

\subsubsection{De wettelijke bevoegdheid tot inbeslagneming}

De 'justitiekansler" is jurist en benoemd om de regering te assisteren in rechtszaken. De 'justitiekansler' is een adviseur van de koning. Hij vertegenwoordigt de kroon in civiele procedures en ziet toe op de gerechten en de wetgeving, in naam van de koning. Hij kan tegen de rechter ${ }^{32}$ of ambtenaren een procedure beginnen wegens plichtsverzuim, en is net als de parlementaire ombudsman een speciale officier van Justitie in speciale zaken. De gewone officier is de 'riksaklagared' ${ }^{\text {ss }}$ Alleen de 'justitiekansler' is in drukpersdelicten gerechtigd om een strafvervolging in te stellen (TF 9:2). Het Openbaar Ministerie en de politie zijn hier niet bevoegd. ${ }^{\text {ss }}$

\section{De juridische procedure bij uitings- en drukpersdelicten}

Iemand die een document publiceert kan alleen door de rechter aansprakelijk worden gesteld voor de inhoud in een juridische procedure zoals omschreven in de TF 1:1.

Uitings-en drukpersdelicten worden aangebracht bij de arrondissementsgerechten ('tingsrätter') hoofdzakelijk in de grotere steden. Slechts ongeveer 28 van de 100 arrondissementsgerechten in Zweden hebben jurisdictie inzake de persvrijheid. De procesvoorschriften in een drukpers- en uitingszaak zijn gedeeltelijk in de TF en

51. Het doel van de inbeslagneming is immers niet het beperken van de informatie. Hakan Strömberg, Tryckfrihetsratit, Lund 1989 , p. $81-82$.

52 Op grond wan 'Regeringsformen' 12:8 zijn alleen zij bevoegd een strafrechtelijke procedure te beginnen tegen rechters van het loogste (administratieve) gerecht (woor helt begaan van strafbare reiten tijdens de uitocfening van hun functie).

53. Hilding Eek, Das Problem einer Sonderstellung der Presse im Strafverfahren, Verhandlungen der Fachgruppe für Strafrechtsvergleichung Kiel, Frankfurt a/M 1965-29, p. 74; Hăkan Strömberg, Press Law in Sweden in: Phina Lahav, Press Law in Modern Democracies, A Comparative Siudy, New York 1985, p. 244-245.

54 De procedure noet beginnen binnen zes maanden na openbaarmaking. De verjaring is hier kort omdat het hier gaat om de vrijheid van meningsuiting en drukpers. Hilding Eek, Das Problem einer Sonderstellung der Presse im Strafverfahren, Verhandlungen der Fachgruppe für Strafrechtsvergleichung Kiel, Frankfurt a/M 1966-29, p. 74.

55 Zic Kap. 27:4 BrB 'Rättegangsbalk'. 
gedeeltelijk in een bijzondere wet geregeld. Het procesverloop in een uitings- en drukperszaak onderscheidt zich van een gewone zaak, doordat een jury meewerkt. In een proces inzake de vrijheid van meningsuiting en drukpers bestaat het gerecht uit een panel van 3 professionele juristen en een jury. ${ }^{56}$ De juryrechtspraak is een van de meest opvallende kenmerken in het Zweedse uitings- en drukpersproces. In 1815 is de juryrechtspraak geïntroduceerd naar het voorbeeld van het Angelsaksisch systeem. Wanneer het proces begint beslist de rechter of de gedaagde verantwoordelijk is voor de publicatie. De jury wordt dan gevraagd vast te stellen of door de gedaagde een strafbaar feit is begaan. Het is de jury niet toegestaan om een andere wettelijke bepaling toe te passen dan de door de officier van Justitie genoemde. De jury overlegt in het geheim. De vragen van de rechters dienen met ja of nee te worden beantwoord. Om de gedaagde te kunnen veroordelen zijn 6 van de 9 stemmen van de jury noodzakelijk. Meestal wordt deze meerderheid van zes personen niet gehaald.$^{57}$ Als de jury iemand vrijspreekt is deze beslissing definitief. ${ }^{58}$ Deze beslissing kan niet meer ongedaan gemaakt worden door een instantie in hoger beroep. In geval van een schuldigverklaring neemt het hof een onafhankelijke beslissing. ${ }^{39}$ Meestal volgt het hof daarbij de beslissing van de jury. Wanneer zowel de jury als de rechters vinden dat er een strafbaar feit is begaan bepaalt de rechter welke sanctie er opgelegd dient te worden. Omdat de meeste beslissingen ad hoc plaatsvinden, geeft TF 1:4 de volgende instructie aan de rechters en de jury:

"Tedereen wiens plicht het is te oordelen in gevallen van misbruik van de vrijheid van drukpers moet zich ervan bewust zijn dat de drukpersvrijheid de basis is van een vrije samenleving. In twijfelgevallen dient vrijspraak te volgen in plaats van veroordeling. ${ }^{\text {two }}$

56 Op grond van de wet van 1991:1559, 9:1 en in werking getreden op 1 januari 1992 is het mogelijk een zaak af te handelen met 2 professionele juristen wanneer een van hen om geldige redenen de zaak niet meer kan bijwonen. Olle Nyman, Some Basic Features of Swedish Constitutional Law in: Stig Strömholm, An Introduction to Swedish Law, Uppsala 1988, p. 75; Hakan Strömberg, Press Law in Sweden in: Phina Lahav, Press Law in Modern Democracies, A Comparative Study, New York 1985, p. 246-247; Hilding Eek, Die Sonderstellung der Presse in Strafverfallinen in Schweden, Verhandlungen der Fachgruppe für Strafrechtsvergigleichung Kiel, Stockholm 1965-29, p. 80-81; Hăkan Strömberg, Tryekfrihetsrätt, Lund 1989, p. 82 .

57 Zeker wanneer het ambtenaren in openbare dienst betreft is de jury yan mening dat xij kritiek moeten kunnen incasseren. Zelfs grove beledigingen, die objectief genomen misschien strafbaar żja, worden door de jury geseponeerd. Håkan Strömberg Press Law in Sweden in: Phina Lahav, Press Law in Modern Democracies, A Comparative Study, New York 1985, p. 247.

58 De jury hoeft haar beslissing niet te motiveren. Hăkan Strömberg, Press Law in Sweden in: Phina Lahav, Press Law in Modern Democracies, A Comparative Study, New York 1985, p. 247.

59 Het mag in zijn eindbeslissing afwijken van het oordeel van de jury bijvoorbeeld een lagere straf opleggen dan de jury heeft geëist of vrij spreken. Ook in hoger beroep zijn de rechters niet gebonden alan een schuldigverklaring door de jury.

60 Håkan Strömberg, Press Law in Sweden in: Phina Lahav, Press Law in Modern Democracies, A Comparative Study, New York 1985, p. 247. 
Bovenstaand geeft aan dat de wet een groot gewicht toekent aan de drukpersurijheid. De jury als garantie tegen de macht van de regering is nauwelijks van betekenis omdat bijna alle drukpers- en uitingszaken betrekking hebben op particuliere belediging. De rol van de jury in deze zaken is dubieus. Tegenstanders van een jury beweren dat het resultaat onvoorspelbaar wordt. Volgens Strömberg ondermijnt de juryrechtspraak het systeem van jurisprudentiële consistentie. ${ }^{61}$ Verder duren rechtszaken lang en zijn kostbaar. De uitkomst is vaak onzeker. Voorstanders zijn van mening dat in een proces waarbij een publieke instantie betrokken is een jury relevant kan zijn.

\section{De juridische aansprakelijkheid}

De Zweedse TF kent een systeem van beperkte verantwoordelijkheid. Daarbij dient er een onderscheid te worden gemaakt tussen periodieke en niet-periodieke drukwerken. Voor de laatstgenoemde is de auteur verantwoordelijk. Hij is echter gerechtigd anoniem te blijven. In zo'n geval is de uitgever verantwoordelijk. Wanneer er geen uitgever is, dan is de drukker verantwoordelijk. Is deze niet bekend dan is de handelaar verantwoordelijk. Bij periodieken is in de eerste plaats de uitgever die bij het ministerie van Justitie geregistreerd staat de enige verantwoordelijke. Is de uitgever niet bekend dan ligt de verantwoordelijkheid bij de eigenaar van de krant, daarna bij de drukker en dan bij de handelaar. ${ }^{62}$ De vraag naar wie verantwoordelijk is, wordt in het begin van de procedure beslist door de rechter. Wanneer men besloten heeft om de aanklacht tegen de drukker te richten dan is alleen hij verantwoordelijk. De idee achter deze beperking van verantwoordelijkheid is dat iedereen vrij moet kunnen zijn om ter publicatie aan te bieden wat hij wil. Wel heeft de redacteur het recht bepaalde informatie uit te sluiten die misschien bezwarend zou kunnen zijn. In feite is dit censuur. Met censuur wordt bedoeld: beperkingen op het openbaringsrecht (TF 1:2). Iedere Zweedse burger heeft recht te publiceren zonder beperkingen vooraf. Censuur is verboden. Evenals het vragen naar de identiteit van de schrijver of informanten.

Zowel tijdens het vooronderzoek als ter terechtzitting mogen geen vragen worden gesteld door de officier van Justitie of klager, naar de identiteit van de schrijver of informanten. Niemand die zich bezig houdt met drukken of uitgeven mag de naam van de schrijver of informant bekend maken. Men kan hier dan ook niet van een

61 Hăkan Strömberg, Press Law in Sweden in: Phina Lahav, Press Law in Modern Democracies, A Comparative Study, New York 1985, p. 247.

62 Dit geldt eveneens voor de radio en televisie. Patricia Wilhelm, Protection of Sources, An International Review of Journalistic and Legal Practice, The Norwegian Institute of Journalism/International Federation of Journalists, Fredrikstad 1988, p. 66 e.v. 
verschoningsrecht spreken maar van een verplichting om geen mededelingen te doen. Bij drukpersdelicten is de beslissing ower de omvang wan de schuld alleen gebaseerd op de inhoud van het drukwerk. Ook hier is het uitgangspunt dat de burger het recht heeft te publiceren zonder beperkingen wooraf. De vraag is hoe zich dat verhoudt met de inbeslagneming. Op grond van de TF (10:8) kan immers een hele oplage die bestemd is om verspreid te worden in beslag worden genomen bij de redactie, een uitgever of drukker. Er is daarbij geen rekening gehouden met de mogelijke geheimhoudingsplicht van mediamedewerkers jegens hun informanten. Dit in tegenstelling tot, zoals we in hoofdstuk 2 hebben kunnen lezen, de Duitse regeling. Daar heeft de wetgever uitdrukkelijk gewezen op de samenhang tussen het verschoningsrecht, het redactiegeheim en de inbeslagneming. Ik denk dat dit juist is. Door deze samenhang niet te onderkennen kan de vrijheid van meningsuiting en drukpers maar ook de informatie- en garingsvrijheid ernstig in het gedrang komen.

\subsection{Zelfregulering door de pers}

Het samenwerkingsorgaan van de pers heeft een ethische code ontwikkeld voor de pers die de strekking van de TF restrictiever maakt. Deze ethische code bevat publicatieregels, professieregels en advertentieregels. De 'Court of Honor' is speciaal opgericht voor journalisten die de ethische code overtreden. Ook is er een persombudsman die tot taak heeft "het bevorderen wan een journalisiieke ethiek in kranten en tijdschriften." De persombudsman mag direct vragen aan de redacteur of hij een artikel wil veramderen. De beslissingen worden genomen door middel van 'statements of opinion'. Men is vrij deze al dan niet op te volgen. De ethische code is een morele procedure. Er kan geen schadevergoeding gegeven worden aan de beledigde partij. ${ }^{\alpha}$

\section{De betekenis van art. 10 EVRM in het Zweedse recht}

De Europese Conventie en het eerste protocol werd door Zweden ondertekend op 28 november 1950 en 20 maart 1952. Het Verdrag en het protocol werden op 4 februari 1952 en 22 juni 1953 geratificeerd. Pas op 13 mei 1966 werd het individuele klachtrecht erkend. In Zweden zijn verdragen in tegenstelling tot internationaal gewoonterecht niet direct een onderdeel van het nationale recht ${ }^{\text {verdragen moeten }}$ eerst geimplementeerd worden in het nationale recht door middel van een statuut

63 JK Beslut 1983-11-14, Dnr. 2865-83-30, p. 288-289 (B8). Voor de delicten die buiten de TF vallen geldt hoofdstuk 27:2 van 'Rärtegangsbalken'. Alleen verschoningsgerechtigden, zoals artsen, advocatev etcetera, en personen die op grond van de wet of een statuut cen geheimhoudingsplicht hebben, vallen onder deze bepaling.

64 Hakkan Strömberg, Tryckfrihetsrätt, Lund 1989, p. 30-37.

65 Per 1 januari 1995 verandert dit. 
dat internationale verplichtingen transformeert in nationaal recht. De gerechten en de administratieve organen in Zweden passen dan ook niet direct de bepalingen van de Conventie toe maar, indien noodzakelijk, gelijksoortige bepalingen van de Zweedse wet welke dezelfde rechten en vrijheden bevatten als het Verdrag. ${ }^{6}$ Een kenmerk van de Zweedse constitutionele traditie is de parlementaire soevereiniteit en het principe dat regels van internationaal recht niet automatisch een onderdeel vormen van het nationale recht. ${ }^{68}$ De Zweedse gerechten verwijzen zelden naar bepalingen in de Europese Conventie, wanneer het betreft de vrijheid van meningsuiting en drukpers. Dit komt ook doordat de TF en YF, volgens het Zweedse Hof, verder gaat dan art. 10 EVRM.

\section{Conclusie}

De wrijheid van drukpers is geregeld in de TF. Voor de andere uitingsvrijheden geldt de YF. De YF verwijst naar de TF. Deze laatste wet is de oudste en vormt hier het uitgangspunt. Zowel de strafrechtelijke als de strafvorderlijke aspecten van de vrijheid van meningsuiting en drukpers staan geregeld in de TF. Voor wat betreft de inbeslagneming geldt dat de inbeslagneming alleen betrekking heeft op exemplaren die bestemd zijn voor de verspreiding (TF 10:8). De inbeslagneming bij uitgevers en drukkers alsook bij de media is mogelijk. Wanneer er sprake is van misbruik van 'tryckfriheten' kunnen alle gegevensdragers in beslag genomen worden rekening houdend met het proportionaliteitsbeginsel. De inbeslagneming is een voorlopige maatregel. Binnen twee weken moet de JK een klacht (TF 10:2) indienen bij de rechter die dan uiteindelijk beslist of de inbeslagneming dient te worden gecontinueerd (TF 10:4, 5). De inbeslagneming is behalve om de verspreiding van uitingsen drukpersdelicten te voorkomen ook mogelijk ten behoeve van een eventuele confiscatie of voor het aan de dag brengen van de waarheid. Bij de inbeslagneming voor het aan de dag brengen van de waarheid kan de identiteit van de informant een rol spelen. Deze wordt beschermd. Iedereen die zich bezig houdt met drukken en uitgeven is gehouden aan de geheimhoudingsplicht. Hoe zich dit verhoudt tot de inbeslagneming bij uitgevers en drukkers is niet in de TF weergegeven zoals dat bijvoorbeeld in de Duitse 'StrafprozeBordnung' het geval is.

Uitgangspunt van de TF is dat een hele oplage die bestemd is om verspreid te worden in beslag kan worden genomen bij de redactie, een uitgever of een drukker

66 H. Danelius, Human Rights in Sweden, Lund 1981, p. 13; A.Z. Drzemezewski, European Human Rights Convention in Domestic Law, A Comparative Study, Oxford 1983, p. 136-141.

67 A.Z. Drzenczewski, European Human Rights Convention in Domestic Law, A Comparative Study Oxford 1983, p. 136.

68 Zie de uitspraak van de 'Regeringsrätten' (Hoogste Administratief Hof) waarin werd beslist dat de Europese Conventio niet direct toepasbaar is in het Zweedse wetssysteem. Regeringsrättens arsbok (1974), ref. 61, 121-1.22. 
zonder dat er een verband wordt gelegd met de geheimhoudingsplicht. De inbeslagneming op bijvoorbeeld een redactie kan tot gevolg hebben dat informanten bekend worden. Mensen zullen met dit risico in gedachte, voorzichtiger worden gegevens door te spelen aan de media. Via een 'achterdeur' kan de vrijheid van meningsuiting en drukpers alsook de informatievrijheid en de garingsvrijheid ernstig worden beperkt. 


\section{Conclusie}

\section{$1 \quad$ Inleiding}

In de voorgaande hoofdstukken kwam de spanning tussen de vrijheid van meningsuiting en drukpers en het strafvorderlijke dwangmiddel inbeslagneming aan de orde in een internationaal en rechtsvergelijkend perspectief. Centraal stond de vraag in hoeverre de vrijheid van meningsuiting en drukpers zoals geformuleerd in de verschillende constituties en de mensenrechtenverdragen een belemmering vormt voor de toepassing van het strafvorderlijke dwangmiddel inbeslagneming. Welke drempels werpt de vrijheid van meningsuiting en drukpers op tegen de strafvorderlijke inbeslagneming van gegevensdragers? En heeft de wetgever bij het redigeren van de inbeslagnemingsbepalingen rekening gehouden met de vrijheid van meningsuiting en drukpers?

In de opeenvolgende hoofdstukken werd de relatie tussen de strafvorderlijke inbeslagneming en de vrijheid van meningsuiting en drukpers besproken in Nederland, Duitsland, Engeland en Zweden. Gelet op de overeenkomsten en verschillen tussen bovengenoemde landen met betrekking tot deze materie zal hier worden bezien wellke conclusies voor Nederland uit de rechtsvergelijkende exercitie kunnen worden getrokken. Daarbij wordt, omwille van overzichtelijkheid, een onderverdeling gemaakt tussen de materiële en de procedurele aspecten van de inbeslagneming voor het aan de dag brengen van de waarheid en de materiële en procedurele aspecten van de inbeslagneming ter verbeurdverklaring en ter onttrekking aan het verkeer.

\section{De vrijheid van meningsuiting en drukpers en de materiële aspecten van de} inbeslagneming voor het aan de dag brengen van de waarheid

In art. 7 lid 1 van de Nederlandse Grondwet staat dat censuur verboden is. Dit betekent dat zowel de lagere wetgever als de formele wetgever nooit het openbaren zelf kan reguleren via voorafgaand verlof of door middel van het geven van regels met betrekking tot de inhoud van gedachten en gevoelens. Alleen achteraf, na publicatie, mag op grond van de clausule 'behoudens ieders verantwoordelijkheid voor de wet' de inhoud van geschriften worden getoetst door de rechter. Met wet wordt een wet in formele zin bedoeld. 
De bescherming die voor het openbaringsrecht geldt, geldt niet in dezelfde mate voor het verspreidingsrecht. Het aan het openbaringsrecht gekoppelde recht op het verspreiden van gedachten en gevoelens kan zowel beperkt worden door de formele wetgever ais door de lagere wetgever. De differentiatie tussen een 'de geesteswereld betreffend' recht tot openbaren van je mening en een 'de ruimtelijke sfeer' betreffend recht tot verspreiden is door de jurisprudentie van de Hoge Raad in 1950, in het Tilburg-arrest (Hoge Raad 28 november 1950, NJ 1951, 137) gemaakt en overgenomen in art. 7 lid 1 Grondwet. Voor die tijd werd openbaarmaking als overkoepelend begrip gebruikt voor het publiceren tot en met het verspreiden van geschriften onder het publiek. Pas later dus, in het Tilburgse-drukpersarrest, brengt de rechter een scheiding aan tussen het openbaren en het in het openbaar bekend maken (verspreiden). Dit door de rechter geconstrueerde verspreidingsrecht deelt niettemin tot op zekere hoogte in de bescherming van het openbaringsrecht, daar een algeheel verbod of vergunningvereiste niet is toegestaan. In de latere jurisprudentie is de constructie uit het arrest over de Tilburgse APV verder verfijnd. Niet alleen mocht de verspreidingsvrijheid niet in het algemeen verboden of van een voorafgaand verlof afhankelijk gesteld worden, maar ook dienden de beperkingen 'gebruik van enige betekenis" van het verspreidingsmiddel over te laten (Nuth-criterium).

Een voorbeeld van een beperking van de verspreidingsvrijheid is het strafvorderlijke dwangmiddel inbeslagneming. De vraag is hoe de inbeslagneming zich verhoudt tot de vrijheid van meningsuiting en drukpers, en in het bijzonder tot de verspreidingsvrijheid.

Op grond van art. $94 \mathrm{~Sv}$ is het mogelijk om voorwerpen in beslag te nemen voor het aan de dag brengen van de waarheid. Daarbij wordt geen onderscheid gemaakt tussen voorwerpen en gegevensdragers. Ook 'gegevens' op 'dragers' kunnen in beslag genomen worden. Het accent ligt dan op het begrip 'drager'. Legt men daarentegen het accent op het begrip 'gegeven' dan komt men, zoals we in paragraaf 4.3.1 hebben kunnen zien, tot een geheel andere conclusie. Zelf ben ik geneigd om het accent te leggen op 'gegevens'. Het gaat immers bij de inbeslagneming voor het aan de dag brengen van de waarheid om de informatie. Wil men deze informatie op dragers in beslag kunnen nemen dan zal er voor gegevensdragers een aparte regeling moeten komen die rekening houdt met de vrijheid van meningsuiting en drukpers.'

Zo'n aparte regeling bestaat al in Duitsland. Daar is bij de inbeslagneming voor het aan de dag brengen van de waarheid een onderscheid gemaakt tussen voorwerpen en gegevensdragers. De inbeslagneming van gegevensdragers voor het aan de dag brengen van de waarheid is niet mogelijk wanneer deze zich in bewaring bevinden bij een gepriviligeerde mediamedewerker of de redactie, een uitgever, drukkerij of 'Rundfunk'. Het moet dan wel gaan om materiaal dat van derden verkregen is. Eigen materiaal mag wel in beslag worden genomen. De grondgedachte in Duitsland achter de 'Paragraphen 53 en 97 Abs. 5 StPO' is de bescherming van de vertrou-

1 Zie het Voorontwerp van Wet op het Journalistiek Privilege van E. Jurgens in Mediaforum 1991-2, Bijl. p. 13. 
wensrelatie tussen de media en hun informanten. Deze bescherming van deze vertrouwensrelatie zorgt ervoor dat mediamedewerkers onafhankelijk kunnen functioneren. Alleen wanneer het verschoningsrecht en het redactiegehein gewaarborgd is, kunnen de media hun controle- en informatieve functie goed vervullen. De informatievrijheid en de grondwettelijke bescherming van de informatiebronnen tegen inbeslagneming staan in direct verband met elkaar. Dit verband tussen het verschoningsrecht, het redactiegeheim en het inbeslagnemingsverbod van informatiebronnen bij de media is typerend voor de Duitse regeling en heeft te maken met de institutionele bescherming van de media in 'Art. 5 Abs. 1 Satz 2 Grundgesetz'.

Wanneer we nu de Duitse situatie vergelijken met de Engelse dan valt ons allereerst op dat ook in Engeland in de 'Police and Criminal Evidence Act 1984' een onderscheid wordt gemaakt tussen voorwerpen en gegevensdragers. In Engeland worden drie categorieën gegevensdragers genoemd in de 'Police and Criminal Evidence Act 1984' namelijk 'legally privileged material', 'excluded material' en 'special procedure material'. 'Legally privileged material' heeft betrekking op de 'communications' tussen een juridisch adviseur en zijn cliënt ('section' 10(1)(a)). 'Excluded material' heeft betrekking op 'personal records', 'human tissue' of 'human tissue fluid' en 'journalistic material'. 'Journalistic material' moet betreffen 'documents' of 'records other than documents". Onder documenten wordt hier verstaan; a. geschreven stukken, een plan, tekening etcetera, b. een foto, c. een diskette, geluidsband, c.d. etcetera, d. films, microfilms, negatieven etcetera. Voor alle drie de categorieën geldt dat het materiaal 'must be held in confidence'. 'Special procedure material' is daarentegen onder andere journalistiek materiaal hetwelk niet geclassificeerd kan worden als 'excluded material', ofwel omdat het geen documenten betreft ofwel zijn het documenten maar voldoen ze niet aan de eis van vertrouwelijkheid (bijvoorbeeld een film of foto van een demonstratie). Voor eerstgenoemde categorie "materials' geldt dat deze niet in beslag genomen mogen worden. De twee andere soorten 'materials' mogen wel in beslag genomen worden. Een onderscheid in rechtsbescherming tussen eigen en materiaal van derden verkregen wordt daarbij niet gemaakt. De enige bescherming tegen te rigoureuze inbeslagneming is het proportionaliteitsbeginsel. Zo zal de politie op grond van de 'Police and Criminal Evidence Act 1984", rekening houdend met het proportionaliteitsbeginsel, geen gegevensdrager in haar bezit mogen houden of nemen wanneer een foto of een 'copy" ook voldoende is ('section' 22(4)). In de zaak 'Reynolds vs. Commissioner of Police of the Metropolis' besliste de 'Court of Appeal' dat de politie niet bevoegd is om grote aantallen documenten in beslag te nemen zonder aan te geven dat "each file or bundle might reasonably constitute evidence" ((1984) 3 All ER 649, CA). Impliciet wordt dus wel degelijk bij de inbeslagneming van zowel eigen materiaal als materiaal dat van derden verkregen is rekening gehouden met de vrijheid van meningsuiting en drukpers maar men gaat niet zover om materiaal van derden dat zich bevindt bij een journalist, uitgever, drukker of radio- c.q. televisiestation uit te sluiten van inbeslagneming.

Ook in Zweden gaat men niet zover om materiaal dat zich bevindt bij een journalist, uitgever, drukker of radio- of televisiestation uit te sluiten van de inbeslagneming. 
Dit is wreemd nu gezien hebben dat de geheimhoudingsplicht in Zweden zo'n belangrijke rol speelt. ledereen die zich bezighoudt met drukken en uitgeven mag ॥mmers een beroep doen op de gebeimhoudingsplicht. Door geen relatie te leggen tussen deze plicht en de inbeslagneming hol je deze geheimhoudingsplicht in feite uit. $^{2}$

Vergelijken we bovengenoemde regelgevingen met elkaar dan zien we dat de bescherming van de vrijheid van meningsuiting en drukpers in Duitsland althans wettelijk het meest vergaand is. In Nederiand wordt er onder andere door Jurgens over nagedacht om art. 94 Sv zodanig te veranderen dat er in de wet een onderscheid wordt gemaakt tussen voorwerpen en gegevensdragers. Gegevensdragers zouden dan niet in beslag genomen mogen worden wanneer het gaat om journalistieke werkzaamheden. Dit betekent dat niet alleen werk van journalisten niet in beslag mag worden genomen voor het aan de dag brengen van de waarheid maar ook werk van bijvoorbeeld cineasten en auteurs. Zowel eigen- als materiaal dat van derden verkregen is dient beschermd te worden. Op deze manier wordt het problematische onderscheid tussen eigen- en derden materiaal zoals dat in Duitsland het geval is voorkomen. Door wettelijk vast te leggen dat het journalistiek privilege ${ }^{3}$ als uitgangspunt dient, zal de rechter, in het concrete geval, slechts bij aanwezigheid van zeer dringende reden, kunnen komen tot een inbreuk op dit recht. Inbeslagneming is dan slechts in zeer uitzonderlijke situaties te rechtvaardigen namelijk in die gevallen waarin sprake is van zwaar lichamelijk letsel. In eerste instantie zal moeten worden bekeken in hoeverre de pollitie of justitie zelf redelijkerwijs bij machte is de gewenste informatie te vergaren. Dit uitgangspunt stemt overeen met de geldende richtlijn van de procureurs-generaal bij de gerechtshoven van juli 1981 waarin staat dat strafvorderlijke inbeslagneming zoveel mogelijk achterwege dient te blijven opdat "journalisten hun werkzaamheden zo goed mogellik kunnen verrichten."

\section{De vrijheid van meningsuiting en drukpers en de procedurele aspecten van de inbeslagneming voor het aan de dag brengen van de waarheid}

Wanneer we kijken naar de bevoegdheid bij de inbeslagneming van gegevensdragers voor het aan de dag brengen van de waarheid dan zien we dat in Nederland op grond van het huidige Wetboek van Strafvordering de gewone opsporingsambtenaar in prinicpe alleen speciale inbeslagnemingsbevoegdheden heeft. Alleen wanneer zij

2 De Zweedse 'Tryckfrihetsförordning' kent een systeem van beperkte en trapsgewijze verantwoordelijkheid. Het idee achter deze beperkte vorm wan verantwoordelijkheid is dat iedereen vrij moet kumnen zajp om te schrijyen en ter publicatie aan te bieden wat hij wil.

3 Voorontwerp van Wet op het Journalistiek Privilege van E. Jurgens in Mediaforum 1991-2, Bijl. p. 13; Wetsvoorstel en MVT, TK 4-5-1993, 23133 nrs. 1-3.

4 Richtlijn over de positie van de pers buj politie-optreden (1981) in: Leidratad van de ministers (1988) te verkrijgen bij het ministerie van Justitie en het ministerie van Binnenlandse Zaken. 
in de uitoefening van een andere bevoegdheid een daarvoor vatbaar voorwerp aantreffen zijn zij tot inbeslagneming bevoegd. In navolging van pleidooien in de literatuur stelt de Commissie Herijking Wetboek van Strafvordering voor om in plaats van het huidige art. $96 \mathrm{~Sv}$ aan elke opsporingsambtenaar een algemene bevoegdheid tot inbeslagneming te geven. De enige beperking is dat voor een situatie buiten heterdaad sprake dient te zijn van een misdrijf als omschreven in art. 67 eerste lid Sv. Door het grote antal misdrijven dat onder dit artikellid wordt aangeduid of opgesomd bestaan er praktisch weinig belemmeringen meer voor opsporingsambtenaren. De vraag die we ons hier kunnen stellen is of dit een gewenste ontwikkeling is. Is de politie, die er alle belang bij heeft om strafbare feiten op te helderen, de juiste instantie is om te beslissen over de inperking van de op de vrijheid van meningsuiting en drukpers?

In Duitsland was het antwoord op bovengenoemde vraag negatief. Daar heeft men gekozen voor de rechter wanneer het gaat om de inbeslagneming van eigen materiaal voor het aan de dag brengen van de waarheid ('Paragraph 98 Abs. 1 StPO'). Alleen wanneer er 'Gefahr im Verzug' dreigt zijn ook de officier van Justitie en de hulp-officier bevoegd tot inbeslagneming. 'Gefahr im Verzug' ontstaat wanneer het doel van de maatregel in gevaar komt bijvoorbeeld wanneer er gevaar bestaat "des öffentlichen Interesses an unverzögerter Verbreitung." Er dient echter een uitzondering te worden gemaakt voor de inbeslagneming van eigen materiaal bij de redactie, een uitgever, een drukkerij of de 'Rundfunk'. Hier is alleen de rechter bevoegd. Ook als het gaat om 'Gefahr im Verzug'. Gezien de hoge rang die de vrijheid van meningsuiting en drukpers volgens 'Art. 5 Grundgesetz' toekomt, is de inbeslagneming bij de pers en bij de 'Rundfunk' slechts bij 'dringende noodzakelijkheid' mogelijk. Er dient zowel door de rechter als door de officier van Justitie en de hulp-officier van Justitie rekening te worden gehouden met het proportionaliteitsbeginsel.

Wanneer het gaat om beslissingen van de officier van Justitie of de hulp-officier bestaat de mogelijkheild om de rechtmatigheid daarvan te toetsen bij de rechter en wel de 'Amtsrichter' of het 'Landgericht'. Zo bepaalt 'Paragraph 98 Abs. 2 StPO' dat in geval van inbeslagneming zonder rechterlijk bevel degene die dat voorwerp vrijwillig heeft uitgeleverd, ten alle tijde een rechterlijke beslissing kan vragen. De rechter moet dan onderzoeken of de wettelijke voorwaarden voor de inbeslagneming op het moment van zijn beslissing vervuld zijn. De rechterlijke beslissing achteraf komt dan in de plaats van de niet door de rechter bevolen inbeslagneming ("Paragraph 111e Abs. 2 StPO'). Wanneer het gaat om een beslissing van de rechter tot toepassing van dwangmiddelen staat het rechtsmiddel van bezwaar ('Beschwerde') open ('Paragraph 304 StPO'). Het doel van het rechtsmiddel bezwatr is de rechter een rechterlijk oordeel te vragen omtrent de toelaatbaarheid van de toepassing van het dwangmiddel. Met het rechtsmiddel van bezwaar wordt de aangevochten beslissing zowel juridisch als feitelijk getoetst. Het tot deze toetsing competente gerecht is de strafkamer van het 'Landgericht' (Art. $73 \mathrm{GVG}$ ). Het rechtsmiddel van bezwaar kent twee varianten; het eenvoudige bezwaar en het onmiddellijke bezwaar ('Paragraph' $311 \mathrm{StPO}$ ). Het eenvoudige bezwaar is niet aan een termijn gebonden en 
kan door de 'iudex a quo' zelf worden afgedaan voorzover het gegrond wordt verklaard. Het onmiddellijke bezwaar moet binnen een week aan de strafkamer van het 'Landgericht" worden voorgelegd. Deze wint informatie in, geeft partijen gelegenheid gehoord te worden en beslist op grond van de stukken. Het onmiddellijke bezwaar wordt door de wet als te hanteren rechtsmiddel voorgeschreven voor de gevallen dat vanwege rechtszekerheid een snelle definitieve beslissing noodzakelijk is.

In Engeland is de politie bevoegd tot de inbeslagneming van gegevensdragers voor het aan de dag brengen van de waarheid. In die gevallen waarin de inbeslagneming gelijktijdig met een huiszoeking plaatsvindt is een speciale procedure in het leven geroepen ('Police and Criminal Evidence Act 1984'). Zo is bij de inbeslagnerning van 'excluded material' en 'special procedure material' een 'production order" vereist die de politie aanvraagt bij de 'circuit judge'. Een 'production order' eist van de persoon die het bewijsmateriaal bezit dat hij/zij dit materiaal aan de politie overdraagt of dat hij/zij toestaat dat een politieagent toegang krijgt tot het bewijsmateriaal. De persoon voorkomt hiermee een huiszoeking. In tegenstelling tot een 'search warrant' is een 'production order' altijd 'inter partes'. Dat wil zeggen dat je de mogelijkheid krijgt om bij de rechter te klagen tegen een voorgenomen of een reeds uitgevoerde inbeslagneming.

Bezien we hier de situatie in Zweden dan bestaat het verschil met de andere landen daarin dat in Zweden in die gevallen waarin de vrijheid van meningsuiting en drukpers in het geding is niet de politie bevoegd is verklaard gegevensdragers in beslag te nemen, maar de 'justitiekansler' (TF 9:2). ${ }^{5}$ De justitiekansler' is net als de ombudsman een speciale officier van Justitie in speciale zaken. De 'justitiekansler' kan voorafgaand aan een procedure in beslag nemen voor het aan de dag brengen van de waarheid. Bínnen twee weken moet de 'justitiekansler' dan een klacht indienen bij de arrondissementsrechtbank ('tingsrätter') van een van de, hoofdzakelijk, grotere steden (TF 10:2). Daar wordt uiteindelijk beslist of de inbeslagneming dient te worden gecontinueerd (TF 10:4, 5). De procedure moet beginnen binnen zes maanden na openbaarmaking. De verjaringstermijn is hier kort omdat het gaat om de vrijheid van meningsuiting en drukpers. Het procesverloop in een drukpers- of uitingszaak onderscheidt zich van een gewone zaak, omdat een jury meewerkt. De juryrechtspraak is een van de meest opvallende kenmerken wan het Zweedse recht. De reden om juryrechtspraak in te voeren bij drukpers-en uitingsdelicten was dat het veelal gaat om delicten met maatschappelijke en politieke implicaties. Men was van mening dat het belangrijk is dat de burger in dit soort zaken zijn mening kan geven. In 1815 is de juryrechtspraak geïntroduceerd naar het voorbeeld van het Angelsaksische systeem. Wanneer het proces begint, beslist de rechter of de gedlaagde verantwoordelijk is voor de publicatie. De jury wordt dan gevraagd of een strafbaar feit is begaan. Het is de jury niet toegestaan om een andere wettelijke bepaling toe

5 Ook de officier van Justitie mag im beslag nemen. Echter hij moet onmiddellijk de JK hiervan op de hoogte stellen. Deze laatste beslist of de inbesllagneming in stand blift of niet. 
te passen dan door de officier van Justitie is genoemd. De jury overlegt in het geheim. De vragen van de rechters dienen met ja of nee te worden beantwoord. Om de gedlaagde te kunnen veroordelen zijn 6 van de 9 stemmen van de jury roodzakelijk. Meestal wordt deze meerderheid van zes personen niet gehald. Als de jury iemand wrijspreekt is deze beslissing definitief. Deze beslissing kan niet meer ongedaan gemaakt worden door een instantie in hoger beroep. In geval van een veroordeling neemt het hof een onafhankelijke beslissing. Meestal volgt het hof daarbij de beslissing van de jury. Wanneer zowel de jury als de rechters vinden dat er een strafbaar feit is begaan zal de rechter een sanctie opleggen. Omdat de meeste beslissingen ad hoc plaatsvinden, geeft de TF 1:4 de volgende instructie aan de rechters en de jury:

"Iedereen wiens plicht het is te oordelen in gevallen van misbruik van de vrijheid van drukpers moet zich ervan bewust zijn dat de drukperswrijheid de basis is van een vrije samenleving. In twijfelgevallen dient vrijspraak te volgen in plaats van een veroordeling."

Bezien we de Duitse, Engelse en Zweedse situatie en vergelijken we die met de Nederlandse dan lijken de Duitse en de Zweedse regelgeving het meeste recht te doen aan de vrijheid van meningsuiting en drukpers. In Duitsland is niet de politie maar de rechter, de officier van Justitie en de hulp-officier (deze twee laatst genoemde alleen bij 'Gefahr im Verzug') bevoegd bij de inbeslagneming van gegevensdragers voor het aan de dag brengen van de waarheid. Wanneer het gaat om de inbeslagneming van eigen materiaal bij de media is alleen de rechter bevoegd. Ook wanneer 'Gefahr im Verzug' dreigt. In Engeland en in Zweden wordt dit onderscheid niet gemaakt. In Engeland is in alle gevallen de politie bevoegd. Alleen wanneer de inbeslagneming gepaard gaat met een huiszoeking zijn extra processuele waarborgen in het leven geroepen. De achterliggende gedachte is niet zozeer de vrijheid van meningsuiting en drukpers maar de privacy. In Zweden is een speciale ambtenaar belast met de inbeslagneming van gegevensdragers. De inbeslagneming is daar een voorlopige maatregel. Binnen twee weken moet de 'justitiekansler' een klacht (TF 10:2) indienen bij de rechter die dan uiteindelijk beslist of tot inbeslagneming dient te worden gecontinueerd (TF 10:4,5). Bij de procedure wordt een jury betrokken. De vraag is of we in Nederland nu ook zo'n speciale ambtenaar en een jury in het lewen moeten roepen bij de inbeslagneming van gegevensdragers? Misschien hoeven we niet zover te gaan, wanneer mensen die journalistieke werkzaamheden verrichten een beroep kunnen doen op het journalistieke verschoningsrecht en wanneer zowel eigen als materiaal van derden verkregen beschermd wordt tegen inbeslagneming. Met uitzondering van die situaties dat mensen zwaar lichamelijk letsel oplopen; dan is de politie of justitie bevoegd de gewenste informatie te vergaren (in die gevallen dat ze zelf hiertoe niet bij machte zijn geweest.) Er kan dan geen beroep worden gedaan op het journalistiek privilege.

Vergelijken we de verschillende procedures met elkaar dan blijkt dat alle procedures openbaar zijn. Sinds 1 januari 1994 is ook de raadkamerprocedure in Nederland 
bij de inbeslagneming, de verbeurdverklaring en de onttrekking aan het verkeer openbaar:

4 De vrijheid van meningsuiting en drukpers en de materiële aspecten van de inbeslagneming ter verbeurdverklaring en ter onttrekking aan het verkeer

In het woorafgaande hebben we gesproken over de inbeslagneming voor het aan de dag brengen van de waarheid. Behalve de inbeslagneming voor het aan de dag brengen wan de waarheid kennen we ook nog de inbeslagneming ter verbeurdverklaring en ter onttrekking aan het verkeer. Voor wat betreft de inbeslagneming ter verbeurdverklaring geldt dat bij de inbeslagneming wordt geanticipeerd op het oordeel van de rechter. Bij een veroordeling wordt het goed definitief aan de macht van de veroordeelde onttrokken. In Nederland is de verbeurdverklaring een vermogensstraf en een bijkomende straf wat impliceert dat de oplegging facultatief is (ook niet in beslag genomen voorwerpen kunnen verbeurd worden verklaard). Het doel van de verbeurdverklaring is niet alleen leedtoevoeging maar ook preventie. Omdat de inbeslagneming niet noodzakelijk is heeft de beslagleggende ambtenaar een grote beleidsvrijheid bij het beslissen of het voorwerp wel of niet in beslag genomen dient te worden. Er dient rekening te worden gehouden met de beginselen van een behoorlijke procesorde, zoals het vertrouwensbeginsel, het verbod van 'détournement de pouwoir', het proportionaliteitsbeginsel. De inbeslagneming dient achterwege te blijven wanneer deze duidelijk onredelijk zou zijn. Dit laatste geldt eveneens voor de onttrekking aan het verkeer. Ook hier dient de inbeslagneming achterwege te blijven wanneer deze duidelijk onredelijk is. Of een inbeslagneming onredelijk is is afhan* kelijk van het concrete geval. Het verschil met de inbeslagneming ter verbeurdverklaring is dat de onttrekking aan het verkeer primair bedoeld is ter beveiliging van de maatschappij. De inbeslagneming is een noodzakelijke voorwaarde. Er is minder speelruimte voor opsporingsambtenaren. Dat de inbeslagneming hier kennelijk onredelijk is, zal hier minder snel worden aangenomen. Het betreft hier een typische politic- c.q. veiligheidsmaatregel ten dienste van justitie, die zilch zuiver afspeelt in de sfeer van de opportuniteit. Wanneer er meerdere bijvoorbeeld vermeende godslasterlijke geschriften of pamfletten worden aangetroffen van dezelfde soort kan inbeslagneming plaatsvinden door de politie van de gehele voorraad. De vraag is hoe zich dit verhoudt met de vrijheid van meningsuiting en drukpers in art. 7 van de Grondwet en art. 10 EVRM. Voldoet de Nederlandse regeling van de inbeslagneming ter verbeurdverklaring en ter onttrekking aan het verkeer aan bovengenoemde bepalingen? 
In de zaak Bluf! trad de spanning tussen de strafvorderlijke inbeslagneming en de vrijheid van meningsuiting en drukpers duidelijk aan het licht.' In deze zaak stond, zoals we in hoofdstuk 1 hebben gezien, de publicatie van een oud kwartaaloverzicht van de BVD uit 1981 centraal. Toen Bluf! nr. 267 net van de pers kwam en voor verzending gereed gemaakt werd, viel een politiemacht binnen bij de drukker en nam de hele oplage in beslag (art. $98 \mathrm{en} /$ of $98 \mathrm{a} \mathrm{Sr}$, staatsgeheimen). Op vordering van de officier van Justitie werd de gehele oplage van het weekblad Bluf! van 29 april 1987 door de rechtbank te Amsterdam onttrokken aan het verkeer (vergelijk art. 36c Sr). De inhoud van Bluf! nr. 267 kon, zo werd door de officier van Justitie gesteld en door de rechtbank aangenomen, niet door de beugel; geheimhouding was, met het oog op de veiligheid van de staat of zijn bondgenoten, geboden (artt. $98 \mathrm{en} /$ of $98 \mathrm{a} \mathrm{Sr}$ ). Bluf! tekende tegen de beschikking van de rechtbank cassatieberoep aan bij de Hoge Raad. De belangrijkste argumenten van Bluf! waren dat de drukpersvrijheid betekent dat alleen achteraf dus na publicatie (bedoeld wordt hier na openbaarmaking en verspreiding) door een strafrechter besloten kan worden dat een oplage moet worden verbeurd verklaard of onttrokken aan het verkeer. Door de hele oplage van te voren in beslag te nemen is er in werkelijkheid censuur uitgeoefend. Volgens de Hoge Raad was er helemaal geen sprake van censuur. De inbeslagneming en de onttrekking aan het verkeer waren volgens de Hoge Raad géén beperkingen die konden worden gelijkgesteld met het onderwerpen aan de voorwaarde van 'voorafgaand verlof' ais bedoeld in art. 7 lid 1 van de Grondwet. Dit is juist. Er was inderdaad geen sprake van censuur. De beperking had immers niet betrekking op de inhoud maar op de verspreiding. Vervolgens stelt de Hoge Raad dat

"Tot de middelen waarmee de belangen, die de artt. 98 en $98 \mathrm{a} \mathrm{Sr}$ beogen te beschermen, behoren niet alleen de strafrechtelijke vervolging en eventuele veroordeling van degenen die de in deze artikelen strafbaar gestelde feiten hebben begaan, maar ook de inbeslagneming en de onttrekking aan het verkeer volgens de bepalingen van het Wetboek van Strafvordering van voor het begaan van zodanige feiten bestemde drukwerken. Toepassing van deze middelen valt te rekenen tot de bij de genoemde verdragsbepalingen toegelaten beperkingen van het in die bepaling verzekerde recht en kan niet worden gelijkgesteld met het onderwerpen aan de voorwaarde van "voorafgaand verlof' als bedoeld in voormeld grondwetsartikel ook al wordt als gevolg daarvan het desbetreffende drukwerk met de daarin neergelegde gedachten en gevoelens niet openbaar"

(met 'niet openbaar' zal hier de Hoge Raad waarschijnlijk 'niet verspreid' bedoeld hebben). Met dit laatste, dat zolang er maar geen sprake is van censuur alle inbreuken op de vrijheid van meningsuiting en drukpers geoorloofd zijn, ben ik het niet eens. Immers de gedachte achter art. 7 van de Grondwet is dat inbreuken op de vrijheid van meningsuiting en drukpers slechts in beperkte mate en bij hoge uitzondering

7 HR 17-11-1987, NJ 1988, 394 met noot van Th. van Veen; HR 18-9-1989, NJ 1990, 94 met noot van Th. van Veen. 
mogelijk zijn. Zo mag de verspreiding van in casu geschriften die vermeende staatsgeheimen bevatten, wel beperkt worden door de politie op grond van art. 7 Grondwet in het belang van de openbare orde of de veiligheid van anderen, maar deze beperkingen mogen niet leiden tot een 'algeheel verbod'. Van een 'algeheel verbod' is sprake wanneer er geen mogelijkheid meer bestaat om de geschriften te verspreiden, bijvoorbeeld doordat een hele oplage in beslag is genomen of doordat de drukpersen en drukplaten in beslag zijn genomen. Ook de rechter mag op grond van de clausule 'behoudens ieders verantwoordelijkheid volgens de wet' geschriften die staatsgeheimen bevatten onttrekken aan het verkeer of verbeurd verklaren zij het dat "het in den geest der Grondwet is repressieve maatregelen, met ander woorden de strafbaarstelling en vervolging van drukpersdelicten op zoodanige wijze te regelen, dat niet indirect het preventieve toezicht weder insluipe", aldus minister Modderman tijdens de parlementaire behandeling van het Wetboek van Strafrecht in de Tweede Kamer. ${ }^{8}$ Zeker wanneer het betreft discussies over publieke aangelegenheden dient de rechter extra voorzichtig te zijn. Niet alleen omdat door de verbeurdverklaring van een hele oplage de bestaanspositie van bijvoorbeeld een dagblad of tijdschrift in gevaar gebracht kan worden, maar ook omdat het discussiëren over publieke aangelegenheden een basisvoorwaarde is voor een democratische rechtsorde en voor de fundering van de overige grondwettelijke vrijheden. De media nemen hier een speciale positie in. Het is haar taak om het publiek goed te informeren zodat er de mogelijkheid bestaat tot kritisch volgen van de overheid. In die gevallen waarin het niet gaat om publieke aangelegenheden zoals bij discriminatoir beledigende geschriften kan de rechter in het uiterste geval wanneer er sprake is van geweld of wanneer er een aantoonbaar verband bestaat tussen de meningsuiting en de dreigende ernstige strafbare gedraging de hele oplage verbeurd verklaren of onttrekken aan het verkeer. Er kan dan geen beroep meer worden gedaan, althans niet met succes, op de vrijheid van meningsuiting en drukpers.

Het Europese Hof gaat ervan uit dat beperkingen of deze nu preventief dan wel repressief zijn, eng dienen te worden geïnterpreteerd. Beperkingen dienen gebaseerd te zijn op een wet die moet voldoen aan het vereiste van 'accesibility' en 'forseeability' en bovendien 'noodzakelijk te zijn in een democratische samenleving' (art. 10 lid 2 EVRM). Of een beperking 'noodzakelijk is in een democratische samenleving' is afhankelijk van de vraag of een 'interference' ingegeven is door een 'pressing social need' en of er een redelijke verhouding bestaan tussen de zwaarte van de inbreuk en het gewicht van het belang dat met de inbreuk werd gediend ('proportionality'). Ook moeten de aangevoerde rechtvaardigingsgronden voor de inbreuk relevant en toereikend zijn. Het gaat hier niet alleen om de rechtsregel zelf, maar ook om de wijze waarop die wordt toegepast. Daarbij wil het Hof ook de feiten en omstandigheden betrekken die in dit concrete geval een rol spelen. In zijn algemeenheid kun je stellen dat het Hof meer ruimte laat voor de vrijheid van meningsui-

8 In: E. Diemer, Vrijheid van drukpers: Eenige opmerkingen over haar staatsrechtelijke regeling in Nederland, diss. VU, Rotterdam 1937, p. 122. 
ting en drukpers wanneer het gaat om discussies over publieke aangelegenheden dan wanneer dit niet het geval is (Sunday Times, EHRM 26-4-1979, NJ 1980, 146). Het discussiëren over publieke aangelegenheden is een basisvoorwaarde voor een democratische rechtsorde. Het is niet woor niets dat de ontvangstvrijheid uitdrukkelijk wordt genoemd in art. 10 lid 1 EVRM. Immers van communicatie is eerst sprake als de zender met zijn boodschap de beoogde ontvanger ook inderdaad bereikt. Een democratische samenleving is niet mogelijk zonder een goed geinformeerd publiek. Om dat publiek goed te informeren is een speciale taak weggelegd voor de pers. Ook de kunstenaar heeft hierin een taak. Zo wordt in de zaak Müller door het Hof (EHRM 8 juli 1986, NJ 1987, 901) een verband gelegd tussen kunst en het publieke debat. Afhankelijk van de speciale verantwoordelijkheid van de betrokkene kan dit tot een ruimere of tot een engere interpretatie van de beperkingsmogelijkheden van de vrijheid van meningsuiting en drukpers leiden (Rapport van de Commissie van 30 september 1975 , Handyside, B. 22, p. 4). De inbeslagneming van een hele oplage geschriften of films of de onttrekking aan het verkeer of de verbeurdverklaring van genoemde gegevensdragers zal door het Hof wellicht niet zo snel worden gezien als een beperking die noodzakelijk is in een democratische samenleving in die gevallen waarin het gaat om publicaties en personen die bijdragen aan het publieke debat. Dat will niet zeggen dat in alle andere gevallen een hele oplage gegevensdragers in beslag mag worden genomen, verbeurd verklaard of onttrokken mag worden aan het verkeer. In de zaak Müller oordeelde de Europese Commissie dat de inbeslagneming ter verbeurdverklaring van alle onzedelijke schilderijen disproportioneel was en niet noodzakelijk in een democratische samenleving. Uitzonderingen moeten volgens de Commissie strict worden geïnterpreteerd.

In Nederland heeft men zoals we in het voorafgaande hebben kunnen lezen bij het redigeren van de inbeslagnemingsbepalingen in het Wetboek van Strafvordering geen rekening gehouden met de vrijheid van meningsuiting en drukpers in art. 7 van de Grondwet en art. 10 EVRM. De politie kan op grond van art. 94 Sv een hele oplage vermeende staatsgeheimen in beslag nemen. Ook de rechter kan een hele oplage staatsgeheimen verbeurd verklaren of onttrekken aan het verkeer. $Z$ ij.j het dat zowel de opsporingsambtenaren als de rechter rekening dienen te houden met het proportionaliteits- en subsidiariteitsbeginsel.

Ook in Duitsland wordt met deze beginselen rekening gehouden. In 'Paragraph $111 \mathrm{~m}$ Abs. 1 StPO* wordt het proportionaliteitsbeginsel zelfs expliciet genoemd. Op grond van 'Paragraph $111 \mathrm{~m}$ Abs. 2 StPO' worden bepaalde delen van een geschrift waarin geen strafbare feiten staan van een inbeslagneming uitgesloten. Zo kan de inbeslagneming bijvoorbeeld tot de bijlage van een krant beperkt blijven. 'Absatz 2 ' laat nog verdergaande beperkingen toe in die zin dat de inbeslagneming enkele archiefexemplaren uitzondert. 'Absatz 4 van Paragraph $111 \mathrm{~m}$ StPO' will het voor de betrokkenen mogelijk maken om de inbeslagneming af te wenden doordat dezen 
gebruik kunnen maken van de mogelijkheid, om het gedeelte van een geschrift waarop de inbeslagneming betrekking theeft, niet te verspreiden of te vermenigvuldigen. Voorwaarde is wel dat een inbeslagnemingsbevel precies aangeeft welke delen van een geschrift tot inbeslagneming aanleiding geven ('Paragraph $111 \mathrm{~m} \mathrm{Abs.} 3$ StPO').

De situatie in Engeland wijkt enigszins af van die in Duitsland. Allereerst kent Engeland geen geschreven Constitutie. De drempels die 'Art. 5' van de Duitse Grondwet opwerpt moeten in Engeland worden opgeworpen door 'statute law' en "common law'. De vrijheid van meningsuiting en drukpers bestaat in Engeland dan ook alleen voorzover deze niet verboden is bij "statute law' of 'common law'. Wanneer we kijken naar de 'Contempt of Court Act 1981', de 'Obscene Publications Act 1959 and 1964', de 'Official Secrets Act 1989', de 'Race Relations Act 1976', de 'Public Order Act 1986 ' en de 'Police and Criminal Evidence Act 1984' alsook naar de jurisprudentie dan zien we dat er helaas niet veel waarborgen geboden worden voor de vrijheid van meningsuiting en drukpers. Bovengenoemde wetten kunnen dusdanig worden geïnterpreteerd dat er al snel sprake is van een strafbare meningsuiting. Wanneer de politie van mening is dat er sprake is van een strafbare meningsuiting kan een hele oplage in beslag genomen worden en door de rechter worden geconfisceerd of onttrokken worden aan het verkeer.

In Zweden mogen in die gevallen dat er sprake is van misbruik van 'tryckfriheten' gegevensdragers in beslag worden genomen of geconfisqueerd (TF 1:3). Het verspreidingsrecht kan dus in zijn geheel worden beperkt (TF 10;7,8). Dit om de schadelijke gevolgen van verspreiding van strafrechtelijk verboden gegevensdragers te beperken of te voorkomen. Een aantal manieren om de schadelijke gevolgen van verspreiding van strafrechtelijk verboden gegevensdragers te beperken of te voorkomen zijn een uitgifteverbod, confiscatie of inbeslagneming. Een uitgifteverbod is slechts mogelijk nadat een procedure heeft plaatsgevonden waaruit blijkt dat er sprake is van een uitings- of drukpersdelict (TF 10:5). Verder is een uitgifteverbod alleen mogelijk wanneer Zweden zich in staat van oorlog bevindt en mag zij niet langer duren dan zes maanden. Bovendien moet het gaan om ernstige strafbare feiten genoemd in 'hoofdstuk 4:1-3, 4 TF'. Behalve een uitgifteverbod noemde ik hierboven ook nog de confiscatie als mogelijkheid om de gevolgen van verspreiding van strafrechtelijk verboden gegevensdragers te beperken of te voorkomen. De confiscatie mag slechts plaatsvinden na een procedure waaruit voor de rechter blijkt dat er een drukpersdelict is gepleegd (TF 10:5). Voor de confiscatie geldt dat in geval van misbruik van de drukpersvrijheid alle materiaal dat bestemd is om verspreid te worden kan worden vernietigd inclusief de drukplaten (TF 7:7) en exclusief het archiefmateriaal (TF 4:4). In tegenstelling tot de confiscatie welke slechts mag plaatsvinden na een procedure waaruit voor de rechter blijkt dat een drukpersdelict is gepleegd, kan de justitiekansler' en de officier van Justitie (onder bepaalde voorwaarden) voorafgaand aan een procedure in beslag nemen. De inbeslagneming is een voorlopige maatregel. Binnen twee weken moet de 'justitiekansler' een klacht (TF 10:2) indienen bij de rechter die dan uiteindelijk beslist of de inbeslagneming dient te worden gecontinueerd (TF 10:4, 5). In principe mag een hele oplage in beslag worden genomen (TF 
10:8) zij het dat indien mogelijk rekening wordt gehouden met het proportionaliteitsbeginsel (TF 10:6).

Vergelijken we bovengenoemde landen dan zien we dat het proportionaliteitsbeginsel een grote rol speelt bij de inbeslagneming. Ook in de Europese jurisprudentie speelt het proportionaliteitsbeginsel een belangrijke rol. Beperkingen op de vrijheid van meningsuiting en drukpers moeten strict worden geformuleerd. Zeker wanneer het gaat om discussies over publieke aangelegenheden zal de inbeslagneming door opsporingsambtenaren van een gehele oplage gegevensdragers of de verbeurdverklaring c.q. onttrekking aan het verkeer door de rechter niet snel door het Europese Hof worden gezien als een beperking die noodzakelijk is in een democratische samenleving. Het is immers in beginsel juist in het belang van een democratische samenleving dat dit materiaal wordt gepubliceerd en verspreid. ${ }^{\text {to }}$

\section{De vrijheid van meningsuiting en drukpers en de procedurele aspecten van de inbeslagneming ter verbeurdverklaring en ter onttrekking aan het verkeer}

Behalve de materiële aspecten van de inbeslagneming ter verbeurdverklaring en ter onttrekking aan het verkeer kunnen ook nog de procedurele aspecten worden genoemd. In Nederland is de procedure bij de verbeurdverklaring en onttrekking aan het verkeer niet anders geregeld dan bij de inbeslagneming voor het aan de dag brengen van de waarheid.

In Duitsland daarentegen is dat wel het geval. Bij de 'Einziehungsbeschlagnahme' geeft 'Paragraph 111n lid 1 StPO' weer wie bevoegd zijn tot de inbeslagneming van gegevensdragers. Voor de inbeslagneming van boeken of bandopnamen etcetera, met uitzondering van opiniebladen, is behalve de rechter bij 'Gefahr im Verzug' ook de officier van Justitie bevoegd. Bij de inbeslagneming van opiniebladen is alleen de rechter bevoegd ('Paragraph 74d Strafgesetzbuch' (StGB). Dit omdat hier de inbeslagneming van vaak tijdsgevoelige informatie grote gevolgen kan hebben voor het woortbestaan wan een uitgever zeker wanneer het een hele oplage betreft. De procedure is hetzelfde geregeld als bij de inbeslagneming voor het aan de dag brengen van de waarheid.

In Engeland is de procedure bij de inbeslagneming van gegevensdragers ter onttrekking aan het werkeer en ter verbeurdverklaring niet geregeld in de 'PACE Act 1984' maar in de 'Obscene Publications Act 1959 and 1964' en de 'Public Order Act 1986. Gaat het om de inbeslagneming van staatsgeheimen, zaken die betrekking hebben op de openbare orde en obscene publicaties dan is de speciale procedurele bescherming die in het leven is geroepen bij de inbeslagneming en de huiszoeking op grond van de 'PACE Act 1984' niet van toepassing. In tegenstelling tot de 'Police and Criminal Evidence Act 1984' bestaat in de 'Obscene Publications Act 1959 and 
1964' geen 'special procedure". Wanneer het gaat om staatsgeheimen, zaken die betrekking hebben op de openbare orde en obscene publicaties zijn verdergaande beperkingen mogelijk. Veelal wordt al voor de publicatie ingegrepen in de vrijheid wan meningsuiting en drukpers door middel van een civiele procedure. Niet alleen is dit een ernstige inbreuk op de vrijheid van meningsuiting en drukpers maar ook wordt door middel van een civiele procedure de jury en de zware strafrechtelijke bewijslast omzeild. Vanaf de jaren tachtig worden er in dit soort zaken alleen nog maar civiele procedures opgestart. Binnen die civiele procedures bestaan verschillende 'prior restraints'. Een daarvan is een 'interim injunction'. Een 'interim injunction' heeft tot gevolg dat een publicatie gestaakt moet worden zolang het civiele proces duurt. Na afloop van het proces, wanneer blijkt dat er bijvoorbeeld geen sprake is van een 'breach of confidence' is de publicatie waak verouderd en dus oninteressant geworden. Wanneer we kijken naar de 'Obscenity Act' dan zien we dat de politie beoordeelt of een artikel 'least obscene' is of 'most obscene'. In de zaak R. vs. Croydon magistrates, ex p Rickman" besliste de rechter dat "he would reach a decision on the basis of the evidence of a police officer consisting of descriptions of the nature of the material." Terwijl dit nu toch juist de taak is van de rechter. Verder kan de politie vermeende obscene boeken in beslag nemen door een 'forfeiture order' te vragen aan een 'magistrates court'. In die gevallen waarin een eigenaar van een boekenwinkel slechts enkele obscene boeken in zijn bezit heeft en 'does not deserve to be convicted of a criminal offence' zal het hierbij blijven. De 'forfeiture power' wordt dan gebruikt om uitgevers en auteurs van hun recht op een 'trial by jury' te beroven. Terwijl het nu juist in dit soort zaken uitermate belangrijk is dat er een 'trial by jury' plaatsvindt. Zij beslissen immers wat 'public morals' inhouden en wanneer mensen 'depraved and corrupted' kunnen zijn als gevolg van een bepaalde publicatie. Bovendien blijkt uit de praktijk dat jury's liberaler beslissen dan rechters. In theorie zou het dus zo moeten zijn dat zowel de auteur als de uitgever in de gelegenheid moet worden gesteld om te worden gehoord. Echter omdat zij in de praktijk veelal niet op de hoogte worden gesteld van lopende zaken, is het niet ongewoon dat materiaal wordt vernietigd zonder dat de auteur of de uitgever de mogelijkheid heeft gehad 'to oppose the case'.

Een ander probleem is dat gegevensdragers worden teruggegeven zonder dat de rechter in staat is geweest te bepalen of materiaal obsceen is of niet. Zo werd op 3 februari 1970 de film 'Flesh' van Andy Warhol in beslag genomen. Toen de fill $\mathrm{m}$ in beslag was genomen, werd door de 'Commissioner of Police' advies ingewonnen bij de 'Director of Public Prosecutions'. Vijf weken later zei de 'Attorney-General' in de 'House of Commons' dat de 'Director of Public Prosecutions' had bevolen dat 'no action for obscenity should be taken'. De film werd teruggegeven zonder dat de zaak voor de rechter was geweest. Dit soort problemen zouden kunnen worden voorkomen door het advies van de 'Director of Public Prosecutions' in te winnen 
voordat er in beslag wordt genomen. De taak van de Director of Public Prosecutions" is dan "to supervise the strict applications of the law before the damage is done and to ensure some degree of unifomity throughout the country. "Zeker nu het begrip obsceen moeilijk te definiëren valt is dit noodzakelijk.

Behalve door middel van een civiele procedure wordt de vrijheid van meningsuiting en drukpers beperkt door een informeel systeem van controle zoals het 'Services, Press and Broadcasting Committee', het 'British Board of Film Censors' en de 'D-notices'. Op grond van deze systemen kunnen geschriften al gecensureerd worden voordat ze openbaar worden gemaakt en/of verspreid worden. Dit is niet alleen pun censuur, het snijdt bovendien de weg af naar de rechter en is daardoor nog minder acceptabel dan de civiele procedure ${ }^{12}$ die vaak wordt opgestart om een publicatie te stoppen.

In Zweden bestaat er ook zo'n informeel systeem van controle. Dit systeem heeft als doel "het bevorderen van een journalistieke ethiek in kranten en tijdschriften. "De persombudsman mag direct vragen aan de redacteur of hij een artikel wil veranderen. Dit alles maakt de strekking van de TF restrictiever. Daarnaast is het de "justitiekansler' die beslist of een geschrift 'vermeende staatsgeheimen' bevat. Deze dient binnen twee weken een klacht in (TF 10;2) bij de rechter die dan uiteindelijk beslist of de inbeslagneming dient te worden gecontinueerd (TF 10;4,5). Blijkt uiteindelijk naar het oordeel van de rechter dat dat niet het geval is dan zijn de geschriften of films toch een tijd uit de roulatie geweest.

In Nederland bestaat gelukkig niet zo'n informeel systeem van controle. Wel bestaat er een formeel controlesysteem op grond van het Wetboek van Strafvordering. Op grond van het huidige Wetboek van Strafvordering heeft de gewone opsporingsambtenaar in prinicpe alleen speciale inbeslagnemingsbevoegdheden. Alleen wanneer zij in de uitoefening van een andere bevoegdheid een daarvoor vatbaar voorwerp aantreffen zijn zij tot inbeslagneming bevoegd. In navolging van pleidooien in de literatuur stelt de Commissie Herijking Wetboek van Strafvordering voor om in plaats van het huidige art. $96 \mathrm{~Sv}$ aan elke opsporingsambtenaar een algemene bevoegdheid tot inbeslagneming te geven. De enige beperking is dat voor een situatie buiten heterdaad sprake dient te zijn van een misdrijf als omschreven in art. 67 eerste lid Sv. Door het grote aantal misdrijven dat onder dit artikellid wordt aangeduid of opgesomd bestaan er praktisch weinig belemmeringen meer voor opsporingsambtenaren. Het is dan ook nog maar de vraag of dit een gewenste ontwikkeling is. De politie, die er alle belang bij heeft om strafbare feiten op te helderen, is volgens mij niet

12. On de zware strafrechtelijke bewijslast en de aanwezigheid wan een jury te omzeilen wordt er vaak een civiele procedure opgestart om eem publicatie te stoppen. In cen civiele procedure kumnen 'interim injunctions' worden gegeven die tot gevolg hebben dat een publicatic gestaakt moet worden zolang het civiele proces duurt, Blijkt er na afloop dat er geen sprake is wan een 'breach of confidence' dan is de publicatie vaak verouderd. Volgens de Europese Commissie is er alls gevolg van tijdelijke rechterijike verboden sprake van een inbreuk op art. 10 EVRM (ECHR 25-6-1991, Human Rights News 1991, zaak 273). 
de juiste instantie om te beslissen over de effectuering van het recht op de vrijheid van mieningsulting en drukpers. In Duitsland heeft de wetgever niet voor niets een onderscheid gemaakt tussen uitingen in opiniebladen en uitingen in bijvoorbeeld films en boeken. Gaat het om opiniebladen dan is alleen de rechter bevoegd in beslag. te nemen. Opiniebladen zijn immers tijdsgevoelig. Inbeslagneming van cen hele oplage kan de bestaanspositie van een uitgever in gevaar brengen. Rechters worden geacht beter in staat te zijn grondrechten af te wegen tegen het opsporings- en vervolgingsbelang dan de politie. Voor de inbeslagneming van films, boeken etcetera is ook de officier van Justitie bevoegd wanneer 'Gefahr im Verzug' dreigt. Omdat de strafrechtelijke bepalingen, zoals de pornografiebepalingen, de bepalingen die betrekking hebben op staatsgeheimen etcetera vaag zijn geformuleerd is het beter om de officier van Justitie bij 'Gefahr im Verzug' de bevoegdheid te geven om gegevensdragers in beslag te nemen dan een politie-agent. Op deze manier wordt voorkomen dat gegevensdragers in beslag worden genomen die later teruggegeven moeten worden omdat de officier van Justitie denkt het bewijs niet rond te krijgen. Dat het toekennen van inbeslagnemingsbevoegdheden aan de rechter en de officier van Justitie ook nadelen heeft is onvermijdelijk. In Duitsland is het immers zo dat wanneer de politie zulke geschriften ontdekt eerst een rechter of een officier van Justitie moet worden ingeschakeld. De strafbare drukwerken zijn dan vaak al verdwenen. Dat in Duitsland toch voor bovengenoemde regeling is gekozen heeft te maken met het feit dat hier de vrijheid wan meningsuiting en drukpers in het geding is. Dwangmiddelen kunnen een inbreuk maken op dit grondrecht. Daarom dienen dwangmiddelen met de grootst mogelijke waarborgen worden omgeven. Een van die waarborgen is dat bij de inbeslagneming van niet-tijdsgevoelige informatie de officier van Justitie bevoegd dient te zijn en bij de inbeslagneming wan tijdsgevoelige informatie de rechter-commissaris. De rechter-commissaris is immers behalve rechtshandhaver ook rechtsbeschermer. Hij is meer nog dan de officier van Justitie in staat om een juiste afweging te maken. Met de keuze voor een officier van Justitie en een rechter-commissaris kan wellicht ook voorkomen worden dat, of helemaal geen procedure wordt opgestart, of pas lange tijd ua de inbeslagneming. Zeker niewwsgevoelig materiaal dient niet langer dan noodzakelijk uit de roulatie te zijn geweest.

\section{Aanbevelingen}

Tot besluit zullen de aanbevelingen die in de voorafgaande paragrafen zijn genoemd in deze paragraaf worden gerecapituleerd. Zoals in de inleiding van deze conclusie reeds werd opgemerkt is de rechtsvergelijking bedoeld om enige aanbevelingen te formuleren tot verbetering wan de Nederlandse bepalingen inzake inbeslagneming. Zolang deze bepalingen immers niet worden gewijzigd bestaan er voor de Nederlandse rechter geen aanknopingspunten om meer recht te doen aan de vrijheid van meningsuiting en drukpers (art. 7 Grondwet en art. 10 EVRM). 
1. Om te beginnen dient er in het Wetboek van Strafvordering, net als dat in Duitsland, Engeland en Zweden het geval is, een onderscheid te worden gemaakt tussen voorwerpen en gegevensdragers. Gegevensdragers mogen, volgens het initiatief-wetsvoorstel van Jurgens, niet in beslag worden genomen voor het aan de dag brengen van de waarheid wanneer het gaat om journalistieke werkzaamheden. Het accent ligt hier op 'gegevens' en niet, zoals in de Wet Computercriminaliteit, op 'dragers'. Het gaat de politie inmers om de informatie en niet zozeer om de dragers van die informatie. Daarbij dient niet alleen eigen materiaal, zoals in Duitsland, maar ook derden-materiaal beschermd te worden. Door wettelijk vast te leggen dat het journalistiek privilege als uitgangspunt dient, zal de rechter, in het concrete geval, slechts bij aanwezigheid van zeer dringende redenen, kunnen komen tot een inbreuk op dit recht. Inbeslagneming is dan slechts in zeer uitzonderlijke situaties te rechtvaardigen namelijk in die gevallen waarin er zwaar lichamelijk letsel veroorzaakt wordt. In eerste instantie zal moeten worden bekeken in hoeverre de politie of justitie zelf redelijkerwijs bij machte is de gewenste informatie te vergaren. Is zij zelf niet bij machte om de gewenste informatie te verkrijgen dan kan de politie in beslag nemen daarbij rekening houdend met het proportionaliteitsbeginsel en subsidiariteitsbeginsel.

2. Bij de inbeslagneming ter verbeurdverklaring en ter onttrekking aan het verkeer dient, net als in Duitsland, rekening te worden gehouden met het onderscheid tussen tijdsgevoelige informatie en informatie die niet tijdsgevoelig is. Bij de tweede categorie is de officier van Justitie bevoegd tot inbeslagneming. Gaat het om de inbeslagneming van tijdsgevoelige informatie dan is alleen de techter-commissaris bevoegd. Behalve het onderscheid tussen tijdsgevoelige informatie en informatie die niet tujdlsgevoelig is dient er een onderscheid te worden gemaakt tussen discussies over publieke aangelegenheden en discussies die dat niet zijn. Volgens het Europese Hof dient het publieke debat beschermd te worden. Gaat het om een publiek debat dan zal de inbeslagneming, verbeurdverklaring en onttrekking aan het verkeer van een hele oplage gegevensdragers al snel disproportioneel zijn. Volgens de Europese Commissie dient er ook bij onzedelijke geschriften gecontroleerd te worden of de inbeslagneming ter verbeurdverklaring of ter onttrekking aan het verkeer proportioneel is. In de zaak Müller oordeelde de Commissie dat de 'confiscation' van alle schilderijen disproportioneel was en niet noodzakelijk in een democratische samenleving. Deze visie sluit aan bij mijn opvatting dat zowel preventieve beperkingen, zoals de inbeslagneming, als repressieve beperkingen, zoals de onttrekking axin het verkeer en de verbeurverklaring, de verspreiding van gegevensdragers niet onmogelijk mag maken tenzij er sprake is van aantoonbaar verband tussen de meningsuiting en fysiek geweld. De inbeslagneming en de verbeurdverklaring casu quo onttrekking an het verkeer dient achterwege te blijven wanneer het gaat om het publieke debat. 
$$
34
$$ 


\section{Samenvatting}

\section{Inleiding}

In dit proefschrift wordt het spanningsveld beschreven tussen de vrijheid van meningsuiting en drukpers en het strafvorderlijke dwangmiddel inbeslagneming in een internationaal en rechtsvergelijkend perspectief. Centraal staat de vraag in hoeverre de vrijheid van meningsulting en drukpers een belemmering vormt voor de toepassing van het strafvorderlike dwangmiddel inbeslagneming. In de opeenvolgende hoofdstukken wordt de vrijheid van meningsuiting en drukpers en de strafvorderlijke inbeslagneming besproken in Nederland en in Duitsland, Engeland en Zweden.

\section{Hoofdstuk 1 De vrijheid van meningsuiting en drukpers en het strafvorderlijke} dwangmiddel inbeslagneming in Nederland

In het eerste hoofdstuk wordt nagegaan hoe de vrijheid van meningsuiting en drukpers is geregeld in art. 7 van de Grondwet (paragraaf 1) alsook in art. 10 EVRM en, zij het summier, in art. 19 IVBPR (paragraaf 2) waarbij uiteraard ook de relevante jurisprudentie behorende bij genoemde wetsartikelen aan de orde komt. Het doel van deze beschrijving is kennis te nemen van de reikwijdte van de vrijheid van meningsuiting en drukpers, immers de reikwijdte van de vrijheid van meningsuiting en drukpers heeft implicaties voor het stratvorderlijke dwangmiddel inbeslagneming (paragraaf 3).

Wanneer we kijken naar art. 7 van de Nederlandse Grondwet dan zien we dat de openbaringsvrijheid staat opgenomen in de Grondwet. De verspreidingsvrijheid daarentegen is rechtersrecht en onderworpen aan een ander rechtsregime dan de openbaringsvrijheid. Zo mag de verspreidingsvrijheid in tegenstelling tot de openbaringsvritheid wel vooraf worden beperkt door bijvoorbeeld een opsporingsambtenaar. Echter dit betekent niet dat deze beperkingen zover mogen gaan dat er van dat verspreidingsrecht niets meer overblift. De verspreidingsvrijheid wordt door de Hoge Raad in het Tilburg-arrest (HR 28-11-1950, NJ 1951, 137) immers omschreven als een "conditio sine qua non" voor de openbaringsvrijheid. De vrijheid van meningsuiting. en drukpers wordt pas effectief door de verspreiding. Beperkingen dienen dan ook 'gebruik van enige betekenis' van het werspreidingsmiddel over te laten (HR 17 maart 
1953 , NJ 1953, 389). Een voorbeeld van een beperking op de vrijheid van meningsulting en drukpers is het strafvorderlijke dwangmiddel inbeslagneming. De vraag is hoe de inbeslagneming zich verhoudt met de vrijheid van meningsuiting en drukpers en meer in het bijzonder de verspreidingsvrijheid.

Op grond van art. $94 \mathrm{~Sv}$ is het mogelijk om voorwerpen in beslag te nemen woor het aan de dag brengen van de waarheid, ter verbeurdverklaring en ter onttrekking aan het verkeer. Bij de inbeslagneming voor het aan de dag brengen van de waarheid, die slechts tujdelijk is, kan volstaan worden met de inbeslagneming van eén gegevensdrager. Tenminste als men uit gaat van het feit dat 'gegevensdragers' vallen onder het begrip "woorwerp' in art. 94 Sv. Men legt dan het accent op het begrip 'drager". Legt men daarentegen het accent op het begrip 'gegeven' dan komt men, zoals we in paragraaf 4.3.1 hebben kunnen zien tot een geheel andere conclusie. Zelf ben ik geneigd om het accent te leggen op "gegevens'. Het gaat bij de inbeslagneming voor het aan de dag brengen van de waarheid om de informatie. Wil men deze informatie op dragers in beslag kunnen nemen dan zal er voor gegevensdragers, die betrekking hebben op de journalistieke werkzaamheid, een aparte regeling moeten komen die rekening houdt met de vrijheid van meningsuiting en drukpers.

Voor wat betreft de inbeslagneming ter verbeurdverklaring geldt dat in tegenstelling tot de inbeslagneming van een voorwerp voor het aan de dag brengen van de waarheid, bij de inbeslagneming ter verbeurdverklaring wordt geanticipeerd op het oordeel van de rechter. Bij een veroordeling wordt het goed definitief aan de macht van de veroordeelde onttrokken. In Nederland is de verbeurdverklaring een vermogensstraf en een bijkomende straf wat impliceert dat de oplegging facultatief is. Ook niet in beslag genomen voorwerpen kunnen worden verbeurd verklaard. Het doel van de verbeurdverklaring is niet alleen leedtoevoeging maar ook preventie. Omdat de inbeslagneming niet noodzakelijk is heeft de beslag leggende ambtenaar een grote beleidsvrijheid bij het beslissen of het voorwerp wel of niet in beslag genomen dient te worden.

Bij de onttrekking aan het verkeer daarentegen is de inbeslagneming een noodzakelijke voorwaarde. Er is minder speelruimte voor opsporingsambtenaren. Dat de inbeslagneming hier kennelijk orredelijk is zal hier minder snel worden aangenomen. Het betreft hier een typische politie- c.g. veiligheidsmaatregel ten dienste van justitie, die zich zuiver afspeelt in de sfeer van de opportuniteit. Wanneer er meerdere bijvoorbeeld vermeende staatsgeheimen of godslasterlijke gescliriften of pamfletten worden aangetroffen van dezelfde soort kan inbeslagneming plaatsvinden door de politie van de gehele voorraad.

In de zaak Bluf! (HR 17-11-1987, NJ 1988, 394 en HR 18-9-1989, NJ 1990, 94) stond de publicatie van een oud kwartaaloverzicht van de BVD uit 1981 centraal. In het weekblad Bluf! nr. 267 werd dit kwartaaloverzicht afgedrukt. Toen Bluf! nr. 267 net van de pers kwam en woor verzending gereed gemaakt werd viel een politiemacht binnen bij de drukker en nam de hele oplage in beslag (art. 98 en/of $98 \mathrm{a}$ Sr, staatsgeheimen) in het kader van een gerechtelijk vooronderzoek tegen NN. Op wordering wan de officier van Justitie werd de gehele oplage van het weekblad Bluf! 
van 29 april 1987 door de rechtbank te Amsterdam onttrokken aan het verkeer (vergelijk art. 36c Sr). De inhoud van Bluf! nr. 267 kon -zo werd door de officier van Justitie gesteld en door de rechtbarik aangenomen- niet door de beugel; geheimhouding was, met het oog op de veiligheid van de staat of zijn bondgenoten, geboden (artt. $98 \mathrm{en} /$ of $98 \mathrm{a} \mathrm{Sr}$ ). Bluf! tekende tegen de beschikking van de rechtbank cassatieberoep aan bij de Hoge Raad. De belangrijkste argumenten van Bluf! waren dat de drukpersvrijheid betekent dat alleen achteraf dus na publicatie (bedoeld wordt hier na openbaarmaking en verspreiding) door een strafrechter besloten kan worden dat een oplage moet worden verbeurd verklaard of onttrokken aan het verkeer. Door de hele oplage van te voren in beslag te nemen is er in werkelijkheid censuur uitgeoefend. Volgens de Hoge Raad was er helemaal geen sprake van censuur. De inbeslagneming en de onttrekking aan het verkeer waren volgens de Hoge Raad géén beperkingen die konden worden gelijkgesteld met het onderwerpen aan de voorwaarde van 'voorafgaand verlof' als bedoeld in art. 7 lid 1 van de Grondwet. Dit is juist. Er was inderdaad geen sprake van censuur. De beperking had immers niet betrekking op de inhoud maar op de verspreiding. Vervolgens stelt de Hoge Raad dat

"Tot de middelen waarmee de belangen, die de artt. 98 en $98 \mathrm{a} \mathrm{Sr}$ beogen te beschermen, behoren niet alleen de strafrechtelijke vervolging en eventuele veroordeling van degenen die de in deze artikelen strafbaar gestelde feiten hebben begaan, maar ook de inbeslagneming en de onttrekking aaan het verkeer volgens de bepalingen van het Wetboek van Strafvordering van voor het begaan van zodanige feiten bestemde drukwerken. Toepassing van deze middelen valt te rekenen tot de bij de genoemde verdragsbepalingen toegelaten beperkingen van het in die bepaling verzekerde recht en kan niet worden gelijkgesteld met het onderwerpen aan de woorwaarde van 'voorafgaand verlof' als bedoeld in woormeld grondwetsartikel ook al wordt als gevolg daarvan het desbetreffende drukwerk met de daarin neergelegde gedachten en gevoelens niet openbaar"

(met 'niet openbaar' zal hier de Hoge Raad waarschijnlijk 'niet verspreid' bedoeld hebben). Met dit laatste dat zolang er maar geen sprake is van censuur alle inbreuken op de vrijheid van meningsuiting en drukpers geoorloofd zijn ben ik het niet eens. Immers de gedachte achter art. 7 van de Grondwet is dat inbreuken op de vrijheid van meningsuiting en drukpers slechts in beperkte mate en bij hoge uitzondering mogelijk zijn. Zo mag de verspreiding van in casu geschriften die vermeende staatsgeheimen bevatten, wel beperkt worden door de politie op grond van art. 7 Grondwet in het belang van de openbare orde of de veiligheid van anderen maar deze beperkingen mogen niet leiden tot een 'algeheel verbod'. Van een 'algeheel verbod' is sprake wanneer er geen mogelijkheid meer bestaat om de geschriften te verspreiden, bijvoorbeeld doordat een hele oplage in beslag is genomen of doordat de drukpersen en drukplaten in beslag zijn genomen. Ook de rechter mag op grond van de clausule 'behoudens ieders verantwoordelijkheid volgens de wet' geschriften die staatsgeheimen bevatten onttrekken aan het verkeer of verbeurd verklaren zij het dat "het in den geest der Grondwet is repressieve maatregelen, met ander woorden de strafbaarstelling 
en vervolging van drukpersdelicten op zoodanige wijze te regelen, dat niet indirect het preventieve toezicht weder instuipe", aldus minister Modderman tijdens de parlementaire behandeling van het Wetboek wan Strafrecht in de Tweede Kamer. Zeker wanneer het betreft discussies over publieke aangelegenheden dient de rechter extra voorzichtig te zijn. Niet alleen omdat door de verbeurdverklaring of onttrekking aan het verkeer van een hele oplage de bestaanspositie van bijvoorbeeld een dagblad of tijdschrift in gevaar gebracht kan worden, maar ook ondat het discussiëren over publieke aangelegenheden een basisvoorwaarde is voor een democratische rechtsorde en voor de fundering vari de overige grondwettelijke vrijheden. De media nemen hier een speciale positie in. Het is haar taak om het publiek goed te informeren zodat er de mogelijkheid bestaat tot kritisch volgen van de overheid. In die gevallen waarin het niet gaat om publieke aangelegenheden zoals bij discriminatoir beledigende geschriften kan de rechter in bet uiterste geval wanneer er sprake is van geweld of wanneer er een aantoonbaar verband bestaat tussen de meningsuiting en de dreigende ernstige strafbare gedraging de hele oplage verbeurd verklaren of onttrekken aan het verkeer. Er kan dan geen beroep meer worden gedaan op de wrijheid van meningsuiting en drukpers.

Het Europese Hof gaat ervan uit dat beperkingen of deze nu preventief dan wel repressief zijn, eng dienen te worden geïnterpreteerd. Volgens het Europese Hof dient een beperking 'noodzakelijk te zijn in een democratische samenleving'. Dit betekent dat een 'interference' ingegeven moet zijn door een 'pressing social need' en dat er bovendien een redelijke verhouding moet bestaan tussen de zwaarte van de inbreuk en het gewicht van het belang dat met de inbreuk werd gediend ('proportionality'). Ook moeten de aangevoerde rechtvaardigingsgronden voor de inbreuk relevant en toereikend zijn. Het gaat hier niet alleen om de rechtsregel zelf maar ook om de wijze waarop die wordt toegepast. Daarbij wil het Hof ook de feiten en omstandigheden betrekken die in dit concrete geval een rol spelen. In zijn algemeenheid kun je stellen dat het Hof meer ruimte laat voor de vrijheid van meningsuiting en drukpers wanneer het gaat om discussies over publieke aangelegenheden dan wanneer dit niet het geval is. Daarbij moet een politicus meer kritiek kunnen incasseren dan een gewone burger. Het discussiëren over publieke aangelegenheden is een basiswoorwaarde voor een democratisch rechtsorde. Het is niet voor niets dat de ontvangstvrijheid uitdrukkelijk wordt genoemd in art. 10 lid 1 EVRM. Immers van communicatie is eerst sprake als de zender met zijn boodschap de beoogde ontvanger ook inderdaad bereikt. Een democratische samenleving is niet mogelijk zonder een goed geïnformeerd publiek. Om dat publiek goed te informeren is een speciale taak weggelegd voor de pers. Ook de kunstenaar heeft hierin een taak. Zo wordt in de zaak Müller door het Hof (EHRM 8 juli 1986, NJ 1987, 901) een verband gelegd tussen kunst en het publieke debat. Afhankelijk van de speciale verantwoordelijkheid van de betrokkene kan dit tot een ruimere of tot een engere interpretatie van de beperkingsmogelijkheden van de vrijheid van meningsuiting en drukpers leiden (Rapport van de Commissie van 30 september 1975, Handyside, B. 22, p. 4). 
Hoofdstuk 2 De vrijheid van meningsuiting en drukpers en het strafvorderlijke dwangmiddel inbeslagneming in Duitslland

In het tweede hoofdstuk staat dezelfde problematiek centraal maar dan in een ander land namelijk Duitsland. In de Duitse Grondwet ('Grundgesetz' (GG)) wordt naast de vrijheid van meningsuiting en drukpers, in tegenstelling tot Nederland, ook de verspreidingsvrijheid en de informatievrijheid genoend. Art. $5 \mathrm{GG}$ garandeert bovendien de "institutionelle Eigenständigkeit der Presse". Het is de taak van de pers mensen te informeren. Dat is niet alleen het wezen van de pers maar ook het wezen van de democratie. Voor het functioneren van een democratisch systeem is dan ook een beperkt verschoningsrecht ('Zeugnisverweigerungsrecht') en een beperkt inbeslagnemingsverbod onontbeerlijk. Bij het redigeren van de inbeslagnemingsbepalingen in het Duitse Wetboek van Strafvordering ('Strafprozeßordnung' (StPO)) heeft men rekening gehouden met 'Art. 5 Grundgesetz'. In tegenstelling tot Nederland wordt er in Duitsland wel een onderscheid gemaakt tussen voorwerpen en gegevensdragers. De inbeslagneming van geschriften, geluid-, beelddragers en databanden etcetera voor het aan de dag brengen van de waarheid, die zich in bewaring bevinden bij gepriviligeerde mediamedewerkers of de redactie, een uitgever, drukkerij, 'Rundfunk', is niet toelaatbaar in die gevallen waarin het verschoningsrecht een rol speelt. De grondgedachte in Duitsland achter de 'Paragraphen 53 en 97 Abs. 5 Strafprozeßordnung' is de bescherming van de vertrouwensrelatie tussen de pers en hun informanten. Deze bescherming van de vertrouwensrelatie tussen media en hun informanten zorgt ervoor dat media-medewerkers onafhankelijk kunnen functioneren. Een voorwaarde is wel dat het moet gaan om materiaal dat van derden verkregen is. Eigen materiaal kan wel in beslag worden genomen door de rechter. Wanneer er 'Gefahr im Verzug' dreigt zijn ook de officier van Justitie en de hulp-officier bevoegd tot inbeslagneming. Er dient echter een uitzondering te worden gemaakt voor de inbeslagneming van eigen materiaal bij de redactie, een uitgever, een drukkerij of de 'Rundfunk'. Hier is alleen de rechter bevoegd. Ook als het gaat om 'Gefahr im Verzug' ('Paragraph 98 StPO Abs. 1).

Op bovengenoemde voorwarde is veel kritiek gekomen. Immers door het verschoningsrecht niet te erkennen voor het materiaal dat een journalist zelf verzamelt, wordt het wezen van journalistieke arbeid in feite miskent. Immers een journalist verzamelt zijn informatie onopvallend en overal. Reporters en journalisten kunnen in een moeilijke situatie terecht komen wanneer zij op grond van de door het Openbaar Ministerie gevorderde medewerking worden gezien als handlangers van justitie. Gezien het feit dat in de praktijk is gebleken dat het onderscheid tussen eigen materiaal en materiaal dat van derden verkregen is niet duidelijk is te maken, valt dit onderscheid te betwijfelen.

Typerend voor Duitsland is verder dat het 'Zeugnisverweigerungsrecht" gekoppeld wordt aan een inbeslagnemingsverbod ('Paragraph 97 StPO' jo. 'Paragraph 53 StPO'). De grondgedachte in Duitsland achter de 'Paragraphen 53 en 97 Abs. 5 StPO' is de bescherming van de vertrouwensrelatie tussen de media en hun informanten. 
Deze bescherming van de vertrouwensrelatie tussen de media en hun informanten zorgt ervoor dat mediamedewerkers onafhankelijk kunnen functioneren. Alleen wanneer het verschoningsrecht en het redactiegeheim gewaarborgd is, kunnen de media hun controle- en informatieve functie goed vervullen. De informatievrijheid en de grondwettelijke bescherming van de informatiebronnen tegen inbeslagneming staan in direct verband met elkaar. De 'informationsschutz' is een logisch gevolg van de in art. 5 'Grundgesetz' genoemde karakteristieke positie van de media. De talak wan de media is het publiek te informeren over politieke gebeurtenissen. Door het weergeven van verschillende opvattingen wordt het voor burgers mogelijk gemaakt om kritisch te kunnen beslissen. Zij zijn "die orientierende Kraft in der offentlichen Auseinandersetzung." Aan de inlichtingenfunctie van de media kan de controlefunctie gekoppeld worden. De media zijn de "scharfaugigen Wächter" van de democratie die misstanden ontdekken en de openbare discussie daarover aanzwengelen of in de woorden van het Europese Hof "the press is the purveyor of information and public watchdog" (EHRM 25 maart 1985, NJ 1987, 900). Het begrip mediavrijheid heeft in Duitsland vooral betrekking op institutionele vrijheid. Een schrijver die een boek schrijft, een cineast die een film maakt of een groep burgers die een pamflet schrijven kunnen geen beroep doen op de bescherming die 'Paragraph 97 StPO' jo. 'Paragraph 53 StPO' bieden. Hun materiaal kan in beslag worden genomen door de rechter en wanneer er 'Gefahr im Verzug' dreigt door de officier van Justitie of de hulpofficier. Door zoals Jurgens te kiezen voor 'journalistiek materiaal' hef je bovengenoemd probleem op. Iedereen die zich bezig houdt met journalistieke arbeid kan dan een beroep doen op het verschoningsrecht en het daaraan gekoppelde inbeslagnemingsverbod.

Behalve bij de inbeslagneming voor het aan de dag brengen van de waarheid is ook bij de 'Einziehungsbeschlagnahme' het spanningsveld tussen het strafvorderlijke dwangmiddel inbeslagneming en de vrijheid van meningsuiting en drukpers op een interessante manier aangepakt. Zo wordt bij de 'Einziehungsbeschlagnahme' ('Paragraph $111 \mathrm{~m}$ Abs. 1 StPO'), hetwelk zowel betrekking heeft op de inbeslagneming van gegevensdragers ter verbeurdverklaring als op de inbeslagneming om onbruikbaarmaking te voorkomen, net als bij de voorlopige hechtenis, uitdrukkelijk gewezen op het proportionaliteitsbeginsel. Dit omdat de inbeslagneming van een gehele oplage de economische bestaanspositie van bijvoorbeeld een drukkerij in gevaar kan brengen. Volgens 'Paragraph $111 \mathrm{~m}$ Abs. 2 StPO' worden dan ook bepaalde delen van een geschrift waarin geen strafbare feiten staan van een inbeslagneming uitgesloten. $\mathrm{Zo}$ kan de inbeslagneming bijvoorbeeld tot de bijlage van een krant beperkt blijven. 'Absatz 2' laat nog verdergaande beperkingen toe in die zin dat de inbeslagneming enkele archiefexemplaren uitzondert, 'Absatz 4' van 'Paragraph $111 \mathrm{~m} \mathrm{StPO'}$ ' wil het voor de betrokkenen mogelijk maken om van zijn bevoegdheid gebruik te maken om een inbeslagneming af te wenden. Daarom is het verplicht dat een inbeslagnemingsbevel precies aangeeft welke delen van een geschrift tot inbeslagneming aanleiding geven ('Paragraph $111 \mathrm{~m}$ Abs. $3 \mathrm{StPO}$ ). De inbeslagneming kan volgens 'Paragraph $111 \mathrm{~m}$ Abs. 4 StPO' worden voorkomen wanneer betrokkenen gebruik maken 
van de mogelijkheid, om het gedeelte van een geschrift waarop de inbeslagneming betrekking heeft, niet te verspreiden of te vermenigvuldigen.

'Paragraph 111n Abs. 1 StPO' geeft weer wie bevoegd zijn tot de inbeslagneming van gegevensdragers. Voor de inbeslagneming van pamfletten, boeken of bandopnamen etcetera, met uitzondering van opiniebladen, is de rechter en bij 'Gefahr im Verzug' de officier van Justitie bevoegd. De hulp-officieren zijn niet bevoegd. De werordening tot inbeslagneming dient binnen een week door de rechter te worden bekrachtigd. Voor de inbeslagneming van opiniebladen en gegevensdragers die hiermee overeenkomen is alleen de rechter bevoegd ('Paragraph 74d Strafgesetzbuch" (StGB)). Dit omdat hier de inbeslagneming van vaak tijdsgevoelige informatie grote gevolgen kan hebben voor het voortbestaan van een uitgever zeker wanneer het een hele oplage betreft.

\section{Hoofdstuk 3 De vrijheid van meningsuiting en drukpers en het strafvorderlijke dwangmiddel inbeslagneming in Engeland}

Omdat Engeland geen geschreven constitutie kent worden in dit hoofdstuk zowel de wetten besproken die van belang zijn voor het bepalen van de reikwijdte van de vrijheid van meningsuiting en drukpers als ook de jurisprudentie. De vrijheid van meningsuiting en drukpers bestaat in Engeland voorzover deze niet verboden is bij 'statute law' of 'common law'. Wanneer we kijken naar de 'Contempt of Court Act 1981', de 'Obscene Publications Act 1959 and 1964', de 'Official Secrets Act 1989', de 'Race Relations Act 1976', de 'Public Order Act 1986' en de 'Police and Criminal Evidence Act 1987' alsook naar de jurisprudentie dan zien we dat de reikwijdte die is toegekend aan de vrijheid van meningsuiting beperkt is. Er worden nauwelijks drempels opgeworpen tegen de inbeslagneming. De enige regeling die enigszins rekening houdt met de wrijheid van meningsuiting en drukpers is de 'Police and Criminal Evidence Act 1984'. In deze 'Act' wordt de inbeslagneming van gegewensdragers gekoppeld aan de huiszoeking. De inbeslagneming wan 'excluded material', 'legally privileged material' en 'special procedure material' is met extra processuele waarborgen omkleed wanneer er sprake is van een huiszoeking. Welke watarborgen dit zijn komt hieronder aan de orde. Allereerst een nadere verduidelijking van bovengenoemde categorieën "material".

'Excluded materials' zijn 'personal records' of 'human tissue of human tissue fluid' of 'journalistic material'. 'Journalistic material' moet betreffen 'documents' of 'records other than documents'. Onder documenten wordt hier verstaan:
a. geschreven stukken, een plan, tekening etcetera;
b. een foto;
c. een diskette, geluidsband, c.d. etcetera;
d. films, microfilms, negatieven etcetera. 
Voor alle drie de categorieèn geldt dat het materiaal "must be held in confidence". Voor een journalist betekent dit dat het moet gaan om documenten die van derden verkregen zijn. Er moet sprake zijn van een vertrouwensrelatie tussen de journalist en een derde. Foto's gemaakt wan een demonstratie vallen hier dus niet onder. Deze kunnem eventueel wel geclassificeerd worden als 'special procedure material". 'Special procedure material' is onder andere journalistiek materiaal hetwelk niet geclassificeerd kan worden als 'excluded material', ofwel omdat het geen documenten betreft ofwel zijn het documenten maar voldoen ze niet aan de eis van vertrouwelijkheid. Voor zowel 'excluded" als 'special procedure material' geldt dat een politieagent op grond van de "Police and Criminal Evidence Act 1984" alles in beslag mag nemen. Zij het dat de politie op grond van de 'Police and Criminal Evidence Act 1984' niets in haar bezit zal houden wanneer een foto of een 'copy' ook voldoende is ('section" 22(4)). Zo besliste de 'Court of Appeal' in cle zaak 'Reynolds vs. Commissioner of Police of the Metropolis' dat de politie niet bevoegd is om grote aantallen documenten in beslag te nemen zonder aan te geven dat 'each file or bundle might reasonably' constitute evidence" ((1984) 3 All ER 649, CA). Impliciet wordt op deze manier toch rekening gehouden met de vrijheid van meningsuiting en drukpers. Een uitzondering op de bevoegdheid tot huiszoeking en inbeslagneming is legally privilleged material'. Dit materiaal, dat onder andere betrekking heeft op de 'communications' tussen een juridisch adviseur en zijn cliënt ('section' 10 (1)(a)) mag niet in beslag genomen. worden.

Verder is er een speciale procedure in het leven geroepen bij de inbeslagneming van gegevensdragers tijdens een huiszoeking. Zo is bij de inbeslagneming van 'excluded material' en 'special procedure material' een 'production order' vereist die de politie aanvragt bij de 'circuit judge'. Een 'production order' vereist van de persoon die het bewijsmateriaal bezit dat hij/zij dit materiaal aan de politie overdraagt of dat hij/zij toestaat dat een politieagent toegang krijgt tot het bewijsmateriaal. De persoon voorkomt hiermee een huiszoeking. In tegenstelling tot een 'search warrant" is een "production order' altijd 'inter partes'. Dat wil zeggen dat je de mogelijkheid krijgt om bij de rechter te klagen tegen een voorgenomen of een reeds uitgevoerde inbeslagneming tenzij er onder een oude 'Act' vóór 1984 een 'written authority other than a warrant" nodig was om toegang te verkrijgen tot "excluded material". Dan behouden deze 'Acts' hun geldigheid en is een procedure niet langer 'inter partes' (zie onder andere de 'Official Secrets Act 1989', de 'Obscene Publications Act 1959 and 1964' en de 'Public Order Act 1986'). De vraag is of dit niet op gespannen voet staat met het "fair trial" beginsel in art. 6 EVRM. Zeker nu de "Official Secrets Act 1989', de 'Obscene Publications Act 1959 and 1964' en de 'Public Order Act 1986' niet veel waarborgen bieden voor de vrijheid van meningsuiting lijkt me dit niet zo'n goede regeling. De 'Official Secrets Act 1989', de 'Obscene Publications Act 1959 and 1964' en de 'Public Order Act 1986' zïjn immers onduidelijk geformuleerd. Zij werpen nauwelijks drempels op tegen de inbeslagneming van gegevensdragers. Daar komt nog bij dat op grond van deze wetten een informeel systeem van controle is opgezet zoals het 'Services, Press and Broadcasting Committee', het 'British Board 
of Film Censors' en de 'D-notices'. Op grond van dit informele systeem kunnen geschriften al gecensureerd worden voordat ze openbaar worden gemaakt en/of verspreid worden. Dit is niet alleen puur censuur het snijdt bovendien de weg af naar de rechter en is daardoor nog minder acceptabel dan de civiele procedure die vaak wordt opgestart om een publicatie te stoppen.

\section{Hoofdstuk 4 De wrijheid van meningsuiting en drukpers en het strafvorderlijke dwangmiddel inbeslagneming in Zweden}

De vrijheid van drukpers is geregeld in 'Tryckfrihetsförordningen' (TF). Alle aspecten die te maken hebben met de vrijheid van drukpers staan geregeld in deze wet. Daarnaast is sinds 1992 de Wet op de Uitingsvrijheid ('Yttrandefrihetsgrundlagen' (YF)) in werking getreden. De YF heeft betrekking op onder andere geluidsbanden, film, video, radio, televisie. In de YF wordt uitdrukkelijk verwezen naar de TF. De inbeslagneming van gegevensdragers is niet geregeld in het Wetboek van Strafvordering maar in de TF. In de TF staan zowel de materiële als de procedurele aspecten geregeld van de inbeslagneming. Om met eerstgenoemde aspecten te beginnen. Net als in Duitsland en in Engeland wordt er in Zweden een onderscheid gemalakt tussen voorwerpen en gegevensdragers. Voor gegevensdragers gelden speciale regels. Er wordt geen onderscheid gemaakt in bescherming tussen de verschillende soorten gegevensdragers. Voor bijvoorbeeld films geldt min of meer dezelfde bescherming als voor geschriften. Deze bescherming bestaat hierin dat aan de inbeslagneming van gegevensdragers bepaalde voorwaarden worden verbonden.

Zo dient de 'justitiekansler', een speciale officier van Justitie en bevoegd om bij drukpersdelicten gegevensdragers in beslag te nemen (TF 9:2), er bij cle inbeslagneming op te letten dat deze alleen betrekking heeft op exemplaren die bestemd zijn voor de verspreiding (TF 10:8). Exemplaren die aan burgers verkocht zijn of aan bibliotheken zijn gegeven mogen niet worden in beslag genomen. Exemplaren daarentegen die zich bevinden bij een drukker, uitgever of een boekhandel mogen well in beslag worden genomen. Daarbij dient rekening te worden gehouden met het proportionaliteitsbeginsel (TF 10:6). Indien nodig is de inbeslagneming van een bepaald deel, de bladzijde of de passage voldoende. Bij de inbeslagneming voor het aan de dag brengen van de waarheid kan zelfs de inbeslagneming van eén exemplaar voldoende zijn (TF 10:8, 14). In geval van misbruik van 'tryckfriheten' kunnen alle gegevensdragers in beslag worden genomen of geconfisceerd (TF 1:3). Dit om de schadelijke gevolgen van verspreiding van strafrechtelijk verboden gegevensdragers te beperken of te voorkomen (TF 10:7, 8).

Dat de inbeslagneming van gegevensdragers bij uitgevers, drukkers etcetera, zoals we hierboven hebben kunnen lezen, wel mogelijk is is merkwaardig. Zeker nu in Zweden de geheimhoudingsplicht zo'n belangrijke rol speelt. Niemand die zich bezig houdt met drukken of uitgeven mag in Zweden de naam van de schrijver bekend maken. Bij drukpersdelicten is de beslissing over de omvang van de schuld alleen 
gebaseerd op de inhoud van het drukwerk. De Zweedse TF kent een systeem van beperkte en trapsgewijze verantwoordelijkheid. Het idee achter deze beperkte vorm wan verantwoordelijkheid is dat iedereen vrij moet kunnen zijn om te schrijven wat hij wil. Door het niet koppelen van de geheimhoudingsplicht aan een inbeslagnemingsverbod hol je de geheimhoudingsplicht in feite uit.

Behalve de materiële aspecten van de inbeslagneming staan ook de procedurele aspecten van de inbeslagneming opgesomd in de TF. Een van die procedurele aspecteri van de inbeslagneming is de juridische procedure. Deze wijkt bij drukpersdelicten af van de reguliere juridische procedure. Drukpers- en uitingsdelicten worden aangebracht bij de arrondissementsgerechten ('tingsrätter') hoofdzakelijk in de grotere steden. Het procesverloop in een drukpers- of uitingszaak onderscheidt zich van een gewone zaak, omdat een jury meewerkt. In een proces inzake de drukpers- en uitingsvrijheid bestaat het gerecht uit een panel van 3 maximaal en minimaal 2 (zie wet van 1991:1559, 9:1) professionele juristen en een jury. De juryrechtspraak is een van de meest opvallende kenmerken in het Zweedse drukpers- en uitingsvrijheidproces. De reden om de juryrechtspraak in te voeren bij drukpers- en uitingsdelicten is dat het hier vaak gaat om delicten met maatschappelijke en politieke implicaties. Men was van mening dat het belangrijk is dat de burger in dit soort zaken zijn mening kan geven.

\section{Hoofdstuk 5 Conclusie}

\section{Inleiding}

In de voorgaande hoofdstukken heb ik een samenvatting gegeven van de spanning tussen de vrijheid van meningsuiting en drukpers en het strafvorderlijke dwangmiddel inbeslagneming in de afzonderlijke rechtsorden. In dit hoofdstuk worden de verschillende rechtsstelsels met elkaar vergeleken. Daarbij wordt, omwille van overzichtelijkheid, eèn onderverdeling gemaakt tussen de materiële en de procedurele aspecten van de inbeslagneming voor het aan de dag brengen van de waarheid en de materiële en procedurele aspecten van de inbeslagneming ter verbeurdverklaring en ter onttrekking aan het verkeer.

2 De vrijheid van meningsuiting en drukpers en de materiële aspecten van de inbeslagneming voor het aan de dag brengen van de waarheid

Censuur is verboden. Dat staat in art. 7 lid 1 van de Nederlandse Grondwet. Dit betekent dat zowel de lagere wetgever als de formele wetgever nooit het openbaren zelf kan reguleren via voorafgaand verlof of door middel van het geven van regels met betrekking tot de inhoud van gedachten en gevoelens. Alleen achteraf, na publicatie, mag op grond van de clausule behoudens ieders verantwoordelijkheid voor de 
wet' de inhoud van geschriften worden getoetst door de rechter. Met wet wordt een wet in formele zin bedoeld.

De bescherming die voor het openbaringsrecht geldt, geldt niet in dezelfde mate voor het verspreidingsrecht. Het aan het openbaringsrecht gekoppelde recht op het verspreiden van gedachten en gevoelens kan zowel beperkt worden door de formele wetgever als door de lagere wetgever. De differentiatie tussen een 'de geesteswereld betreffend' recht tot openbaren van je mening en een 'de ruimtelijke sfeer' betreffend recht tot verspreiden is door de jurisprudentie van de Hoge Raad in 1950, in thet Tillburg-arrest (Hoge Raad 28 november 1950, NJ 1951, 137) gemaakt en overgenomen in art. 7 lid 1 Grondwet. Voor die tijd werd openbaarmaking als overkoepelend begrip gebruikt voor het publiceren tot en met het verspreiden van geschriften onder het publiek. Pas later dus, in het Tilburgse-drukpersarrest, brengt de rechter een scheiding aan tussen het openbaren en het in het openbaar bekend maken (verspreiden). Dit door de rechter geconstrueerde verspreidingsrecht deelt niettemin tot op zekere hoogte in de bescherming van het openbaringsrecht, daar een algeheel verbod of vergunningvereiste niet is toegestaan. In de latere jurisprudentie is de constructie uit het arrest over de Tilburgse APV verder verfijnd. Niet alleen mocht de verspreidingsvrijheid niet in het algemeen verboden of van een voorafgaand verlof afhankelijk gesteld worden, maar ook dienden de beperkingen 'gebruik van enige betekenis' van het verspreidingsmiddel over te laten (Nuth-criterium). Een voorbeeld van een beperking van de verspreidingsvrijheid is het strafvorderlijke dwangmiddel inbeslagneming. De vraag is hoe de inbeslagneming zich verhoudt tot de vrijheid van meningsulting en drukpers, en in het bijzonder tot de verspreidingsvrijheid.

Op grond van art. $94 \mathrm{~Sv}$ is het mogelijk om voorwerpen in beslag te nemen voor het aan de dag brengen van de waarheid. Ook 'gegevens' op 'dragers' kunnen in beslag genomen worden. Er bestaat voor gegevensdragers geen aparte regeling die rekening houdt met de vrijheid van meningsuiting en drukpers.

Zo'n aparte regeling bestaat wel in Duitsland. Daar is bij de inbeslagneming voor het aan de dag brengen van de waarheid een onderscheid gemaakt tussen voorwerpen en gegevensdragers. De inbeslagneming van gegevensdragers voor het aan de dag brengen van de waarheid is niet mogelijk wanneer deze zich in bewaring bevinden bij een gepriviligeerde mediamedewerker of de redactie, een uitgever, drukkerij of 'Rundfunk'. Het moet dan wel gaan om materiaal van derden verkregen. Eigen materiaal mag wel in beslag worden genomen.

Wanneer we nu de Duitse situatie vergelijken met de Engelse dan valt ons allereerst op dat ook in Engeland in de 'Police and Criminal Evidence Act 1984" een onderscheid wordt gemaakt tussen voorwerpen en gegevensdragers. Een onderscheid in rechtsbescherming tussen eigen en materiaal van derden verkregen wordt daarbij niet gemaakt. De enige bescherming tegen te rigoureuze inbeslagneming is het proportionaliteitsbeginsel. Zo zal de politie op grond van de 'Police and Criminal Evidence Act 1984", rekening houdend met het proportionaliteitsbeginsel, geen gegevensdrager in haar bezit mogen houden of nemen warneer een foto of een 'copy' ook voldoende is ('section' 22(4)). In de zaak 'Reynolds vs. Commissioner of Police of 
the Metropolis' besliste de 'Court of Appeal' dat de politie niet bevoegd is om grote aantallen documenten in beslag te nemen zonder aan te geven dat "each file or bundle might reasonably constitute evidence" (1984, 3 All ER 649, CA). Impliciet wordt dus wel degelijk bij de inbeslagneming van zowel eigen materiaal als materiaal dat van derden verkregen is rekening gehouden met de vrijheid van meningsuiting en drukpers maar men gaat niet zover om materiaal van derden dat zich bevindt bij een gepriviligeerde mediamedewerker, uitgever, drukker of radio- c.q. televisiestation uit te sluiten van inbeslagneming.

Ook in Zweden galat men niet zover om materiaal dat zich bevindt bij een journalist, uitgever, drukker of radio- of televisiestation uit te sluiten van de inbeslagneming. Dit is vreemd nu we gezien hebben dat de geheimhoudingsplicht in Zweden zo'n belangrijke rol speelt bij de inbeslagneming voor het aan de dag brengen van de waarheid. Iedereen die zich bezighoudt met drukken en uitgeven mag immers een beroep doen op de geheimhoudingsplicht. Door geen relatie te leggen tussen deze plicht en de inbeslagneming hol je de geheimhoudingsplicht in feite uit. Waarschijnlijk heeft het achterwege laten van deze koppeling te maken met het feit dat de inbeslagneming gericht is op beperking van de verspreiding. Alleen exemplaren die bestemd zijn voor de verspreiding mogen in beslag genomen worden (TF 10:8). Dit betekent dat exemplaren die zich bevinden bij een uitgever of een boekhandel wel in beslag mogen worden genomen maar exemplaren bij een bibliotheek bijvoorbeeld niet. In beginsel is het zo dat bij de inbeslagneming voor het aan de dag brengen van de waarheid ook in Zweden de inbeslagneming van ến exemplaar voldoende is (TF $10: 8,14$ ).

Vergelijken we bovengenoemde regelgevingen met elkaar dan zien we dat de bescherming van de vrijheid van meningsuiting en drukpers in de Duitse wet het meest vergaand is. In Nederland wordt erover nagedacht om art. $94 \mathrm{~Sv}$ zodanig te veranderen dat er in de wet een onderscheid wordt gemaakt tussen voorwerpen en gegevensdragers. Gegevensdragers zouden dan niet in beslag genomen mogen worden wanneer het gaat om journalistieke werkzaamheden. Dit betekent dat niet alleen werk van journalisten niet in beslag mag worden genomen voor het aan de dag brengen van de waarheid, zoals in Duitsland, maar ook werk van cineasten, auteurs etcetera. Volgens Jurgens in zijn 'Voorontwerp van Wet op het Journalistiek Privilege' is een journalist niet langer verplicht zijn bronnen te onthullen. Zowel eigen- als materiaal van derden verkregen dient beschermd te worden. Op deze manier wordt het problematische onderscheid tussen eigen- en materiaal van derden verkregen zoals dat in Duitsland het geval is voorkomen. Door bovendien wettelijk vast te leggen dat het journalistiek privilege als uitgangspunt dient, zal de rechter, in het concrete geval, slechts bij aanwezigheid van zeer dringende reden, kunnen komen tot een inbreuk op dit recht. Inbeslagneming is dan slechts in zeer uitzonderlijke situaties te rechtvaardigen namelijk in die gevallen dat er zwaar lichamelijk letsel is toegebracht. Er kan dan geen beroep worden gedaan op het journalistiek privilege. In eerste instantie zal dan echter wel moeten worden bekeken in hoeverre de politie of justitie zelf redelijkerwijs bij machte is de gewenste informatie te vergaren. Dit 
uitgangspunt stemt overeen met de geldende richtijn van de procureurs-generaal bij de gerechtshoven van juli 1981 waarin staat dat strafvorderljke inbeslagneming zoveel mogelijk achterwege dient te blijven opdat joumalisten hun werkzaamheden zo goed mogelijk kunnen verrichten."

\section{De vrijheid van meningsuiting en drukpers en de procedurele aspecten van de inbeslagneming voor het aan de dag brengen van de waarheid}

Op grond van het huidige Wetboek van Strafvordering heeft de gewone opsporingsambtenaar in principe alleen speciale inbeslagnemingsbevoegdheden. Alleen wanneer zij in de uitoefening van een andere bevoegdheid een daarvoor vatbaar voorwerp aantreffen zijn zij tot inbeslagneming bevoegd. In navolging van pleidooien in de literatuur stelt de Commissie Herijking Wetboek van Strafvordering voor om in plaats van het huidige art. $96 \mathrm{~Sv}$ aan elke opsporingsambtenaar een algemene bevoegdheid tot inbeslagneming te geven. De enige beperking is dat voor een situatie buiten heterdaad sprake dient te zijn van een misdrijf als omschreven in art. 67 eerste lid Sw. Door het grote aantal misdrijwen dat onder dit artikellid wordt aangeduid of opgesomd bestaan er praktisch weinig belemmeringen meer voor opsporingsambtenaren. Men kan zich afvragen of het wenselijk is dat de politie, die er alle belang bij heeft om strafbare feiten op te helderen, de bevoegde instantie is om te beslissen over situaties waarin het recht op de vrijheid van meningsulting en drukpers in het geding is.

In Duitsland is bij de inbeslagneming van eigen materiaal voor het aan de dag brengen van de waarheid de rechter bevoegd ('Paragraph 98 Absatz 1 StPO'). Alleen wanneer er 'Gefahr im Verzug' dreigt is ook de officier van Justitie en de hulp-officier bevoegd tot inbeslagneming. 'Gefahr im Verzug' ontstaat wanneer het doel van de maatregel in gevaar komt bijvoorbeeld wanneer er gevaar bestaat "des offentlichen Interesses an unverzögerter Verbreitung". Er dient echter een uitzondering te worden gemaakt voor de inbeslagneming wan eigen materiaal bij de redactie, een uitgever, een drukkerij of de 'Rundfunk'. Hier is alleen de rechter bevoegd. Ook als er 'Gefahr im Verzug” dreigt.

In Engeland is net alls in Nederland de politie bevoegd tot de inbeslagneming van gegevensdragers voor het aan de dag brengen van de waarheid. Alleen in die gevallen waarin de inbeslagneming gelijktijdig met een huiszoeking plaatsvindt is een speciale procedure in het leven geroepen. Deze procedure houdt in dat de politie een "production order" aanwraagt bij de "circuit judge'. Een "production order" eist van de persoon die het bewijsmateriaal bezit dat hij/zij dit materiaal aan de politie overdraagt of dat hij/zij toestaat dat een politieagent toegang krijgt tot het bewijsmateriaal. De persoon voorkomt hiermee een huiszoeking. In tegenstelling tot een 'search warrant' is een 'production order' altijd 'inter partes'. Dat wil zeggen dat je de mogelijkheid krijgt om bij de rechter te klagen tegen een voorgenomen of een reeds uitgevoerde inbeslagneming. 
Bezien we de situatie in $Z$ weden dan verschilt $Z$ weden van de voorafgaande landen doordat in Zweden in die gevallen warin de wrijheid van meningsuiting en drukpers in het geding is niet de politie bevoegd verklaard gegevensdragers in beslag te nemen, maar de 'justitiekansler' en onder bepaalde voorwaarden de officier van Justitie (TF 9:2). Deze laatste moet echter de 'justitiekansler' onmiddellijk van de inbeslagneming op de hoogte stellen. Deze laatste beslist dan of de inbeslagneming in stand blijft. De "justitiekansler" of de officier van Justitie kan voorafgaand aan een juridische procedure in beslag nemen voor het aan de dag brengen van de waarheid. Binnen twee weken moet de "justitiekansler" dan een klacht indienen bij de arrondissementsrechtbank ("tingsrätter") van hoofdzakelijk een van de grotere steden (TF 10:2). Daar wordt uiteindelijk beslist of tot inbeslagneming dient te worden gecontinueerd (TF 10:4, 5). De procedure moet beginnen binnen zes maanden na openbaarmaking. De verjaringstermijn is hier kort omdat het gaat om de vrijheid van meningsuiting en drukpers. Het proceswerloop in een drukpers- of uitingszaak onderscheidt zich van een gewone zaak, omdat een jury meewerkt.

Bezien we de Duitse, Engelse en Zweedse situatie en vergelijken we die met de Nederlandse dan lijken de Duitse en de Zweedse regelgeving het meeste recht te doen aan de vrijheid van meningsuiting en drukpers. In Duitsland is niet de politie maar de rechter en de officier van Justitie (bij 'Gefahr im Verzug') bevoegd bij de inbeslagneming voor het aan de dag brengen van de waarheid. Wanneer het gaat om de inbeslagneming van eigen materiaal bij de media is alleen de rechter bevoegd. In Engeland en in Zweden wordt dit onderscheid niet gemaakt. In Engeland is in alle gevallen de politie bevoegd. Alleen wanneer de inbeslagneming gepaard gaat met een huiszoeking zijn extra processuele waarborgen in het leven geroepen. De achterliggende gedachte is niet zozeer de vrijheid van meningsuiting en drukpers maar de privacy. In Zweden is naast de officier van Justitie een speciale officier van Justitie belast met de inbeslagneming van gegevensdragers. De inbeslagneming is daar een voorlopige maatregel. Binnen twee weken moet de 'justitiekansler' een klacht (TF 10:2) indienen bij de rechter die dan uiteindelijk beslist of tot inbeslagneming dient te worden gecontinueerd (TF 10:4,5). Bij de procedure wordt een jury betrokken. De vraag is of we in Nederland nu ook zo'n speciale ambtenaar en een jury in het leven moeten roepen bij de inbeslagneming van gegevensdragers? Misschien hoeven we niet zover te gaan wanneer mensen die journalistieke werkzaamheden verrichten een beroep kunnen doen op het journalistieke verschoningsrecht en wanneer zowel eigen als materiaal van derden verkregen beschermd wordt tegen inbeslagneming. Tenzij er, bijvoorbeeld tijdens een demonstratie, ongeregeldheden ontstaan waarbij mensen zwaar lichamelijk letsel oplopen dan is de politie of justitie bevoegd de gewenste informatie te vergaren (in die gevallen dat ze zelf hiertoe niet bij machte zijn geweest). Er kan dan geen beroep worden gedaan op het verschoningsrecht:

Behalve een vergelijking tussen de verschillende landen met betrekking tot de bevoegdheidsvraag kan er ook een vergelijking worden gemaakt tussen de verschillende procedures. In Duitsland, Engeland en Zweden is de procedure bij de inbeslagne- 
ming van gegevensdragers openbaar. In Nederland is dat sinds de Wet Herziening Raadkamerprocedure (Wet van 8-11-1993, Stb. 1993, 591) per 1 januari 1994 ook het geval.

\section{De vrijheid van meningsuiting en drukpers en de materiële aspecten van de inbeslagneming ter verbeurdverklaring en ter onttrekking aan het verkeer}

In het voorafgaande hebben we gesproken over de inbeslagneming voor het aan de dag brengen van de waarheid. Behalve de inbeslagneming voor het aan de dag brengen van de waarheid kennen we in Nederland ook nog de inbeslagneming ter verbeurdverklaring en ter onttrekking aan het verkeer. Bij de inbeslagneming ter verbeurdverklaring wordt het goed bij een veroordeling definitief aan de macht van de veroordeelde onttrokken. In Nederland is de verbeurdverklaring een vermogensstraf en een bijkomende straf wat impliceert dat de oplegging facultatief is. Omdat de inbeslagneming niet noodzakelijk is heeft de beslag leggende ambtenaar een grote beleidsvrijheid bij het beslissen of het voorwerp wel of niet in beslag genomen dient te worden. Er dient zowel door opsporingsambtenaren als door de rechter rekening te worden gehouden met de beginselen van een behoorlijke procesorde, in het bijzonder het subsidiariteits- en proportionaliteitsbeginsel. De inbeslagneming dient achterwege te blijven wanneer deze duidelijk onredelijk zou zijn. Dit laatste geldt eveneens voor de onttrekking aan het verkeer. Ook hier dient de inbeslagneming achterwege te blijven wanneer deze duidelijk onredelijk is. Of een inbeslagneming onredelijk is is afhankelijk van het concrete geval.

Net als in Nederland wordt ook in Duitsland met deze beginselen rekening gehouden. Het proportionaliteitsbeginsel wordt in 'Paragraph $111 \mathrm{~m}$ Abs. 1 StPO' zelfs expliciet genoemd.

Ook in Engeland wordt, zij het in geringere mate, rekening gehouden met het proportionaliteits- en subsidiariteitsbeginsel. In Zweden mag in principe een hele oplage in beslag worden genomen (TF 10:8) zij het dat ook hier indien mogelijk, rekening wordt gehouden met het subsidiariteits- en proportionaliteitsbeginsel (TF 10:6).

Vergelijken we bovenstaand met de Nederlandse situatie dan zien we dat in alle hier genoemde landen het proportionaliteitsbeginsel een rol speelt. Ook het Europese Hof houdt in haar uitspraken rekening met het proportionaliteitsbeginsel. Beperkingen op de wrijheid wan meningsuiting en drukpers moeten immers noodzakelijk zijn in een democratische samenleving. Dat betekent dat er sprake moet zijn van een 'pressing social need' en dat er een redelijke verhouding ("proportionality") moet bestaan tussen de zwaarte van de inbreuk en het gewicht van het belang dat met de inbreuk werd gediend. De inbeslagneming van een hele oplage geschriften of films of de onttrekking aan het verkeer of de verbeurdverklaring van genoemde gegevensdragers zal door het Hof wellicht niet zo snel worden gezien als een beperking die noodzake- 
lijk is in een democratische samenleving. Zeker niet in die gevallen waarin het gaat om publicaties en personen die bijdragen aan het publieke debat.

\section{De vrijheid van meningsuiting en drukpers en de procedurele aspecten van de inbeslagneming ter verbeurdverklaring en ter onttrekking aan het verkeer}

Behalve de materiële aspecten van de inbeslagneming ter verbeurdverklaring en ter onttrekking aan het verkeer kunnen ook nog de procedurele aspecten worden genoemd. In Nederland is de procedure bij de verbeurdverklaring en onttrekking aan het verkeer niet anders geregeld dan bij de inbeslagneming voor het aan de dag brengen van de waarheid.

In Duitsland daarentegen is dat wel het geval. Bij de 'Einziehungsbeschlagnahme' geeft 'Paragraph $111 \mathrm{n}$ Abs. 1 StPO' weer wie bevoegd zijn tot de inbeslagneming van gegevensdragers. Voor de inbeslagneming van boeken of bandopnamen etcetera, met uitzondering van opiniebladen, is de rechter bevoegd en in geval van "Gefahr im Verzug' de officier van Justitie. De hulp-officieren zijn niet bevoegd. Voor de inbeslagneming van opiniebladen is alleen de rechter bevoegd ('Paragraph 74d Strafgesetzbuch' (StGB). Dit omdat hier de inbeslagneming van vaak tijdsgevoelige informatie grote gevolgen kan hebben voor het voortbestaan van een uitgever zeker wanneer het een hele oplage betreft. De procedure is hetzelfde geregeld als bij de inbeslagneming voor het aan de dag brengen van de waarheid.

In Engeland is de juridische procedure bij de inbeslagneming van gegevensdragers ter onttrekking aan het verkeer en ter verbeurdverklaring niet geregeld in de PACE Act maar in de 'Obscene Publications Act 1959 and 1964' en de 'Public Order Act 1986'. Gaat het om de inbeslagneming van staatsgeheimen, zaken die betrekking hebben op de openbare orde en obscene publicaties dan is de speciale procedurele bescherming die in het leven is geroepen bij de inbeslagneming en de huiszoeking op grond van de PACE Act niet van toepassing. In tegenstelling tot de 'Police and Criminal Evidence Act' bestaat in bovengenoemde 'Acts' geen 'special procedure'. Wanneer het gaat om staatsgeheimen, zaken die betrekking hebben op de openbare orde en obscene publicaties zijn verdergaande beperkingen mogelijk. Veelal wordt al voor de publicatie ingegrepen in de vrijheid van meningsuiting en drukpers door middel van een civiele procedure. Binnen die civiele procedures bestaan verschillende 'prior restraints'.

Behalve door middel van een civiele procedure wordt de vrijheid van meningsuiting en drukpers beperkt door een informeel systeem van controle zoals het 'Services, Press and Broadcasting Committee', het 'British Board of Film Censors' en de 'D-notices'. Op grond van deze systemen kunnen geschriften al gecensureerd worden woordat ze openbaar worden gemaakt en/of verspreid worden. Dit is niet alleen puur censuur, het snijdt bovendien de weg af naar de rechter en is daardoor nog minder acceptabel dan de civiele procedure die vaak wordt opgestart om een publicatie te stoppen. 
In Zweden bestaat er ook $20^{3} \mathrm{n}$ informeel systeem van controle. Dit systeem heeft als doel 'het bevorderen van een journalistieke ethiek in kranten en tijdschriften'. De persombudsman mag direct vragen aan de redacteur of hij een artikel wil veranderen. Dit alles maakt de strekking van de TF restrictiever. Daarnaast is het de "justitiekansler" die beslist of een geschrift "vermeende staatsgeheimen" bevat. Deze dient binnen twee weken een klacht in (TF 10;2) bij de rechter die dan uiteindelijk beslist of tot inbeslagneming dient te worden gecontinueerd (TF 10;4,5). Blijkt uiteindelijk naar het oordeel van de rechter en de jury dat dat niet het geval is dan zijn de geschriften of films toch een tijd uit de roulatie geweest.

In Nederland bestaat gelukkig niet zo'n informeel systeem van controle. Wel bestaat er een formeel controlesysteem op grond van het Wetboek van Strafvordering. Op grond van het huidige Wetboek van Strafvordering heeft de gewone opsporingsambtenaar in principe alleen speciale inbeslagnemingsbevoegdheden. Alleen wanneer zij in de uitoefening van een andere bevoegdheid een daarvoor vatbaar voorwerp aantreffen zijn zij tot inbeslagneming bevoegd. Zoals we bij de inbeslagneming voor het aan de dag brengen van de waarheid hebben kunnen lezen is in de literatuur gepleit om in plaats van het huidige art. 96 Sv aan elke opsporingsambtenaar een algemene bevoegdheid tot inbeslagneming te geven. De enige beperking is dat voor een situatie buiten heterdaad sprake dient te zijn van een misdrijf als omschreven in art. 67 eerste lid Sv. Door het grote aantal misdrijven dat onder dit artikellid wordt aangeduid of opgesomd bestaan er praktisch weinig belemmeringen meer voor opsporingsambtenaren. De politie, die er alle belang bij heeft om strafbare feiten op te helderen, is volgens mij niet de juiste instantie om te beslissen over de effectuering van het recht op de vrijheid van meningsuiting en drukpers. In Duitsland heeft de - wetgever niet voor niets een onderscheid gemaakt tussen uitingen in opiniebladen en uitingen in bijvoorbeeld films en boeken. Gaat het om opiniebladen dan is alleen de rechter bevoegd in beslag te nemen. Opiniebladen zijn immers tijdsgevoelig. Inbeslagneming van een hele oplage kan de bestaanspositie van een uitgever in gevaar brengen. Rechters worden geacht beter in staat te zijn grondrechten af te wegen tegen het opsporings- en vervolgingsbelang dan de politie. Voor de inbeslagneming van films, boeken etcetera is de rechter en bij 'Gefahr im Verzug" de officier van Justitie bevoegd. Omdat de strafrechtelijke bepalingen, zoals de pornografiebepalin" gen, de bepalingen die betrekking hebben op staatsgeheimen etcetera vaag zijn geformuleerd heeft de Duitse wetgever ervoor gekozen om bij 'Gefahr im Verzug' de officier van Justitie de bevoegdheid te geven gegevensdragers in beslag te nemen in plaats van de politie. Op deze manier wordt voorkomen dat gegevensdragers in bes\ag worden genomen die later teruggegeven moeten worden omdat de officier van Justitie denkt het bewijs niet rond te krijgen.

Dat het toekennen van inbeslagnemingsbevoegdheden aan de rechter en de officier van Justitie, zoals in Duitsland gebeurd, ook nadelen heeft is onvermijdelijk. Vaak zijn de strafbare drukwerken immers al verdwenen. Dat in Duitsland toch voor bovengenoemde regeling is gekozen heeft te maken met het feit dat hier een grondrecht, in casu de vrijheid van meningsuiting en drukpers, in het geding kan zijn. Dwangmid- 
delen kunnen een inbreuk maken op dit grondrecht. Daarom dienen dwangmiddelen met de grootst mogelijke waarborgen worden omgeven. Een van die waarborgen is dat wanneer het gaat om de inbeslagneming van niet-tijdsgevoelige informatie niet de politie maar de officier van Justitie bevoegd te verklaren. Gaat het om tijdsgewoelige informatie dan dient alleen de rechter-commissaris bevoegd te zijn. De rechter-commissaris is immers behalve rechtshandhaver ook rechtsbeschermer. Hij is meer nog dan de officier van Justitie in staat om een juiste afweging te maken. Met de keuze voor een officier van Justitie en een rechter-commissaris kan wellicht voorkomen worden dat, of helemaal geen procedure wordt opgestart, of pas lange tijd na de inbeslagneming. Zeker nieuwsgevoelig materiaal dient niet langer dan noodzakelijk wit de roulatie te zijn geweest.

\section{Aanbevelingen}

Tot besluit zullen de aanbevelingen die in de voorafgaande paragrafen zijn genoemd in deze paragraaf worden gerecapituleerd. Zoals in de inleiding van deze conclusie reeds werd opgemerkt is de rechtsvergelijking bedoeld om enige aanbevelingen te formuleren tot verbetering van de Nederlandse bepalingen inzake inbeslagneming. Zolang deze bepalingen immers niet worden gewijzigd bestaan er voor de Nederlandse rechter geen aanknopingspunten om meer recht te doen aan de vrijheid van meningsuiting en drukpers (art. 7 Grondwet en art. 10 EVRM).

1. Om te beginnen dient er in het Wetboek van Strafvordering, net als dat in Duitsland, Engeland en Zweden het geval is, een onderscheid te worden gemaakt tussen voorwerpen en gegevensdragers. Gegevensdragers mogen, volgens het initiatief-wetsvoorstel van Jurgens, niet in beslag worden genomen voor het aan de dag brengen van de waarheid wanneer het gaat om journalistieke werkzaamheden. Het accent ligt hier op 'gegevens' en niet, zoals in de Wet Computercriminaliteit, op 'dragers'. Het gaat de politie immers om de informatie en niet zozeer om de dragers van die informatie. Daarbij dient niet alleen eigen materiaal, zoals in Duitsland, maar ook derden-tmateriaal beschermd te worden. Door wettelijk vast te leggen dat het journalistiek privilege als uitgangspunt dient, zal de rechter, in het concrete geval, slechts bij aanwezigheid van zeer dringende redenen, kunnen komen tot een inbreuk op dit recht. Inbeslagneming is dan slechts in zeer uitzonderlijke situaties te rechtvaardigen namelijk in die gevallen waarin er zwaar lichamelijk letsel veroorzaakt wordt. In eerste instantie zal moeten worden bekeken in hoeverre de politie of justitie zelf redelijkerwijs bij machte is de gewenste informatie te vergaren. Is zij zelf niet bij machte om de gewenste informatie te verkrijgen dan kan de politie in beslag nemen daarbij rekening houdend met het proportionaliteitsbeginsel en subsidiariteitsbeginsel. 
2. Bij de inbeslagneming ter verbeurdverklaring en ter onttrekking aan het verkeer dient, net als in Duitsland, rekening te worden gehouden met het onderscheid tussen tijdsgevoelige informatie en informatie die niet tijdsgevoelig is. Bij de tweede categorie is de officier van Justitie bevoegd tot inbeslagneming. Gaat het om de inbeslagneming van tijdsgevoelige informatie dan is alleen de rechter-commissaris bevoegd. Behalve het onderscheid tussen tijdsgevoelige informatie en informatie die niet tijdsgevoelig is dient er een onderscheid te worden gemaakt tussen discussies over publieke aangelegenheden en discussies die dat niet zijn. Volgens het Europese Hof dient het publieke debat beschermd te worden. Gaat het om een publiek debat dan zal de inbeslagneming, verbeurdverklaring en onttrekking aan het verkeer van een hele oplage gegevensdragers al snel disproportioneel zijn. Volgens de Europese Commissie dient er ook bij onzedelijke geschriften gecontroleerd te worden of de inbeslagneming ter verbeurdverklaring of ter onttrekking aan het verkeer proportioneel is. In de zaak Müller oordeelde de Commissie dat de 'confiscation' van alle schilderijen disproportioneel was en niet noodzakelijk in een democratische samenleving. Deze visie sluit aan bij mijn opvatting dat zowell preventieve beperkingen, zoals de inbeslagneming, als repressieve beperkingen, zoals de onttrekking aan het verkeer en de verbeurverklaring, de verspreiding van gegevensdragers niet onmogelijk mag maken tenzij er sprake is van aantoonbaar verband tussen de meningsuiting en fysiek geweld. De inbeslagneming en de verbeurdverklaring casu quo onttrekking aan het verkeer dient achterwege te blijven wanneer het gaat om het publieke debat. 


\section{Summary}

\section{Introduction}

This thesis describes the area of tension between the freedom of speech and the press and the coercive measure of seizure provided for under the Dutch law of criminal procedure in an international and comparative context. The extent to which freedom of speech and the press form an impediment to seizure is its centrall issue. In subsequent chapters, the regulation of freedom of speech and the press and seizure in the Netherlands, Germany, England and Sweden is considered.

\section{Chapter 1 Freedom of speech and the press and the coercive measure of seizure under Dutch law}

The first chapter is dedicated to the rules governing freedom of speech and the press as laid down in article $7(1)$ of the Netherlands Constitution, in article 10 ECHR and, albeit summarily, in article 19(2) ICCP, and to relevant case law. The scope of freedom of speech has implications for the measure of seizure (art. 3 ICCP), the purpose of describing these rules is therefore to give an idea of their scope.

In the Netherlands, freedom of disclosure is enshrined in the Constitution. Freedom to disseminate information, however, is judge-made law and governed by a different legal doctrine. Freedom of dissemination may be restricted in advance, for example, by an investigating officer. This is not to say, however, that these restrictions are so rigid that the right to disseminate information is in effect eliminated. In the Tilburg case (HR 28-11-1950, NJ 1951, 137), the Netherlands Supreme Court characterized freedom to disseminate information as a "conditio sine qua non" for the existence of the freedom of disclosure. Freedom of speech and the press call only be effectively exercised by the dissemination of information. Restrictions should, therefore, leave room for "a significant degree of availability" of the means of dissemination (HR 17 March 1953, NJ 1953,389). An example of such a restriction is the coercive measure of seizure that is enforceable under the law of criminal procedure. The nature of the relationship between seizure and freedom of speech and the press, more particularly the freedom to disseminate information, is one aspect the author seeks to determine. 
Article 94 of the Dutch Code of Criminal Procedure (CCP) provides for seizure for the purposes of uncovering the truth "forfeiture and in order to remove objects from circulation. When objects are temporarily seized in order to uncover the truth, it is sufficient to seize one information carrier, that is, if one considers 'information carriers' to fall within the notion of 'objects' of article $94 \mathrm{CCP}$. In such case, the emphasis is placed on the word 'carrier'. However, if the emphasis is placed on 'information', a completely different conclusion can be drawn, as is described in section 4.3.1. The author is inclined to focus on the 'information' component of "information carrier". When objects are seized in order to uncover the truth, information is the issue. In order to seize information available on carriers relating to journalism, a separate rule needs to be developed that pays regard to freedom of speech and the press.

As far as seizing objects for the purpose of forfeiture is concerned, contrary to the seizure of objects for the purpose of bringing out the truth, the court's judgment is anticipated. Upon conviction, the property is forfeit and thereby definitively removed from the offender's power. In the Netherlands, forfeiture is a penalty intended to adversely affect the assets of the offender. It is also an additional penalty; it is left to the court's discretion to impose it or not. Objects not seized may also be declared forfeit. The purpose of forfeiture is not merely to compound the injury, but also prevention. Since seizure of objects is not mandatory, whether an object is to be seized or not is to a large extent at the discretion of the officer in charge of the seizure.

For the purposes of removal of objects from circulation, however, seizure is a precondition. In this case, investigating officers can exercise far less discretion and the court will not readily assume that the seizure was 'clearly unreasonable'. Seizure for the purpose of removal of objects from circulation is a typical police or security measure for the benefit of the criminal justice system and is guided by the opportuniteitsbeginsel, a principle under which public prosecutors have the discretionary power of waiving prosecution on the grounds of 'public interest.' For example, where several copies of alleged state secrets, blasphemous writings or pamphlets of the same kind are found, the police may seize the entire stock.

In the BLUF! case (HR 17-11-1987, NJ 1988, 394, HR 18-9-1989, NJ 1990, 94), the central issue was the publication of an old 1981 quarterly report by the Netherlands Security Service. The report had been disclosed in issue no. 267 of the weekly Bluf!. As the issue rolled off the presses and was being prepared for shipping, a police squad raided the printers and seized the entire edition in the course of the preliminary investigation against 'NN" (name unknown) pursuant to artt. 98 and/or 98a Dutch Penal Code (PC) [state secrets]. Upon application by the Public Prosecutor's Office, the entire edition of the weekly Bluf! of 29 April 1987 was taken out of circulation by the Amsterdam District Court (cf art. 36c PC). The Bluf! no. 267, the Public Prosecutor submitted, went too far and the District Court concurred; for reasons of the security of the State and of its allies, secrecy was imperative (artt. 98 and/or 98a PC). Bluf! lodged an appeal with the Netherlands Supreme Court against the 
Amsterdam District Court judgment. Blufl argued principally that freedom of the press entails that the judge in criminal matters could only order that an edition be forfeit or removed from circulation after publication (read: after disclosure and dissemination). Seizing the entire issue in advance is, in effect, censorship it was contended. The Supreme Court did not agree. According to the Supreme Court, seizure and removal from circulation were not restrictions that could be equated with subjecting disclosure to the condition of 'prior consent' as specified in article $7(1)$ of the Constitution. The author deems this correct. It was not a question of censorship, since the restriction did not pertain to the contents, but to its dissemination.

In the same judgment, the Supreme Court subsequently took the position that

"the measures which secure the interests that articles 98 and 98 a DPC purport to protect are not restricted to criminal prosecution and the possible conviction of those who have committed the criminal offenses defined in the articles, but also include seizure and removal from circulation of printed matter intended for the commission of such acts, as governed by the Code of Criminal Procedure. Enforcement of these measures is part of the restrictions on the right safeguarded in the European Convention on Human Rights and does not compare with subjection to a condition of 'prior consent' as specified in article 7 of the Constitution, even if the printed matter in question and the thoughts and feelings reflected in it are not publicly disclosed as a result"

(in saying 'not publicly disclosed' the Supreme Court probably meant 'not disseminated'). The author does not concur with the Supreme Court's view that so long as there is no question of censorship any interference with the freedom of speech and the press is lawful, since the reasoning behind article 7 of the Constitution is that interference is only possible to a limited extent and only in rare cases. For example, pursuant to the same article, the police are authorized to restrict dissemination of writings allegedly containing state secrets, as in the Bluf! case, for reasons of public order or the security of others, but such restrictions may not lead to a 'general prohibition'. Such a prohibition can be said to obtain when dissemination of the material is no longer possible, because, for instance, an entire edition or the printing presses and the plates have been seized. Under the statutory restriction: "subject to a person's responsibility under the law ${ }^{\prime \prime}$ the court may also order removal from circulation or forfeiture of writings containing state secrets, although, during the parliamentary debate on the draft of the Dutch Penal Code in the Lower House, Modderman, then Minister of Justice, said: "To thus regulate repressive measures, that is to enact substantive and procedural rules governing printing press offenses, so that preventive control does not sneak back in again, is in the spirit of the Constitution." Where the discussion of public affairs is concerned, judges should be particularly cautious. Not only because loss of an entire edition may put the economic survival of a newspaper or magazine at risk, but also because discussing public affairs is a prerequisite for the democratic legal order and for the establishment of other constitutional freedoms. 
The media have a special task here. It is their duty to adequately inform the general public and so to create the conditions for a critical attitude towards the authorities. In cases of discriminatory defamatory writings where public affairs are not at stake, the court may declare an entire edition forfeit or have it removed from circulation in extreme cases only, where there is violence or a demonstrable relation between the expressed opinion and an imminent serious criminal act. Consequently, freedom of speech and the press cannot be invoked in such cases.

The European Court of Human Rights has held that restrictions, be they preventive or repressive, must be narrowly construed and that they must meet the requirement of being "necessary in a democratic society". This means that interference must have been prompted by a 'pressing social need" and that, in addition, there must be a reasonable relation between the degree of interference and the weight of the interest served by it (proportionality). In addition, there must be sufficient, relevant grounds to justify such interference. It is not sufficient to merely consider the rule; its application should also be examined. The ECHR wishes to include the facts and circumstances of the case. It can be said in general that the ECHR allows more room for the freedom of speech and the press in case of debates on public affairs, because politicians are expected to be exposed to more criticism than ordinary citizens. Discussing public matters is a prerequisite of democratic legal order, as is evidenced by the inclusion of the freedom to receive information and ideas in article 10(1) ECHR. Communication has clearly not been achieved so long as the message has not reached the intended recipient. Without a well-informed public there is no democratic society and the press has a special duty to inform the public properly. This is also the duty of artists. The Miller case, in which the ECHR linked art with public debate (ECHR 8 July 1986 , NJ 1987, 901), is a case in point. The scope of interference with the freedom of speech and the press is interpreted in a broad or more restrictive way, depending on the responsibility of the person in question (Commission's Report of 30 September 1975, Handyside, B. 22, p. 4).

\section{Chapter 2 Freedom of speech and the press and the coercive measure of seizure under German law}

In the second chapter, the subject is discussed in relation to Germany. In contradistinction to the Netherlands, freedom of dissemination and freedom to receive information are expressly laid down in the German Constitution (Grundgesetz [GG]), as are freedom of speech and the press. Moreover, article 5 GG guarantees the "institutionelle Eigenstandigkeit der Presse" (the institutional independence of the press). The press has a duty to inform the public. This is not only the essence of the press, but also of democracy. For the proper functioning of a democratic system, a limited use of witness privilege (Zeugnisverweigenungsrecht) and the prohibition against seizure is appropriate. When the provisions governing seizure were drafted for the German Code of Criminal Procedure (Strafprozessordinung [StPO]), article 5 GG was taken 
into account. In Germany, contrary to the situation in the Netherlands, a distinction is made between objects and information carriers. Seizure of matters such as writings, sound, images and information carriers held in confidence by privileged media workers, editorial offices, publishers, printers or radio- and television stations, for the purpose of uncovering the truth, is prohibited in those cases where privilege applies. The German artt. 53 and 97(5) (StPO) were drafted to protect the relationship of confidentiality between the press and their sources. This protection ensures that media workers can operate independently. The material, however, must have been obtained from third parties. Original material may be seized by the judge. In Germany, the judge is empowered to order the seizure of original material to uncover the truth (art. 98(1) StPO). Only in cases of Gefahr im Verzug (danger in delay) are the Public Prosecutor and his deputy so empowered. Gefahr im Verzug obtains when the purpose of the measure is at risk, for instance, when "by undelayed dissemination, public interest" is jeopardized. However, an exception needs to be made for the seizure of original material from editorial offices, publishers, printers or radio- and television stations. In these cases, only the judge has the power to order seizure, also in the event of Gefahr im Verzug. The latter has met with a lot of criticism, since denying professional privilege for material gathered by the journalist himself, implies failing to appreciate the essence of journalistic work; they unobtrusively and ubiquitously gather information themselves. Reporters and other journalistic professionals may find themselves in a predicament if they were to be regarded as tools of the prosecution system because they were ordered to cooperate by the Public Prosecutor's Office. Since, in practice, the distinction between original material and that obtained from third parties seems almost impossible to draw, the relevance of the distinction is questionable.

A special characteristic of German legislation is witness privilege (Zeugniswerweigerungsrecht). This is linked to the prohibition of seizure (art. $97 \mathrm{StPO}$ in conjunction with art. $53 \mathrm{StPO}$ ). The principle underlying artt. 53 and $97(5) \mathrm{StPO}$ is protection of the confidential relationship between the media and their sources. Such protection ensures the independent functioning of media workers. Only where witness privilege and editorial confidentiality is safeguarded, can the media properly serve as watchdog and source of information. Freedom to receive and impart information and constitutional protection of its sources against seizure are directly related. The protection of information (Informationsschutz) follows logically from the special position of the media outlined in article 5 GG. It is the duty of the media to inform the public about political events. By presenting different points of view, the media, as the "orientierende Kraft in der öffentlichen Auseinandersetzung", the guiding force behind public debate, enables the public to form discriminating opinions. This informative function can be linked with the watchdog function. The media are the 'watchful guardians' of democracy, uncovering wrongs and sparking public debate, in the words of the European Court of Human Rights: "the press is the purveyor of information and public watchdog"(ECHR 25 March 1985, NJ 1987, 900). In Germany, the concept of media freedom relates primarily to institutional freedom. Individual writers, film makers 
or a group of citizens authoring a pamphiet do not enjoy the protection of art. 97 in conjunction with art. $53 \mathrm{StPO}$. Their material may be seized by judicial order, or, in case of the likelihood of material disappearing (Gefahr im Verzug) by order of the Public Prosecutor or his or her deputy. By qualifying material as 'journalistic material', as Jurgens does, this problem can be avoided, because, in consequence, anyone who is involved in journalistic activities may invoke privilege and the concomitant prohibition of seizure.

Both in seizure to uncover the truth and for the purpose of Einziehungsbeschlagnahme (removal from circulation) the friction between the coercive measure of seizure and freedom of speech and the press has been removed in an interesting way. In the case of Einziehungsbeschlagnahme (art. $111 \mathrm{~m}(1) \mathrm{StPO}$ ), which is applicable to both the seizing of information carriers for the purpose of forfeiture and seizure to prevent these from being rendered useless, proportionality is expressly referred to (as in the case of preliminary detention), since seizure of an entire edition might threaten the economic survival of, for instance, a printing business. Art. $111 \mathrm{~m}(2)$ $\mathrm{StPO}$ excludes therefore the seizure of that part of a document which does not relate to the alleged criminal offense. It is possible, for instance, for only the supplement of a newspaper to be seized. Section 2 of the same article allows even stricter limitations in the sense that seizure excluded a few morgue copies. Section 4 of art. $111 \mathrm{~m}$ StPO makes it possible for the person threatened by seizure to avoid it. Seizure may be avoided if the person threatened by it chooses not to disseminate or duplicate that part of the writing which would otherwise be seized. Section 3 of art. $111 \mathrm{~m}$ StPO prescribed that an order for seizure accurately specify which parts of the document give cause for seizure.

Art. 111 (1) StPO lists those persons empowered to seize information carriers. The judge and Public Prosecutors ('Gefahr im Verzug'), but not their deputies, are empowered to seize such materials as pamphlets, books or tape recordings. An order for seizure must be endorsed by the court within a week. Only the judge is empowered to seize news magazines (art. 74d Strafgesetzbuch [German Penal Code] (StGB)), because seizing time-sensitive information may have a grave consequences for the publisher's economic survival, especially where an entire edition is seized.

\section{Chapter 3 Freedom of speech and the press and the coercive measure of seizure under English law}

Since England does not have a written constitution, both the statutes that are important in determining the scope of the freedom of speech and the press and relevant case law are discussed in this chapter. Freedom of speech and the press can be exercised in England, provided this is not prohibited by statute or at common law. As a result of the Contempt of Court Act 1981, the Obscene Publications Acts 1959 and 1964, the Official Secrets Act 1989, the Race Relations Act 1976, the Public Order Act 1986 and the Police and Criminal Evidence Act 1984, and decided cases, 
a limited scope has been afforded to the freedom of speech. There are hardly any restrictions related to seizure. The only statute which allows the freedom of speech and the press some scope is the Police and Criminal Evidence Act 1984. In this Act, seizure of information carriers is linked to the search of premises. Seizure of 'excluded material', Tegally privileged material' and 'special procedure material' is accompanied by additional procedural safeguards in the case of a search. The author sums up these safeguards, after specifying the categories of 'material'

'Excluded materials' are 'personal records', 'human tissue or human tissue fluid' or 'journalistic material'. The latter are either 'documents' or 'records other than documents'. 'Documents' include:
a. writings, plans, drawings etc;
b. photographs;
c. diskettes, audiotapes, compact discs etc.",
d. films, microfilms, negatives etc.

Material of all three categories must be 'held in confidence'. For journalists this means that the documents must have been obtained from third parties and that there must be a confidential relationship between the journalist and the third party. Photographs taken at demonstrations do not fall within this category. These may be classified as 'special procedure material'. 'Special procedure material' is confidential material that cannot be classified as 'excluded materiall, either because it does not comprise "personal records' or because it is not "journalistic material' (Section 14 PACE). Under the Pollice and Criminal Evidence Act 1984, police officers may seize all material, either 'excluded' or 'special procedure', however, the police may not retain anything if a photograph or a "copy' would be sufficient (S. 22(4) PACE). In Reynolds v. Commissioner of Police of the Metropolis, the Court of Appeal ruled that the police were not empowered to seize large numbers of documents without specifying that "each file or bundle might reasonably constitute evidence" ((1984) 3 All ER 649, CA). Here, albeit implicitly, freedom of speech and the press is at least taken into consideration. Items subject to legal privilege are exempt from the power of search and seizure. Such material, including lawyer-client "communications" cannot be seized ( $\mathrm{S}$. 10(1)(a) PACE).

There is a special procedure for the seizure of information carriers during a search of premises. To seize 'excluded material' or 'special procedure material', for instance, the police need to apply for a 'production order' from the circuit judge. A 'production order' demands that the person possessing the evidence surrender it to the police or to grant a police officer access to it. In this way, the person in possession of the evidence can avoid a search of the premises. In contradistinction to a search warrant, a production order is always inter partes, that is to say that the person in question may lodge a complaint against a planned or executed seizure, unless under one of the other Acts previous to PACE written authority other than a warrant was required to gain access to "excluded material". In such case, the Acts are operative and procee- 
dings are no longer inter partes (see for instance, the Official Secrets Act 1989, the Obscene Publications Act 1959 and 1964 and the Public Order Act 1986). One can argue whether this rule is not at odds with the principle of 'fair trial' as laid down in article 6 ECHR. However, since the Official Secrets Act 1989, the Obscene Publications Act 1959 and 1964 and the Public Order Act 1986 fail to offer substantial safeguards, it would seem to be an inadequate rule. These previous Acts contain vague definitions and scarcely restrict seizure of information carriers. Secondly, an informal system of control has been set up under these Acts, such as the Services, Press and Broadcasting Committee, the British Board of Film Censors and the 'Dnotices'. On the basis of this informal system, a writing may be censored even prior to publication and/or dissemination. This is not only a form of unadulterated censorship, it also blocks the institution of court proceedings and is therefore even less acceptable than the civil proceedings frequently instituted to halt publication of certain information.

\section{Chapter 4 Freedom of speech and the press and the coercive measure of seizure under Swedish Iaw}

In Sweden, freedom of the press is regulated by Tyckfriluetsförordningen (TF), which deals with all its aspects. Rules for the seizure of information carriers are also provided by this statuite and not by the Code of Criminal Procedure. In addition, in 1993 an Act regulating freedom of speech came into effect, the Yttrandefrihetsgrundlag (YF). The YF refers to the TF and deals, inter alia, with radio, TV, video, audio tapes and films. The TF incorporates both substantive and procedural aspects of seizure. The substantive aspects are first discussed by the author. As in Germany and England, a distinction is made between objects and information carriers. There are special rules for information carriers, but there is no subdivision into categories. A similar form of protection applies to films as to writings, namely that seizure of information carriers is subject to specific requirements.

The justitiekansler, a special prosecutor who has the power to seize information carriers in the case of printing press offenses (TF 9:2), must ensure that only copies intended for dissemination are seized (TF 10:8). Copies sold to the public or presented to libraries canmot be seized. Copies that are present at printers, publishers or bookstores may be seized. If this is the case, the proportionality of the action must be assessed (TF 10:6). If seizure is required, it is sufficient to seize a specific part, page or excerpt. In the case of seizure for the purpose of uncovering the truth, seizure of a single copy would suffice (TF $10: 8,14$ ). In case of abuse of freedom of the press (tryckfriheten), all information carriers may be seized or confiscated (TF 1:3) in order to prevent or limit the adverse effects of dissemination of information carriers prohibited under criminal law (TF 10:7,8).

The possibility of seizing information carriers at, for instance, publishers and printers, as described above, strikes the author as rather odd. Particularly since in 
Sweden, as in Germany and England, the principle of confidentiality plays an important part where information carriers are seized in order to uncover the truth. In Sweden, there is a general prohibition on divulging the name of the author for any person who is involved in printing or editing. In the case of printing press offenses, the decision as to the degree of criminal responsibility is based on the contents of the printed matter only. The Swedish Tyyckfrihetsforrordningen has a system of limited (vicarious) liability. The reasoning behind this limited form of liability is that a person must be free to write whatever he or she wants. When the prohibition on divulging the name of the author is not linked to the prohibition of seizure, this principle is in effect eroded.

The procedural aspects of seizure are also incorporated in the TF. One of the procedural aspects is the legal proceedings in case of printing press offenses, which differ from regular legal proceedings. Printing press offenses and offenses involving freedom of speech are generally brought before the district courts (tingsrätter) of the larger cities. Proceedings distinguish themselves from ordinary proceeding in that there is a jury. In proceedings involving freedom of the press and freedom of speech, the court comprises a panel of two to three professional jurists and a jury (Act of 1991: 1559, 9:1). Trial by jury is one of the most striking characteristics in these proceedings. The reason for introducing a jury system is that cases involving freedom of speech and the press often have social and political implications. It was held desirable that a jury of citizens render its opinion in these cases.

\section{Chapter 5 Conclusion}

\section{Introduction}

In the previous chapters, the author summarily describes the tension in the various legal orders between freedom of speech and the press on the one hand and the coercive measure of seizure provided for under criminal procedure on the other. In this chapter, the various legal systems are compared. For reasons of efficiency, a division is made between the substantive and procedural aspects of seizure for the purpose of uncovering the truth and the substantive and procedural aspects of seizure for the purpose of confiscation and removal from circulation.

\section{Freedom of speech and the press and the substantive aspects of seizure for the purpose of uncovering the truth}

Article $7(1)$ of the Netherlands Constitution prohibits censorship. This means that the national and delegated legislators may in no instance draft provisions for disclosure by prior consent or stipulations with regard to the content of thoughts or feelings. Only afterwards, upon publication, may the content of writings, pursuant to the clause 
"subject to a person"s responsibility under the law" be tested by the courts; 'law" meaning an Act of Parliament.

Protection as it applies to the right of disclosure differs from protection of the right to disseminate. The right to disseminate thoughts and feelings which is linked to the right to disclose may be curtailed by either an Act of Parliament or by regulations imposed by lower authorities. In the Tilburg judgment (HR 28 November 1950, NJ 1951,137 ), the Netherlands Supreme Court differentiated between a right to disclose an opinion "pertaining to the world of thought" and the "spatial dimension" pertaining to the right to disseminate. The distinction developed by the Supreme Court has been adopted in article 7(1) of the 1983 Constitution. Before the Supreme Court's judgment, disclosure had been used as an umbrella term for everything from publication up to and including public dissemination. In the Tilburg case, the Supreme Court subsequently distinguished between disclosure and disclosure in public (dissemination). The right to disseminate as construed by the Supreme Court shares to a certain extent in the protection of the right to disclose, since a general ban or a licensing system is prohibited. In subsequent case law, the construction arrived at in the Tilburg case has been refined. Not only could freedom of dissemination not be subjected to a general prohibition nor be made contingent on prior consent, the restrictions should not exclude "a significant degree of availability" of the means of dissemination (the 'Nuth-criterion'). The coercive measure of seizure is an example of such a restriction of the freedom to disseminate. The problem under investigation is the relation between seizure and the freedom of speech and the press, more specifically the freedom of dissemination.

It is possible pursuant article $94 \mathrm{CCP}$ to seize objects for the purpose of uncovering the truth. 'Information' on 'carriers' may also be seized. There exist no separate rules for information carriers involving freedom of speech and the press.

Such separate legislation already exist in Germany, where a distinction is made between objects and information carriers in cases of seizure for the purpose of uncovering the truth. Seizure of information carriers for this purpose is not possible where the carriers are held in confidence by privileged media workers or editorial offices, publishers, printers or radio- and television stations and the material has been obtained from third persons. Original material may be seized.

When the German rules are compared with the rules in England, the first thing worth noting is that the Police and Criminal Evidence Act 1984 also distinguishes between objects and information carriers. No distinction, however, is made between original material and material obtained from third parties. The principle of proportionality forms the only protection against too rigid a seizure. The police are, pursuant to PACE, for instance, not allowed under the principle of proportionality to retain or take into their custody information carriers if a photograph or a copy would be sufficient (S. 22(4) PACE). In Reynolds v. Commissioner of Police of the Metropolis, the Court of Appeal ruled that the police are not empowered to seize large quantities of documents without specifying that "each file or bundle might reasonably constitute evidence" ((1984) 3 All ER 649, CA). So, where seizure of either original material 
or material obtained from others is concerned, there is implicit consideration for the freedom of speech and the press, but the legislator has stopped short of excluding material obtained from third parties that is held in confidence by privileged media workers, publishers, printers or radio or television stations from seizure.

In Sweden such material is also not excluded, which is all the more odd since in Sweden, as was pointed out earlier, the prohibition on divulging the name of the author plays a very significant part in cases of seizure for the purpose of uncovering the truth. Anyone involved in printing or publishing activities may invoke this principle. Since the prohibition on divulging the name of the author and seizure have not been coupled, the principle is in effect eroded. That they are not linked has probably to do with the purpose of the seizure, which is to restrict dissemination. Only coples intended for dissemination can be seized (TF 10:8). This means that copies that are present at a publisher or bookstore may be seized, but those in a library may not. In Sweden, it is in principle sufficient to seize a single copy for the purpose of uncovering the truth (TF 10:8, 14).

A comparison of the various legislations shows that the freedom of speech and the press is best protected under German law. In the Netherlands, amending article $94 \mathrm{CCP}$ has been proposed to allow it to distinguish between objects and information carriers. Should the article be changed, information carriers are excluded from seizure involving journalistic work, which means that not only journalistic work would be exempt from seizure for the purpose of uncovering the truth, as is the case in Germany, but also, for example, work by film makers or authors. On the basis of Jurgens"s Draft Journalistic Privilege Bill, journalists would no longer be obliged to disclose their sources. Both original material and materials obtained from others deserve legal protection. In this way, the difficult distinction made in German law between originall material and material obtained from third parties could be avoided. Furthermore, if legislation determines that professional (journalistic) privilege prevails, the court in a given case could only interfere with this right on the grounds of a "pressing need'. Seizure, in such a situation, could only be justified in exceptional cases, namely those in which serious bodily harm has been inflicted. This would exclude a defense of professional privilege. In such cases, first of all the question as to whether the police or judicial officers are reasonably able to gather the desired information themselves must be examined. This approach is in accord with the existing July 1981 directive issued by the Public Prosecutors (procureurs-generaal) at the Courts of Appeal, in which they recommend that seizure for the purpose of criminal investigation should on the wholle be avoided so that "journalists do their job as well as possible: "

\section{Freedom of speech and the press and the procedural aspects of seizure for the purpose of uncovering the truth}

Under the present Dutch Code of Criminal Procedure, in principle, ordinary investigating officers are vested with special, not general, powers of seiture. Only in cases 
in which they are confronted with an object subject to seizure in the exercise of another power, are they authorized to seize the object. Adopting the view of authoritative writers, the Commissie herijking Wetboek van Strafvordering (Government Commission reviewing the Code of Criminal Procedure) has proposed to confer a general power of seizure on all investigating officers in departure from article $96 \mathrm{CCP}$, with the sole restriction that, in circumstances other than those in which the offenders are caught in flagrante delicto, seizure must relate to an offense listed or referred to in article 67, section 1 Code of Criminal Procedure. Because of the vast number of these offenses, in practice, investigating officers ${ }^{\prime}$ power of seizure will scarcely be restricted in future. The question arises as to whether it is desirable to vest the police, who have a strong interest in resolving criminal cases, with powers authorizing them to assess situations in which the right to freedom of speech and the press is at stake.

In Germany, the court is empowered to order the seizure of original material to uncover the truth (art. 98(1) StPO). Only in cases of Gefahr im Verzug are the Public Prosecutor and his deputy so empowered. Gefahr im Verzug obtains when the purpose of the measure is at risk, for instance, when "by undelayed dissemination, public interest" is jeopardized. However, an exception needs to be made for the seizure of original material from editorial offices, publishers, printers or radio- and television stations. In these cases, the court alone has the power to order seizure, also in the event of Gefahr im Verzug.

In England, as in the Netherlands, the police have the power to seize information carriers for the purpose of uncovering the truth. Only in those cases where seizure coincides with a search of the premises, has a special procedure been devised, under which the police apply for a 'production order' from the circuit judge, ordering the person possessing the evidence to surrender it to the police or to grant the police access to it. In complying with the order, the person in question can avoid a search of the premises. Unlike search warrants, production orders are always inter partes, which makes it possible to lodge a complaint with the court against a planned or completed seizure.

It can be concluded that Sweden differs in this respect from the other countries discussed; in cases involving freedom of speech and the press the power of seizure has not been granted to the police, but to the justitiekansler and the ordinary public prosecutor (TF 9:2). The latter must, however, notify the justitiekansler immediately of the seizure, and it is the justitiekansler who decides whether seizure is to be continued or lifted. For the purpose of uncovering the truth, the justitiekansler or the ordinary public prosecutor may seize materials prior to legal proceedings. Subsequently, he must lodge a complaint with the tingrätter (district court) in generally the larger cities within two weeks (TF 10:2). It is the district court that ultimately decides whether seizure is to be lifted or continued (TF 10:4, 5). Proceedings must be instituted within six months of the disclosure. Because of the issue involved, i.e. freedom of speech and the press, the limitation period is short. Proceedings differ from those in other cases in that there is a jury. 
When comparing the situation in Germany, England and Sweden with that in the Netherlands, it can be concluded that the German and Swedish laws give the best protection to the principle of freedom of speech and the press. In Germany, it is the courts and the public prosecutors, rather than the police, who are empowered to seize original materials for the purpose of uncovering the truth (in case of Gefahr in Verzug). Only the courts have the power to seize original material from the media. In England and Sweden, such a distinction is not made. In England, the police are empowered in all cases. Only where seizure coincides with a search of premises, have additional safeguards been established for reasons of privacy rather than freedom of speech and the press. In Sweden, apart from the ordinary public prosecutor, a special prosecutor (justitiekansler) is charged with the seizure of information carriers. Such a seizure is a provisional measure. The justitiekansler must lodge a complaint (TF 10:2) within two weeks with the court at whose discretion it is whether the seizure is to be lifted or to be continued (TF 10:4,5). A jury is involved in these proceedings. The question that arises is whether it is desirable to create such a special officer or to set up a jury in cases of information carrier seizure in the Dutch situation. Such a step would not be necessary if journalists were protected against seizure of both original material and that obtained from others by professional privilege. Only in cases of disturbances and serious bodily harm, for instance during demonstrations, would the police or judicial officers be allowed to gather the information required (where they have not been able to gather this information themselves) and professional privilege would not apply.

In addition to a comparison of the power of seizure in the various countries under study, a comparison can be made of these respective procedures. In Germany, England and Sweden, the procedure for seizure is a public one. Since the Judges" Chambers Procedure Review Act of November 1993 (Stb. 1993, 591), this is also the case for the Netherlands since the 1st of January 1994.

\section{Freedom of speech and the press and the substantive aspects of seizure for the purposes of removal of objects from circulation and forfeiture}

Besides seizure for the purpose of uncovering the truth discussed in the previous section, in the Netherlands there is also seizure for the purposes of forfeiture and removal of objects from circulation. When objects are seized to be forfeited, they are, upon the conviction of the offender, definitively removed from his control. Forfeiture, as known in the Netherlands, is a penalty which adversely affects the convicted person's assets. It is also an additional penalty which makes it an optional punishment. Since seizure is not legally required, the seizing officer is afforded broad discretion in deciding whether an object should be seized. The principles of due process, such as the principles of subsidiarity and proportionality must be duly regarded. Both the court and the investigating officers must heed these principles. Seizure may not take place where this would be 'clearly unreasonable.' This last criterion also applies 
where objects are to be seized in order to remove them from circulation. Whether seizure is 'unreasonable' depends on the circumstances of each case.

These principles are also respected in Germany. The principle of propotionality is expressly referred to art. $111 \mathrm{~m}(1) \mathrm{StPO}$.

In England, as in the other countries under investigation, the principle of proportionality is observed.

In Sweden in principle, an entire edition may be seized (TF 10:8), be it that, where possible, the principle of proportionality must be applied (TF 10:6).

In comparison, it can be concluded that in all countries under investigation the principle of proportionality is operative. The principle of proportionality is also applied by the European Court of Human Rights, since interference with the freedom of speech and the press must satisfy the condition of being "necessary in a democratic society." This means that a "pressing social need" must exist and that the degree of interference must be proportional to the weight of the interest served by it. The ECHR may not readily consider seizure of an entire edition of writings or films, or removal from circulation or forfeiture of these information carriers, "necessary in a democratic society", particularly not in those cases involving publications and persons which foster public debate.

\section{Freedom of speech and the press and the procedural aspects of seizure for the purposes of forfeiture and removal from circulation}

In the Netherlands, the procedure for seizing objects for the purpose of forfeiture or removal from circulation is the same as for seizure to uncover the truth.

In Germany procedures differ. For the purpose of Einziehungsbeschlagnahme, art. 111n(1) StPO specifies the persons empowered to seize information carriers:the judge and Public Prosecutors ('Gefahr im Verzug'), but not their deputies, are empowered to seize such materials as books and tape recordings. Under art. $74 \mathrm{~d}$ of the German Penal Code (StGB), the judge is vested with the power to seize newsmagazines, because seizure of, often time-sensitive, material may have grave consequences for a publisher's economic survival, especially when an entire edition is seized. The procedure is the same as for seizure for the purpose of uncovering the truth.

In England, the legal procedure for seizure of information carriers for the purpose of removal from circulation or forfeiture is not regulated by PACE, but by the Obscene Publications Acts 1959 and 1964 and the Public Order Act 1986. Where state secrets, public order matters or obscene publications are involved, the special procedural protection created for search and seizure under PACE is not applicable. The Obscene Publications Acts and the Public Order Act do not provide a 'special procedure'. Where state secrets, public order matters or obscene publications are involved, more far-reaching interference with the freedom of the speech and the press is allowed. Frequently, interference with the freedom of speech and the press occurs even 
prior to publication through the institution of civil proceedings, which makes it possible to impose several forms of "prior restraint".

Except for these civil proceedings, the freedom of speech and the press is restricted by an informal system of control such as the Services, Press and Broadcasting Committee, the British Board of Film Censors and the "D-notices". Through this informal system, documents may even be censored before publication and/or dissemination. Apart from being a form of unadulterated censorship, it also blocks people from seeking a court decision and is therefore even less acceptable than the civil proceedings frequently instituted to prevent publication.

Sweden has a similar informal system of control, which aims to promote journalistic ethics in newspapers and magazines.' The press ombudsman may address himself directly to an editor and request alterations. This makes the TF more restrictive in character. Furthermore, it is the justitiekansler who assesses whether a document contains "alleged state secrets". If so, he must lodge a complaint within two weeks (TF 10:2) with the court, which ultimately decides whether seizure should be lifted or contimued (TF 10:4,5). If judge and jury in the end decide that no alleged state secrets are at stake, the documents or films have, in any case, been out of circulation for a while.

In the Netherlands, fortunately, no such informal system of control exists. There is a formal system of control based on the Code of Criminal Procedure. Under this Code, regular investigating officers have, in principle, only special powers of seizure. They may only seize relevant objects when they are confronted with such objects in the exercise of another power. As stated earlier, authoritative writers have advocated vesting all investigating officers with general powers of seizure for the purpose of uncovering the truth in lieu of those provided in article $96 \mathrm{CCP}$, with the sole restriction that, except for situations in which the offender is caught in flagrante delicto, this would apply solely to the offenses as defined in article 67(1) CCP. Since a substantial number of offenses are referred to or specified in this section, in practice, investigating officers' power of seizure is rather broad. It is the author's view that the police, in whose interest it is to detect and resolve criminal offense, are not an appropriate body to decide on matters of freedom of speech and the press. That is why in Germany the legislator has differentiated between utterances made in news magazines and utterances made in, for example, fillms and books. Only the courts are empowered to seize news magazines, since such magazines are time-sensitive. Seizure of an entire edition may put a publisher's economic survival at risk. It is felt that judges are better equipped to weigh constitutional rights against the interests of the police in investigating and prosecuting alleged offense. Judges and Public Prosecutors ('Gefahr im Verzug") are empowered to seize such materials as films and books. Since criminal provisions, such as the provisions governing pornography and state secrets, are rather broadly formulated, the German legislator has opted in vesting the power to seize information carriers in Public Prosecutors ("Gefahr im Verzug') instead of the police, in order to avoid that information carriers seized 
have to be handed back, because the Public Prosecutor subsequently fears that he may not be able to prove the case conclusively.

Of course, there are also drawbacks to vesting the power of seizure in judges and Public Prosecutors, as in Germany. Frequently, the illegally printed matter has disappeared in the intervening period. The reason why this regulation has nevertheless been made in Germany is that constitutional rights may be at stake, in this instance the freedom of speech and the press. These constitutional rights may be infringed upon by coercive measures, making it imperative to build in as many safeguards as possible in respect of the implementation of these measures. One safeguard is that in cases of seizure of non time-sensitive information, Public Prosecutors ${ }_{\text {y }}$ rather than the police, are empowered to seize. Where time-sensitive information is concerned, only examining magistrates should have the power to seize, inasmuch as he or she is not only a law enforcer, but also a guardian of justice. Examining magistrates are in an even better position than Public Prosecutors to make a proper assessment of the interests involved. If the power to seize were to be vested in Public Prosecutors and examining magistrates, the risk that proceedings are not instituted, or only long after seizure, may perhaps be avoided. In particular, material with a news value should not be out of circulation for any longer than necessary.

\section{Recommendations}

To conclude this summary the recommendations made in the preceding chapters are summed up. As was said in the introduction to the conclusion, a comparison of different legal systems would enable the author to formulate a number of recommendations for improving the Dutch provisions in respect of seizure. As long as these provisions are not amended, the courts are left without any without a instrument to duly observe the right to freedom of speech and the press (art. 7 of the Constitution and art. 10 ECHR:

1. For the purposes of the Code of Criminal Procedure, "objects" and "information carriers' should be distinguished as is done in Germany, England and Sweden. A bill introduced by the Dutch MP Jurgens proposes that, where journalistic work is concerned, seizure of information carriers for the purpose of uncovering the truth should be prohibited. The accent is on 'information' in this case and not on 'carriers', as in the Dutch Computer Offenses Act. It is information that the police are after, not the carriers of such information. Not only original materials, as in Germany, but also materials obtained from third persons should enjoy legal protection. As a result of a statutory regulation of journalistic privilege, judges would only have the power to interfere with this privilege in cases of pressing reasons. Consequently, seizure would only be justified in extraordinary circumstances, namely in those cases, in which serious bodily harm is inflicted. To begin with, an assessment has to be made as to whether the police are not reasonably capable of gathering the information 
themselves. If they are not reasonably capable of doing so, they may seize materials, however, in due observance with the principles of proportionality and subsidiarity.

2. In the case of seizure for the purposes of forfeiture or removal from circulation, a balanced distinction should be made, based on the German example, between time-sensitive and non time-sensitive information. In case of time-sensitive information, the power of seizure is to be vested in the examining magistrates. Where the seizure of non-time-sensitive information is concerned, powers should rest with the Public Prosecutors. In addition, a distinction should be made between discussions of public matters and discussions of non-public matters. According to the European Court of Human Rights, public debate warrants protection. Seizure for the purpose of forfeiture or removal from circulation will be readily assumed to be disproportionate in cases of public debate. The European Commission of Human Rights holds that also in cases of writings offending public decency, the disproportionality of the seizure should assessed. In the Müller case, the Commission felt that confiscation of all the paintings was disproportional and not 'necessary in a democratic society.' The Commission's opinion corresponds with the author's view that both preventive interference, such as seizure, and repressive interference, such as removal from circulation and forfeiture, should not render dissemination of information carriers impossible, unless there is a demonstrable causal link between the speech and physical violence. Seizure and forfeiture, or, as the case may be, removal from circulation, must not take place in cases involving public debate. 



\section{Lijst van aangehaalde literatuur}

Aarts, C.I. en M. van der Pluijm, Verboden boeken, Verboden door pausen, dictators, puriteinen en boekenhaters, Amsterdam 1989.

Akkermans, P.W.C., (red.), De Grondwet. Een artikelsgewijs commentaar, Zwolle 1992. Aler, G.P.A., De politiebevoegdheid bij opsporing en controle, Enige aspecten van de regeling van de dwangmiddelen in het Wetboek van Strafvordering en in bijzondere wetten, Zwolle 1982.

Alkema, E.A., Studies over Europese Grondrechten. De invloed van de Europese Conventie op het Nederlandse recht, Deventer 1978.

Alkema, E.A., De vrijheid van de kunst als onderdeel van de grondrechtelijke communicatievrijheid mede in het licht van het EVRM in: G.A.I. Schuijt, T. Pronk (red.), Hoe vrij is de kunst?: onderdrukking, censuur en andere beperkingen aan de vrijheid van expressie, Amsterdam 1992, p. 9-19.

Ameling, K., Probleme des Rechtsschutzes gegen strafprozessuale Grundrechtseingriffe, Neue Juristische Wochenschrift 1979, p. 1687-1692.

Anastassopoulos, Professional Secrecy, IFJ Information 1982, vol. XXXIl, p. 10.

Aster, D., How the British Press censors itself, Index on Censorship 6-1977, p. 3-8. Austin, R., The Spycatcher Saga: Public Secrecy from Private Rights in: D. Kingsford Smith and D. Oliver, Economical with the Truth: The Law and the Media in a Democratic Society, Oxford 1990, p. 27-42.

Axberger, H.G., Tryckfrihetens Gränser, Stockholm 1984.

Aquina, H.J. De prijs van een goede samenleving, politieke kosten en baten volgens Socrates en zijn rechters, Wijsgerig perspectief op maatschappij en wetenschap 1989/1990 , p. $41-47$.

Bailey, S.H., D.J. Harris, B.L. Jones, Civil Liberties, Cases and Materials, London 1991.

Bakhoven, W.P., Inbeslagneming en bare gevolgen, Tijdschrift voor Strafrecht 1938, p. 154-203.

Balmer, H.R., Search and Seizure: A Comment, Criminal Law Review 1967, p. 19-20. Banakas, E.K. (ed.), United Kingdom Law in the 1980s, Comparative and Common Law Studies for the Xllth International Congress of Comparative Law, London 1988. Barendt, E., Freedom of Speech, Oxford 1985.

Bellekom, Th.L., Vrijheid van meningsuiting en de Grondwet in: Presidium Libertatis, Deventer 1975, p. 115-125. 
Bellekom, Th.L., Botsing wan grondrechten: De wrijheid van meningsuiting contra het gelijkheidsbeginsel, NJCM-Bulletin 1983, p. 270-273.

Bellekom, Th.L. De jurisprudentie van het EHRM met betrekking tot de beperkingsgronden van de artt. $8 \mathrm{t} / \mathrm{m} 11$ Europese Conventie, NJCM-Bulletin 1990, p. 68-74.

Bemmelen, J.M., van, Belediging en de vrijheid van meningsuiting, Nederlands Juristenblad 1969, p. 443-448.

Bergh, $G$., van den, De artit. 7 en 9 van de Grondwet in het licht van de moderne techrilek, Nederlands Juristenblad 1940, p. 62-72.

Beunders, Henri, De strijd on het beeld, Over de behoefte aan censutu, s'-Gravenhage 1994.

Biesheuvel, M. Het Softenondrama en de vrije meningsuiting, NJCM-Bulletin 1979 $16 / 17$, p. $58-81$.

Bindman, G., Incitement to Racial Hatred in the United Kingdom, Have we got the Law we need?, in: S. Coliwer (ed.), Striking a Balance, Hate Speech, Freedom of Expression and non-discrimination, London 1992, p. 258-262.

Binnenhof 19-11-1987, Ergernis rond Fassbinder.

Birkinshaw, P. Reforming the Secret State, Open University Press 1991.

Blauw, J.H. Kort Geding in het strafrecht, studiepockets nr. 23, Zwolle 1992.

Blok, A.J., en L.Ch. Besier, Het Nederlandsche Strafproces, deel 1, Haarlem 1925.

Boerefijn, I., Extreem rechts en het internationale recht, LBR-Bulletin 1993, p. 7-12.

Bornkamm, J., Pressefreiheit und Faimess des Strafverfahrens, Rechtsvergleichung, Baden-Baden 1980.

Brakman, I. en R. Hopmans, NJV Postief over verschoningsrecht voor journalisten, Mediaforum 1991-5, p. 55.

Brandt, K., Strafpozessuale Zwangsmaßnahmengegen Presseuntemehmen, Göttingen 1969.

Boukema, P.J., Enkele aspecten van de vrijheid van meningsuiting in de Duitse Bondsrepubliek en in Nederland, dissertatie VU, Amsterdam 1966.

Boukema, P.J. Vrijheid wan meningsuiting en art. 7 van de Grondwet, Rechtsgeleerd Magazijn Themis 1969 , p. 119-140.

Buning, Cock, De zaak-Boomsma, politiek beladen storm in een glas water?, $N J B$ 1994 , p. $874-876$.

Burkens, M.C. e.a., Beginselen van de democratische rechtsstaat, Zwolle 1992.

Burkens, M.C., Algemene leerstukken wan grondrechten naar Nederlands constitutioneel recht, Handboeken staats- en bestuursrecht, deel II, Zwolle 1989.

Callender, Smith, R., Press Law, Contempt and the Phillimore Committee, London 1978.

Campbell, D., Paradoxes of Secrecy, Index on Censorship 8-1988, p. 16-19.

Caplan, $J$, The Criminal Liability of the Media under section 2 of the Official Secrets Act, Joumal of Criminal Law 1987, p. 67-74.

Card, R., Public Order, The New Law, London 1987. 
Claessen, P.D.A., Plakwerordening en drukpersvrijheid, Tyjdschnift woor overheidsudwimistratie 1983 , p. 526-529.

Cleiren, C.P.M., De openheid van de wet, de geslotenheid wan het recht, inaugurele rede Erasmus universiteit, Arnhem 1992.

Cleiren, C.P.M., Beginselen van een goede procesorde, een analyse van rechtspraak: in strafzaken, Arnhem 1989.

Colenbrander, H.T., Ontstacn der Grondwet, deel Il, 's-Gravenhage 1909.

Commentaar NJCM rapport Commissie, NJCM-Bulletin 1991, p. 361-379.

Commissie Vermogensstraffen, Eindrapport, Staatsuitgeverij: 's-Gravenhage 1972.

Commissie Herijking Wetboek van Strafvordering (vz. Ch.M.J.A. Moons), Herziening van het gerechtelijk woononderzoek, Een rappon van de Commissie Herijking Wetboek van Strafiordering, Arnhem 1990.

Corell, H., O. Egerstedt, S. Heuman, G. Regner, Sekretesslagen, 1980 ars lagstiftning med kommentarer, Stockholm 1980.

Corstens, G.J.M., Beginselen van behoorlijk procesrecht, Trema 1985, p. 173-190.

Corstens, G.J.M., Waarborgen rondom het vervolgingsbeleid, IJmuiden 1974.

Council of Europe, Activities in the Mass media field, doc. DH-MM (86) 3, p. 9.

Coveliers, H., Verschoningsrecht, ook in België?, Mediaforum 1991-5, p. 56-57.

Cross, R., P.A. Jones and R. Card, Introduction to Criminal Law, London 1988.

Danelius, H., Human rights in Sweden, Lund 1981.

Danelius, H., Mänsliga Rättigheter, Lund 1989.

Delitz, M., Zeugnisvenweigenungsrecht und beschlagnahmeprivileg der presse unter besonderer Berïcksichtingung des anglo-amenkanischen Rechts, dissertatie Ludwig-Maximi-

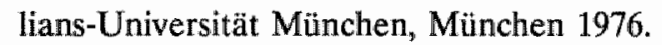

Diemer, E., Vrijheid van drukpers: Eenige opmerkingen over haar staatsrechtelijke regeling in Nederland, dissertatie VU, Rotterdam 1937.

Dijk, P., van, en G.J.H. van Hoof, De Europese Conventie in theorie en praktijk, Nijmegen 1990.

Dommering, E.J., De informatiedriehoek, Enige beschouwingen over de regulering van informatiestromen, inaugurele rede UvA, Deventer 1989.

Drzemczewski, A.L, European Human Rights Convention in Domestic Law, A Comparative Study, Oxford 1983.

Dresen, P., De vrije meningsuiting, Amsterdam 1949.

Duchacek, J.D., Freedom of Expression in: J.D. Duchacek, Rights and Liberties in the World Today, Constitutional Promise and Reality, Studies in Comparative Politics, Santa Barbara 1990, Chapter 5.

Duffy, P.J., The Sunday Times Case: Freedom of Expression. Contempt of Court and the European Convention on Human Rights, The Human Rights Review 1979, p. 17-53.

Duk, W., Beoordelingsvrijheid en beleidsvrijheid, Rechtsgeleerd Magazijn Themis 1988, p. 156-169. 
Easterman, A Sense of Proportion, The Rushdie Affair, Index on Censorship 4-1990, p. 9-11.

Eek, H., Die Sonderstellung der Presse im Strafverfahren in Schweden, Verhandelungen der Fachgruppe für Strafrechtsvergleichung Kiel, Frankfurt a/M 1965-29.

Eissens, W.J.G.M. en B. Staal, Dwangmiddelen in het strafproces, Arnhem 1981.

Erhard, $\mathrm{B}_{,}$, Mediales Zeugnisverweigenungsrecht und Beschlagnahmeverbot im spannungsverhältinis zwischen Medienfreiheit und Strafverfolgung, Schriftenreihe für Rundfunkrecht an der Universitảt Köln, Band 38, 1984.

Ewing, K.D., C.A. Gearty, Freedom under Thatcher, Oxford 1990.

Fawcett, J.E.S., The Application of the European Convention on Human Rights, Oxford 1987.

Forman, D., Threats to British broadcasting, Index on Censorship 8-1987, p. 1.

Franken, H. e.a., Informatietechniek en strafrecht. Rapport van de Commissie-Computercriminaliteit, Staatsuitgeverij: ministerie van Justitie 1987.

Frowein, J. en W. Peukert, Europaïsche Menschenrechtskonvention: EMRK-Kommentar, Kehl am Rhein 1985, p. 229 e.v.

Furmston, M.P., R. Kerridge, B.E. Sufrin, The Effect on English Domestic Law of Membership of the EC and the Ratification of the European Convention on Human Rights into United Kingdom Domestic Law, The Hague 1983.

Fuss, E.W., Pressefreiheit und Geheimnisschutz, Neue Juristische Wochenschrift 1962, p. 2225-2228.

Garnham, N., How free is British broadcasting?, Index on Censorship 5-1982, p. 26-28. Giltay Veth, N.J.P., De sub judice-regeh, fatsoensregel of rechtsregel?, Enige verkenningen, inaugurele rede, RUL Leiden 1980.

Glorie, C., Opsporing verzocht, Inbeslagneming van journalistiek materiaal. Journalist verlengstuk van justitie?, doctoraal scriptie UvA, Instituut voor Informatierecht.

Goldschmidt, Jenny E., Botsing van grondrechten: De vrijheid van meningsuiting contra het gelijkheidsbeginsel, NICM-Bulletin 1983, p. 277-280.

Groenhuijsen, M.S. en F.P.E. Wiemans, Van elektriciteit naar computercriminaliteit, monografieën strafrecht-9, Arnhem 1989.

Grosser A. und J. Seifert (Hrg.), Die Spiegel-Affäre, Band I, Freiburg 1966.

Groß, R., Zum Zeugnisverweigerungsrecht der Mitarbeiter von Presse und Rundfunk in: Festschrift für Gerhard Schiedermair, München 1976, p. 223-243.

Groß, R., Pressestrafrechtliche Verantwortlichkeit, Neue Juristische Wochenschrift 1978, p. 918-920.

Habraken, P.J.R., Het lek van Nootdorp, Beschouwingen over het verschoningsrecht van journalisten, $A A 1989$, p. 825-833.

Hemels, J., De drukpers als middel tot misdrijf of machtsmisbruik?, Tijdschrijft voor Criminologie 1989, p. 287-304.

Guillou, J., 'A Swedish Watergate', Index on Censorship 2-1974, p. 29-33.

Hampton, C., Criminal Procedure, London 1982. 
Hampstead, Lord of, Do we need a Bill of Rights?, The Modem Law Review 1976 , p. $121-129$.

Hargreaves, F. and H. Levenson, A Practitioner's Guide to the Police and Criminal Evidence Act 1984, Legal Action Group 1985.

Heijder, A, De strafrechtelijke bescherming van de eigendom, Rechtsgeleend Magazijn Themis 1976, p. 354-373.

Heijer, A., Enkele aspecten van de strafrechtelijke bescherming van staatsgeheimen in: J. Remmelink, Naar eer en geweten, Liber Amicomum, Arnhem 1987, p. 181-193. Hennessy, British secrecy and the proposed reform of the Official Secrets Act, Index on Censorship 8-1988, p. 9-12.

Heringa, A.W. en R. de Winter, De kleefkracht van de vrijheid van meningsuiting, Nederlands Juristenblad 1982, p. 352-354.

Herzog, R., Hierarchie der Verfassungsnormen und ihre Funktion beim Schutz der Grundrechte, Europäische Grundrechte 1990.

Hewitt, P., The Abuse of Power, Civil Liberties in the UK, London 1982.

Hoeven, J., van der, De placts van de Grondwet in het constitutionele recht, Zwolle 1958.

Hoeven, J., van der, Toetsen aan de Grondwet. Hoe en door wie?, Nederlands Juristenblad 1991, p. 784-787.

Holmberg, E., Frihet och answar i tryck och radio, Stockholm 1968.

Holmberg, E., Offentlighetsprincipen och myndigheterna, Stockholm 1987.

Hurwitt, M. and P. Thornton, Civil Liberty, London 1978.

Hussain, M., A Muslim's perspective, The Rushdie Affair, Index on Censorship 4-1990,

p. 12-13.

Jaconelli, J., Enacting a Bill of Rights, The Legal Problems, Oxford 1980.

Jagusch, H., Pressefreiheit, Redaktionsgeheimnis, Bekanntmachen von Staatsgeheimnissen, Neue Juristische Wochenschrift 1962, p. 177-183.

Janssens, F., Beledigende uitlatingen in de media, NICM-Bulletin 1995, p. 124-141. Jareborg, N., Brotten III, Institutet för Rättvetenskaplig Forskning, Skrifter 14, Lund 1982 .

Jareborg, N., Yttrandefrihetsbrott, Institutet för Rättvetenskaplig, Forskning Skrifter 14, Stockholm 1987.

Jong, $\mathrm{O}$, de, Zonder "besloten beroep" verschoningsrecht mogelljk, De joumalist 1991 , p. 30 .

Jurgens, E. en C.J. Glorie, Wet op het Journalistiek Privilege, Mediaforum 1991-2, p. 13-20.

Jurgens, E., Nogmaals: Journalistiek 'verschoningsrecht', Mediaforum 1991-11/12, p. 119-122.

Kalsbach, T., Die gerichtliche Nachpriafung won Maßnahmen der Staatsanwaltschaft in Strafuerfahren, Berlin 1967.

Khan, A.N. and A.F. Dickey, Incitement to Racial Hatred, Australia 1976. 
Kerridge, R., Incorporation of the European Convention on Human Rights into United Kingdom Domestic Law in: M.P. Furmston, R. Kerridge, B.E. Sufrin, The Effect on English Domestic Law of Membership of the EC and the Ratification of the European Convention on Human Rights into United Kingdom Domestic Law, The Hague 1983, p. 247-282.

Kistenkas, F.H. Verspreidingsdogmatiek of belangenafweging? Tijdschrift voor overheidsadministratie 1987 , p. 356-361.

Kleinknecht/Meyer, Kurz-Kommentar, StrafprozeBordmung, Genichsverfassungsgesetz, Nebengesetze und ergänzende Bestimmungen, München 1989.

KJug, U., Presseschutz im Strafprozeß, Ein Rechtsgutachten im 'Spiegel-Verfahren', Berlin und Neuwied 1965.

Knuttel, W.P.C., Verboden boeken in de Republiek der Vereenigde Nederlanden, 'sGravenhage 1914.

Kohl, H., Press Law in the Federal Republic of Germany in: P. Lahav, A Comparative Study, Press Law in Modem Democracies, New York 1985, p. 185-228.

Koopmans, $T$, Het verschoningsrecht van de journalist, Preadvies, Deventer 1978. Kupfer, T., Media concentration and diversions in opinion, Agenda Socialist Group European Parliament, p. 4.

Kunert, K.H., Das Gesetz über das Zeugnisverweigerungsrecht der Mitarbeiter von Presse und rundfunk, Monatsschrift für Deutsches Recht 11/1975, p. 885-893. Landen, D., van der, Straf en maatregel, dissertatie KU Brabant, Arnhem 1992. Lawrence, R.J., Rights and Remedies in: C. Campbell (ed.), Do we need a Bill of Rights?, London 1980, p. 10-16.

Leijten, J.C.M., Van vogels, vuurwapens en door rechters bevoordeelde dieven in: Naar eer en geweten, Liber Amiconum J. Remmelink, Arnhem 1987, p. 309-318. Leijten, J.C.M., Niet straffeloos beledigen, Nederlands Juristenblad 1993, p. 639. Lepa, M., Der Inhalt der Grundrechte nach der Rechtsprechung, Köln 1976.

Levenson, H. and F. Fairweather, Police Powers, A Practitioner's Guide, London 1990. Lewis, A., Bentham's View of Journalists' Privilege and The Independent Case in:

D. Kingsford Smith, D. Oliver, Economical with the Truth, The Law and the Media in a Democratic Society, 1990, p. 85-108.

Lidstone, V.B.K., A Guide to the Police and Criminal Evidence Act 1984, London 1985.

Lillieroth, Lu, Larebok om Sekretesslagstifiningen, Göteborg 1984.

Lisken, H., Pressefreiheit und StrafprozeB, Zeatschrift fuir Rechtspolitik 1988, p. 193-197. Lloyd, J., The Culture of Press Freedom, Index on Censorship 8-1988, p. 20-24. Löffler, M., Der Verfassungsauftrag der Presse, Modelfall Spiegel, Karlsruhe 1963. Löffler, M., Die Gesetzgebungskompetenz von Bund und Ländern auf dem Gebiet des Presserechts, Neue Juristische Wochenschrift 1972, p. 1515-1516.

Löfler, M., Die öffentlichte Aufgabe der Medien, Bütburger Gespräche 1974-1976, Jahrbuch 1974-1976, Trier 1977, p. 29-36. 
Löffler, M., Lücken und Mängel im neuen Zeugnisverweigerüngs- und Beschlagnahmerecht von Presse und Rundfunk, Neue Juristische Wochersschrift 1978, p. 913-918.

Löffler, M., Das neue Zeugnisverweigerungs- und Beschlagnahmerecht im Presseund Rundfunkbereich, Neue Juristische Wochenschrift 1978, p. 1617-1618.

Loof-Donker, A.M.F., E.M. Peeters en P.H. van der Tang-Van Loenen, Kanttekeningen bij de wijze waarop de Nederlandse wetgever omgaat met het begrip "openbare orde' als doelcriterium voor de beperking van grond- en mensenrechten, NICMBulletin 1994, p. 503-518.

Löw, K., Die Grundrechte, Das Recht der freien Meinungsäußerung, München-New York-Paris 1982.

Löwe-Rosenberg, Großkommentar, Die Strafprozeßordnung und das Gerichtsverfiassungsgezetz, Erster Band, 1989.

Mallmann, W., Pressepflichten und öffentliche Aufgabe der Presse, Juristenzeitung 1966, p. 625-632.

Manen, W., van, De constitutie van de uitingsurijheid, Mediaforum 1990-1/12, p. 115-116.

Maarseveen, H.Th.J.F., van, Grondwetswijziging inzake de drukpersvrijheid, Nederlands Juristenblad 1971, p. 32-41.

Maarseveen, H.Th.J.F., Vrijheid van zelfexpressie, Nederlands Juristenblad 1980, p. 617-628.

Marsh, N.S., Public Access to Government held Information, London 1987.

Marston, J., Public Order, A Guide to the Public Order Act 1986, London 1987.

McBride, J, The ECHR and the Protection of Civil Liberties in the UK in: P. Wallington, Civil Liberties, Oxford 1984, p. 201-225.

McCabe S., National Security and Freedom of Information in: L. Gostin, Civil Liberties in Conflict, London 1988, p. 185-207.

MoCormick, D.N., Privacy and Obscenity in: R. Dhavan, C. Davis (ed.), Censorship and Obscenity, London 1978, p. 76-97.

McDonald, R., Film Censor's Bulletin, Index on Censorship 6-1977, p. 26-28.

Meij, J.M., de, Overheid en uitingsvrijheid, WRR-rapport in de serie Voorstudies en achtergronden mediabeleid, "s-Gravenhage 1982.

Meij, J.M., de, Vitingsvrijheid. De vrije informatiestroom in grondwettelijk perspectief, Amsterdam 1989.

Meij, J.M., de, De feitelijke mogelijkheid tot wrije meningsuiting, Mediaforum 1989-2, p. 16-18.

Meij, J.M., de, Ruime uitleg WOB bemoeilijkt journalistiek, Mediaforum 1990-7/8, p. 76-77.

Meij, J.M., de, 'Ze waren geen SS-ers, nee...', NJB 1995, p. 549-550.

Melander, H., 'More on the Swedish Watergate', Index on Censorship 3-1974, p. 107108. 
Melai, A.L., Het Wetboek van Sraffordering, werklaard en van aantekeningen voorzien (losbladig), M.S. Groenhuijsen, Th. A. de Roos en A.H.J. Swart (red.), Arnhem (z.j.).

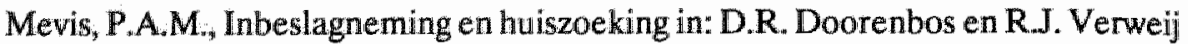
(red.), Hercodificatie Wetboek van Strafivordering, Nijmegen 1991, p. 103-139.

Meyer J, Zur Beschlagnahme selbstrecherchierten Materials von Journalisten in: H.H. Jescheck und Th. Vogler (Hrg.), Festschift für H. Tröndle Berlin-New York 1989 , p. $839-854$.

Michael, $J_{\text {s. }}$ The Politics of Secrecy: The Case for a Freedom of Information Law, London 1979.

Miller, C.J Contempt of Court, Criminal Law Review 1982, p. 71-84.

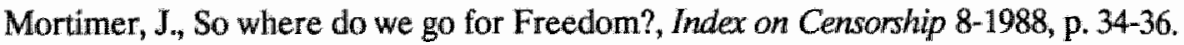

Muskens, M.E.W. en H.M. Poelman, Art. $33 \mathrm{a}$ Sr: verbeurdverklaring en 'derden', Delikt en Delinkment 1985, p. 844-858.

Naeye, $J_{\text {. }}$ Deel IV - De reikwijdte van fundamentele rechten in strafzaken - enkele thema's, p. 223-303 in: Nederlandse Juristen Vereniging, Handelingen 1995, Preadviezen van E.A. AJkema, H.A. Groen, P.J. Wattèl, J. Naeyé, De reikwijdte van fundamentele rechten, deel 1, Zwolle 1995.

Nederlandse Juristen Vereniging, Brochure Verschoningsrecht, 's-Gravenhage 1989.

Nederlandse Juristen Vereniging, Handelingen 1949, deel 1, 's-Gravenhage 1949 , eerste druk.

Nederlandse Juristen Vereniging, Handelingen 1988, Preadviezen van F. VellingaSchootstra e.a., Gegevensbescherming, 118, deel 1, 's-Gravenhage 1988.

Neut, J.L., van der, Discriminatie en Strafrecht, monografieën Strafrecht, deel 6, Arnhem 1986.

Neut, J.L., van der, Dient eenvoudige belediging strafbaar te blijven, Delikt en Delinkwent 1981, p. 732-735.

Nietzsche, F., Ecce homo, Wie man wird. Was man ist, Frankfurt am Main 1977.

Nieuwenhuis, A., Persvrijheid en persbeleid, Mediafonm 1991-7/8, p. 76-78.

Niftrik, H.M., van, Spreken is zilver, zwijgen een privilege, Mediaforum 1990-3, p. 33-34.

Nisser, C.W. The Freedom of Expression in the Swedish Radio and TV, Revue des droits de l'homme 1975, p. 145-150.

Noyon-Langemeijer/Remmelink, Het Wetboek van Strafrecht, 1984.

Nowak, M., UNO-Pakt über biargerliche und politische Rechte und Fakultativ protokoll: CCPR-Kommentar, Kehl am Rhein 1989.

Nyman, O., Some Basic Features of Swedish Constitutional law in:" S. Strơmholm, An Introduction to Swedish Law, Uppsala 1988, p. 47-77.

O'Higgens, P., Cases and Materials on Civil Liberties, London 1980.

Pannick, D., Legal Indignations, 'Spycatcher' in: D. Kingsford Smith, Dawn Oliver, Economical with the Truth. The Law and the Media in a Democratic Society, Oxford 1990 , p. $17-26$ 
Partsch, K.J.. Freedom of Conscience and Expression in: L. Henkin, Intermational Bill of Rights, New York 1981, p. 216-230.

Pauli, A., Der Schutz von Presse und Rundfunk vor dem Zugriff staatlicher Verfolgunguorgane, dissertatie Albertus Magnus Universität Köln, München 1988.

Peters, J.A, Commentaar op 'De strijd tegen rassendiscriminatie als beperkingsgrond woor de vrijheid van meningsuiting', NJCM-Bulletin 1987, p. 139-141.

Peters, J.A., Het primaat van de vrijheid van meningsuiting, vergelijkende aspecten Nederland-Amerika, Leiden 1981.

Pollakiewicz, J. en V. Foltzer, The European Human Rights Constitution in Domestic Law, Human Rights Law Journal 1991, p. 65-141.

Pollard, D. and D. Hughes, Constitutional and Administrative Law: Text and Materials, London 1990.

Polyvio, P.G., Search and Seizure, Constitutional and Common Law, Oxford 1982. Ponting, C., The Right to Know, Index on Censorship 8-1988, p. 16-19.

Pot, C.W., van der, Donner, Handboek van het Nederlandse staatsrecht bewerkt door L. Prakke, Zwolle 1989.

Prakken, T., De affaire Bluf!, Crimineel Jaarboek 1989, p. 134-140.

Prakken, T., Met de NJ de politiek in?, Nederlands Juristenblad 1990, p. 460-461. Ree, E., van, Snelle gekwetstheid bedreigt vrijheid van meningsuiting in: De Volkskrant 29-10-1991.

Reh, H.J. und R. Groß, Die Pressebeschlagnahme, Neue Juristische Wochenschrift 1962 , p. 517-519.

Reissenberger, M. 'ZDF-BeschluB - unzumutbar', Deutsche Richterzeitung 1988, p. 189.

Remmelink, J., Iets over de verbeurdverklaring en onttrekking aan het verkeer, Nederlands Juristenblad 1965, p. 85-98 en p. 109-119.

Remmelink, J., In het strafrecht zit een spelmoment, Ars Aequi 1992, p. 145-150. Rijn, A.B., van, De functie van de vrijheid van meningsuiting in beide Duitse staten, diss. RL, Zwolle 1985.

Robertson, G. and A.G.L. Nicol, Media Law, The Rights of Joumalists and Broadcasters, London 1990.

Robertson, G., Freedom, The Individual and the Law, Harmondsworth 1989, 6th edn.

Rolph, C.H. (ed.), The Trial of Lady Chatterley, London 1961.

Rosen, M., The Sunday Times Thalidomide case: Contempt of Court and The Freedom of the Press, British Institute of Human Rights i.s.m. Writers Scholars Education Trust, London 1979.

Scarman, Lord, Human Rights, The Current Situation in: C. Campbell (ed.), Do we need a Bill of Rights?, London 1980, p. 2-9.

Schneider, P. Pressefreiheit und Staatssicherheit, Mainz 1968.

Schokkenbroek, J.G.C., De margin of appreciation-doctrine in de jurisprudentie van het Europese Hof, NJCM-Bulletin 1990, p. 41-58. 
Schuijt, G.A.I., Media en de vrijheid van het politieke debat, Mediaforum 1991-9, p. $91-93$.

Scott, J., Government, Press and the Public Interest, Index on Censorship 2-1988, p. 2, 24-26.

Smith, S.A., de Constitutional and Administrative Law, London/Harmondsworth 1985, 5th edn.

Sprey, L, De databank en art. 7 Grondwet, Informatierecht/AMI 1988, p. $71-74$. Staatscommissie Cals-Donner, Tweede Rapport 1969, Staatsuitgeverij: 's-Gravenhage 1971.

Staatscourant 2-6-1980, nr. 103, Richtlijnen voor het beleid van het Openbaar Ministerie en de politie inzake inbeslagneming.

Stone, I.F., Het proces Socrates, Baarn 1988.

Strömberg, Oversikt äver tryckfrihetsrätten, Lund 1978.

Strömberg, H., Press Law in Sweden in: P. Lahav, Press Law in Modern Democracies, A Comparative Study, New York 1985, p. 229-261.

Strömberg, H., Handlingsoffentlighet och sekretess, Lund 1986.

Strömberg, H., Tryckfrihetsrätt, Lund 1989.

Studium Generale Katholieke Universiteit Nijmegen, Documentatie censuur, Nijmegen 1988.

Supperstone, $\mathrm{M}_{\text {, }}$ Press Law in the United Kingdom in: P. Lahav, Press law in Modem Democracies, A Comparative Study, New York 1985, p. 9-78.

Supperstone, M., Brownlie's Law of Public Order and National Security, London 1981. Suyver, J.J.H., Vergelijkend onderzoek naar enige dwangmiddelen tijdens de opsporing.

Preadvies voor de Vereniging voor de vergelijkende studie van het recht van België en Nederland, ministerie van Justitie: 's-Gravenhage 1979.

Ulich, 'Reporter sind keine Buttel der Polizei', Deutsche Richterzeitung 1988, p. 53-55. Taheri, A., Reflections on an invalid fatwa, The Rushdie Affair, Index on Censorship 4-1990, p. 14-16.

Tak, P.J.P. en J.A.W. Lensing, Het vooronderzoek rechtsvengelijkend onderzocht, Arnhem 1990.

Tettingen, P., Schutz der Kommunikationsfreiheiten im deutschen Verfassungsrecht, Juristenzeitung 1990 , p. 846-854.

Thorbecke, Aanteekening op de Grondwet, deel ll, 1841, tweede druk.

Tomesen, L, De strafvorderlijke inbeslagneming en het rapport van de Commissie Moons. Een gemiste kans?, in: G.P.M.F. Mols (eindred.), Schaduwen vooruit, Rechtsgeleerde opstellen over het woorbereidend onderzoek in strafzaken, Arnhem 1992, p. 37-45.

Tomesen, L., The seizure of journalistic material, Revista de la Facultad de Ciencias de la Información, Madrid 1994, p. 157-164.

Trouw 19-11-1987, Kamer tegen verbod 'Fassbinder'.

Vecht, R.A., Informatieverstrekking door de media, Mediaforum 1991-1, p. 4-6. 
Velde, J, van de, Raad van Europa, Het publieke debat en de vrijheid van meningsuiting (Castells vs. Spain, Thorgeirson vs. Island, Schwabe vs. Austria), NJCM-Bulletin 1993 , p. $418-435$.

Vellinga-Schootstra, F., Inbeslagneming en huiszoeking, dissertatie RU Groningen, Alphen a/d Rijn 1982.

Vellinga-Schootstra, F., Beklagenswaardig beslag, enkele opmerkingen over de positie van de derde-belanghebbende, Delikt en Delinkwent 1988, p. 300-305.

Vellinga-Schootstra, F., Teruggave van in beslag genomen voorwerpen, Delikt en Delinkwent 1989, p. 121-136.

Verwey, W., Inval bij de Morgen alweer vergeten!, in: Documentatie Censuur, Studium Generale, Nijmegen 1988, p. 35-36.

Vissers, F., Drie onderwerpen betreffende de inbeslagneming ten behoeve van de strafvordering, Tijdschrift voor de politie 1937, p. 312.

Vlies, I.C., van der, Vrijheid van meningsuiting en het belang van de openbare orde,

Tijdschrift voor overheidsadministratie 1982, p. 455-461.

Volkskrant, De, 17-5-1991, 'Gevoelig' archief wordt beter toegankelijk.

Voorduin, J.C., Geschiedenis en Beginselen der Nederlandsche Wetboeken, Utrecht 1839.

Voorhoof, D. en J. Baert, Rechter en persvrijheid (Tribunes), Tegenspraak 1984, p. 14-20.

Voorhoof, D., De zaak Metro: een aanslag op de persvrijheid?, Panopticon 1985, p. 225-237.

Vrij Nederland 9-2-1991, nr. 6, Lex Dura, Verschoning.

Wade, Lord, Introducing a Bill of Rights in: C. Campbell (ed.), Do we need a Bill of Rights?, London 1980, p. 17-22.

Walker, R. J. and Walker, The English Legal System, London 1990.

Walter, N., Blasphemy: Punishment is worse than practice, The Rushdie Affair, Index on Censorship 4-1990, p. 21-22.

Wenham, B., Whose standards? Index on Censorship 8-1988, p. 31-34.

Wernstedt, S., Offentlighets- och sekretesspraxis efter 1980, Stockholm 1985.

Wiarda, G.J., Extensieve en restrictieve verdragstoepassing door het Europese Hof voor de rechten van de mens; een middenkoers?, in: Ad Personam, Opstellen aangeboden aan Prof.mr. ChJ. Enschede, Zwolle 1981, p. 371-385.

Wilhelm, P., Protection of Sources, An International Review of Joumalistic and Legal Practice, The Norwegian Institute of Journalism/International Federation of Journalists, Frederikstad 1988.

Williams, D.G.T., Racial Incitement and Public Order, Criminal Law Review 1966, p. $320-327$.

Williams, D.G.T., London Government Act 1963, The Modern Law Review 1964, p. $447-457$.

Winter, R.E., de, De heersende leer. Honderd jaar verspreidingsjurisprudentie: 1892-1992, dissertatie RL, 's-Gravenhage 1993. 
Winter, R.E., de, Straffeloos beledigen, Nederlands Juristenblad 1993, p. 638. Zander, M., The Police and Criminal Evidence Act 1984, London 1990.

Zellick, G., Violence as Pornography, Criminal Law Review 1970, p. 189-200.

Zellick, G., Two Comments on Search and Seizure under the Obscene Publications Act, Criminal Law Review 1971, p. 504-514.

Zellick, G., Films and the Law of Obscenity, The 'Flesh' Case, Criminal Law Review 1971, p. 126-150. 


\section{Lijst van aangehaalde jurisprudentie}

\section{NEDERLAND}

\section{Rechtbank}

Rb. "s-Gravenhage 10-12-1929, NJ 1930, 459.

Rb. 's-Gravenhage 28-01-1938, NJ 1939, 880.

Rb. 's-Hertogenbosch 02-05-1961, NJ 1961, 439.

Rb. 's-Hertogenbosch 21-04-1965, NJ 1966.

Rb. Middelburg 29-01-1980, NJ 1980, 596.

Pres. Rb. Amsterdam 06-11-1980, NJ 1981, 502 (Scientology kerk tegen de VARA). Rb. Amsterdam 18-04-1984, NJCM-Bulletin 1985, p. 57-64.

Rb. Zwolle 19-12-1984, NJCM-Bulletin 1985, p. 50-56.

Rb. Arnhem 08-02-1985, NJCM-Bulletin 1985, p. 303-309.

Rb. Breda 16-05-1988, KG 1988, 239.

Rb. Alkmaar 14-06-1989, Parketnr. 14.007144.89.

Rb. 's-Gravenhage 15-05-1990, Mediaforum 1990-9, p. 91, 102 (Beslag op videobanden).

Rb. Groningen 09-06-1994, Mediaforum 1995-7/8, p. B65.

\section{Hof}

Hof 's-Gravenhage 06-02-1922, W 10977.

Hof 's-Gravenhage 26-02-1940, NJ 1940, 486.

Hof 's-Gravenhage 17-04-1941, NJ 1941, 716.

Hof Leeuwarden 24-03-1964, NJ 1965, 285.

Hof 's-Gravenhage 26-04-1972, NJ 1972, 431.

Hof 's-Hertogenbosch 6-10-1976, NJ 1981, 38.

Hof Arnhem 27-10-1983, NJ 1984, 80.

Hof 's-Gravenhage 11-12-1986, KG 1987, 97; NJ 1988, 143.

Hof Amsterdam 02-03-1992, Mediaforum 1992-5, p. 61-62 en B33-B34 (Journalisten stad radio Amsterdam). 
Hof Amsterdam 16-02-1989, ongepubliceerd, te kennen uit W.F. Korthals Altes dissertatie 'Naar een journalistiek privilege', Amsterdam 1989, p. 15.

Hof 24-11-1991, nr. 93.6307.

Hof Leeuwarden, 09-06-1994, Mediaforum 1995-7/8, p. B37.

\section{Hoge Raad}

HR 08-03-1915, NJ 1915.

HR 21-05-1921, NJ 1921, 564, W 10728.

HR 02-11-1927, NJ 1927, 533.

HR 06-04-1936, NJ 1936, 813.

HR 31-05-1937, NJ 1938, 150.

HR 13-01-1948, NJ 1948, 158.

HR 14-12-1948, NJ 1949, 95.

HR 04-04-1950, NJ 1950, 693.

HR 28-11-1950, NJ 1951, 137.

HR 15-12-1950, NJ 1951, 221.

HR 17-03-1953, NJ 1953, 389.

HR 22-02-1957, NJ 1957, 310.

HR 15-12-1959, NJ 1960, 255.

HR 12-01-1960, NJ 1960, 273.

HR 22-03-1960, NJ 1960, 274.

HR 29-11-1960, NJ 1961, 206.

HR 23-05-1961, NJ 1961, 427.

HR 13-11-1963, NJ 1963, 38.

HR 14-04-1964, NJ 1964, 435.

HR 25-10-1966, NJ 1967, 175.

HR 24-01-1967, NJ 1967, 270.

HR 30-05-1967, NJ 1968, 4.

HR 04-01-1969, NJ 1970, 42.

HR 07-12-1971, NJ 1972, 197; AA 1973, p. 236-253 (Marconist).

HR 27-04-1971, NJ 1972, 341.

HR 29-01-1974, NJ 1974, 125.

HR 03-12-1974, NJ 1975, 163.

HR 18-03-1975, NJ 1975, 232.

HR 27-04-1976, NJ 1976, 427.

HR 28-06-1977, NJ 1977, 508.

HR 11-11-1977, NJ 1978, 399; NJCM-Bulletin 1985, p. 50-56.

HR 24-01-1978, NJ 1978, 323.

HR 29-05-1978, NJ 1978, 358.

HR 06-06-1978, NJ 1979, 29.

HR 12-12-1978, NJ 1979, 142. 
HR 20-03-1979, NJ 1979, 310.

HR 18-05-1979, NJ 1980, 213; NJCM-Bulletin 1985, p. 310-318.

HR 22-05-1979, NJ 1979, 505.

HR 26-06-1979, NJ 1979, 620.

HR 04-09-1979, NJ 1979, 636.

HR 02-10-1979, NJ 1980, 105.

HR 06-05-1980, NJ 1981, 427.

HR 13-01-1981, NJ 1981, 363 .

HR 20-01-1981, NJ 1981, 351.

HR 27-10-1981, NJ 1982, 103.

HR 01-12-1981, NJ 1982, 234.

HR 24-06-1982, nr. 12275.

HR 17-01-1983, nr. 122158.

HR 28-06-1983, NJ 1984, 64 (Plakverbod Zevenaar).

HR 13-09-1983, NJ 1984, 151.

HR 24-04-1984, NJ 1985, 115.

HR 12-06-1984, NJ 1985, 36.

HR 08-10-1985, NJ 1986, 214.

HR 17-12-1985, NJ 1986, 591.

HR 21-01-1986, NJ 1986, 441.

HR 11-03-1986, NJ 1987, 462.

HR 03-06-1986, NJ 1987, 174.

HR 26-05-1987, NJCM-Bulletin 1987, p. 607-624.

HR 23-06-1987, NJ 1988, 43.

HR 05-01-1988, NJCM-Bulletin 1989, p. 439-446; Gemeentestem 1989, 6872, p. $77-79$

(Haarlemse Plakverbod).

HR 13-09-1988, NJ 1989, 403.

HR 29-11-1988, DD 1989, 2205E-2210E, p. 459-460.

HR 18-09-1989, NJ 1990, 94.

HR 31-10-1989, NJ 1990, 257.

HR 09-01-1990, NJB 1990, 2409, p. 1324.

HR 27-02-1990, NJ 1990, 612.

HR 18-01-1991, NJB 1991, 2633, p. 1073.

HR 19-02-1991, Mediaforum 1991-5, 2610, Bijl. p. 33-37 (Beslag op videobanden 11)

HR 16-03-1993, NJB 1993, 127, p. 291.

\section{ARRS}

VzARRS 27-05-1982, AB 1982, 62 (Roze Front).

ARRS 19-01-1987, AB 1988, 58 (Geluidswagens Oegstgeest).

VZARRS 22-09-1987, AB 1988, 249. 
ARRS 08-04-1988, NJCM-Bulletin 1989, p. 821-835; ARRS 08-04-1988, AB 1989, 88.

VzARRS 01-06-1989, KG 1989, 272 (Demonstratieverbod Centrumdemocraten Rotterdam).

\section{EUROPEES}

\section{ECRM}

ECRM 21-03-1975, Application nr. 6538/74, Decisions and Reports vol. 2 (The Times).

ECRM 06-07-1976, Decisions and Reports vol. 8 (De Geillustreerde Pers).

ECRM 11-10-1979, NJ 1980, 525 (Glimmerveen en Hagenbeek).

ECRM 25-06-1991, Human Rights News 1991, zaak 273.

ECRM 09-09-1993, Application nr. 16616/90, Report of the Commission (Vereniging Weekblad 'Bluf!'); NJCM-Bulletin 1994, p. 146-153.

\section{EHRM}

EHRM 16-07-1971, Series A, vol. 13 (Ringeisen).

EHRM 21-02-1975, Series A, vol. 18 (Golder).

EHRM 07-12-1976, Series A, vol. 23 (Kjeldsen, Busk, Madsen and Pedersen).

EHRM 07-12-1976, Series A, vol. 24; NJ 1978, 236 (Handyside).

EHRM 28-06-1978, Series A, vol. 27.

EHRM 06-09-1978, Series A, vol. 28; Human Rights Review 1979, p. 20-40;

AA 1979, 327 (Klass and others).

EHRM 26-04-1979, Series A, vol. 30; NJ 1980, 146 (Sunday Times).

EHRM 25-03-1983, Series A, vol. 61 (Silver and others).

EHRM 02-08-1984, Series A, vol. 82 (Malone).

EHRM 25-03-1985, NJ 1987, 900 (Barthold).

EHRM 08-07-1986, Series A, vol. 103; NJ 1987, 901 (Lingens).

EHRM 26-03-1987, Series A, vol. 116 (Leander).

EHRM 24-05-1988, Series A, vol. 133; NJCM-Bulletin 1988, p. 455-676; NJ 1991, 685 (Müller and others).

EHRM 21-06-1988, Series A, vol. 139; NJCM-Bulletin 1988, p. 566-570 (Platform “Ärzte für Leben’).

EHRM 22-02-1989, Revue trimestrielle des droits de l'homme 1990, p. $51-61$ (Barfod). EHRM 20-11-1989, Series A, vol. 165; NJ 1991, 738 (Affaire Markt Intern Verlag

GmbH et Klaus Beermann).

EHRM 24-04-1990, Series A, vol. 176B (Huvig en Kruslin). 
EHRM 26-04-1991, Council of Europe nr. 21/1990/212/274 (Ezelin).

EHRM 23-05-1991, Council of Europe nr. 6/1990/197/257 (Oberschlick).

EHRM 26-11-1991, Council of Europe nr. 50/1990/241/312 (Sunday Times nr. 2).

EHRM 26-11-1991, Council of Europe nr. 51/1990/242/313 (Observer and Guardian).

EHRM 23-04-1992, Council of Europe nr. 2/1991/254/325; Series A, vol. 236; NJ 1994, 102 (Castells).

EHRM 25-06-1992, Council of Europe nr. 47/1991/299/370; Series A, vol. 239 (Thorgeirson).

EHRM 28-08-1992, Council of Europe nr. 46/1991/298/369 (Schwabe).

EHRM 23-06-1994, Series A, vol. 291; NJCM-Bulletin 1995, p. 82-85 (Jacubowski). EHRM 20-09-1994, Series A, vol. 295; NJCM-Bulletin 1995, p. 176-191; NJ 1995, 366 (Otto-Preminger-Institut).

EHRM 23-09-1994, Series A, vol. 298; NJCM-Bulletin 1995, p. 167-175 (Jersild). EHRM 09-02-1995, Council of Europe nr. 44/1993/439/518; NJCM-Bulletin 1995, p. 65-66 en p. 480-487 (Vereniging Weekblad 'Bluf!').

\section{DUITSLAND}

AG Hannover 18-11-1980, Az. 44 Gs 638/80.

LG Hannover 22-12-1980, NStZ 1981, p. 154.

LG Berlin 16-07-1981, AfP 1981, p. 417.

LG Luneberg 12-12-1983, JZ 1984, p. 343; MDR 1984, p. 603.

OLG Koblenz 24-103-1966, DVBl. 1966, p. 576.

OLG Köln 09-01-1968, NJW 1968, p. 666 (Springer-Verlag).

OLG Frankfurt 21-08-1973, NJW 1973, p. 2074.

BGH 22-12-1959, 31, $312 \mathrm{f}$.

BGH 25-05-1965, NJW 1965, p. 1388 (Berufsverbot gegen einen Journalisten)

BVerfGE 04-06-1957, 7, 29; NJW 1957, p. 1355.

BVerfGE 06-10-1959, 10, 118; NJW 1960, p. 29.

BVerfGE 28-2-1961, 12, 202; NJW 1961, p. 547.

BVerfGE 05-07-1963, nr. 50308 (Der Spiegel)

BVerfGE 15-12-1965, 19, 342; NJW 1966, p. 243.

BVerfGE 27-7-1966, 20, 144; NJW 1966, p. 1703.

BVerfGE 03-08-1966, 20, 45; NJW 1966, p. 1259.

BVerfGE 05-08-1966, 20, 162; NJW 1966, p. 1603 (Der Spiegel).

BVerfGE 04-04-1967, 21, 271; NJW 1967, p. 976.

BVerfGE 11-03-1969, 25, 296; NJW 1969, p. 1019 (Stern).

BVerfGE 03-10-1969, 27, 71. 
BVerfGE 19-07-1972, 33, 367; NJW 1972, p. 2214.

BVerfGE 28-11-1973, 36, 193; NJW 1974, p. 358 (Hessen).

BVerfGE 13-02-1974, 36, 314.

BVerfGE 08-10-1974, 38, 103.

BVerfGE 03-12-1974, NJW 1975, p. 892.

BVerfGE 06-02-1979, 50, 234 (Köiner Volksblatt).

BVerfGE 03-04-1979, 51, 97; NJW 1979, p. 153.

BVerfGE 06-11-1979, 52, 283 (Tendenzschutz).

BVerfGE 04-03-1981, 56, 247 (Neue Hannoversche Presse).

BVerfGE 10-05-1983, 64, 108 (Chiffregeheimnis).

BVerfGE 25-01-1984, 66, 117 (Wallraff).

BVerfGE 14-05-1985, NJW 1985, p. 2395 (Brokdorf)

BVerfGE 01-10-1987, NJW 1988, p. 329; EuGRZ 1987, p. 438 (Beschlagnahme von selbstrecherchiertem Filmmaterial einer Fernsehanstalt).

BVerfGE 01-10-1987, NStZ 1988, p. 33; EuGRZ 1987, p. 438 (Beschlagnahme von selbstrecherchierten Materials beim Rundfunk).

\section{ENGELAND}

Costa Rica vs. Erlanger (1877) 46 L J 375 Ch.

Thomson vs. Chain Libraries Ltd. (1954) 2 All ER 616.

Attorney-General vs. Mulholland and vs. Foster (1963) 2 QB 477; 1 All ER 767.

Attorney-General vs. Clough (1963) 1 QB 773.

Attorney-General vs. Butterworth (1963) 1 QB 696.

John Calder (Publications) Ltd. vs. Powell (1965) 1 QB 509; 1 All ER 159.

R. vs. Britton (1967) 1 All ER 486.

R. vs. Malik (1968) All ER 582; 1 WLR 353.

R.vs. Savundranayagan and Walker (1968) 3 All ER 439; 1 WLR 1761; 52 Cr. App. R. 637.

DPP vs. A and BC Chewing Gum Ltd. (1968) 1 QB 159.

DPP vs. A and BC Chewing Gum Ltd. (1967) 2 All ER 504.

Thorne vs. BBC (1967) 2 All ER 1225.

R. vs. Calder and Boyars Ltd. (1968) 52 Cr. App. R. 706; 3 All ER 644.

R. vs. Calder and Boyars Ltd. (1969) 1 QB 151.

R. vs. Anderson and others (1971) 56 Cr. App. R. 115; 3 WLR 939; 3 All ER 1152.

R. vs. Anderson and others (1972) 1 QB 304; 36 JCL 158.

DPP vs. Whyte (1972) AC 849.

R. vs. Stamford (1972) 2 All ER 427.

Ealing BC vs. RRB (1972) 2 WLR 71.

Derrick vs. Customs and Excise Commissioners (1972) 2 QB 28.

Attorney-General vs. Times Newspapers Ltd. (1972) 3 All ER 1136.

Knuller (Publishing, Printing and Promotions) Ltd. vs. DPP (1973) AC 435. 
R. vs. Metropolitan Police Commissioner ex p Blackburn (nr. 3) (1973) OB 241; $37 \mathrm{JCL} 268$.

Attorney-General vs. Times Newspapers Ltd. (1973) 1 QB 710; 1 All ER 815;

3 All ER 54.

Nasty Tales (1973) 137 IPN 82.

Attorney-General vs. Times Newspapers Ltd. (1974) AC 273.

R. vs. Staniforth (1976) 2 WLR 849.

Crossman Diaries AG vs. Jonathan Cape (1976) QB 752.

Inside Linda Lovelace (1976) 126 NLJ 126.

DPP vs. Jordan (1976) 3 All ER 775; (1977) AC 699.

Attorney-General's Reference (nr. 2) (1978) 3 All ER 1166; 1 WLR 1123.

R. vs. Lemon and Gay News Ltd. (1979) 1 All ER 898.

Times Newspaper Ltd. vs. UK (1979) European Human Rights Reports 1979, p.

245.

Roandale vs. Metropolitan Police Commissioner (1979) Crim. LR 254.

Gleaves vs. Deakin and Others (1979) 2 All ER 497.

Attorney-General vs. Leveller Magazine Ltd. (1979) AC 440.

Attorney-General's Reference (nr. 5) (1980) 3 All ER 816; (1981) 1 WLR 88.

British Steel Corporation vs. Granada Television Ltd. (1981) 1 All ER 417.

Gold Star Publications Ltd. vs. DPP (1981) 2 All ER 257; 1 WLR 732.

Attorney-General vs. Lundin (1982) 75 Cr. App. R. 90.

Mandla vs. Dowell Lee (1983) 2 AC 548; 1 All ER 1062; 2 WLR 620.

Reynolds vs. Commissioner of Police of the Metropolis (1984) 3 All ER 649.

R. vs. Snaresbrook Crown Court ex p Commissioner of Police for the Metropolis (1984) 79 Cr. App. R. 184.

R. vs. Ponting (1985) Crim. LR 318.

R. vs. Leicester Crown Court ex p DPP (1987) 1 WLR 1371.

Attorney-General vs. Guardian Newspapers Ltd. (1987) 3 All ER 316; 1 WLR 1248. Attorney-General vs. Newspaper Publishing Ltd. (1987) 3 All ER 276.

R. vs. Secretary of State for the Home Department ex p Ruddock (1987) 2 All ER 518.

R. vs. Galvin (1987) 3 WLR 93.

R. vs. Bristol Crown Court ex p Bristol Press and Picture Agency Ltd. (1987) Crim. LR 329, 330.

Attorney-General (UK) vs. Heinemann Publishers Australia Pty Ltd. (1987) 8 WLR 341 , NS.

Attorney-General (UK) vs. Heinemann Publishers Australia Pty Ltd. (1987) 75 ALR 353.

Attorney-General (UK) vs. Heinemann Publishers Australia Pty Ltd. (1987) 78 ALR 449.

Attorney-General vs. Guardian Newspapers Ltd. (nr. 2) (1988) 3 All ER 545; 3 WLR 776.

R. vs. Owen (1988) 86 Cr. App. R. 291. 
R. vs. Bow St Magistrates ex p Nocyp Ltd. (1988) 3 WLR 827.

John Graham-Kerr (1989) 88 Cr. App. R. 302.

Lord Advocate vs. Scotsman Publishing Ltd. (1989) 2 All ER 852.

Ltd. and another vs. Morgan-Grampian (Publishers) Ltd. and another (1990) 2 WLR 421; 1 All ER 616; 2 WLR 1000; 2 All ER 1.

\section{ZWEDEN}

NJA 1935 , p. 113

NJA 1944, p. 702

NJA 1956, p. 48

NJA 1957 , p. 352

NJA 1966, p. 565

NJA 1969 , p. 364

SvJT 1970, p. 2

SwJT 1974, p. 84

NJA 1975, p. 585 (IB-affären)

NJA 1976, p. 150

NJA 1978 , p. 81

NJA 1978, p. 3

NJA 1987, p. 285 ।

NJA 1987, p. 285 II

NJA 1988, p. 118 


\section{Curriculum Vitae}

Luciënne Tomesen, Jahrgang 1961, hat Rechtswissenschaft und Philosophie an der Katholischen Universität Brabant studiert. Sie war wissenschaftlich tätig an den Universitäten Cambridge, Nottingham, Straßburg und Uppsala und am Max Planck Institut in Freiburg. Sie war Assistentin und Dozentin im Bereich Strafrecht und Kriminologie an der Rijksuniversiteit Limburg. Sie ist wissenschaftlich Mitarbeiterin der 'Organisation Européenne de la Culture et de la Recherche'. Künstlerische Produktionen bei der 'Fondation Jouissance' standen unter ihrer Leitung. Sie hat publiziert auf den Gebieten der Philosophie, Kunst, Poesie, europäischen Kultur, des Strafrechts und der Menschenrechte. Sie ist Herausgeberin der Publikation 'Denken über Kultur in Europa' (1994) und Mitautorin des 'Konzepts einer Kulturvorschrift im Vertrag von Maastricht' (1991). Sie schrieb den Gedichtband 'Les enfants du paradis' (1995). Einige Gedichte dieses Bandes sind von Komponisten vertont worden. Im Augenblick (1995) schreibt sie an einem Roman. 